Prepared in cooperation with the Federal Emergency Management Agency

\title{
Floods of 2011 in New York
}

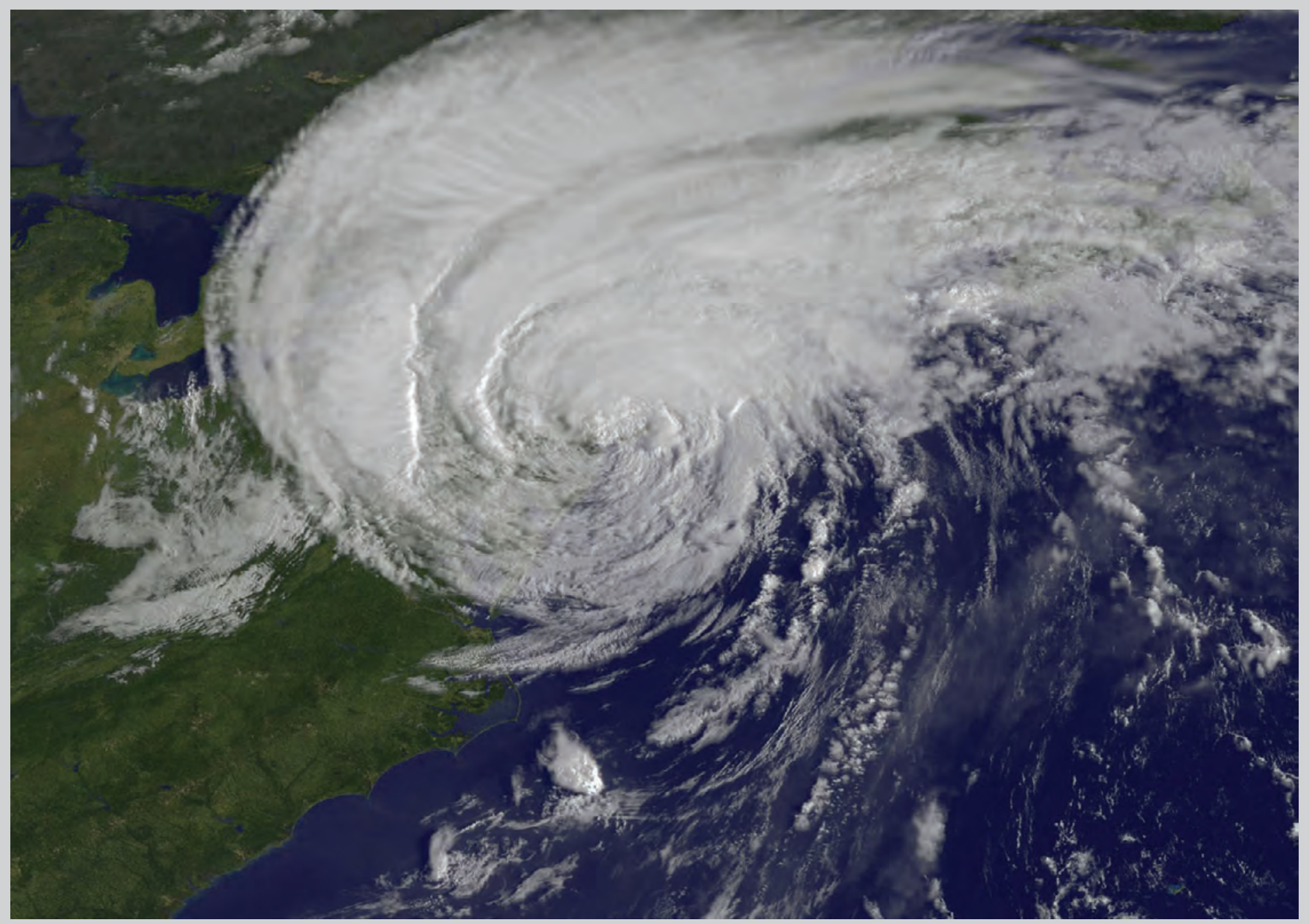

Scientific Investigations Report 2014-5058 
Cover. Satellite image of Hurricane Irene, August 28, 2011 (10:30 a.m.), courtesy of the National Aeronautics and Space Administration (NASA). 


\section{Floods of 2011 in New York}

By Richard Lumia, Gary D. Firda, and Travis L. Smith

Prepared in cooperation with the Federal Emergency Management Agency

Scientific Investigations Report 2014-5058 


\title{
U.S. Department of the Interior SALLY JEWELL, Secretary
}

\section{U.S. Geological Survey \\ Suzette M. Kimball, Acting Director}

\author{
U.S. Geological Survey, Reston, Virginia: 2014
}

For more information on the USGS - the Federal source for science about the Earth, its natural and living resources, natural hazards, and the environment, visit http://www.usgs.gov or call 1-888-ASK-USGS.

For an overview of USGS information products, including maps, imagery, and publications, visit http://www.usgs.gov/pubprod

To order this and other USGS information products, visit http://store.usgs.gov

Any use of trade, firm, or product names is for descriptive purposes only and does not imply endorsement by the U.S. Government.

Although this information product, for the most part, is in the public domain, it also may contain copyrighted materials as noted in the text. Permission to reproduce copyrighted items must be secured from the copyright owner.

Suggested citation:

Lumia, Richard, Firda, G.D., and Smith, T.L., 2014, Floods of 2011 in New York: U.S. Geological Survey Scientific Investigations Report 2014-5058, 236 p., http://dx.doi.org/10.3133/sir20145058. 


\section{Acknowledgments}

Thanks are extended to Alan Springett of the Federal Emergency Management Agency (FEMA) and to New York State Department of Transportation for providing data and cooperating with the U.S. Geological Survey (USGS) to compute updated flood frequencies for streamgages. The National Weather Service, New York State Department of Environmental Conservation, New York State Canal Corporation, National Resources Conservation Service, and New York City Department of Environmental Protection each provided data that are included in this report.

Thanks are also extended to all of the USGS hydrologists and hydrologic technicians who made extraordinary efforts during and after the floods in collecting and analyzing the data for this report. The authors would also like to acknowledge William F. Coon and Phillip J. Zarriello of the USGS for their detailed technical reviews of the report and Mary S. Ashman (USGS) for her thorough editorial review of the report. The major contributions to the graphics in the report by the geographic information system and publications units of the USGS New York Water Science Center are also much appreciated. 



\section{Contents}

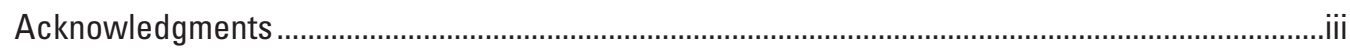

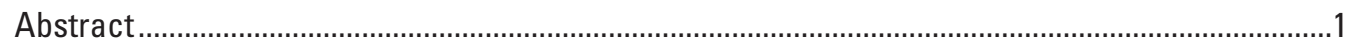

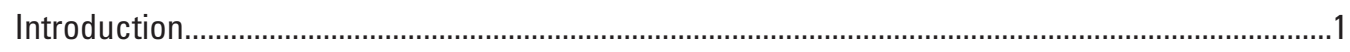

Purpose and Scope .....................................................................................................

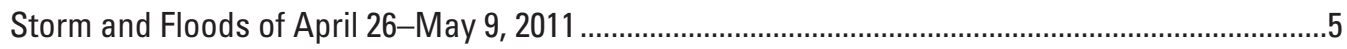

Antecedent Conditions .......................................................................................................

Precipitation

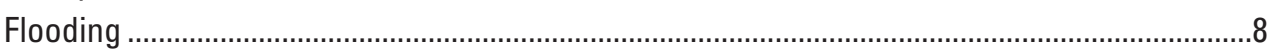

Flood Discharge and Frequency ................................................................................

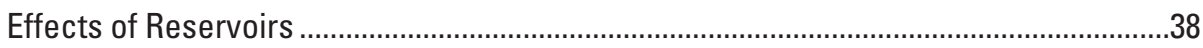

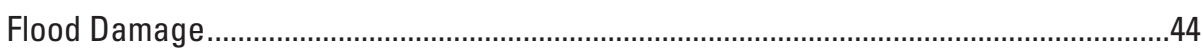

Storm and Floods of August 28-29, 2011 (Tropical Storm Irene)................................................50

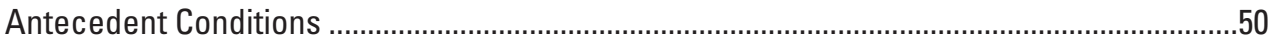

Precipitation

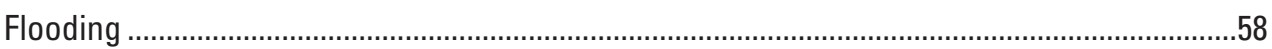

Flood Discharge and Frequency ..................................................................................58

Flood Profiles of Schoharie Creek ...........................................................................106

Coastal Flooding in Extreme Southeastern New York and Long Island........................106

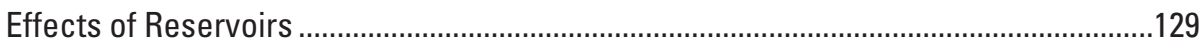

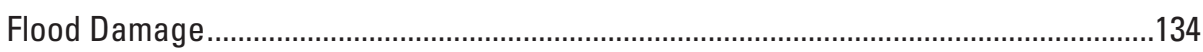

Storm and Floods of September 7-11, 2011 (Tropical Storm Lee)...............................................145

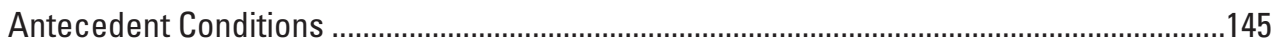

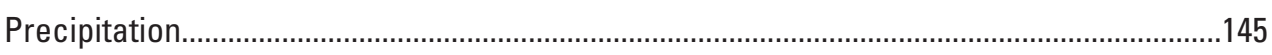

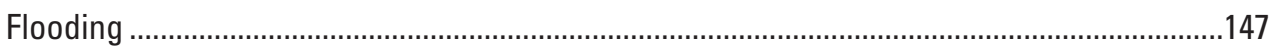

Flood Discharge and Frequency ...............................................................................156

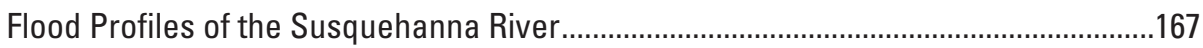

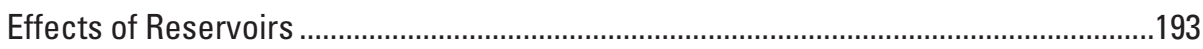

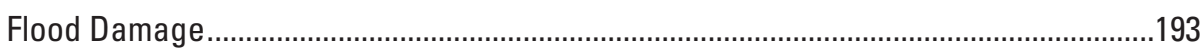

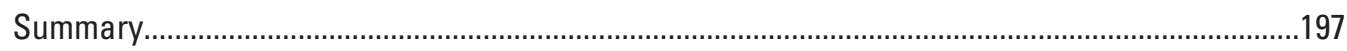

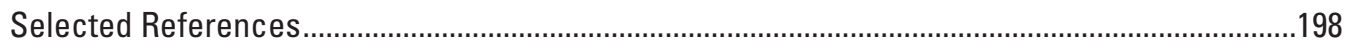

Appendix 1. Map Numbers, U.S. Geological Survey Streamgage Numbers and Names, and Selected Flood Information Used in the Study ...........................................................201

Appendix 2. Selected Photographs of Flood Damage Caused by the Floods of 2011 in

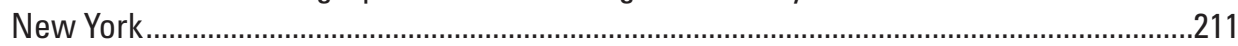

Appendix 3. Selection and Accuracy of High-Water Marks ....................................................227 


\section{Figures}

1. Map showing climate divisions of New York

2. Map showing maximum annual exceedance probabilities and recurrence intervals for three major floods in 2011 in selected U.S. Geological Survey streamgage basins in New York

3. Maps showing water equivalent of snow on $A$, April 15, B, April 1, C, April 29, and D, April 26, 2011, in New York and surrounding areas.

4. Graph showing daily-temperature data at Lake Placid, New York, during April 2011 ......8

5. Graphs showing daily discharge data at U.S. Geological Survey streamgages on the $A$, Hudson River, $B$, West Branch Oswegatchie River, and $C$, Ausable River for March 1-April 30, 2011.

6. Photographs showing a small tributary to the upper Hudson River showing flow conditions prior to the storms in $A$, April 2011, and B, August 2011.

7. Maps showing rainfall amounts for each day during the storm of $A$, April 26, $B$, April 27, C, April 28, and D, April 29, 2011, for New York and surrounding areas ........11

8. Map showing rainfall totals for the storm of April 26-29, 2011, in New York and surrounding areas

9. Graph showing cumulative daily rainfall during April 1-30, 2011, recorded at Lake Placid, New York.

10. Map showing locations of selected U.S. Geological Survey streamgages and major drainage basins in New York.

11. Map showing annual exceedance probabilities and recurrence intervals for the flood of April 26-May 9, 2011, in selected U.S. Geological Survey streamgage basins in New York

12. Graph showing peak discharges for the flood of April 26-May 9, 2011, previous maximum known discharges, and 1-percent annual exceedance probability (100-year) discharges at selected streamgages, as a function of drainage area

13. Graph showing peak discharges for the floods of April 26-May 9, 2011, and 1- and 0.2 -percent annual exceedance probability (AEP) (100- and 500-year) discharges at seven U.S. Geological Survey streamgages on the Hudson River, as a function of drainage area.....

14. Graphs showing highest 1-, 3-, and 7-consecutive daily mean discharges, selected $\mathrm{n}$-day frequencies, and trend-analysis data for the streamgages $A$, Hudson River at North Creek, $B$, Raquette River at Piercefield, $C$, Raquette River at South Colton, and $D$, Ausable River near Au Sable Forks, New York

15. Graphs showing annual peak discharges through 2011 , selected flood frequencies, and trend-analysis data for selected streamgages in New York

16. Graph showing annual peak discharges, moving flood frequencies, and trends of the moving 1-percent AEP (100-year) discharges through 2011 at the Hudson River at North Creek, New York, streamgage.

17. Graphs showing discharge hydrographs for April 25-May 1, 2011, and 1-percent annual exceedance probabilities for selected streamgages in the $A-C$, Hudson, $D-H$, Mohawk, and $I$, Raquette River Basins in New York

18. Graphs showing discharge hydrographs for April 25-May 1, 2011, for selected previous floods, selected flood frequencies, and a list of the largest four floods for the streamgages $A$, Hudson River at North Creek, $B$, West Canada Creek at Kast Bridge, and $C$, Raquette River at South Colton, New York 
19. Graphs showing stage hydrographs for April 25 to May 1, 2011, stage frequencies, and stage-frequency durations for the strreamgages $A$, Hudson River at North Creek, $B$, Hudson River at Hadley, $C$, West Canada Creek at Kast Bridge, and $D$, Raquette River at South Colton, New York

20. Map showing locations of high-water marks collected for the flood of April 2629, 2011, at selected sites along the upper Hudson River from Lake Luzerne to Mechanicville, New York

21. Graphs showing daily inflows, outflows, and water-surface elevations relative to National Geodetic Vertical Datum of 1929 at selected lakes and reservoirs in northern New York, April 1-May 31, 2011.

22. Map showing counties of New York that were declared major disaster areas following the flooding of April 26-May 9, 2011

23. Graphs showing daily discharge data for the streamgages $A$, Schoharie Creek at Prattsville, B, East Branch Delaware River at Margaretville, and C, Ausable River at Au Sable Forks, New York, for August 1-31, 2011.

24. Maps showing daily rainfall totals during August 28-29, 2011, for New York and surrounding areas

25. Map showing rainfall totals for the storm of August 28-29, 2011, in A, north, and $B$, south areas of New York and surrounding areas

26. Graph showing cumulative hourly rainfall during August 27-29, 2011, recorded at five weather stations in New York and Vermont

27. Map showing annual exceedance probabilities and recurrence intervals for the flood of August 28-29, 2011, in selected U.S. Geological Survey streamgage basins in New York

28. Graph showing peak discharges for the flood of August 28-29, 2011, previous maximum known discharges, and 1-percent annual exceedance probability (100-year) discharges at selected streamgages, as a function of drainage area at selected sites in New York

29. Graph showing peak discharges for the flood of August 28-29, 2011, and 1- and 0.2 -percent annual exceedance probability (100- and 500-year) discharges at six U.S. Geological Survey streamgages on Schoharie Creek, New York, as a function of drainage area...

30. Graphs showing $m$ 1-, 3-, and 7-consecutive day mean discharges, selected n-day frequencies, and trend-analysis data for selected streamgages in New York

31. Map showing total storm runoff, in inches, for August 27-September 2, 2011, at selected streamgage basins in New York and vicinity.

32. Graphs showing annual peak discharges through 2011, selected flood frequencies, and trend-analysis data for selected streamgages in New York

33. Graphs showing annual peak discharges, moving flood frequencies, and trends of the moving 1-percent annual exceedance probability (100-year) discharges through 2011 at $A$, Schoharie Creek at Prattsville, $B$, Schoharie Creek at Burtonsville, and $C$, East Branch Delaware River at Margaretville, New York

34. Graphs showing discharge hydrographs for August 27-September 2, 2011, and 1-percent annual exceedance probabilities for selected streamgages in the $A$, Hoosic River, $B-G$, Schoharie Creek/Mohawk River, $H-J$, Lower Hudson River/ Ramapo River, $K-M$, Delaware River/Neversink River, and $N-Q$, Lake Champlain, Basins, New York.

35. Graphs showing discharge hydrographs for August 27-September 2, 2011, selected previous floods, selected flood frequencies, and a list of the largest four floods for selected streamgages in New York 
36. Graphs showing stage hydrographs for August 27-September 2, 2011, stage frequencies, and stage-frequency durations for selected streamgages in New York......103

37. Graph showing a generalized profile of Schoharie Creek for the flood of August 2829, 2011, with the elevations of high-water marks, approximate Federal Emergency Management Agency flood profiles, approximate stream-bottom elevations, and locations of local communities and U.S. Geological Survey streamgages in New York

38. Map showing locations of high-water-mark sites selected for the flood of August 28-29, 2011, along Schoharie Creek from Hunter to Fort Hunter, New York .....108

39. Graphs showing peak water-surface elevations of Schoharie Creek at 30 sites from Hunter to Fort Hunter, New York, during the flood of August 28-29, 2011, and annual exceedance probability elevations from published Federal Emergency Management Agency profiles

40. Photograph showing the covered bridge over Schoharie Creek in North Blenheim, New York, with the maximum elevations of the August 28, 2011, flood and two previous floods.

41. Map showing the locations of high-water marks collected $A$, by Federal Emergency Management Agency at 72 selected sites in the Delaware and lower Hudson River Basins and $B$, by the New York State Canal Corporation at 13 sites along the mainstem Mohawk River for the flood of August 28-29, 2011

42. Map showing the locations of high-water marks and peak water-surface elevations recorded by the U.S. Geological Survey at coastal areas in New York City and Long Island, New York, for the flood of August 28, 2011

43. Map showing the locations of 43 high-water marks in selected coastal areas in New York City and on Long Island, New York, for the flood of August 28, 2011

44. Graphs showing hourly inflows, outflows, and water-surface elevations at selected reservoirs in southeastern New York, August 28-29, 2011

45. Graphs showing water-surface elevations at three lake gages on Lake Champlain and $A$, inflows from two tributaries, and $B$, wind direction and speed, for late August to early September 2011

46. Map showing the counties of New York that were declared major disaster areas following the flooding of August 28-29, 2011

47. Graphs showing daily discharge data for the streamgages $A$, Chenango River at Greene, $B$, Susquehanna River at Vestal, $C$, Susquehanna River near Waverly, and $D$, Cayuga Inlet near Ithaca, New York, for August 15-September 15, 2011

48. Map showing moisture from the remnants of Tropical Storm Lee and Hurricane Katia on September 7, 2011

49. Map showing rainfall totals in inches from Tropical Storm Lee and its remnants during September 1-10, 2011.

50. Maps showing daily rainfall totals from the remnants of Tropical Storm Lee during A, September 6, B, September 7, C, September 8, and D, September 9, 2011, for New York and surrounding areas

51. Map showing rainfall totals for the storm of September 6-9, 2011, in New York and surrounding areas.

52. Graph showing cumulative hourly rainfall during September 5-9, 2011, recorded at three weather stations in south-central New York.

53. Map showing annual exceedance probabilities and recurrence intervals for the flood of September 7-11, 2011, in selected U.S. Geological Survey streamgage basins in New York. 
54. Graph showing peak discharges for the flood of September 8-9, 2011, previous maximum known discharges, and 1-percent annual exceedance probability (100-year) discharges at selected streamgages as a function of drainage area in New York

55. Graph showing peak discharges for the flood of September 8-9, 2011, and 1- and 0.2 -percent annual exceedance probability (100- and 500-year) discharges at seven U.S. Geological Survey streamgages on the Susquehanna River as a function of drainage area in New York

56. Graphs showing highest 1-, 3-, and 7-consecutive-day mean discharges, selected $\mathrm{n}$-day frequencies, and trend-analysis data for selected streamgages in New York...168

57. Graphs showing annual peak discharges through 2011, selected flood frequencies, and trend-analysis data for selected streamgages in New York

58. Graph showing annual peak discharges, moving flood frequencies, and trends of the moving 1-percent annual exceedance probability (100-year) discharges through 2011 at the Susquehanna River at Vestal, New York streamgage

59. Graphs showing discharge hydrographs for September 5-11, 2011, and 1-percent annual exceedance probabilities for selected streamgages on the Susquehanna, Chenango, and Mohawk Rivers, New York

60. Graphs showing discharge hydrographs for September 5-11, 2011, selected previous floods, selected flood frequencies, and a list of the largest four floods for selected streamgages in New York

61. Graphs showing stage hydrographs for September 5-11, 2011, stage frequencies, and stage-frequency durations for selected streamgages in New York

62. Graph showing a generalized profile of the Susquehanna River for the flood of September 8-9, 2011, with the elevations of high-water marks, approximate Federal Emergency Management Agency flood profiles, approximate streambottom elevations, and locations of local communities and U.S. Geological Survey streamgages in New York

63. Map showing locations of high-water-mark sites selected for the flood of September 8-9, 2011 along the Susquehanna River from Unadilla, New York to Athens, Pennsylvania.

64. Graphs showing peak water-surface elevations of the Susquehanna River at 18 sites from Unadilla, New York, to Athens, Pennsylvania, during the flood of September 8-9, 2011, and Federal Emergency Management Agency flood elevations for selected frequencies.

65. Graphs showing hourly inflows, outflows, and water-surface elevations at $A$, East Sidney Lake and $B$, Whitney Point Lake with hourly discharges at the Otselic River at Cincinnatus streamgage in New York for September 5-15, 2011

66. Map showing the counties of New York that were declared major disaster areas following the flooding of September 8-9, 2011 


\section{Tables}

1. Annual 2011 and historic precipitation for 10 climate divisions of New York

2. Rainfall for the storm of April 26-29, 2011, at selected locations in New York and surrounding areas

3. Rainfall frequencies for storms of 1-,2-, and 4-day durations at selected locations in New York

4. Period-of-record peak discharges through March 2011 and peak discharges during the floods of April 26-May 9, 2011, at selected U.S. Geological Survey streamgages in New York

5. T-year recurrence interval with corresponding annual exceedance probability and P-percent chance annual exceedance probability for flood-frequency flows..

6. Trend tests for annual peak discharges at selected U.S. Geological Survey streamgages in New York for the period of record and the most recent 30 years or less (through 2011).

7. High-water marks collected by the New York State Department of Environmental Conservation at 17 selected sites along the upper Hudson River in New York during the flood of April 26-29, 2011

8. Data for six lakes and reservoirs in northern New York for the floods of AprilMay 2011

9. Rainfall for the storm of August 28-29, 2011, at selected locations in New York and surrounding areas

10. Rainfall frequencies for storms of 6-, 12- and 24-hour durations at selected locations in New York and Vermont.

11. Period-of-record peak discharges through July 2011 and peak discharges during the flood of August 28-29, 2011, at selected U.S. Geological Survey streamgages in New York

12. Total storm runoff and selected statistics for August 27 to September 2, 2011, at selected U.S. Geological Survey streamgages in New York

13. Peak water-surface elevations at 30 high-water-mark sites, including seven U.S. Geological Survey streamgages, along the Schoharie Creek in New York during the floods of August 28-29, 2011, January 19-20, 1996, and April 4-5, 1987, and corresponding elevations for the 10-, 2-, 1-, and 0.2-percent annual exceedance probability floods

14. High-water marks collected by the Federal Emergency Management Agency at 72 selected sites in the Delaware and lower Hudson River Basins in New York for the flood of August 28-29, 2011

15. High-water marks collected along the Mohawk River in New York by the New York State Canal Corporation at 13 selected sites for the flood of August 28-29, 2011, and by the U.S. Geological Survey at 8 selected sites for the flood of June 26-29, 2006 ....134

16. Peak storm-tide data for Hurricane Irene at U.S. Geological Survey tide gages and at selected coastal sites in New York for August 28, 2011

17. High-water marks collected by the Federal Emergency Management Agency at 43 selected coastal sites in Richmond, Kings, Queens, Nassau, and Suffolk Counties, New York, for the flood of August 28-29, 2011

18. Data for seven reservoirs in southeastern New York for the flood of August 28 29,2011

19. Rainfall for the storm of September 5-9, 2011, at selected locations in New York and surrounding areas. 
20. Rainfall frequencies for storms of 3-, 6-, 12-, and 24-hour durations at selected locations in south-central and east-central New York

21. Period-of-record peak discharges through August 2011 and peak discharges during the flood of September 7-11, 2011, at selected U.S. Geological Survey streamgages in New York

22. Peak water-surface elevations at 18 high-water-mark sites, including 8 U.S. Geological Survey streamgages, along the Susquehanna River in New York during the floods of September 8-9, 2011, and June 28-29, 2006, and corresponding elevations for the 10-, 2-, 1-, and 0.2-percent annual exceedance probability floods

23. Data for two lakes in the Susquehanna River Basin in New York for the flood of September 5-11, 2011

\section{Conversion Factors, Datum, and Abbreviations}

Inch/Pound to SI

\begin{tabular}{|c|c|c|}
\hline Multiply & By & To obtain \\
\hline \multicolumn{3}{|c|}{ Length } \\
\hline inch (in.) & 2.54 & centimeter $(\mathrm{cm})$ \\
\hline foot $(\mathrm{ft})$ & 0.3048 & meter $(\mathrm{m})$ \\
\hline mile (mi) & 1.609 & kilometer (km) \\
\hline \multicolumn{3}{|c|}{ Area } \\
\hline square mile $\left(\mathrm{mi}^{2}\right)$ & 259.0 & hectare (ha) \\
\hline square mile $\left(\mathrm{mi}^{2}\right)$ & 2.590 & square kilometer $\left(\mathrm{km}^{2}\right)$ \\
\hline \multicolumn{3}{|c|}{ Volume } \\
\hline gallon (gal) & 3.785 & liter $(\mathrm{L})$ \\
\hline gallon (gal) & 0.003785 & cubic meter $\left(\mathrm{m}^{3}\right)$ \\
\hline gallon (gal) & 3.785 & cubic decimeter $\left(\mathrm{dm}^{3}\right)$ \\
\hline billion gallons (Bgal) & $3.785412 \times 10^{6}$ & cubic meters $\left(\mathrm{m}^{3}\right)$ \\
\hline cubic foot $\left(\mathrm{ft}^{3}\right)$ & 28.32 & cubic decimeter $\left(\mathrm{dm}^{3}\right)$ \\
\hline cubic foot $\left(\mathrm{ft}^{3}\right)$ & 0.02832 & cubic meter $\left(\mathrm{m}^{3}\right)$ \\
\hline million cubic feet $\left(\mathrm{mil} \mathrm{ft} \mathrm{f}^{3}\right)$ & 0.02832 & million cubic meter $\left(\mathrm{mil} \mathrm{m}^{3}\right)$ \\
\hline \multicolumn{3}{|c|}{ Flow rate } \\
\hline cubic foot per second $\left(\mathrm{ft}^{3} / \mathrm{s}\right)$ & 0.02832 & cubic meter per second $\left(\mathrm{m}^{3} / \mathrm{s}\right)$ \\
\hline
\end{tabular}

Temperature in degrees Fahrenheit $\left({ }^{\circ} \mathrm{F}\right)$ may be converted to degrees Celsius $\left({ }^{\circ} \mathrm{C}\right)$ as follows:

${ }^{\circ} \mathrm{C}=\left({ }^{\circ} \mathrm{F}-32\right) / 1.8$

Vertical coordinate information is referenced to either the National Geodetic Vertical Datum of 1929 (NGVD 29) or the North American Vertical Datum of 1988 (NAVD 88).

Horizontal coordinate information is referenced to the North American Datum of 1983 (NAD 83) and the World Geodetic System 84 (WGS 84).

Barge Canal Datum (BCD) is site specific and there are local conversion factors, in feet, to National Geodetic Vertical Datum of 1929. 
Military time (24-hour time) is used in the report.

Elevation, as used in this report, refers to the distance above the National Geodetic Vertical Datum of 1929 (NGVD 29) or the North American Vertical Datum of 1988 (NAVD 88).

Water year is the 12-month period October 1 through September 30. The water year is designated by the calendar year in which it ends. Thus, the year ending September 30, 2011, is called the "2011 water year."

\section{Abbreviations}

AEP

FEMA

HWM

NGS

NOAA

NRCS

NWS

NYCDEP

NYSCC

NYSDEC

NYSDOT

$\mathrm{RI}$

USGS annual exceedance probability

Federal Emergency Management Agency

high-water mark

National Geodetic Survey

National Oceanic and Atmospheric Administration

National Resources Conservation Service

National Weather Service

New York City Department of Environmental Protection

New York State Canal Corporation

New York State Department of Environmental Conservation

New York State Department of Transportation

recurrence interval

U.S. Geological Survey 


\title{
Floods of 2011 in New York
}

\author{
By Richard Lumia, Gary D. Firda, and Travis L. Smith
}

\section{Abstract}

Record rainfall combined with above-average temperatures and substantial spring snowmelt resulted in record flooding throughout New York during 2011. Rainfall totals in eastern New York were the greatest since 1895 and as much as 60 percent above the long-term average within the Catskill Mountains area and the Susquehanna River Basin. This report documents the three largest storms and resultant flooding during the year: (1) spring storm during April and May, (2) Tropical Storm Irene during August, and (3) remnants of Tropical Storm Lee during September. According to the Federal Emergency Management Agency (FEMA), the cost of these three storms exceeded $\$ 1$ billion in Federal disaster assistance.

A warm and wet spring in northern New York resulted in record flooding at 21 U.S. Geological Survey (USGS) active streamgages during late April to early May with the annual exceedance probabilities (AEPs) of 11 peak discharges equaling or exceeding 1 percent. Nearly 5 inches of rain during late April combined with a rapidly melting snowpack caused widespread flooding throughout northern New York, resulting in many road closures, millions of dollars in damages, and 23 counties declared disaster areas and eligible for public assistance. On May 6, Lake Champlain recorded its highest lake level in over 140 years.

Hurricane Irene entered New York State on August 28 as a tropical storm and traveled up the eastern corridor of the State, leaving a path of destruction and damage never seen in many parts of New York. Thirty-one counties in New York were declared disaster areas with damages of over $\$ 1.3$ billion dollars and 10 reported deaths. Storm rainfall exceeded 18 inches in the Catskill Mountains area of southeastern New York with many other areas of eastern New York receiving over 7 inches. Catastrophic flooding resulted from the extreme rainfall in many locations, including Schoharie Creek and its tributaries, the eastern Delaware River Basin, the Ausable and Bouquet River Basins in northeastern New York, and several other stream basins throughout southeastern New York. Downstream reaches of the Mohawk River also had substantial flooding. Sixty-two USGS streamgages throughout eastern New York documented record high stream flows and elevations with AEPs of 25 peak discharges equaling or exceeding 1 percent. The USGS streamgage for the Schoharie
Creek at Prattsville recorded its greatest peak discharge in 109 years of record at 120,000 cubic feet per second (greater than the 0.2-percent AEP discharge) on August 28. The peak water-surface elevation at the streamgage in Prattsville was 5 feet higher than its previous record in 1996. USGS personnel surveyed 184 high-water marks (HWMs) at 30 locations along an 84-mile reach of Schoharie Creek and compared the elevations to those published by FEMA for the 10-, 2-, 1-, and 0.2-percent AEP floods. Elevations in the lower reaches of the basin exceeded published elevations for the 0.2-percent AEP flood.

Remnants of Tropical Storm Lee brought a third major storm to New York in September 2011. Moisture from Lee began moving into New York on September 7 and intensified over the already saturated Susquehanna River Basin. Most of the rain fell on September 8 with storm totals nearing 13 inches in some areas (12.73 inches at Apalachin in Tioga County). Major disaster declarations were issued for 15 counties in and around central New York, making them eligible for individual or public assistance. Ten USGS streamgages within the Susquehanna River Basin documented record-high stream discharges and elevations on September 8, and all were greater than the 1-percent AEP discharge. USGS personnel surveyed $20 \mathrm{HWMs}$ at 18 locations along a 114mile reach of the Susquehanna River and compared the elevations to those published by FEMA for the 10-, 2-, 1-, and 0.2-percent AEP floods. Several of the surveyed HWMs exceeded published elevations for the 0.2-percent AEP flood.

\section{Introduction}

Major flooding followed three separate storms during 2011 across central and eastern New York State and adjacent states as a result of extreme rainfall, temperatures, and snowpack: (1) April-May spring storm, (2) Tropical Storm Irene in August, and (3) remnants of Tropical Storm Lee in September. Enhanced precipitation from these storms helped to make 2011 New York's wettest year on record (since 1895) with a yearly total precipitation of 54.16 inches (in.) on average across the State (a normal year produces 39.7 in.), according to the National Oceanic and Atmospheric Administration $(2011 \mathrm{k})$. It was also the eighth warmest year on record in New York. Historic annual and 2011 annual 
precipitation over 10 climate divisions of New York (fig. 1; National Oceanic and Atmospheric Administration, 2004) is summarized in table 1. Rainfall totals in the Catskill Mountains area and the Susquehanna River Basin (climate division 2) were the greatest since 1895 and as much as 59 percent above the long-term average.

The winter of 2010-11 had normal precipitation but below normal temperatures, which delayed the melting of more than 16 in. of water in the snowpack in the Adirondack Mountains of northern New York (National Oceanic and Atmospheric Administration, 20111). The wettest spring on record combined with above-normal temperatures that melted the dense snowpack, resulting in major flooding across northern New York during late April and early May.

The summer of 2011 brought two major tropical storm systems through New York. Hurricane Irene weakened to a tropical storm that moved onshore at New York City and north through eastern New York on August 28 with torrential downpours of as much as $18 \mathrm{in}$. recorded in less than 24 hours in the Catskill Mountains area. Record flooding throughout much of eastern New York resulted. The remnants of Tropical
Storm Lee brought heavy rains again to an already rainsoaked New York in early September. The heaviest rains were centered over the Susquehanna River Basin in south-central New York with over 12 in. recorded in some areas during September 6-9 (with most falling on September 8). Record flooding occurred in the Susquehanna River Basin.

The U.S. Geological Survey (USGS), in cooperation with the Federal Emergency Management Agency (FEMA), conducted this study during 2012-13 to characterize these three storms, document the flooding, and support future flood-mitigation efforts. FEMA calculated the cost of the three storms to be nearly $\$ 1$ billion in Federal disaster assistance (Federal Emergency Management Agency, 2011a-c) as of February 24, 2014. It should be noted that flood-frequency analyses were done after the annual peak for the 2011 water year was determined by using USGS streamflow data, a log-Pearson type III (LP-III) distribution, and the guidelines of the Interagency Advisory Committee on Water Data (1982). For nonurbanized basins, the results of the LP-III analysis were weighted by the results of the regional flood-frequency analyses for streamgages with unregulated

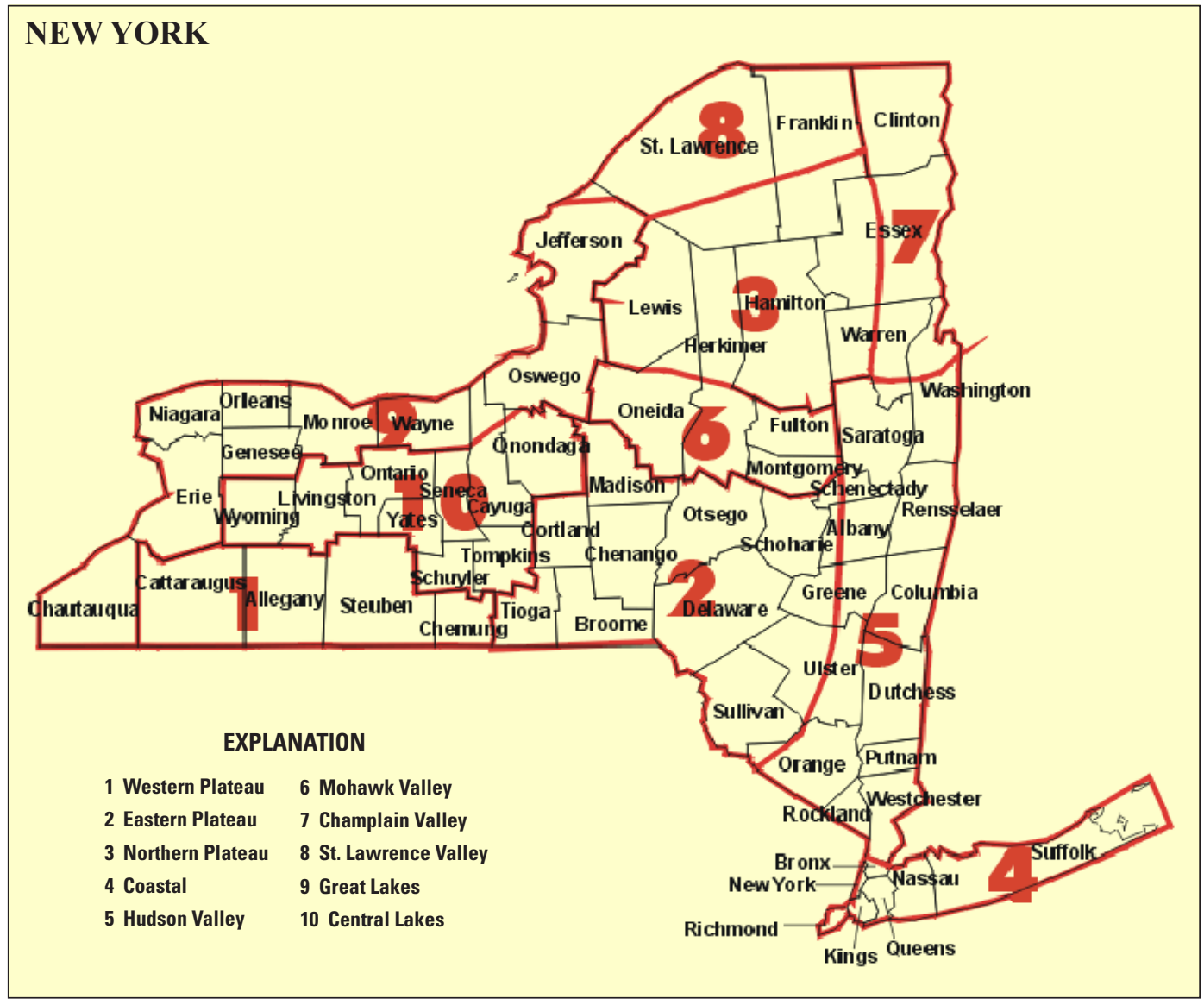

http://www.cpc.ncep.noaa.gov/products/analysis_monitoring/regional_monitoring/CLIM_DIVS/new_york.gif

Figure 1. Climate divisions of New York. (National Oceanic and Atmospheric Administration, 2004) 
Table 1. Annual 2011 and historic precipitation for 10 climate divisions of New York.

[Data from National Oceanic and Atmospheric Administration (2011k) are based on records since 1895; climate-division locations are shown on figure 1; rank is the order from largest to smallest since 1895; all listed trends are upward]

\begin{tabular}{rlccccccc}
\hline $\begin{array}{c}\text { Climate } \\
\text { division } \\
\text { number }\end{array}$ & Climate division name & $\begin{array}{c}\text { Average } \\
\text { annual } \\
\text { precipitation } \\
\text { (inches) }\end{array}$ & $\begin{array}{c}\text { Previous } \\
\text { maximum } \\
\text { annual } \\
\text { precipitation } \\
\text { (inches) }\end{array}$ & $\begin{array}{c}\text { Year of } \\
\text { previous } \\
\text { maximum }\end{array}$ & $\begin{array}{c}\text { 2011 annual } \\
\text { precipitation } \\
\text { (inches) }\end{array}$ & $\begin{array}{c}\text { Rank of 20111 } \\
\text { precipitation }\end{array}$ & $\begin{array}{c}\text { Percent- } \\
\text { age of 2011 } \\
\text { precipitation } \\
\text { above } \\
\text { average }\end{array}$ & $\begin{array}{c}\text { Trend of } \\
\text { annual } \\
\text { precipitation } \\
\text { (inches per } \\
\text { century) }\end{array}$ \\
\hline 1 & Western Plateau & 36.8 & 49.00 & 1945 & 48.94 & 2 & 33.0 & 8.39 \\
2 & Eastern Plateau & 41.5 & 57.51 & 1996 & 65.92 & 1 & 58.8 & 9.35 \\
3 & Northern Plateau & 44.2 & 55.42 & 1990 & 56.24 & 1 & 27.2 & 2.28 \\
4 & Coastal & 44.5 & 66.37 & 1983 & 59.76 & 3 & 34.3 & 8.36 \\
5 & Hudson Valley & 42.5 & 56.71 & 1996 & 60.26 & 1 & 41.8 & 6.40 \\
6 & Mohawk Valley & 44.3 & 57.89 & 1972 & 50.06 & 4 & 13.0 & 3.48 \\
7 & Champlain Valley & 35.2 & 46.49 & 1990 & 53.22 & 1 & 51.2 & 2.45 \\
8 & St. Lawrence Valley & 36.6 & 47.42 & 1954 & 40.35 & 20 & 10.2 & 1.52 \\
9 & Great Lakes & 36.2 & 49.30 & 1977 & 45.11 & 6 & 24.6 & 7.73 \\
10 & Central Lakes & 33.3 & 46.25 & 1972 & 45.32 & 3 & 36.1 & 8.64 \\
\hline
\end{tabular}

streamflows (Lumia and others, 2006). Recurrence intervals at streamgages with substantial urbanization or regulated flows were calculated from statistical analyses of annual peak discharges during the urbanized or regulated period only (through 2011). No adjustments were made for the available storage in reservoirs before or during floods or for changes in regulations or increased urbanization during the period of record. Recurrence intervals at streamgages along the main stem of the Delaware River from Callicoon to Port Jervis were computed by fitting systematic annual peak-discharge data to an LP-III distribution for the period of record (Schopp and Firda, 2008).

\section{Purpose and Scope}

This report documents the 2011 flooding in New York State following the (1) April-May spring storm and snowmelt, (2) Tropical Storm Irene in August, and (3) remnants of Tropical Storm Lee in September. The climate and flood data associated with each of these three floods are presented in maps, graphs, and tables that focus on the area where the greatest flooding occurred. The westernmost part of New York State was not affected by substantial flooding in 2011.

The 2011 water year (October 2010 through September 2011) was atypical in that major floods occurred at different times and at different places during the same year. A composite map (fig. 2) shows the drainage basins for active USGS streamgages, which are color coded to reflect the annual exceedance probabilities (AEPs) for the maximum discharges at the streamgages during the three major floods during the 2011 water year. A full-size view of the map on figure 2 can be accessed by the computer link at the end of the figure caption. The AEP values used on figure 2 and throughout this report are given in percentages of the chance of exceedance (for example, the $0.01 \mathrm{AEP}$ is shown as a 1-percent chance AEP). The inverse of the AEP flood was commonly referred to in the past as the flood-recurrence interval (RI). For example, a 1-percent chance AEP flood (a flood having a 1-percent chance of being equaled or exceeded in any given year) is also referred to as a flood with a 100-year recurrence interval. Use of the recurrence interval (RI) to describe a flood magnitude can be misleading because it is often interpreted as the period of time between floods of a given magnitude, but statistically it refers to the likelihood of a flood of a given magnitude in any year. For this reason, the USGS, FEMA, and other agencies have adopted the use of the term AEP for flood-related work. The technical nature of the flood data and the target audience for this report permits the use of both forms of flood-frequency presentation without the danger of creating confusion.

As indicated on figure 2, much of the State experienced major flooding at some time during the 2011 water year. Extreme western New York was one of the few upstate areas spared substantial flooding. Streamgages and numbers shown on figure 2 are listed in appendix 1 (at the end of the report), along with the estimated recurrence interval of each of the three events at the streamgage. The basin color (fig. 2) represents the most extreme of the three events in appendix 1, and a more detailed analysis of each of the events is given below. 


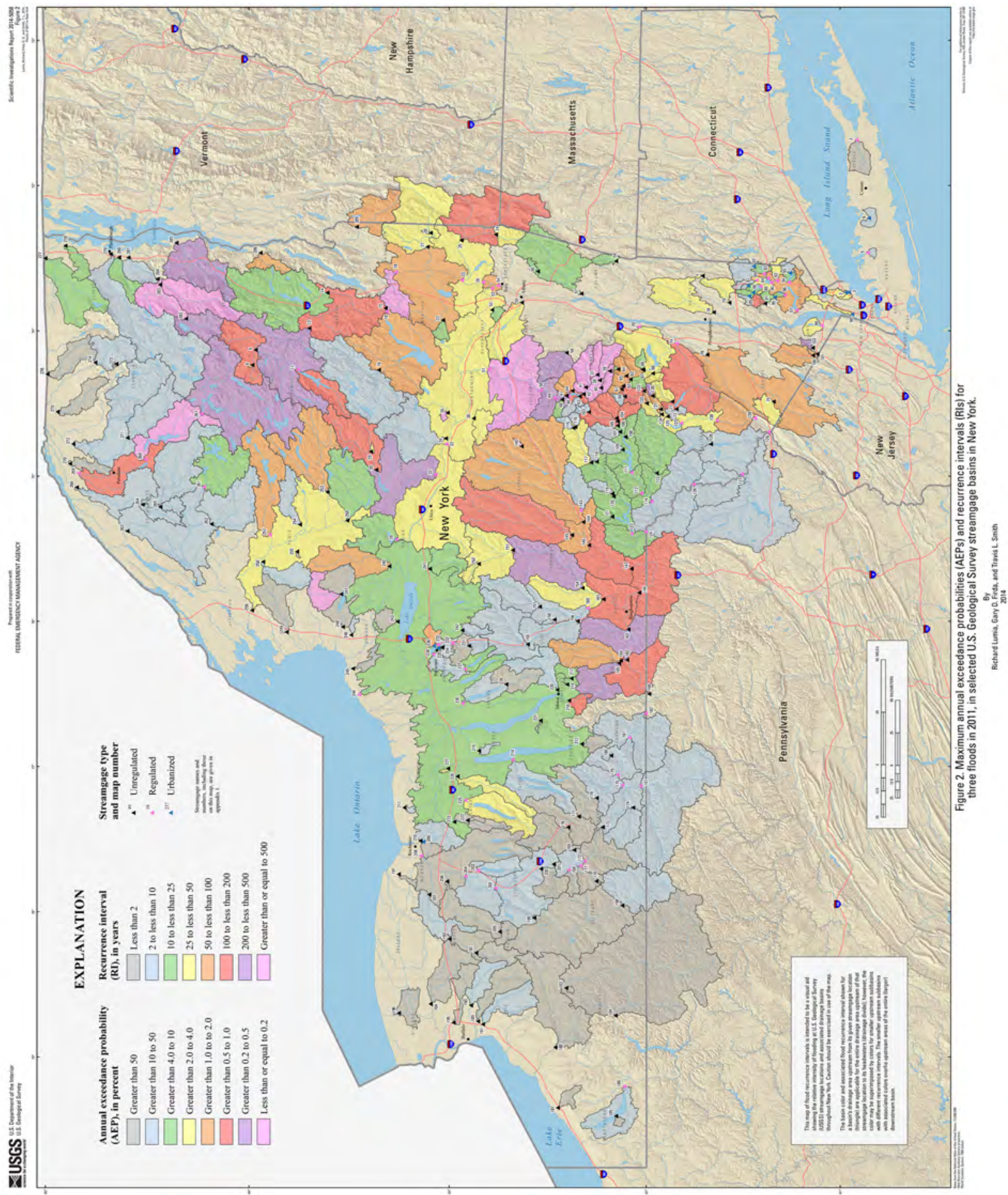

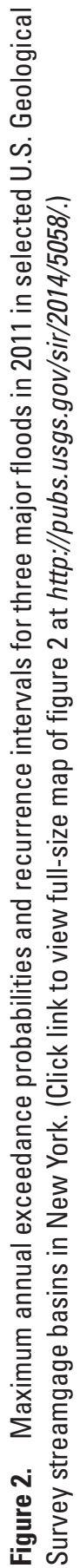




\section{Storm and Floods of April 26-May 9, 2011}

Record spring precipitation in 2011 combined with above-average temperatures and a melting snowpack resulted in record flooding on several streams in and around the Adirondack Mountains of northern New York (climate division 3, fig. 1). The greatest flooding occurred from late April to early May in the upper Hudson River, Raquette River, Ausable River, West Canada Creek, and Black River Basins. A slow-moving warm front in west-central New York caused additional flooding in the Finger Lakes region (climate division 10, fig. 1) on April 26-27 and damaged hundreds of roads in several counties. A few tornadoes that were reported in the area on April 27-28 caused localized damage.

The wet spring of 2011 that produced 5 in. of rain during late April in parts of upstate New York, combined with a rapidly melting snowpack from above-normal temperatures, caused widespread flooding of streams throughout northern New York and in other parts of the State. The resulting floods caused many road closures and 23 counties to be declared as Federal disaster areas and generated $\$ 60$ million in damages (Federal Emergency Management Agency, 2011c). In northern and parts of central New York, record flows were recorded at 17 active streamgages, and record stage was recorded at five lake/reservoir gages during late April to early May. Peak discharges equaled or exceeded the 1-percent AEP discharge at 11 streamgages. Four streamgages on the upper Hudson River recorded their maximum known peak stage and discharge during April 28-29. The peak discharge at the Hudson River at North Creek streamgage recorded its greatest peak stage and discharge in more than 104 years of record (greater than the 0.5-percent AEP or 200-year discharge). Lake Champlain recorded its highest lake level in over 140 years on May 6.

\section{Antecedent Conditions}

By the end of March 2011, more than 30 in. of dense snow containing a water equivalent of over 16 in. remained throughout the Adirondack Mountains of northern New York. The distribution of snow-water equivalent in New York for various days in April is shown on figure 3 as modeled radar images (National Oceanic and Atmospheric Administration, 20111). The National Weather Service (NWS) station at Lake Placid in northern New York indicates that the average air temperature (fig. 4) was above normal during April, and most snow was melted by April 26-27 as maximum temperatures rose to over $70^{\circ} \mathrm{F}\left(76^{\circ} \mathrm{F}\right.$ at Lake Placid on April 27).

As the snow melted during April, the runoff increased streamflows throughout northern New York to above normal by April 12 and to much above normal by the time the heavy rains began on April 26. Streamflows during the spring for three USGS streamgages (figs. 5A-C) are representative of antecedent flow conditions in the Adirondack Mountain area prior to the late April rains. The daily flow exceedance statistics for the period of record of each streamgage indicate that the 2011 daily discharges at each site exceeded the 25 th percentile during several days in mid- to late April and set record-high daily flows at the Hudson River near Newcomb (fig. 5A) and the Ausable River near Au Sable Forks (fig. 5C). The 2011 daily discharges at the West Branch Oswegatchie River (fig. 5B) were near or above the 25th percentile in midApril and just above or near the maximum daily flow for the period of record by late April. Photographs of a small stream tributary to the upper Hudson River near North Creek show a torrent that is out of its channel banks on April 20 (fig. 6A) as a result of prestorm snowmelt. More normal flow conditions for this stream are shown on figure 6B.

\section{Precipitation}

A warm front moved northward across New York on April 26, bringing warm, humid air (temperatures rose above $70^{\circ} \mathrm{F}$ ) and producing heavy showers and thunderstorms that affected areas mainly north and west of Albany. A series of low-pressure areas moved northeastward along the front, resulting in several rounds of heavy rainfall through April 28. Radar images of precipitation on April 26-29 (fig. 7) show the general track and intensity of the storm as it moved through the State (National Oceanic and Atmospheric Administration, $2011 \mathrm{~m})$. The heaviest rains during April 26-28 were concentrated in northern and central New York (fig. 8). Fourday storm totals (table 2) from NOAA weather stations in New York and western Vermont indicate nearly 5 in. of rain at some locations (4.88 in. at Highmarket in Lewis County and 4.52 in. at Lake Placid in Essex County). Rainfall totals decreased to less than 2 in. southeast of the Mohawk River Valley and northwest of the Adirondack Mountains into the St. Lawrence River Valley (fig. 8 (National Oceanic and Atmospheric Administration, 2011a,d)).

The rainfall accumulation at the Lake Placid weather station during April 2011 (fig. 9) was measured as 8.72 in., the greatest April precipitation in nearly 100 years of record at the station (the previous maximum was 6.17 in. in 1967) and 5.87 in. greater than the normal April precipitation (Northeast Region Climate Center, 2013). The maximum 1-day rainfall during April 2011 of 1.90 in. on April 28th is the second greatest 1-day April precipitation on record at Lake Placid; but based on all 1-day maximum precipitation values (all months) for nearly 100 years of record, the 1.90 in. on April 28, 2011, ranks as only the 45th highest, and the recurrence interval of the annual 1-day maximum precipitation (Northeast Region Climate Center, 2013) is less than 2 years (table 3 ). The 2and 4-day rainfalls for Lake Placid and two others stations in northern New York during late April 2011 (shown in red on table 3) were generally at recurrence intervals that were respectively larger than the 1-day but less than 25 years (Northeast Region Climate Center, 2010). Saturated soil conditions and snowmelt prior to the storm combined with the late-April rains resulted in major flooding in several parts of northern New York into early May. 


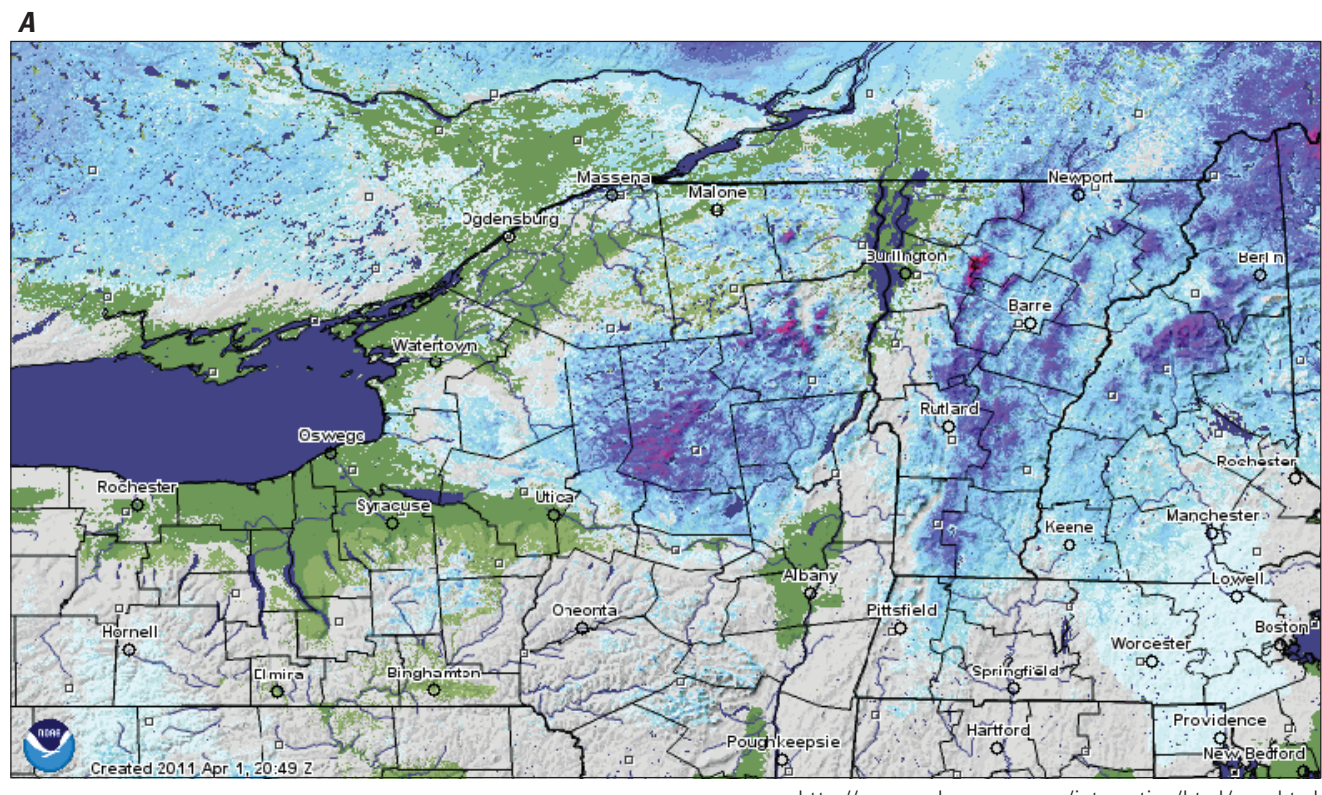

\section{Inches of water equivalent}

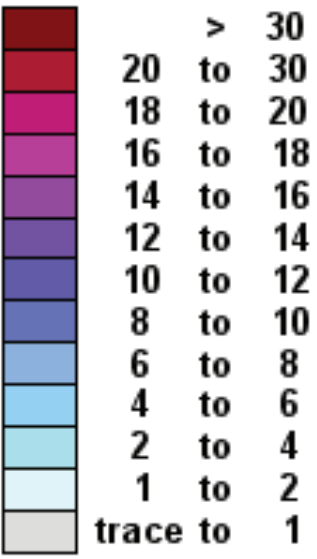

B

http://www.nohrsc.noaa.gov/interactive/html/map.html

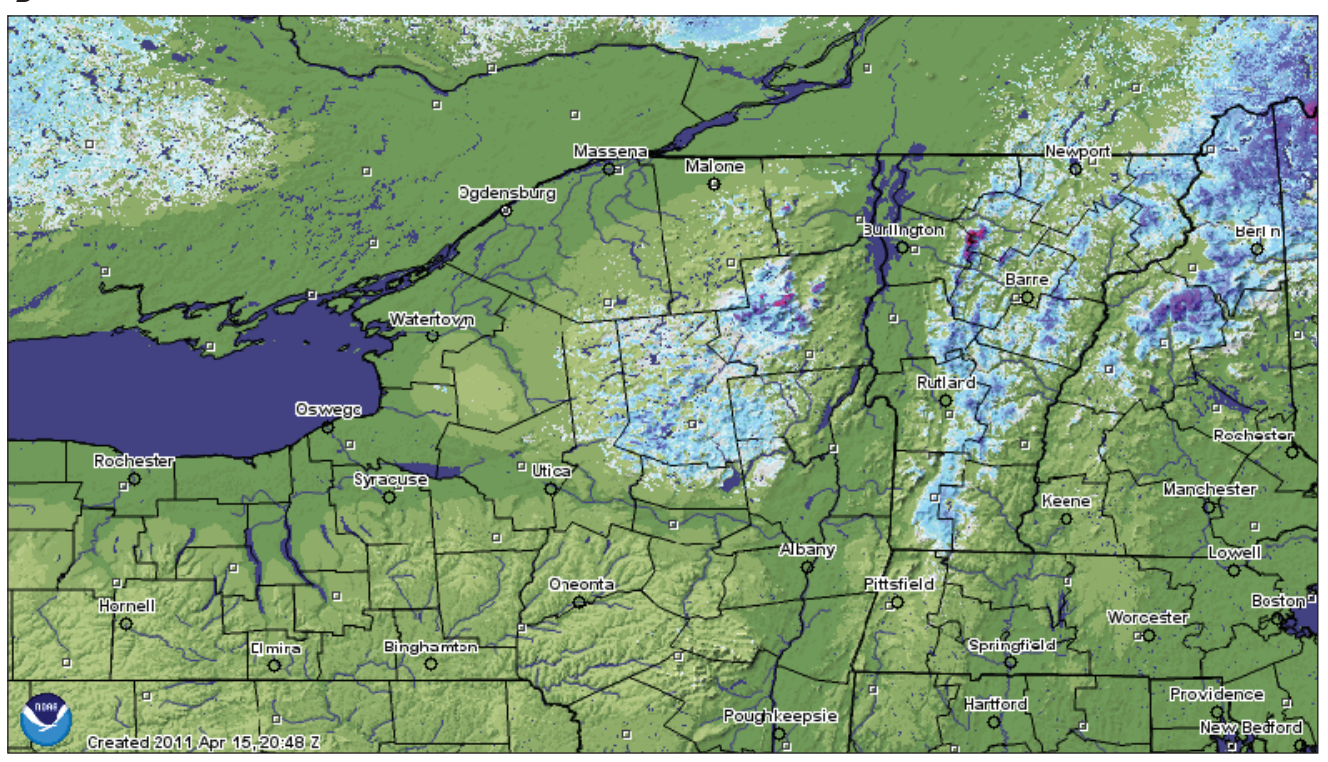

Not Estimated

\section{Elevation in feet}
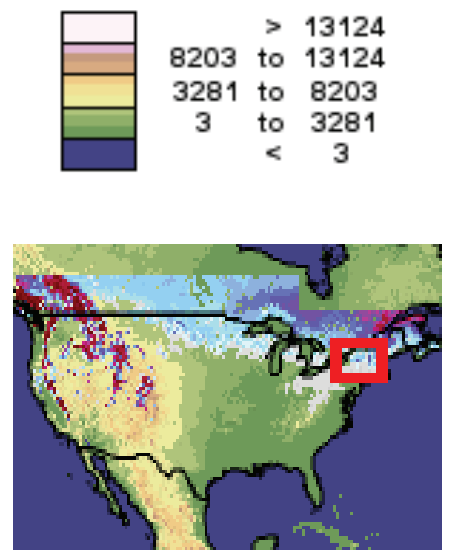

http://www.nohrsc.noaa.gov/interactive/html/map.html

Figure 3. Water equivalent of snow on $A$, April 1, B, April 15, C, April 26, and D, April 29, 2011, in New York and surrounding areas. (National Oceanic and Atmospheric Administration, 2011l; >, greater than; <, less than) 
C

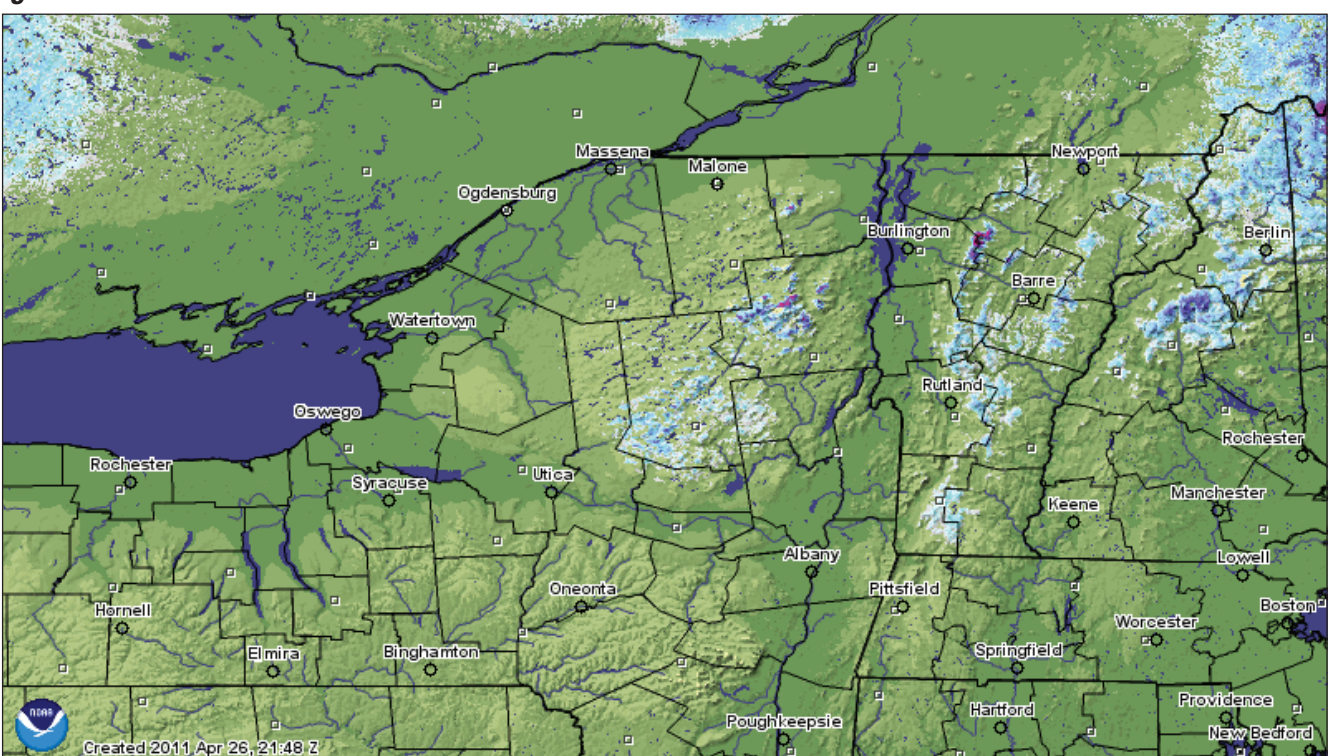

D

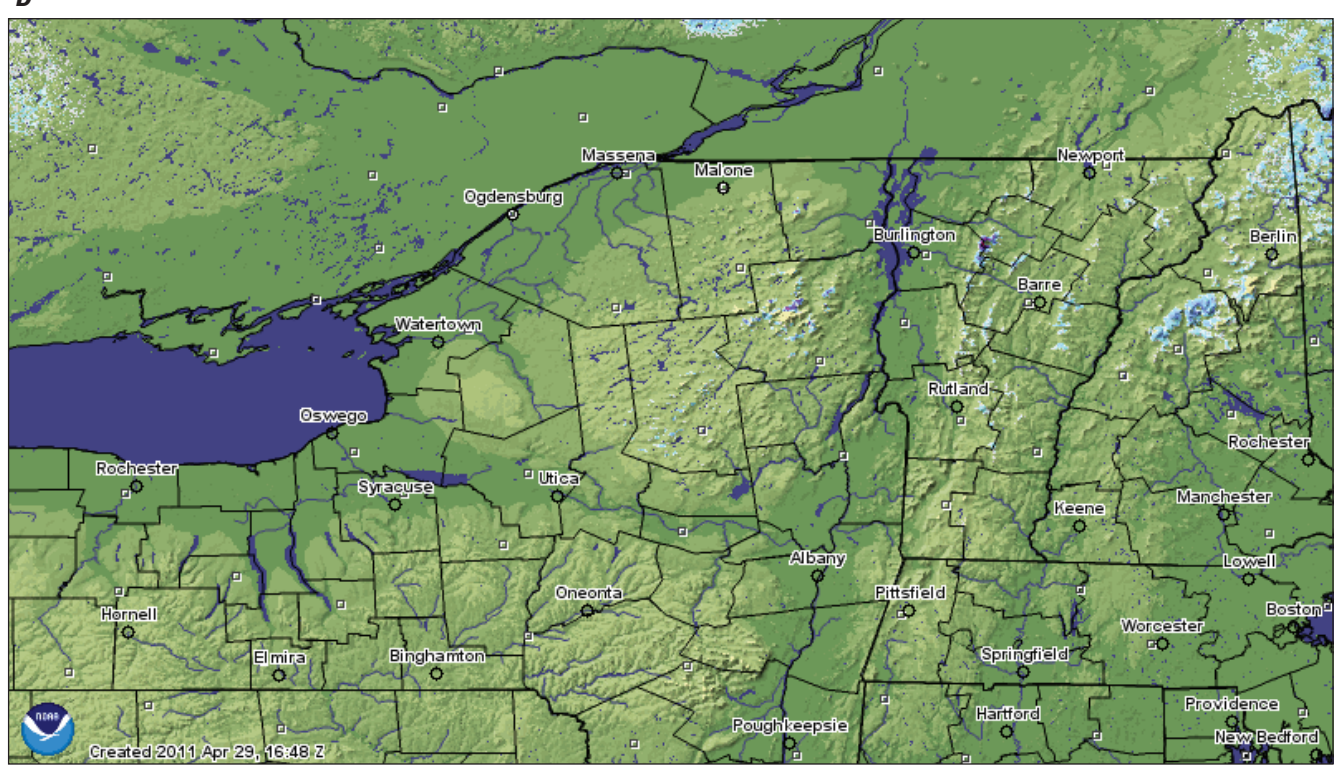

http://www.nohrsc.noaa.gov/interactive/html/map.html
Inches of water equivalent

\begin{tabular}{|ccc|}
\hline & $>$ & 30 \\
20 & to & 30 \\
18 & to & 20 \\
16 & to & 18 \\
14 & to & 16 \\
12 & to & 14 \\
10 & to & 12 \\
\hline 8 & to & 10 \\
6 & to & 8 \\
\hline 4 & to & 6 \\
2 & to & 4 \\
1 & to & 2 \\
\hline trace to & 1
\end{tabular}

Not Estimated

\section{Elevation in feet}
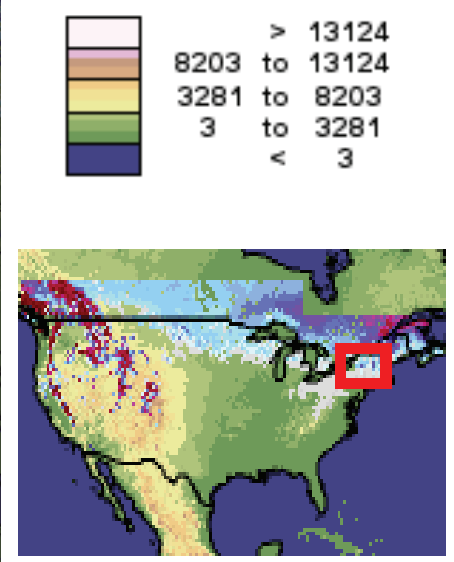

Figure 3. Water equivalent of snow on $A$, April 1, B, April 15, C, April 26, and D, April 29, 2011, in New York and surrounding areas. (National Oceanic and Atmospheric Administration, 2011l; >, greater than; <, less than)—Continued 


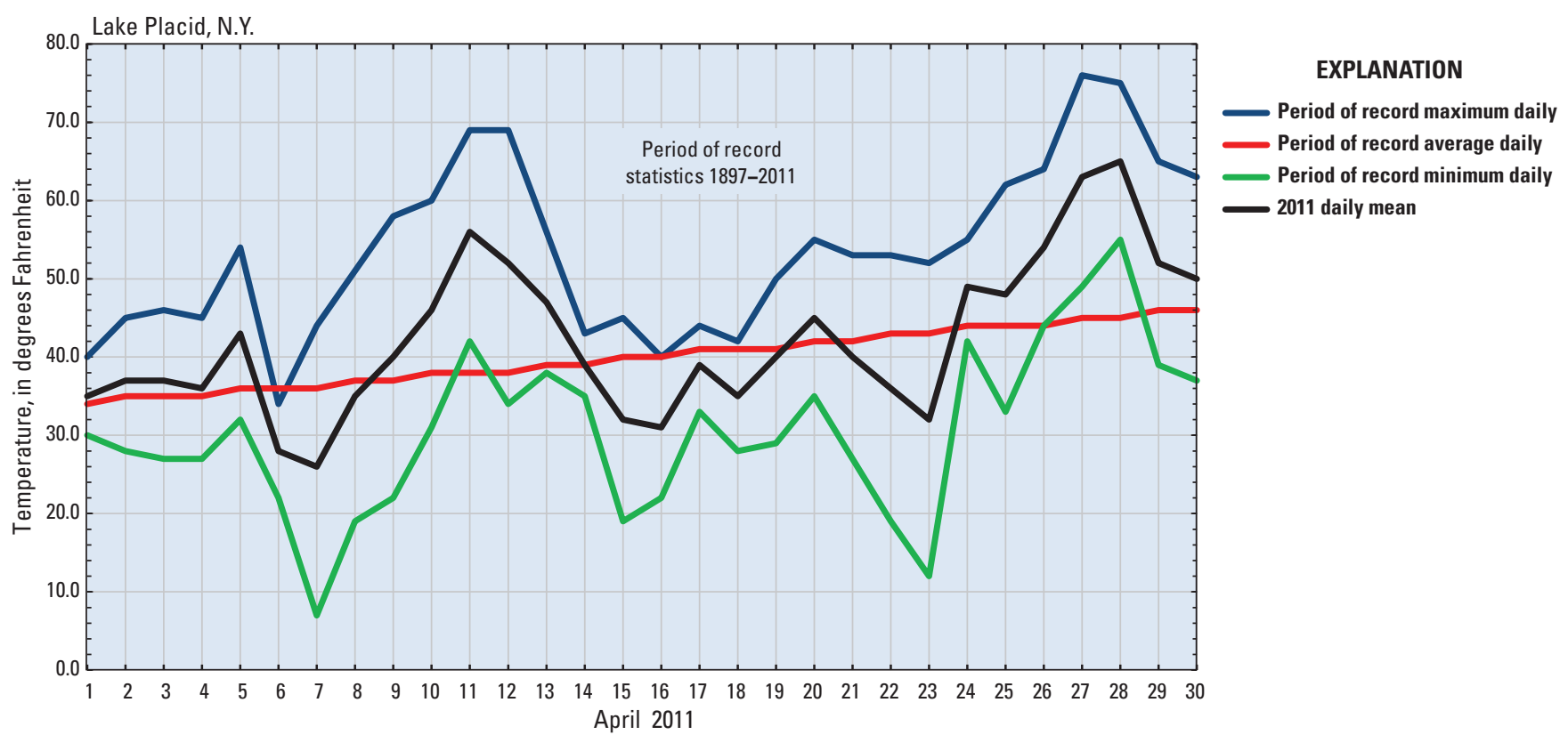

Figure 4. Daily-temperature data at Lake Placid, New York, during April 2011. (National Oceanic and Atmospheric Administration, 2011d)

\section{Flooding}

The warm and wet spring of 2011 resulted in record flooding at 17 active streamgages and 5 active lake/reservoir gages during late April to early May (table 4 and fig. 10). Most of the record flows and stages were in northern New York with a few new records set in the central region of the State. Nearrecord peaks were set at several other streamgages and lake/ reservoir sites (table 4 and fig. 10). Many of the maximum flows for the period of record were on regulated streams, indicating that runoff from snowmelt earlier in the month was depleting available storage by the time the heavy rains fell at the end of April. Eleven peak discharges during late April to early May equaled or exceeded the 1-percent AEP (100-year) discharge (table 4). Map numbers (fig. 10) and associated USGS streamgage numbers and names (table 4) are given in appendix 1 at the end of the report. The relation between the two statistical flood-frequency terminologies is shown in appendix 1 and in table 5 .

\section{Flood Discharge and Frequency}

The most extreme flooding during April-May 2011 occurred on some streams in the upper Hudson and Raquette River Basins, where recorded peak discharges had AEP values less than 0.5 percent (recurrence intervals greater than 200 years). The frequencies of the April-May floods at selected streamgages are shown in a color-coded AEP map of the associated streamgage drainage basins across the State on figure 11. A full-size view of the map on figure 11 can be accessed by the computer link at the end of the figure caption. The most expansive and extreme flooding was in and around the Adirondack Mountains area of northern New York and extended southwest to the Finger Lakes region of westcentral New York. Flooding decreased substantially beyond these areas of the State. Record floods were documented at 17 streamgages and 5 lake/reservoir gages with 11 of them having AEP values less than or equal to 1 percent (recurrence intervals greater than or equal to 100 years).

Peak discharges for 50 selected streamgages where the April-May 2011 flood was the maximum for the year, plotted as a function of drainage area (fig. 12), indicate that the spring 2011 peaks were near or above the previous peak discharge of record and the 1-percent AEP (100-year) discharge at several sites. Streamgage numbers shown on figure 12 are plotted at their respective drainage area only for sites with peak discharges exceeding the 1-percent AEP (100-year) flow. Figure 12 also indicates that the April-May flooding was appreciable for streams of all drainage-basin sizes in the affected area. The general relation of peak discharge and drainage area for streamgages on unregulated streams in the affected area is indicated by the solid line plotted on figure 12 . 

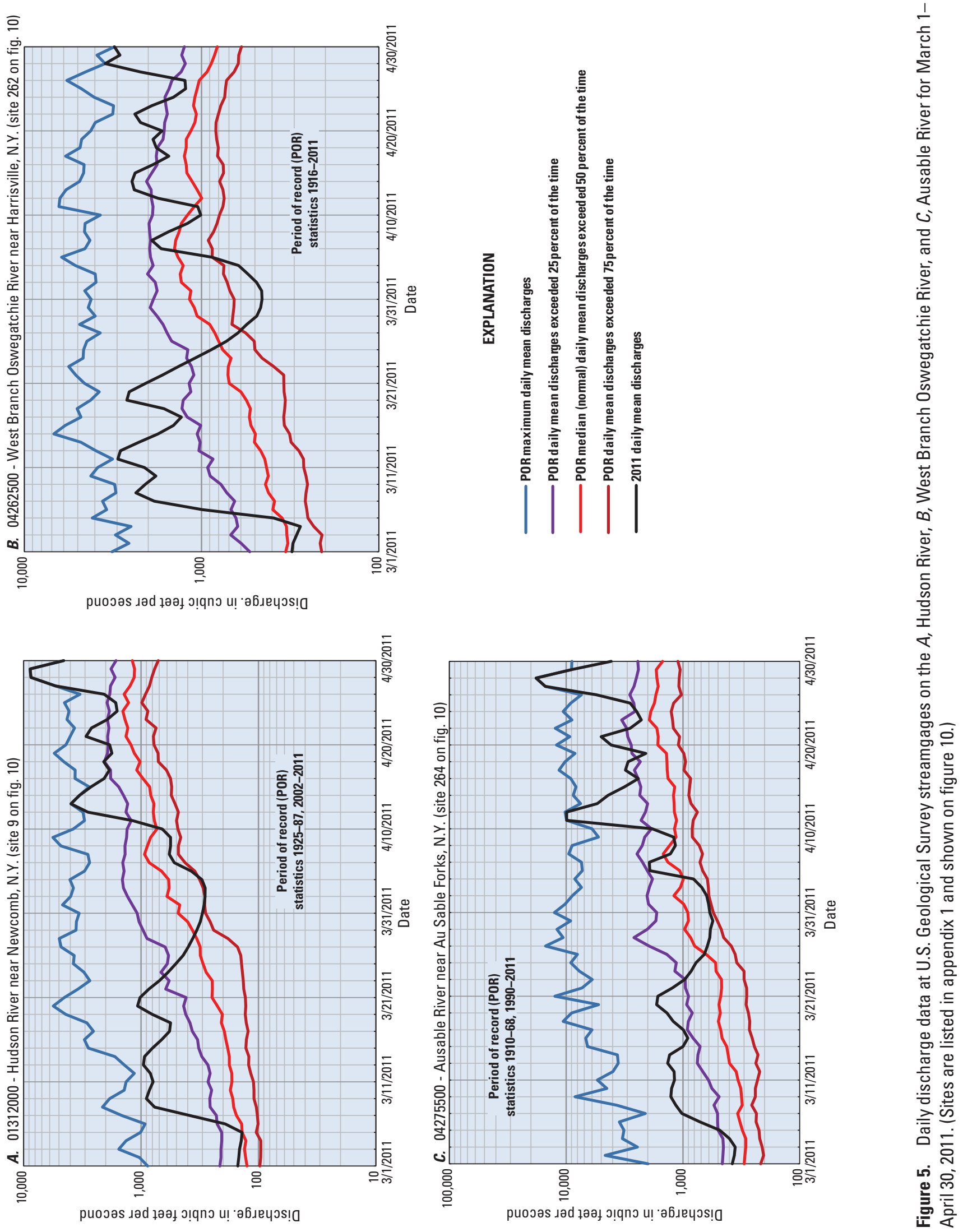


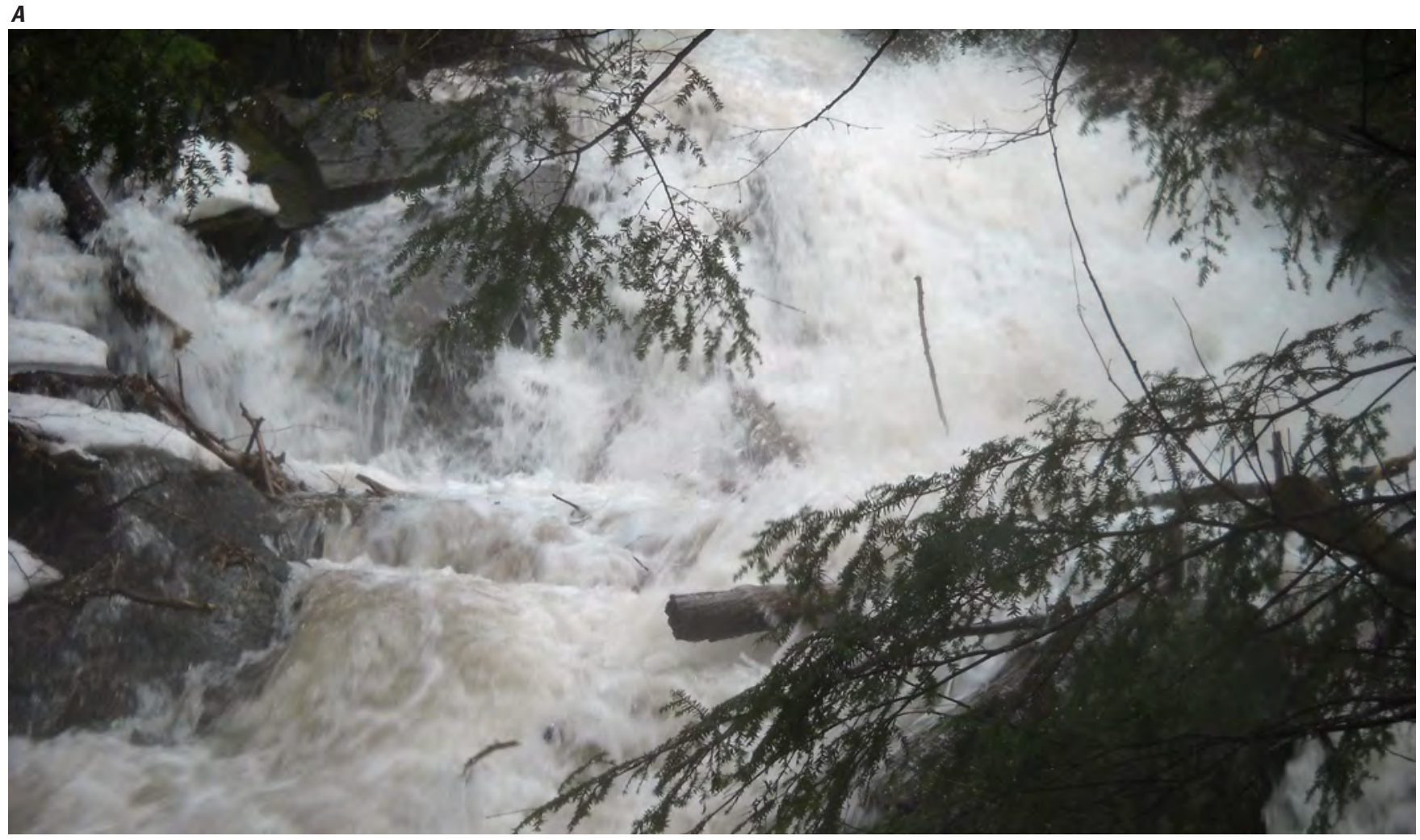

$B$

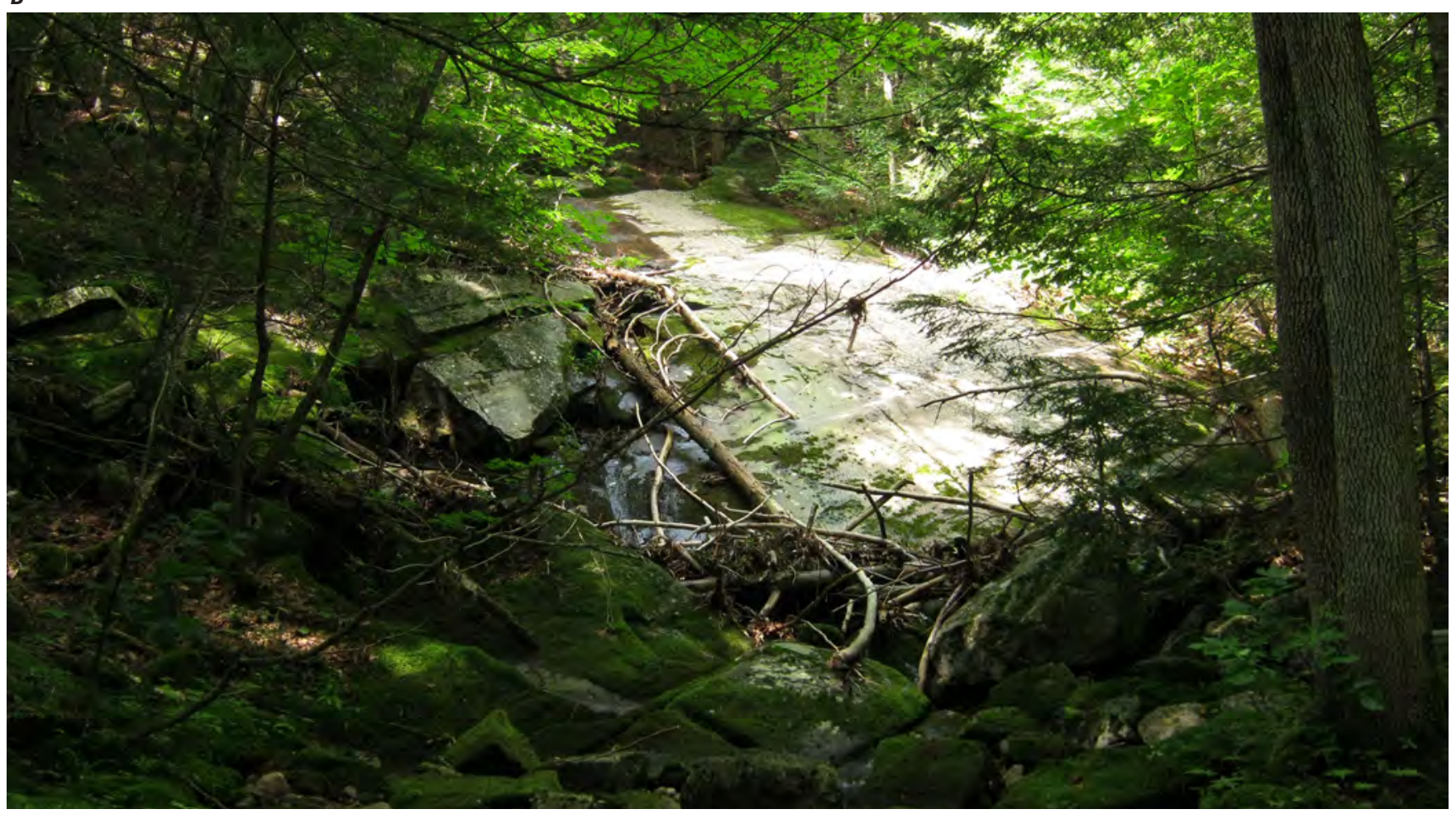

Figure 6. A small tributary to the upper Hudson River showing flow conditions prior to the storms in $A$, April 2011, and $B$, August 2011. (Photographs courtesy of Greg Lawrence, U.S. Geological Survey) 
A

Northeast RFC Taunton, MA: 4/26/2011 1-Day Observed Precipitation

Valid at 4/26/2011 1200 UTC- Created 10/14/12 21:11 UTC

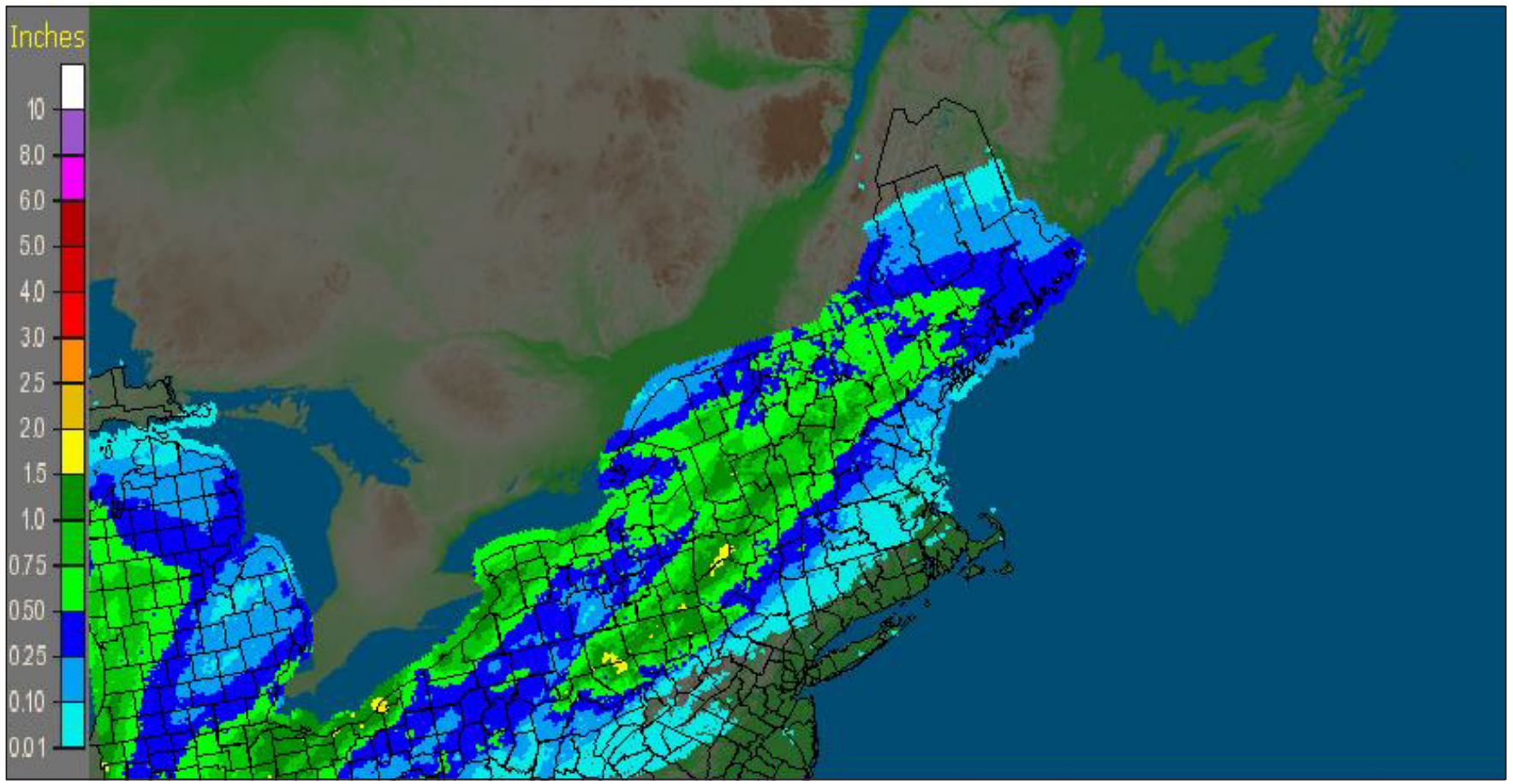

$B$

Northeast RFC Taunton, MA: 4/27/2011 1-Day Observed Precipitation

Valid at 4/27/2011 1200 UTC-Created 10/14/12 21:13 UTC

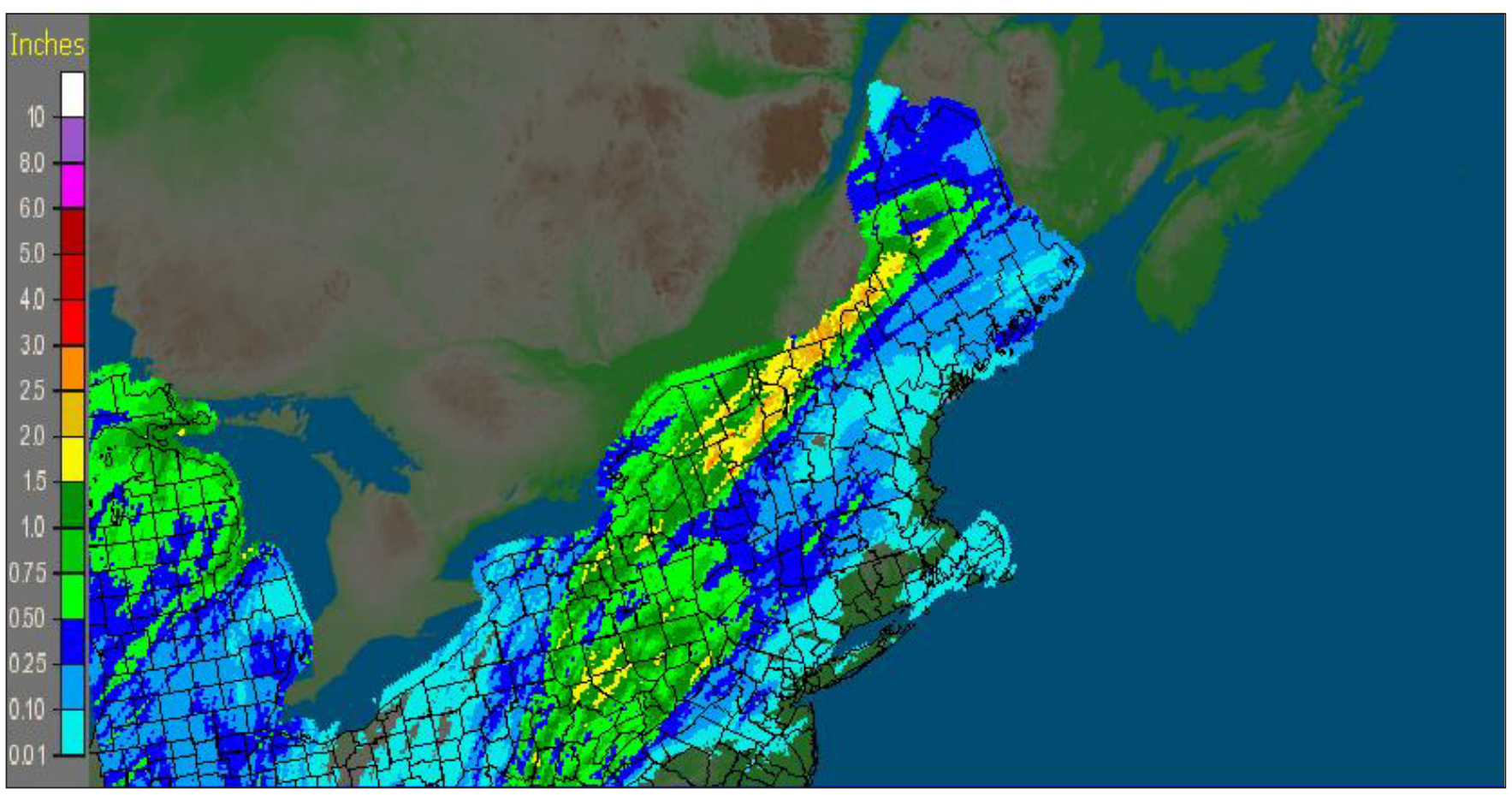

Figure 7. Rainfall amounts for each day during the storm of $A$, April 26, $B$, April 27, $C$, April 28, and D, April 29, 2011, for New York and surrounding areas. (From National Oceanic and Atmospheric Administration, 2011m) 
C

Northeast RFC Taunton. MA: 4/28/2011 1-Day Observed Precipitation

Valid at 4/28/2011 1200 UTC- Created 10/14/12 21:15 UTC

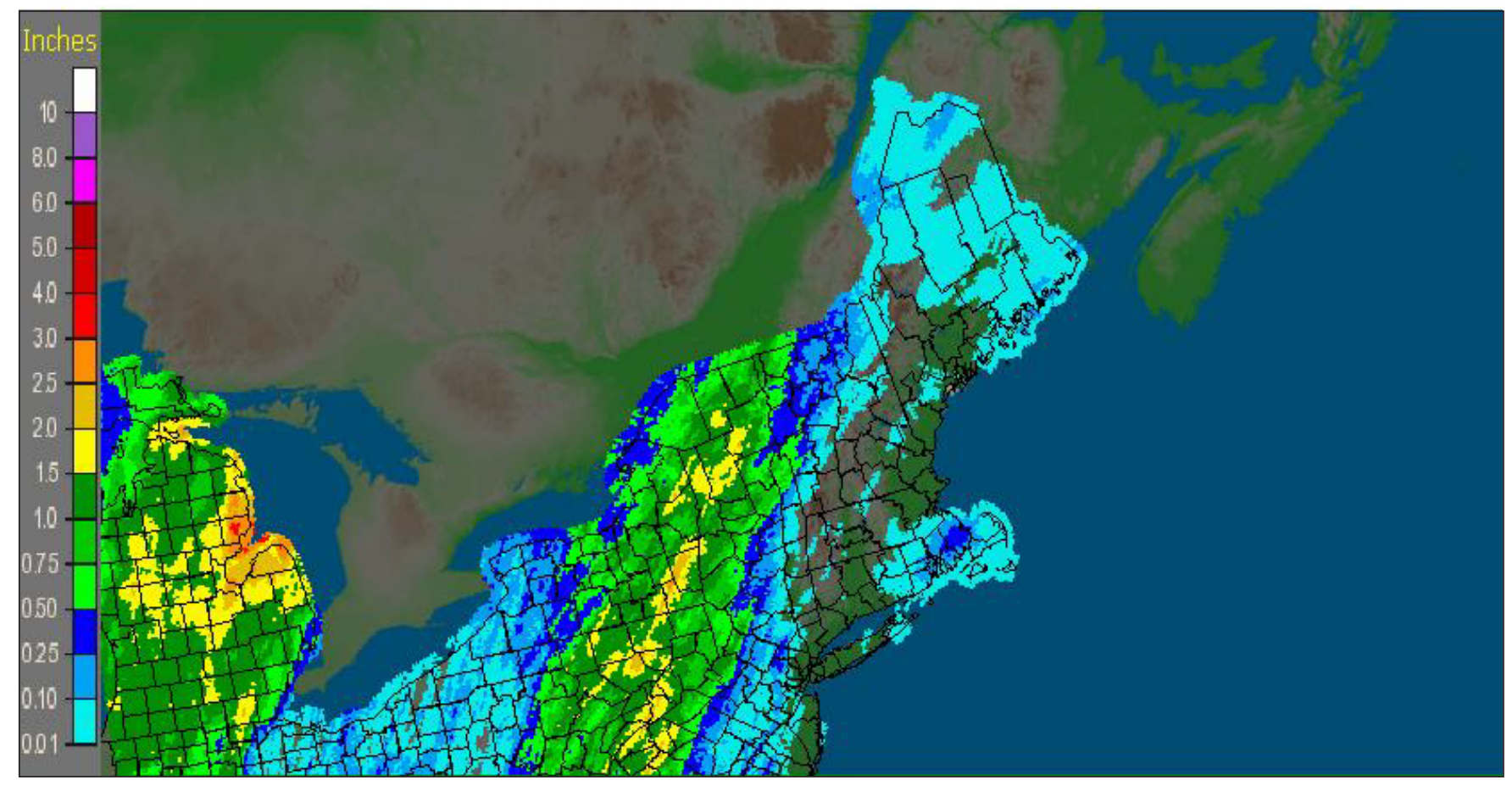

\section{D}

Northeast RFC Taunton. MA: 4/29/2011 1-Day Observed Precipitation Valid at 4/29/2011 1200 UTC- Created 10/14/12 21:18 UTC

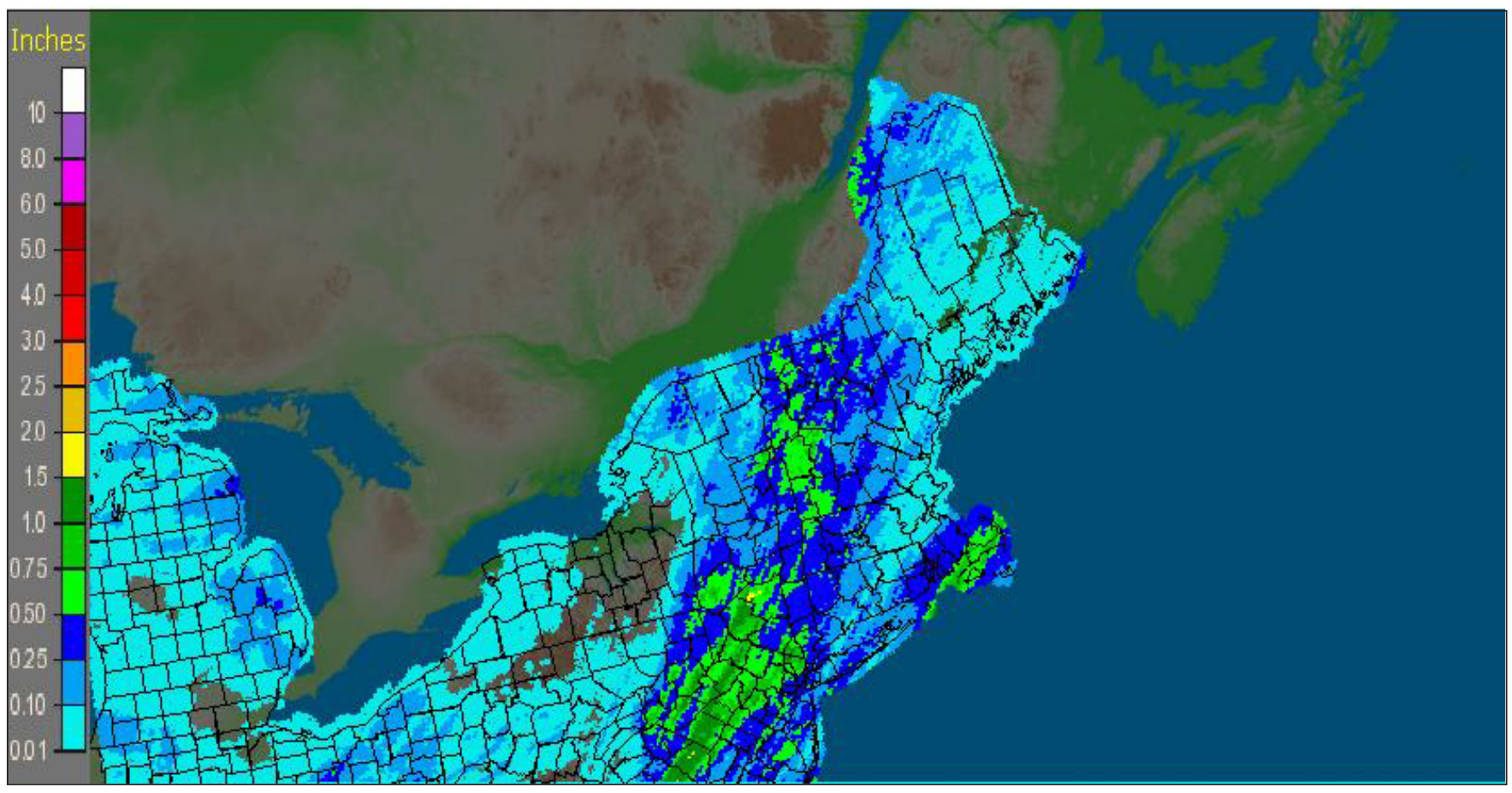

Figure 7. Rainfall amounts for each day during the storm of $A$, April 26, B, April 27, C, April 28, and D, April 29, 2011, for New York and surrounding areas. (From National Oceanic and Atmospheric Administration, 2011m)—Continued 


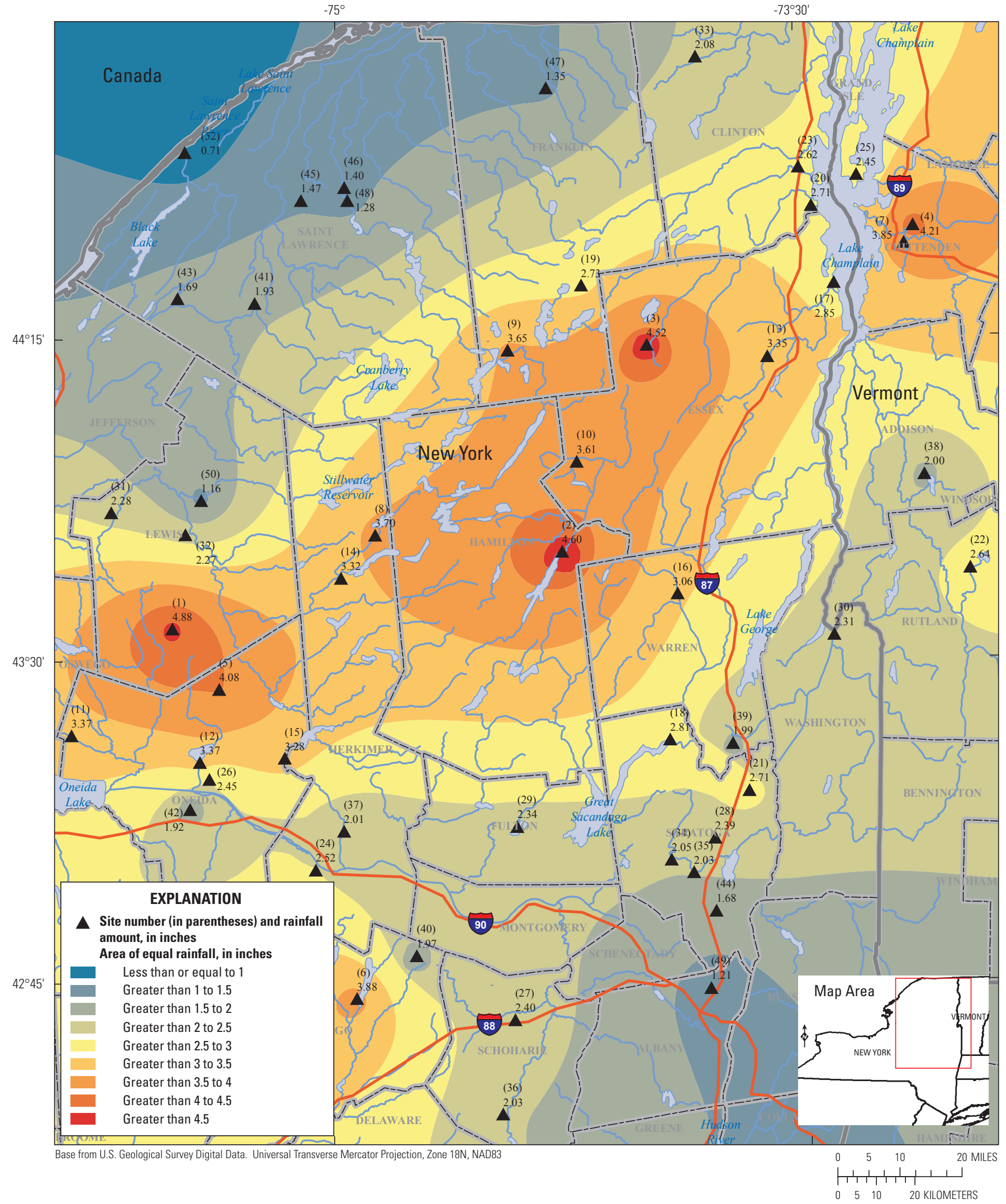

Figure 8. Rainfall totals for the storm of April 26-29, 2011, in New York and surrounding areas. (From National Oceanic and Atmospheric Administration, 2011a,d; Sites and data are listed in table 2.) 
Table 2. Rainfall for the storm of April 26-29, 2011, at selected locations in New York and surrounding areas.

[Data provided by the National Oceanic and Atmospheric Administration (2011a,d); N, north; S, south; E, east; W, west; locations are shown on figure 8]

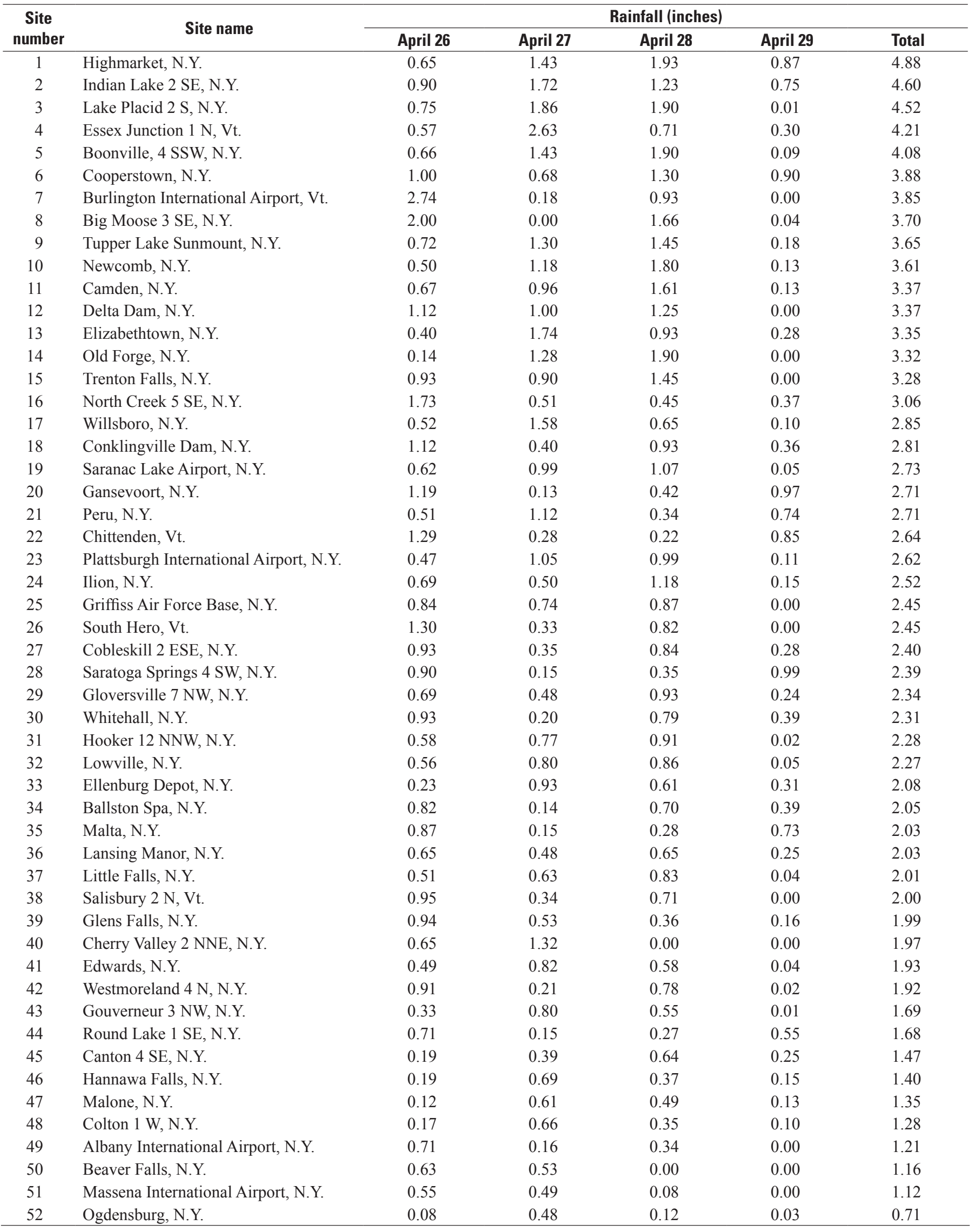




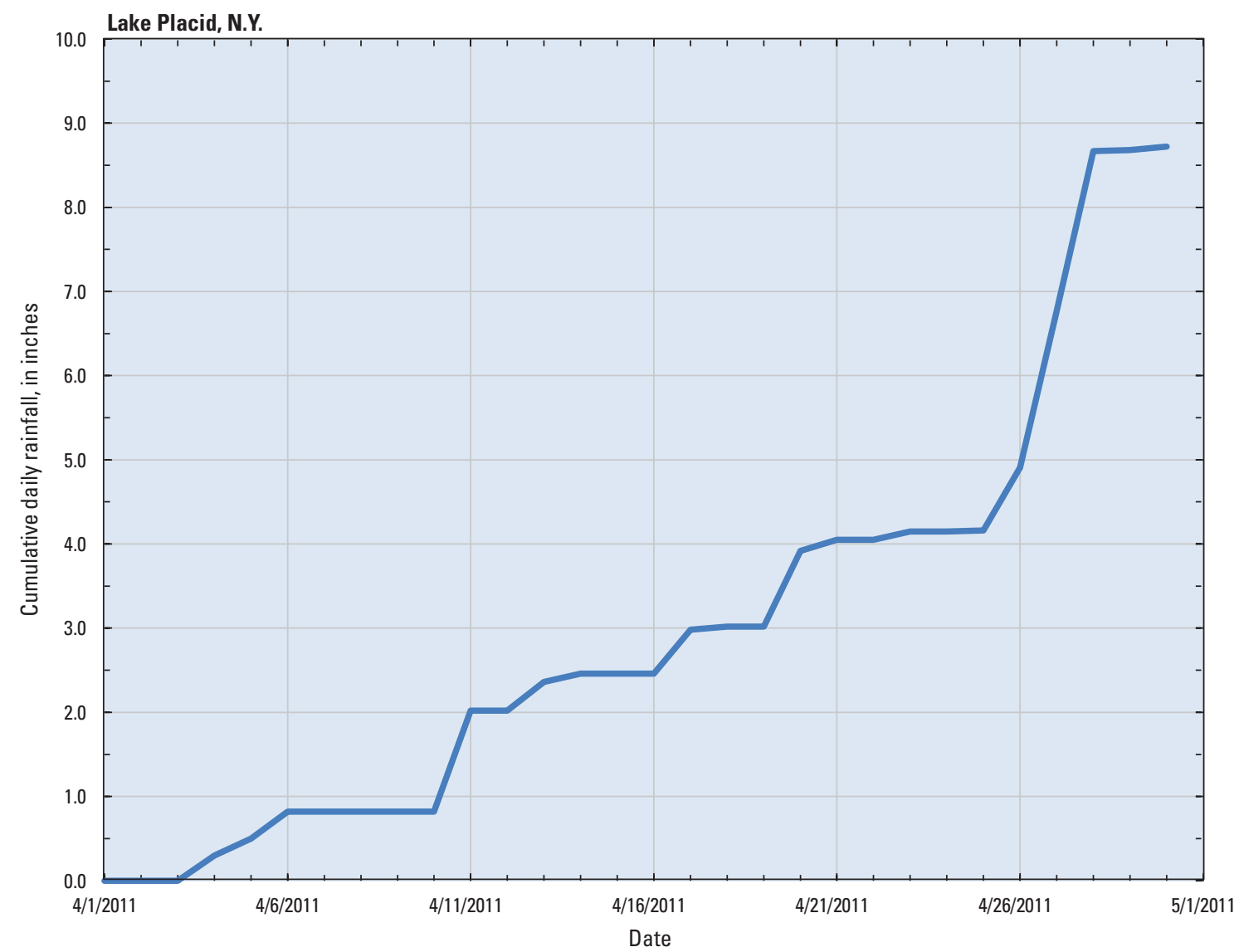

Figure 9. Cumulative daily rainfall during April 1-30, 2011, recorded at Lake Placid, New York. (Site 3 in table 2 and figure 8)

Table 3. Rainfall frequencies for storms of 1-, 2-, and 4-day durations at selected locations in New York.

[April 26-29, 2011, maximum n-day rainfall totals for each site are shown in red. Data from the Northeast Regional Climate Center (2010); locations are shown on figure 8]

\begin{tabular}{|c|c|c|c|c|c|c|c|c|c|c|c|c|c|}
\hline $\begin{array}{c}\text { Site } \\
\text { num- } \\
\text { ber }\end{array}$ & Site name & County & $\begin{array}{l}\text { Recur- } \\
\text { rence } \\
\text { interval } \\
\text { (years) }\end{array}$ & \multicolumn{3}{|c|}{$\begin{array}{l}\text { Rainfall (inches) for } \\
\text { selected duration }\end{array}$} & $\begin{array}{c}\text { Site } \\
\text { num- } \\
\text { ber }\end{array}$ & Site name & County & $\begin{array}{l}\text { Recur- } \\
\text { rence } \\
\text { interval } \\
\text { (years) }\end{array}$ & \multicolumn{3}{|c|}{$\begin{array}{l}\text { Rainfall (inches) for } \\
\text { selected duration }\end{array}$} \\
\hline \multirow{7}{*}{3} & & & 2 & 2.22 & 2.49 & 2.81 & & & & 25 & 3.86 & 4.24 & 4.63 \\
\hline & & & 5 & 2.71 & 3.02 & 3.37 & & & & 50 & 4.50 & 4.90 & 5.31 \\
\hline & & & 10 & 3.16 & 3.49 & 3.86 & & & & 100 & 5.25 & 5.68 & 6.09 \\
\hline & & & 50 & 4.50 & 4.90 & 5.31 & 9 & Tupper Lake & Franklin & & 1.45 & & \\
\hline & & & 100 & 5.25 & 5.68 & 6.09 & & & & 2 & 2.22 & 2.49 & 2.81 \\
\hline & & & 200 & 6.13 & 6.57 & 6.99 & & & & & & 2.75 & 3.65 \\
\hline & & & 500 & 7.52 & 7.98 & 8.39 & & & & 5 & 2.71 & 3.02 & 3.37 \\
\hline \multirow{2}{*}{2} & & & 10 & 3.16 & 3.49 & 3.86 & & & & 200 & 6.13 & 6.57 & 6.99 \\
\hline & & & & & & & & & & 500 & 7.52 & 7.98 & 8.39 \\
\hline
\end{tabular}


Floods of 2011 in New York

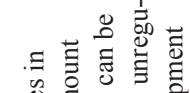

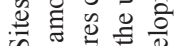

के

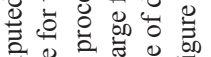

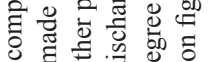

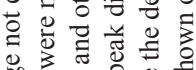

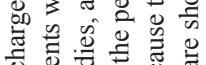

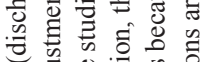

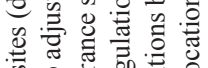

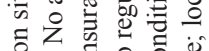

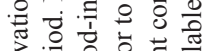

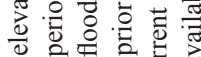

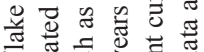

可

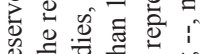

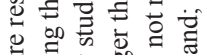

可言总

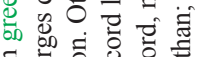

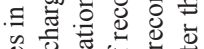

过

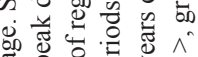

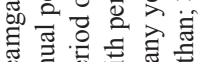

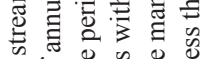

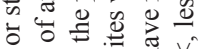

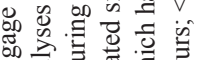

西要专

न

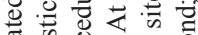

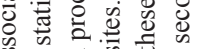

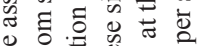

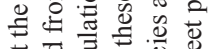

त वे $\overline{\sigma_{0}}=$

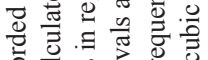

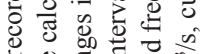

过志方

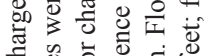

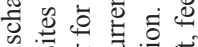

क क t

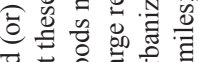

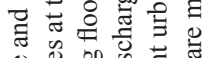

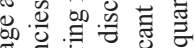

要 要

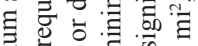

表

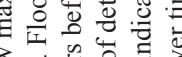

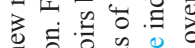

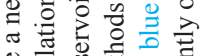

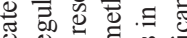

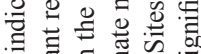

ठ

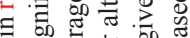

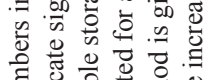

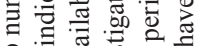

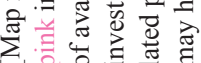

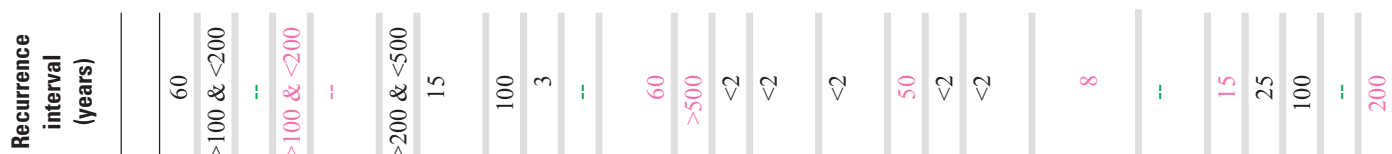

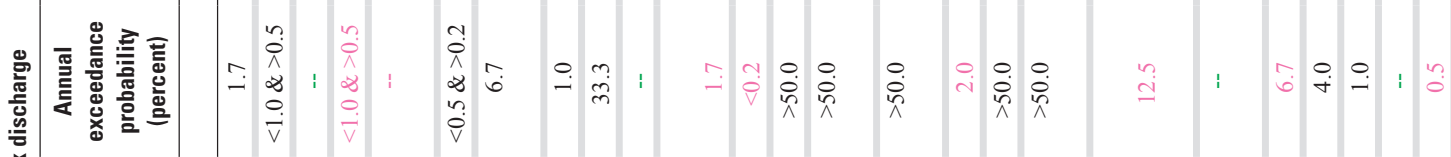

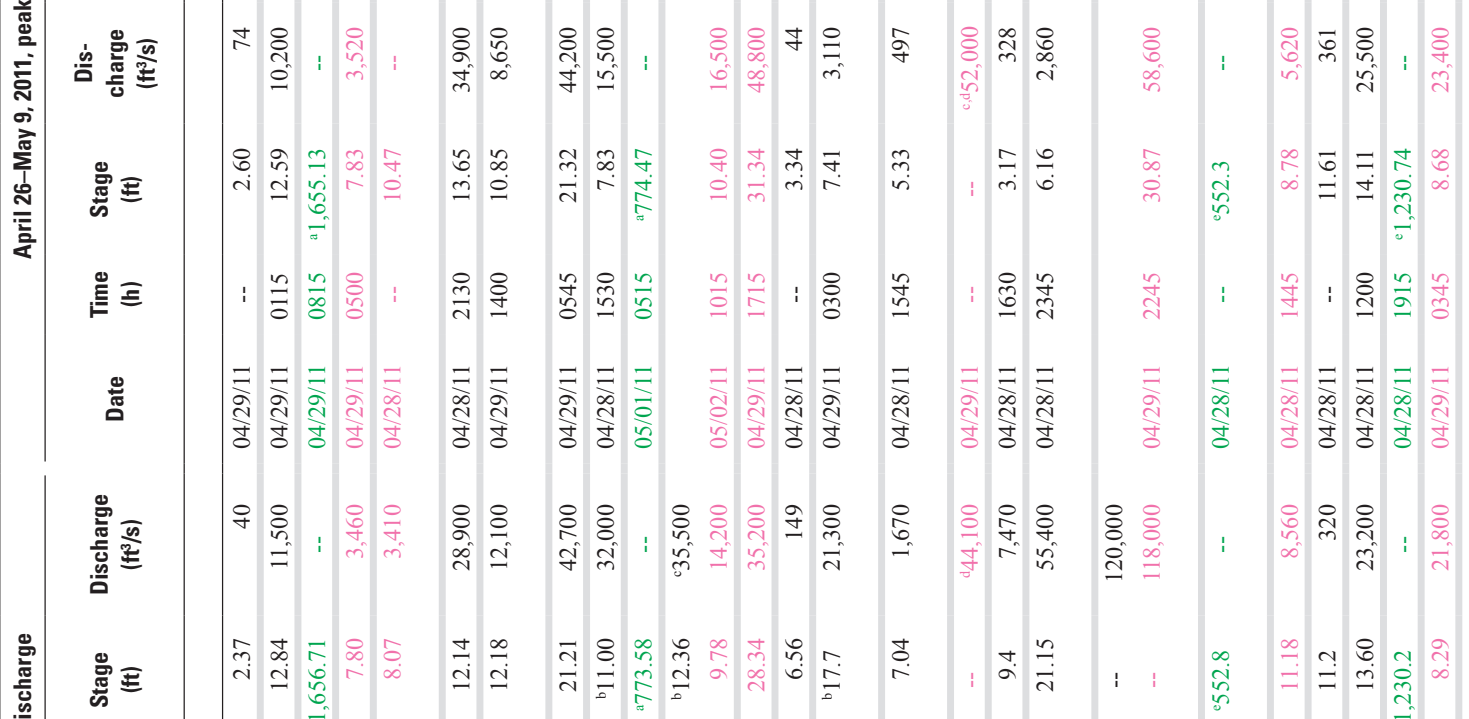

$\cdot \frac{\bar{m}}{\mathrm{c}}$

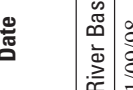

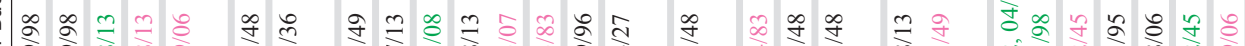

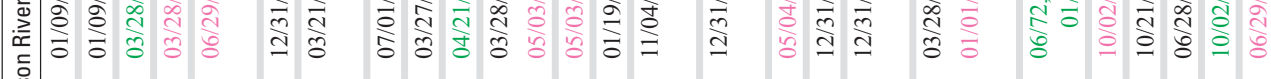
흔 $\quad \begin{gathered}0 \\ \stackrel{0}{0}\end{gathered}$

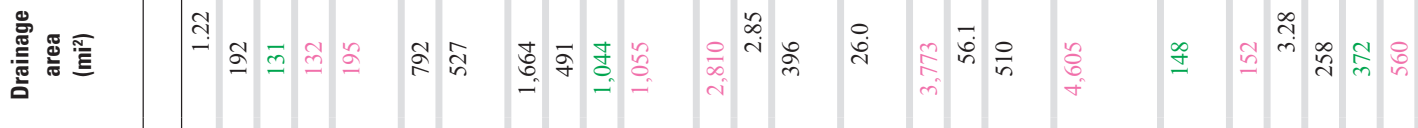

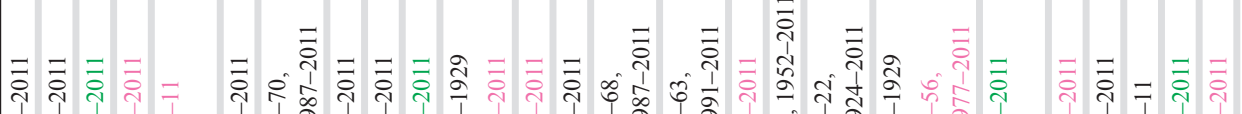

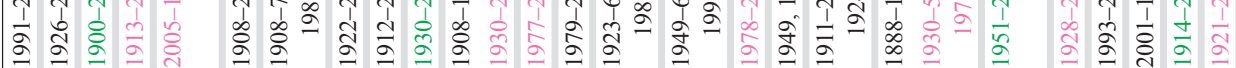
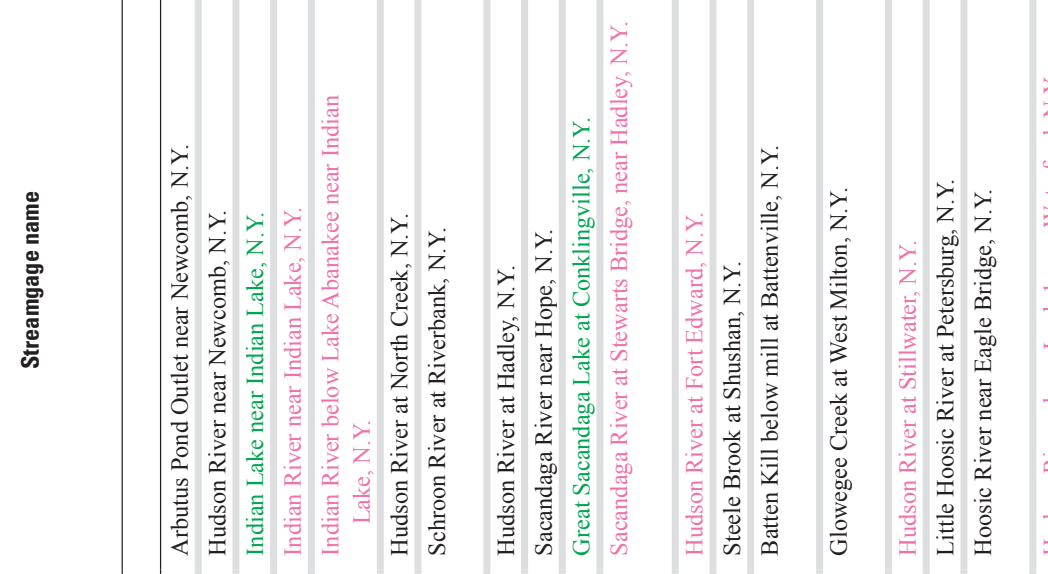

离 㞼

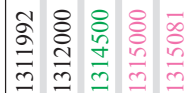

号

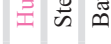

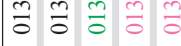

商

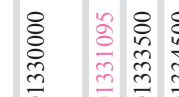

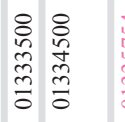

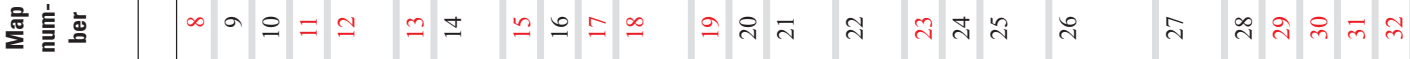




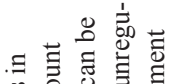

象

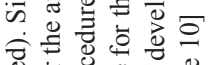

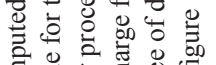

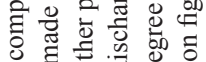

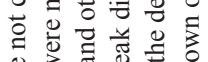

密娄

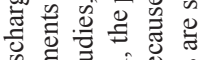

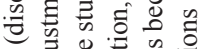

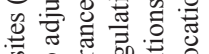

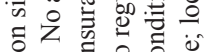

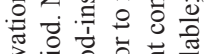

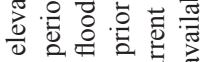

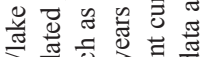

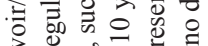

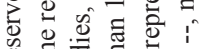

원

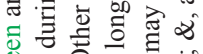

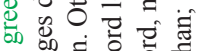

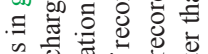

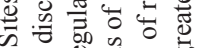

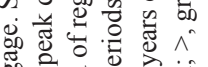

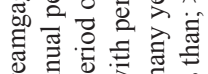

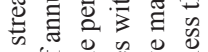

t。

品

可言焉言

匹

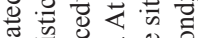

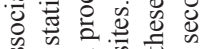

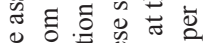

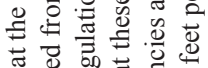

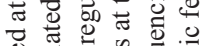

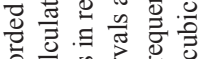

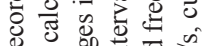

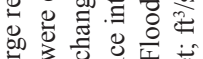

|

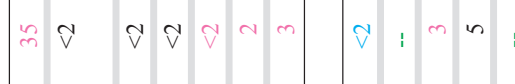

4:

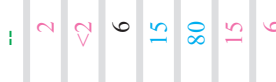

$\operatorname{Rin} \backsim$

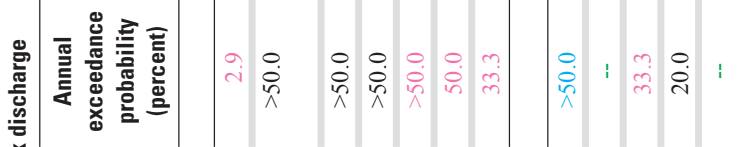

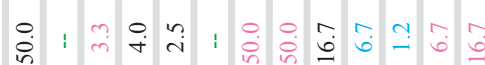

$+\stackrel{\circ}{\circ}$

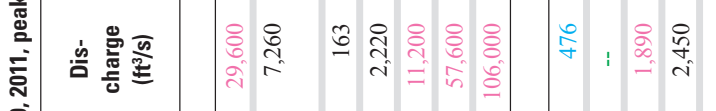

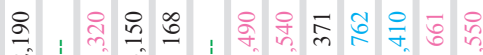

\&:

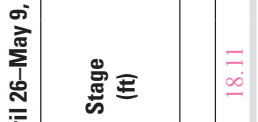

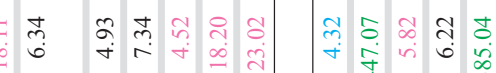

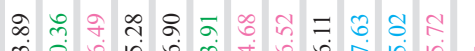

ที่ ถั ฉ.

这

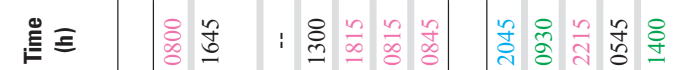

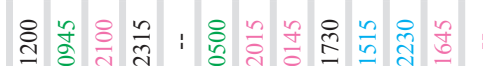

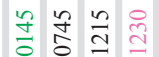

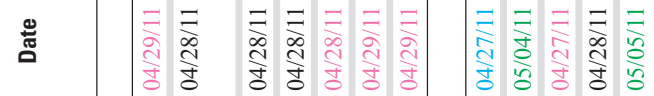

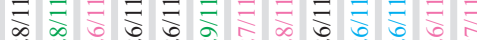

$\underset{5}{\exists} \underset{\infty}{\exists} \bar{\infty}$

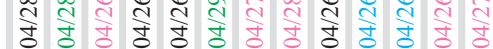

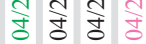

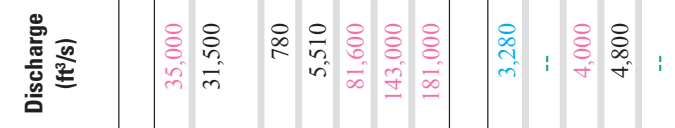

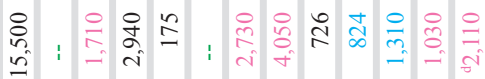

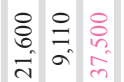

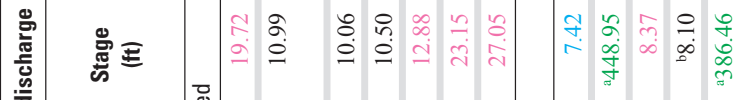

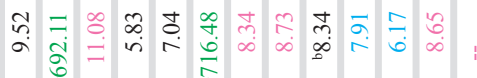

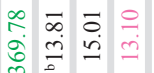

衰

竞

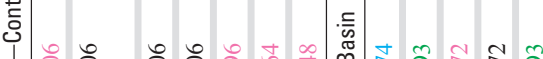

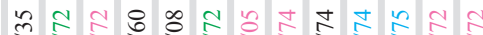

m

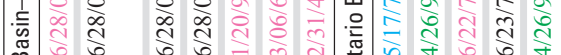

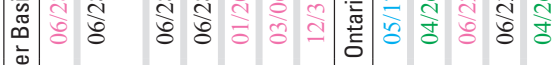

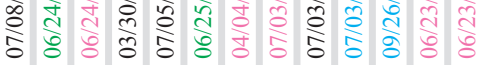

के

$\frac{1}{2}$

产

产总

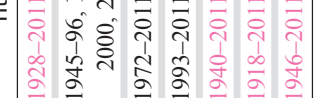

离营

学

ธิ ฐ

च $\bar{z} \bar{z}$ च

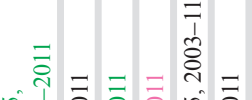

स ปิ으 ली

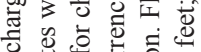

品的考

产苞药

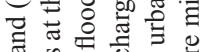

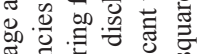

क्षै

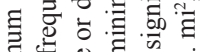

元

西 응

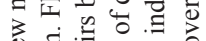

要

渮席

范

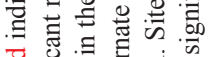

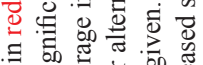

혼

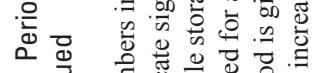

In

तु่

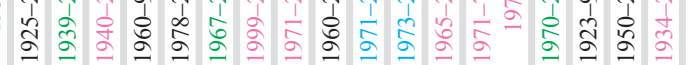

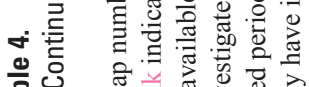

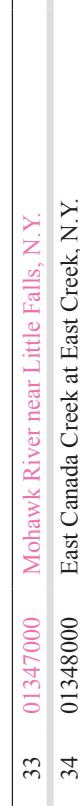

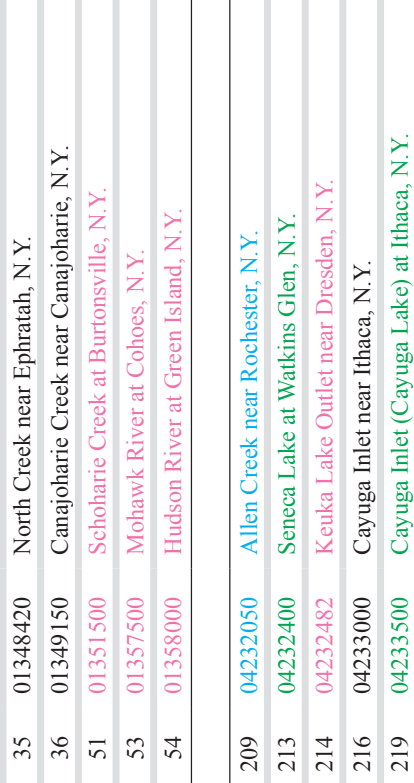

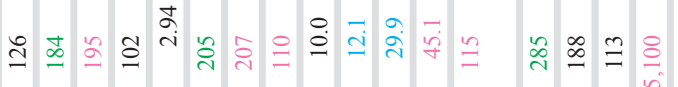
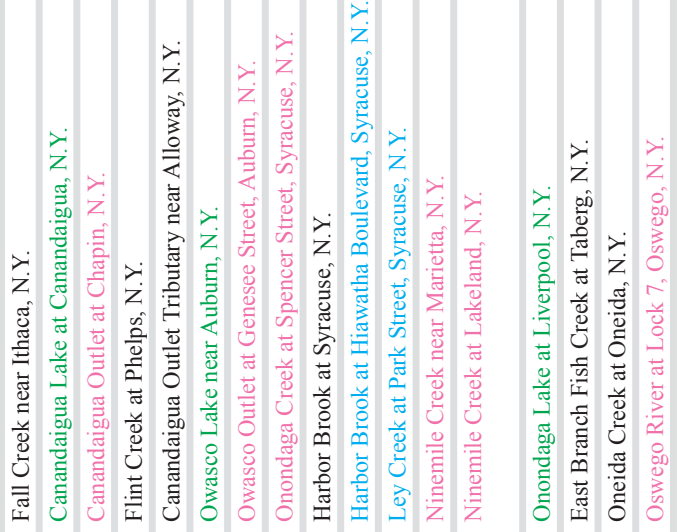

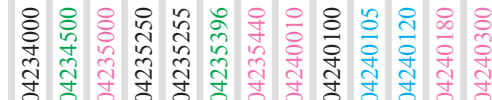

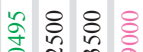

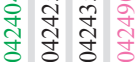

-

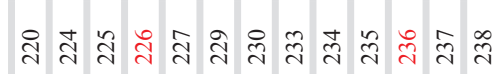

ते 孚紊 
Floods of 2011 in New York

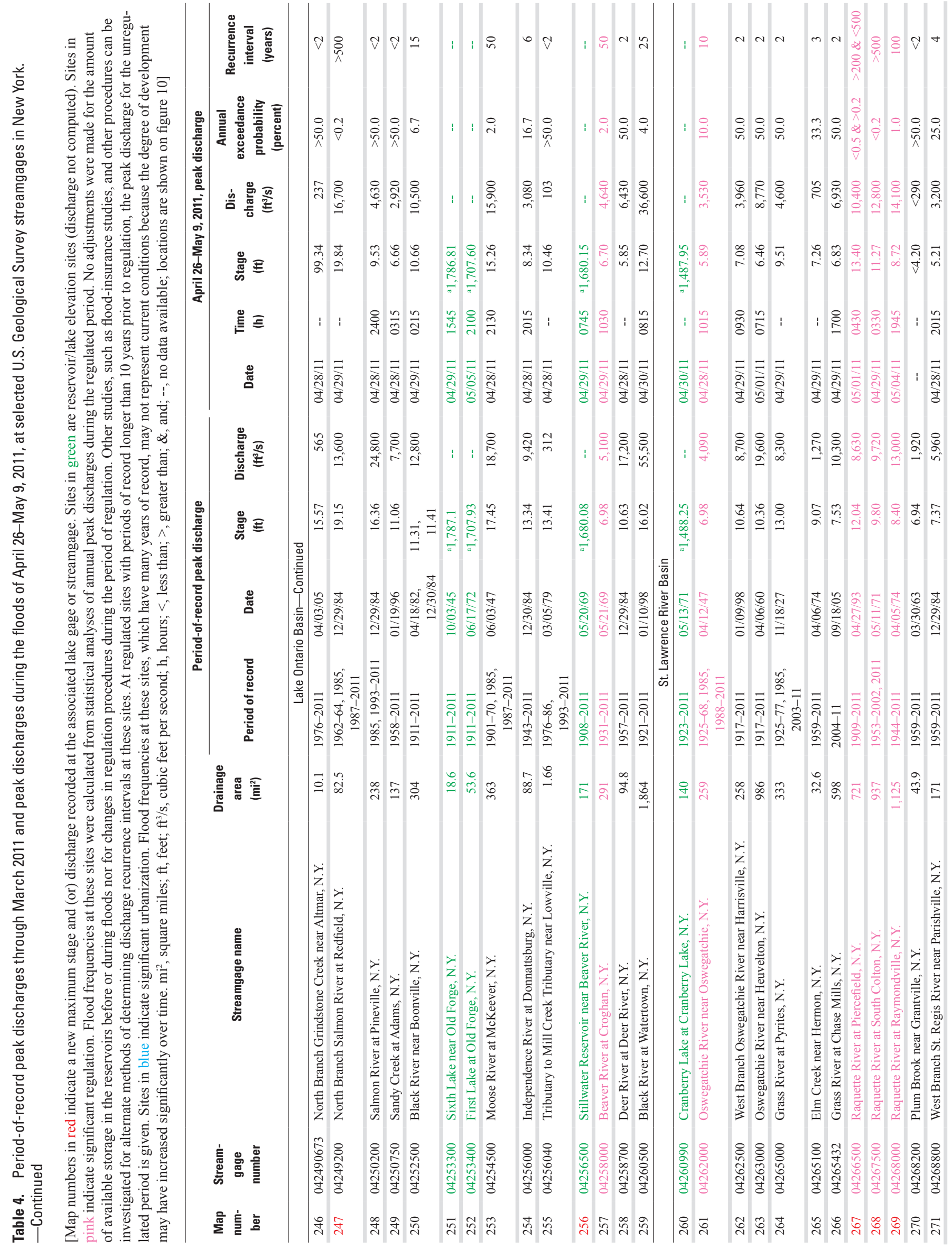


.

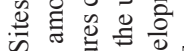

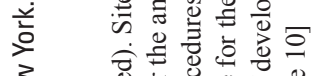

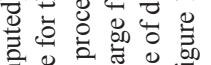

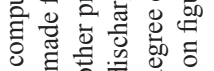

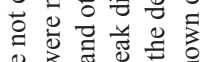

究

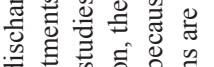

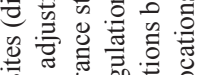

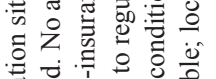

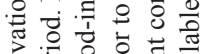

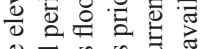

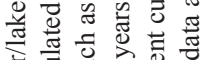

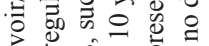

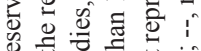

on

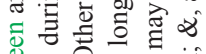

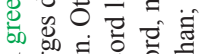

$\exists$ \#

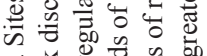

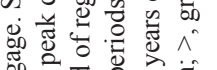

跣记

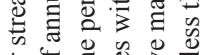

4 宁

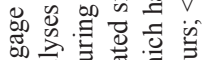

凷要言

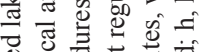

एक

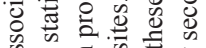

व ह

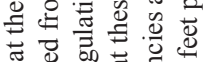

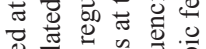

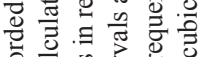

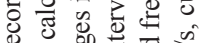

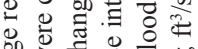

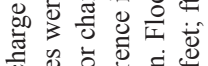

氜 훈

च记

है을

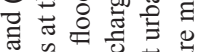

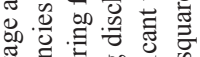

के

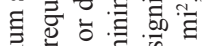

잉

界

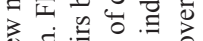

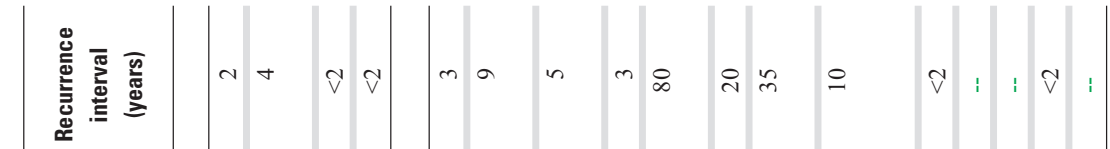

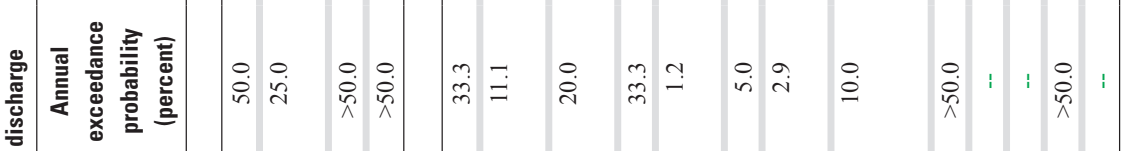

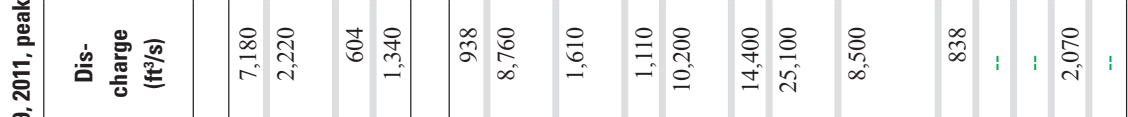

望王

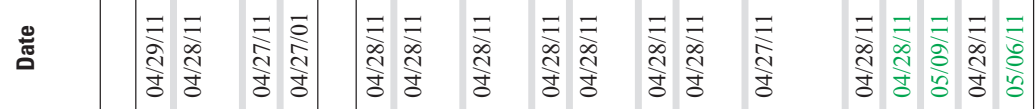

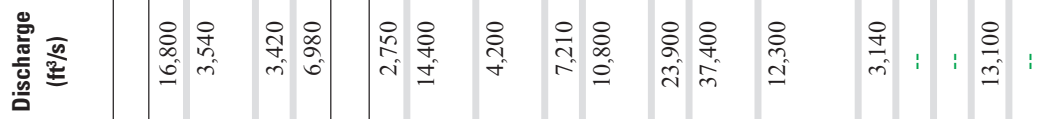

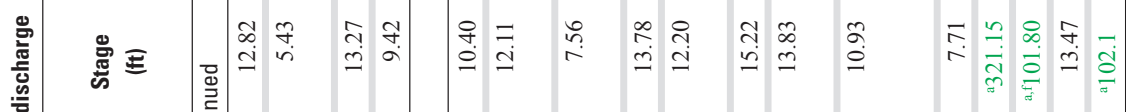

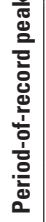

产

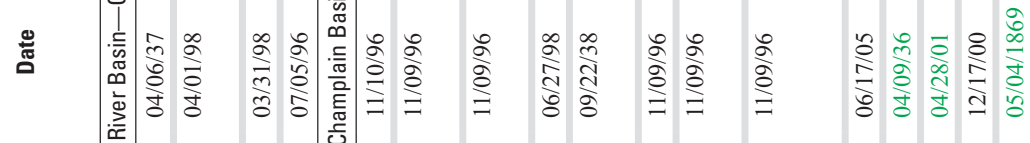

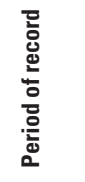

然

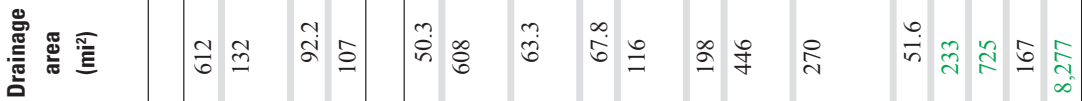

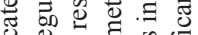

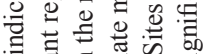

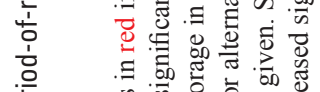

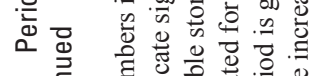

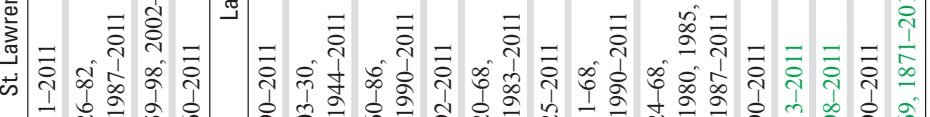

ป

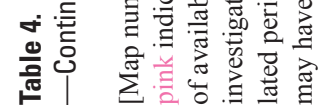
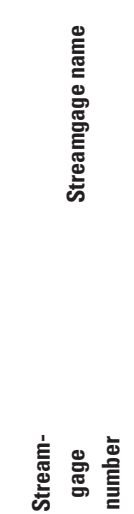

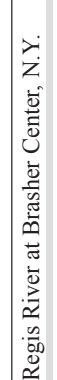

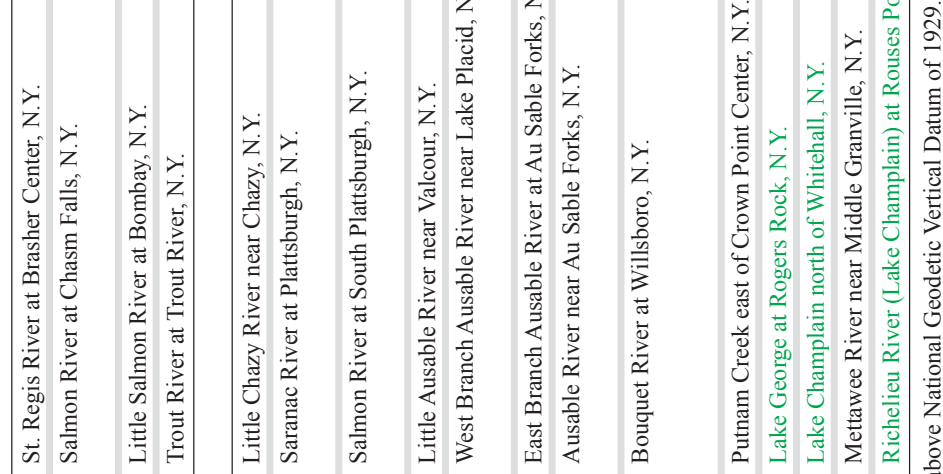

Int

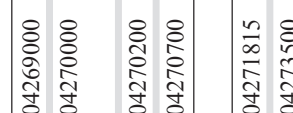

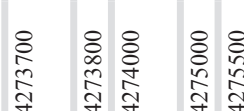

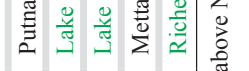

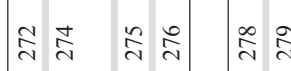

d d वे d d d

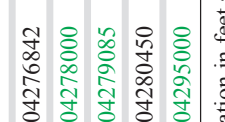

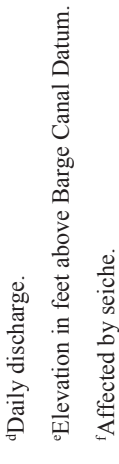




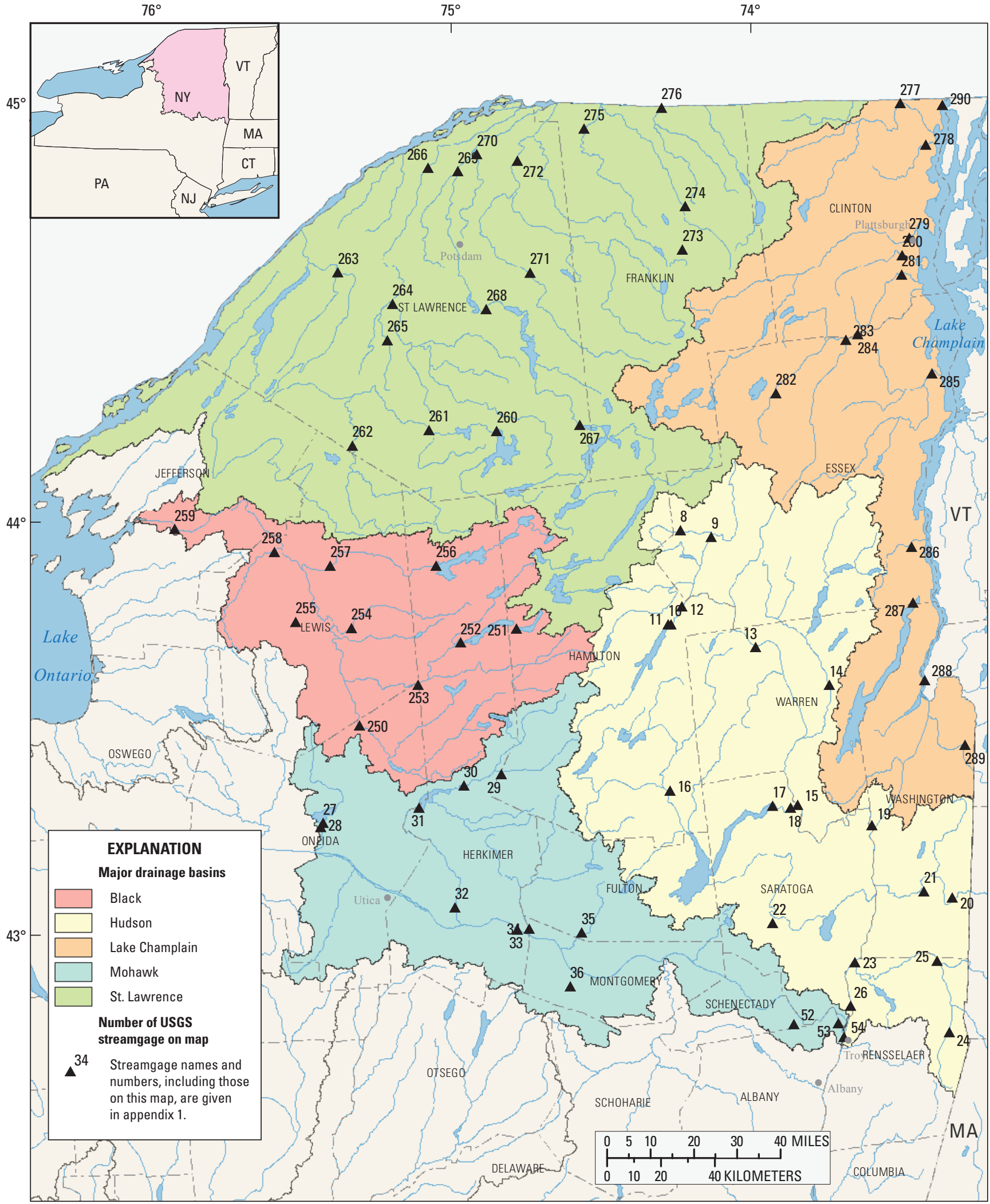

Base from the National Atlas of the United States, 1:2,000,000

Web Mercator Auxiliary Sphere projection,

World Geodetic System, 1984 datum

Figure 10. Locations of selected U.S. Geological Survey streamgages and major drainage basins in New York. 


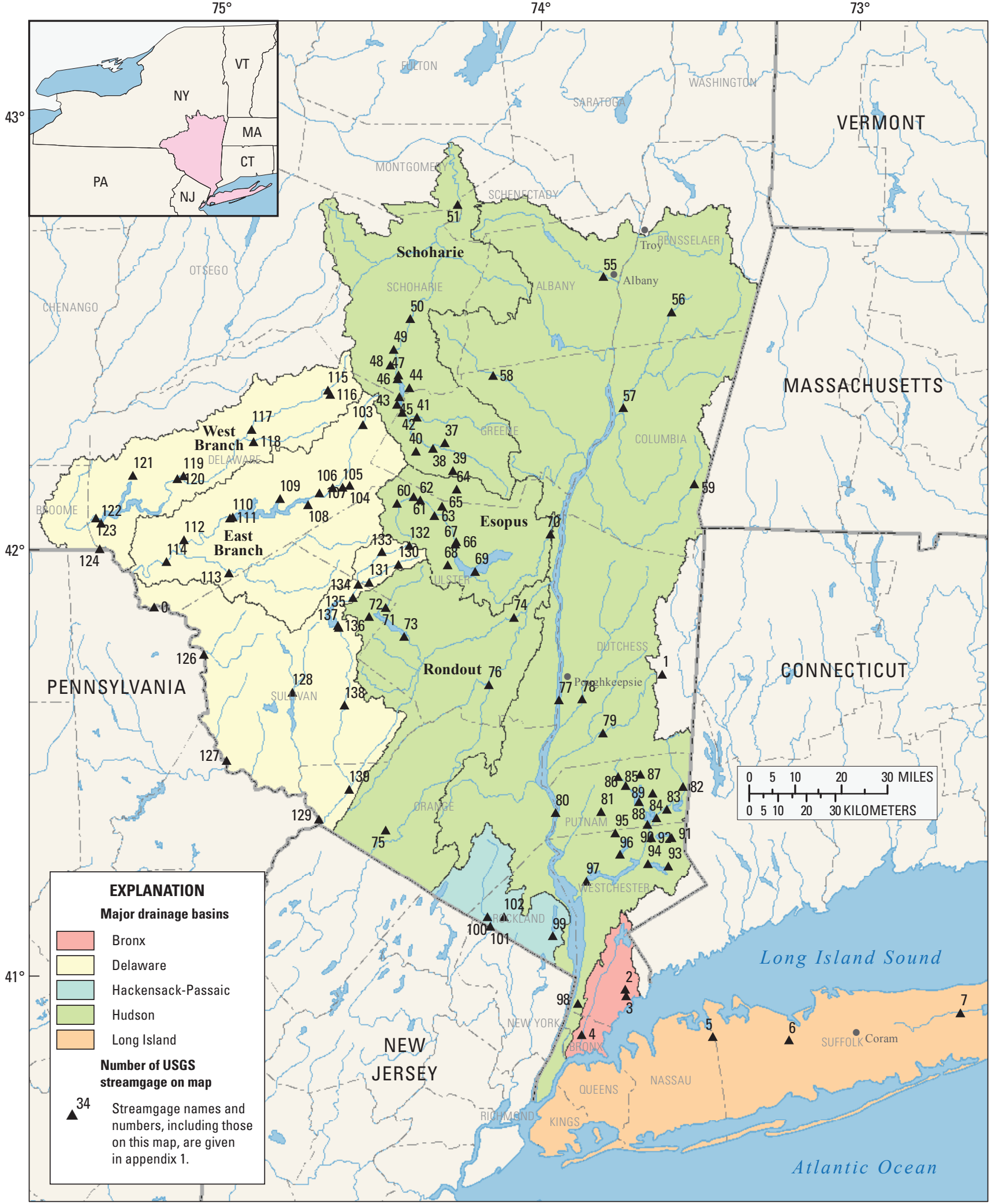

Base from the National Atlas of the United States, 1:2,000,000 Web Mercator Auxiliary Sphere projection,

World Geodetic System, 1984 datum

Figure 10. Locations of selected U.S. Geological Survey streamgages and major drainage basins in New York.-Continued 


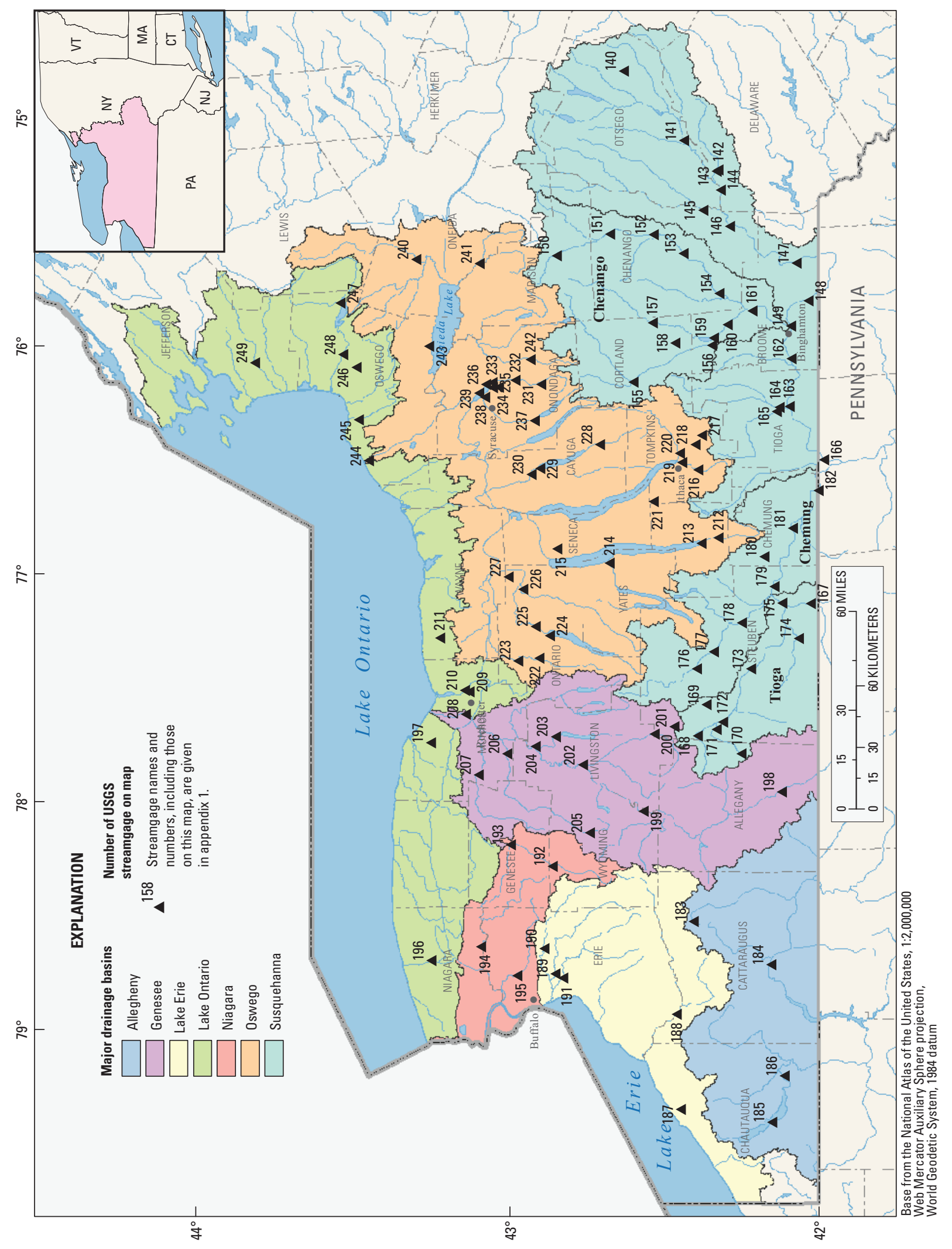

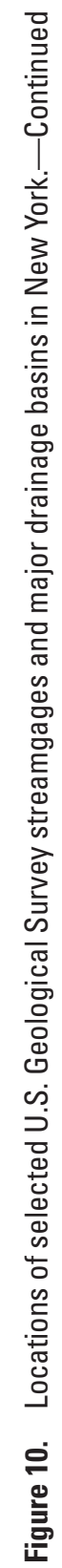




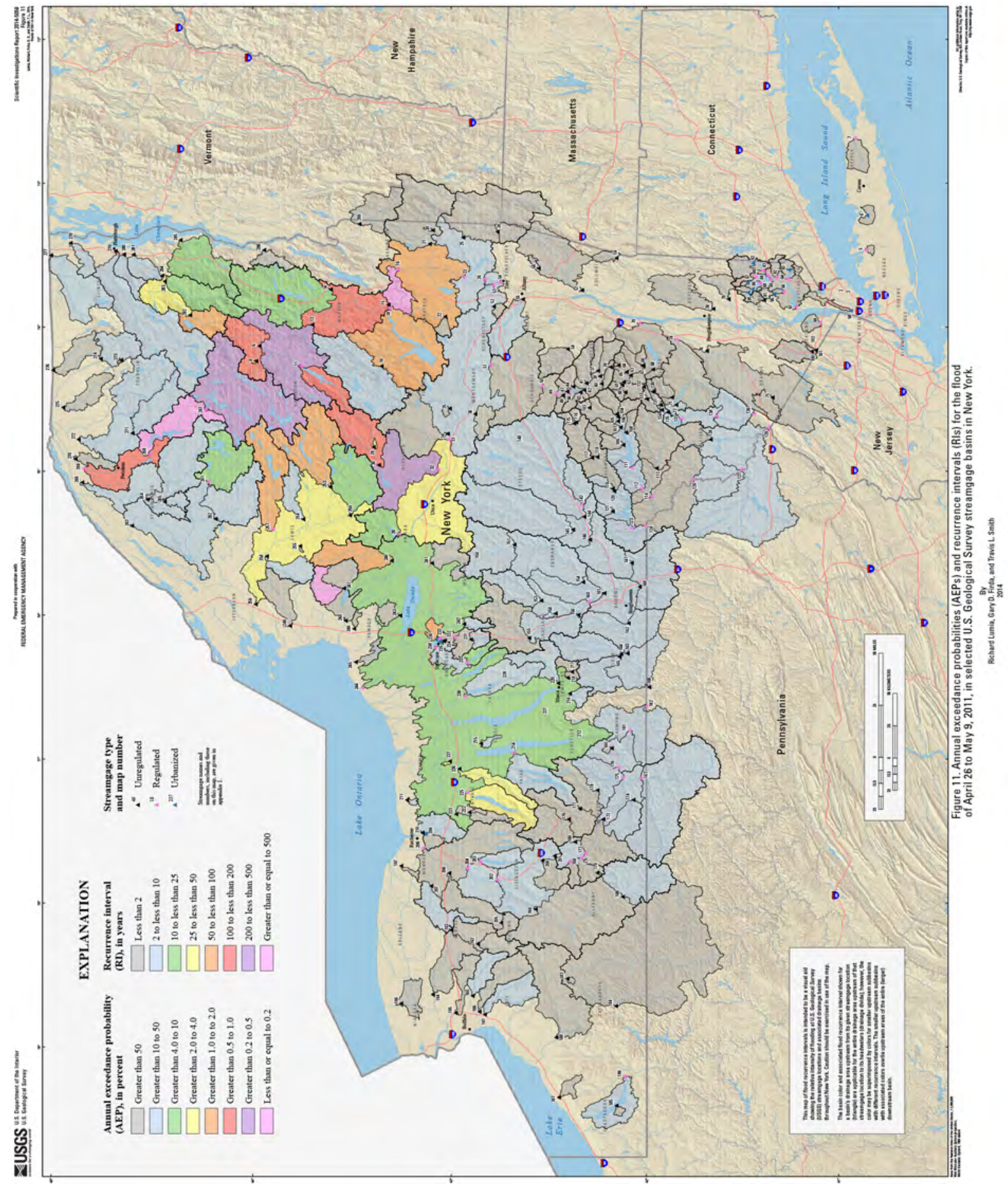

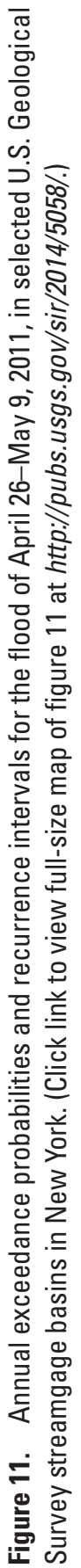


Table 5. T-year recurrence interval with corresponding annual exceedance probability and P-percent chance annual exceedance probability for flood-frequency flows.

\begin{tabular}{ccc}
\hline $\begin{array}{c}\text { T-year recurrence } \\
\text { interval }\end{array}$ & $\begin{array}{c}\text { Annual exceedance } \\
\text { probability }\end{array}$ & $\begin{array}{c}\text { P-percent chance } \\
\text { annual exceedance } \\
\text { probability }\end{array}$ \\
\hline 2 & 0.5 & 50 \\
5 & 0.2 & 20 \\
10 & 0.1 & 10 \\
25 & 0.04 & 4 \\
50 & 0.02 & 2 \\
100 & 0.01 & 1 \\
200 & 0.005 & 0.5 \\
500 & 0.002 & 0.2 \\
\hline
\end{tabular}

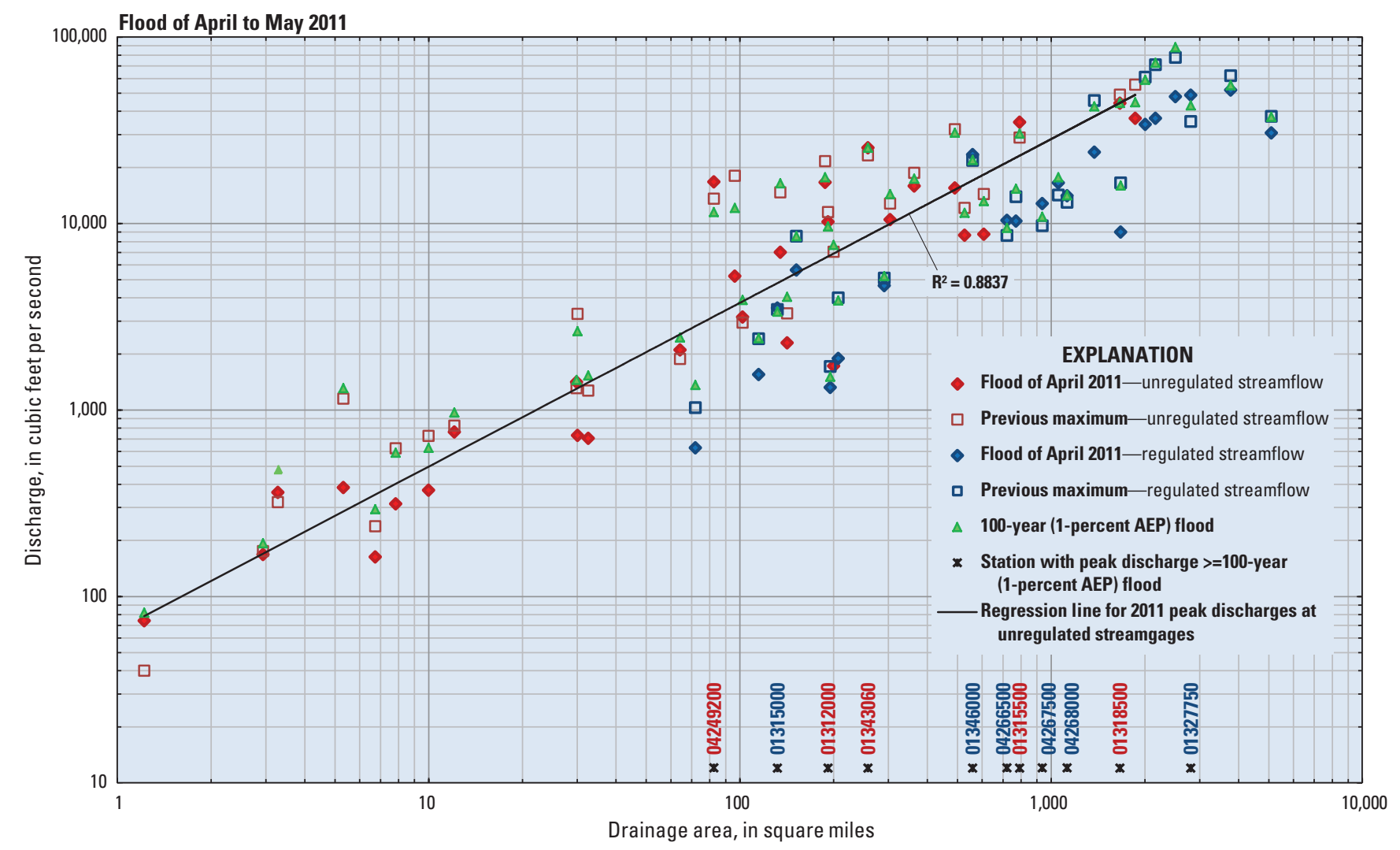

Figure 12. Peak discharges for the flood of April 26-May 9, 2011, previous maximum known discharges, and 1-percent annual exceedance probability (100-year) discharges at selected streamgages, as a function of drainage area. (Sites are listed in appendix 1 and shown on figure $10 ; \geq$, greater than or equal to; AEP, annual exceedance probability) 
The upper Hudson River Basin was particularly hard hit by the April flooding. Of the seven streamgages on the main stem of the Hudson River (fig. 10 and appendix 1) at or upstream from Green Island (near Troy), the four most upstream streamgages recorded peaks less than a 1-percent AEP (>100-year) flow (fig. 13). The Hudson River at North Creek streamgage (01315500) recorded its greatest stage and discharge since record collection began in 1908 (the April peak stage of $13.65 \mathrm{ft}$ was $1.51 \mathrm{ft}$ higher than that of $12.14 \mathrm{ft}$ during the previous record flood on December 31, 1948).

The water equivalent of snow in the Adirondack Mountains combined with high rainfall totals throughout northern New York during April resulted in large volumes of runoff (the amount of water discharged from a drainage basin and passing a specific location during a given amount of time) for several days. The maximum volumes of runoff for the periods of record for 1-, 3-, and 7-consecutive days (n-days), expressed as the mean of daily mean discharges over an n-day period, at four streamgages-Hudson River at North Creek (01315500), Raquette River at Piercefield (04266500) and at South Colton (04267500), and Ausable
River near Au Sable Forks (04275500) — are shown on figures $14 \mathrm{~A}-\mathrm{D}$, respectively. The graphs also show the 10-, 2-, and 1-percent AEP n-day discharges, the 10-year moving average, and a trend line for each site. The n-day runoffs during late April and early May 2011 were 20 to 40 percent greater than the previous maximum n-day runoffs at Hudson River at North Creek (01315500) over the 104-year period of record and significantly exceeded the 1-percent AEP (100year) n-day discharges (fig. 14A). The maximum 7-day runoff from April 26 to May 2, 2011, was more than 6 in. over the entire 792 square-mile $\left(\mathrm{mi}^{2}\right)$ drainage basin. No significant trend is indicated since record collection began in 1908. The Raquette River at Piercefield (04266500) and at South Colton (04267500) n-day runoffs during the April-May flood also exceeded the previous record n-day runoffs (figs. 14B-C). These streamgages represent large drainage basins (721 and $937 \mathrm{mi}^{2}$ ) that are regulated by upstream reservoirs, lakes, and ponds. The maximum 1-, 3-, and 7-consecutive-day mean discharges during April-May 2011 exceeded the 1-percent AEP (100-year) n-day discharge at each Raquette River gage. Runoff from the April-May 2011 flood at the Ausable River

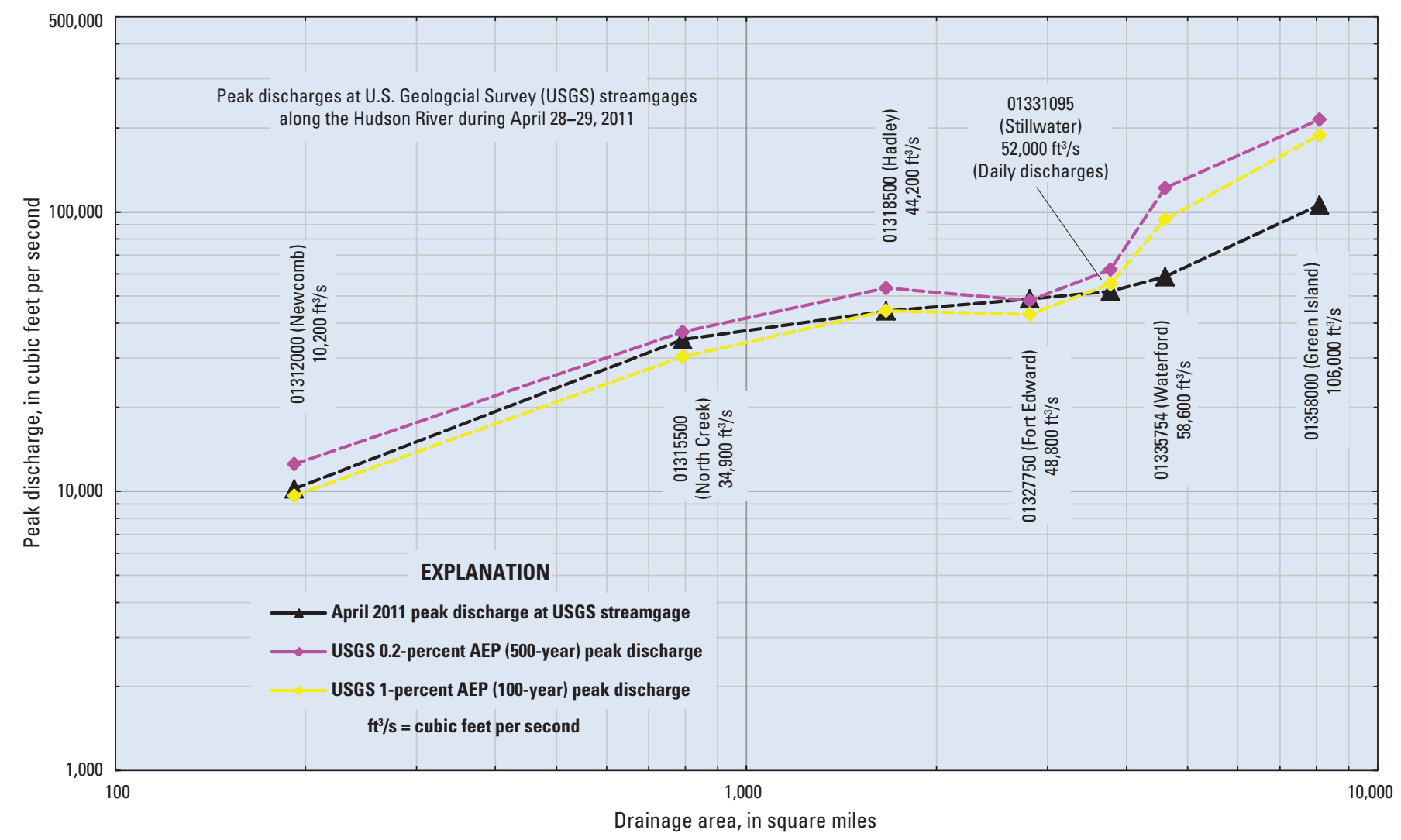

Figure 13. Peak discharges for the floods of April 26-May 9, 2011, and 1- and 0.2-percent annual exceedance probability (AEP) (100and 500-year) discharges at seven U.S. Geological Survey (USGS) streamgages on the Hudson River, as a function of drainage area. (Sites are listed in appendix 1 and shown on figure 10.) 

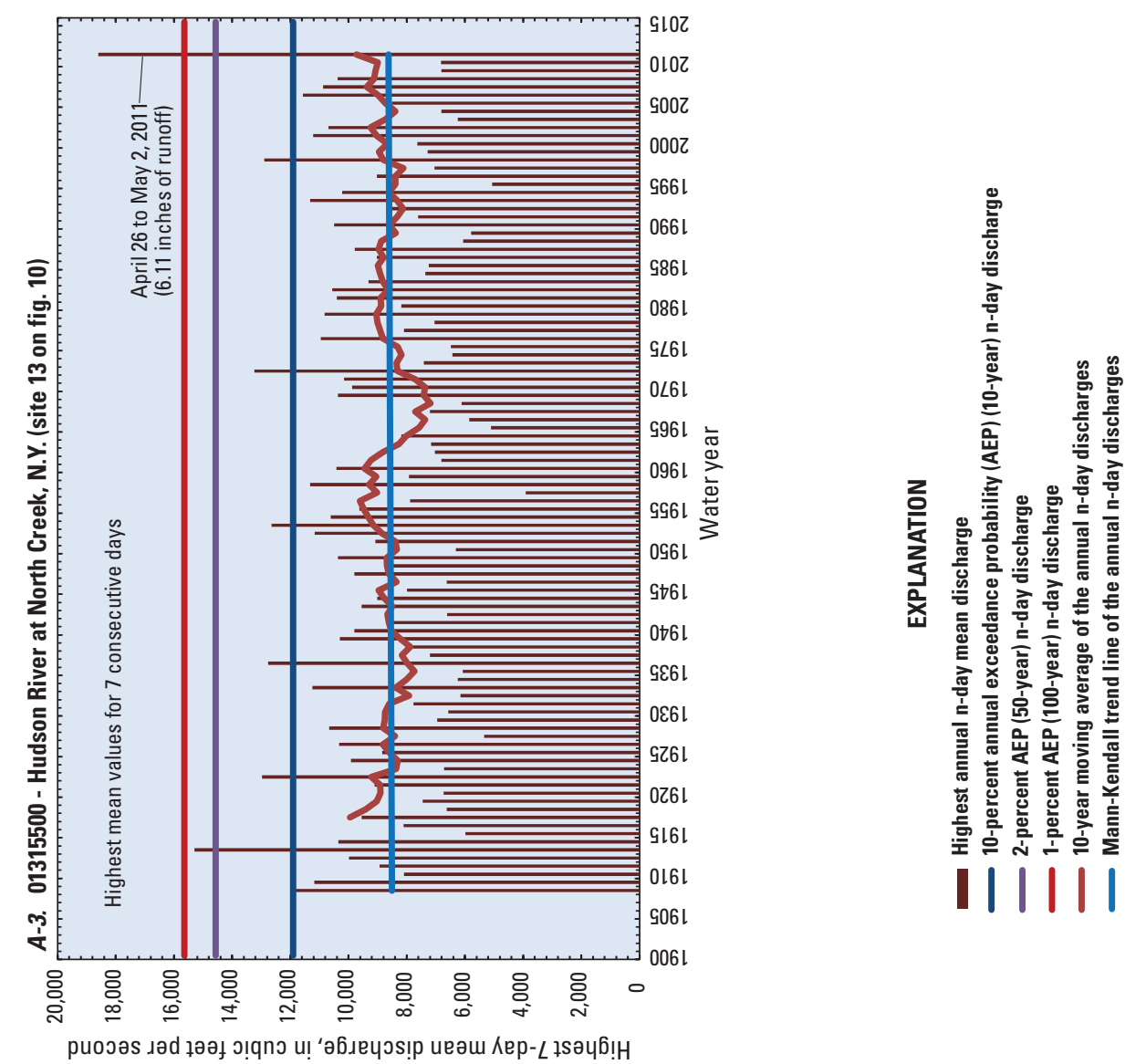

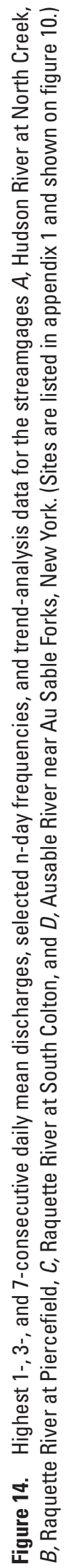
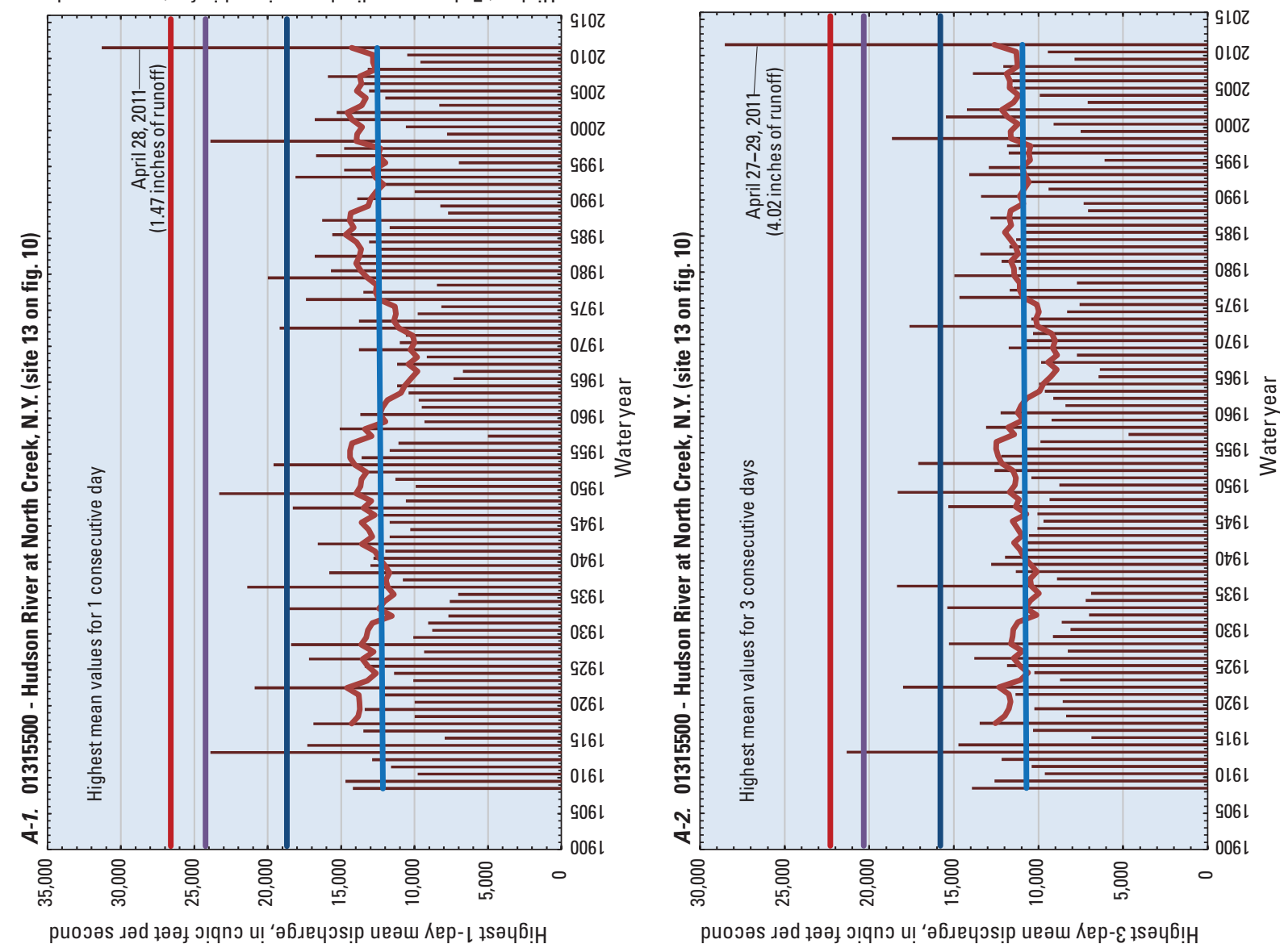

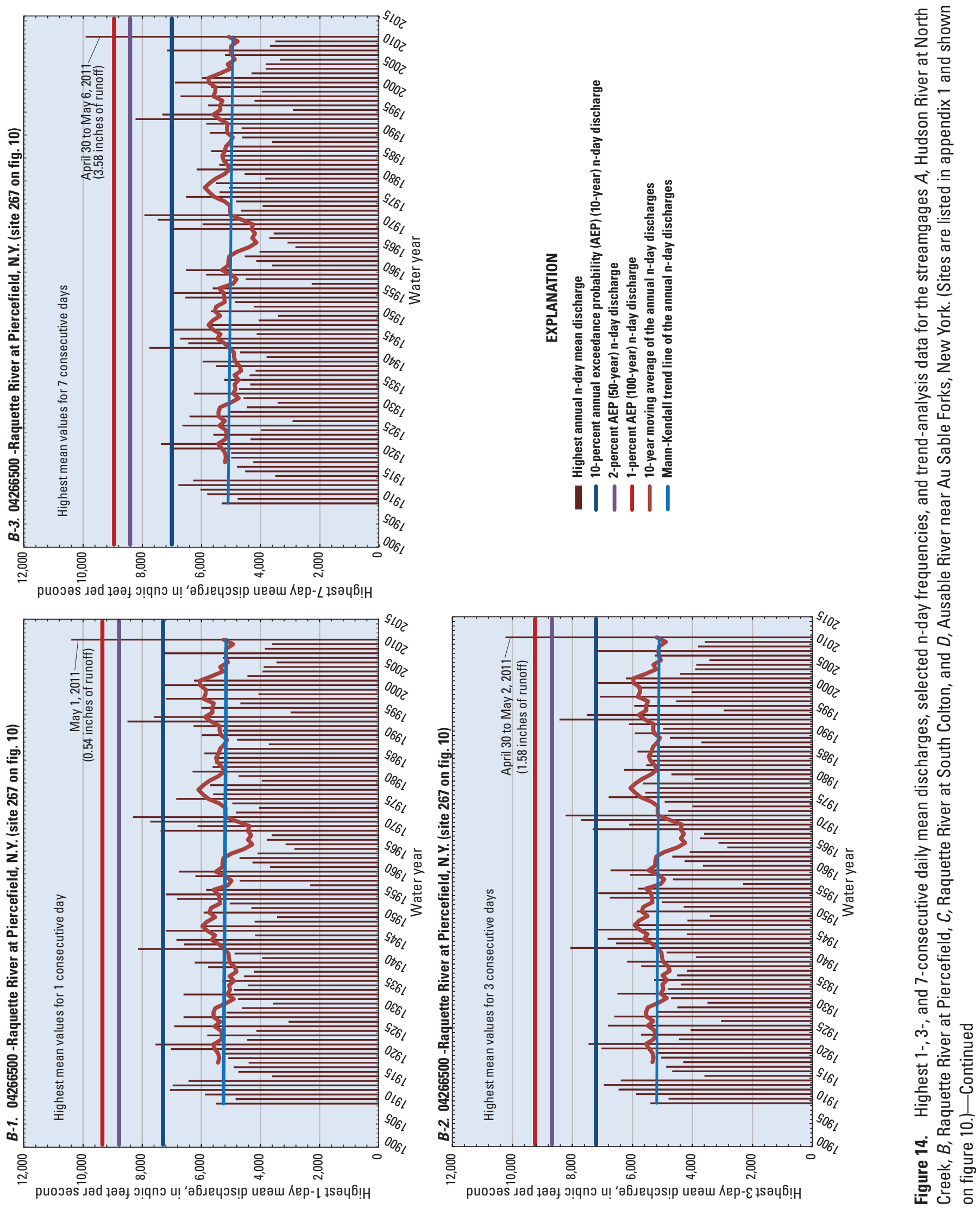

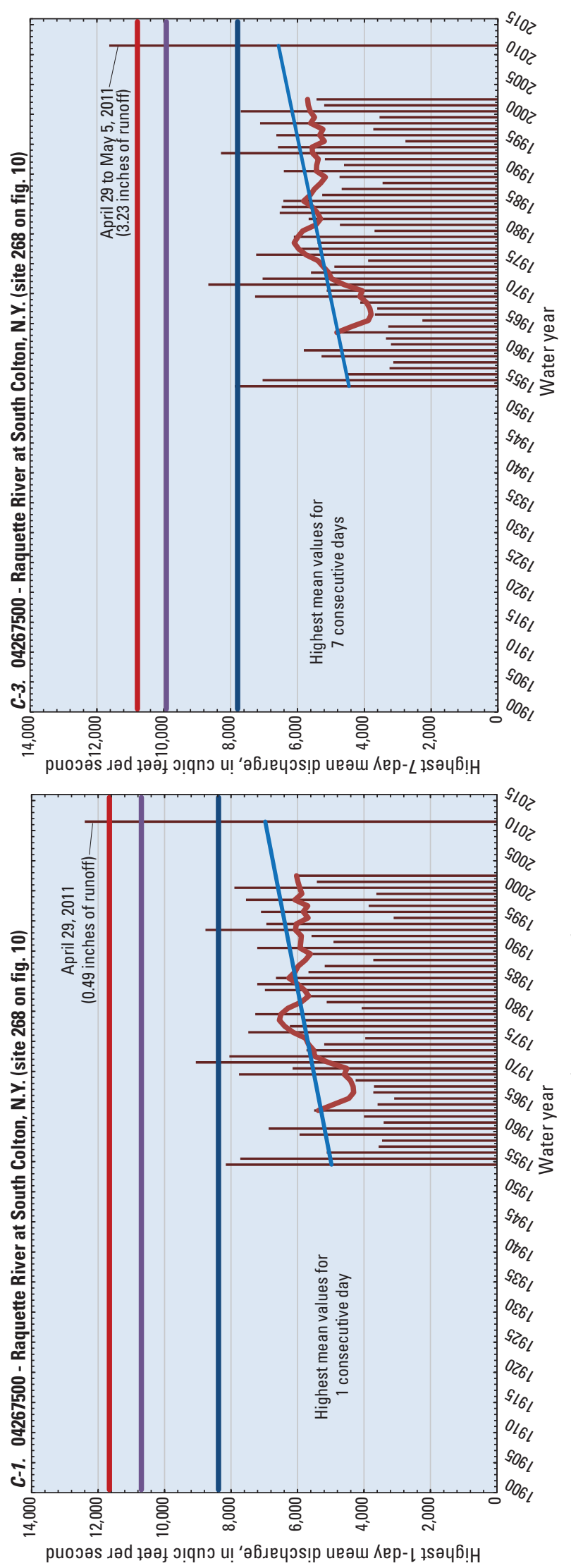
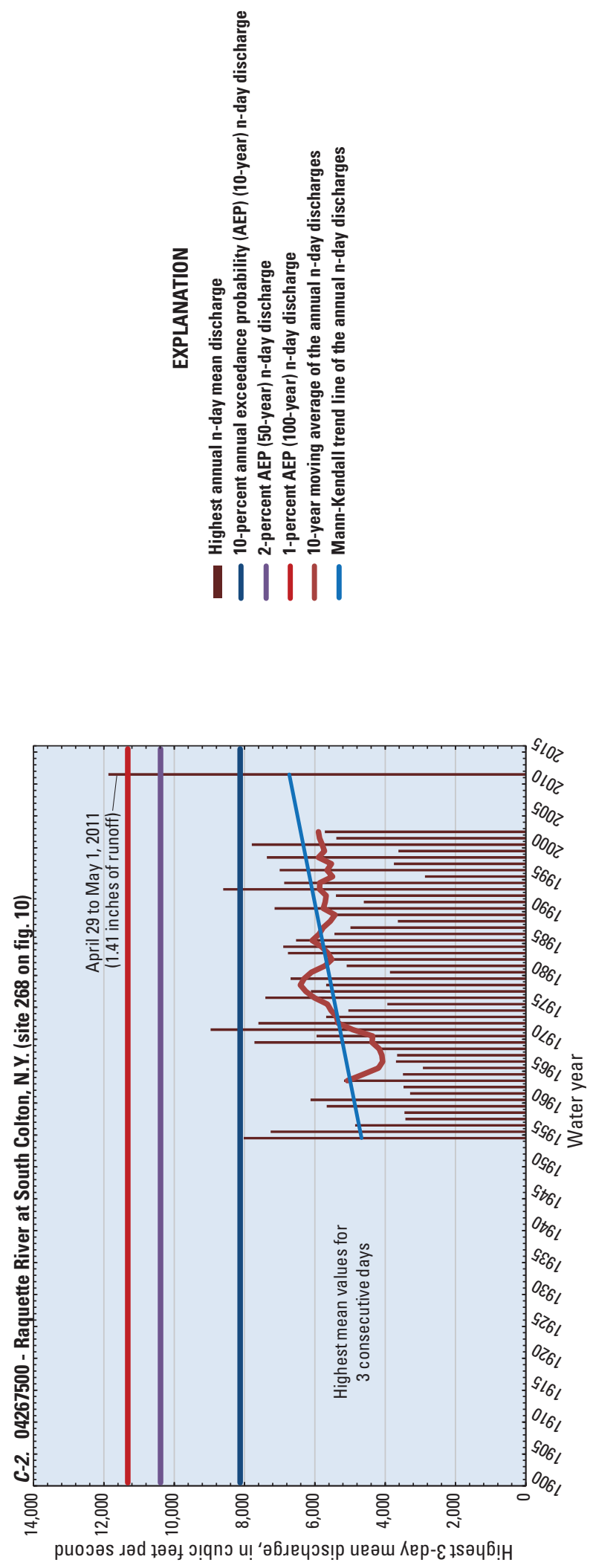

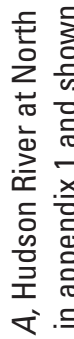

is

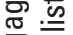

है

离.

象

흔

栗

z

告

한

年 $\frac{0}{0}$

후둔

i)

这

Ф)

흥

产旁

它

몽

त

क

s

둔

흥 훙

is is

元

๘ॅ

ڤ્

츌

증

$\stackrel{0}{\circ}$

证

u

类

ठํ.

인

음 흠

西

लं

亡 竞

过

홒 음

东

我。

힌

言离离 

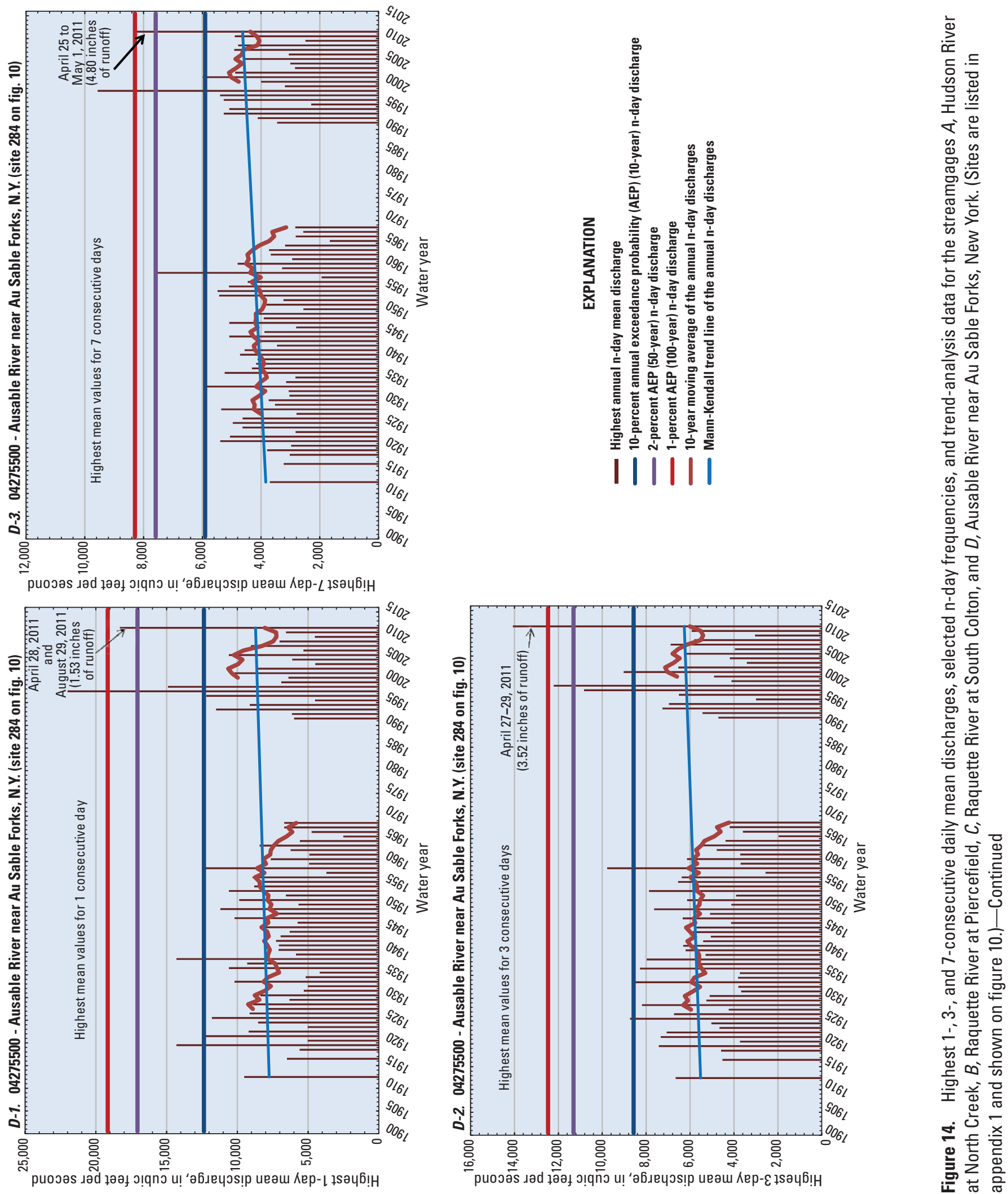
near Au Sable Forks (04275500) was the second largest for 1- and 7-day periods but the greatest 3-day runoff for the period of record (fig. 14D). A large flood that peaked on November 9, 1996, exceeded 1- and 7-day runoff of the 2011 flood. The maximum 3-consecutive-day mean flow (for April 27-29, 2011) at the Ausable River streamgage exceeded the 1-percent AEP (100-year) n-day flow.

An analysis of annual peak discharges at 13 selected USGS streamgages throughout northern New York indicates that the April-May 2011 peak discharges exceeded the 1-percent AEP (100-year) discharge, and many were peaks of record (figs. 15A-M). The streamgages on Indian River near Indian Lake (01315000 just downstream from Indian Lake) recorded the greatest stage and discharge since record collection began in 1913 and exceeded the 1-percent AEP (100-year) peak discharge (fig. 15B). Other peak flows of note during the April-May 2011 flood include those at the Hudson River at North Creek (01315500), which exceeded the previous maximum in December 1948 (fig. 15C) by 25 percent (greater than the 0.5-percent AEP or 200-year discharge, table 4); Sacandaga River at Stewart's Bridge near Hadley (01325000), which recorded its greatest stage and discharge since regulation at Great Sacandaga Lake began in 1930 (fig. 15E); West Canada Creek at Kast Bridge (01346000), where the largest flow since 1913 was recorded (fig. 15H); and three streamgages on the Raquette River (at Piercefield (04266500), South Colton (04267500), and Raymondville (04268000)), where each recorded maximum stage and discharge exceeded or equaled the 1-percent AEP (100-year) flow (figs. 15K-M).

Trends in annual peak flow and n-day runoff were tested by using the Mann-Kendall trend test, a nonparametric test that is resistant to the effects of a small number of unusual values (outliers) and is well suited for variables that exhibit skewness around the general relation. The test is applicable to data that are not serially correlated. Correlation was tested by using methods by Lorentz and others (2011), but no correlation was detected. The strength of the monotonic relation between time and peak discharge is represented by the tau value and level of significance (p-value) (Helsel and Hirsch, 1992, 2002). Significance levels (p-values) of 0.05 and 0.10 were used in these analyses. The median of the slopes for the pairs of data used in each analysis was calculated by using the Thiel-Sen slope estimator (Lorenz and others, 2011).

Results of the trend tests are presented in table 6 for 55 selected streamgages with substantial flooding during 2011 and are shown on graphs for n-day mean discharges (figs. 14A-D) and annual peaks (figs. 15A-M). Trend data for the period of record (long-term trend) and for short-term record (most recent 30 years through 2011 or shorter if less data are available) are reported in table 6 and shown on figures $15 \mathrm{~A}-\mathrm{M}$. Of the 55 selected sites in table 6,41 had annual peak discharges with long periods of record (32 to 108 years), of which 12 sites (29 percent) had a significant upward trend (p-value less than or equal to 0.10 ), and only 2 sites had a statistically significant downward trend.
Short-term trends computed at 42 of the 55 selected sites for the most recent 30 years or less (13-30 years) indicate that 14 sites (33 percent) had statistically significant upward trends (p-values less than or equal to 0.10 ), and no sites had significant downward trends.

The general increase in trends in the annual peak discharge could be caused by climate change, increasing urbanization, or other changes and could affect future water management, infrastructure design, flood planning and management, and other practices. Data trends also indicate that annual peak discharges may not be stationary, as currently presumed in standard flood-frequency analyses (Walter and Vogel, 2010). Underlying components to nonstationary peak flows need to be identified and (or) removed for valid assessment of flood frequencies. A study of trends in peak discharges at 1,312 USGS streamgages throughout the northeastern United States by Walter and Vogel (2010) suggests that in 10 years, at sites exhibiting trends, a 10-year storm frequency is reduced, on average, to a 6.1-year storm frequency; a 25-year storm frequency to a 13.8-year storm frequency; and a 100-year storm frequency to a 48.5-year storm frequency. This analysis, as well as similar analyses of trends in peak discharges, indicate that flows in New York streams need more detailed evaluations, especially if nonstationarity continues to affect many streamgages.

Flood AEP flows computed for the Hudson River at North Creek (01315500) starting after the first 10 years of record (1908-17) and recomputed after each additional year of record through 2011 (maximum discharge for the year occurred on April 28) illustrate the effect of individual annual peak discharges on the magnitude of the AEP flow over time (fig. 16). The 10-year moving average and the computed trend line for the "moving" 1-percent AEP (100-year) floodfrequency values show almost no trend (slightly downward) at this site during its 104-year period of record.

Antecedent conditions, precipitation, runoff patterns, and basin characteristics all play a role in determining the peak water-surface elevation and discharge at a streamgage. Discharge hydrographs for selected streamgages throughout the flooded areas for April 25-May 1, 2011, are shown on figures $17-18$. The graphs on figure 17 compare hydrographs at selected streamgages within a basin and include the 1-percent AEP (100-year) discharge for each site; the plots show the magnitude, frequency, and timing of flows at each location. The Raquette River plots (fig. 17I) show data for April 27-May 3 (slower basin-response time as a result of upstream lakes, ponds, and reservoirs). One of the hydrograph plots of note shows the Hudson River streamgages at Fort Edward (01327750) and Waterford (01335754) with the hydrograph of the intervening Hoosic River near Eagle Bridge streamgage (01334500) (fig. 17C). The Fort Edward streamgage recorded a peak discharge greater than the 500year flood (less than the 0.2-percent AEP discharge), whereas the Hoosic River, which enters the Hudson River downstream from Fort Edward, recorded a "low" peak discharge with a recurrence interval of less than 2 years (greater than 

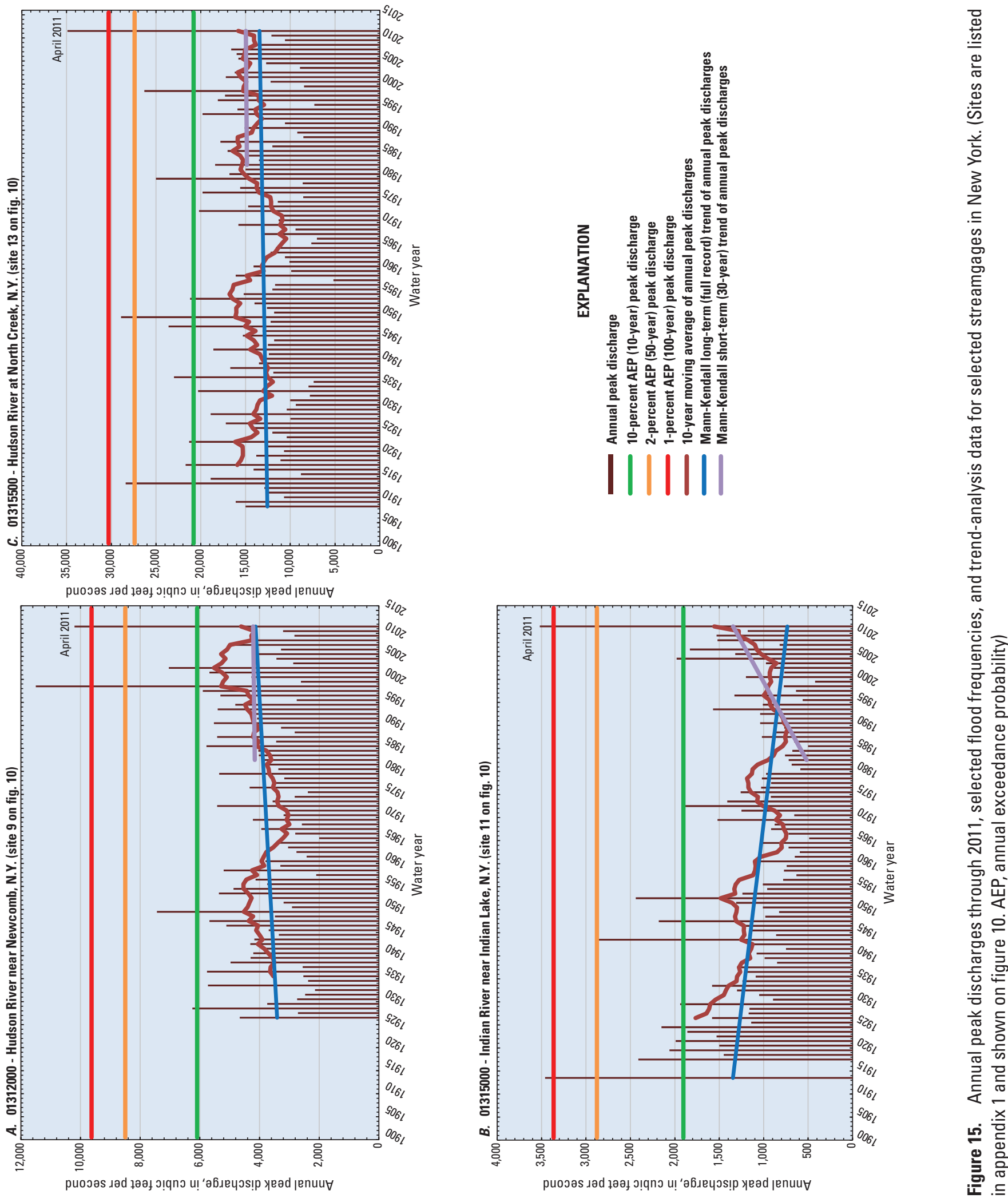

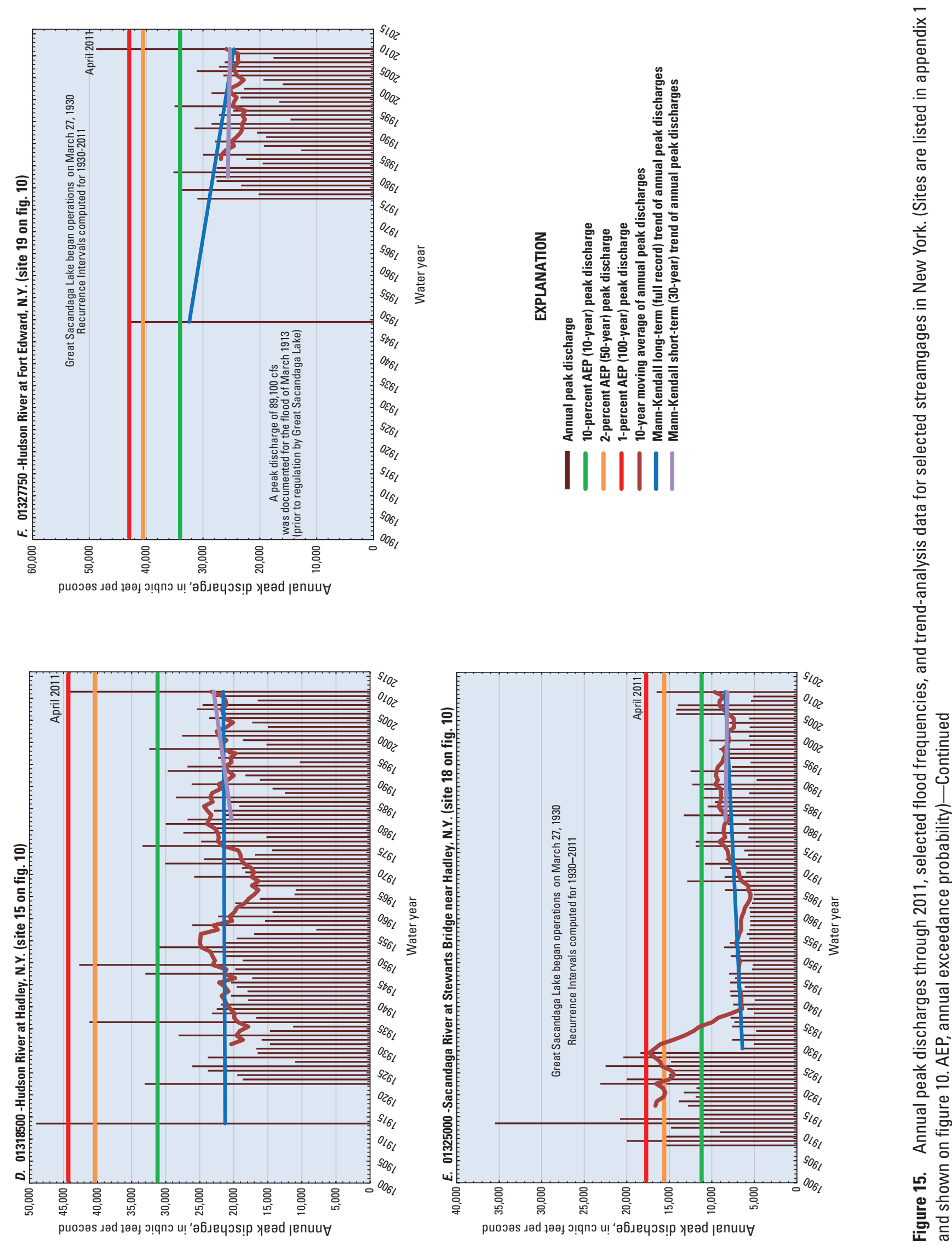

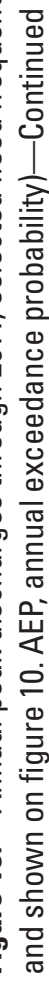



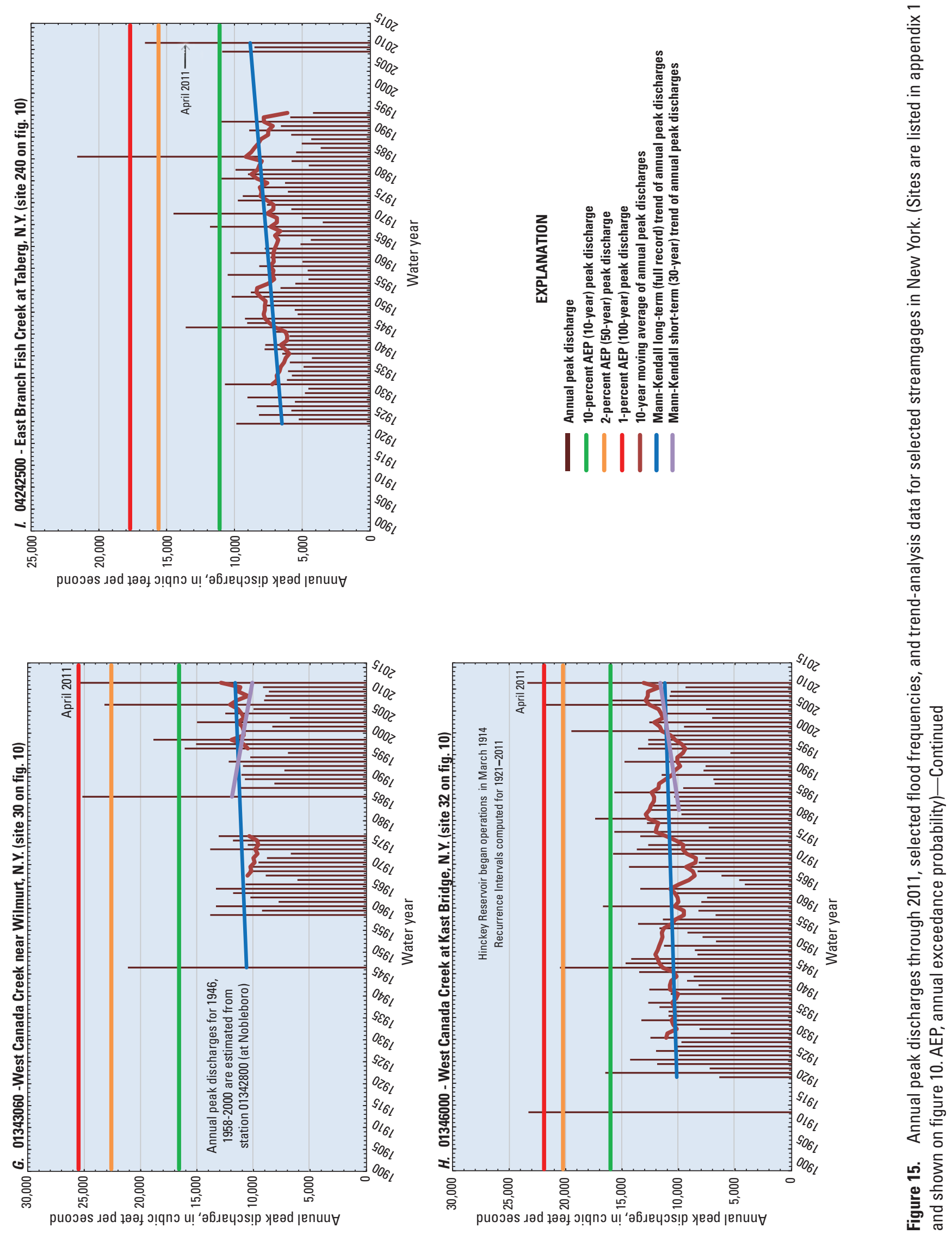

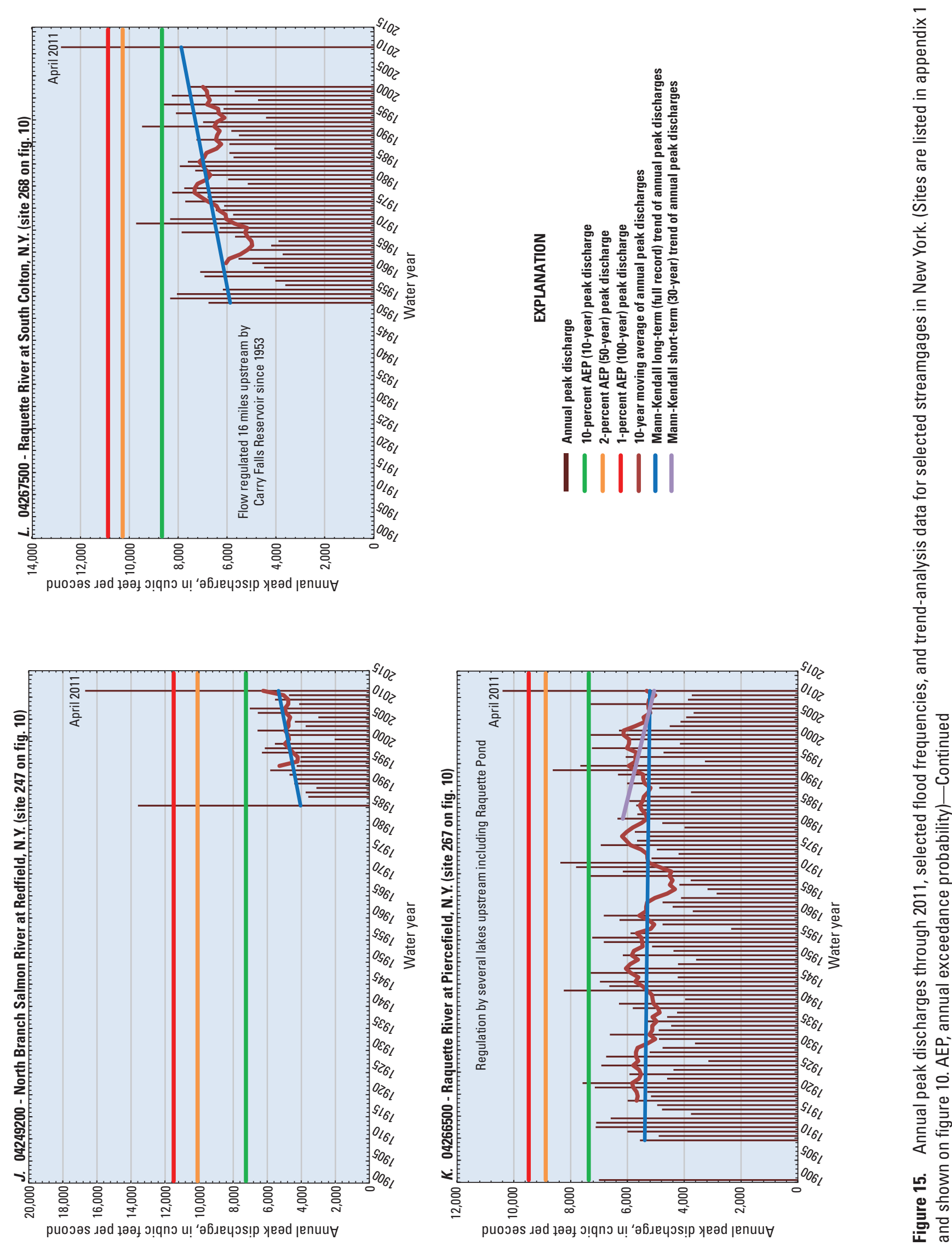

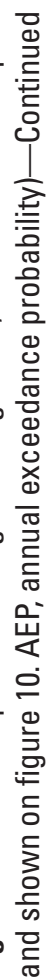



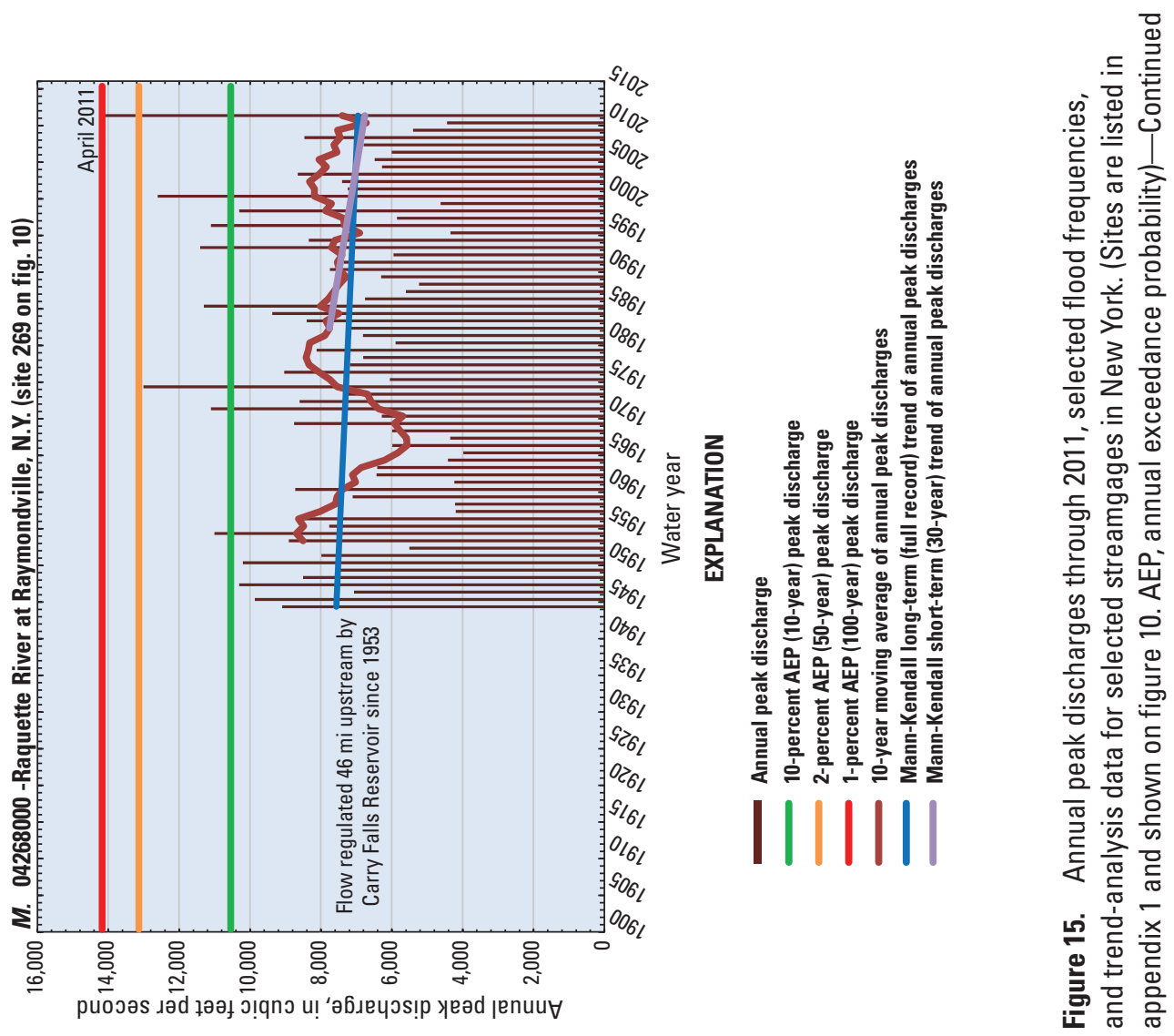
涉

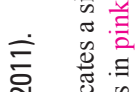

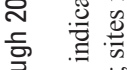

를

㝘交

ᄒ

क

वे है

范 常

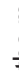

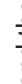

政

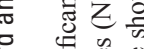$$
\text { . }
$$

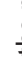

$$
\text { 政 }
$$$$
\text { . }
$$$$
\frac{\sqrt{2}}{2}
$$$$
\text { D }
$$

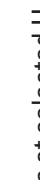$$
\text { 政 }
$$

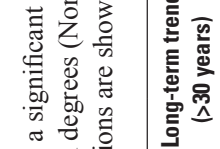

.5.

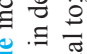

旁

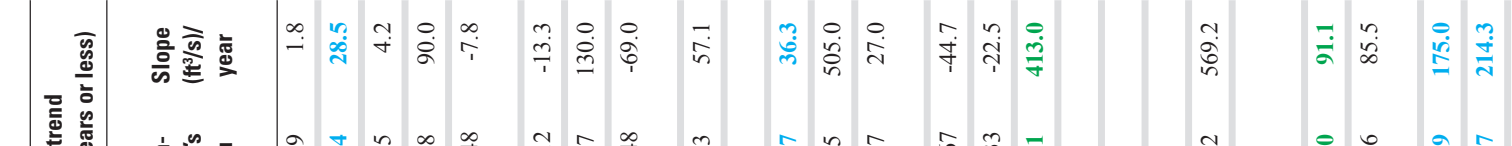

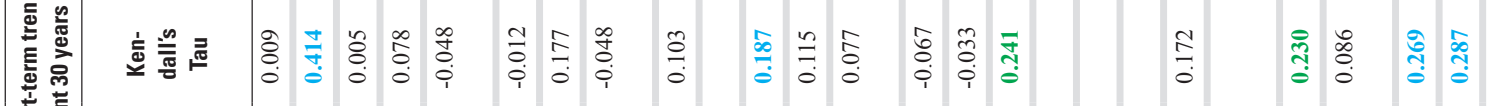

突蓄

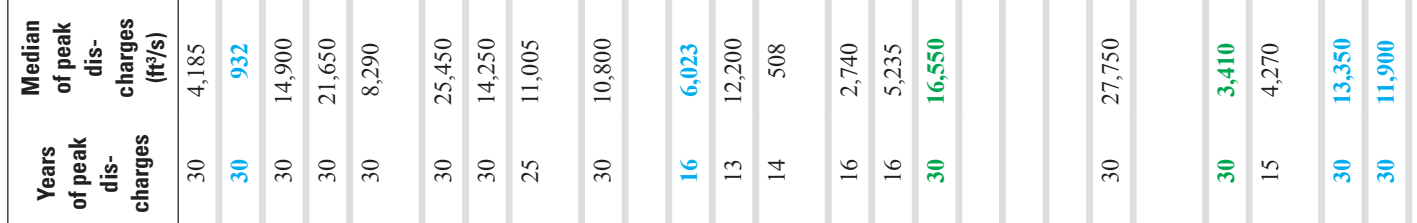

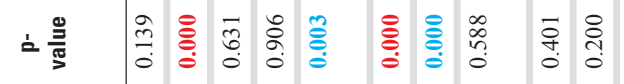

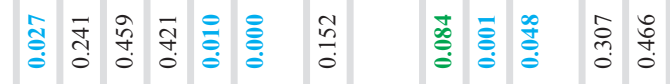

产高畜焉

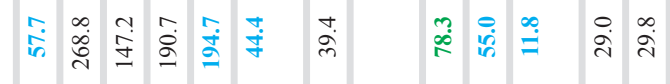

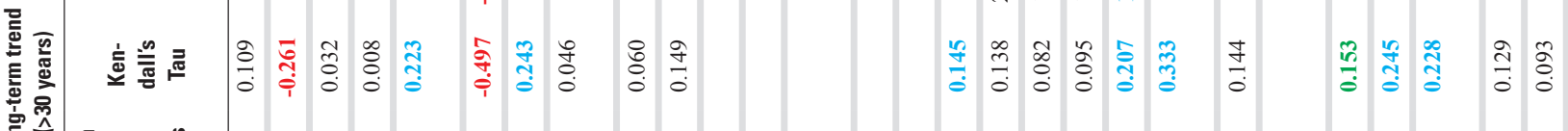

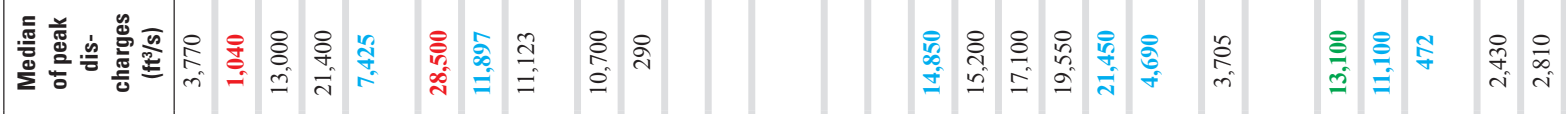

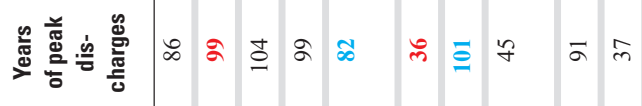

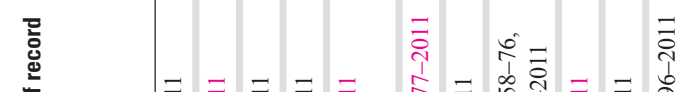

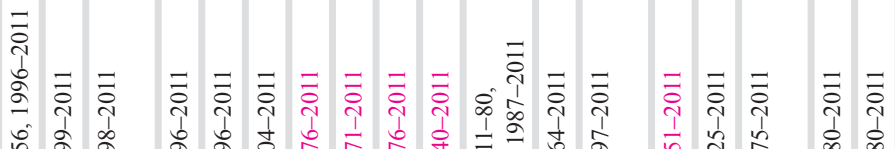

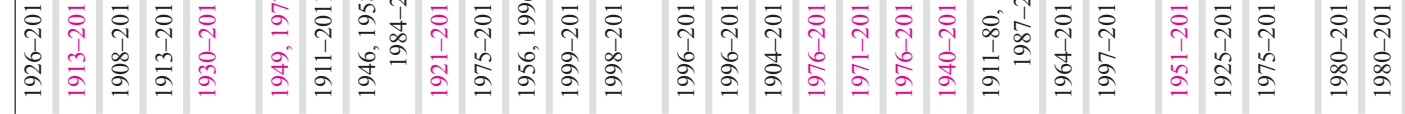

㱐产

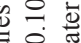

政

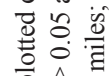

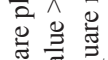

运家

$\forall$ ह

政

告

政

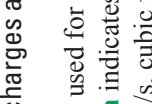

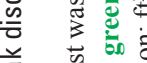

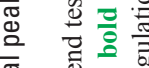

孚

흐

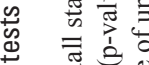

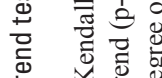

$\rightarrow$ 言

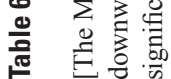

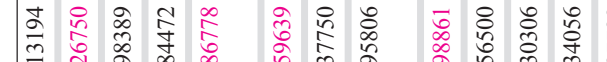

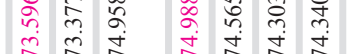

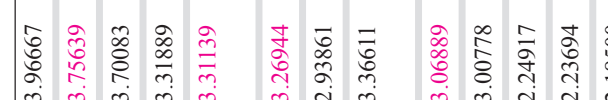

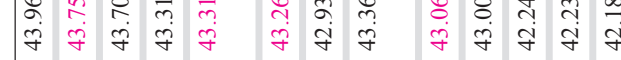

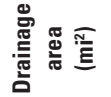

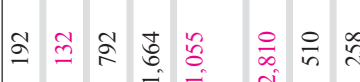

药

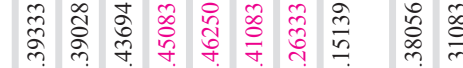

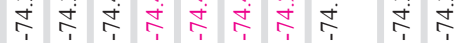

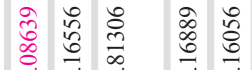

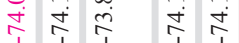

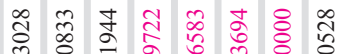

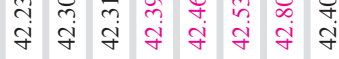

总

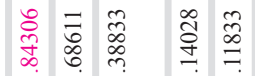

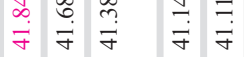

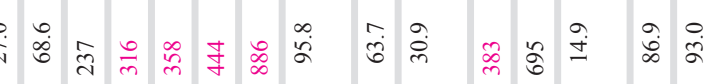

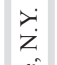

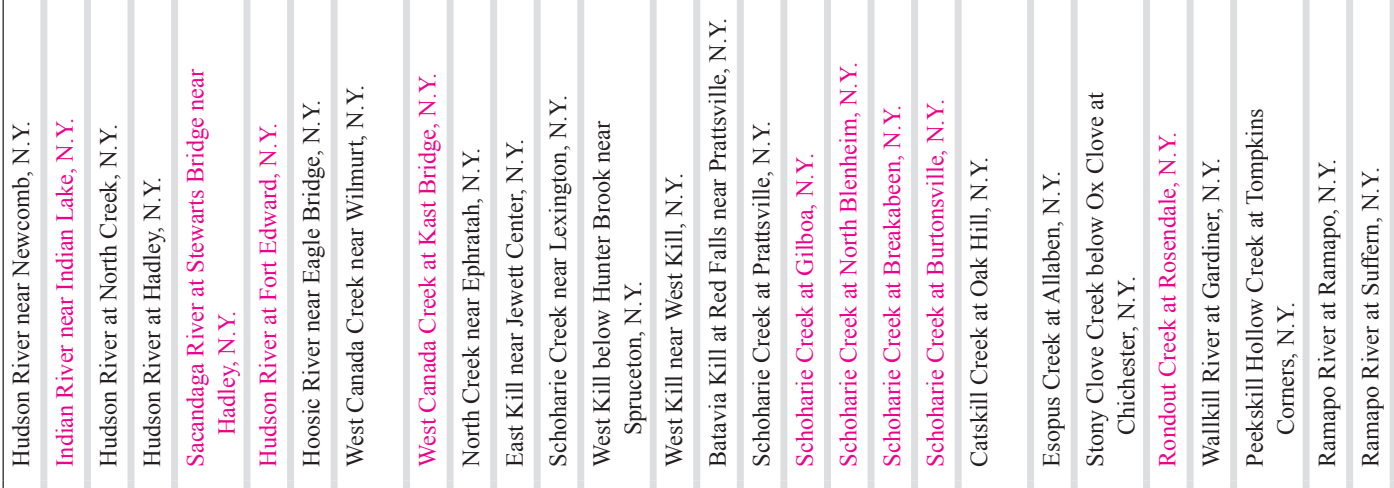

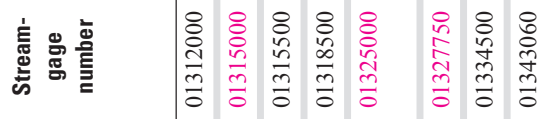
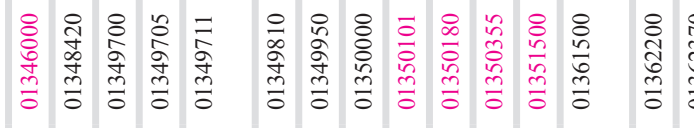

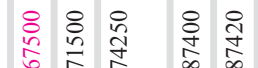

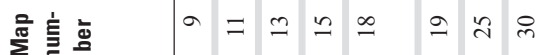

ñ $\check{m}$ iे

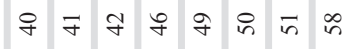

ชู

요 


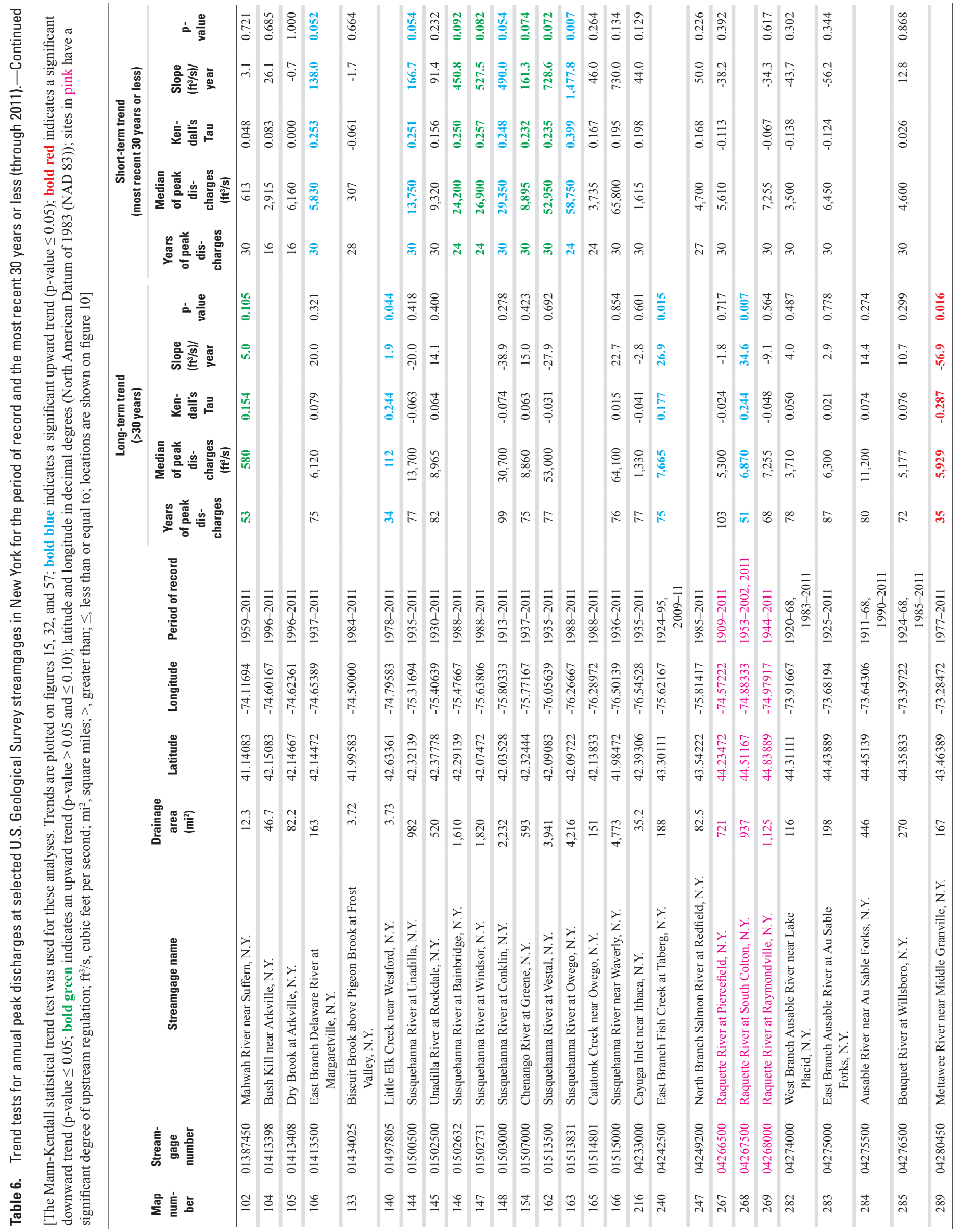




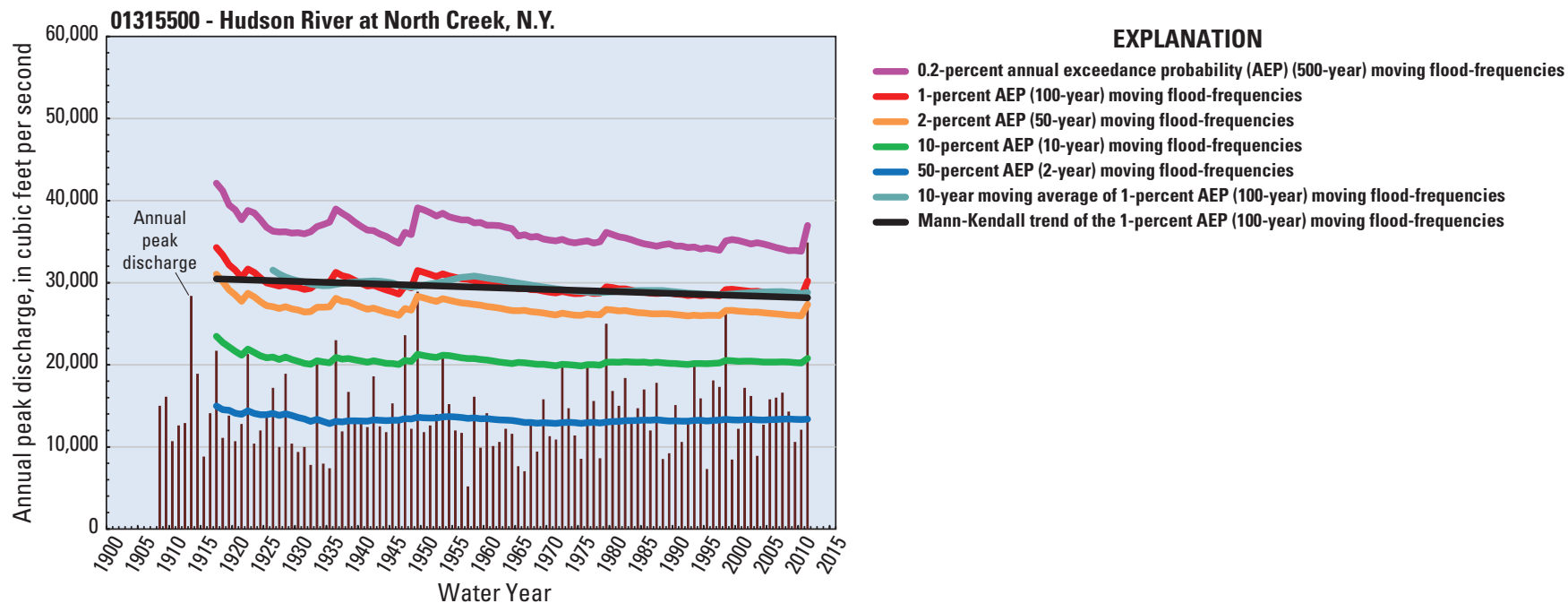

Figure 16. Annual peak discharges, moving flood frequencies, and trends of the moving 1-percent AEP (100-year) discharges through 2011 at the Hudson River at North Creek, New York, streamgage. (Site 13 on figure 10)

50-percent AEP discharge) (table 4). Major flooding on the Hoosic River could have led to catastrophic conditions on the Hudson River near Waterford and farther downstream. Figures 18A-C show discharge hydrographs for three sites in the flooded areas, as well as available hydrographs for previous high flows at each site. Selected flood frequencies and a list of the largest four peak discharges at each streamgage are included for comparison. The peak discharges for previous floods were overlaid on those for the April-May flood for hydrograph-shape comparisons.

The stage or water level of a stream determines which home, business, or roadway becomes inundated during a flood. The magnitude, frequency, and duration of flood stages are all important conditions for flood-plain and water-resource managers or planners to consider. To help evaluate these conditions in flooded areas during the late April to early May 2011 storm, stage hydrographs for selected streamgages show the stream stage (converted to National Geodetic Vertical Datum of 1929 (NGVD 29)) along with stage frequencies (horizontal color-coded range bars) and stage-frequency durations (figs. 19A-D). For example, the stream stage at the Hudson River at North Creek (01315500) remained above the 0.5 -percent AEP (200-year) stage for about 18 hours during April 28-29 and above the 1-percent AEP (100-year) stage for more than 24 hours (fig. 19A). The Raquette River at South Colton (04267500) was above the 0.2-percent AEP (500-year) flood stage for about 32 hours during April 29-30 and above the 1-percent AEP (100-year) stage for more than 2 days (fig. 19D). Other than stages documented at streamgages in table 4, the USGS did not survey the elevations of high-water marks (HWMs) (maximum flood stages) at ungaged locations for this flood. However, 17 HWMs were surveyed by the New York State Department of Environmental Conservation (NYSDEC) along the upper Hudson River from Lake Luzerne downstream to Mechanicville following the April-May, 2011, flood (table 7 and fig. 20).

\section{Effects of Reservoirs}

The April-May flood discharges along reaches of several streams in areas in northern New York were affected by one or more lakes or reservoirs within the basins. Data for Indian Lake, Great Sacandaga Lake, and Hinckley Reservoir (Hudson River Basin); Sixth Lake, First Lake, and Stillwater Reservoir (Black River-Lake Ontario Basin); and Lake Champlain (St. Lawrence River Basin), indicate that all reservoirs exceeded their usable capacity during the flood (table 8).

Water-surface elevations and change in contents (volume of water in a reservoir or lake computed on the basis of a level pool and does not include bank storage) indicate that appreciable amounts of runoff were stored during the flood that may have helped mitigate downstream flooding. Indian Lake and Great Sacandaga Lake in the upper Hudson River Basin each stored nearly 9 in. of runoff at the time of their maximum lake levels; prior to spilling, they stored 6.20 and 3.69 in., respectively. Stillwater Reservoir, in the Black River Basin, stored almost 6 in. of runoff; prior to spilling, it stored 4.79 in. New maximum water-surface elevations were recorded during the April-May flood at Great Sacandaga Lake (82 years of record), Hinckley Reservoir (98 years of record), and Stillwater Reservoir (104 years of record). 

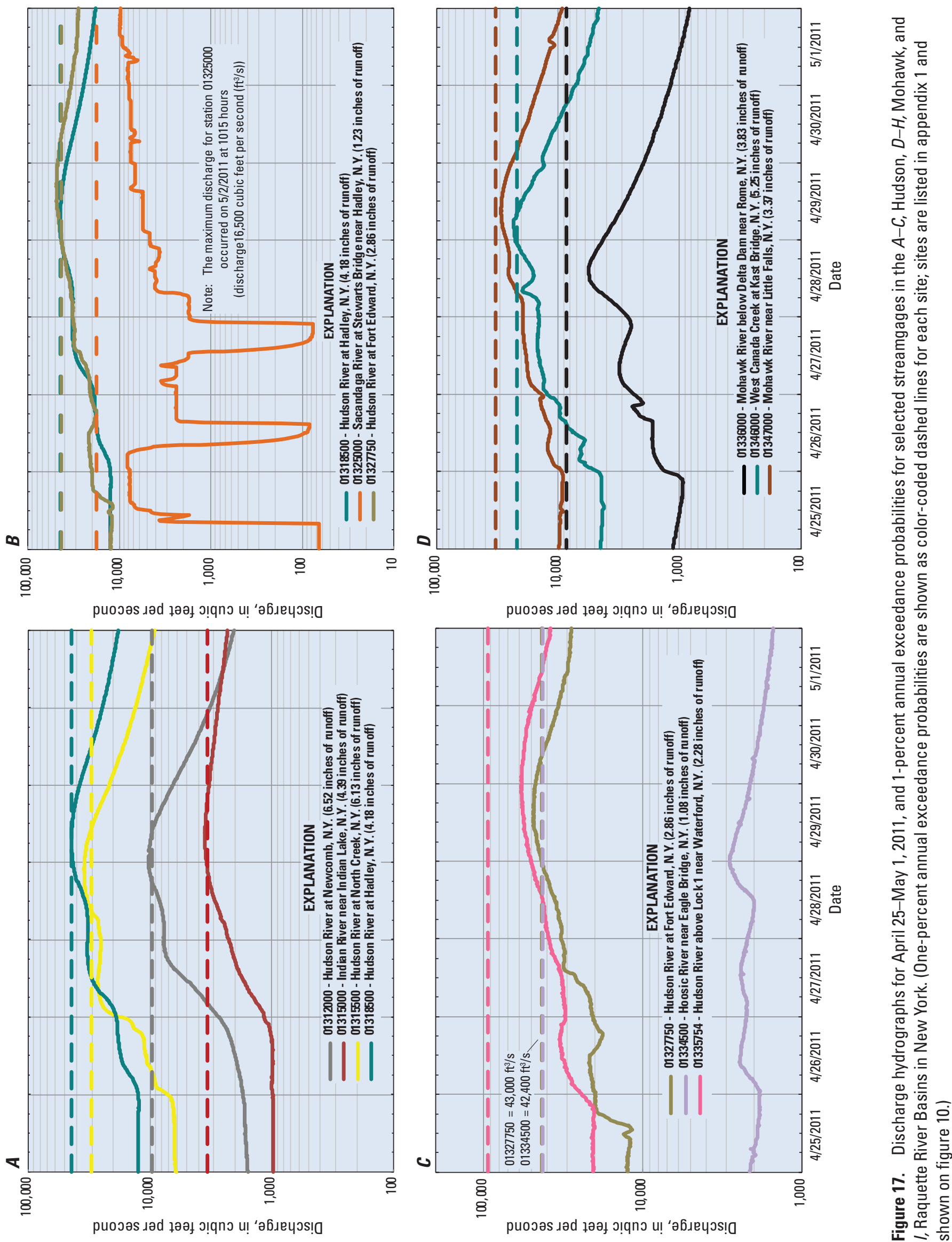


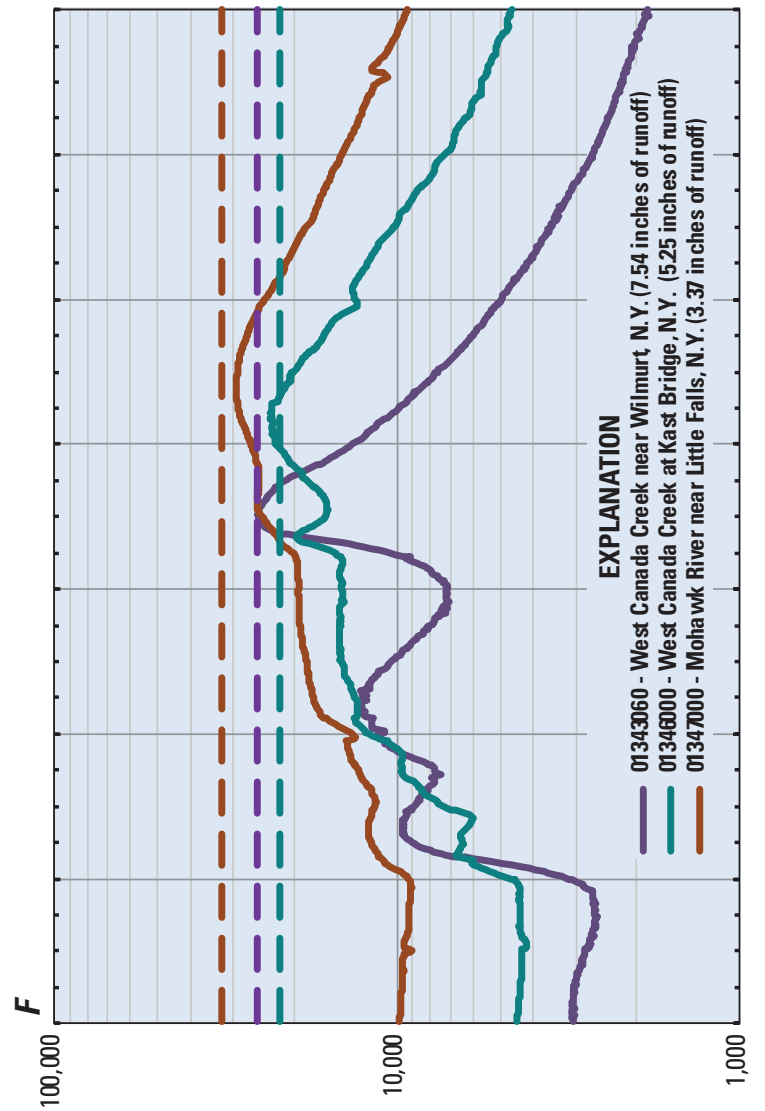

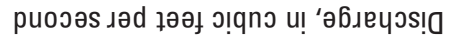

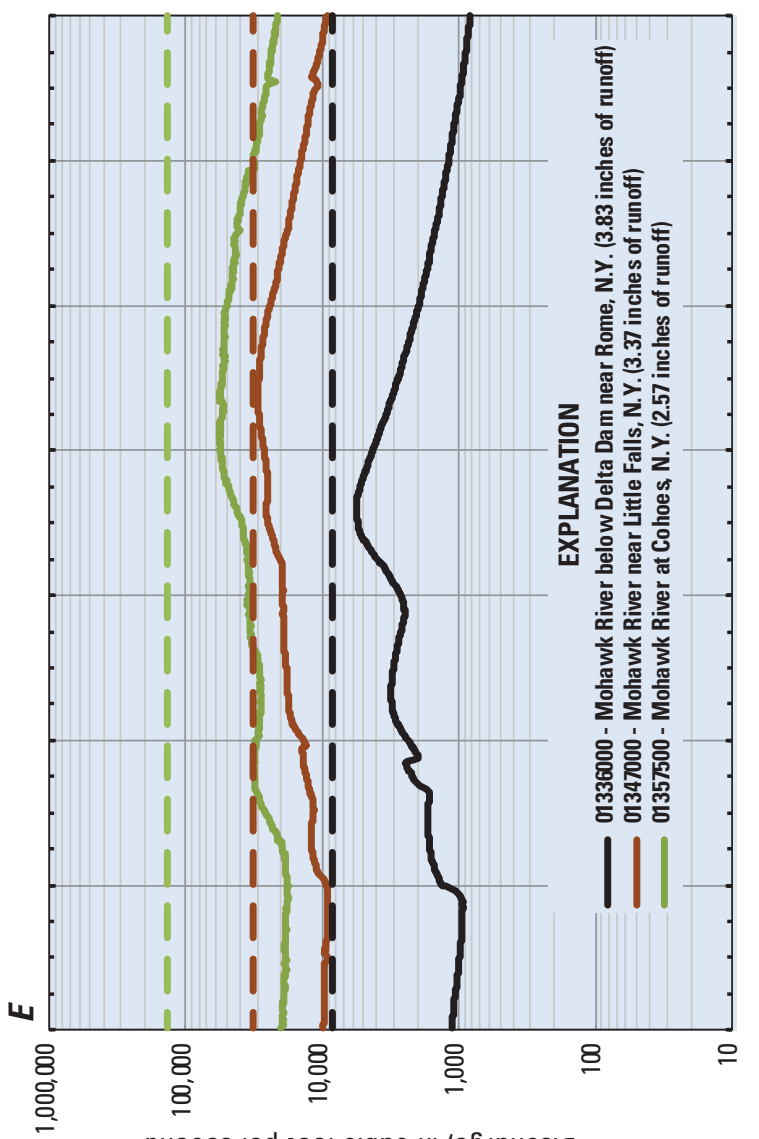

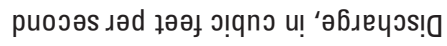

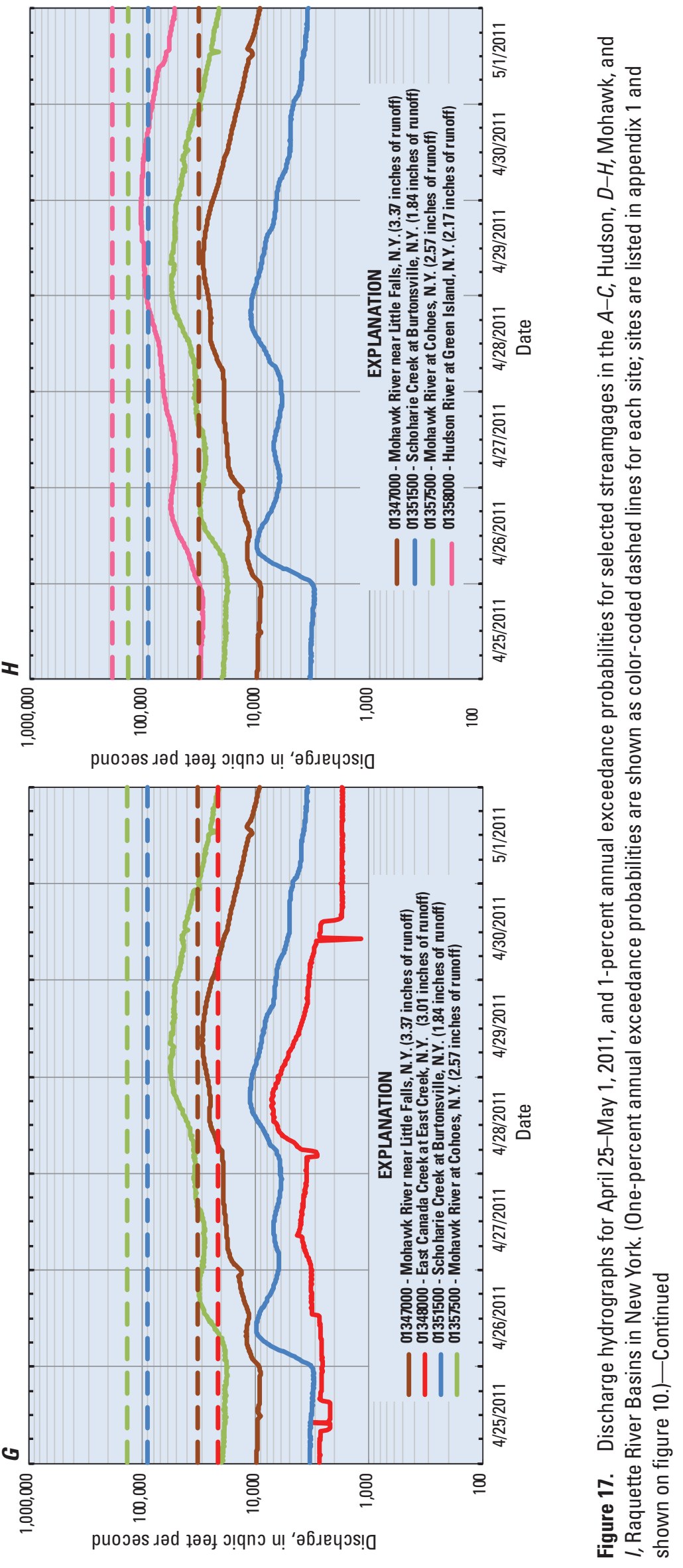



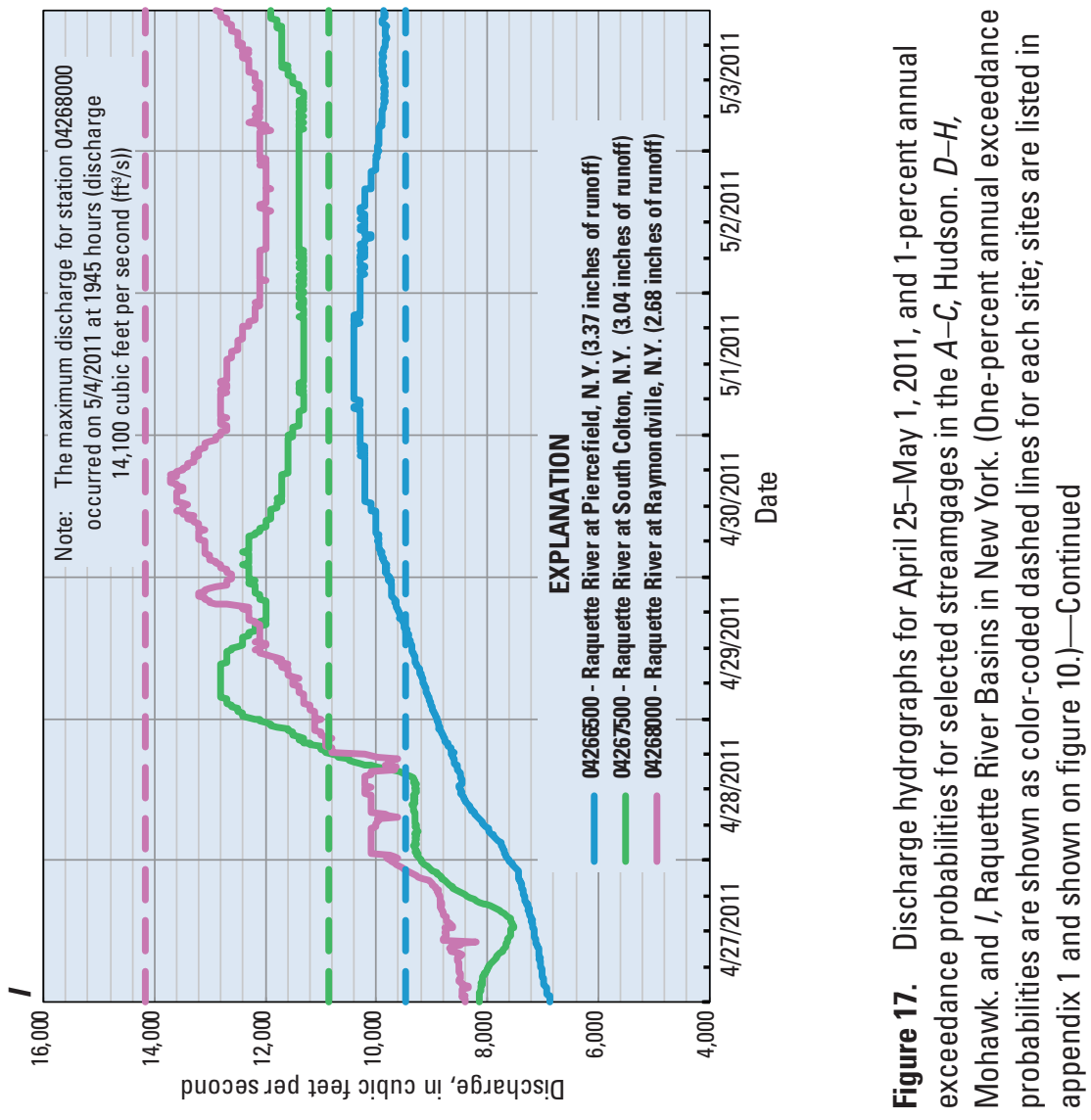

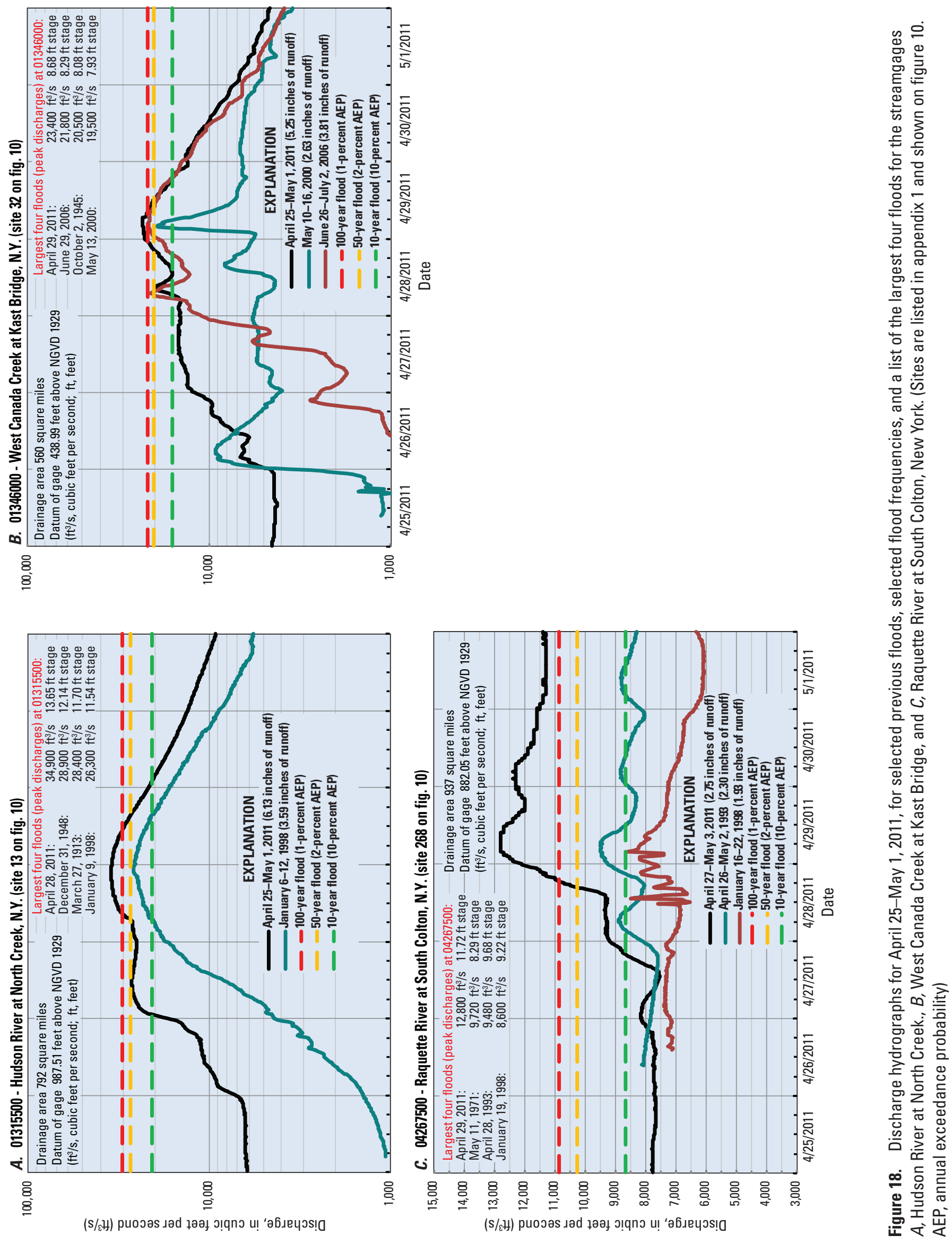

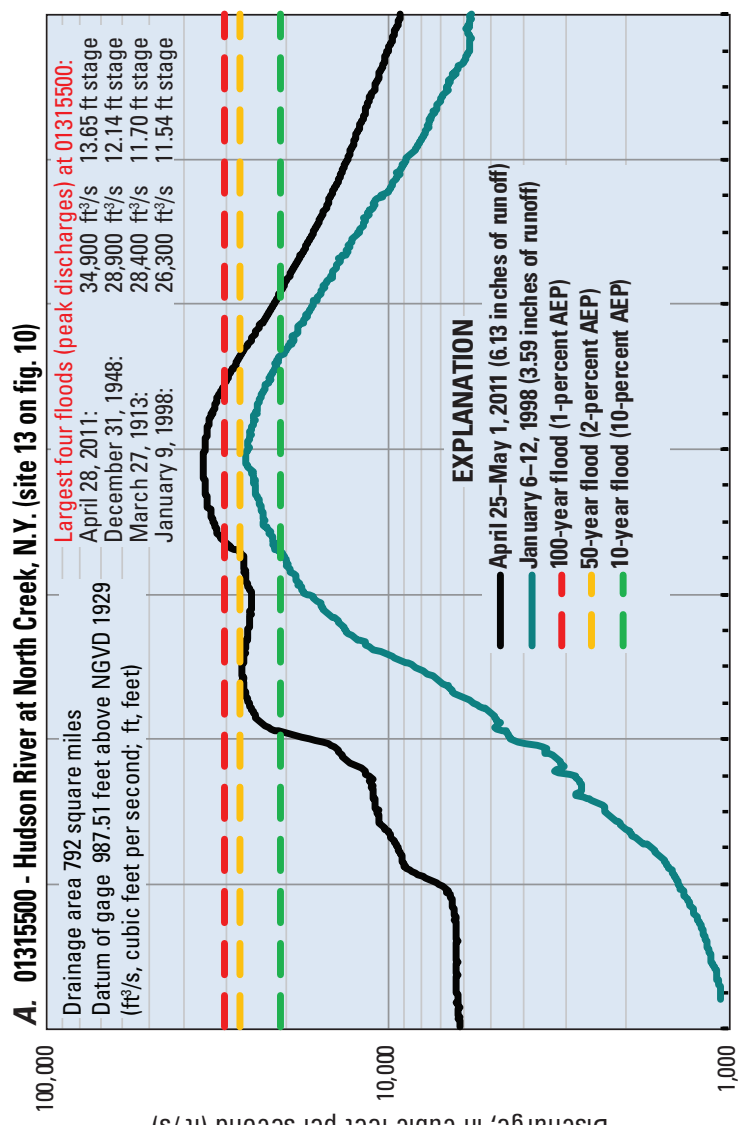

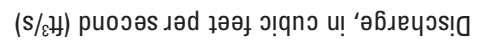

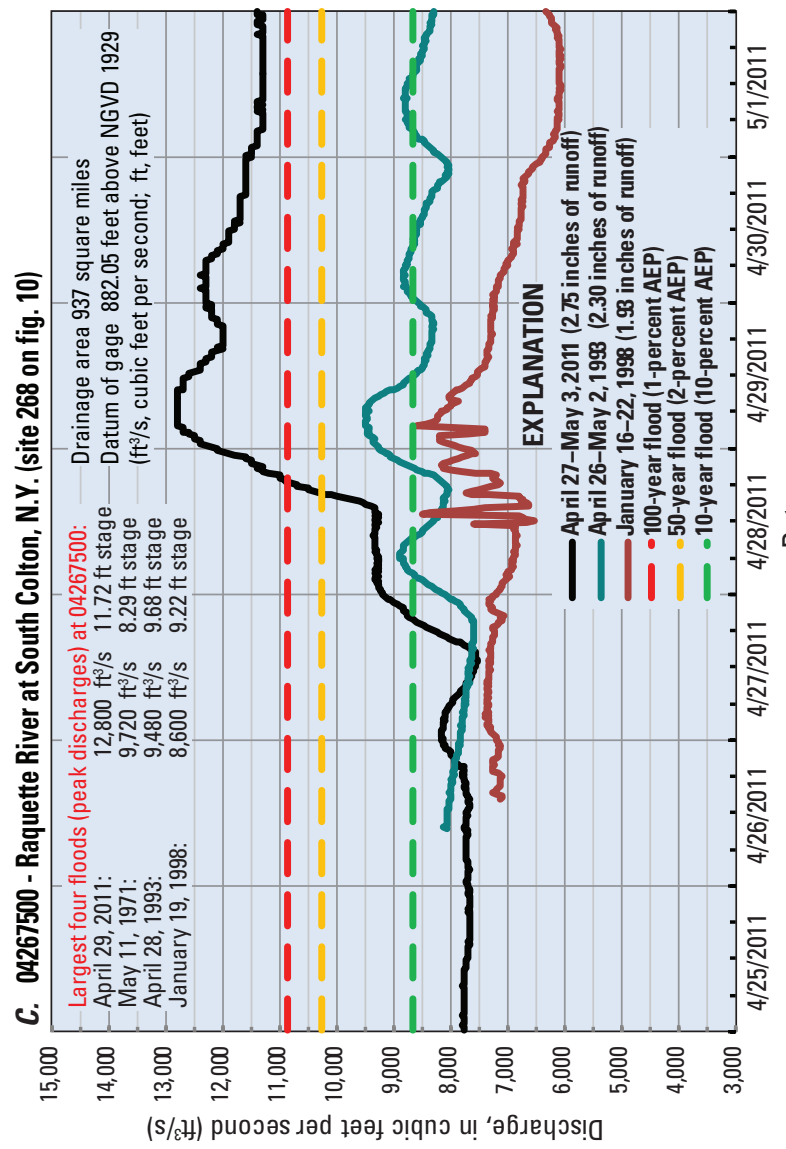

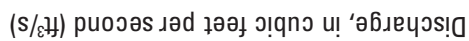




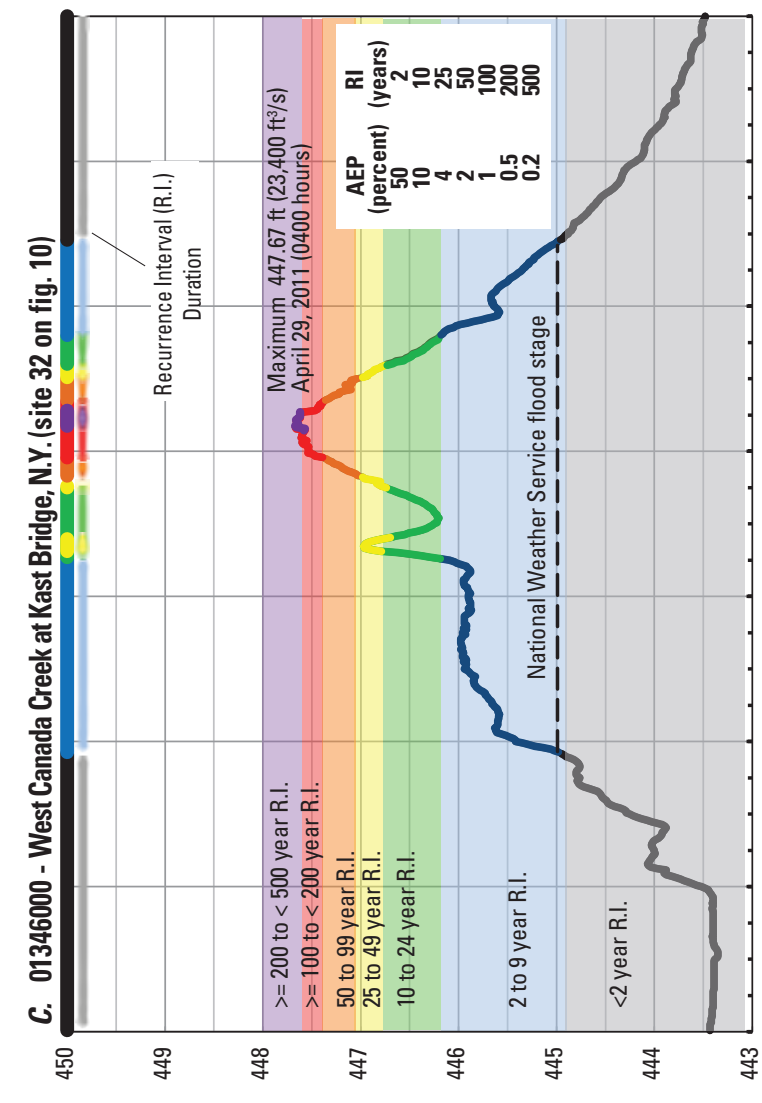

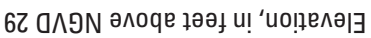

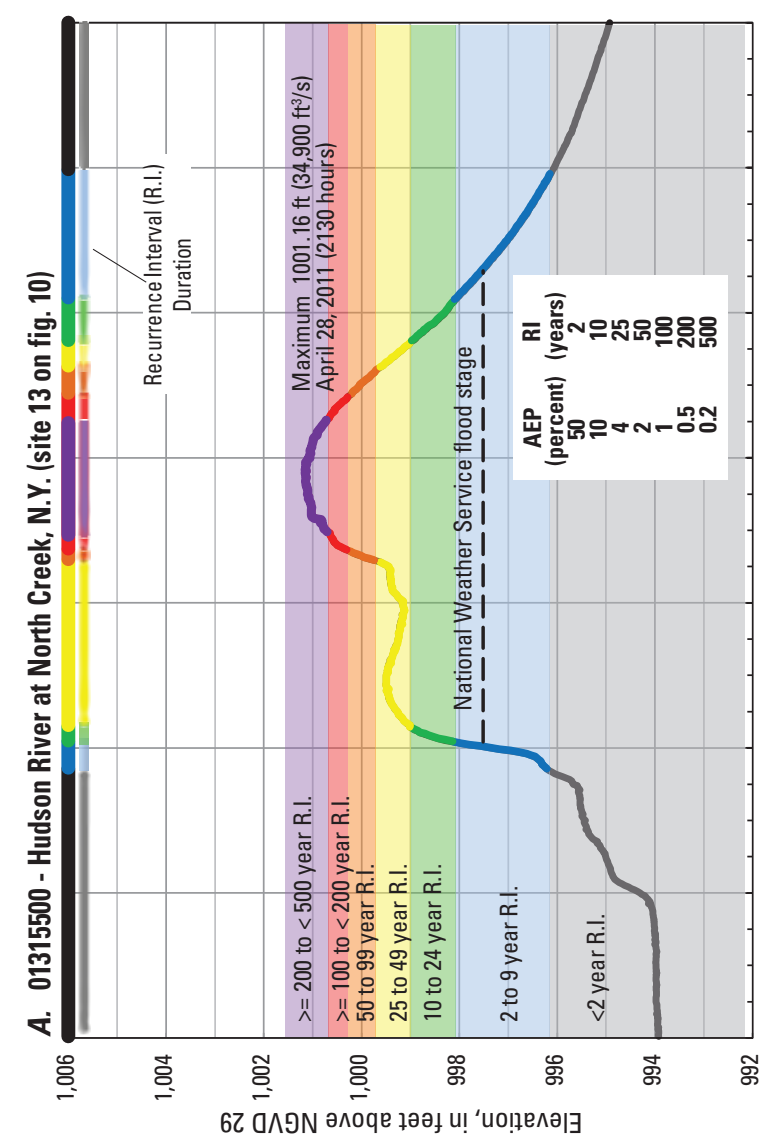

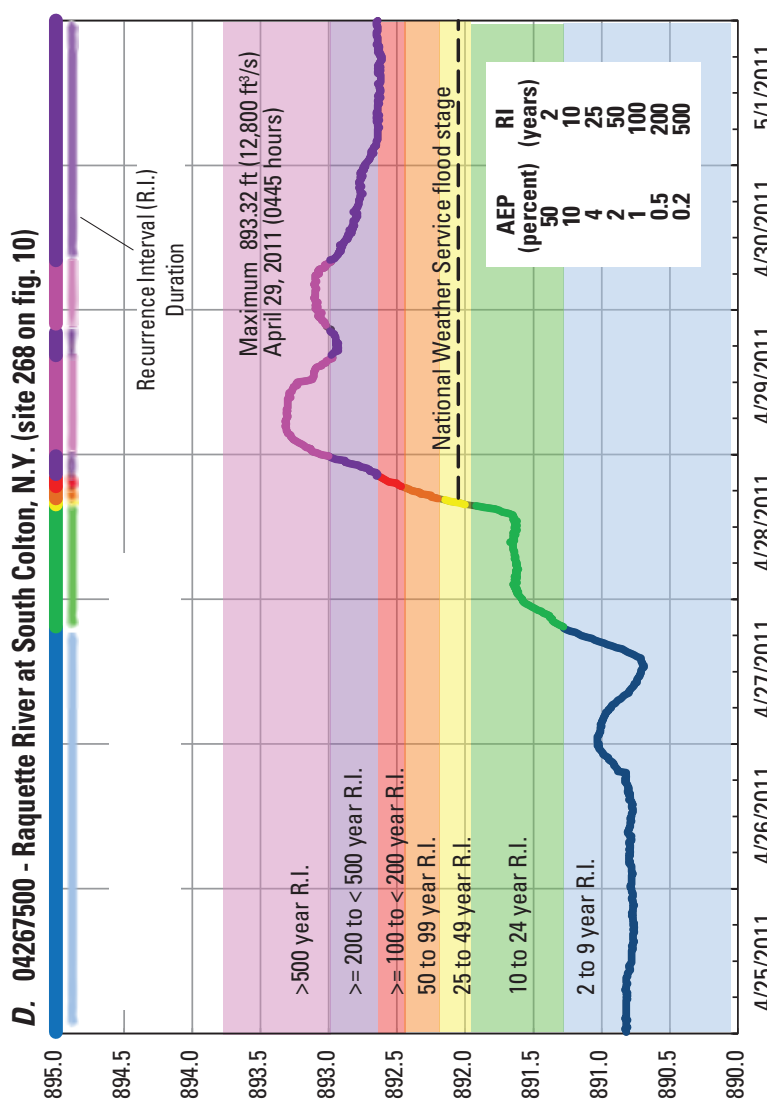

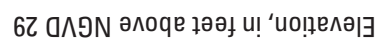

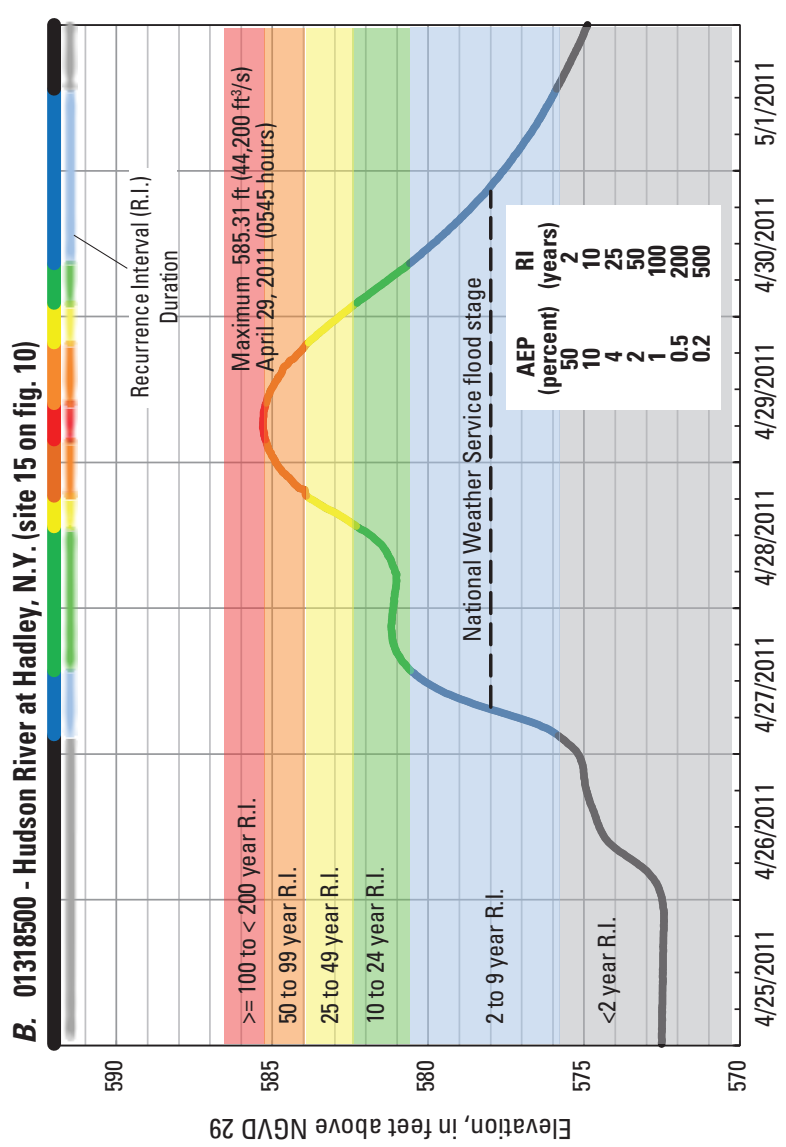

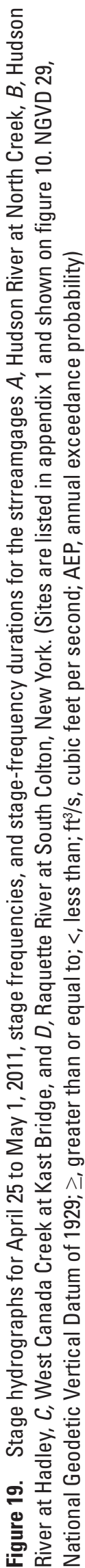


Table 7. High-water marks collected by the New York State Department of Environmental Conservation at 17 selected sites along the upper Hudson River in New York during the flood of April 26-29, 2011.

[Latitude, longitude, and elevation are from the New York State Department of Environmental Conservation (NYSDEC, written commun., 2012); HWM ID, high-water-mark identification; latitude and longitude in decimal degrees, North American Datum of 1983 (NAD 83); elevation in feet above North American Vertical Datum of 1988 (NAVD 88); locations are shown in fig. 20]

\begin{tabular}{|c|c|c|c|c|c|}
\hline Site number & NYSDEC HWM ID & Site name & Latitude & Longitude & Elevation \\
\hline 1 & DEC29 & Hudson River at Lake Luzerne, N.Y. & 43.31440 & -73.83815 & 561.21 \\
\hline 2 & DEC17 & Hudson River downstream of Lake Luzerne, N.Y. & 43.30702 & -73.83315 & 558.72 \\
\hline 4 & DEC15 & Hudson River at Corinth, N.Y. & 43.24923 & -73.83503 & 554.95 \\
\hline 5 & DEC13 & Hudson River upstream of Glens Falls, N.Y. & 43.26414 & -73.68142 & 291.72 \\
\hline 7 & DEC01 & Hudson River downstream of Fort Edward, N.Y. & 43.23162 & -73.59443 & 128.50 \\
\hline 8 & DEC03 & Hudson River downstream of Fort Edward, N.Y. & 43.22495 & -73.60682 & 128.45 \\
\hline 9 & DEC02 & Hudson River downstream of Fort Edward, N.Y. & 43.22945 & -73.58921 & 127.95 \\
\hline 10 & DEC11 & Hudson River upstream of Fort Miller, N.Y. & 43.16892 & -73.58586 & 122.56 \\
\hline 11 & DEC10 & Hudson River at Thomson, N.Y. & 43.12993 & -73.58549 & 109.76 \\
\hline 15 & DEC06 & Hudson River at Stillwater, N.Y. & 42.94069 & -73.64781 & 89.36 \\
\hline 16 & DEC05 & Hudson River at Stillwater, N.Y. & 42.93714 & -73.65689 & 81.78 \\
\hline 17 & $\mathrm{DEC} 04$ & Hudson River at Mechanicville, N.Y. & 42.91829 & -73.67601 & 74.90 \\
\hline
\end{tabular}

Inflows to each lake and reservoir were computed and are plotted with outflows, elevations, and spillway elevations on figures $21 \mathrm{~A}-\mathrm{F}$. Lake elevations only are shown for Lake Champlain (fig. 21G). Most of the reservoirs attenuated or significantly reduced the resulting peak outflows to downstream reaches of each stream. For example, the maximum estimated daily inflow to Sacandaga Reservoir was 26,600 cubic feet per second $\left(\mathrm{ft}^{3} / \mathrm{s}\right)$ on April 28, whereas the maximum daily outflow was $12,300 \mathrm{ft}^{3} / \mathrm{s}$ on May 3 (fig. 21B), and the maximum daily inflow to Stillwater Reservoir was $4,540 \mathrm{ft}^{3} / \mathrm{s}$ on April 28, with a maximum daily outflow of 3,200 $\mathrm{ft}^{3} / \mathrm{s}$ on April 29 (fig. 21F). Inflows to Sacandaga Reservoir were estimated by a drainage-area adjustment of daily discharge data for upstream streamgage Sacandaga River near Hope (01321000), which accounts for 47 percent of the drainage area to the reservoir $\left(1,044 \mathrm{mi}^{2}\right)$.

The USGS New York Water Science Center operates two gages on Lake Champlain, one at the south end of the lake just north of Whitehall (04279085) and the other at the north end near the outlet of the lake at Rouses Point (04295000). The maximum lake stage (103.20 ft relative to NGVD 29) recorded at the Rouses Point gage on May 6 was the highest in 141 years of record (normal for May 6 is $98.8 \mathrm{ft}$ ) and the highest documented stage since at least 1827 (previous maximum stage was $102.1 \mathrm{ft}$ in 1869). The daily mean lake stages at Rouses Point were above $100 \mathrm{ft}$ from April 13 to June 17, 2011, (normally about $98.2 \mathrm{ft}$ ) and above $102 \mathrm{ft}$ from April 28 to June 4, 2011 (normally at $98.3 \mathrm{ft}$ ). The USGS also operates a gage on Lake Champlain at Burlington, Vermont (04294500), and water-surface elevations for each of the three lake gages during April 1-May 31, 2011, are plotted on figure $21 \mathrm{G}$. Winds and seiche caused different lake levels at specific times at each of the three gages.

\section{Flood Damage}

A state of emergency was declared by officials in several towns in New York during the severe flooding of April-May 2011, and the President of the United States declared 23 counties Federal disaster areas on June 10, 2011 (fig. 22; Federal Emergency Management Agency, 2011c). Hundreds of residents that live near the flooded areas, including many along the Hudson River, the Ausable River, and Saranac River, were asked to evacuate their homes because of the flooding. Several roads and bridges were damaged or destroyed throughout the flooded areas. The damage was not confined to northern areas: many counties in central and western New York, including Onondaga, Oneida, Otsego, Yates, Chemung, 


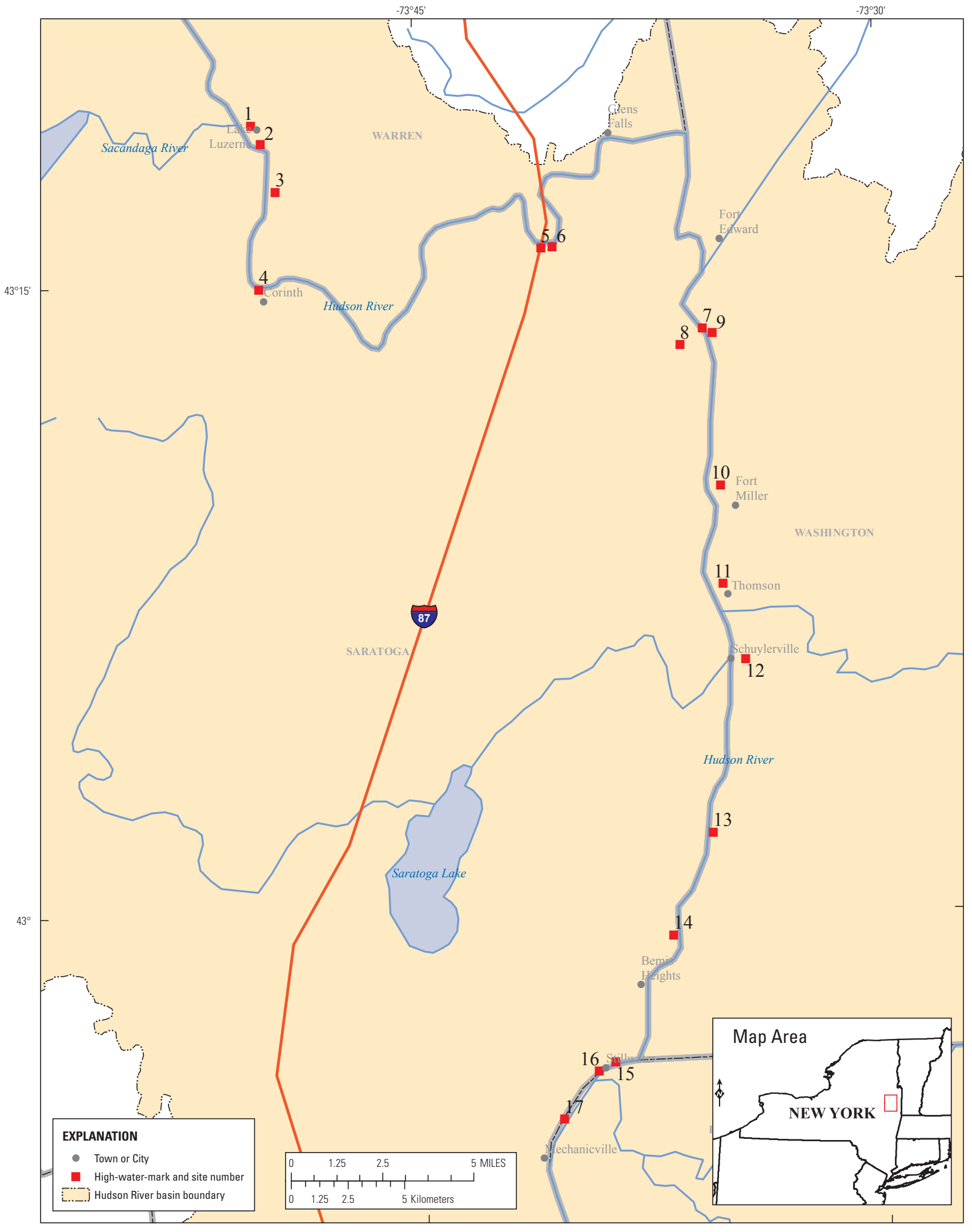

Base from U.S. Geological Survey Digital Data. Universal Transverse Mercator Projection, Zone 18N, NAD83

Figure 20. Locations of high-water marks collected for the flood of April 26-29, 2011, at selected sites along the upper Hudson River from Lake Luzerne to Mechanicville, New York. 


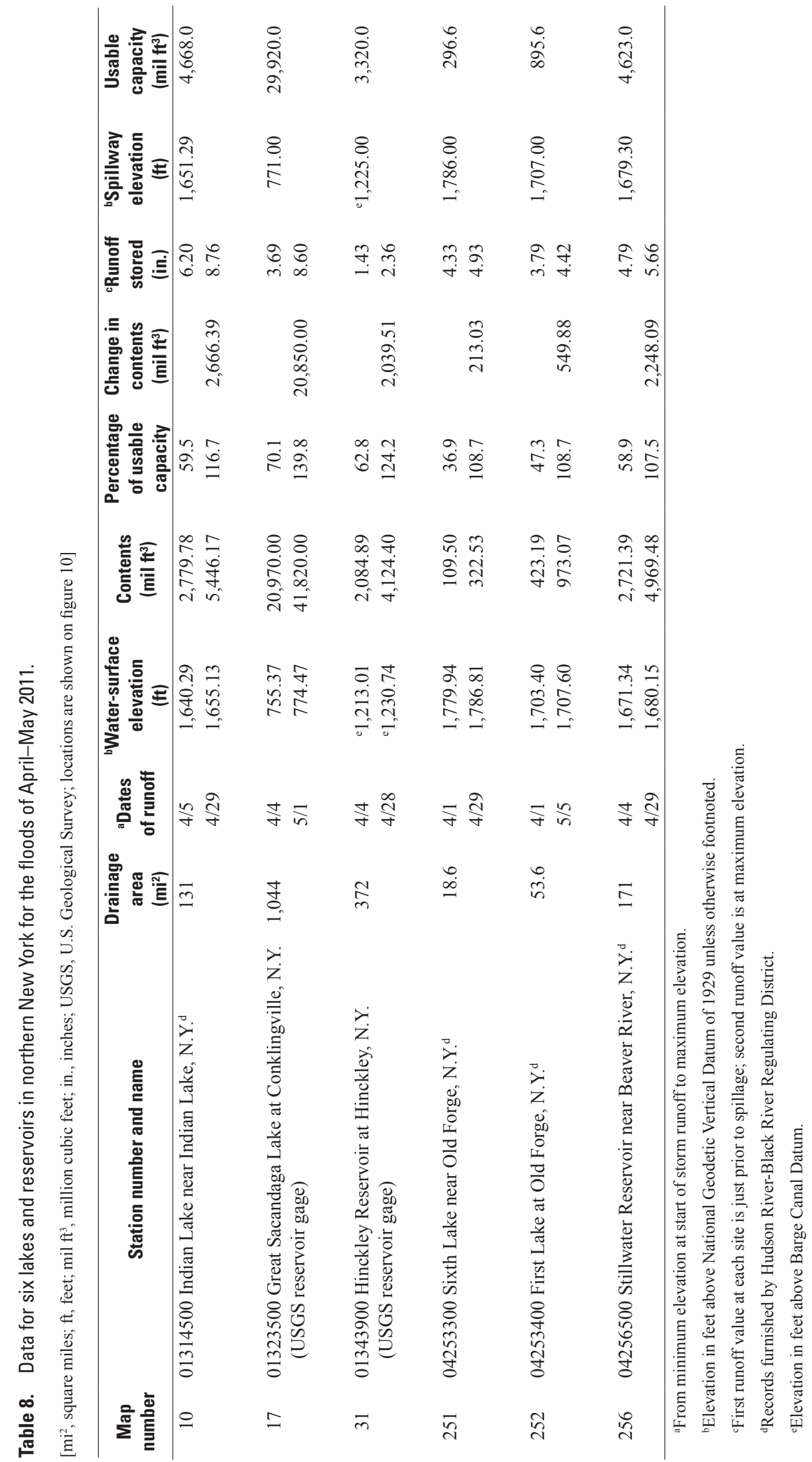




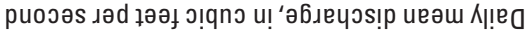

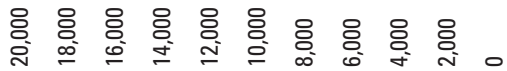

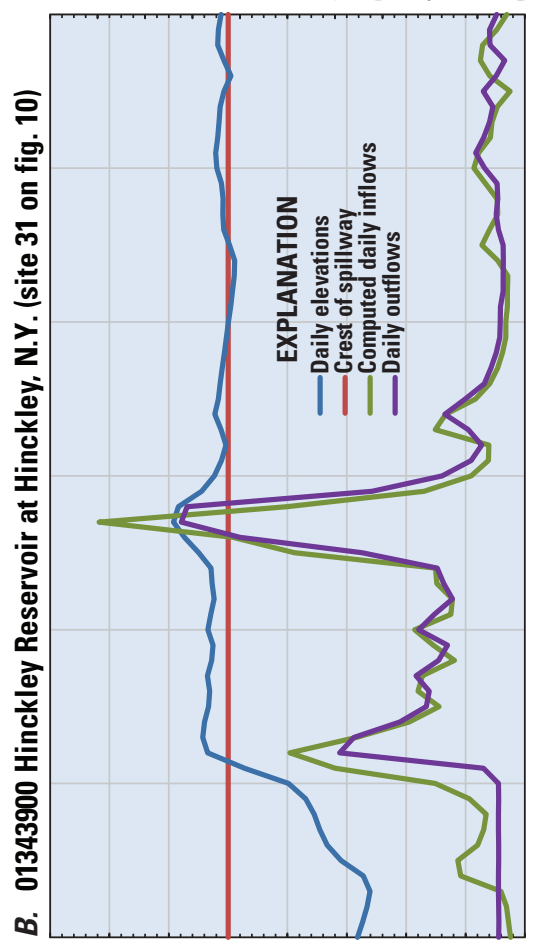

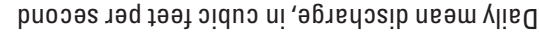

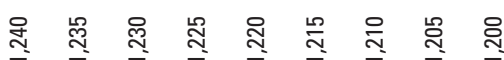

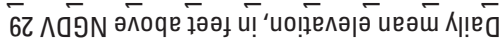

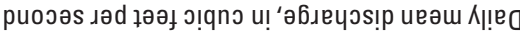

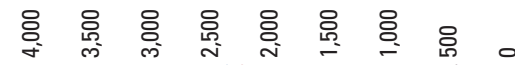
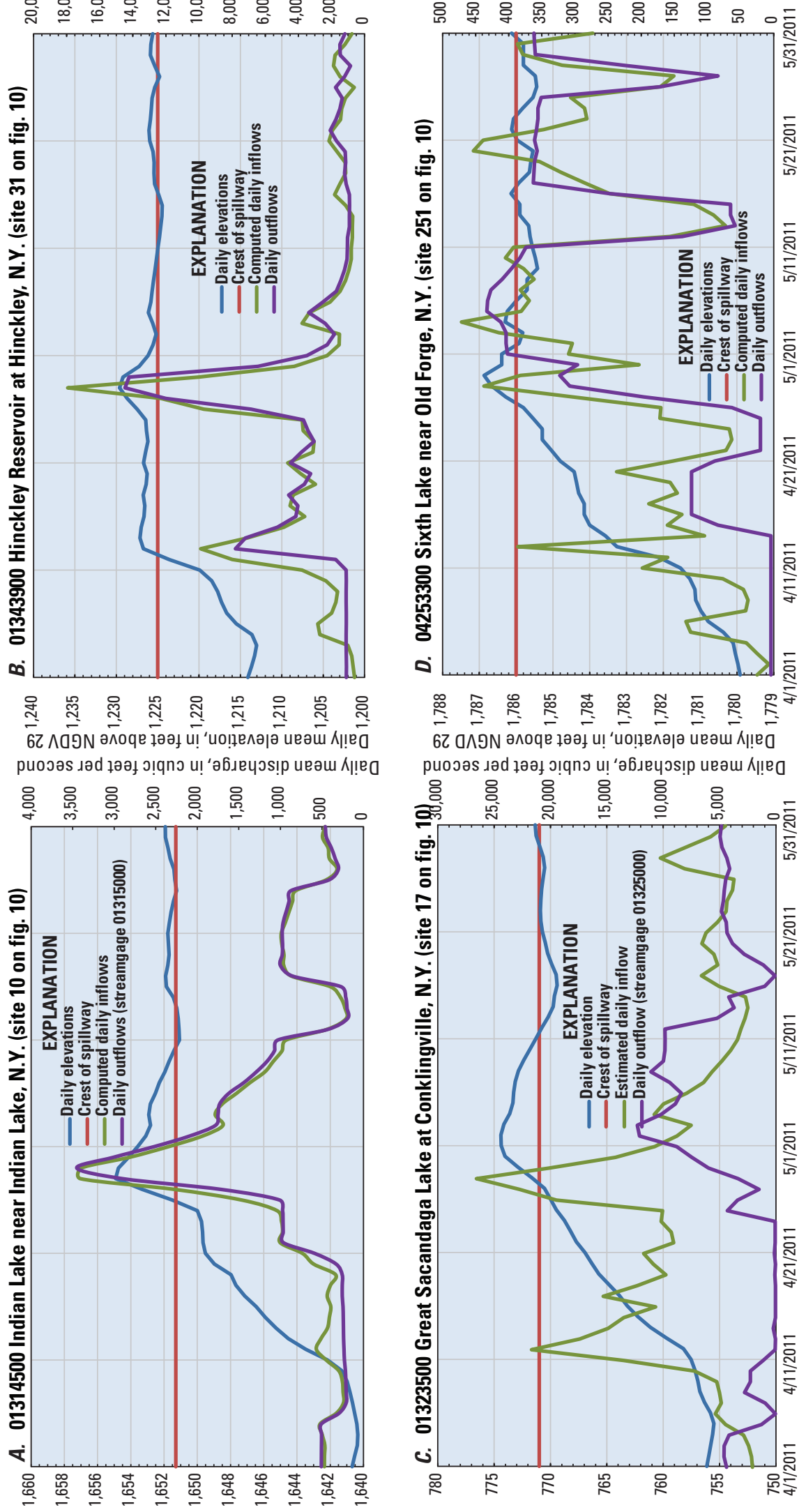

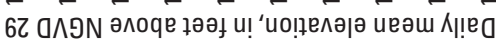

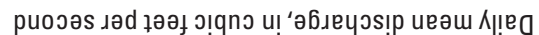
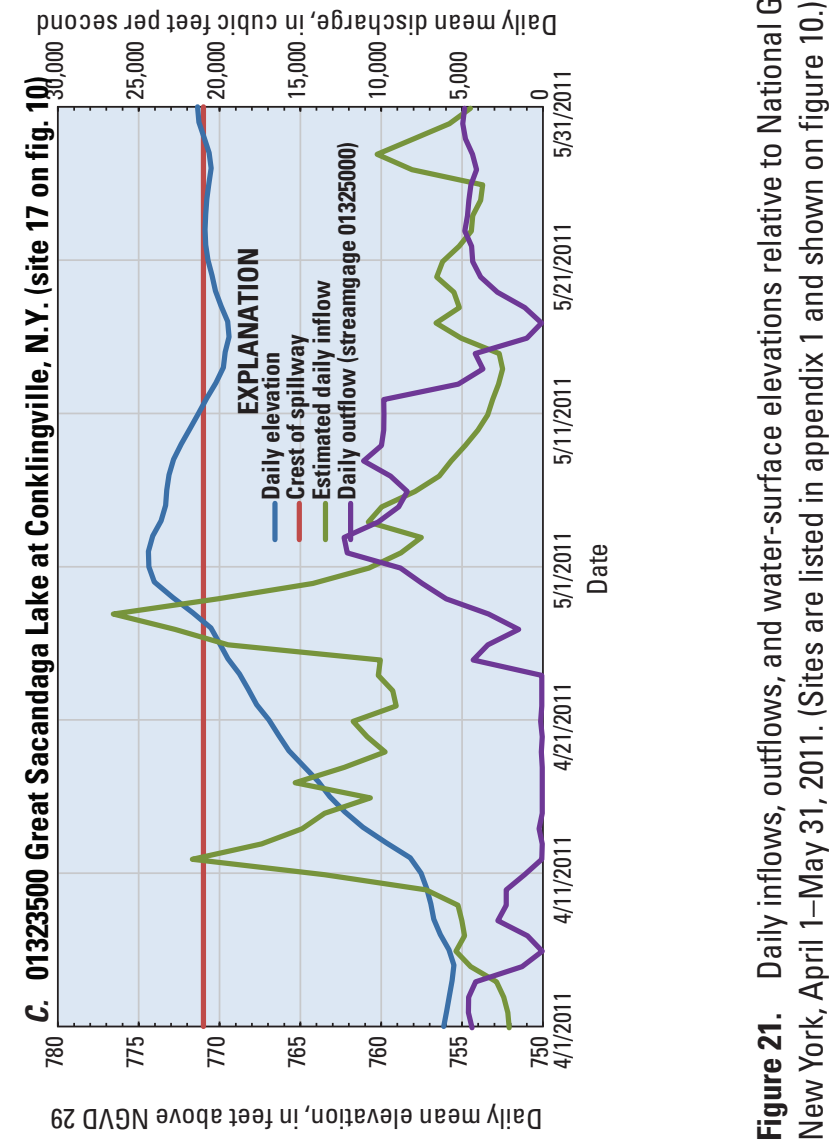

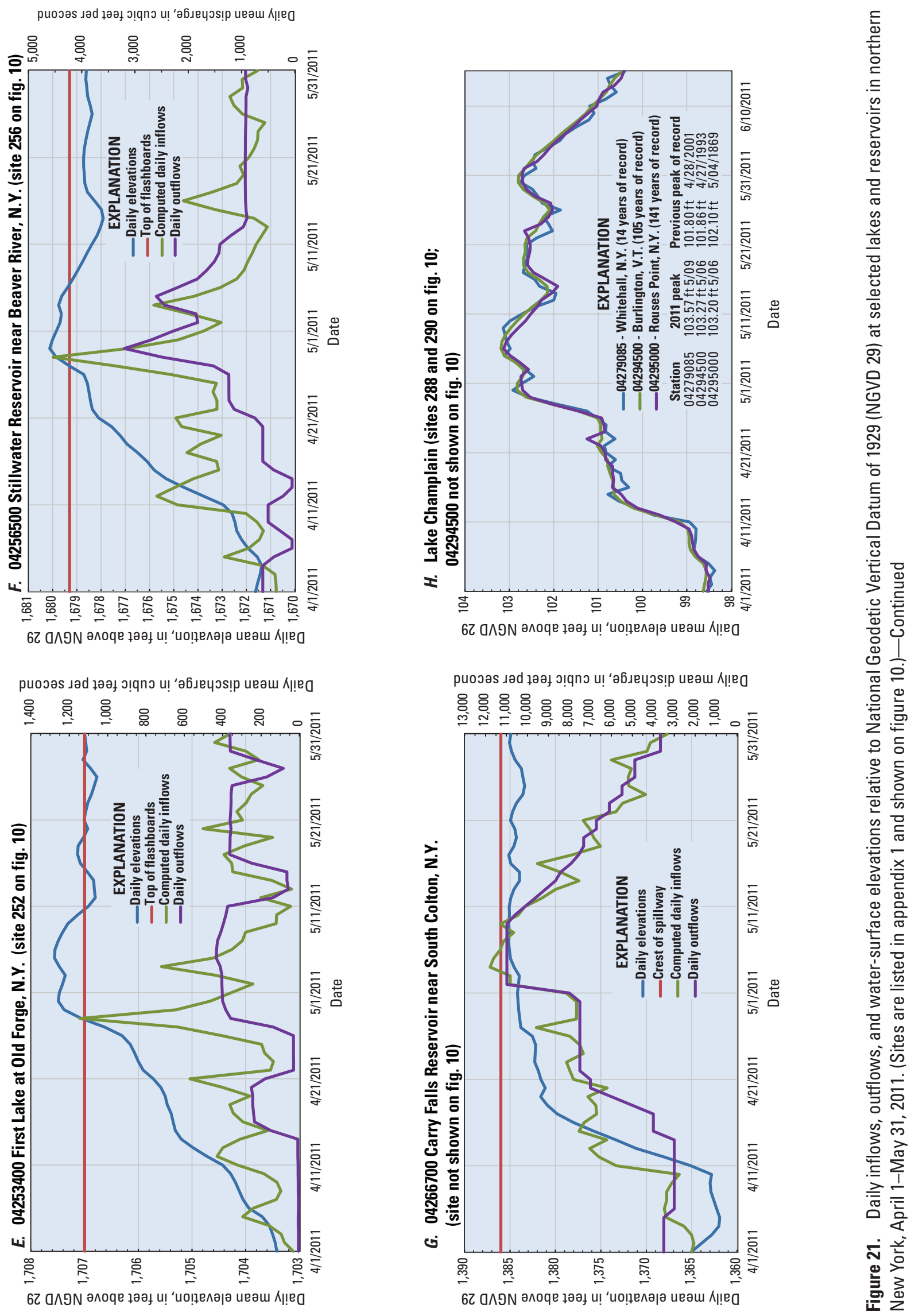

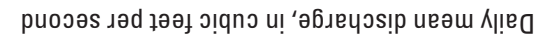

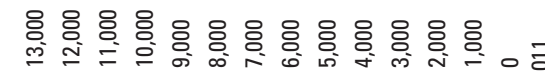

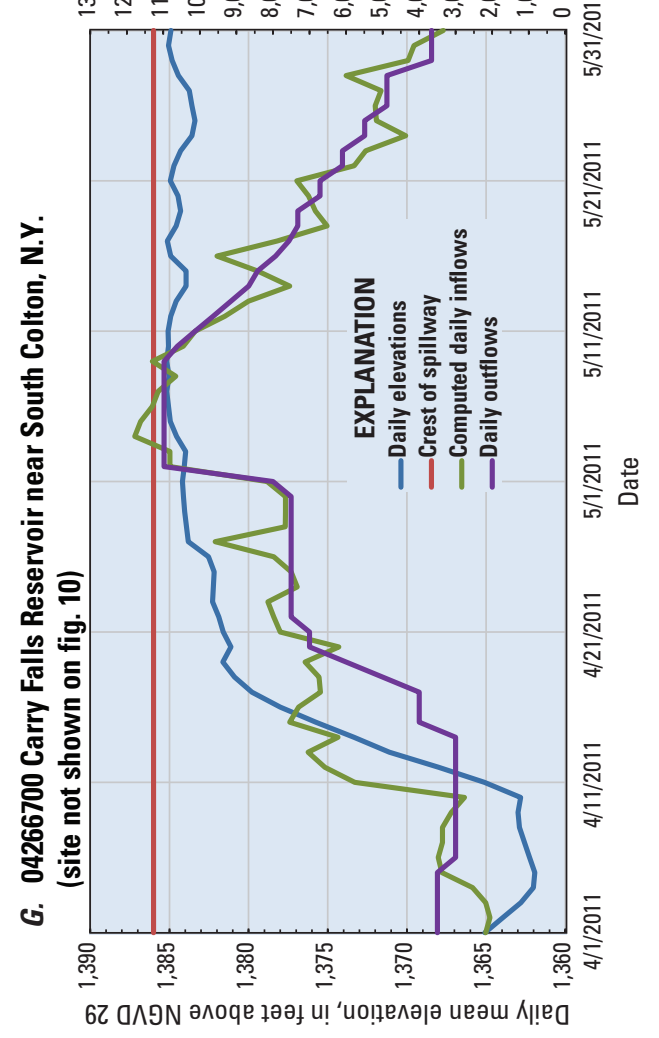

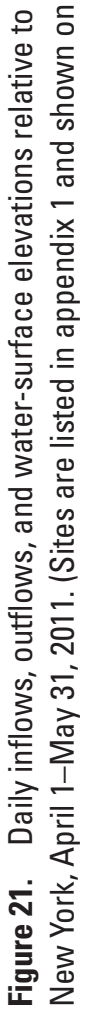



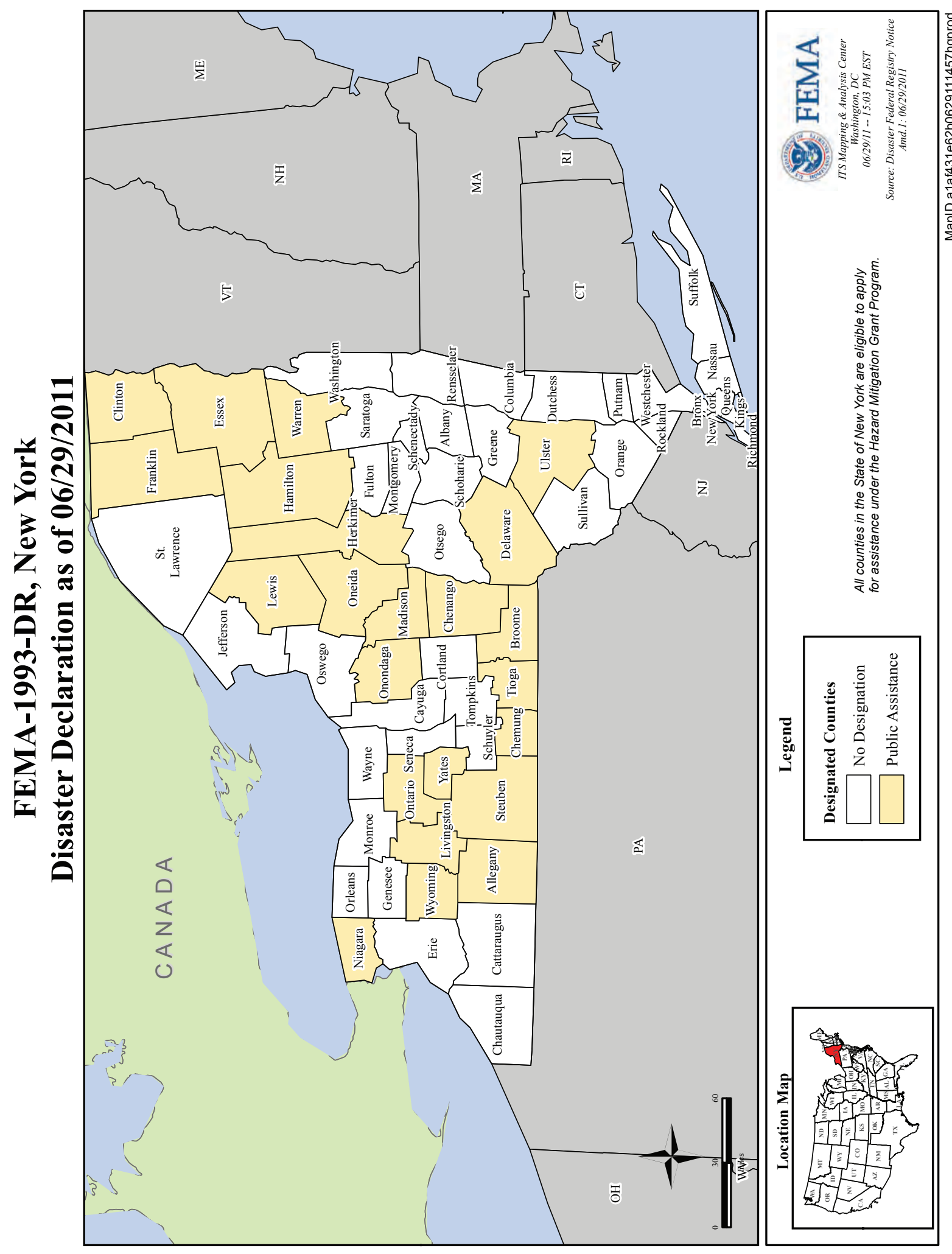

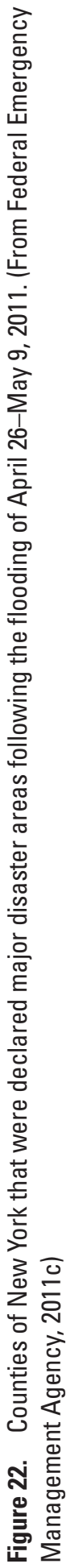


Tioga, Chenango, and Broome Counties, were affected as a result of flash floods on April 26-27. Severe storms in those areas produced tornadoes as reported in Oneida, Chemung, Tompkins, Steuben, and Chenango Counties. Several buildings were damaged, and many trees uprooted. Delaware and Rockland Counties in southeastern New York also incurred damage (National Oceanic and Atmospheric Administration, 2011n).

As the storm moved northeastward on April 27-28, many areas reported flooding of roadways, houses, bridges, and riverside camps. Flooding along the Hudson River in the North Creek area caused the closing of several roads as evacuations began. School districts in Indian Lake, Long Lake, and Johnsburg were closed on April 29 as a result of the flooding. The widespread flooding caused damage along West Canada Creek, Ausable River, Bouquet River, Raquette River, and downstream reaches of the Hudson River to parts of Fort Edward and Schuylerville, where one family had to be rescued from their Schuyler Island home. The New York State Canal Corporation (NYSCC) delayed opening of the New York State Canal System because of high waters and flows. The above-normal snowpack and rainfall within the Lake Champlain Basin caused record flooding accompanied by winds and seiche, which created problems in Whitehall and many other areas along the lakeshore. Many roads, hundreds of homes, and several businesses were damaged, and ferry services at several locations were delayed or closed during the flooding, which continued well into May. In Jefferson County, flooding along the Black River resulted in the death of a 67-year old man who drowned after his canoe overturned near Dexter (National Oceanic and Atmospheric Administration, 2011n). The April-May 2011 flood required nearly \$60 million in Federal disaster assistance (through April 4, 2013) to be disbursed for damages throughout many flooded areas of New York (Federal Emergency Management Agency, 2013b).

\section{Storm and Floods of August 28-29, 2011 (Tropical Storm Irene)}

Remnants of Hurricane Irene entered New York State on August 28 as a tropical storm and traveled up the eastern corridor of the State, leaving an unprecedented path of destruction in many parts of New York. Thirty-one counties in New York were declared Federal disaster areas with damages of over $\$ 1.3$ billion dollars and 10 deaths reported (Federal Emergency Management Agency, 2011a). Storm rainfall exceeded 18 in. in the Catskill Mountains area of southeastern New York with many other areas of eastern New York receiving over 7 in. Catastrophic flooding resulted from the extreme rainfall in many locations, including Schoharie Creek and its tributaries, the eastern Delaware River Basin, the Ausable and Bouquet River Basins in northeastern New York, and several other stream basins throughout southeastern New York. Downstream reaches of the Mohawk River also had substantial flooding. The USGS surveyed $184 \mathrm{HWMs}$ at 30 locations along an 84-mile (mi) reach of Schoharie Creek and compared the elevations to those published by FEMA at those locations for the 10-, 2-, 1-, and 0.2-percent AEP floods.

On August 28, Tropical Storm Irene moved inland and north through New York bringing torrential rains, which resulted in catastrophic flooding and damage to many areas of eastern New York. Record storm rainfall totals were reported at several NWS stations in the Catskill Mountains area. Record stream stages and discharges were recorded at 62 streamgages throughout eastern New York, and peak discharges at 25 of the streamgages exceeded the 1-percent AEP discharge with 6 sites in the Schoharie Creek Basin exceeding the 0.2-percent AEP discharge. Reservoir inflow, outflow, and stage data in and around the Catskill Mountains area indicate that some floodwaters were stored, but most reservoir water elevations exceeded those of their spillways on August 28.

\section{Antecedent Conditions}

Precipitation during June-July 2011 in eastern New York was generally below normal in the Lake Champlain Valley, normal in the lower Hudson River Valley, and slightly above normal in the Catskill Mountains area of southeastern New York. The relatively normal rainfalls of early summer were in stark contrast to the excessive precipitation to come in August.

Streamflows in eastern New York were normal at the beginning of August. Discharges at three streamgages (figs. 23A-C) in the most heavily flooded areas are representative of antecedent-flow conditions prior to the arrival of Tropical Storm Irene on August 28. A few storms with 1 to 2 in. of rain during mid-August saturated the soils and caused streamflows in the Catskill Mountains area to increase to more than the 25 th percentile of their long-term daily flows and remain high as Tropical Storm Irene approached (figs. 23A-B). The Ausable River at Au Sable Forks (04275500) is a tributary to Lake Champlain in northeastern New York, and flow was normal to slightly above normal prior to the arrival of Tropical Storm Irene (fig. 23C).

\section{Precipitation}

Tropical Storm Irene (formerly Hurricane Irene) made its ninth and final landfall along the eastern seaboard over New York City on August 28, 2011, with a massive circulation covering the entire northeastern United States. As the storm moved north-northeast through New York on August 28-29, rainfall totals exceeded 18 in. in some areas of the Catskill Mountains of southeastern New York (18.12 in. at Maplecrest) with many other areas of eastern New York receiving over 7 in. (table 9; National Oceanic and Atmospheric Administration, 2011b, c, e, g; New York City Department of Environmental Protection, written commun., 2012). Over $10 \mathrm{in}$. of rain was reported in the higher elevations of the 

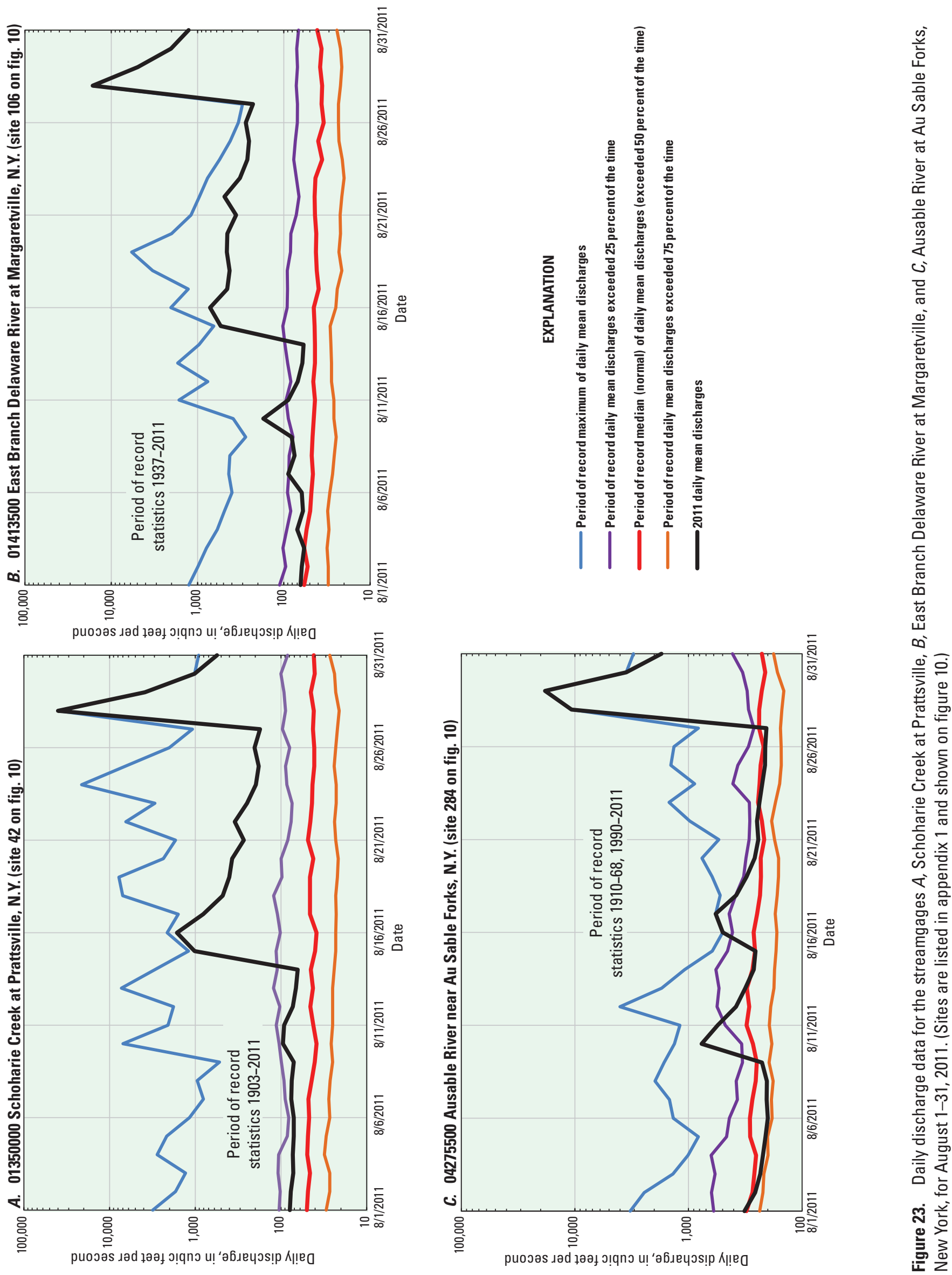
Table 9. Rainfall for the storm of August 28-29, 2011, at selected locations in New York and surrounding areas.

[Data provided by the National Oceanic and Atmospheric Administration (2011b, c, e, g; written commun., 2012), and New York City Department of Environmental Protection (NYCDEP, written commun., 2012); N, north; S, south; E, east; W, west; locations are shown on figure 25]

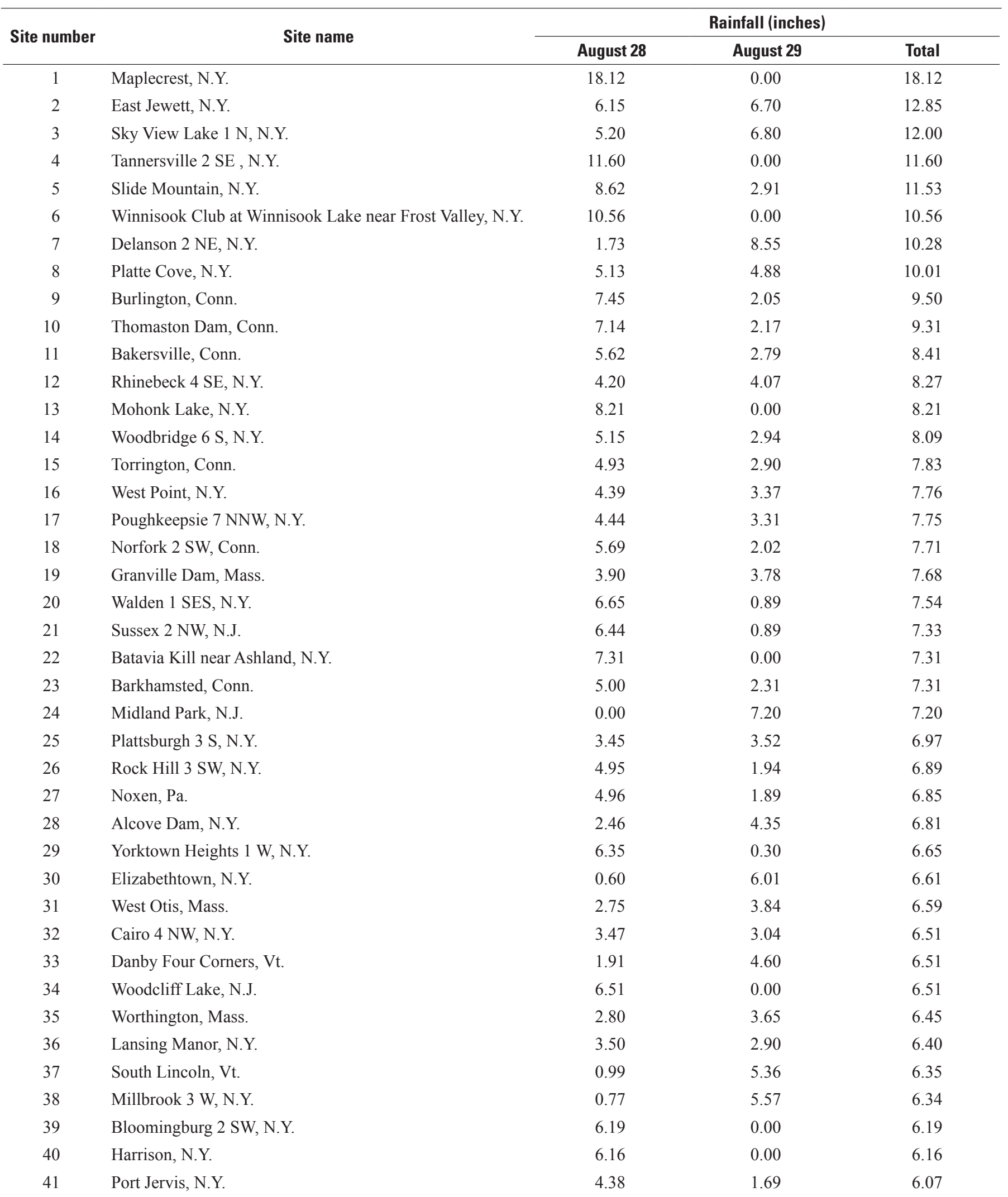


Table 9. Rainfall for the storm of August 28-29, 2011, at selected locations in New York and surrounding areas.-Continued

[Data provided by the National Oceanic and Atmospheric Administration (2011b, c, e, g; written commun., 2012), and New York City Department of Environmental Protection (NYCDEP, written commun., 2012); N, north; S, south; E, east; W, west; locations are shown on figure 25]

\begin{tabular}{|c|c|c|c|c|}
\hline \multirow{2}{*}{ Site number } & \multirow{2}{*}{ Site name } & \multicolumn{3}{|c|}{ Rainfall (inches) } \\
\hline & & August 28 & August 29 & Total \\
\hline 42 & Poughkeepsie Dutchess County Airport, N.Y. & 5.95 & 0.00 & 5.95 \\
\hline 44 & Valatie 1 N, N.Y. & 1.93 & 3.93 & 5.86 \\
\hline 45 & Sandy Hook, N.J. & 0.00 & 5.80 & 5.80 \\
\hline 47 & Gouldsboro, Pa. & 4.62 & 1.03 & 5.65 \\
\hline 48 & Susquehanna, $\mathrm{Pa}$. & 4.12 & 1.52 & 5.64 \\
\hline 49 & Chittenden, Vt. & 0.67 & 4.96 & 5.63 \\
\hline 50 & Buskirk, N.Y. & 1.26 & 4.36 & 5.62 \\
\hline 51 & Clinton Corners, N.Y. & 5.60 & 0.00 & 5.60 \\
\hline 55 & Dalton, Mass. & 2.36 & 3.00 & 5.36 \\
\hline 56 & Ellensburg Depot, N.Y. & 5.20 & 0.11 & 5.31 \\
\hline 57 & Mineola, N.Y. & 1.34 & 3.96 & 5.30 \\
\hline 58 & Stanfordville, Conn. & 2.40 & 2.88 & 5.28 \\
\hline 59 & Putnam Lake, Conn. & 5.26 & 0.01 & 5.27 \\
\hline 60 & Ruoff Farm near Chichester, N.Y. & 5.26 & 0.00 & 5.26 \\
\hline 61 & Richfield Springs 1 ESE, N.Y. & 0.93 & 4.31 & 5.24 \\
\hline 62 & Dannemora, N.Y. & 3.30 & 1.90 & 5.20 \\
\hline 69 & NYCDEP Property near New Kingston, N.Y. & 4.98 & 0.00 & 4.98 \\
\hline 70 & Claryville, N.Y. & 3.12 & 1.76 & 4.88 \\
\hline 71 & Liberty I NE, N.Y. & 4.10 & 0.77 & 4.87 \\
\hline 72 & North Adams Harriman Airport, Mass. & 4.85 & 0.00 & 4.85 \\
\hline 73 & Norwich, N.Y. & 1.23 & 3.60 & 4.83 \\
\hline 74 & Hawley 4 NE, Pa. & 3.78 & 1.03 & 4.81 \\
\hline 75 & Montrose $6 \mathrm{SSW}, \mathrm{Pa}$. & 2.34 & 2.46 & 4.80 \\
\hline 76 & Moscow, N.Y. & 3.94 & 0.85 & 4.79 \\
\hline 77 & Miele Farm near Bovina, N.Y. & 4.79 & 0.00 & 4.79 \\
\hline 78 & Hawley, Pa. & 4.73 & 0.01 & 4.74 \\
\hline 79 & Lake Luzerne, N.Y. & 1.18 & 3.52 & 4.70 \\
\hline 80 & Windsor, N.Y. & 2.40 & 2.30 & 4.70 \\
\hline 81 & Albany International Airport, N.Y. & 4.69 & 0.00 & 4.69 \\
\hline 82 & Rutland, Vt. & 1.37 & 3.16 & 4.53 \\
\hline
\end{tabular}


Table 9. Rainfall for the storm of August 28-29, 2011, at selected locations in New York and surrounding areas.-Continued

[Data provided by the National Oceanic and Atmospheric Administration (2011b, c, e, g; written commun., 2012), and New York City Department of Environmental Protection (NYCDEP, written commun., 2012); N, north; S, south; E, east; W, west; locations are shown on figure 25]

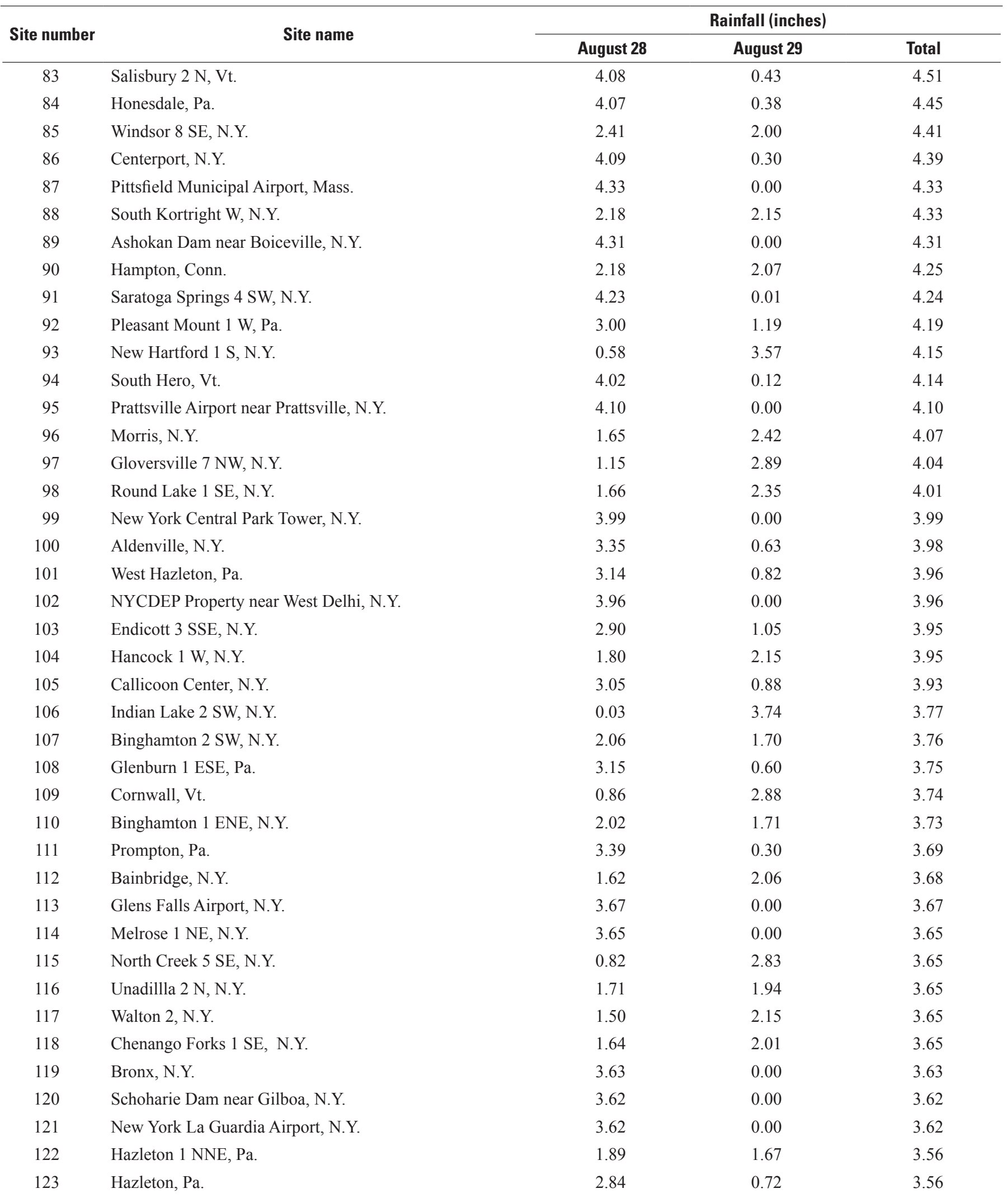


Table 9. Rainfall for the storm of August 28-29, 2011, at selected locations in New York and surrounding areas.-Continued

[Data provided by the National Oceanic and Atmospheric Administration (2011b, c, e, g; written commun., 2012), and New York City Department of Environmental Protection (NYCDEP, written commun., 2012); N, north; S, south; E, east; W, west; locations are shown on figure 25]

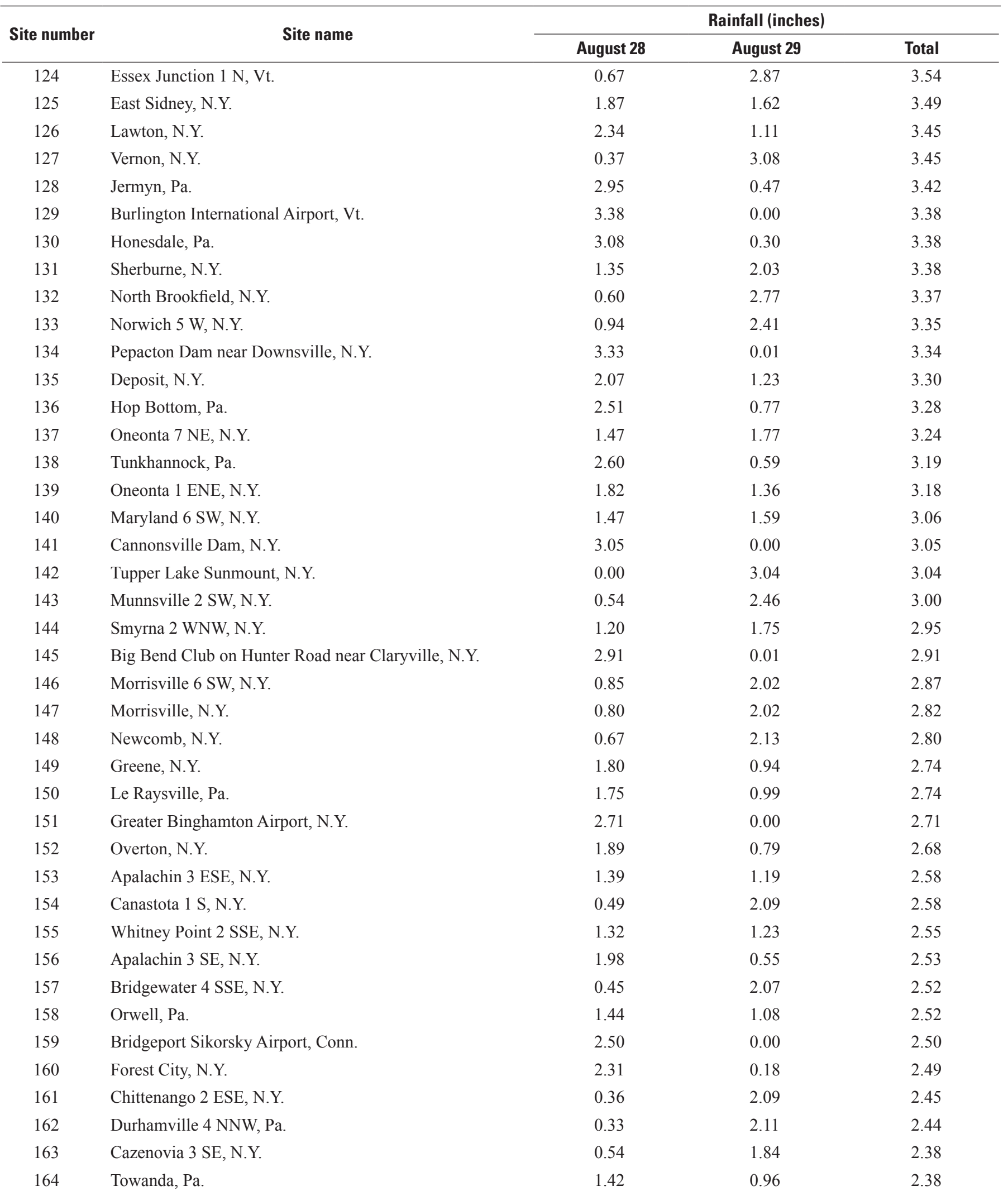


Table 9. Rainfall for the storm of August 28-29, 2011, at selected locations in New York and surrounding areas.-Continued

[Data provided by the National Oceanic and Atmospheric Administration (2011b, c, e, g; written commun., 2012), and New York City Department of Environmental Protection (NYCDEP, written commun., 2012); N, north; S, south; E, east; W, west; locations are shown on figure 25]

\begin{tabular}{|c|c|c|c|c|}
\hline \multirow{2}{*}{ Site number } & \multirow{2}{*}{ Site name } & \multicolumn{3}{|c|}{ Rainfall (inches) } \\
\hline & & August 28 & August 29 & Total \\
\hline 165 & Earlville, N.Y. & 0.74 & 1.62 & 2.36 \\
\hline 167 & Riverhead Research Farm, N.Y. & 2.33 & 0.00 & 2.33 \\
\hline 168 & Westmoreland 4 N, N.Y. & 0.43 & 1.83 & 2.26 \\
\hline 170 & Candor 3 NE, N.Y. & 0.91 & 1.31 & 2.22 \\
\hline 171 & Berkshire 2 ENE, N.Y. & 1.22 & 0.98 & 2.20 \\
\hline 172 & Holland Patent 2 WSW, N.Y. & 0.37 & 1.81 & 2.18 \\
\hline 173 & Candor 2 SE, N.Y. & 1.01 & 1.14 & 2.15 \\
\hline 174 & Cooperstown, N.Y. & 2.10 & 0.04 & 2.14 \\
\hline 178 & Whitney Point Dam, N.Y. & 0.92 & 1.14 & 2.06 \\
\hline 179 & Cortland, N.Y. & 0.98 & 1.07 & 2.05 \\
\hline 180 & Big Moose 3 SE, N.Y. & 1.75 & 0.29 & 2.04 \\
\hline 181 & Old Forge, N.Y. & 0.40 & 1.62 & 2.02 \\
\hline 182 & Highmarket, N.Y. & 0.01 & 1.95 & 1.96 \\
\hline 183 & Boonville 4 SSW, N.Y. & 0.32 & 1.62 & 1.94 \\
\hline 184 & East Smithfield, N.Y. & 1.35 & 0.56 & 1.91 \\
\hline 185 & Tully 2 WSW, N.Y. & 0.46 & 1.44 & 1.90 \\
\hline 192 & Powell, Pa. & 1.11 & 0.68 & 1.79 \\
\hline 193 & Boonville 8 E, N.Y. & 0.24 & 1.53 & 1.77 \\
\hline 194 & Equinunk, Pa. & 1.21 & 0.55 & 1.76 \\
\hline 195 & Cincinnatus, N.Y. & 0.90 & 0.80 & 1.70 \\
\hline 196 & New London Lock 22, N.Y. & 0.36 & 1.34 & 1.70 \\
\hline 197 & Smith Valley 2 SE, N.Y. & 0.67 & 0.96 & 1.63 \\
\hline 198 & East Ithaca 5 E, N.Y. & 0.70 & 0.92 & 1.62 \\
\hline 199 & Roseville 6 ENE, Pa. & 1.07 & 0.55 & 1.62 \\
\hline 200 & White Haven, Pa. & 1.15 & 0.46 & 1.61 \\
\hline 201 & Chemung, N.Y. & 1.03 & 0.56 & 1.59 \\
\hline 202 & Columbia Cross Roads, Pa. & 1.07 & 0.52 & 1.59 \\
\hline 203 & Griffiss Air Force Base, N.Y. & 0.42 & 1.12 & 1.54 \\
\hline 204 & De Witt 1 WSW, N.Y. & 0.30 & 1.23 & 1.53 \\
\hline 205 & Troy, Pa. & 0.92 & 0.56 & 1.48 \\
\hline
\end{tabular}


Table 9. Rainfall for the storm of August 28-29, 2011, at selected locations in New York and surrounding areas.-Continued

[Data provided by the National Oceanic and Atmospheric Administration (2011b, c, e, g; written commun., 2012), and New York City Department of Environmental Protection (NYCDEP, written commun., 2012); N, north; S, south; E, east; W, west; locations are shown on figure 25]

\begin{tabular}{|c|c|c|c|c|}
\hline \multirow{2}{*}{ Site number } & \multirow{2}{*}{ Site name } & \multicolumn{3}{|c|}{ Rainfall (inches) } \\
\hline & & August 28 & August 29 & Total \\
\hline 206 & Canton, $\mathrm{Pa}$. & 1.07 & 0.40 & 1.47 \\
\hline 207 & Groton 3 SSW, N.Y. & 0.66 & 0.75 & 1.41 \\
\hline 208 & Groton 1 NW, N.Y. & 0.61 & 0.79 & 1.40 \\
\hline 209 & Freeville 3 N, N.Y. & 0.61 & 0.78 & 1.39 \\
\hline 210 & Hooker 12 NNW, N.Y. & 0.00 & 1.35 & 1.35 \\
\hline 211 & Mecklenburg 4 SW, N.Y. & 0.53 & 0.82 & 1.35 \\
\hline 212 & Odessa 3 ENE, N.Y. & 0.80 & 0.53 & 1.33 \\
\hline 213 & Freeville 2 NE, N.Y. & 0.69 & 0.63 & 1.32 \\
\hline 214 & Hunts Corners, N.Y. & 0.80 & 0.50 & 1.30 \\
\hline 215 & Locke 2 W, N.Y. & 0.50 & 0.77 & 1.27 \\
\hline 216 & Southport 4 SSW, N.Y. & 0.87 & 0.38 & 1.25 \\
\hline 217 & Elmira 1 ESE, N.Y. & 0.82 & 0.42 & 1.24 \\
\hline 218 & Copenhagen, N.Y. & 0.00 & 1.23 & 1.23 \\
\hline 219 & Lowville, N.Y. & 0.26 & 0.95 & 1.21 \\
\hline 220 & Elmira, N.Y. & 0.82 & 0.37 & 1.19 \\
\hline 221 & Camden, N.Y. & 0.24 & 0.93 & 1.17 \\
\hline 222 & Elmira 1 WNW, N.Y. & 0.79 & 0.38 & 1.17 \\
\hline 223 & West Elmira 1 SSE, N.Y. & 0.71 & 0.46 & 1.17 \\
\hline 224 & Beaver Falls, N.Y. & 1.16 & 0.00 & 1.16 \\
\hline 225 & Horseheads $1 \mathrm{~W}, \mathrm{~N} . \mathrm{Y}$. & 0.68 & 0.38 & 1.06 \\
\hline 226 & Auburn, N.Y. & 0.20 & 0.78 & 0.98 \\
\hline 227 & Brewerton Lock 23, N.Y. & 0.03 & 0.95 & 0.98 \\
\hline 228 & Camillus $1 \mathrm{~W}$, N.Y. & 0.05 & 0.90 & 0.95 \\
\hline 229 & Burnett 1 ESE, N.Y. & 0.34 & 0.58 & 0.92 \\
\hline 230 & Big Flats 1 W, N.Y. & 0.57 & 0.34 & 0.91 \\
\hline 231 & South Corning 5 S, N.Y. & 0.67 & 0.21 & 0.88 \\
\hline 232 & Dundee 6 ESE, N.Y. & 0.49 & 0.36 & 0.85 \\
\hline 233 & Dundee 6 E, N.Y. & 0.33 & 0.50 & 0.83 \\
\hline 234 & Catlin, N.Y. & 0.52 & 0.24 & 0.76 \\
\hline 235 & Watkins Glen 5 NW, N.Y. & 0.31 & 0.44 & 0.75 \\
\hline 236 & Erin, N.Y. & 0.36 & 0.36 & 0.72 \\
\hline 237 & Liverpool 4 NNW, N.Y. & 0.02 & 0.65 & 0.67 \\
\hline 238 & Baldwinsville, N.Y. & 0.03 & 0.61 & 0.64 \\
\hline 239 & Corning, N.Y. & 0.33 & 0.25 & 0.58 \\
\hline 240 & Bath, N.Y. & 0.09 & 0.12 & 0.21 \\
\hline 241 & Waterloo, N.Y. & 0.00 & 0.08 & 0.08 \\
\hline 242 & Bently Creek, N.Y. & 0.04 & 0.00 & 0.04 \\
\hline 243 & Jasper, N.Y. & 0.00 & 0.04 & 0.04 \\
\hline 244 & Hornell, N.Y. & 0.00 & 0.01 & 0.01 \\
\hline
\end{tabular}


Catskill Mountains with East Jewett receiving 12.85 in. Radar images of total daily precipitation on August 28-29 (fig. 24) show the general track and intensity of the storm moving from the New York City area north over Lake Champlain (National Oceanic and Atmospheric Administration, 2011m). The eastern slopes of the Adirondack Mountains to Lake Champlain in northeastern New York received nearly 7 in. of rain during the storm. The distribution of the total 2-day rainfalls (fig. 25) details the extreme amounts in eastern New York compared to the total rainfall in areas west of the Catskill and Adirondack Mountains, which received minimal rainfall during the event.

Record rainfall intensities were measured at some weather stations including Tannersville in the Catskill Mountain area, where 11.60 in. fell in less than 24 hours (National Oceanic and Atmospheric Administration, 2011i). Accumulated hourly rainfalls plotted on figure 26 for several weather stations in eastern New York show that most of their total storm rainfall occurred in less than 24 hours. Rainfallfrequency data were compiled for four weather stations in eastern New York and one in western Vermont (table 10) for 6-, 12-, and 24-hour rainfall totals (Northeast Regional Climate Center, 2010). Rainfall totals at Tannersville, N.Y., for the three durations, were each equal to or greater than the 0.5-percent AEP (200-year recurrence interval) rainfall. August 2011 was the wettest August statewide and throughout eastern New York since at least 1895 (National Oceanic and Atmospheric Administration, 2011k). The lower Hudson River Valley averaged 12.04 in. of rain in August 2011, which is more than 8 in. above normal for the month.

\section{Flooding}

The heavy rains from Tropical Storm Irene over eastern New York resulted in record flooding at 60 active streamgages and two lake/reservoir gages during late August 2011. The prior peak discharge of record, peak discharges during the August 28-29, 2011 flood, and flood frequencies for 154 selected USGS streamgages are presented in table 11 (locations shown in fig. 10).

\section{Flood Discharge and Frequency}

The record floods at many streamgages from Tropical Storm Irene resulted in extreme flood frequencies in many areas of eastern New York as indicated by the associated drainage-basin color code shown on figure 27. A full-size view of the map on figure 27 can be accessed by the computer link at the end of the figure caption. The most extreme flooding was in and around the eastern Catskill Mountains area of southeastern New York and the eastern slopes of the Adirondack Mountains into the Champlain Valley. West of these areas, flooding was substantially less. Record floods were documented at 60 streamgages and two lake/reservoir gages, with 25 of them having AEP values equal to or less than 1 percent (greater than or equal to 100 years). Peak discharges plotted as a function of drainage area (fig. 28) for 94 streamgages where the August 2011 floods were the maximum for the year indicate that the August 2011 flood was near or exceeded both the previous peak discharge of record and the 1-percent AEP (100-year) discharge for most of the selected sites. The documented August 2011 flows span a wide range of basin sizes (fig. 28).

The Schoharie Creek Basin was particularly hard hit by the August flooding. Three of the six streamgages on Schoharie Creek recorded peak discharges that were nearly equal to or greater than the 0.2-percent AEP (500-year) flood discharge (fig. 29). On August 28, 2011, the streamgage at Schoharie Creek at Prattsville (01350000) recorded its highest stage $(24.38 \mathrm{ft})$ and discharge $\left(120,000 \mathrm{ft}^{3} / \mathrm{s}\right)$ since record collection began in 1903 (5.0 ft higher than that during the previous peak of record, $19.39 \mathrm{ft}$ on January 19, 1996). The 2011 peak discharges at the Schoharie Creek streamgages were 1.5 to 2.3 times greater than those recorded during the January 1996 flood. Reaches of the Mohawk River downstream from the confluence with Schoharie Creek also had substantial flooding. Other streams throughout eastern New York with long periods of record (75-101 years) including Catskill Creek, Esopus Creek, Rondout Creek, Ramapo River, East Branch Delaware River, Ausable River (East Branch, West Branch, and main stem), and Bouquet River - all had record flooding during August 28-29, 2011 (table 11).

The heavy rainfall during a relatively short time interval in late August 2011 resulted in large volumes of runoff (the amount of water discharged from a drainage basin and passing a specific location during a given amount of time) in many parts of eastern New York. Similar to the analysis done for the April-May flood, the August 2011 maximum 1-, 3-, and 7-consecutive-day runoff, expressed as the mean of daily mean discharges over an $\mathrm{n}$-day period, was calculated for five streamgages in the Catskill Mountains area (figs. 30AE); Schoharie Creek at Prattsville (01350000), Schoharie Creek at Burtonsville (01351500), Esopus Creek at Allaben (01362200), Esopus Creek at Coldbrook (01362500), and East Branch Delaware River at Margaretville (01413500).

The maximum 1-day mean flow for the Schoharie Creek at Prattsville (01350000) (August 28, 2011; 40,000 ft $3 / \mathrm{s}$ ) was the largest 1-day flow in 104 years of record (50 percent higher than the previous 1-day maximum flow recorded in $1955)$ and significantly exceeded the 1-percent AEP (100-year) 1-day discharge (fig. 30A-1); the 3-day flow (August 28-30) was the second largest, and the 7-day flow the 4th largest during the period of record. The extreme 1-day runoff and the progressively less notable 3 - and 7-day runoffs are indicative of the intensity of the rainfall in this basin. A similar pattern of n-day runoff was observed at the other four streamgages (figs. 30B-E), but the August maximum 3-day runoff was still the largest of record at Schoharie Creek at Burtonsville (01351500), Esopus Creek at Allaben (01362200), and East Branch Delaware River at Margaretville (01413500) and the 
Northeast RFC Taunton, MA: 8/28/2011 1-Day Observed Precipitation Valid at $8 / 28 / 20111200$ UTC- Created 10/15/12 6:48 UTC

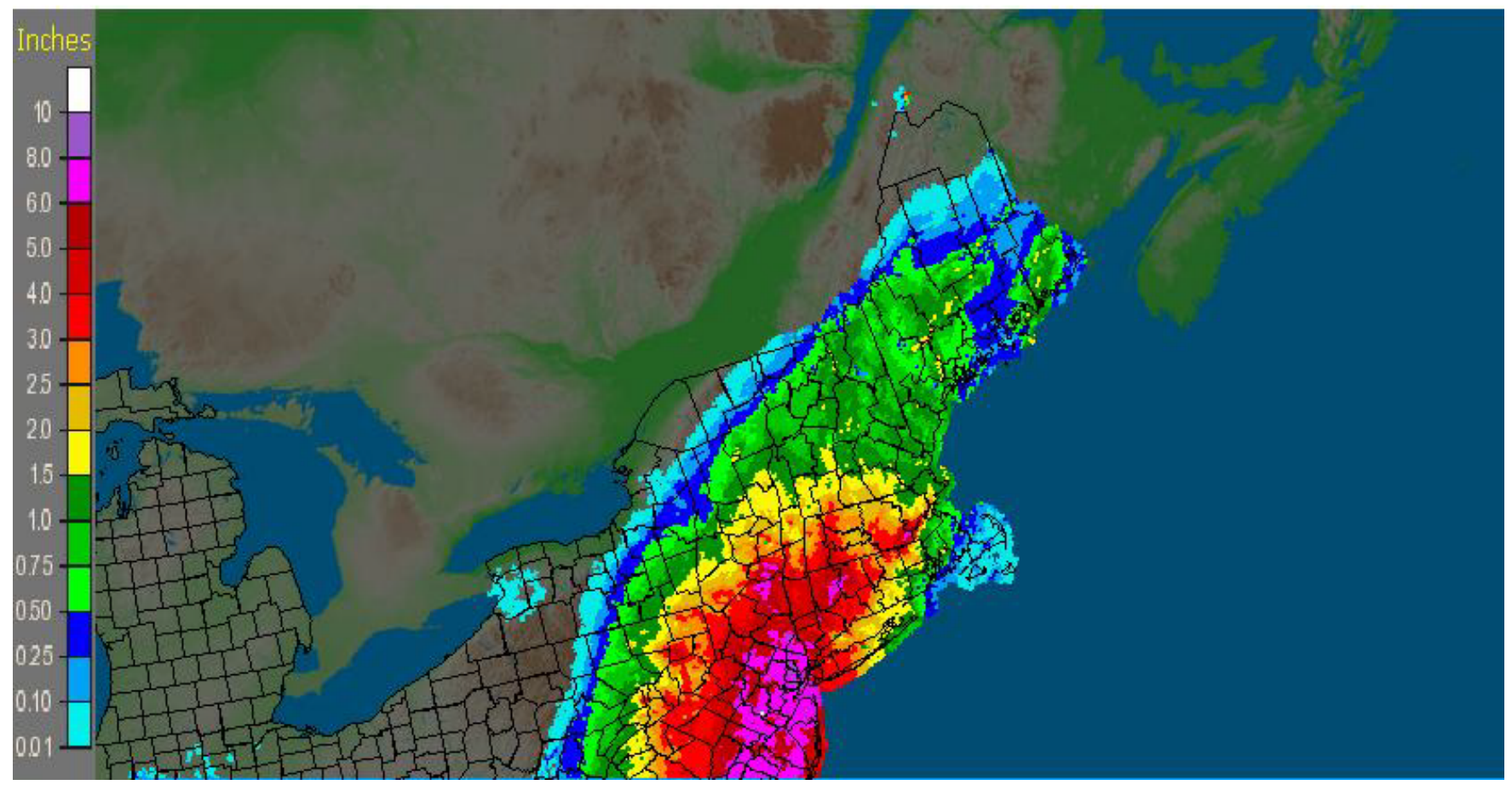

Northeast RFC Taunton. MA: 8/29/2011 1-Day Observed Precipitation Valid at $8 / 29 / 20111200$ UTC- Created 10/15/12 6:50 UTC

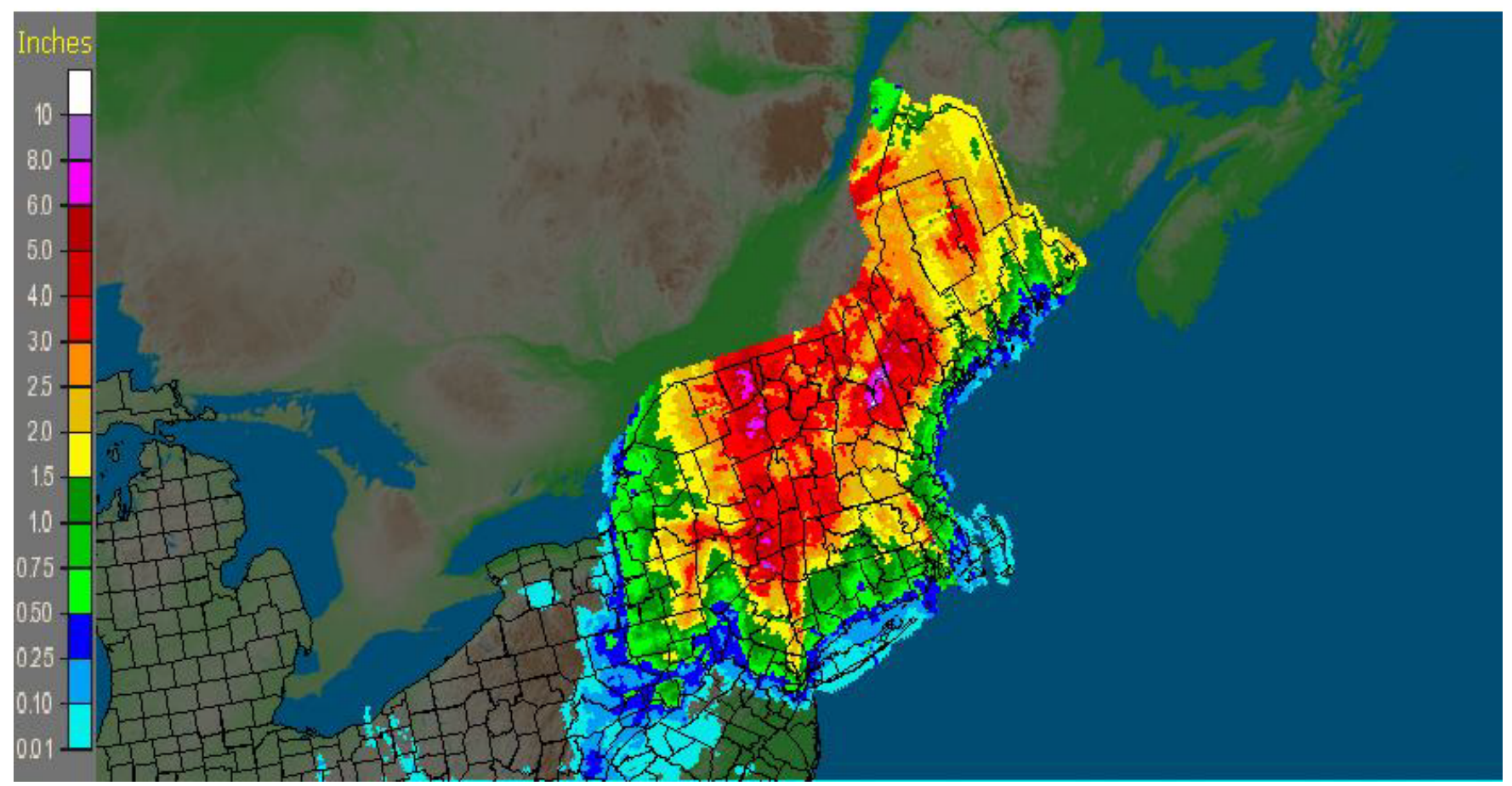

Figure 24. Daily rainfall totals during August 28-29, 2011, for New York and surrounding areas. (From National Oceanic and Atmospheric Administration, 2011m) 
$\boldsymbol{A}$

$-76^{\circ} 30^{\circ}$

$.75^{\circ}$ $-73^{\circ} 30^{\prime}$

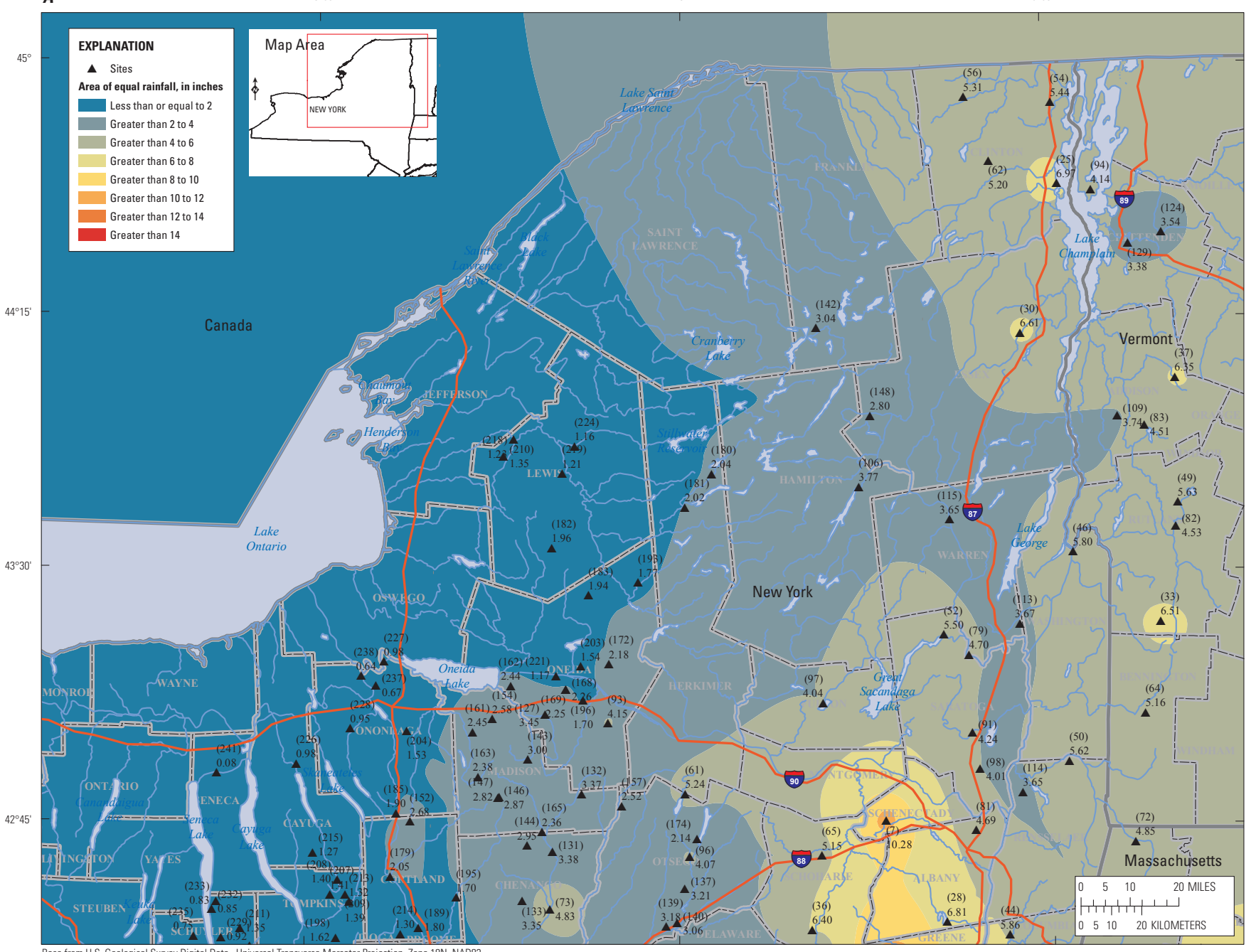

Figure 25. Rainfall totals for the storm of August 28-29, 2011, in $A$, north, and $B$, south areas of New York and surrounding areas. (National Oceanic and Atmospheric Administration (2011b, c, e, g; written commun., 2012), and New York City Department of Environmental Protection (NYCDEP, written commun., 2012) Sites and data are listed in table 9.) 


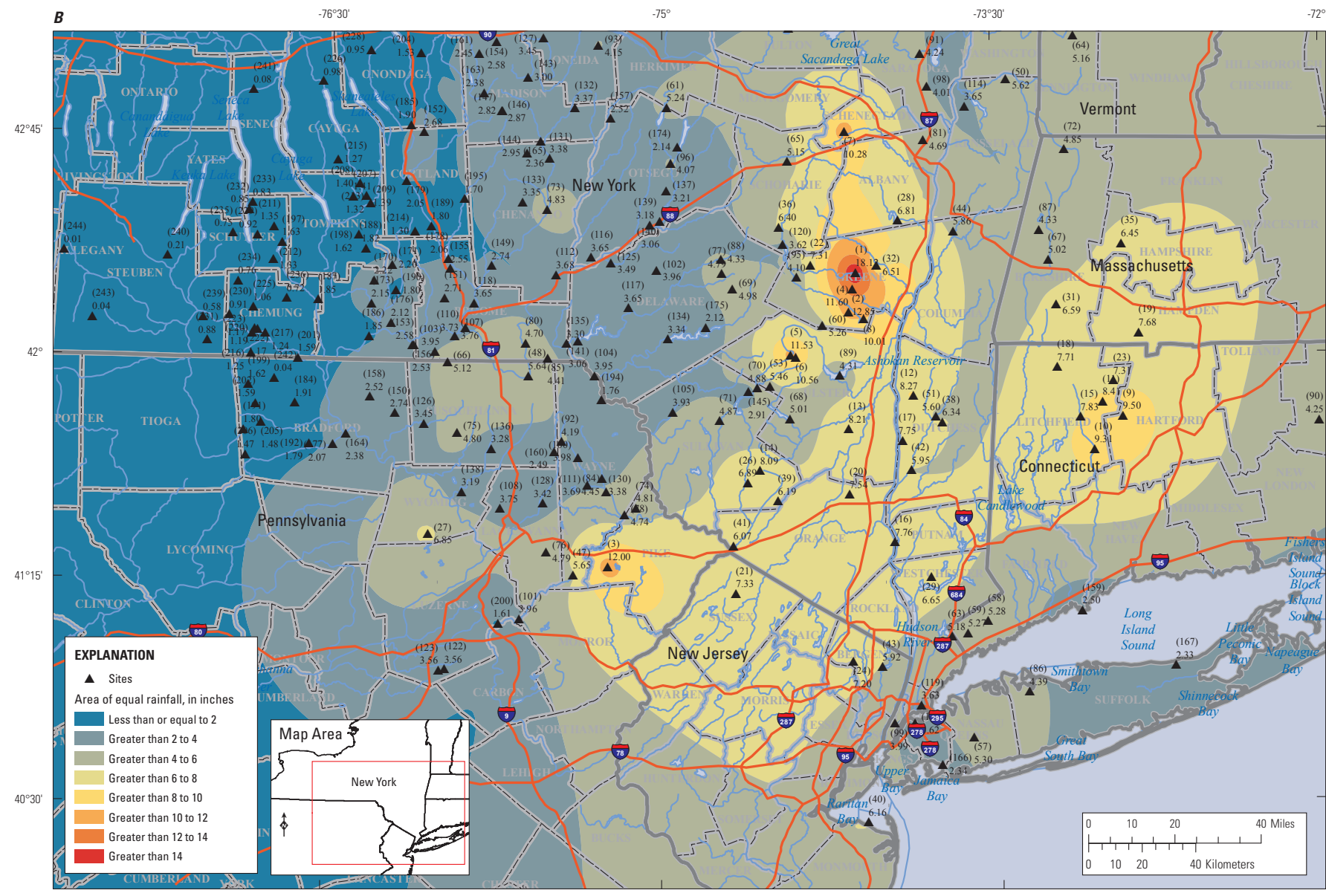

Figure 25. Rainfall totals for the storm of August 28-29, 2011, in A, north, and $B$, south areas of New York and surrounding areas. (National Oceanic and Atmospheric Administration (2011b, c, e, g; written commun., 2012), and New York City Department of Environmental Protection (NYCDEP, written commun., 2012) Sites and data are listed in table 9.)—Continued 


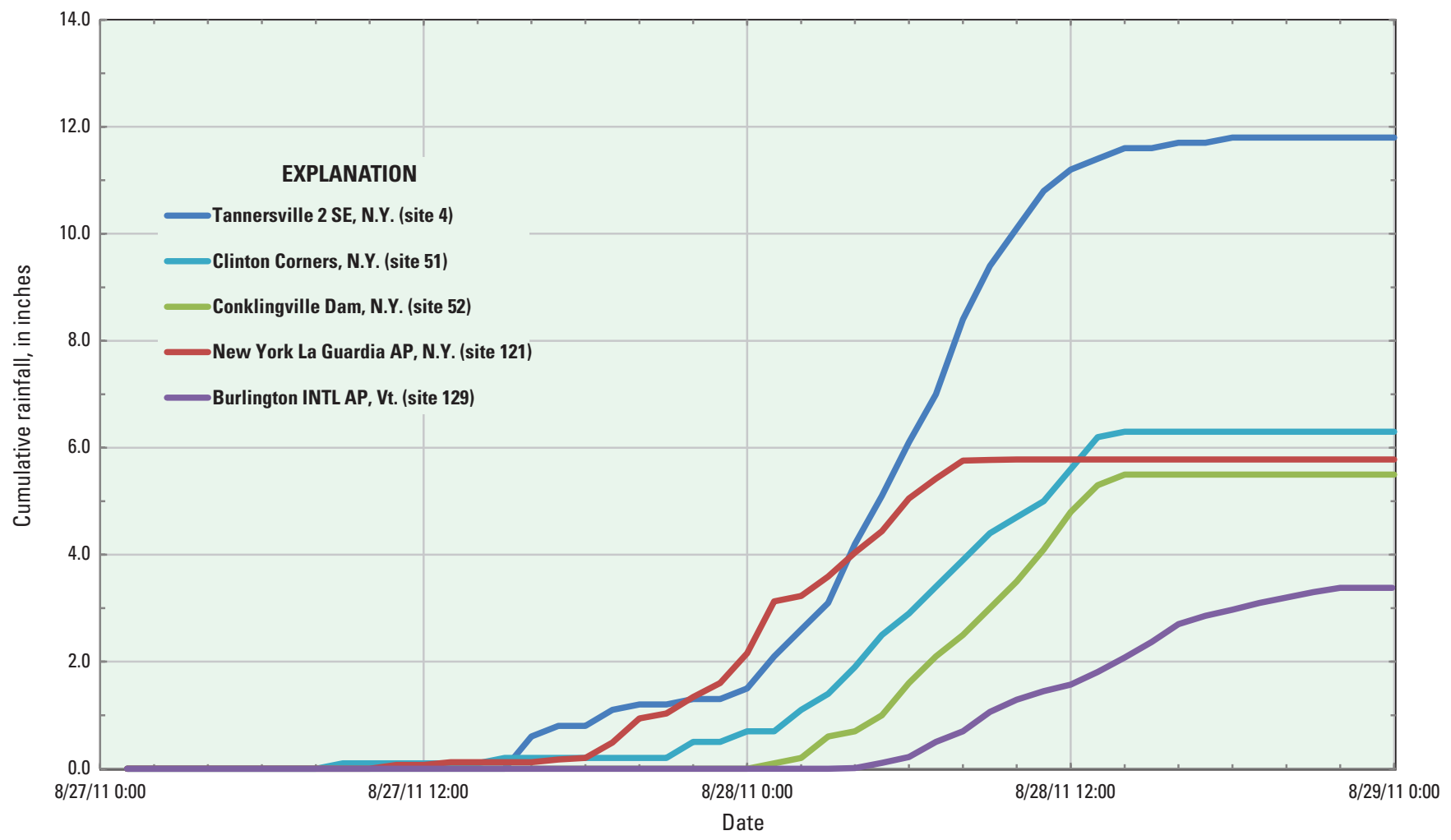

Figure 26. Cumulative hourly rainfall during August 27-29, 2011, recorded at five weather stations in New York and Vermont. (Data from National Oceanic and Atmospheric Administration, 2011i; Sites are listed in table 9 and locations are shown on figure 25.)

largest 7-day runoff of record for the last two streamgages. Slightly upward trends in flood runoffs at the Prattsville streamgage are indicated since record collection began in 1908. Runoffs at the East Branch Delaware River at Margaretville streamgage (01413500) reached record high values during late August to early September for the maximum 1-, 3-, and 7-consecutive-day mean discharges (fig. 30E). The 1- and 3-day runoffs exceeded the 1-percent AEP (100-year) runoffs, whereas the 7-day runoff (August 28-September 3) was slightly less than the 2-percent AEP (50-year) runoff. The Margaretville streamgage also recorded slightly upward trends in runoffs during its 75 years of record.

The 7-day (August 27-September 2, 2011) storm runoff (table 12), which is color-coded in inches over streamgage basins in the eastern half of New York (fig. 31), indicate the greatest runoffs were in and around the Catskill Mountains with lesser amounts extending to the eastern slopes of the Adirondack Mountains and into the Champlain Valley. Storm runoff at streamgages affected by substantial regulation in the basin was adjusted for storage if data on reservoir contents were available. A full-size view of the map on figure 31 can be accessed by the computer link at the end of the figure caption.
Annual peak discharges at 30 selected streamgages in eastern New York (figs. 32A-AD) indicate that the August 2011 peak generally far exceeded the previous annual peak at most sites. The August 2011 peak discharge exceeded the 1-percent AEP (100-year) discharge at 24 of the 30 selected streamgages (figs. 32A-AD). All August 2011 peaks at selected streamgages within the Schoharie Creek Basin (figs. 32C-L) set new peaks of record and exceeded the 1-percent AEP (100-year) discharge, most by a substantial amount

Several of the records for streamgages in the Schoharie Creek Basin indicated a significant upward trend in annual peak discharges (figs. 32C-L, table 6). The record peak discharge for the Catskill Creek at Oak Hill (01361500) streamgage exceeded the 1-percent AEP (100-year) discharge, and the annual peaks for the period 1911-2011 show a significant (p-value 0.000) positive trend (fig. 32M, table 6). Although Rondout Reservoir is upstream from the Rondout Creek at Rosendale (01367500) streamgage, the August 2011 stage $(26.96 \mathrm{ft})$ and discharge $\left(36,500 \mathrm{ft}^{3} / \mathrm{s}\right)$ are maximums for the period of record. Since the Rondout Reservoir began operation in 1950, the annual peak long-term (1951-2011) and short-term (1982-2011) trends at the Rosendale streamgage have been upward (p-values 0.084 and 0.038 , respectively). 
Table 10. Rainfall frequencies for storms of 6-, 12- and 24-hour durations at selected locations in New York and Vermont.

[Maximum rainfall during August 28-29, 2011, for selected durations are shown in red. Data from the Northeast Regional Climate Center, 2010; locations are shown on figure 25]

\begin{tabular}{|c|c|c|c|c|c|c|c|c|c|c|c|c|c|}
\hline \multirow{2}{*}{$\begin{array}{c}\text { Site } \\
\text { num- } \\
\text { ber }\end{array}$} & \multirow{2}{*}{ Site name } & \multirow{2}{*}{ County } & \multirow{2}{*}{$\begin{array}{c}\text { Recur- } \\
\text { rence } \\
\text { inter- } \\
\text { val } \\
\text { (years) }\end{array}$} & \multicolumn{3}{|c|}{$\begin{array}{c}\text { Rainfall for } \\
\text { selected duration } \\
\text { (inches) }\end{array}$} & \multirow{2}{*}{$\begin{array}{c}\text { Site } \\
\text { num- } \\
\text { ber }\end{array}$} & \multirow{2}{*}{ Site name } & \multirow{2}{*}{ County } & \multirow{2}{*}{$\begin{array}{c}\text { Recur- } \\
\text { rence } \\
\text { inter- } \\
\text { val } \\
\text { (years) }\end{array}$} & \multicolumn{3}{|c|}{$\begin{array}{c}\text { Rainfall for } \\
\text { selected duration } \\
\text { (inches) }\end{array}$} \\
\hline & & & & $\begin{array}{c}\text { 6- } \\
\text { hour }\end{array}$ & $\begin{array}{c}12- \\
\text { hour }\end{array}$ & $\begin{array}{c}\text { 24- } \\
\text { hour }\end{array}$ & & & & & $\begin{array}{c}\text { 6- } \\
\text { hour }\end{array}$ & $\begin{array}{c}12- \\
\text { hour }\end{array}$ & $\begin{array}{c}24- \\
\text { hour }\end{array}$ \\
\hline \multirow[t]{10}{*}{4} & Tannersville, N.Y. & Greene & 2 & 2.07 & 2.58 & 3.21 & 121 & New York & Queens & 2 & 2.28 & 2.79 & 3.42 \\
\hline & & & 5 & 2.59 & 3.24 & 4.04 & & La Guardia Airport, N.Y. & & & 2.64 & & \\
\hline & & & 10 & 3.07 & 3.86 & 4.82 & & & & 5 & 2.87 & 3.51 & 4.28 \\
\hline & & & 25 & 3.85 & 4.86 & 6.09 & & & & 10 & 3.41 & 4.17 & 5.08 \\
\hline & & & 50 & 4.58 & 5.80 & 7.28 & & & & & & 4.93 & 5.78 \\
\hline & & & 100 & 5.44 & 6.90 & 8.70 & & & & 25 & 4.27 & 5.25 & 6.37 \\
\hline & & & & 6.30 & & & & & & 50 & 5.07 & 6.22 & 7.56 \\
\hline & & & 200 & 6.47 & 8.24 & 10.41 & & & & 100 & 6.02 & 7.40 & 8.98 \\
\hline & & & & & 9.70 & 11.60 & & & & 200 & 7.15 & 8.79 & 10.67 \\
\hline & & & 500 & 8.12 & 10.40 & 13.21 & & & & 500 & 8.97 & 11.04 & 13.41 \\
\hline \multirow[t]{11}{*}{51} & Clinton Corners, N.Y. & Dutchess & 2 & 2.17 & 2.70 & 3.34 & 129 & Burlington, Vt. & Chittenden & & 1.41 & & \\
\hline & & & 5 & 2.75 & 3.40 & 4.20 & & & & 2 & 1.63 & 1.91 & 2.22 \\
\hline & & & & 3.00 & & & & & & 5 & 2.03 & 2.36 & 2.70 \\
\hline & & & 10 & 3.30 & 4.07 & 4.99 & & & & & & 2.75 & \\
\hline & & & & & & 6.20 & & & & 10 & 2.41 & 2.77 & 3.13 \\
\hline & & & 25 & 4.18 & 5.15 & 6.27 & & & & & & & 3.38 \\
\hline & & & & & 5.50 & & & & & 25 & 3.01 & 3.41 & 3.80 \\
\hline & & & 50 & 5.00 & 6.14 & 7.46 & & & & 50 & 3.55 & 4.00 & 4.41 \\
\hline & & & 100 & 5.99 & 7.34 & 8.88 & & & & 100 & 4.20 & 4.69 & 5.12 \\
\hline & & & 200 & 7.17 & 8.76 & 10.57 & & & & 200 & 4.98 & 5.50 & 5.95 \\
\hline & & & 500 & 9.09 & 11.08 & 13.31 & & & & 500 & 6.19 & 6.78 & 7.26 \\
\hline \multirow[t]{10}{*}{52} & Conklingville Dam, N.Y. & Saratoga & 2 & 1.81 & 2.17 & 3.42 & & & & & & & \\
\hline & & & 5 & 2.27 & 2.71 & 4.28 & & & & & & & \\
\hline & & & 10 & 2.69 & 3.19 & 5.08 & & & & & & & \\
\hline & & & & 3.20 & & 5.50 & & & & & & & \\
\hline & & & 25 & 3.36 & 3.98 & 6.37 & & & & & & & \\
\hline & & & 50 & 4.00 & 4.70 & 7.56 & & & & & & & \\
\hline & & & & & 5.30 & & & & & & & & \\
\hline & & & 100 & 4.73 & 5.53 & 8.98 & & & & & & & \\
\hline & & & 200 & 5.62 & 6.54 & 10.67 & & & & & & & \\
\hline & & & 500 & 7.03 & 8.14 & 13.41 & & & & & & & \\
\hline
\end{tabular}




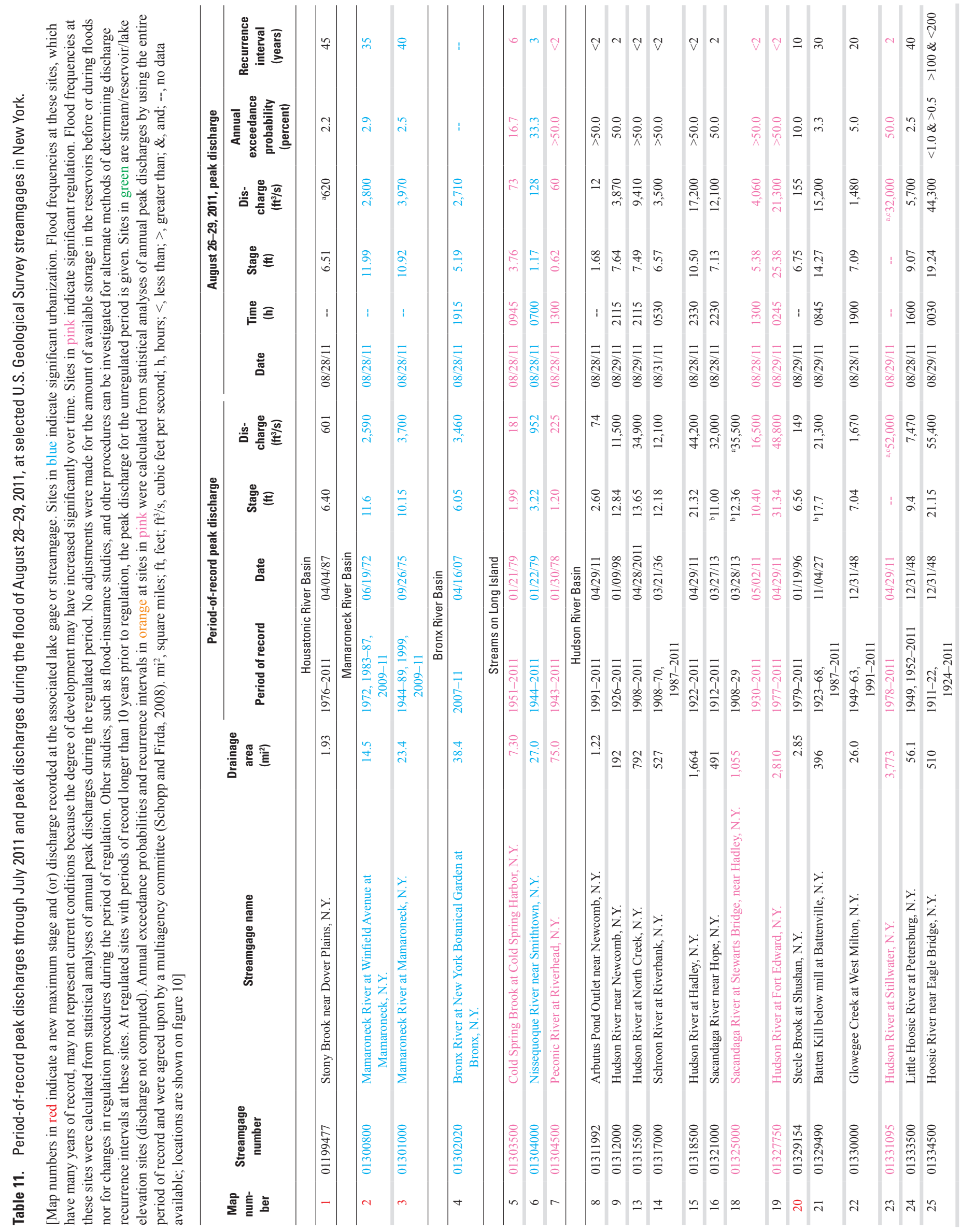



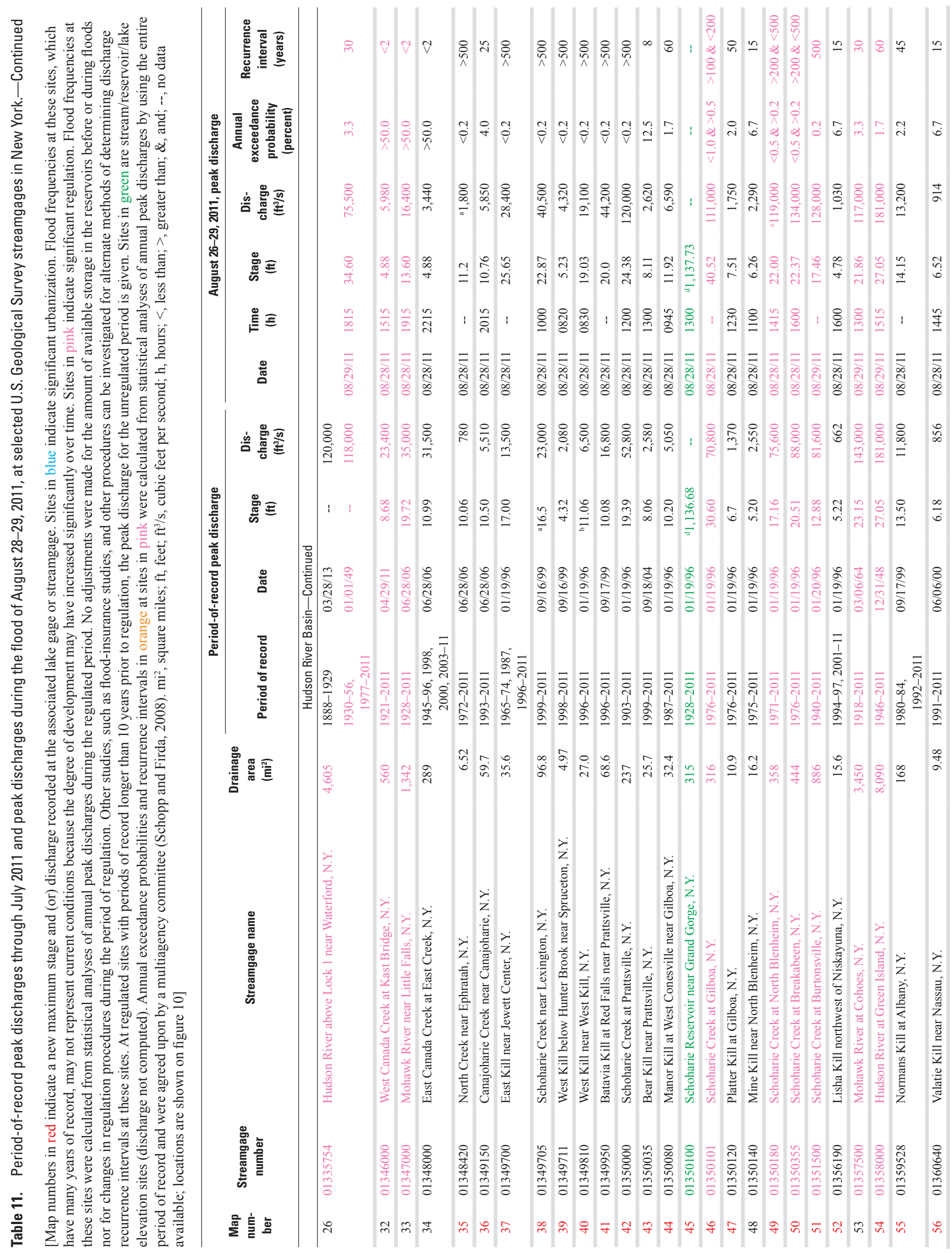


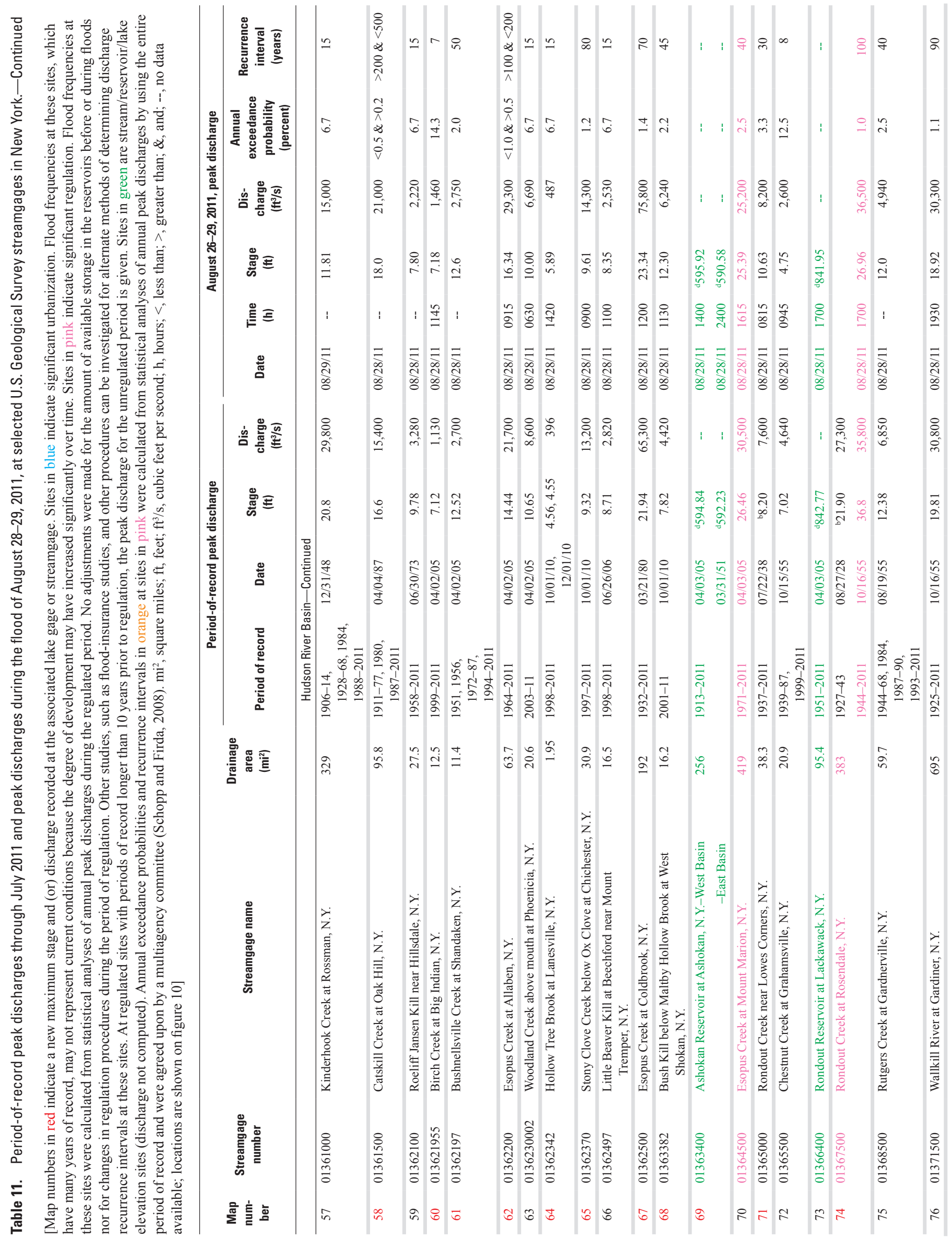



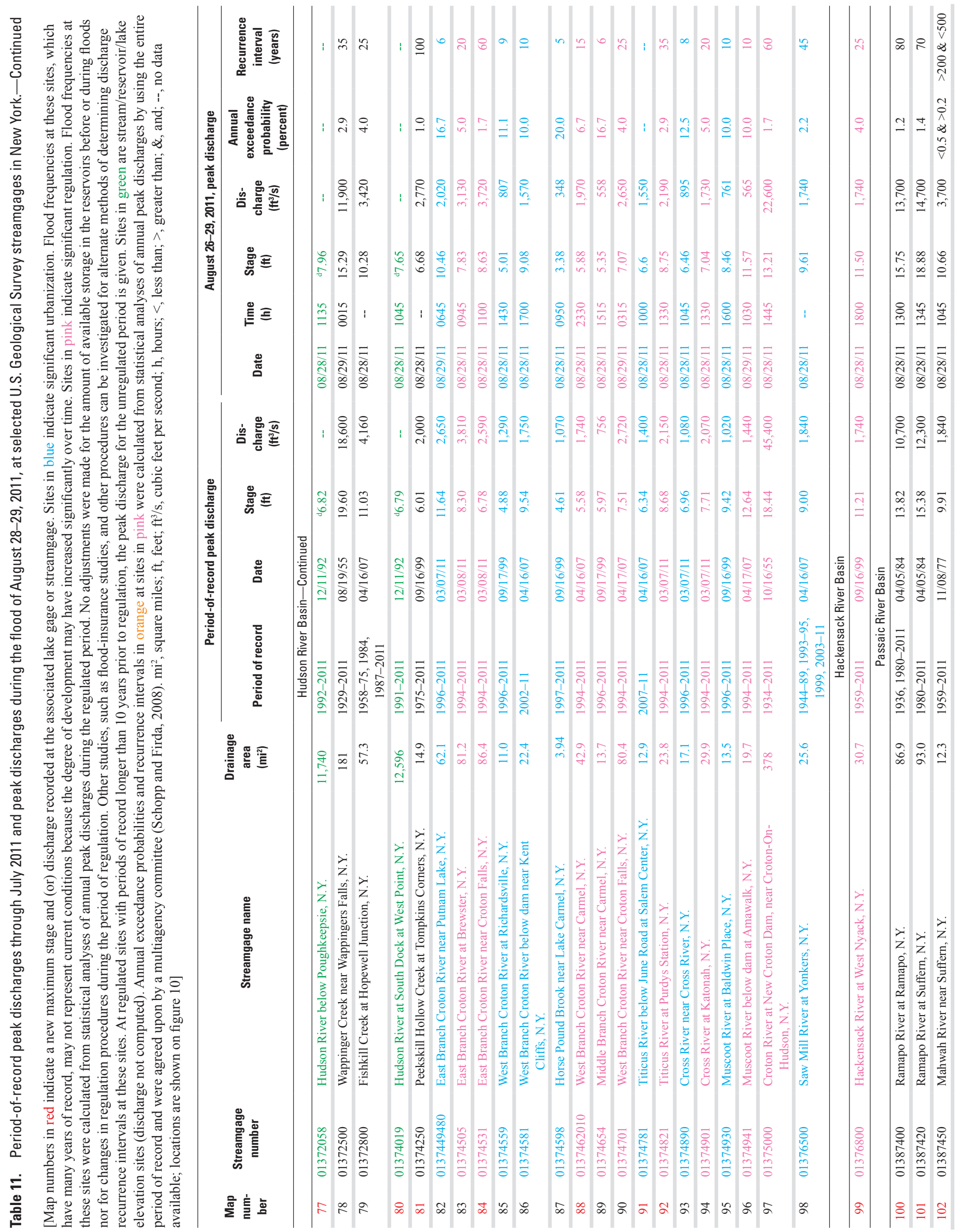


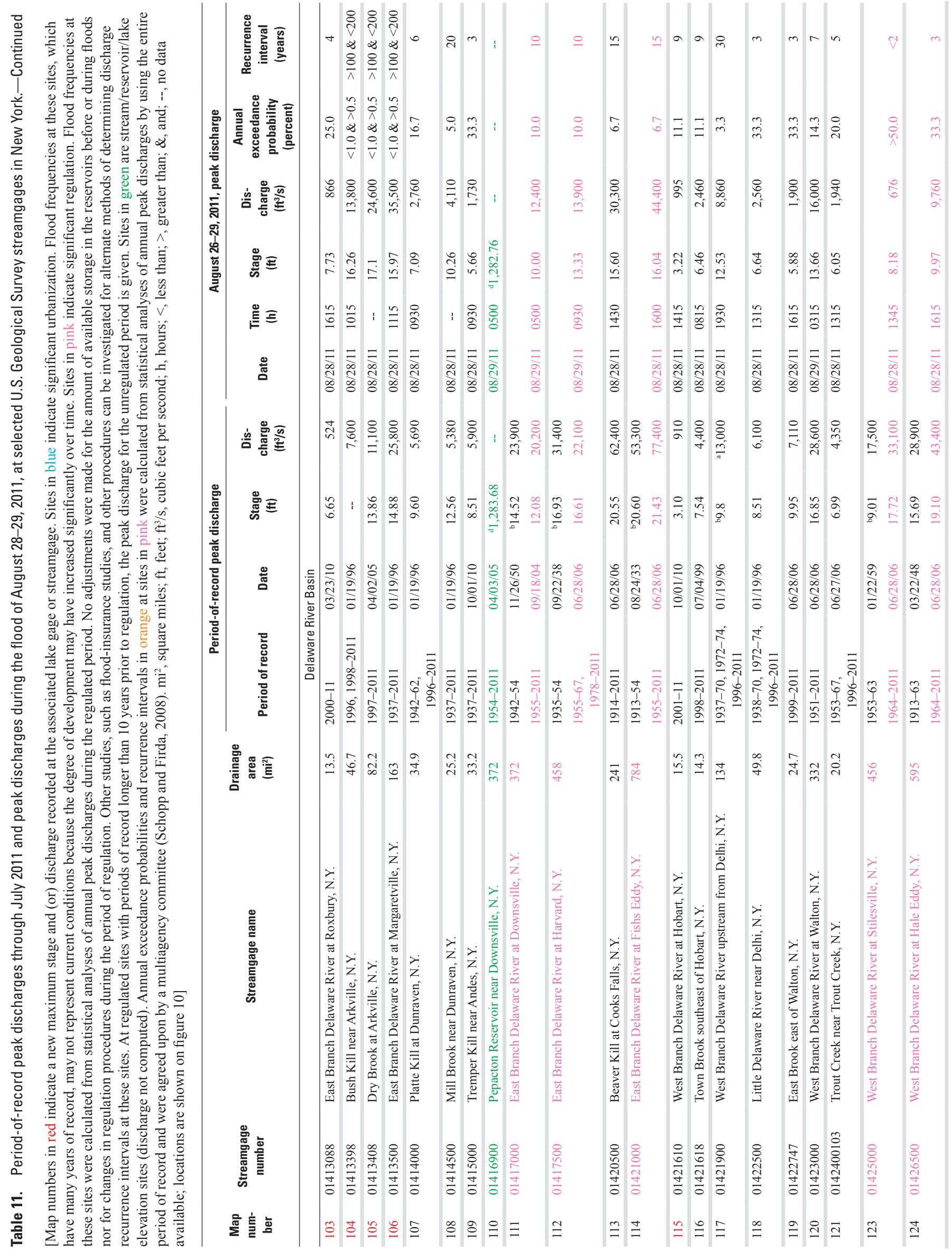



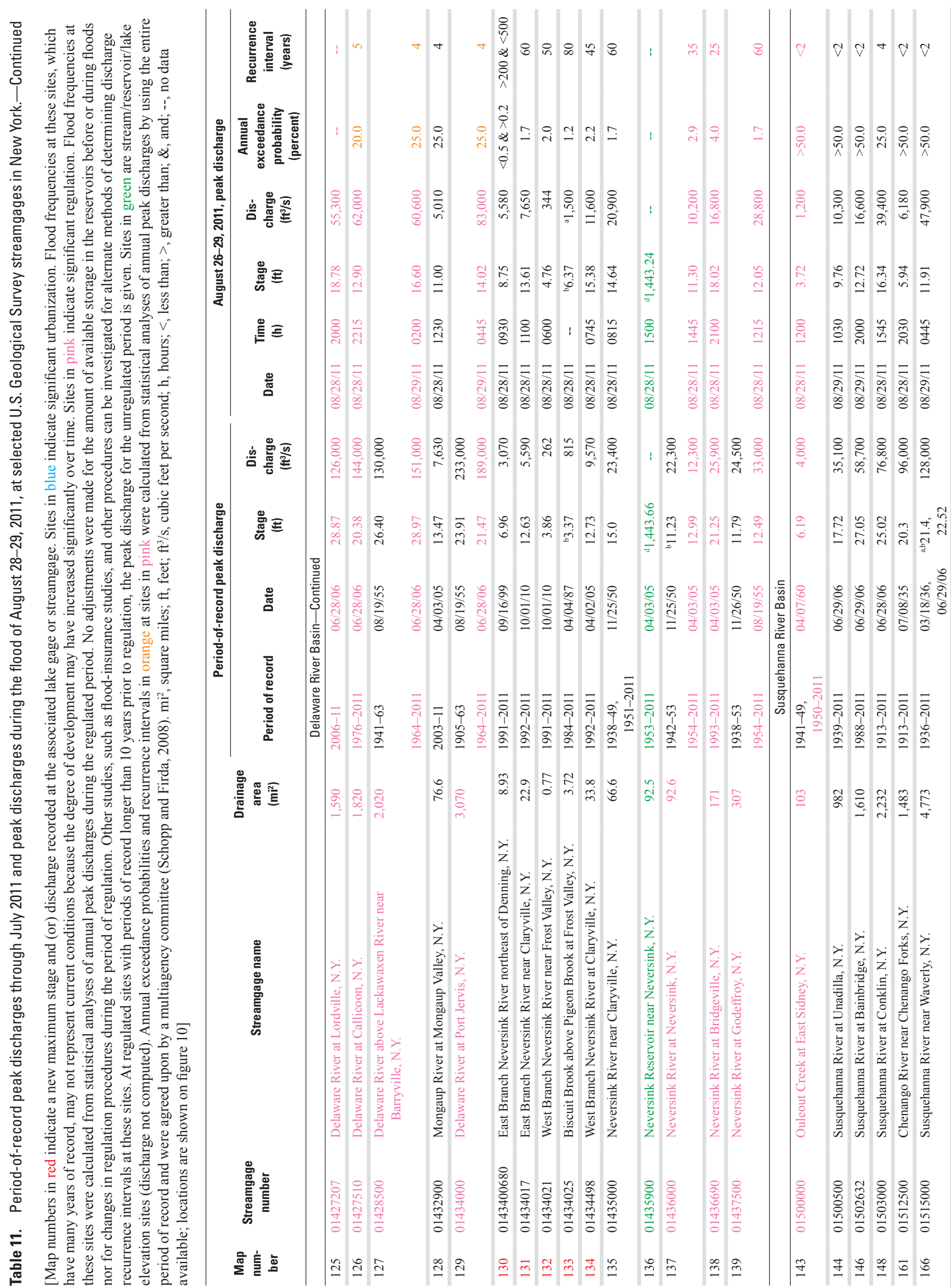


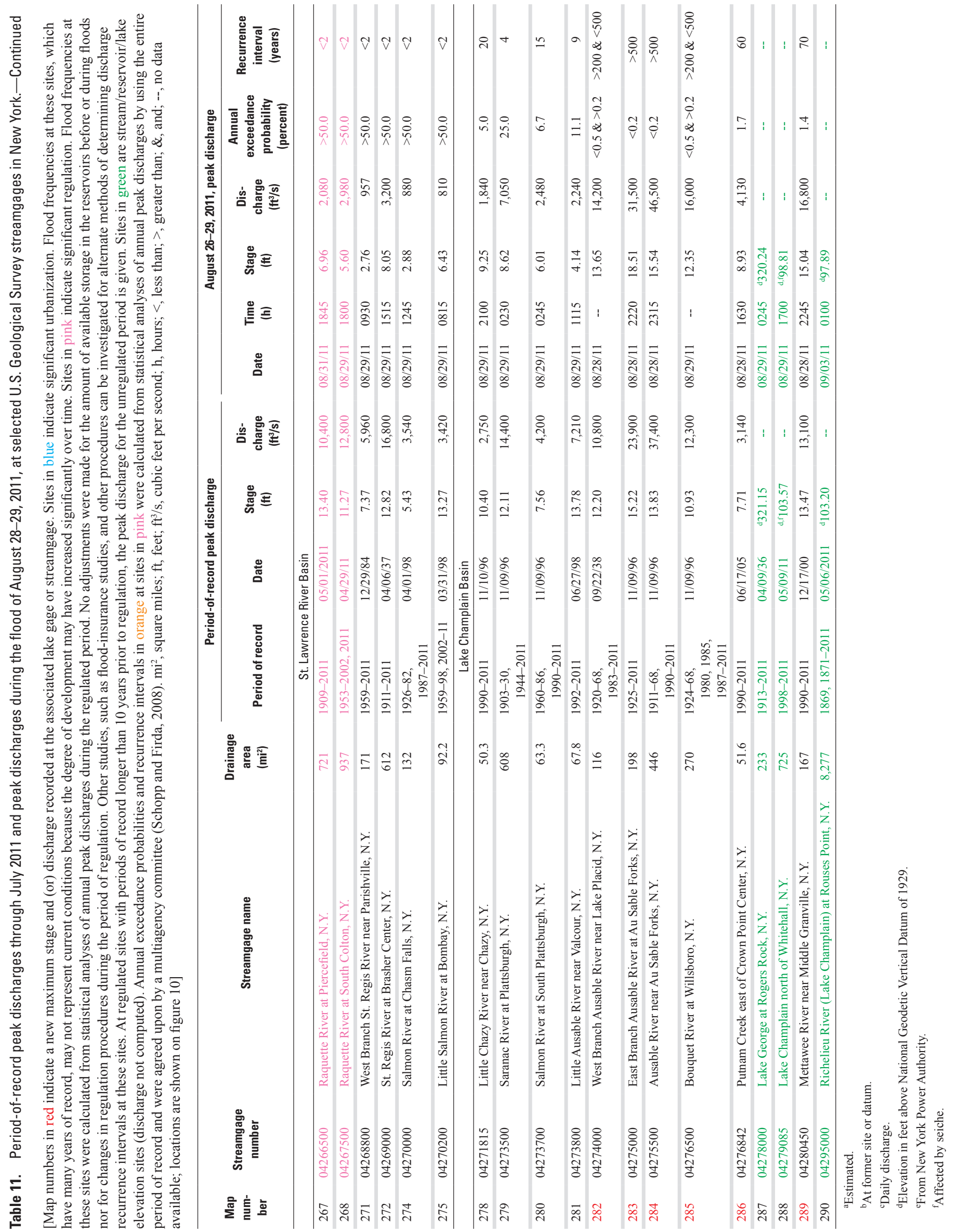




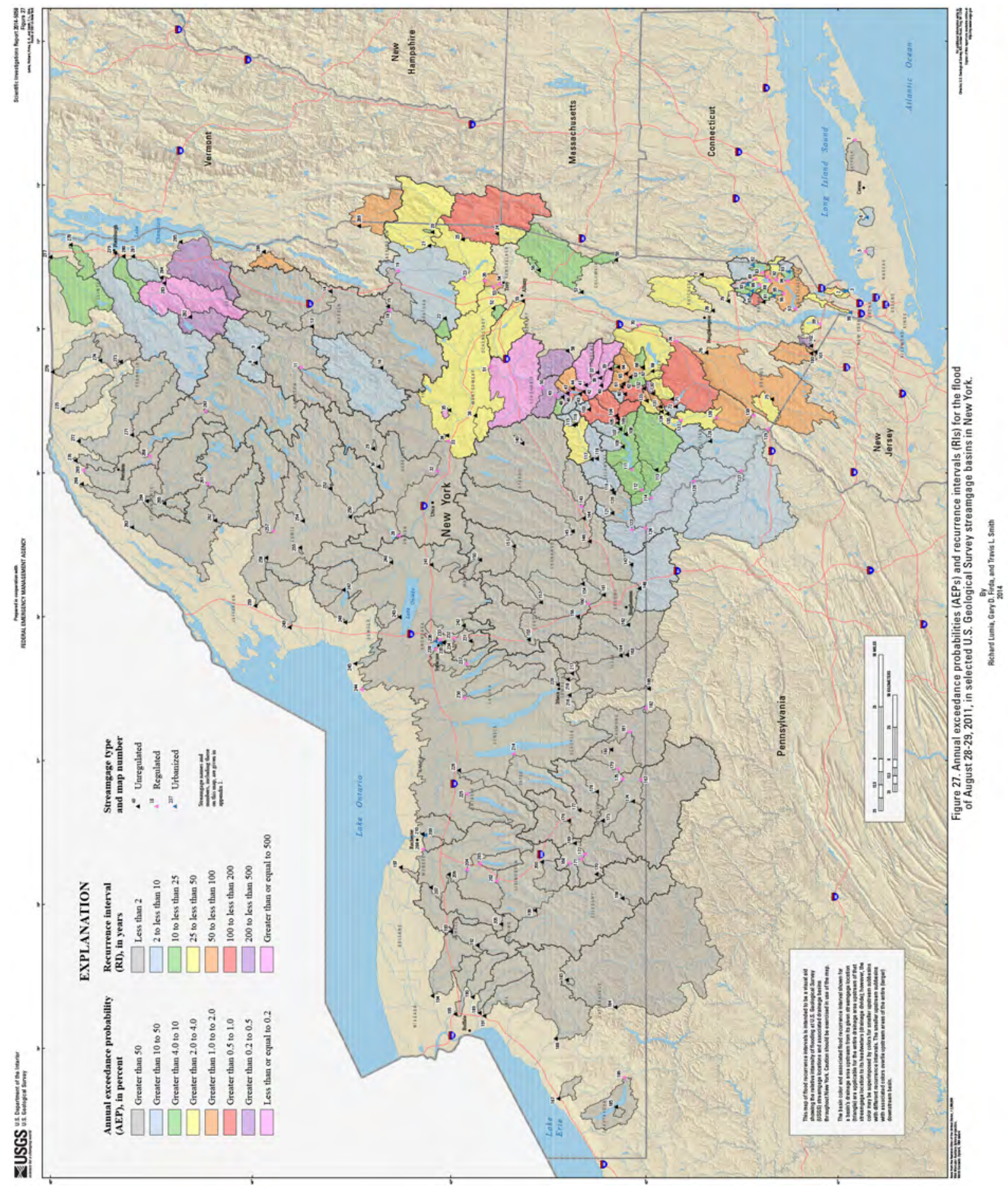

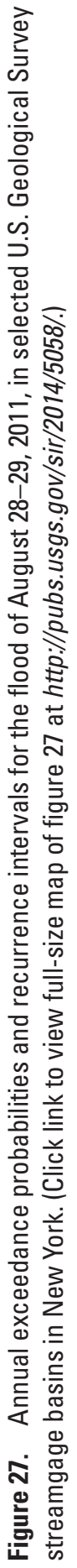




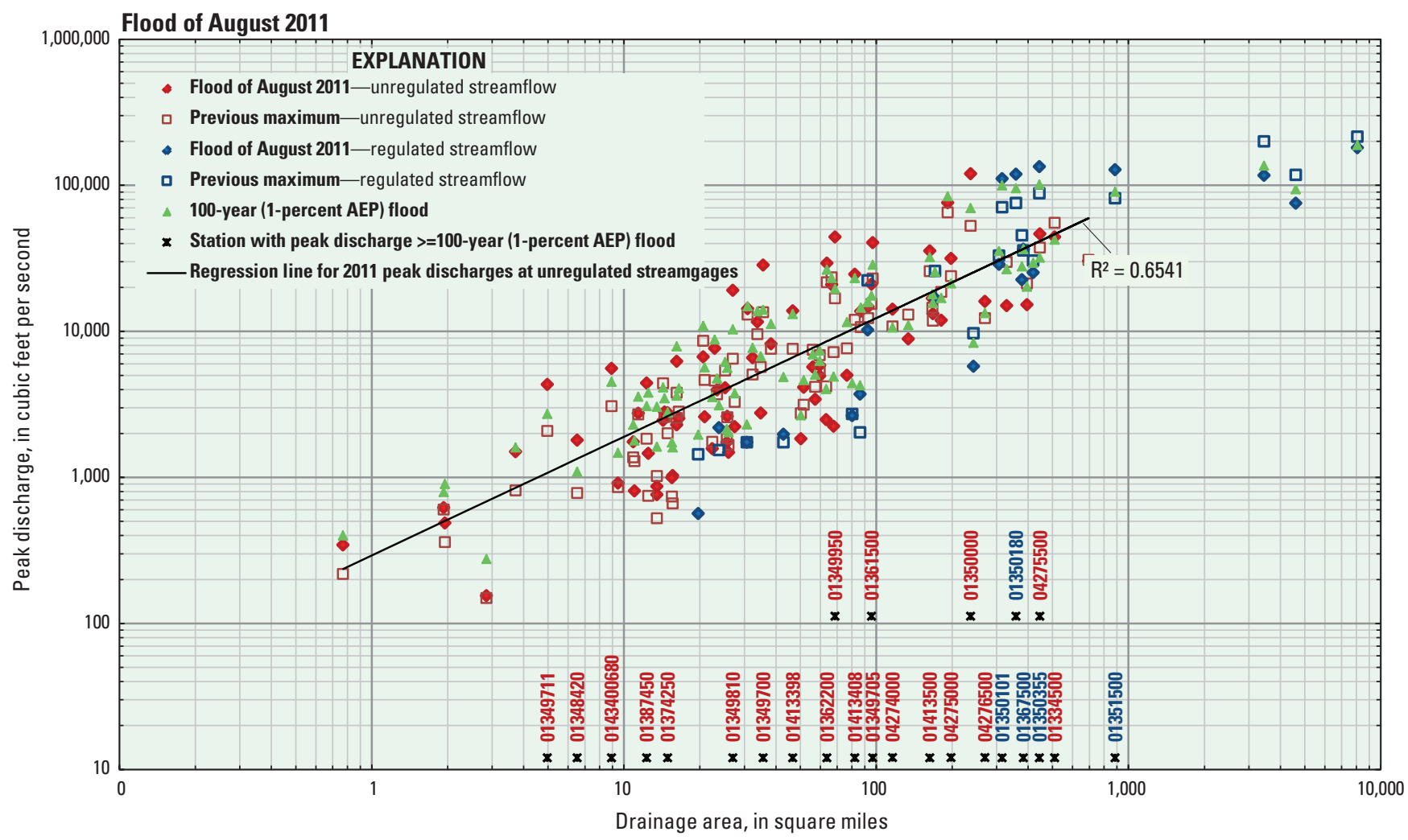

Figure 28. Peak discharges for the flood of August 28-29, 2011, previous maximum known discharges, and 1-percent annual exceedance probability (100-year) discharges at selected streamgages, as a function of drainage area at selected sites in New York. (Sites are listed in appendix 1 and shown on figure 10. AEP, annual exceedance probability; $\geq$, greater than or equal to)

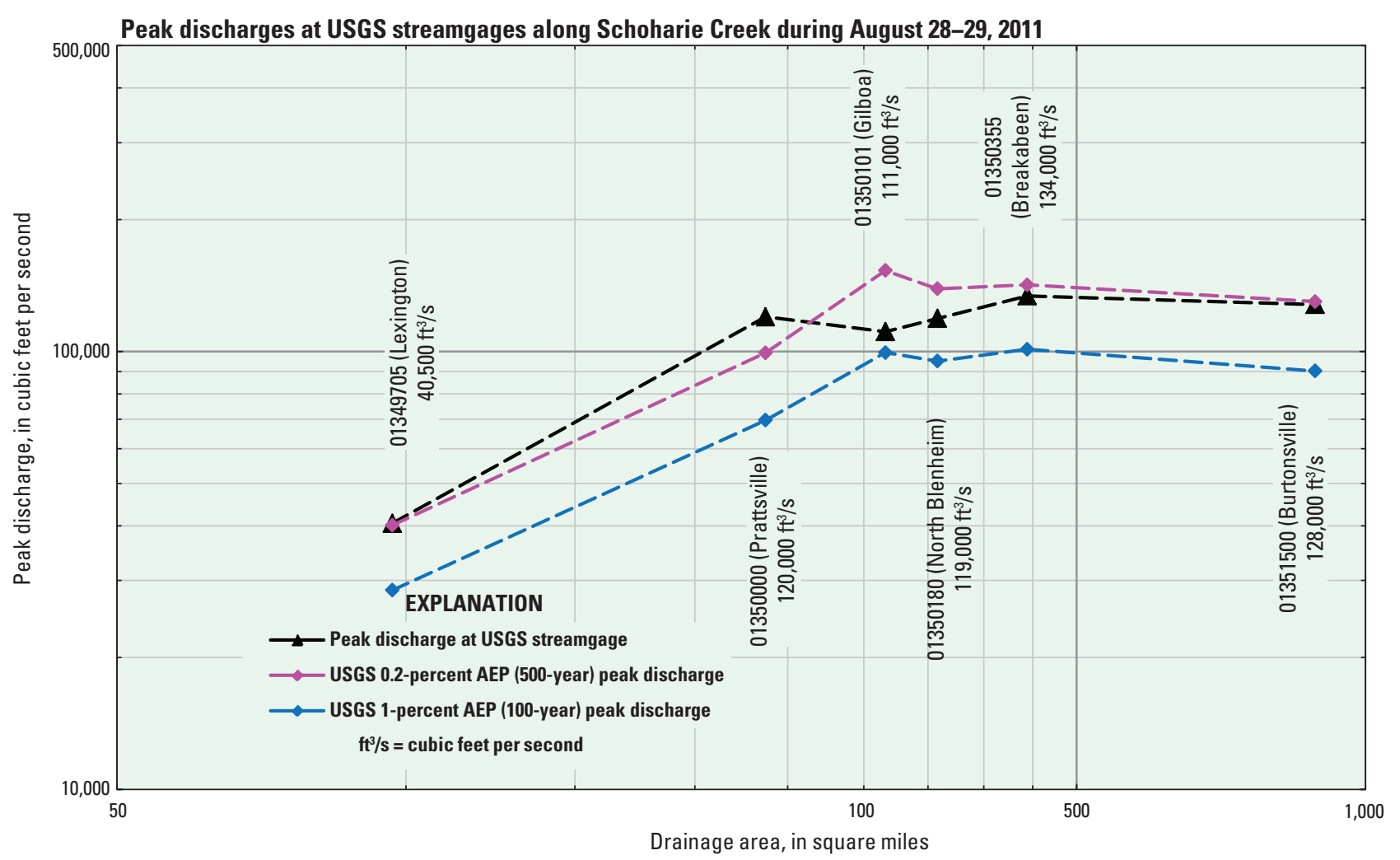

Figure 29. Peak discharges for the flood of August 28-29, 2011, and 1- and 0.2-percent annual exceedance probability (100- and 500-year) discharges at six U.S. Geological Survey streamgages on Schoharie Creek, New York, as a function of drainage area. (Sites are listed in appendix 1 and shown on figure 10. USGS, U.S. Geological Survey; AEP, annual exceedance probability) 

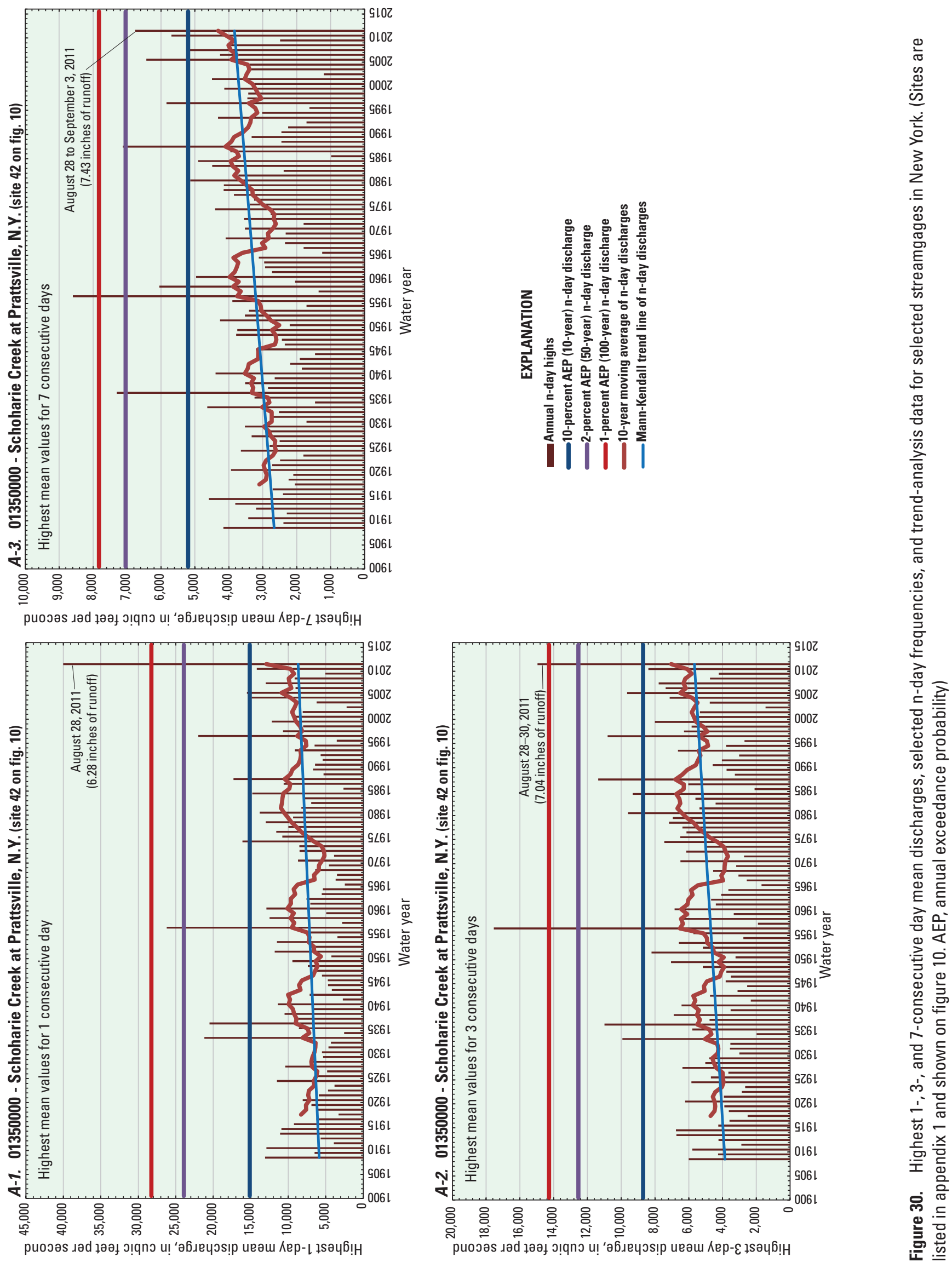

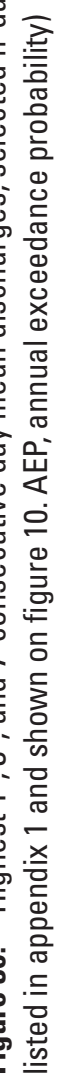



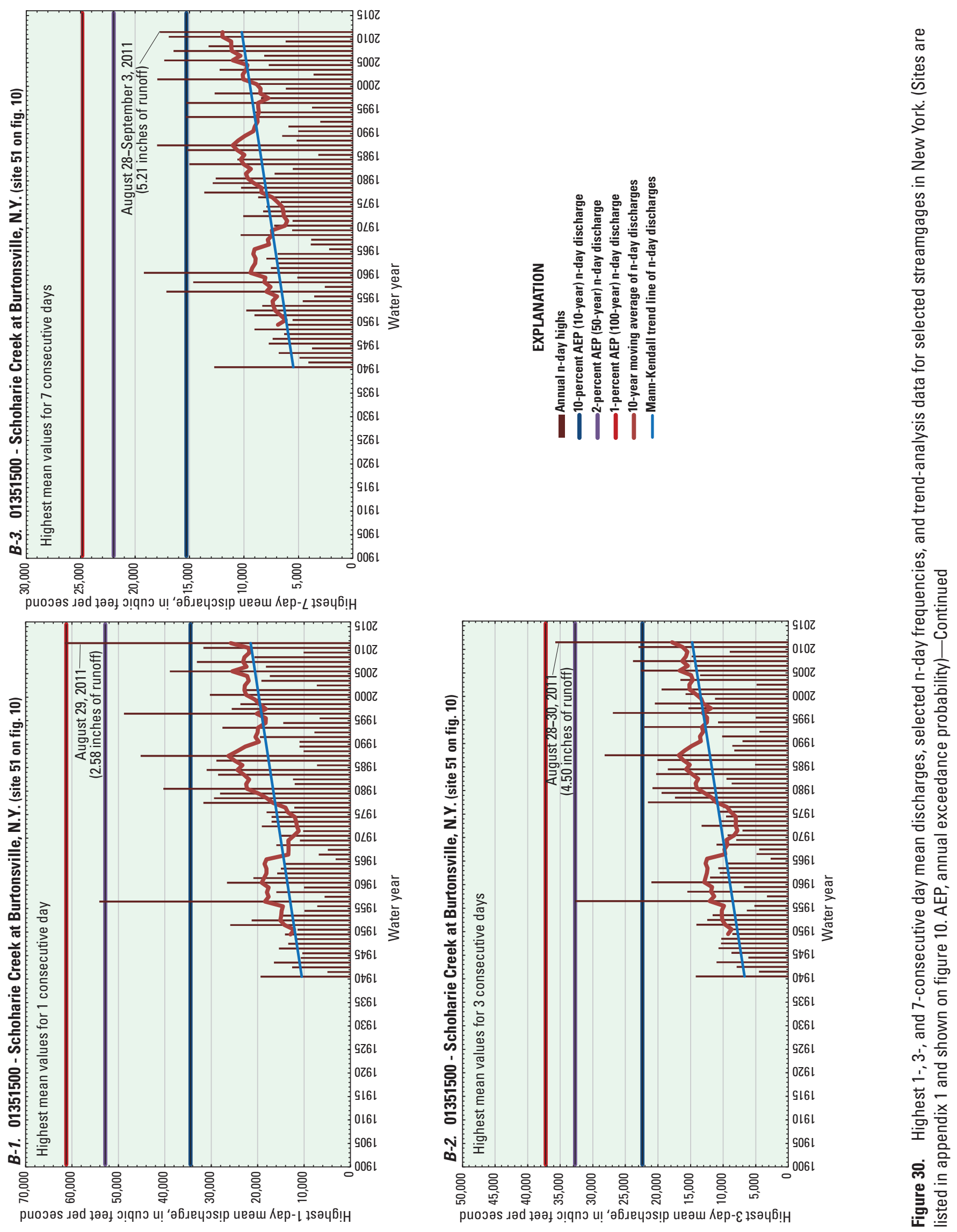


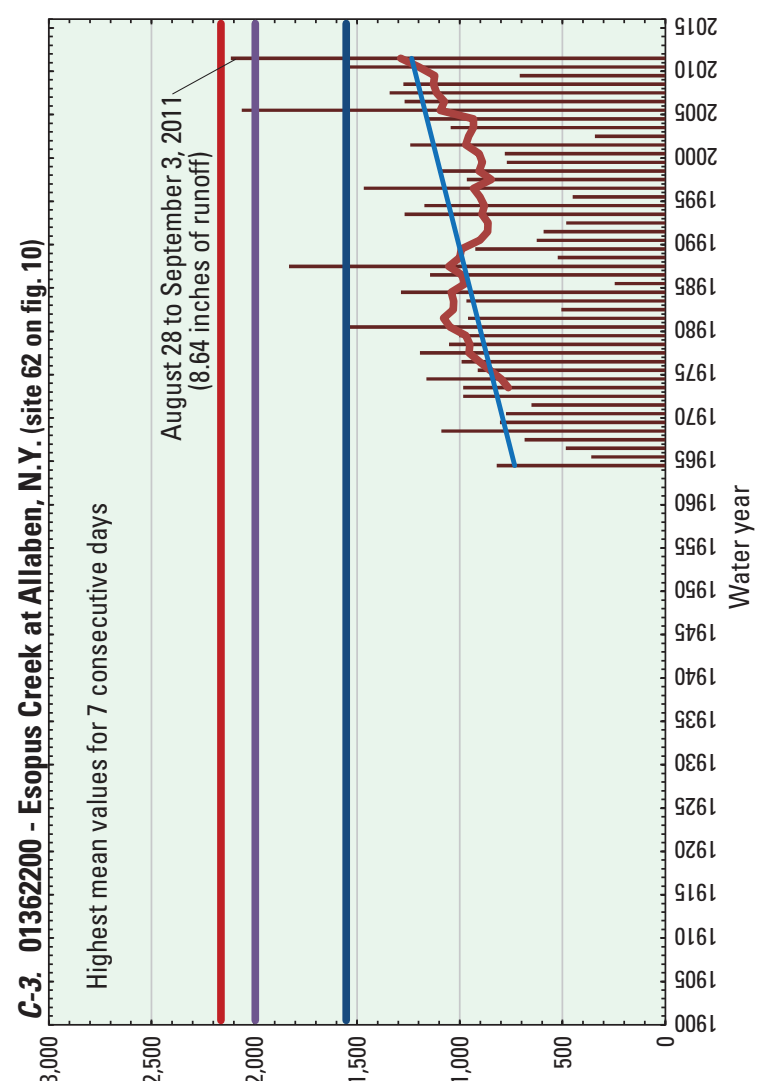

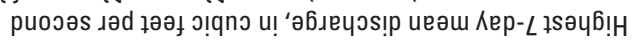

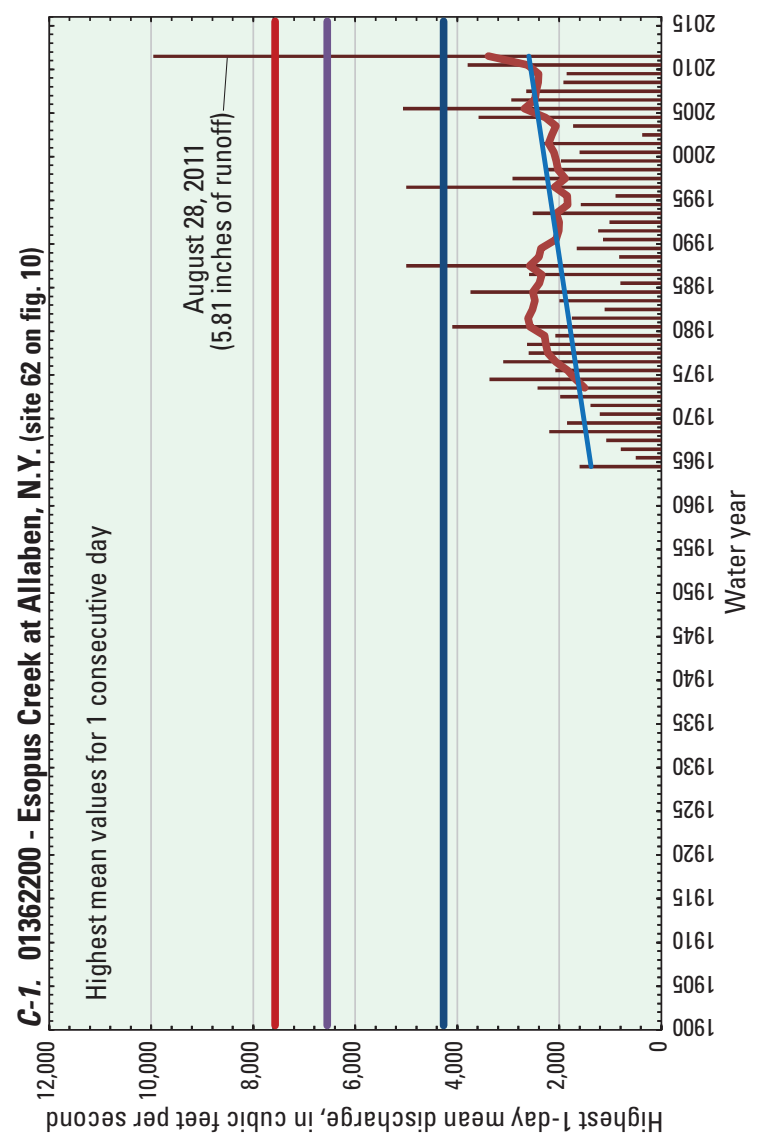

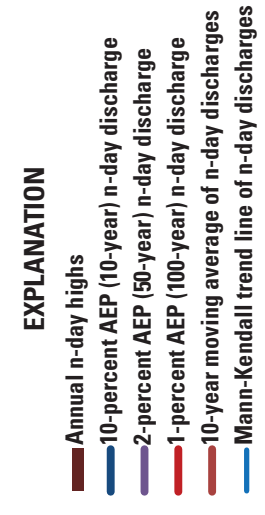

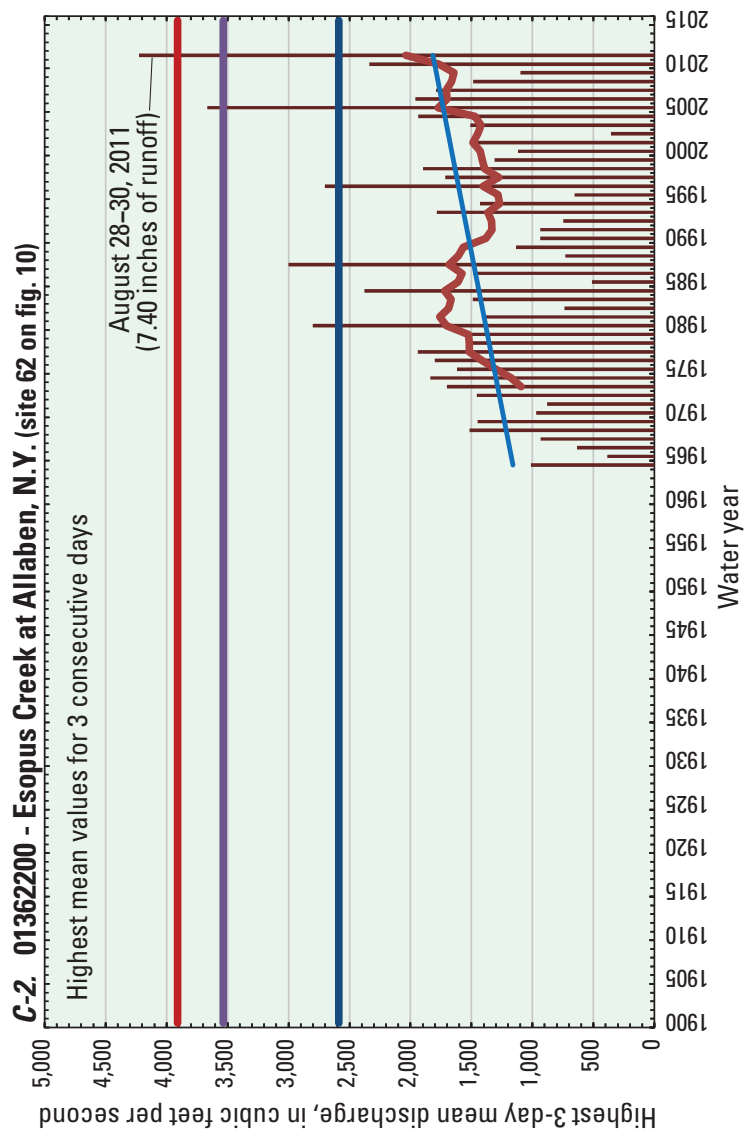

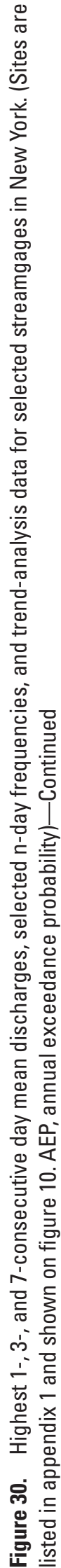



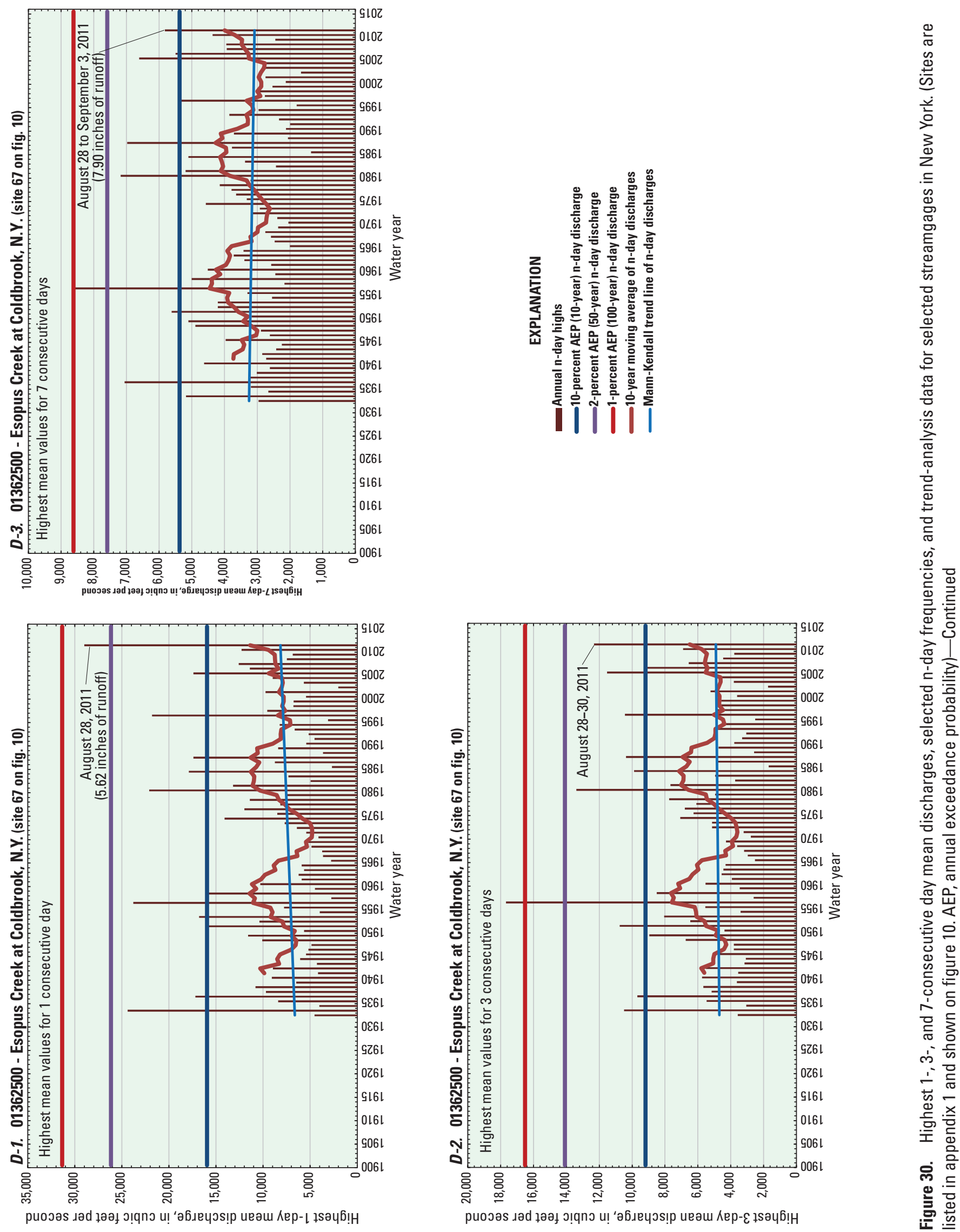

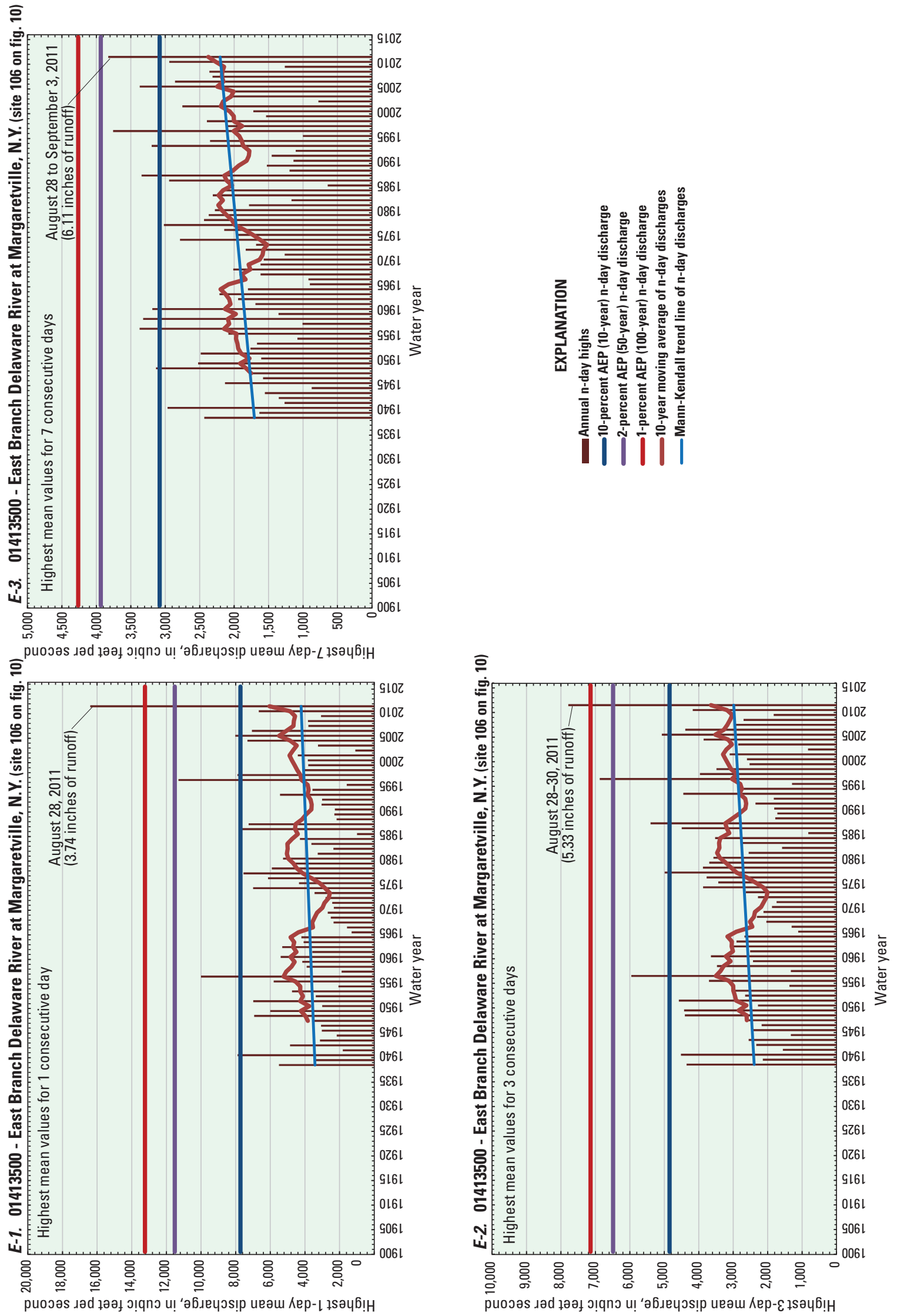
Table 12. Total storm runoff and selected statistics for August 27 to September 2, 2011, at selected U.S. Geological Survey streamgages in New York.

[Latitude and longitude in decimal degrees (North American Datum of 1983 (NAD 83); mi², square miles; runoffs for sites in pink have been adjusted for storage in upstream reservoirs; runoffs in red are greater than or equal to the median storm runoff for selected sites in listed basins; locations are shown on figures 10 and 31]

\begin{tabular}{|c|c|c|c|c|c|c|c|c|c|}
\hline $\begin{array}{c}\text { Map } \\
\text { num- } \\
\text { ber }\end{array}$ & $\begin{array}{c}\text { Streamgage } \\
\text { number }\end{array}$ & Streamgage name & $\begin{array}{c}\text { Drainage } \\
\text { area } \\
\left(\mathrm{mi}^{2}\right)\end{array}$ & Latitude & Longitude & $\begin{array}{l}\text { Storm } \\
\text { runoff } \\
\text { (inch- } \\
\text { es) }\end{array}$ & $\begin{array}{l}\text { Basin } \\
\text { median } \\
\text { storm } \\
\text { runoff } \\
\text { (inches) }\end{array}$ & $\begin{array}{l}\text { Basin } \\
\text { mean } \\
\text { storm } \\
\text { runoff } \\
\text { (inches) }\end{array}$ & $\begin{array}{c}\text { Number } \\
\text { of se- } \\
\text { lected } \\
\text { basin } \\
\text { sites }\end{array}$ \\
\hline & & Upper Hudson River Basin & & & & & 1.54 & 1.80 & 12 \\
\hline 9 & 01312000 & Hudson River near Newcomb, N.Y. & 192 & 43.96667 & -74.13194 & 1.68 & & & \\
\hline 11 & 01315000 & Indian River near Indian Lake, N.Y. & 132 & 43.75639 & -74.26750 & 1.37 & & & \\
\hline 16 & 01321000 & Sacandaga River near Hope, N.Y. & 491 & 43.35278 & -74.27083 & 1.47 & & & \\
\hline 18 & 01325000 & Sacandaga River at Stewarts Bridge near Hadley, N.Y. & 1,055 & 43.31139 & -73.86778 & 1.75 & & & \\
\hline 19 & 01327750 & Hudson River at Fort Edward, N.Y. & 2,810 & 43.26944 & -73.59639 & 1.48 & & & \\
\hline 21 & 01329490 & Batten Kill below mill at Battenville, N.Y. & 396 & 43.10861 & -73.42222 & 3.20 & & & \\
\hline 22 & 01330000 & Glowegee Creek at West Milton, N.Y. & 26.0 & 43.03056 & -73.92778 & 1.57 & & & \\
\hline 28 & 01336000 & Mohawk River below Delta Dam near Rome, N.Y. & 152 & 43.26444 & -75.43667 & 0.40 & & & \\
\hline 30 & 01343060 & West Canada Creek near Wilmurt, N.Y. & 258 & 43.36611 & -74.95806 & 1.25 & & & \\
\hline 32 & 01346000 & West Canada Creek at Kast Bridge, N.Y. & 560 & 43.06889 & -74.98861 & 1.02 & & & \\
\hline 33 & 01347000 & Mohawk River near Little Falls, N.Y. & 1,342 & 43.01472 & -74.77972 & 0.96 & & & \\
\hline 34 & 01348000 & East Canada Creek at East Creek, N.Y. & 289 & 43.01667 & -74.74111 & 0.91 & & & \\
\hline \multirow[t]{2}{*}{36} & 01349150 & Canajoharie Creek near Canajoharie, N.Y. & 59.7 & 42.87611 & -74.60333 & 2.92 & & & \\
\hline & & Schoharie Creek Basin & & & & & 7.38 & 7.14 & 14 \\
\hline 37 & 01349700 & East Kill near Jewett Center, N.Y. & 35.6 & 42.24917 & -74.30306 & 11.13 & & & \\
\hline 38 & 01349705 & Schoharie Creek near Lexington, N.Y. & 96.8 & 42.23694 & -74.34056 & 7.82 & & & \\
\hline 39 & 01349711 & West Kill below Hunter Brook near Spruceton, N.Y. & 4.97 & 42.18500 & -74.27722 & 12.17 & & & \\
\hline 49 & 01350180 & Schoharie Creek at North Blenheim, N.Y. & 358 & 42.46583 & -74.46250 & 7.76 & & & \\
\hline 50 & 01350355 & Schoharie Creek at Breakabeen, N.Y. & 444 & 42.53694 & -74.41083 & 6.44 & & & \\
\hline \multirow[t]{2}{*}{51} & 01351500 & Schoharie Creek at Burtonsville, N.Y. & 886 & 42.80000 & -74.26333 & 5.29 & & & \\
\hline & & Lower Mohawk River Basin & & & & & 2.18 & 2.18 & 2 \\
\hline 52 & 01356190 & Lisha Kill northwest of Niskayuna, N.Y. & 15.6 & 42.78361 & -73.85722 & 2.06 & & & \\
\hline \multirow[t]{2}{*}{53} & 01357500 & Mohawk River at Cohoes, N.Y. & 3,450 & 42.78528 & -73.70806 & 2.30 & & & \\
\hline & & Lower Hudson River Basin & & & & & 4.38 & 5.07 & 22 \\
\hline 54 & 01358000 & Hudson River at Green Island, N.Y. & 8,090 & 42.75222 & -73.68944 & 2.00 & & & \\
\hline 56 & 01360640 & Valatie Kill near Nassau, N.Y. & 9.48 & 42.55194 & -73.59194 & 2.85 & & & \\
\hline 60 & 013621955 & Birch Creek at Big Indian, N.Y. & 12.5 & 42.10889 & -74.45222 & 4.19 & & & \\
\hline 62 & 01362200 & Esopus Creek at Allaben, N.Y. & 63.7 & 42.11694 & -74.38056 & 8.48 & & & \\
\hline 63 & 0136230002 & Woodland Creek above mouth at Phoenicia, N.Y. & 20.6 & 42.07972 & -74.33444 & 9.35 & & & \\
\hline 64 & 01362342 & Hollow Tree Brook at Lanesville, N.Y. & 1.95 & 42.14222 & -74.26528 & 7.72 & & & \\
\hline 65 & 01362370 & Stony Clove Creek below Ox Clove at Chichester, N.Y. & 30.9 & 42.10194 & -74.31083 & 8.43 & & & \\
\hline 66 & 01362497 & $\begin{array}{l}\text { Little Beaver Kill at Beechford near Mount } \\
\text { Tremper. N.Y. }\end{array}$ & 16.5 & 42.01944 & -74.26667 & 4.61 & & & \\
\hline
\end{tabular}
Tremper, N.Y. 
Table 12. Total storm runoff and selected statistics for August 27 to September 2, 2011, at selected U.S. Geological Survey streamgages in New York.-Continued

[Latitude and longitude in decimal degrees (North American Datum of 1983 (NAD 83); mi², square miles; runoffs for sites in pink have been adjusted for storage in upstream reservoirs; runoffs in red are greater than or equal to the median storm runoff for selected sites in listed basins; locations are shown on figures 10 and 31]

\begin{tabular}{|c|c|c|c|c|c|c|c|c|c|}
\hline $\begin{array}{l}\text { Map } \\
\text { num- } \\
\text { ber }\end{array}$ & $\begin{array}{c}\text { Streamgage } \\
\text { number }\end{array}$ & Streamgage name & $\begin{array}{c}\text { Drainage } \\
\text { area } \\
\left(\mathrm{mi}^{2}\right)\end{array}$ & Latitude & Longitude & $\begin{array}{c}\text { Storm } \\
\text { runoff } \\
\text { (inch- } \\
\text { es) }\end{array}$ & $\begin{array}{l}\text { Basin } \\
\text { median } \\
\text { storm } \\
\text { runoff } \\
\text { (inches) }\end{array}$ & $\begin{array}{l}\text { Basin } \\
\text { mean } \\
\text { storm } \\
\text { runoff } \\
\text { (inches) }\end{array}$ & $\begin{array}{l}\text { Number } \\
\text { of se- } \\
\text { lected } \\
\text { basin } \\
\text { sites }\end{array}$ \\
\hline & & Lower Hudson River Basin-Continued & & & & & & & \\
\hline 67 & 01362500 & Esopus Creek at Coldbrook, N.Y. & 192 & 42.01417 & -74.27083 & 7.89 & & & \\
\hline 68 & 01363382 & $\begin{array}{l}\text { Bush Kill below Maltby Hollow Brook at West } \\
\text { Shokan, N.Y. }\end{array}$ & 16.2 & 41.96556 & -74.29333 & 6.95 & & & \\
\hline 71 & 01365000 & Rondout Creek near Lowes Corners, N.Y. & 38.3 & 41.86639 & -74.48750 & 5.28 & & & \\
\hline 72 & 01365500 & Chestnut Creek at Grahamsville, N.Y. & 20.9 & 41.84500 & -74.53972 & 3.01 & & & \\
\hline 74 & 01367500 & Rondout Creek at Rosendale, N.Y. & 383 & 41.84306 & -74.08639 & 4.82 & & & \\
\hline 76 & 01371500 & Wallkill River at Gardiner, N.Y. & 695 & 41.68611 & -74.16556 & 4.58 & & & \\
\hline 78 & 01372500 & Wappinger Creek near Wappingers Falls, N.Y. & 181 & 41.65306 & -73.87306 & 3.60 & & & \\
\hline 87 & 01374598 & Horse Pound Brook near Lake Carmel, N.Y. & 3.94 & 41.47583 & -73.68944 & 2.74 & & & \\
\hline 93 & 01374890 & Cross River near Cross River, N.Y. & 17.1 & 41.26000 & -73.60167 & 3.61 & & & \\
\hline \multirow[t]{2}{*}{95} & 01374930 & Muscoot River at Baldwin Place, N.Y. & 13.5 & 41.33806 & -73.76861 & 3.78 & & & \\
\hline & & Passaic River Basin & & & & & 7.67 & 7.67 & 2 \\
\hline 100 & 01387400 & Ramapo River at Ramapo, N.Y. & 86.9 & 41.14028 & -74.16889 & 7.40 & & & \\
\hline \multirow[t]{2}{*}{101} & 01387420 & Ramapo River at Suffern, N.Y. & 93.0 & 41.11833 & -74.16056 & 7.95 & & & \\
\hline & & Delaware River Basin & & & & & 3.88 & 4.28 & 33 \\
\hline 103 & 01413088 & East Branch Delaware River at Roxbury, N.Y. & 13.5 & 42.29167 & -74.55972 & 3.49 & & & \\
\hline 104 & 01413398 & Bush Kill near Arkville, N.Y. & 46.7 & 42.15083 & -74.60167 & 5.88 & & & \\
\hline 105 & 01413408 & Dry Brook at Arkville & 82.2 & 42.14667 & -74.62361 & 5.87 & & & \\
\hline 106 & 01413500 & East Branch Delaware River at Margaretville, N.Y. & 163 & 42.14472 & -74.65389 & 6.03 & & & \\
\hline 115 & 01421610 & West Branch Delaware River at Hobart, N.Y. & 15.5 & 42.37139 & -74.66944 & 2.53 & & & \\
\hline 116 & 01421618 & Town Brook southeast of Hobart, N.Y. & 14.3 & 42.36111 & -74.66250 & 4.08 & & & \\
\hline 117 & 01421900 & $\begin{array}{l}\text { West Branch Delaware River upstream from } \\
\text { Delhi, N.Y. }\end{array}$ & 134 & 42.28028 & -74.90750 & 3.01 & & & \\
\hline 118 & 01422500 & Little Delaware River near Delhi, N.Y. & 49.8 & 42.25222 & -74.90194 & 3.01 & & & \\
\hline 119 & 01422747 & East Brook East of Walton, N.Y. & 24.7 & 42.17278 & -75.12167 & 3.12 & & & \\
\hline 120 & 01423000 & West Branch Delaware River at Walton, N.Y. & 332 & 42.16611 & -75.14028 & 2.78 & & & \\
\hline 121 & 0142400103 & Trout Creek near Trout Creek, N.Y. & 20.2 & 42.17361 & -75.27972 & 2.08 & & & \\
\hline 123 & 01425000 & West Branch Delaware River at Stilesville, N.Y. & 456 & 42.07472 & -75.39639 & 2.39 & & & \\
\hline 124 & 01426500 & West Branch Delaware River at Hale Eddy, N.Y. & 595 & 42.00306 & -75.38389 & 2.40 & & & \\
\hline 126 & 01427510 & Delaware River at Callicoon, N.Y. & 1,820 & 41.75667 & -75.05778 & 3.00 & & & \\
\hline 127 & 01428500 & $\begin{array}{l}\text { Delaware River above Lackawaxen River near } \\
\text { Barryville, N.Y. }\end{array}$ & 2,020 & 41.50889 & -74.98611 & 2.95 & & & \\
\hline 128 & 01432900 & Mongaup River at Mongaup Valley, N.Y. & 76.6 & 41.66806 & -74.78083 & 2.81 & & & \\
\hline 129 & 01434000 & Delaware River at Port Jervis, N.Y. & 3,070 & 41.37056 & -74.69778 & 2.75 & & & \\
\hline 130 & 0143400680 & $\begin{array}{l}\text { East Branch Neversink River northeast of } \\
\text { Denning, N.Y. }\end{array}$ & 8.93 & 41.96694 & -74.44833 & 8.54 & & & \\
\hline
\end{tabular}


Table 12. Total storm runoff and selected statistics for August 27 to September 2, 2011, at selected U.S. Geological Survey streamgages in New York.-Continued

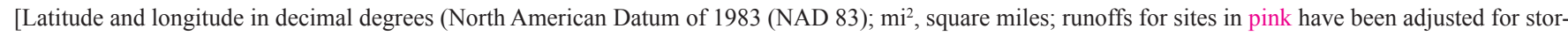
age in upstream reservoirs; runoffs in red are greater than or equal to the median storm runoff for selected sites in listed basins; locations are shown on figures 10 and 31]

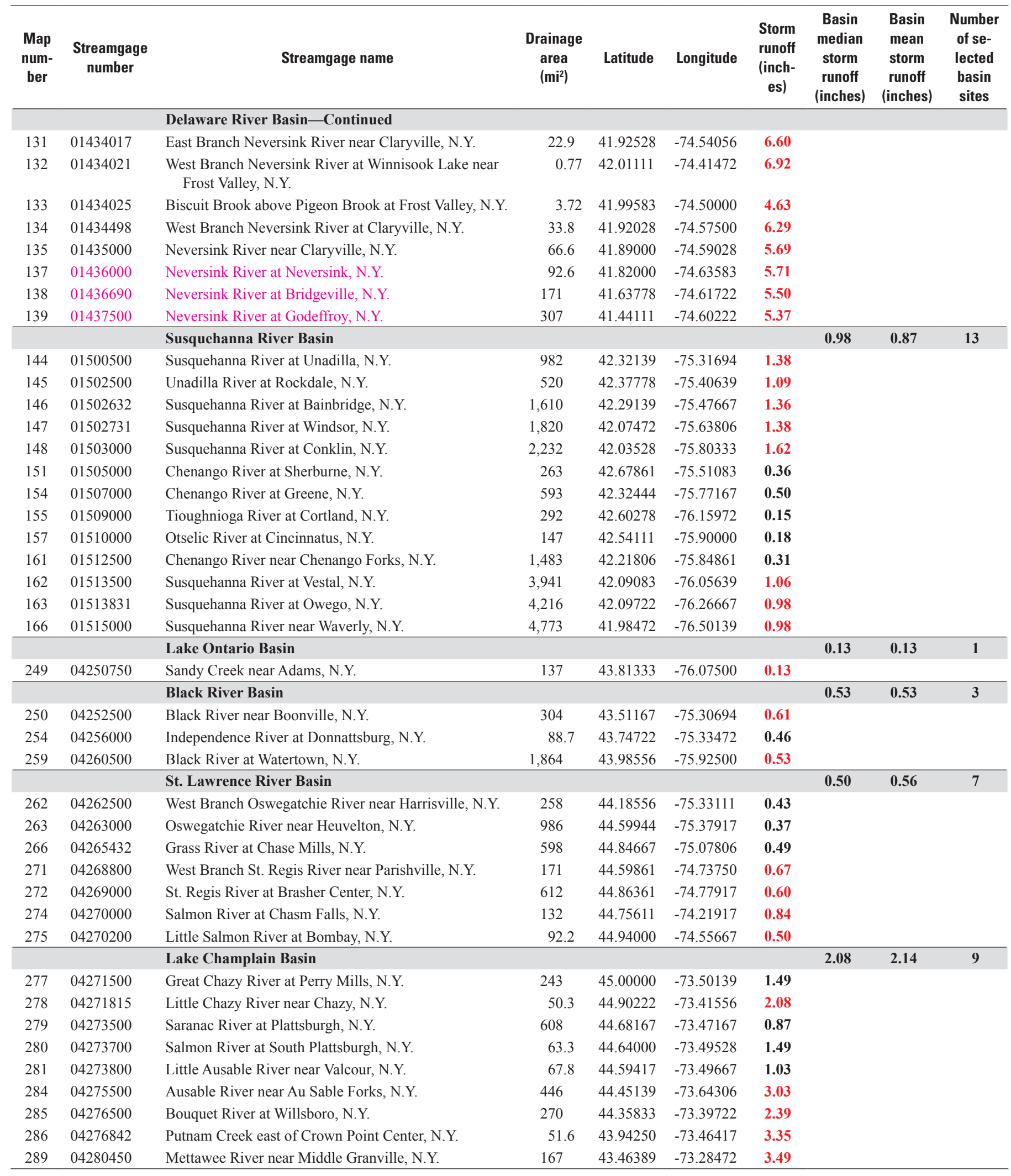




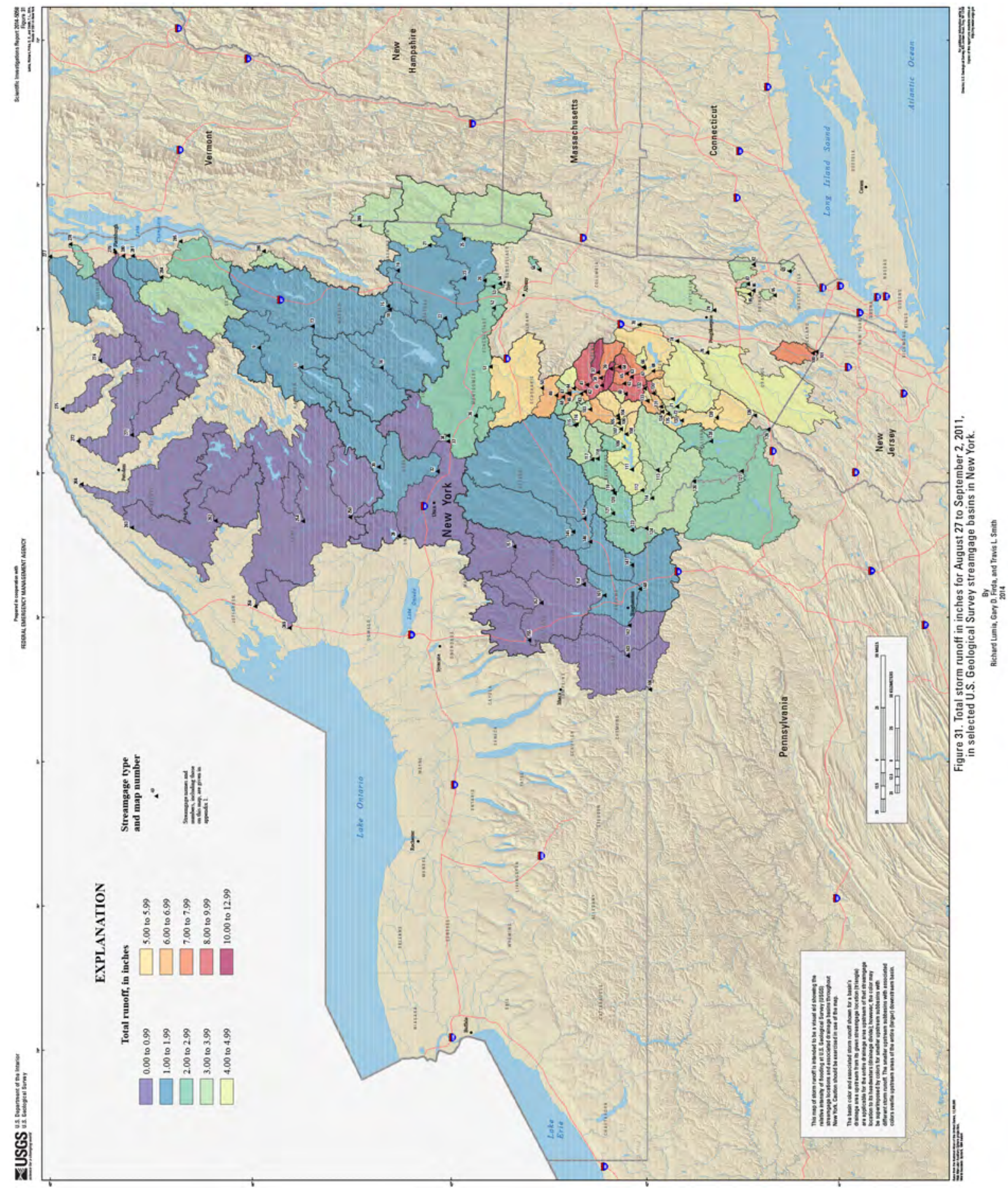

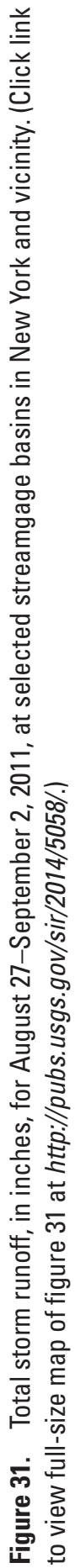



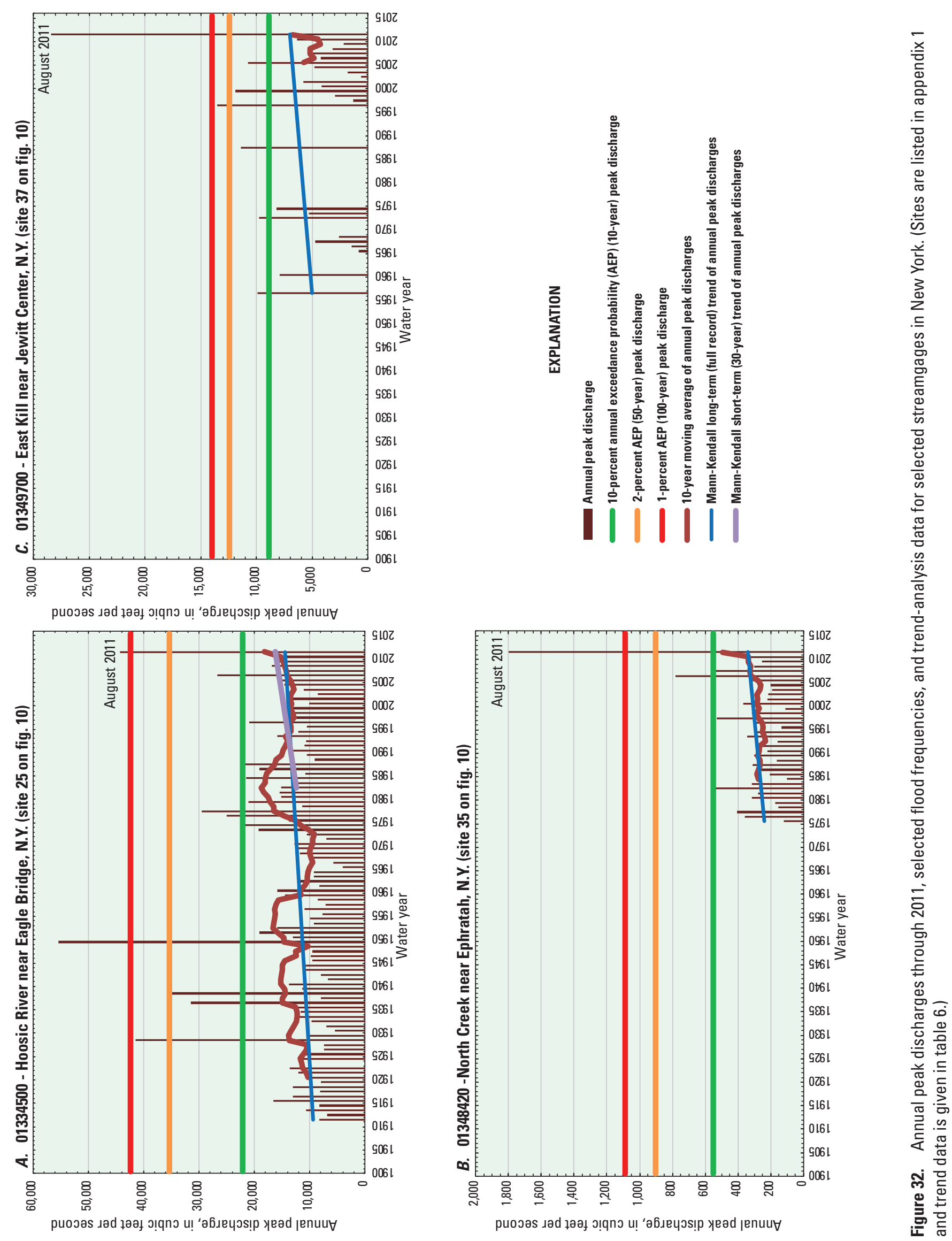

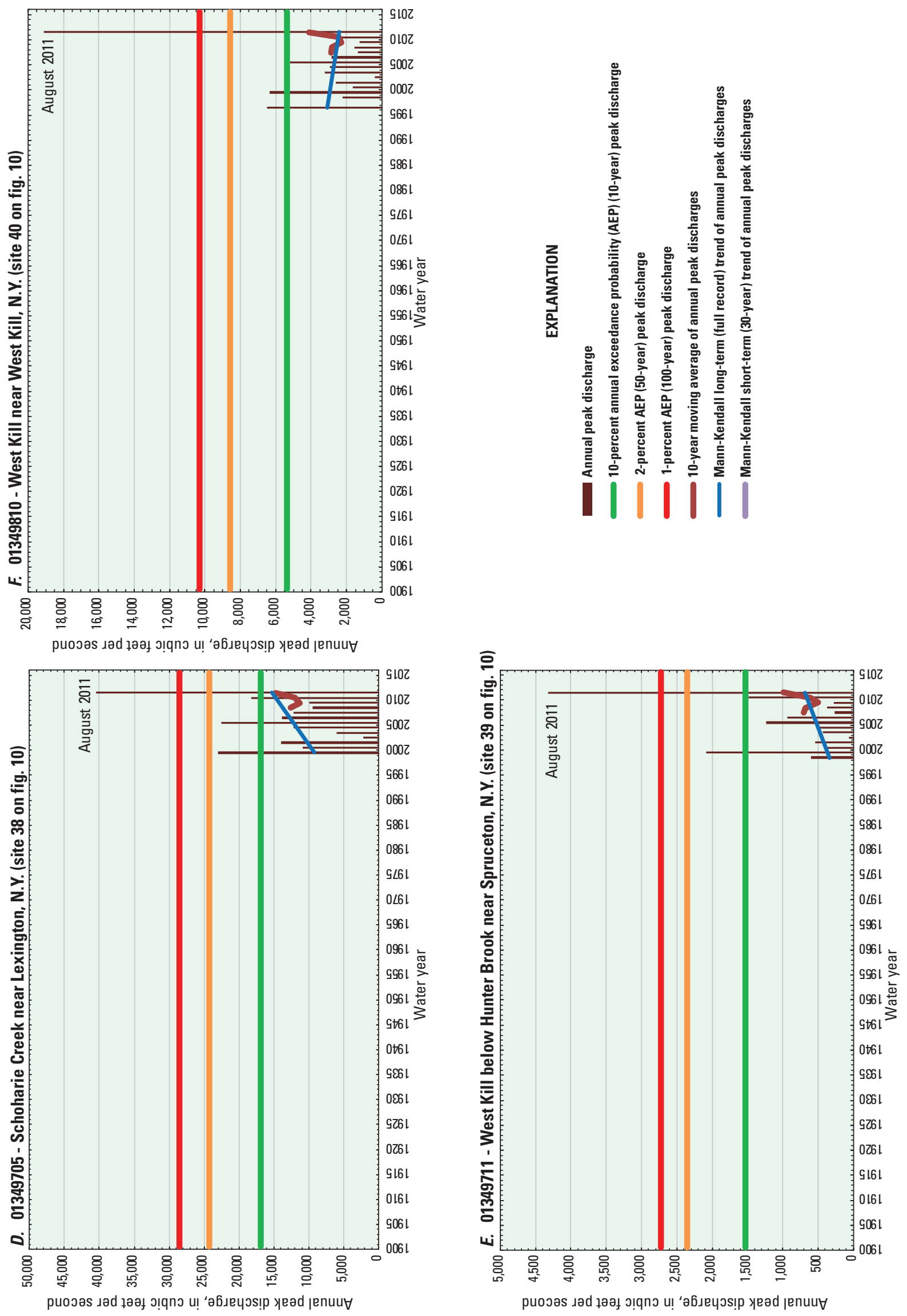

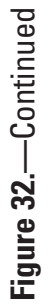



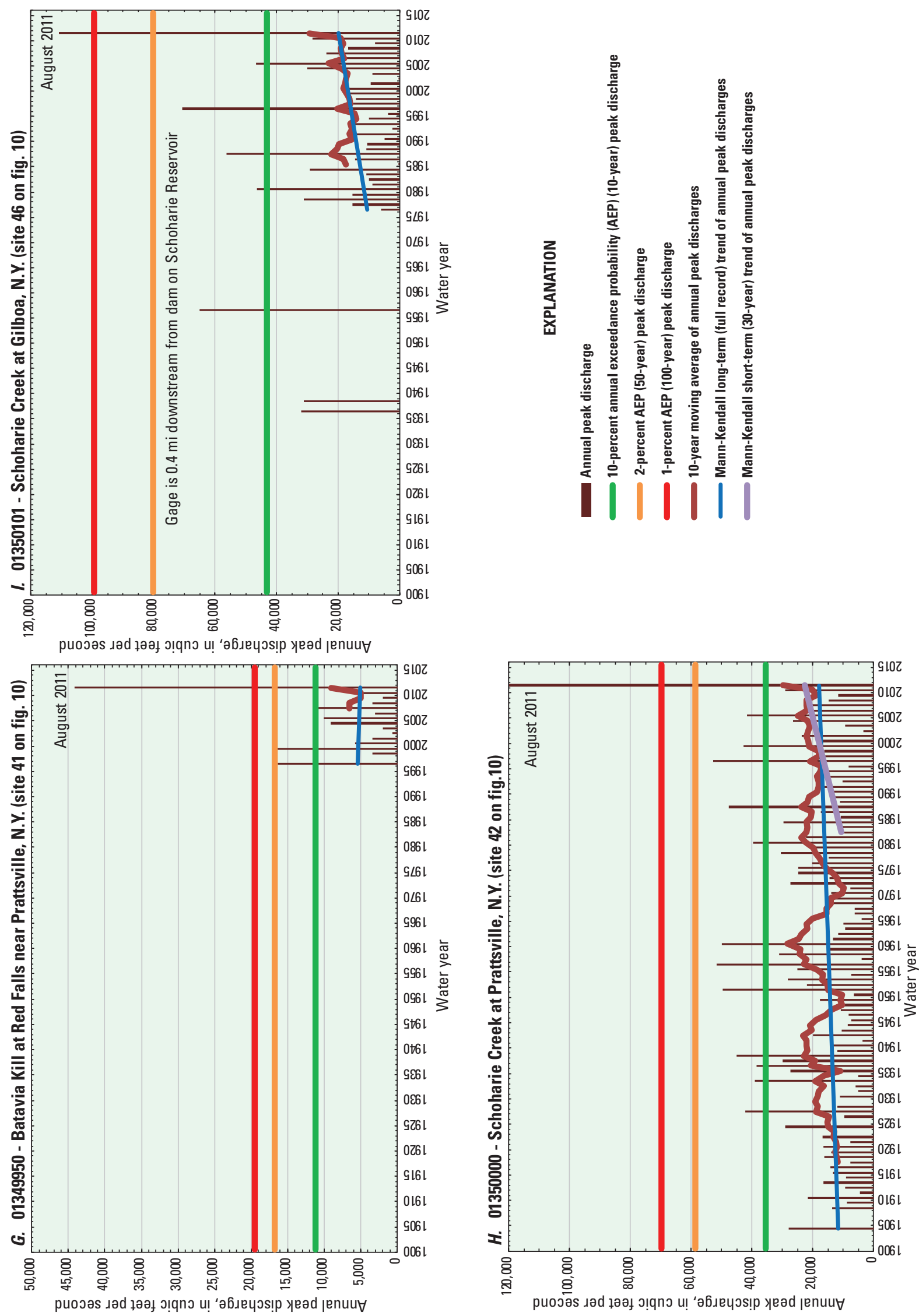

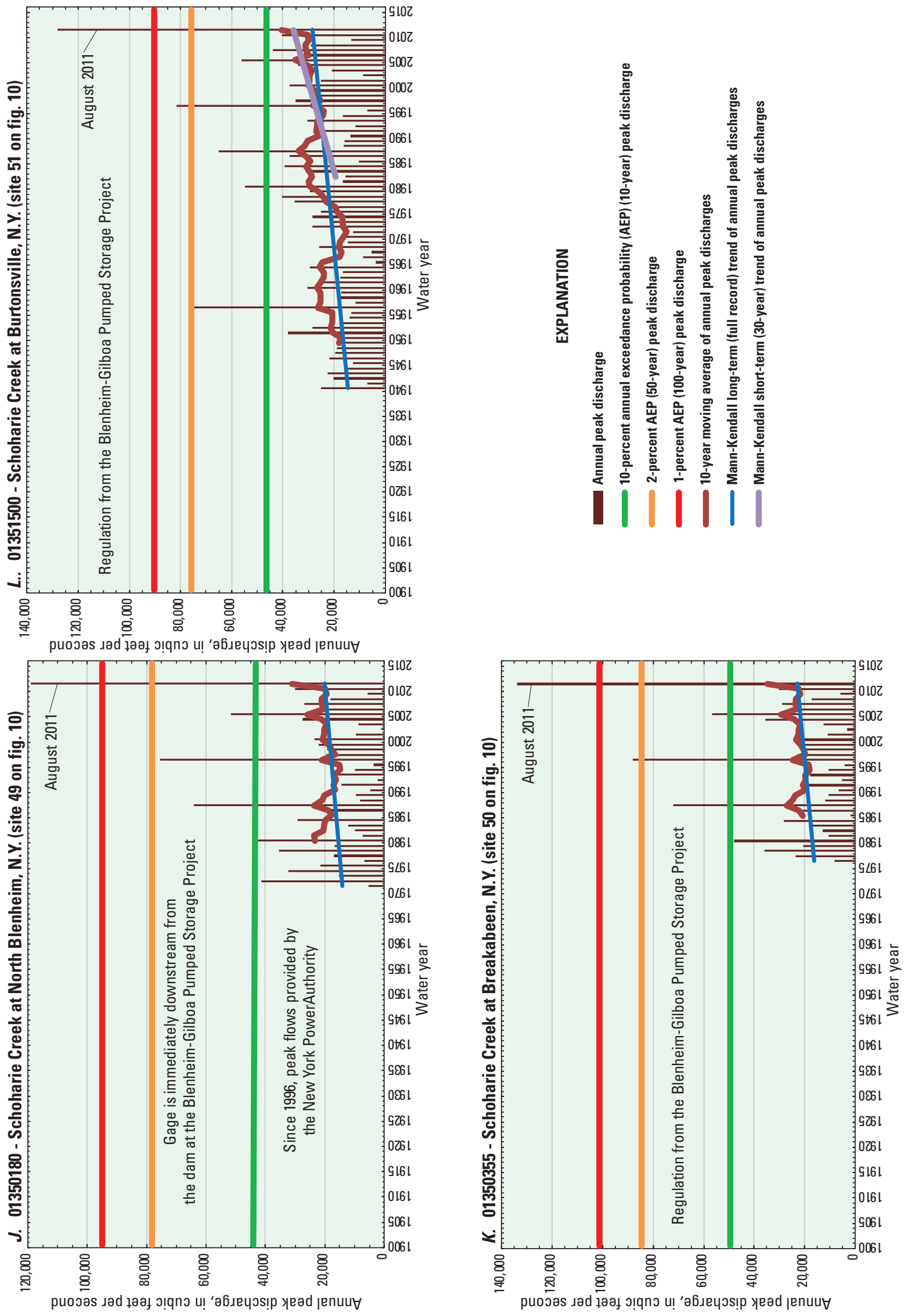

پ. 

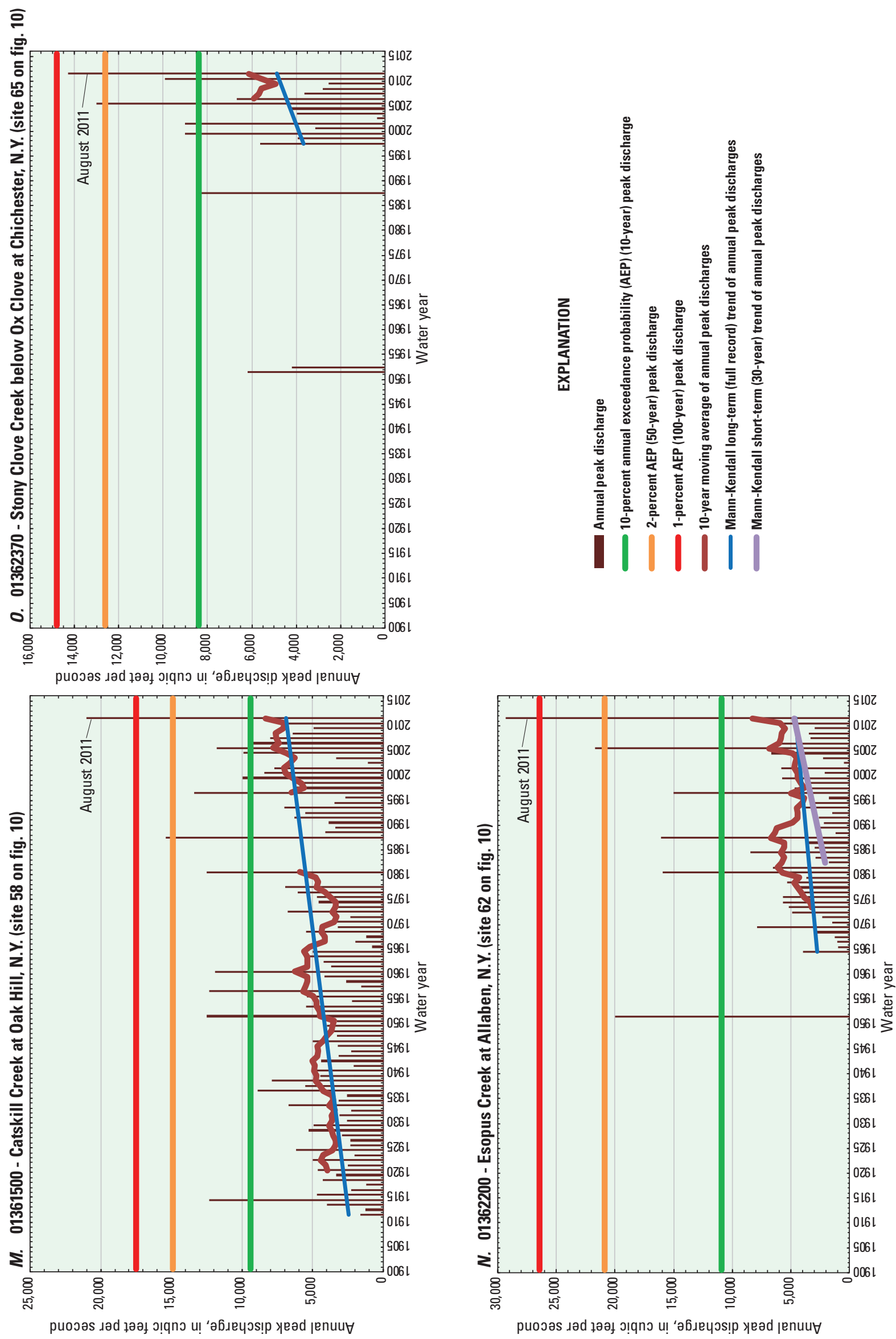

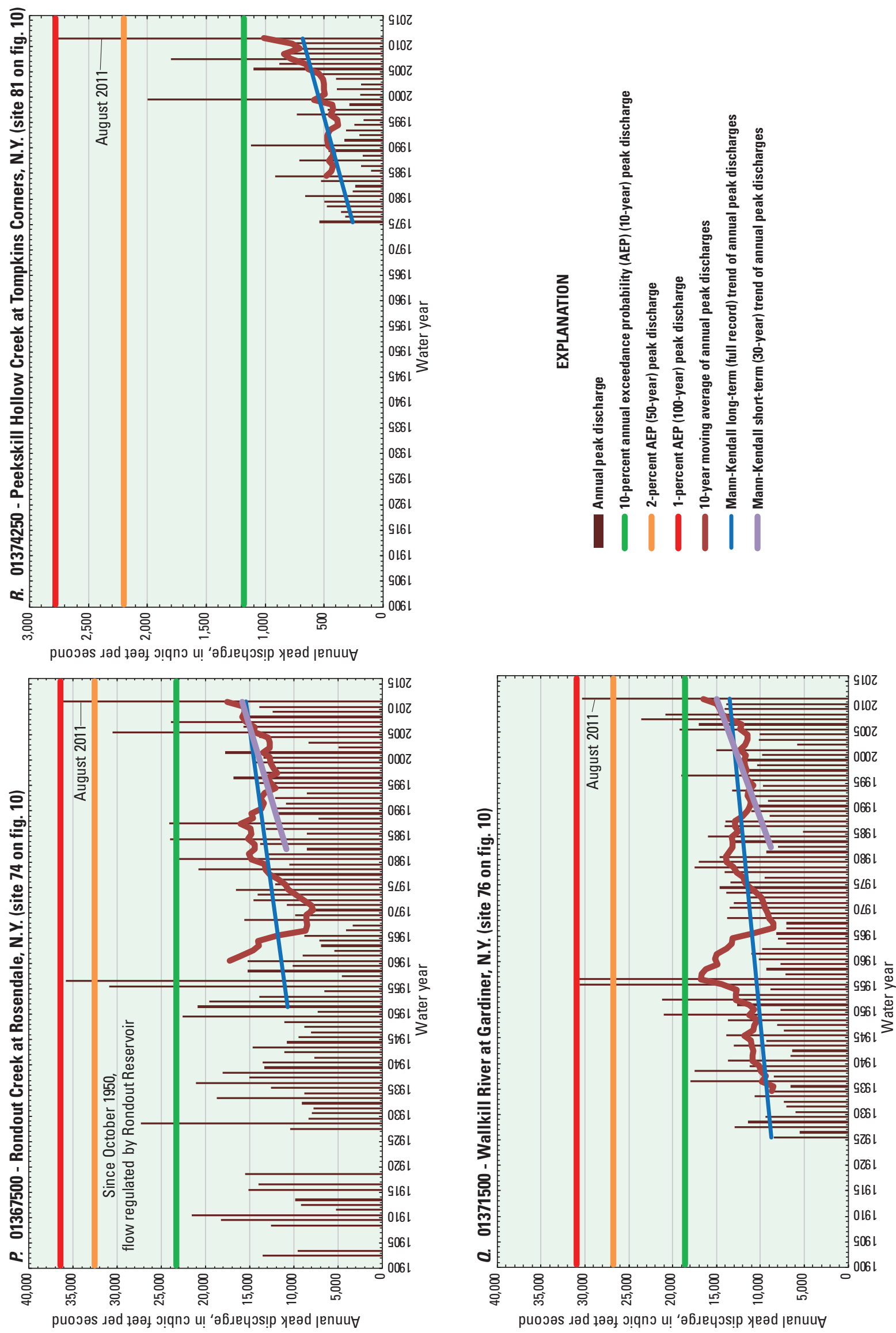

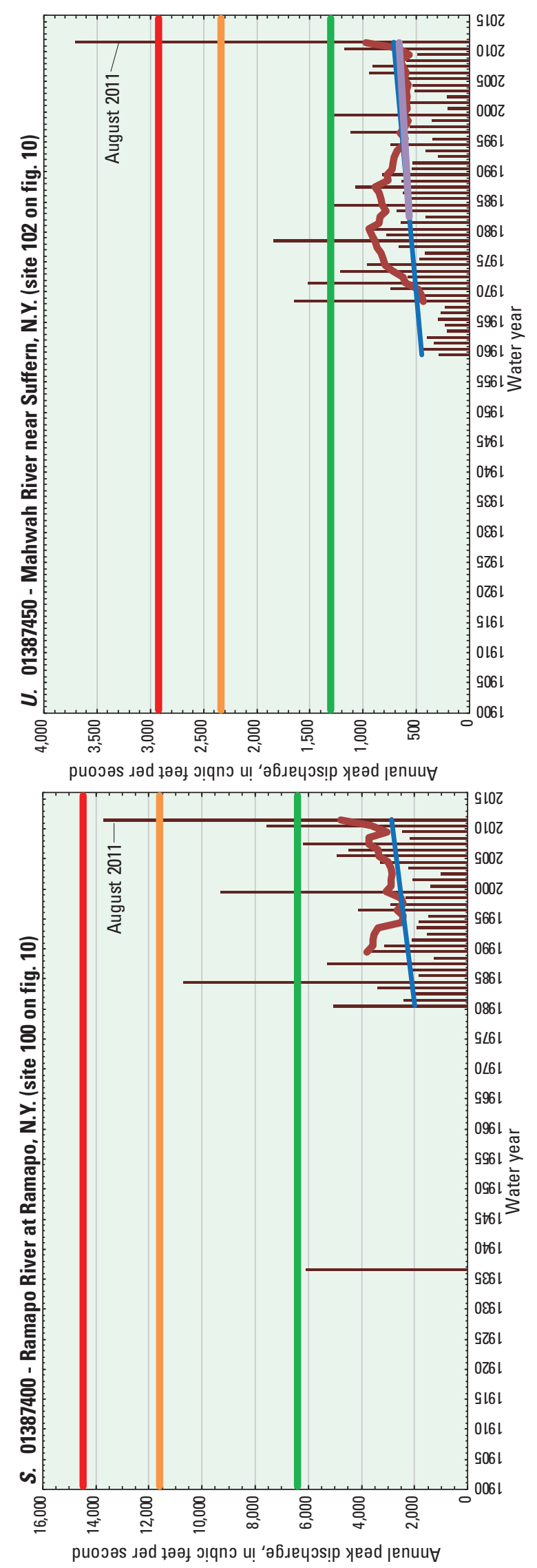
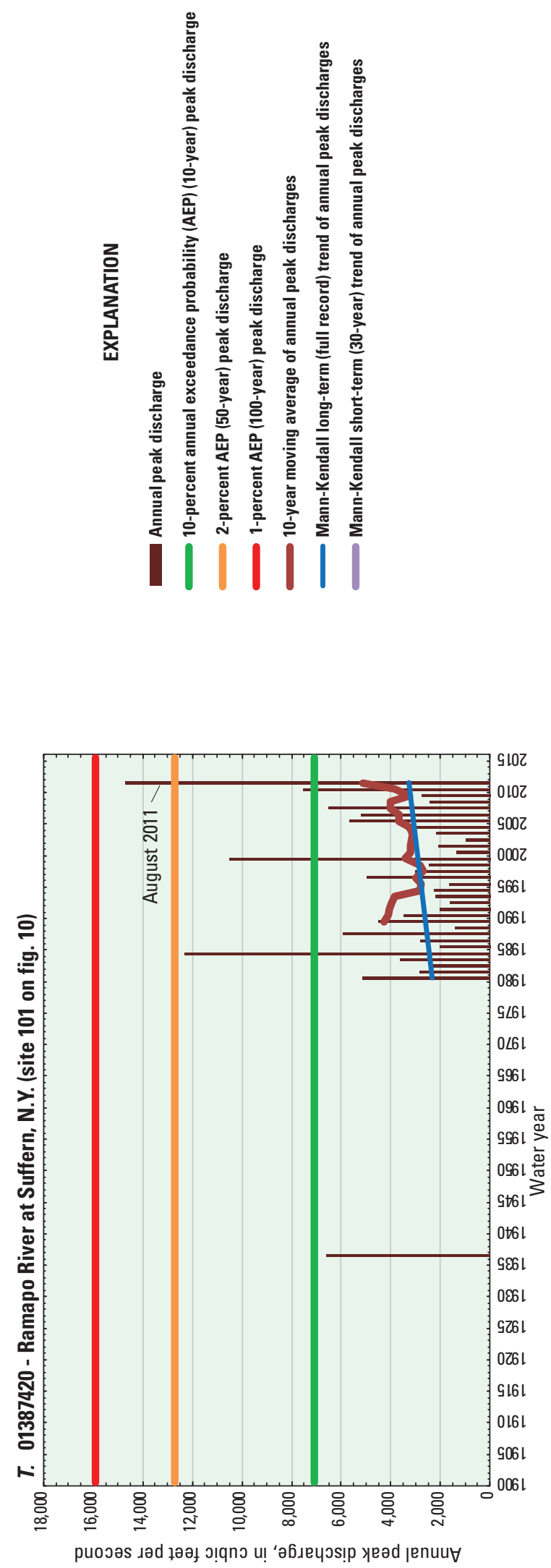

离 

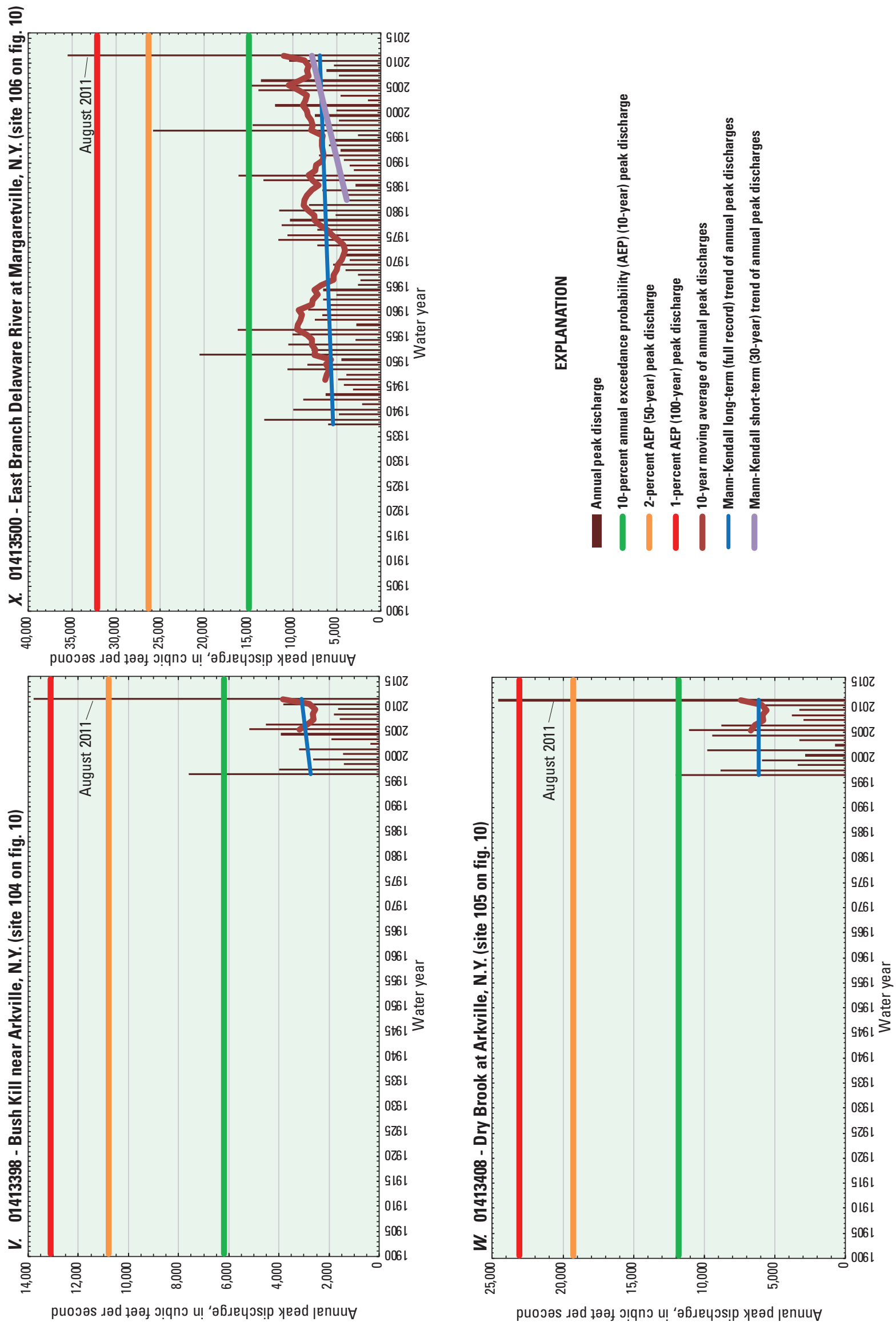

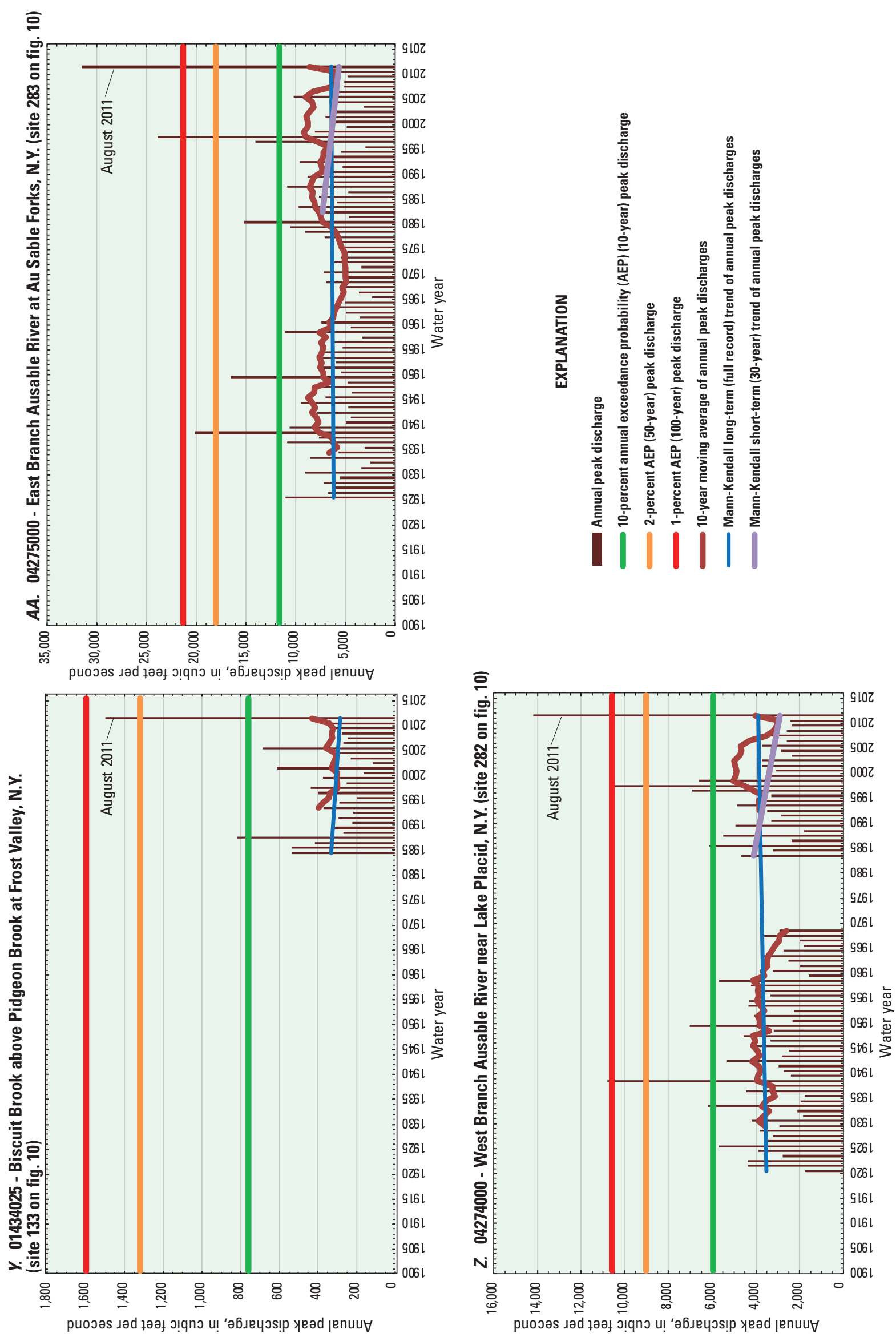

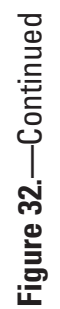



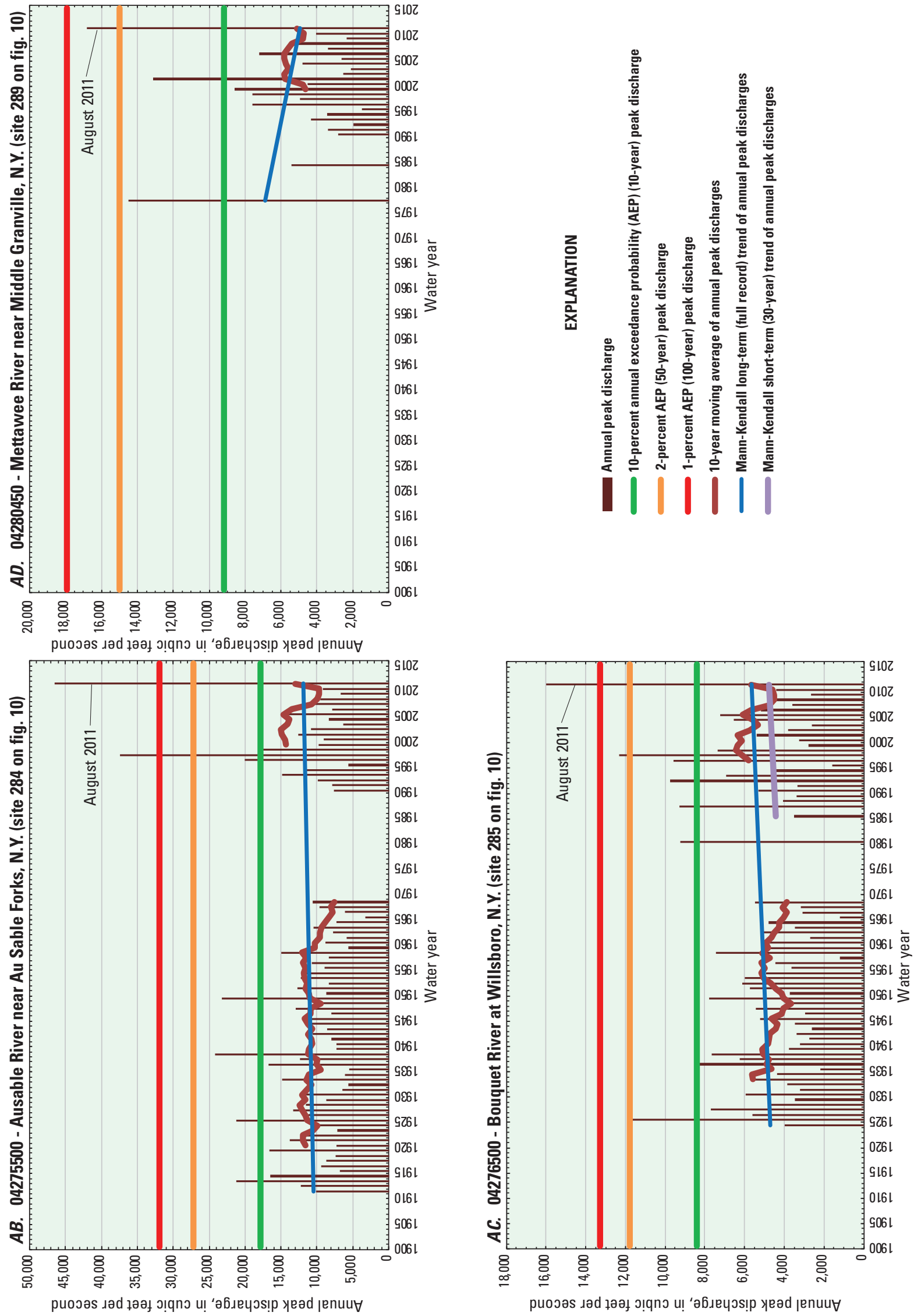
The record peak discharge of $35,500 \mathrm{ft}^{3} / \mathrm{s}$ for the East Branch Delaware River at Margaretville (01413500) streamgage on August 28 was 1.4 times greater than the previous peak of record (25,800 ft $3 / \mathrm{s}$ on January 19, 1996; fig. 32X, table 11). The annual peak discharges at Margaretville had a statistically significant (p-value 0.052) short-term (1982-2011) positive trend, but the long-term (1937-2011) trend was small and not significant (table 6). August 28 flooding in the Ausable and Bouquet River Basins (Lake Champlain Basin) set record peak discharges far exceeding the 1-percent AEP (100-year) flows (figs. 32Z-AC, table 11) and the previous peak of record in November 1996. Annual peak flows do not have significant trends at these four streamgages (figs. 32Z-AC, table 6).

The effects of the August 2011 peak flow and previous annual peak discharges on flood frequencies over time are illustrated on figures 33A-C. Updated flood-frequency values were re-calculated annually following the first 10 years of peak-discharge record and plotted in a continuous line as each year of peak-discharge record was added to the computations. The 10-year moving average and the computed trend line for the moving 1-percent AEP (100-year) flood-frequency values show a statistically significant increase (p-value 0.000 ) for Schoharie Creek at Prattsville (01350000) and Burtonsville (01351500) (figs. 33A-B). The graphs for Burtonsville (fig. 33B) and East Branch Delaware River at Margaretville (01413500) (fig. 33C) indicate that the 1996 flood at each streamgage was previously computed (in 1996) to be a 1-percent AEP (100-year) flood but has been reduced to nearly a 2-percent AEP (50-year) flood as a result of recomputations that included the 1997-2011 flood peaks. The maximum discharge at each site for 2011 occurred on August 28 or 29.

Antecedent conditions, precipitation, runoff patterns, and basin characteristics all play a role in determining the peak water-surface elevation and discharge at a streamgage. Discharge hydrographs for selected streamgages for August 27-September 2, 2011, compare the magnitude, relative frequency, and timing of flows at each location (figs. 34-35). In some cases, unit (15-minute) discharge data are missing because of equipment malfunction or damage to the streamgage that houses the equipment. The Schoharie Creek hydrographs (fig. 34C) from five streamgages indicate that each peak discharge exceeded the 1-percent AEP flow and that reservoir and flood-plain storage had some effect on timing and attenuation of flows throughout the basin during the flood. The Mohawk River upstream from Schoharie Creek had less flooding than flows downstream from the confluence (figs. 34D-G), and flooding could have been worse if two major tributaries (East and West Canada Creeks) had contributed more than the minor flows (less than 50-percent AEP or 2-year peak discharges) (table 11) recorded during late August (figs. 34D and F). Peak discharges on August 28, 2011, on several streams in the East Branch Delaware River Basin (upstream from Pepacton Reservoir) exceeded the 1-percent AEP (100-year) discharge (fig. 34K), whereas the West Branch Delaware River Basin had minimal flooding (table 11). Tropical Storm Irene caused moderate to significant flooding (25- to 80-year floods) in the Neversink River Basin (tributary to the Delaware River) in southeastern New York (figs. 34LM, table 11), whereas heavy rains on August 28-29 over the Ausable and Bouquet River Basins in northeastern New York caused record flooding with some peak flows exceeding the 0.5-percent AEP (200-year) discharge. The East Branch Ausable River (04275000) peaked at nearly the same time as the main stem Ausable River (04275500) near Au Sable Forks (fig. 34P), whereas the time of the peak discharge on the West Branch Ausable River (04274000) is unknown because the streamgage does not record continuous streamflow.

Unit discharge hydrographs for August 27-September 2, 2011, for 14 sites in the flooded areas, hydrographs for previous high flows at each site, selected flood frequencies, and a list of the greatest four peak discharges at each streamgage allow comparisons of hydrograph shape and the relative magnitude and frequency of each flood (figs. 35A-N). The peak discharges for previous floods were overlaid on those for the August 2011 flood to allow hydrograph-shape comparisons. The January 1996 flood hydrographs (previous peaks of record) are included with each of the five Schoharie Creek plots (figs. 35A-E) for comparison. The differences between the 1996 and 2011 peak stages at the Schoharie Creek sites ranged from $1.86 \mathrm{ft}$ (01350355 at Breakabeen) to $9.92 \mathrm{ft}$ (01350101 at Gilboa). The large range in differences is a result of variable hydraulic conditions found at each gaged location along Schoharie Creek during each flood. The spikes on the hydrographs for the Mohawk River at Cohoes (01357500) streamgage (fig. 35F) are somewhat unique (see the 1964 and 1996 hydrographs in fig. 35F); the spikes result from releases from upstream ice jams that caused a temporary surge of water (discharge) at the Cohoes streamgage. The peak discharges and volumes of flow are correct, but the surges of water at high flows produce a nonhomogeneous annual peak dataset. Enhanced peak discharges occur often and are treated as the normal condition of the dataset, and flood frequencies are computed accordingly. For comparison, hydrographs and associated peak discharges during periods of upstream release of ice jams (where data were readily available) were adjusted to reflect the "normal" flow conditions (without surges) at the Cohoes streamgage. Flood-frequency analyses were recomputed and indicate the adjusted 1-percent AEP (100-year) value to be lower, resulting in higher frequencies for flood peaks. Most hydrographs at a given site on figure 35 have similar shapes, but their differences depend on the time of year for each flood (reflecting antecedent baseflow conditions, snowmelt, and storm rainfall patterns and intensities).

The magnitude, frequency, and duration of flood stages for 11 streamgages in the Catskill Mountains area of New York are shown on figure 36 . The stage hydrograph, selected stage frequencies (horizontal color-coded range bars), and frequency durations (color-coded lines at the top of the plot) for the Schoharie Creek at Prattsville (01350000) indicate that the stage rose nearly $21 \mathrm{ft}$ on August 28 and remained above the 0.2-percent AEP (500-year) flood stage for about 3 hours and above the 1-percent AEP (100-year) stage for about 6 hours (fig. 36A). The stage on August 28 increased 
으
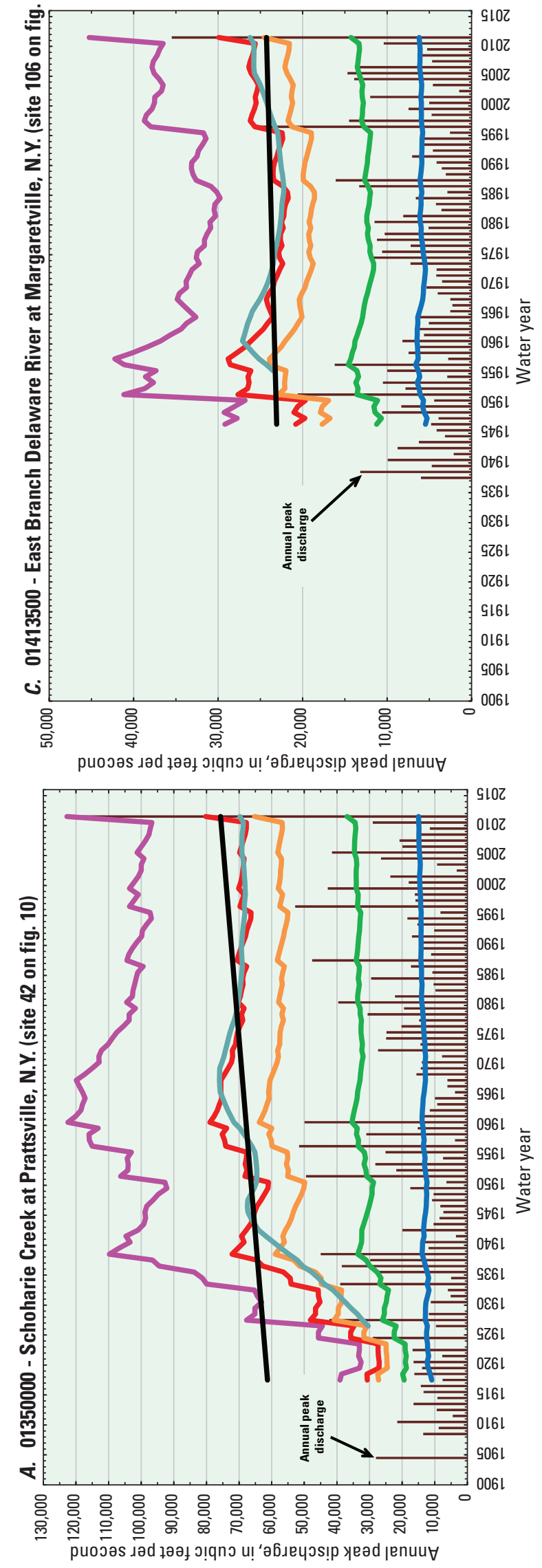
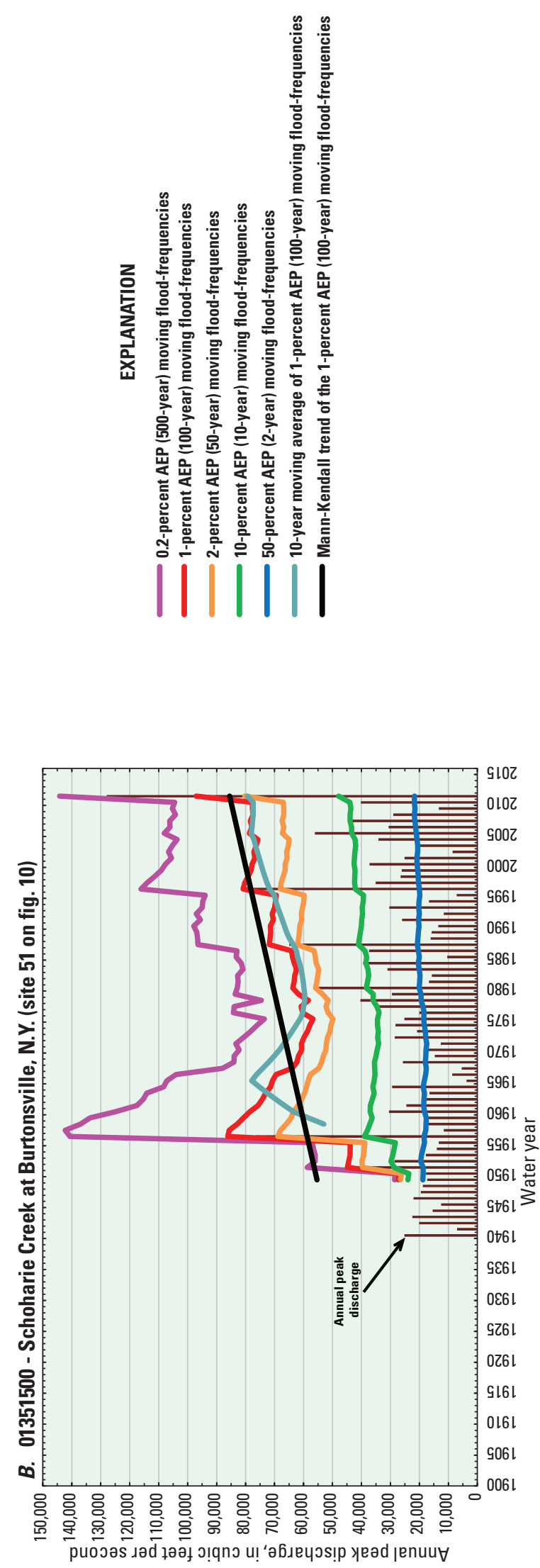

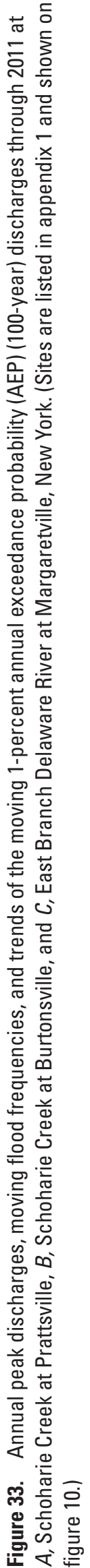



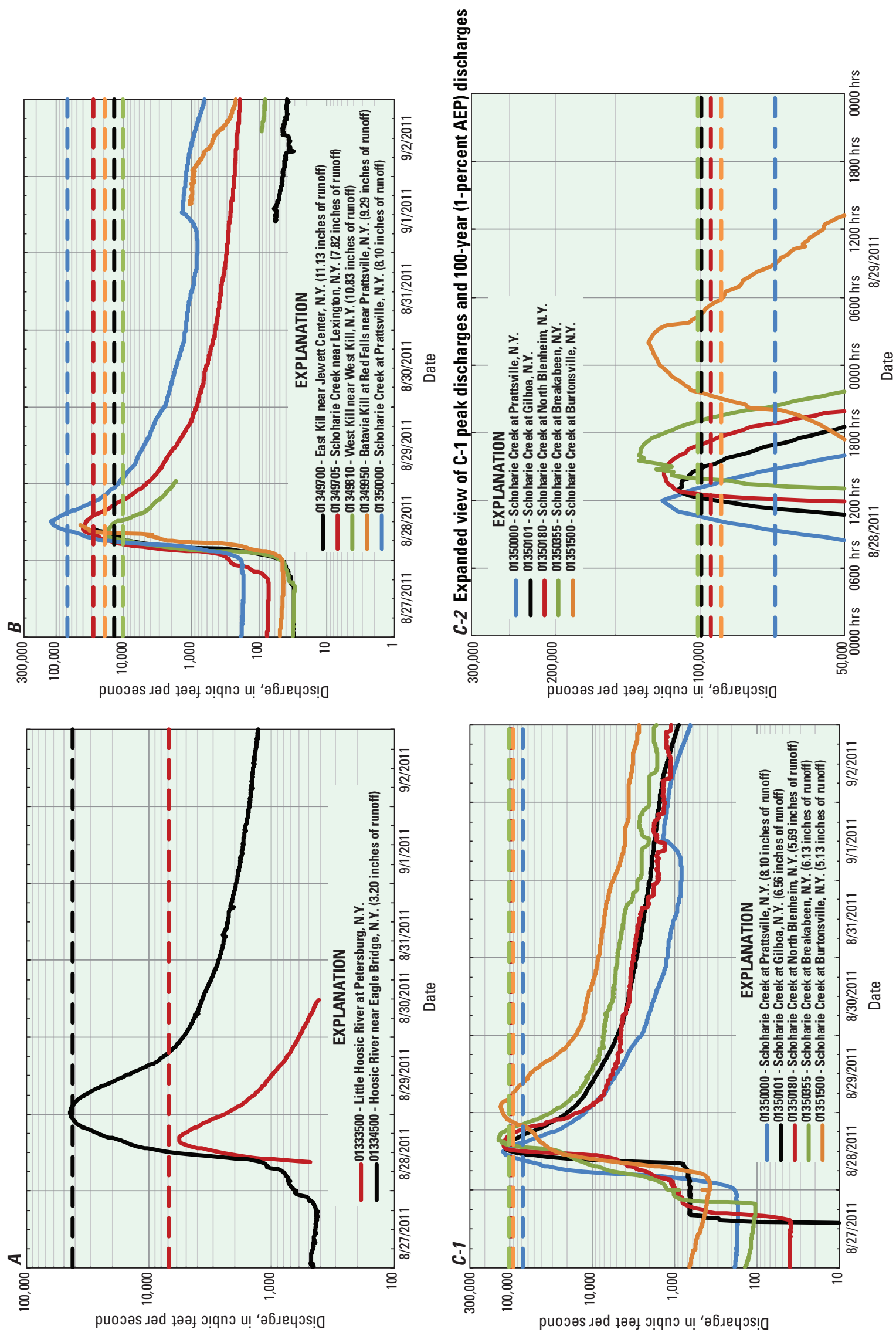

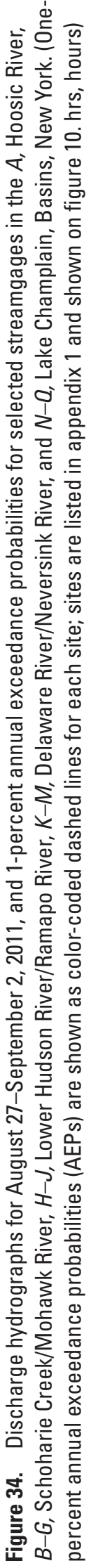



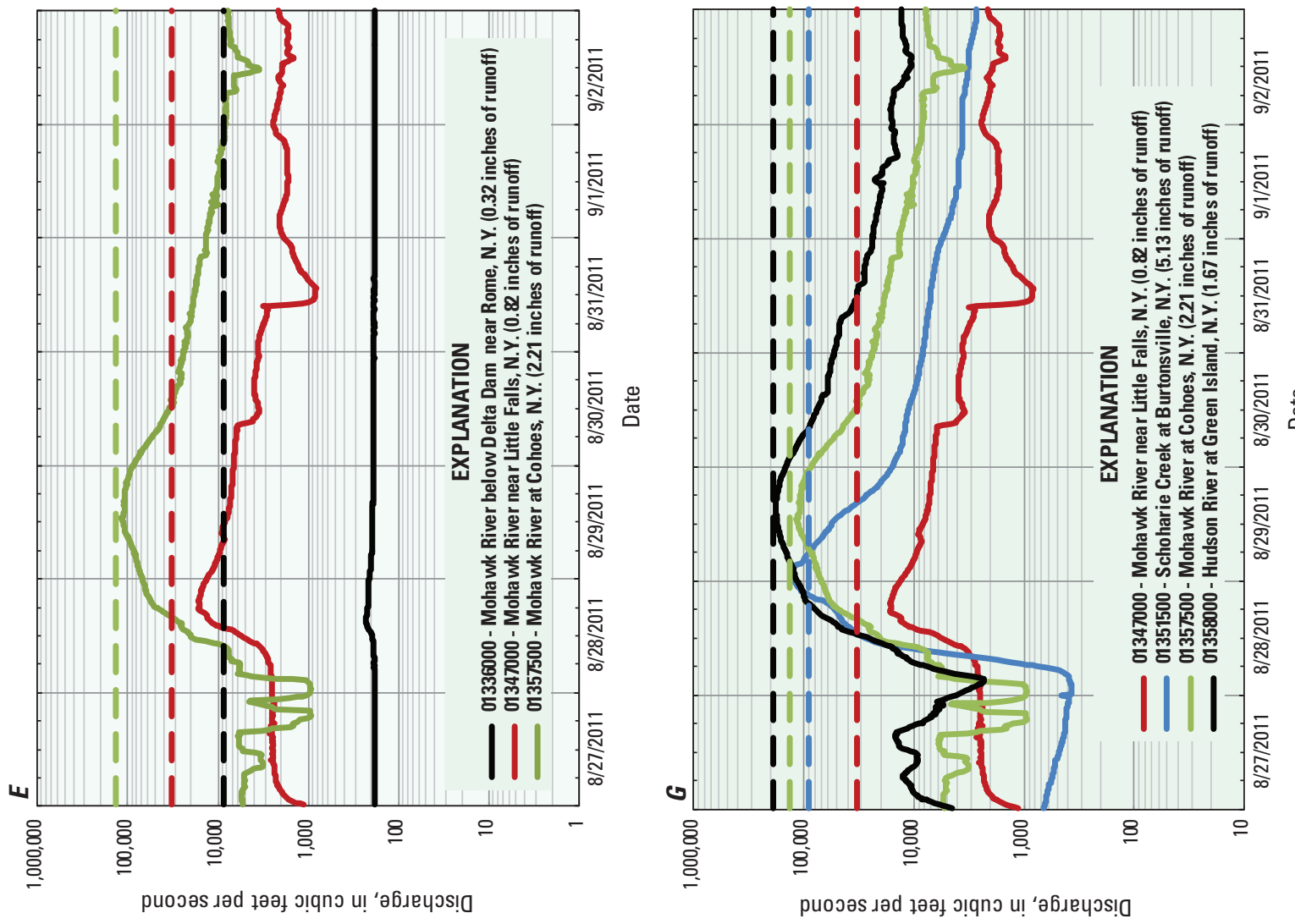

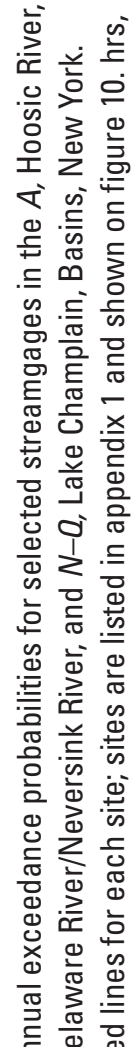

它

䓠发要
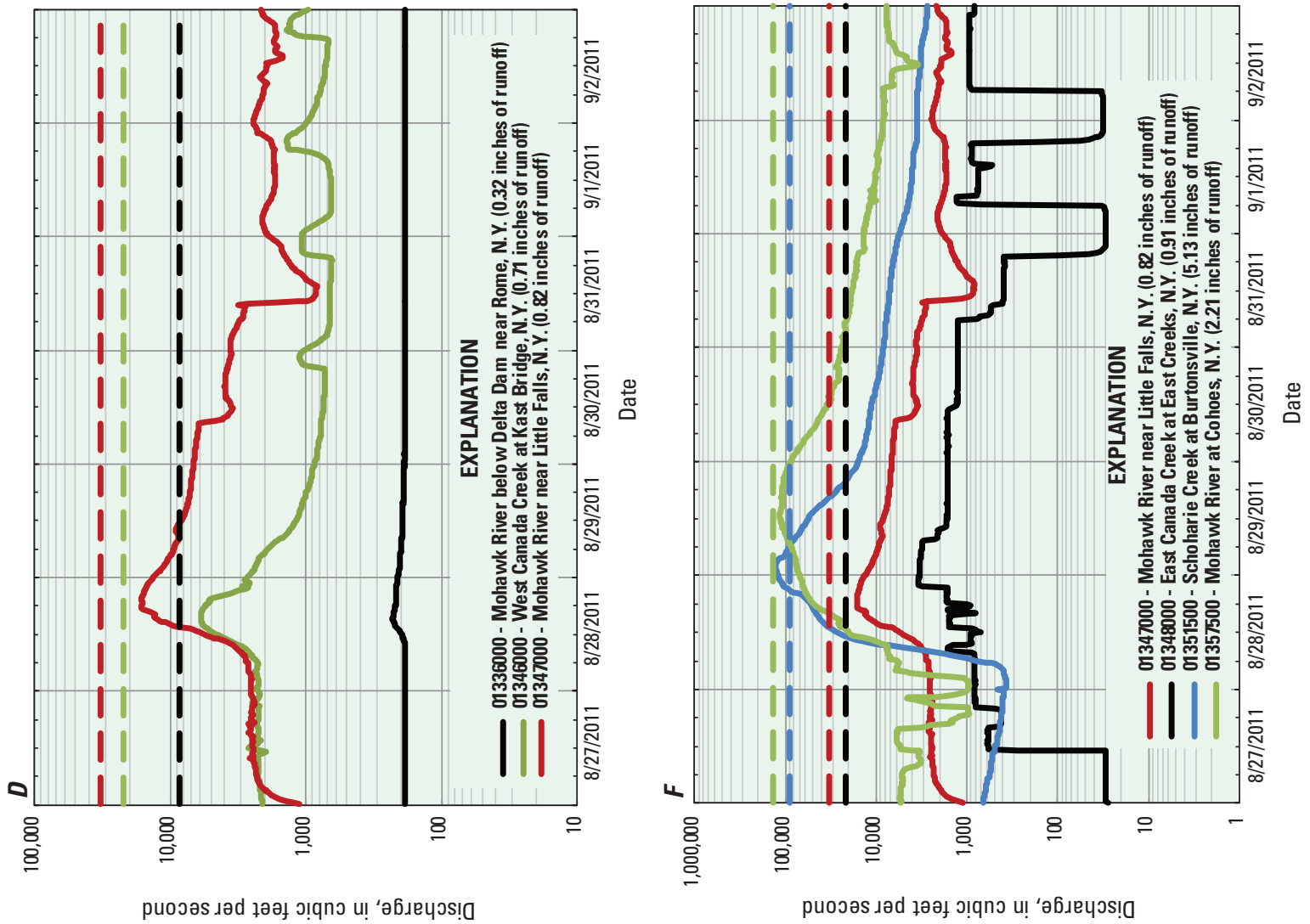

$\leq \pm$

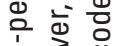

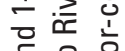

당 응 응

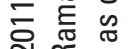

Nis

这

등 민

$\frac{\partial}{0} \frac{\pi}{0} \frac{\pi}{\infty}$

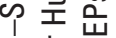

กิ

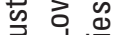

完令蒙

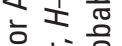

क⿻

등 व

흔

으응 용

릴

힝

㐫 元

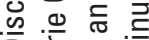

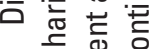

म

os c

奇心它 

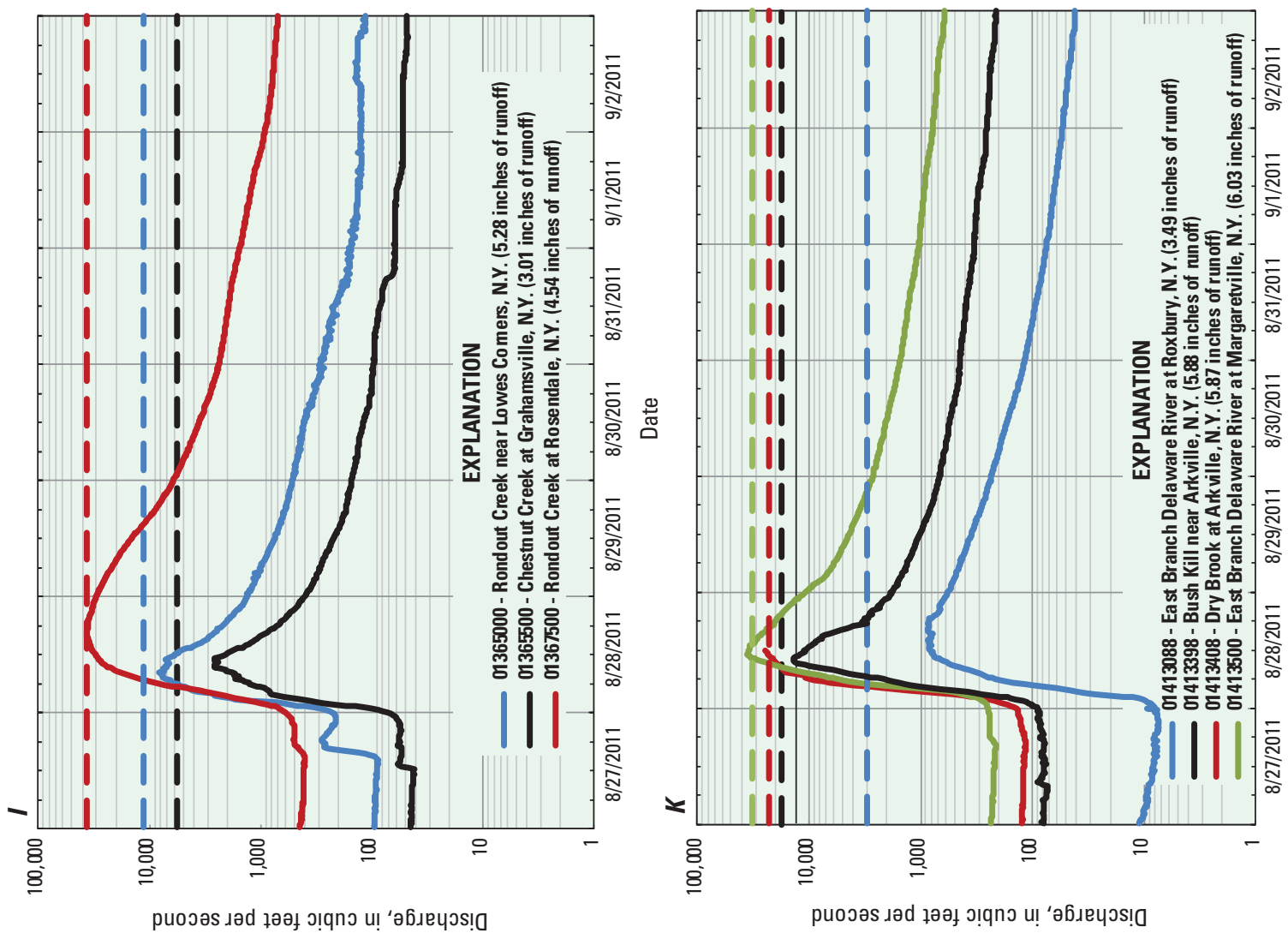

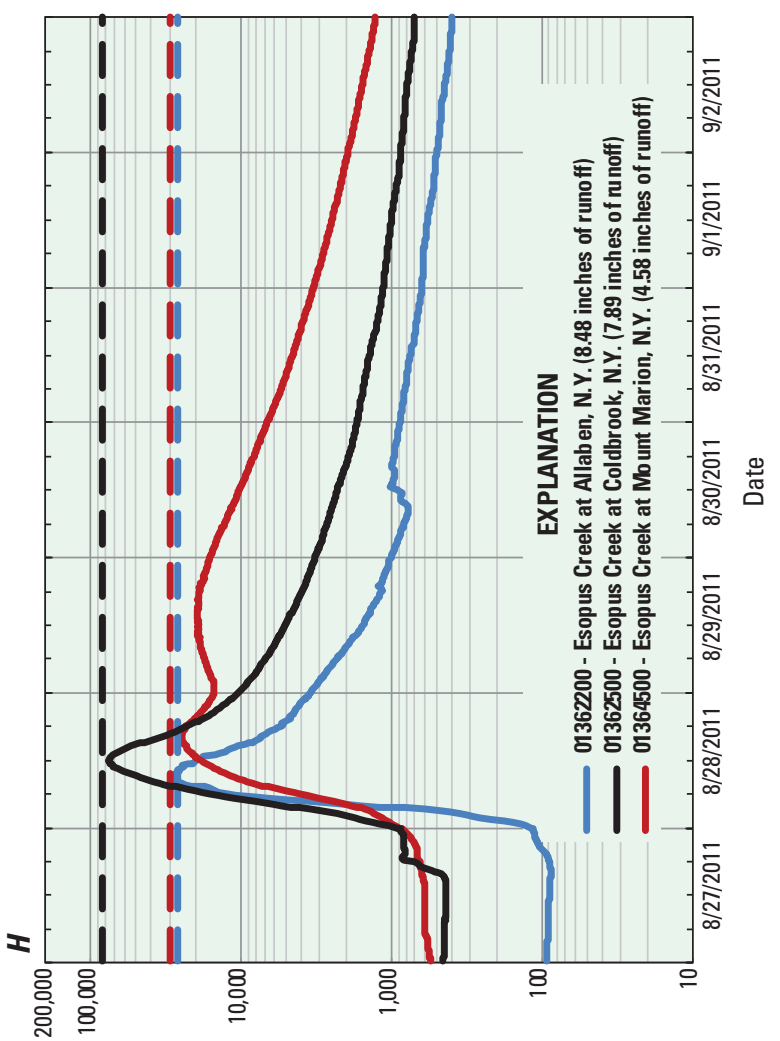

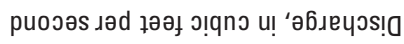

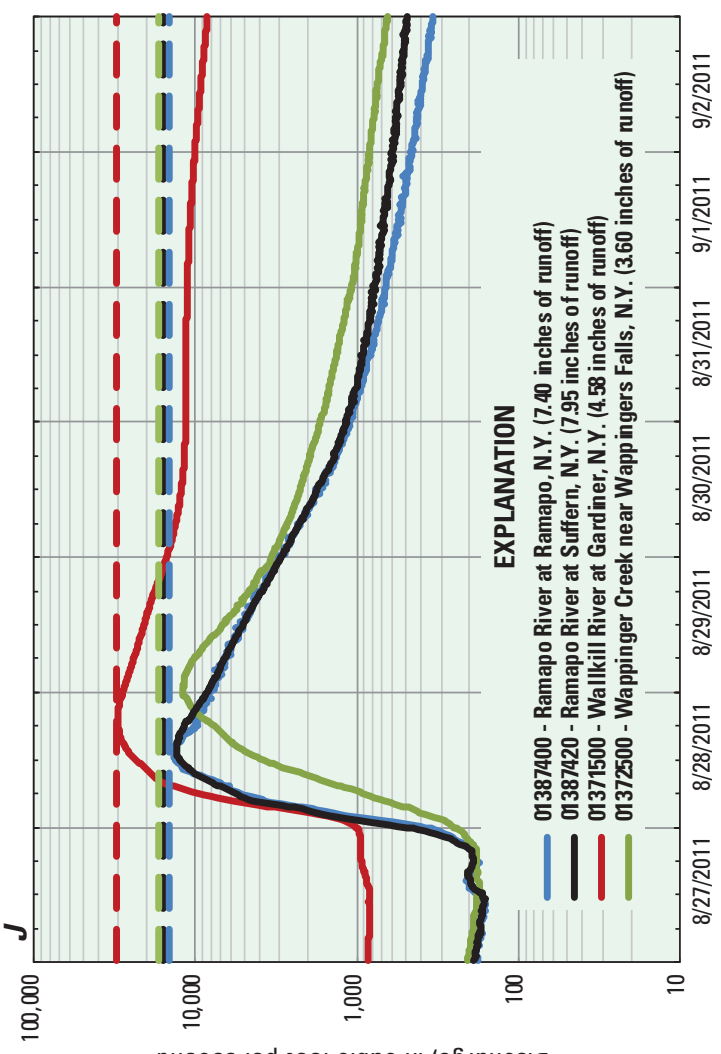

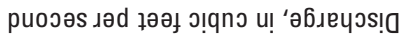

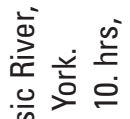

우 힐 일

군

它

$\stackrel{\square}{\leftrightarrows}$

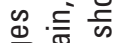

禀 을 뭉

壱 元

离

要

证

i

흐 焉

.

震

贾

市

o d

元

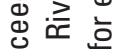

x)

즌

它 豞

范要

砳

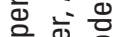

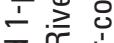

드으응

牙

ㄴ.

这 $\stackrel{2}{\circ} \frac{0}{\infty}$

है

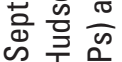

స 产㞵

40

定方言

혼응

क के

등

元姜

을 응 잉

칳

뭉

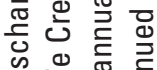

. 음

등 힝

में 든

눙

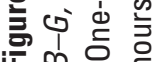



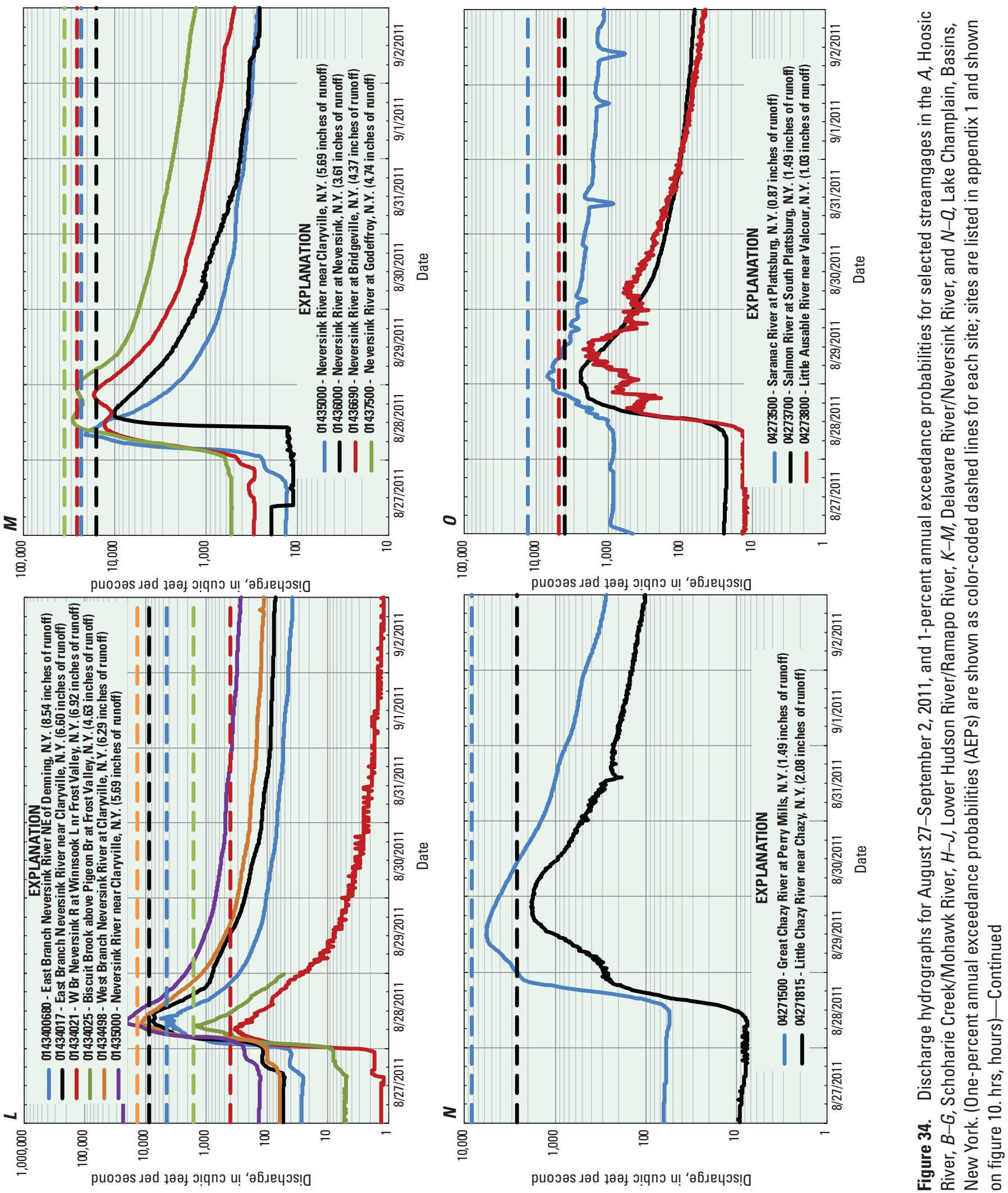


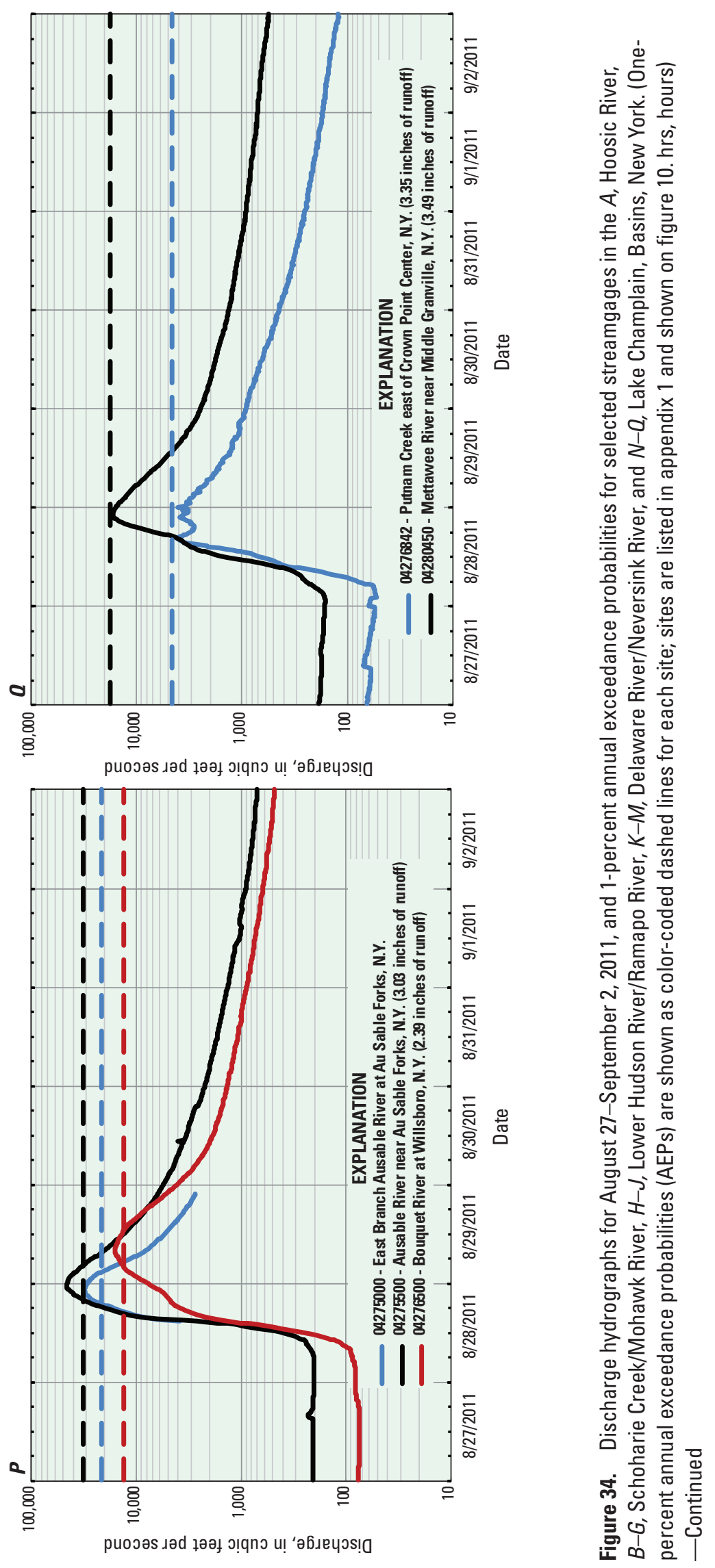



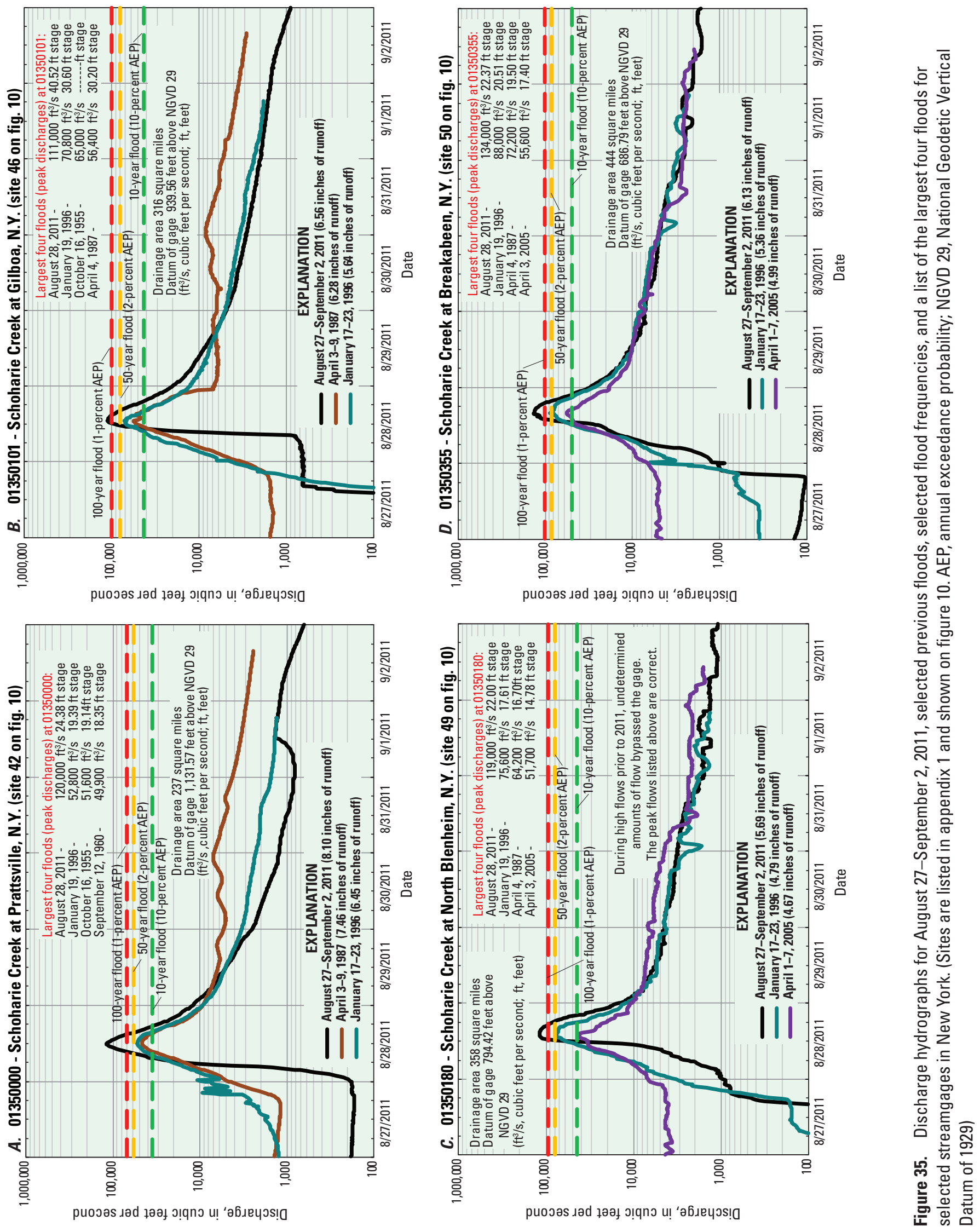


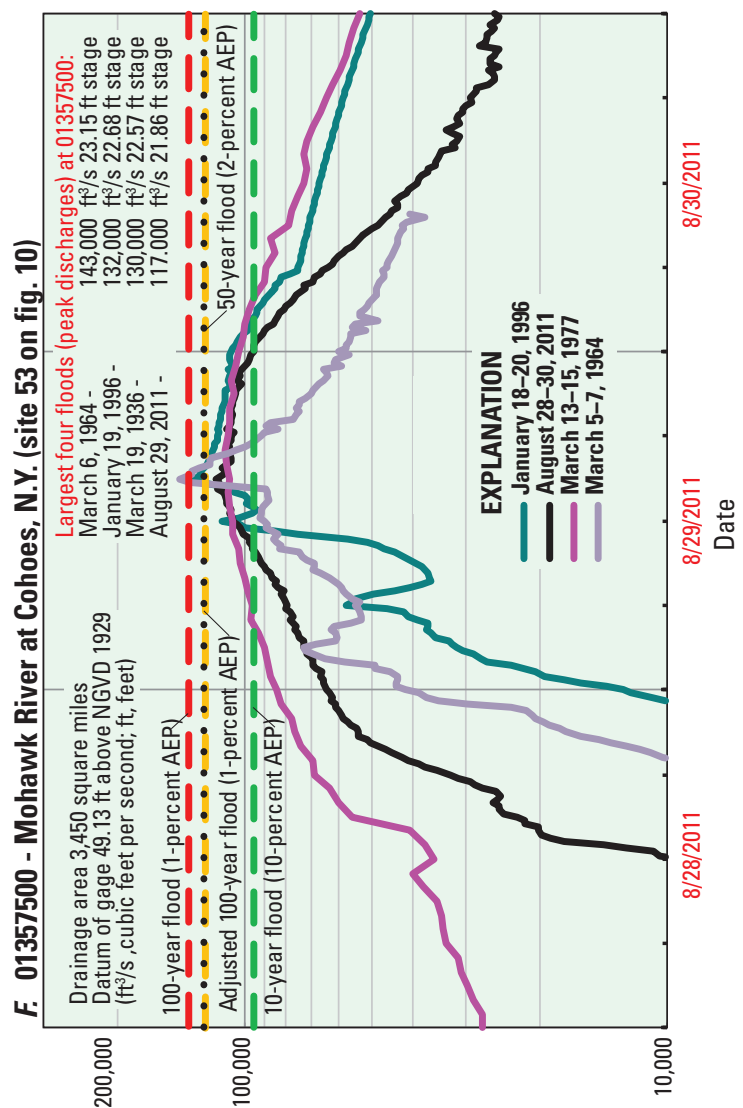

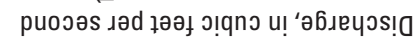

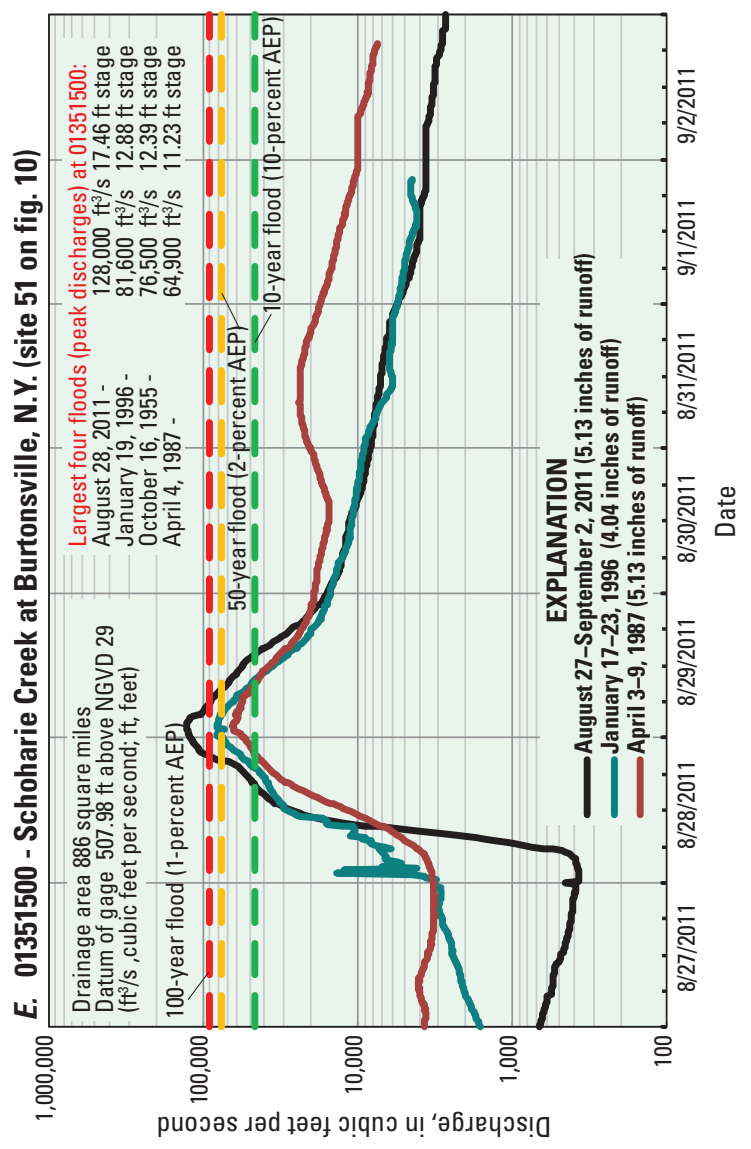

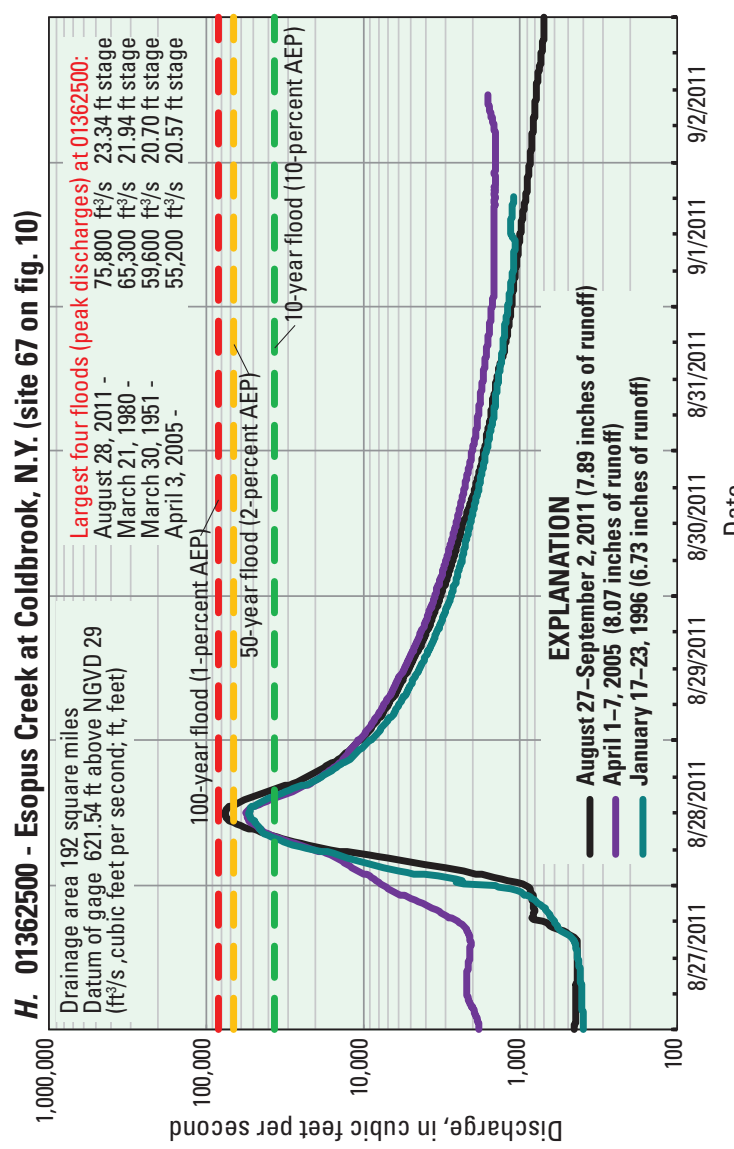

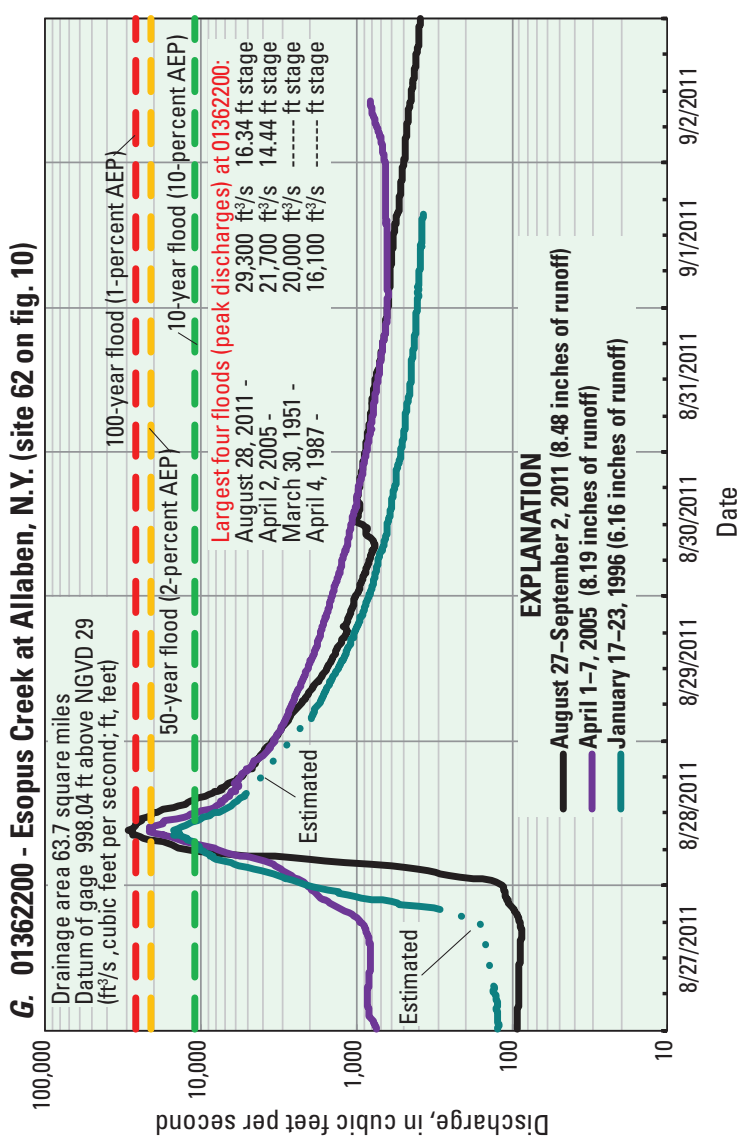

ఫ্ঠ

远

흘

象 节

은 정

言 㝕

范.

흐 홍

过

艺

艼.

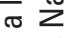

동

s.

은

吾

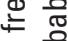

등은

品

용

$\frac{\pi}{0} \frac{d}{d}$

is

응

里

읗 嵌

흥응

嵌

高

定

호

i 을

㐫

营 $\frac{\pi}{x}$

宛 $\frac{x}{0}$

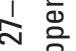

空 $\frac{2}{0}$

氜.

定 웡

흘

离

흉

竞

흘

은

离

.

d 요

เ

는

言 災 

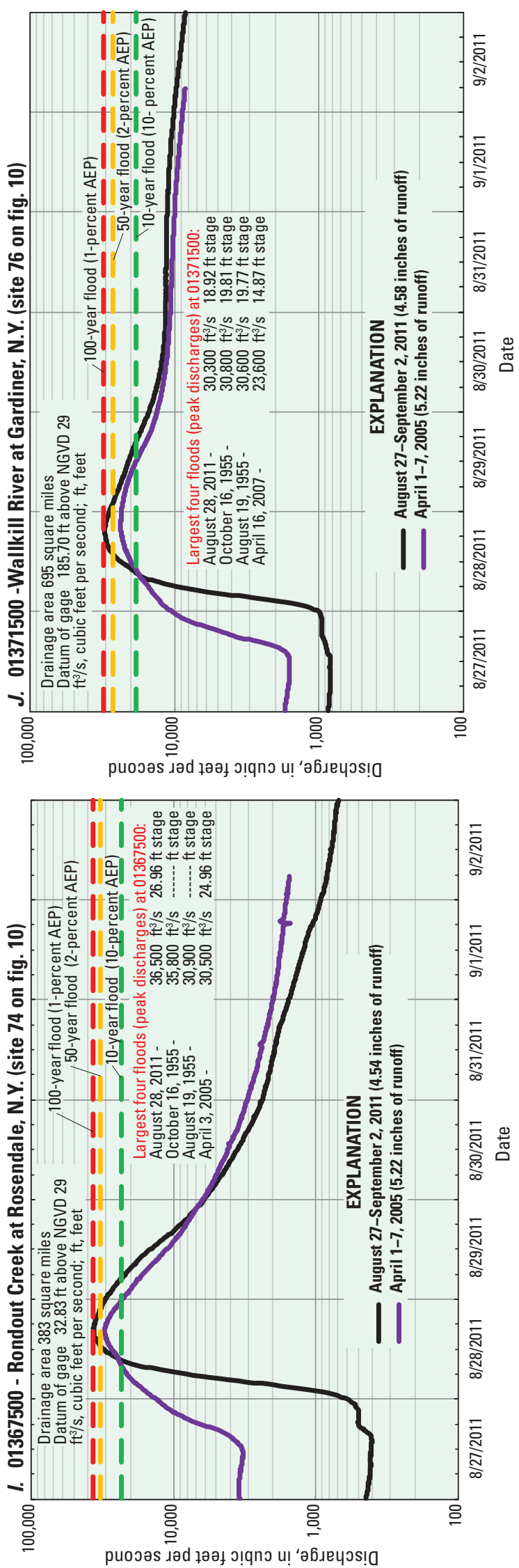

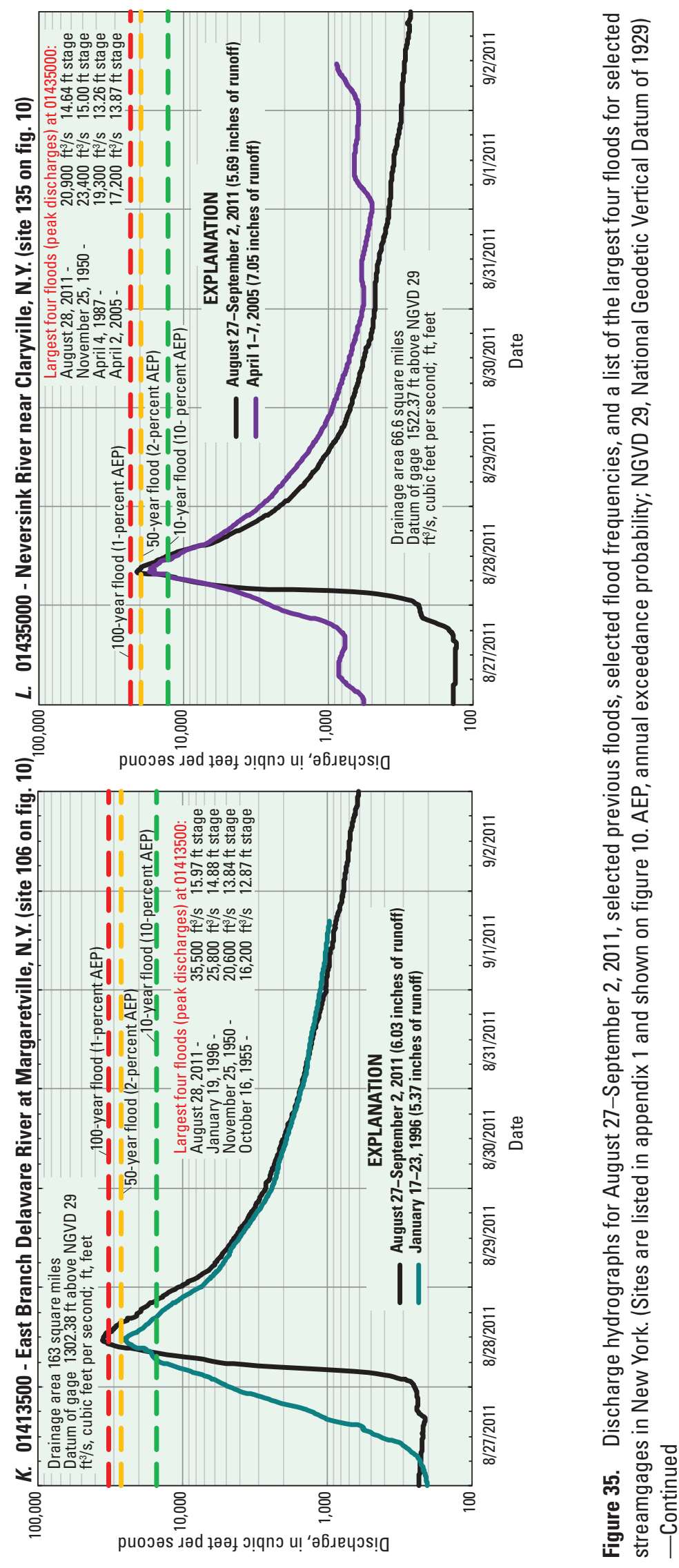



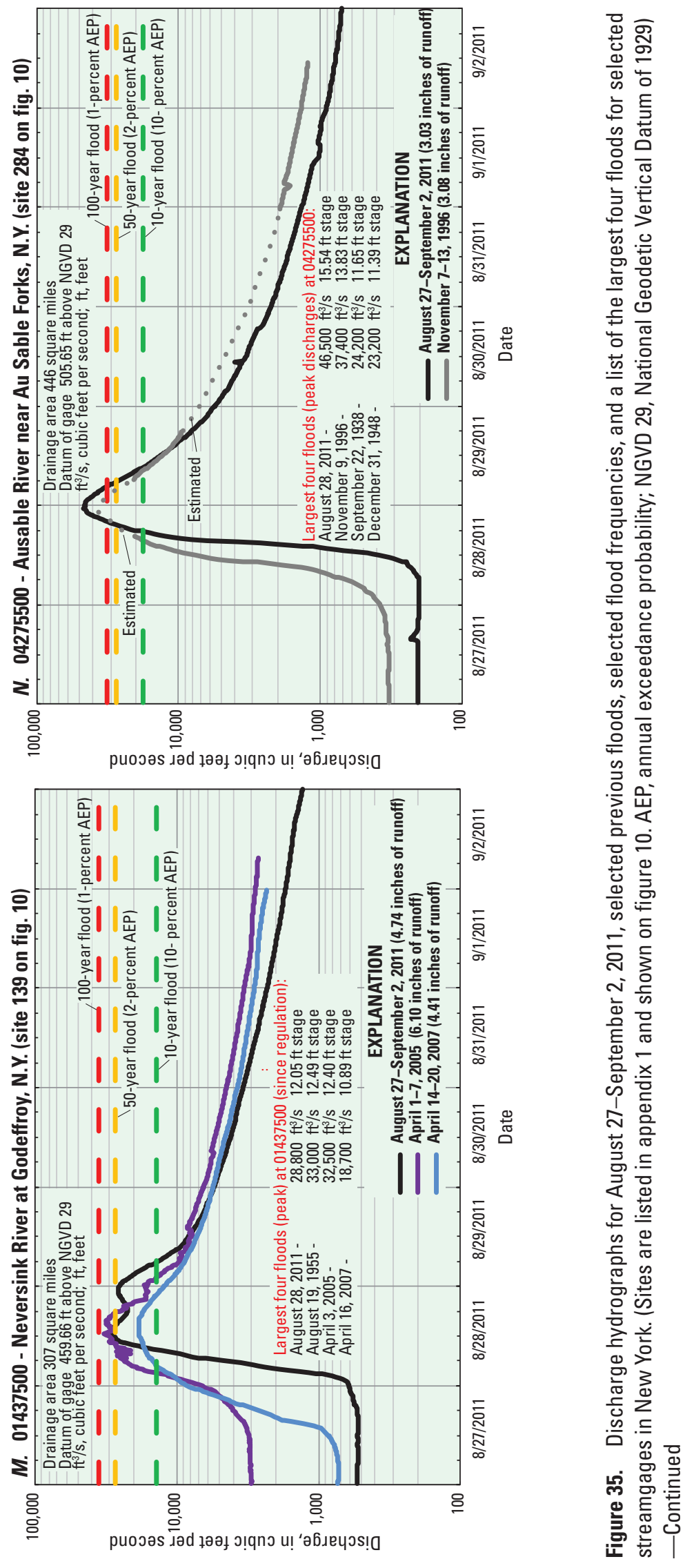

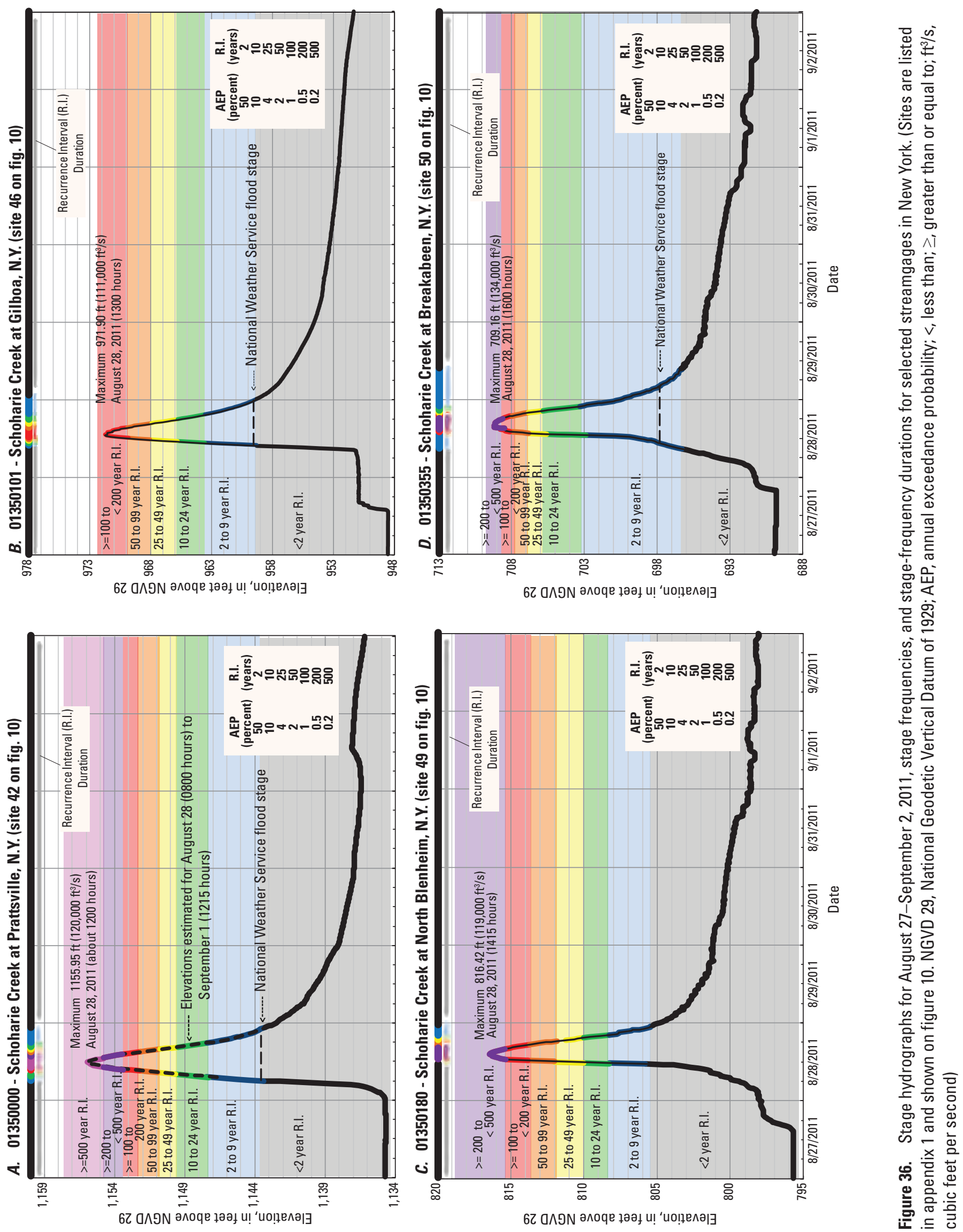

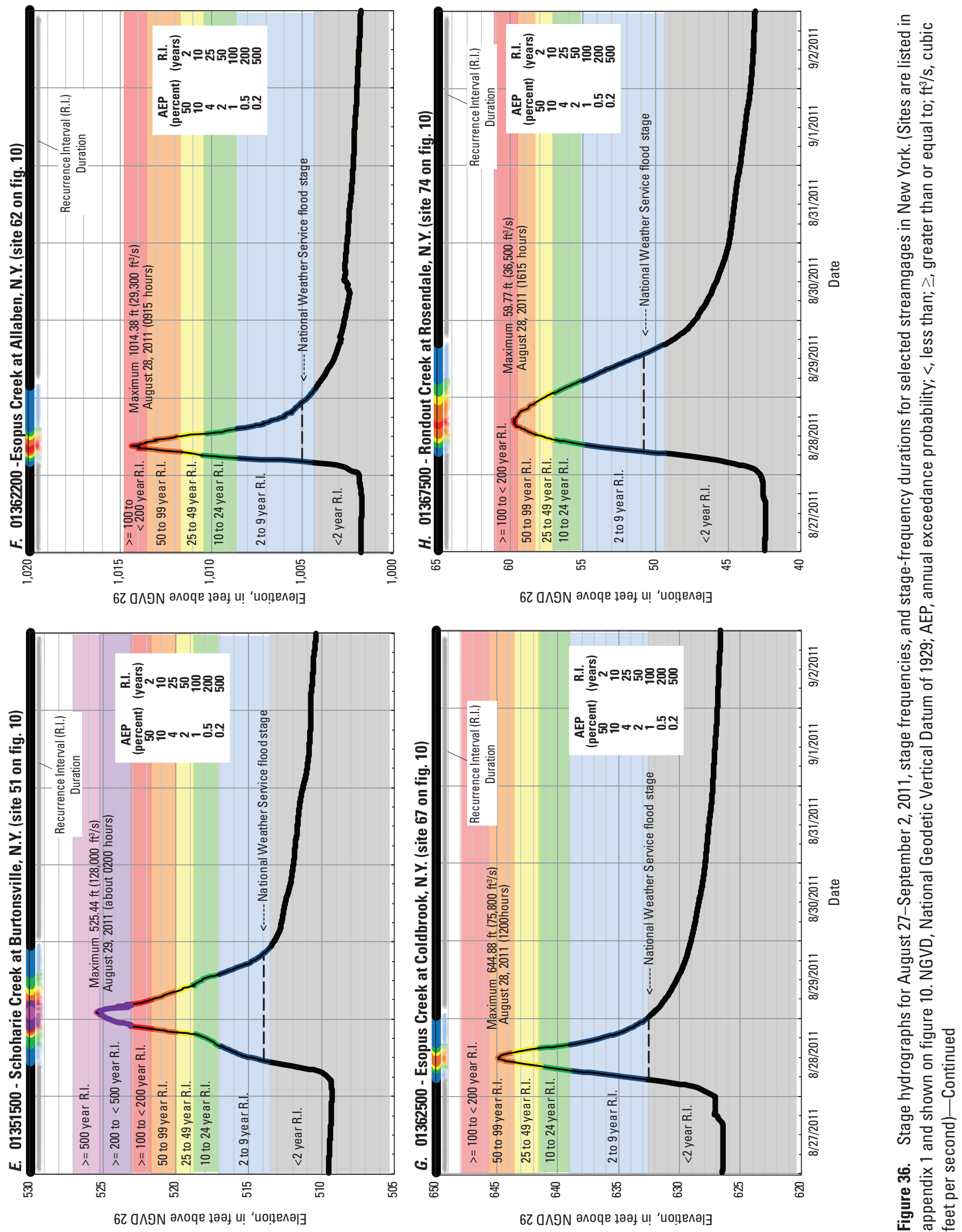


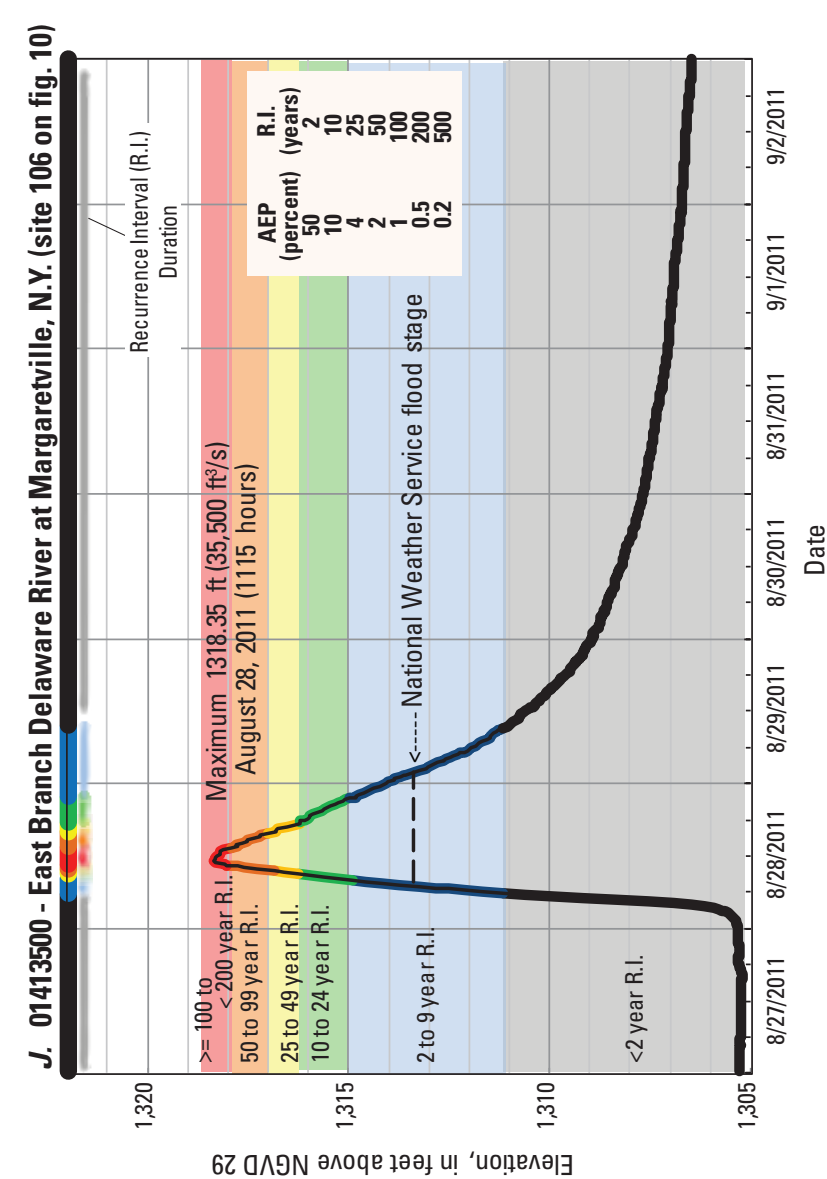

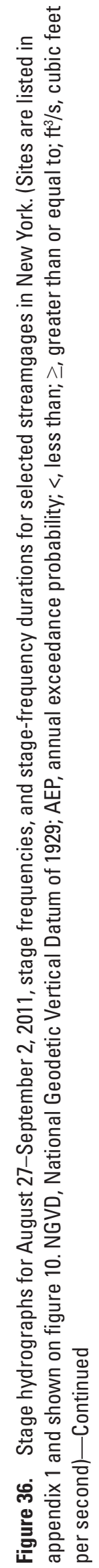
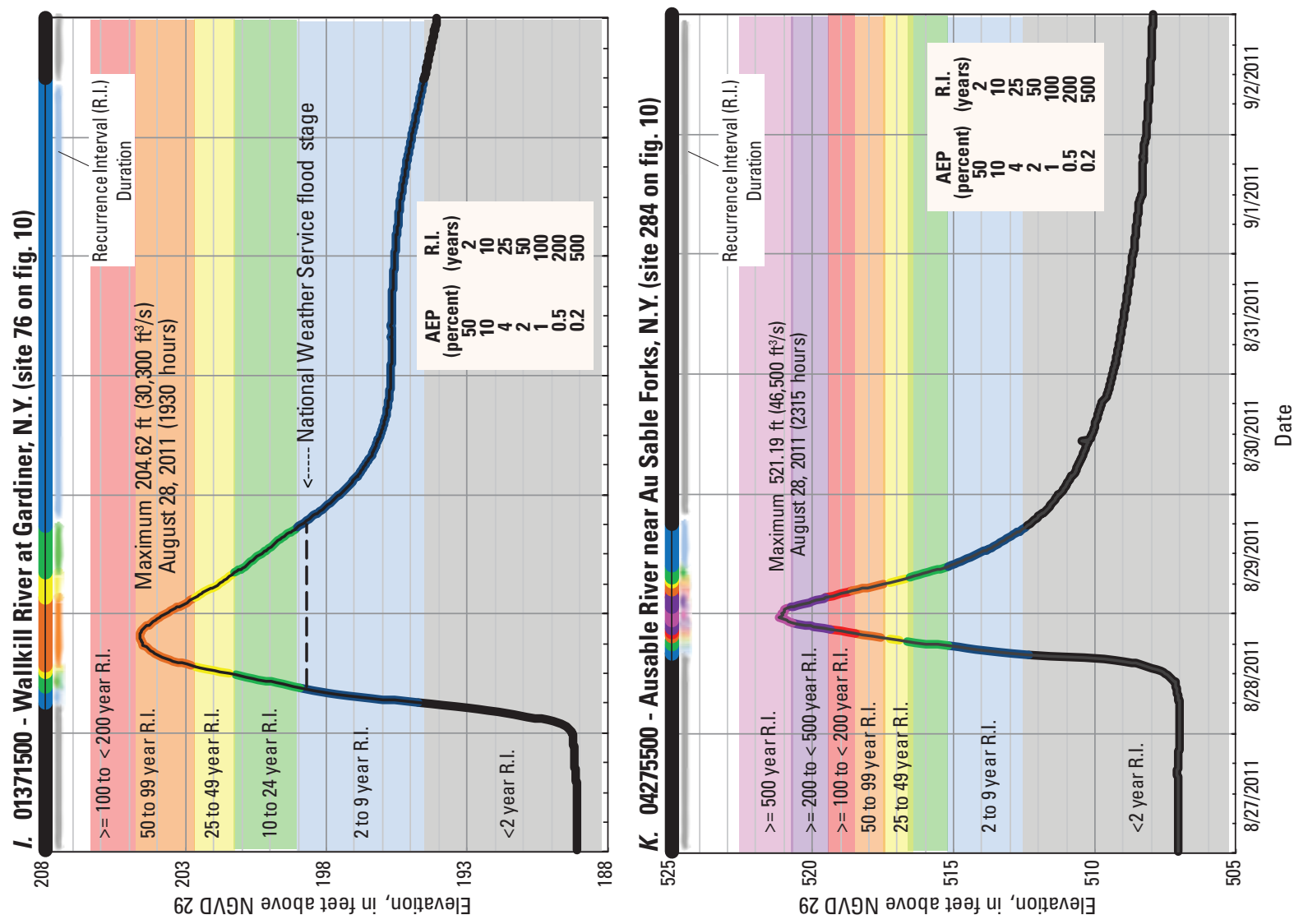
from a low level at 2:00 a.m. to the 50-percent AEP (2-year) stage at 6:00 a.m., peaked at about 12:00 p.m., and receded to below the 50-percent AEP (2-year) stage before the end of the day. In contrast, the much wider stage hydrograph for the Wallkill River at Gardiner (01371500) streamgage indicates that the stage on August 28 rose about $15.5 \mathrm{ft}$ over 20 hours, peaking at $204.62 \mathrm{ft}$ (90-year flood), and remained above the 50-percent AEP (2-year) stage for over 5 days (fig. 36I, table 11). In northern New York, the water level at the Ausable River near Au Sable Forks (04275500) remained above the 1-percent AEP (100-year) stage for about 9 hours, above the 0.5 -percent AEP (200-year) stage for 7 hours, and above the 0.2 -percent (500-year) stage for nearly 4 hours (fig. 36K).

\section{Flood Profiles of Schoharie Creek}

The devastating flooding along Schoharie Creek prompted a more detailed evaluation of the flood stages throughout the length of its reach. HWMs were identified and their elevations measured along an 84-mi reach of Schoharie Creek from the headwaters (near Hunter) to the mouth (near Fort Hunter) to allow documentation and evaluation of the extent and severity of the August 28, 2011, flood. A total of 184 HWMs were surveyed at 30 sites to define a general flood profile along the creek (fig. 37); for reference, the figure also shows approximate stream-bottom elevations, locations of major communities, streamgages (locations shown in fig. 38), and generalized FEMA flood-profile data (shown only to give the approximate locations where published FEMA studies were done).

After the August 2011 flood, the USGS flagged and surveyed 184 HWMs along Schoharie Creek (mostly at bridge crossings) and at 7 streamgages (figs. 37-38). Elevations of HWMs were surveyed upstream and downstream from the structure, when possible, and were rated subjectively by field personnel as "excellent," "good," "fair," or "poor," according to the guidelines by Benson and Dalrymple (1967). HWM elevations (relative to the North American Vertical Datum of 1988 (NAVD 88)) from the August 28 flood were compared with flood-profile elevations published in FEMA floodinsurance studies (Federal Emergency Management Agency, 1989, 2008, 2012a) for selected AEPs and with HWMs from the floods of April 1987 and January 1996 (Lumia, 1998) (table 13, fig. 39). Figure 39 also shows geometry for selected bridges (low chord and top of road elevations) obtained from field surveys or from published FEMA flood-insurance studies.

August 2011 flood elevations were higher than those of April 1987 and January 1996 throughout the study reach (table 13, fig. 39). Flood elevations on August 28 ranged from $0.6 \mathrm{ft}$ (at Hunter) to $11.1 \mathrm{ft}$ (at Mill Point) higher than the January 1996 flood. From Hunter to Jewett (sites 1-5, figs. 39A-E), the August 2011 HWM elevations in these upper reaches of Schoharie Creek were generally between the 10- and 2-percent AEP (10- and 50-year) flood elevations published by FEMA in the most recent flood-insurance study. At Lexington (sites 6-7, figs. 39F-G), 2011 peak elevations were generally greater than the FEMA 1-percent
AEP (100-year) elevations, except for those upstream from the State Route 42 bridge (site 7, fig. 39G), where they were at the 2-percent AEP (50-year) elevations. The August 2011 elevations at Mosquito Point (site 8, fig. 39H) were higher than the FEMA 1-percent AEP (100-year) elevations upstream from the bridge at County Road 2 but lower than the 2-percent AEP (50-year) elevations downstream from the bridge. In Prattsville (site 9, fig. 39I), August 2011 HWM elevations at 19 locations surveyed at the State Route 23 bridge were generally greater than the 1-percent AEP (100-year) FEMA elevations but a few feet lower than the published 0.2-percent AEP (500-year) elevations. No FEMA studies are available for Schoharie Reservoir (site 10, fig. 39J) downstream to Boucks Island in Fultonham (site 17, fig. 39Q). Site number 14 (fig. 39N) shows HWMs at State Route 30 in North Blenheim, near the old covered bridge (built in 1855), which unfortunately was destroyed on August 28 as the floodwater rose $5.3 \mathrm{ft}$ higher than the previous maximum elevation during the January 1996 flood (fig. 40). FEMA studies are available for Middleburg (site 18, fig. 39R) to Esperance (site 24, fig. 39X), and the August 2011 peak elevations were generally at or greater than the FEMA 0.2-percent AEP (500year) elevations published in the most recent flood-insurance studies. FEMA flood-insurance studies are not available for Burtonsville (site 25, fig. 39Y) downstream to the mouth of Schoharie Creek at the Mohawk River near Fort Hunter (site 30, figs. 39A-D).

HWM elevations were surveyed by FEMA (Federal Emergency Management Agency, 2011e) at 72 locations following the August 2011 flood in the Delaware and lower Hudson River Basins (table 14, fig. 41A) and by the NYSCC (New York State Canal Corporation, written commun., 2012) at 13 locations on the Mohawk River from Randall (lock 13) to Vischer Ferry (lock 7) (table 15, fig. 41B). Elevations of the August 2011 HWMs on the Mohawk River ranged from 1.4 to $7.4 \mathrm{ft}$ higher than HWM elevations for the June 2006 flood (table 15) at the same locations.

\section{Coastal Flooding in Extreme Southeastern New York and Long Island}

Tropical Storm Irene battered coastal areas in the southeastern corner of New York and Long Island on August 28. High-water elevations were recorded at USGS tide gages, and elevations of sea-level HWMs measured by other agencies (McCallum and others, 2012) indicate that the storm surge generally ranged from $3.2 \mathrm{ft}$ (Suffolk County) to nearly $10 \mathrm{ft}$ (Nassau County) above NAVD 88 (table 16, fig. 42). One HWM surveyed by the USGS was about $20.8 \mathrm{ft}$ above NAVD 88 in Nassau County, but the accuracy of the measurement is unclear (possible wave runup). FEMA (Federal Emergency Management Agency, 2011d) documented coastal peak water elevations in five counties in and around New York City and western Long Island (table 17, fig. 43). The FEMA peak water elevations ranged from $4.1 \mathrm{ft}$ (Richmond County) to $14.1 \mathrm{ft}$ (Nassau County) above NAVD 88. 


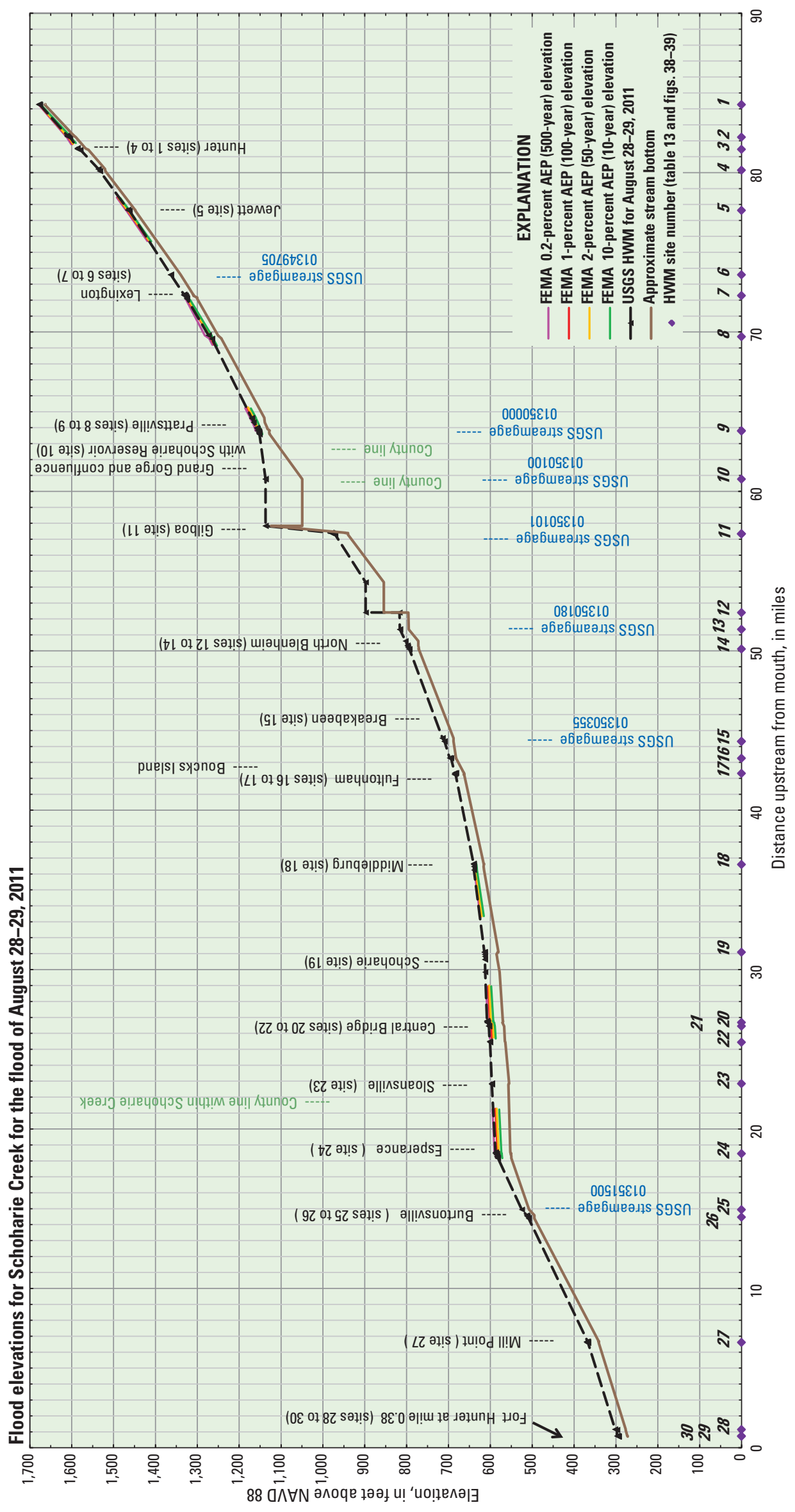

능 응

$\stackrel{\pi}{\mathrm{E}}$

票票

立 흥

$\sum \frac{1}{2}$

㐫

몬.

(⿻)

w $\bar{x}$

苛

西

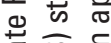

$\pm \bar{c} . \leftrightarrows$

塞焉

을를

흠 खे

路 क

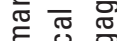

힝

要

i

春出

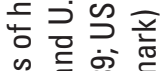

ஸे ธิ

.유월

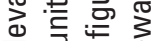

ब है ธ

号

声殅

3 으엉

容苍

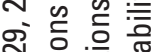

ㄴ.뉴

ำ 잉 흥

菏

은 든은

ठ

등 을

은 푱

능

Е

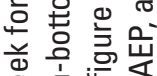

ष

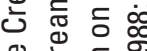

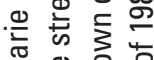

为

등 至

总 言离

흥 음

음 흥.응

인

등 눈은

웡

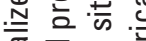

뜬 믄 등

要安

$\varangle \sum \frac{1}{2}$

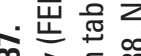

लि $\stackrel{ \pm}{=}$

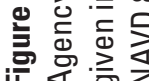




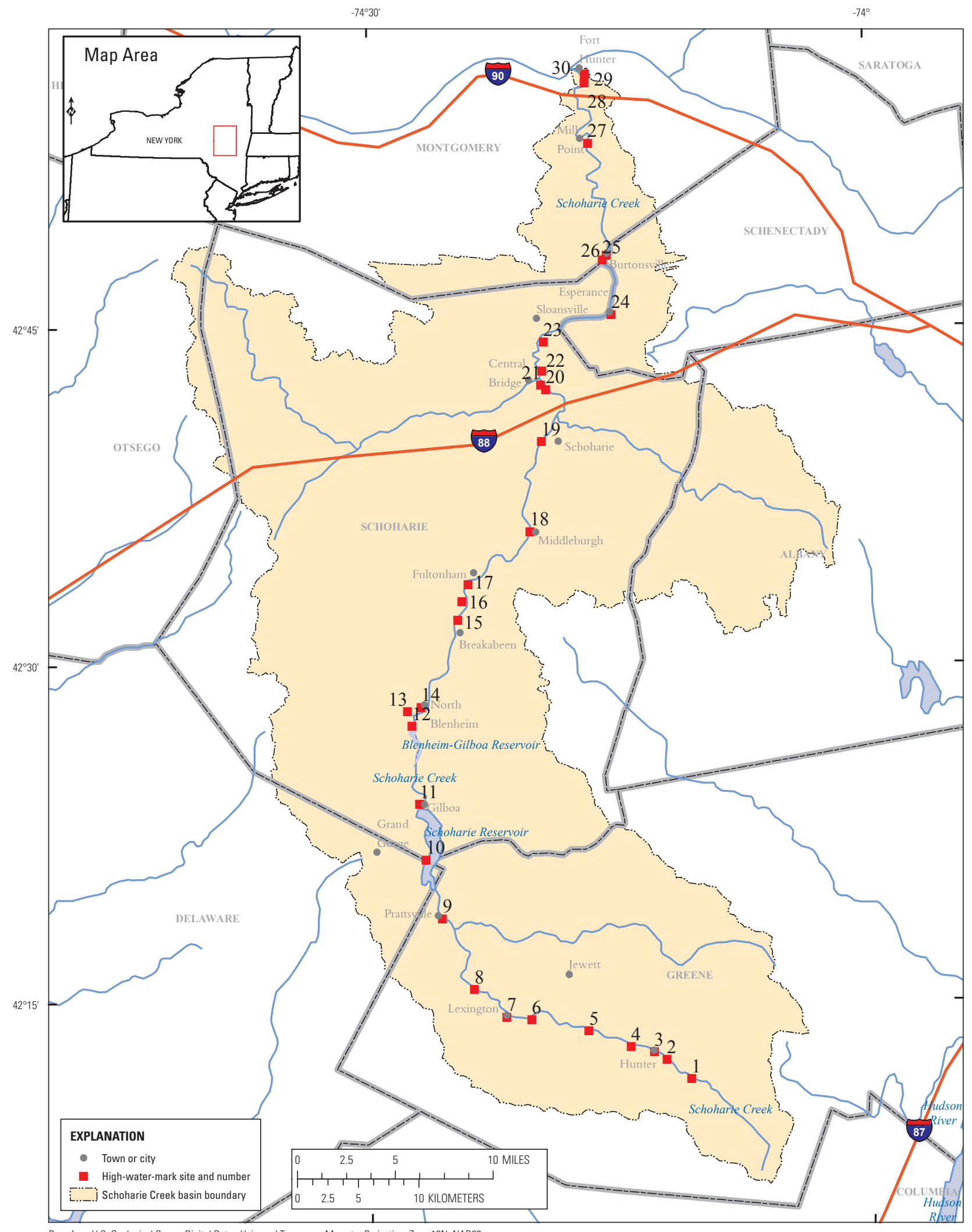

Base from U.S. Geological Survey Digital Data. Universal Transverse Mercator Projection, Zone 18N, NAD83

Figure 38. Locations of high-water-mark sites selected for the flood of August 28-29, 2011, along Schoharie Creek from Hunter to Fort Hunter, New York. 


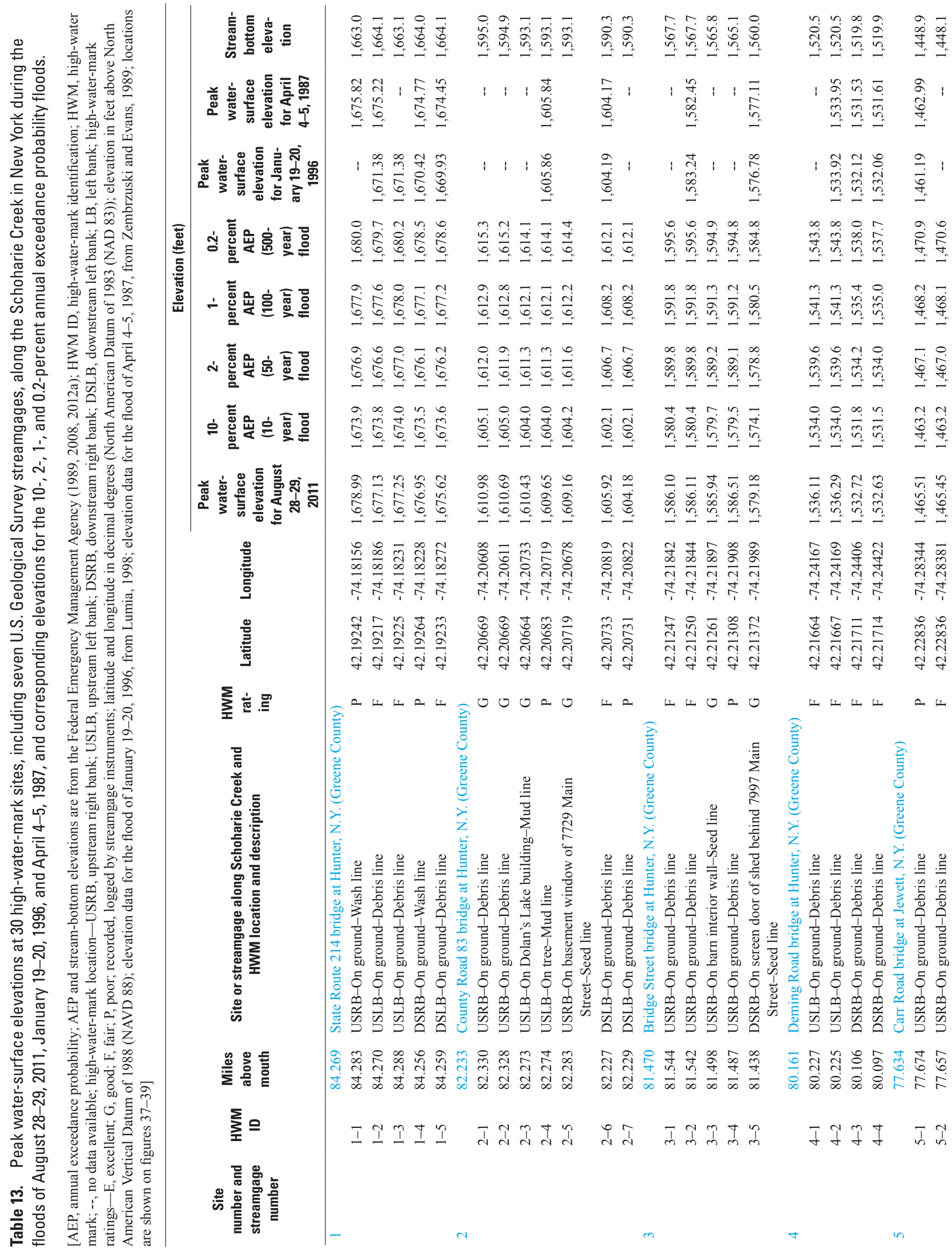




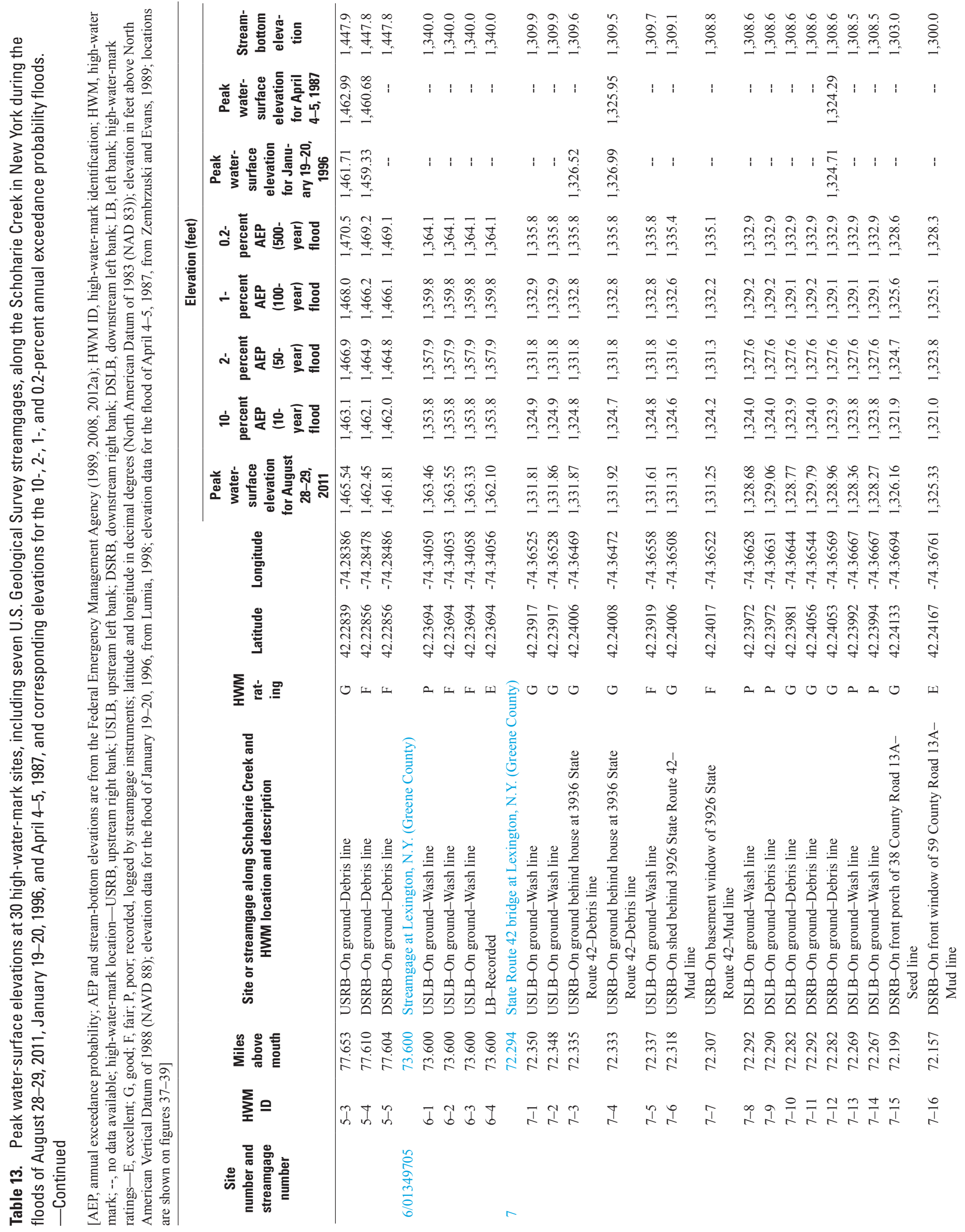




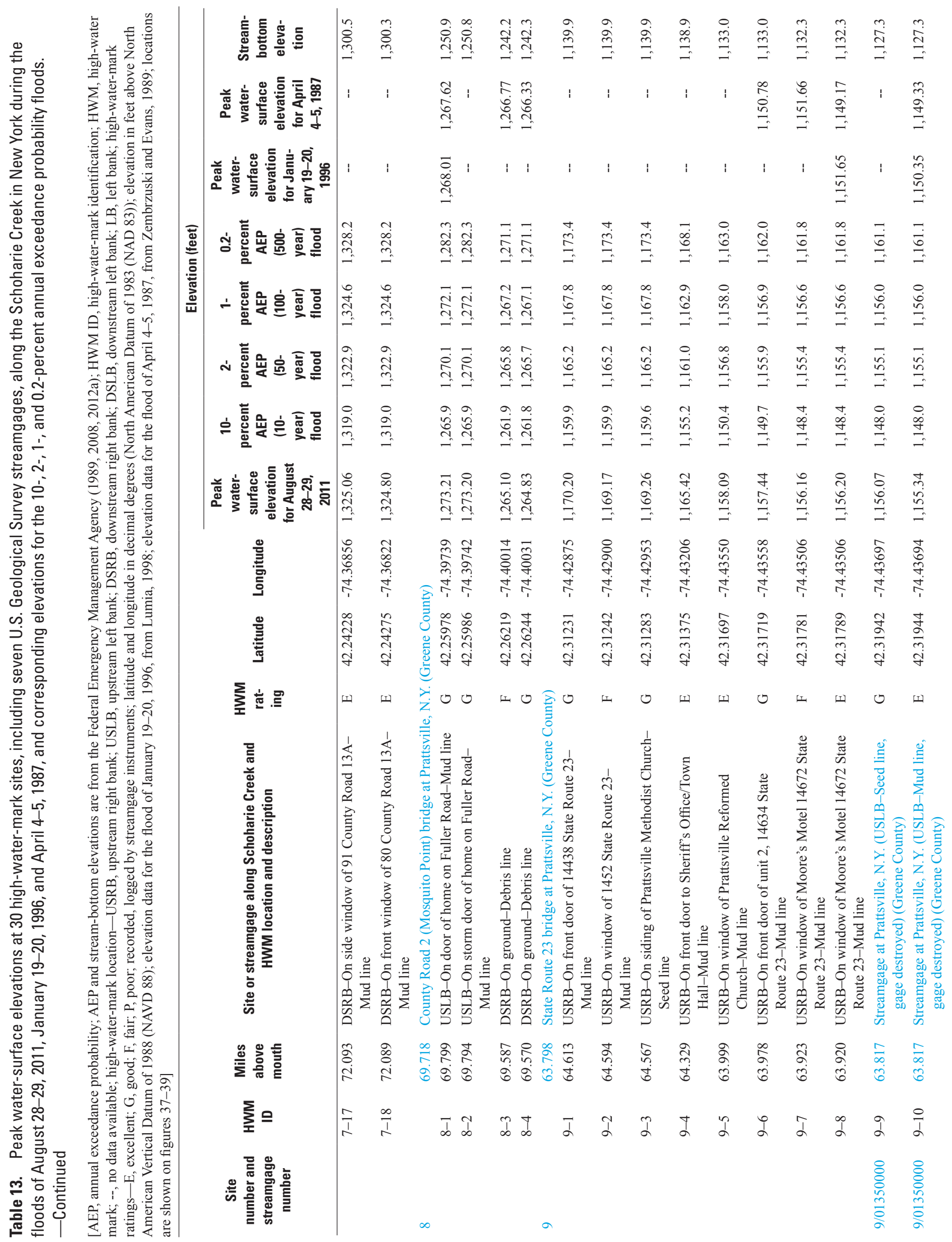




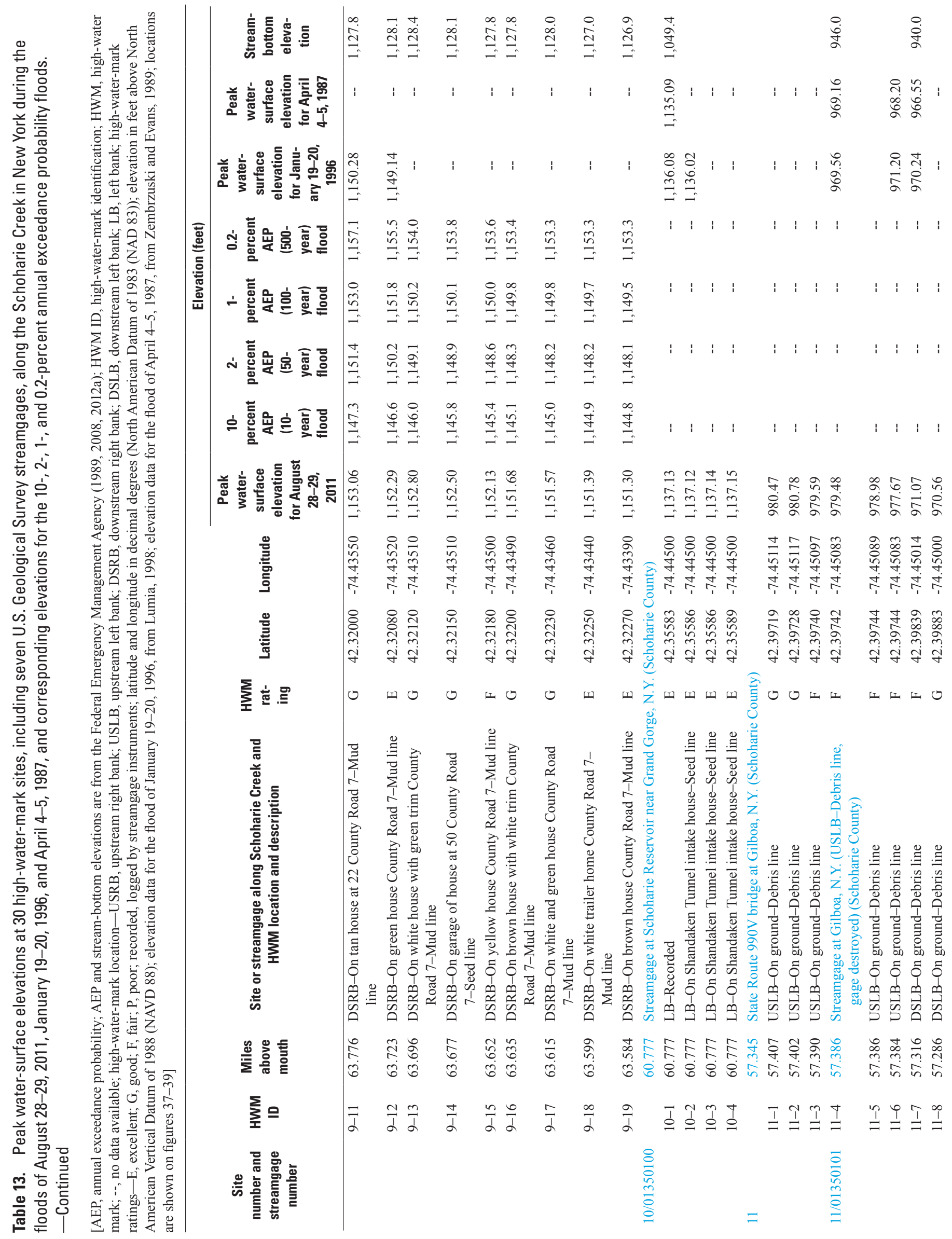




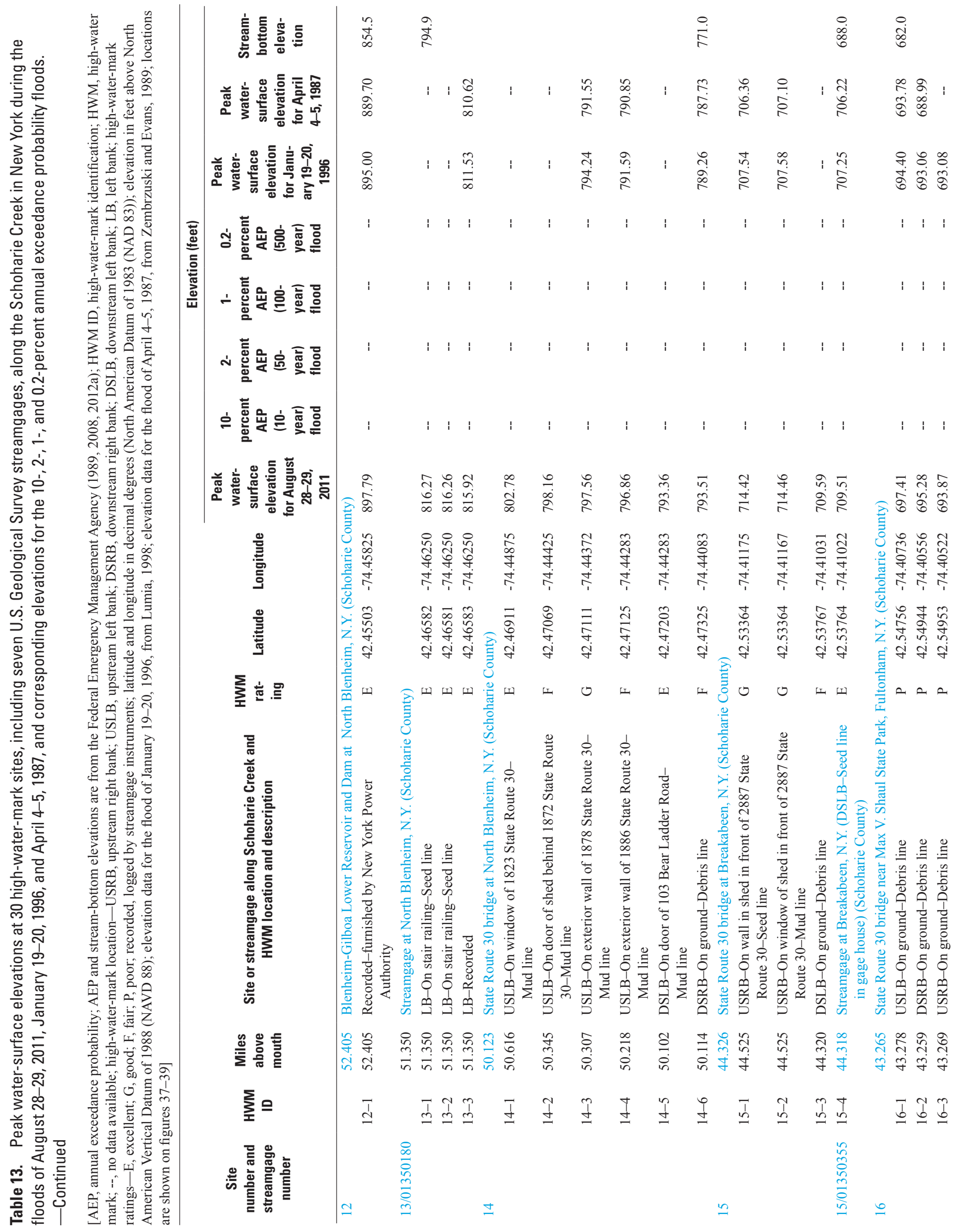




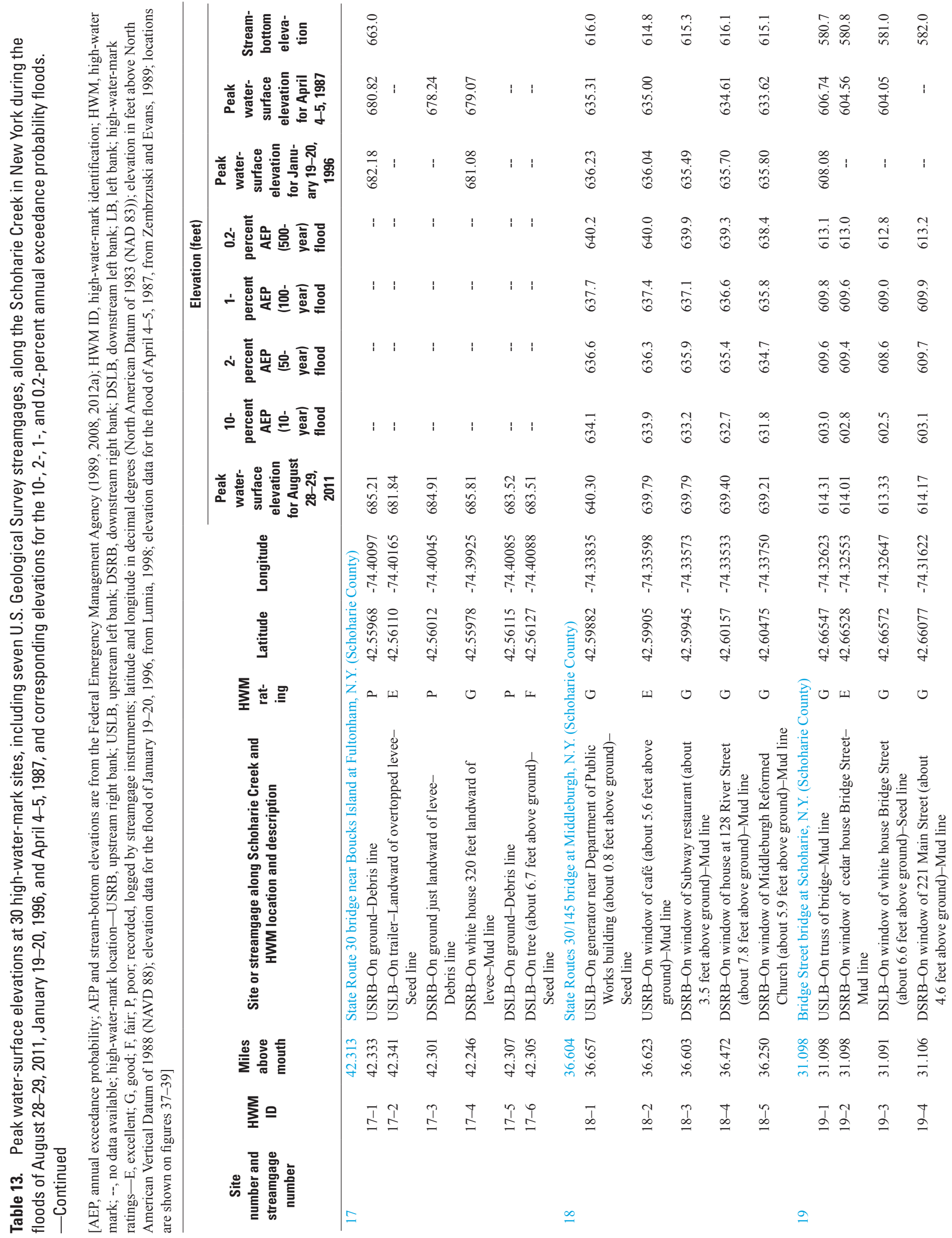




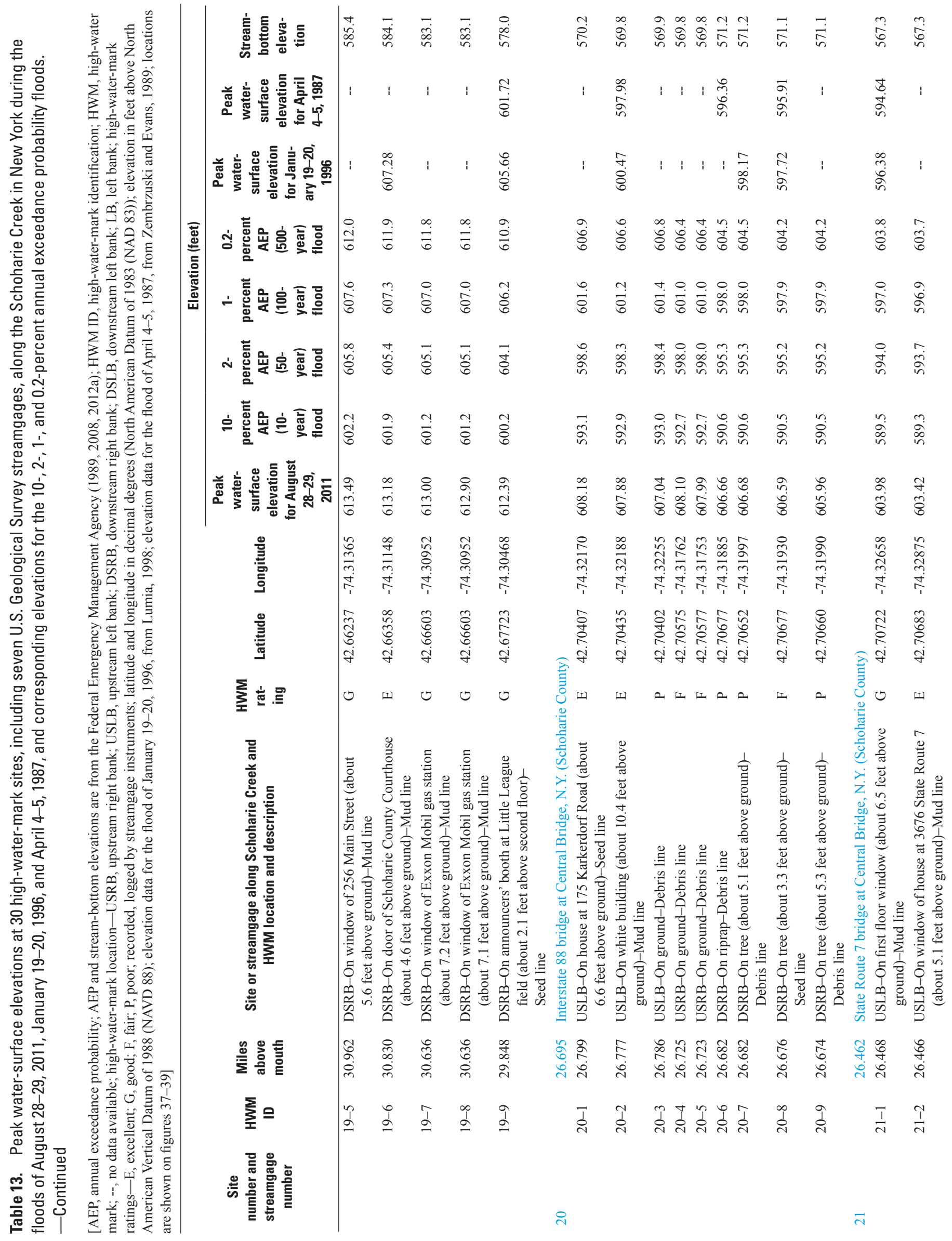




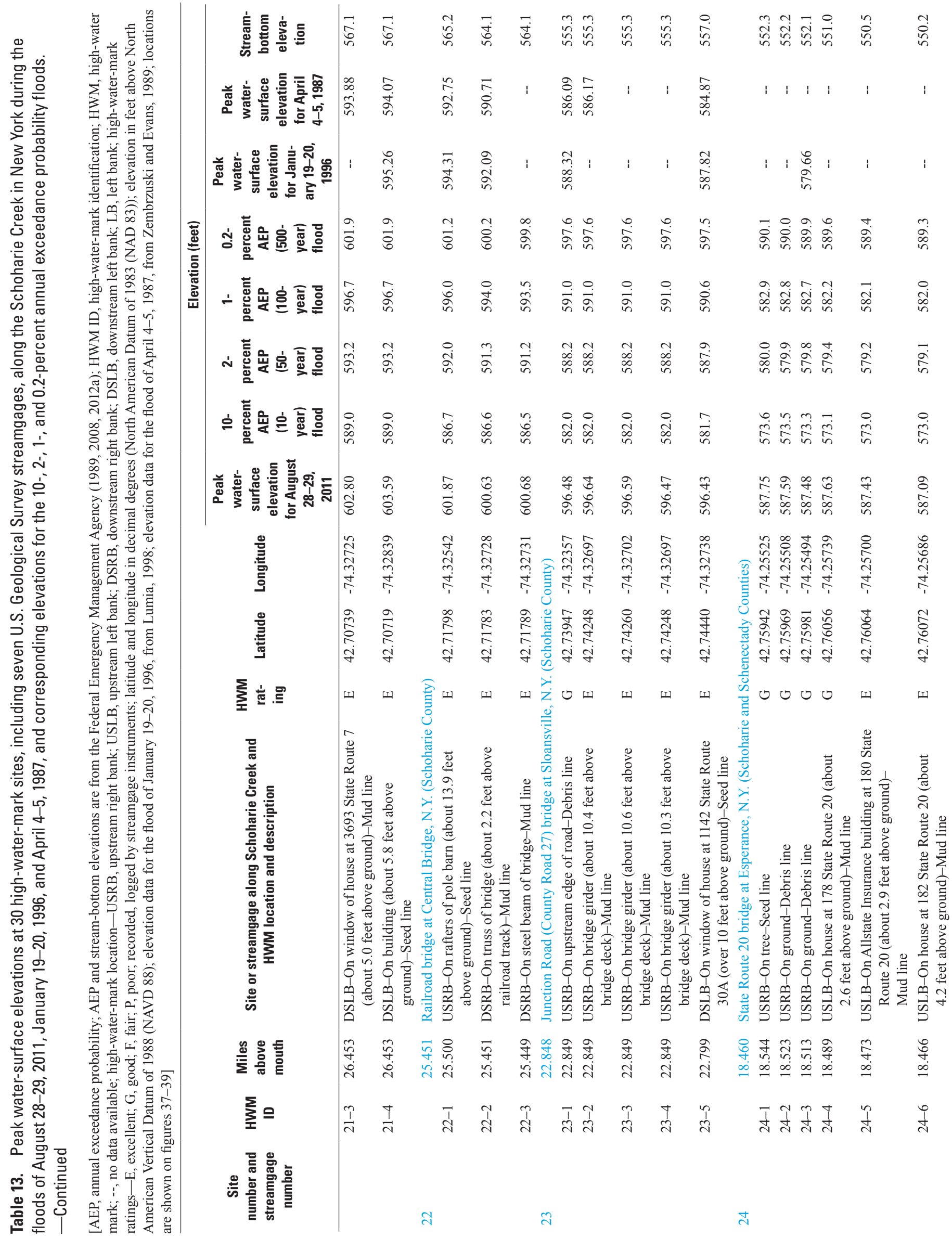




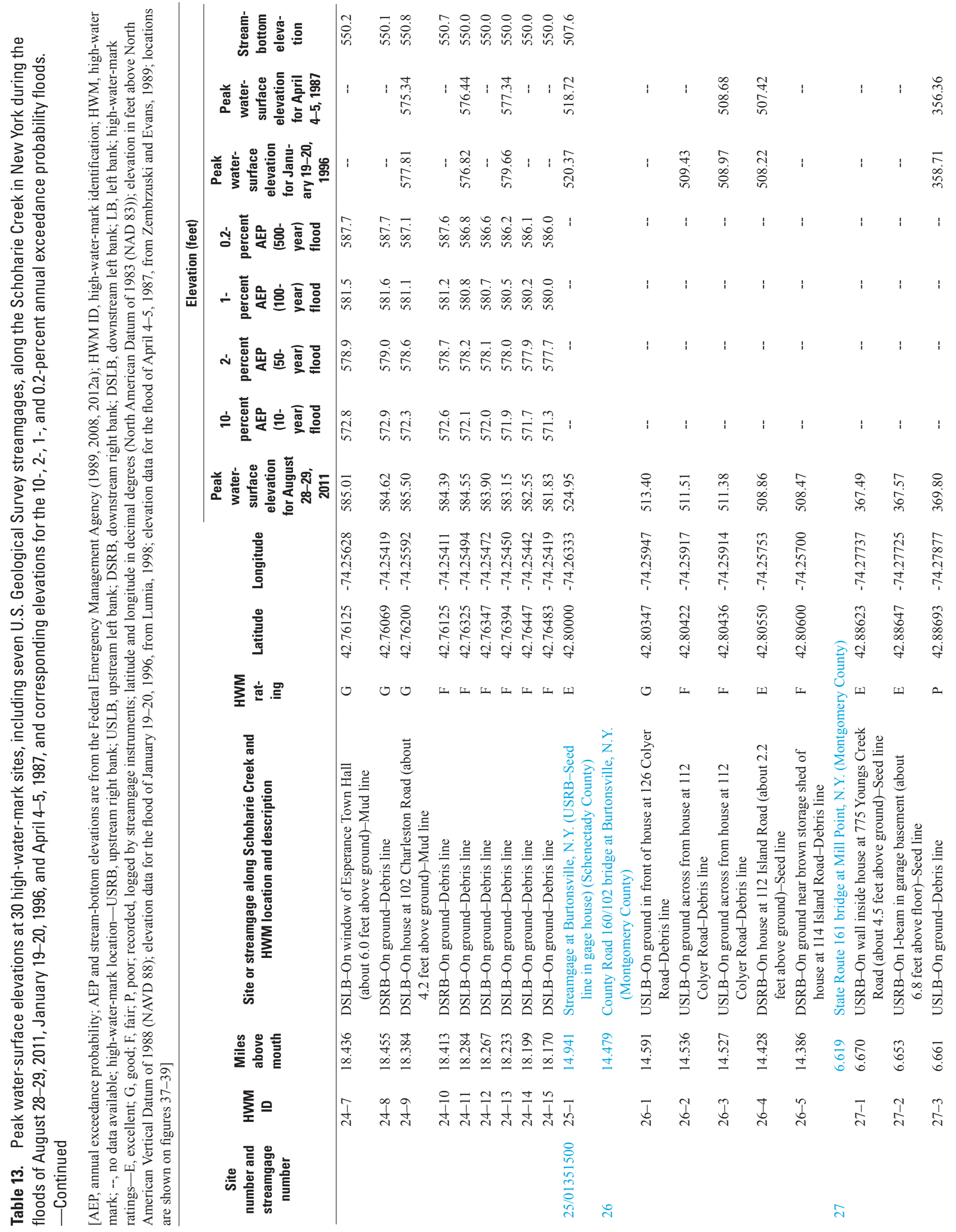




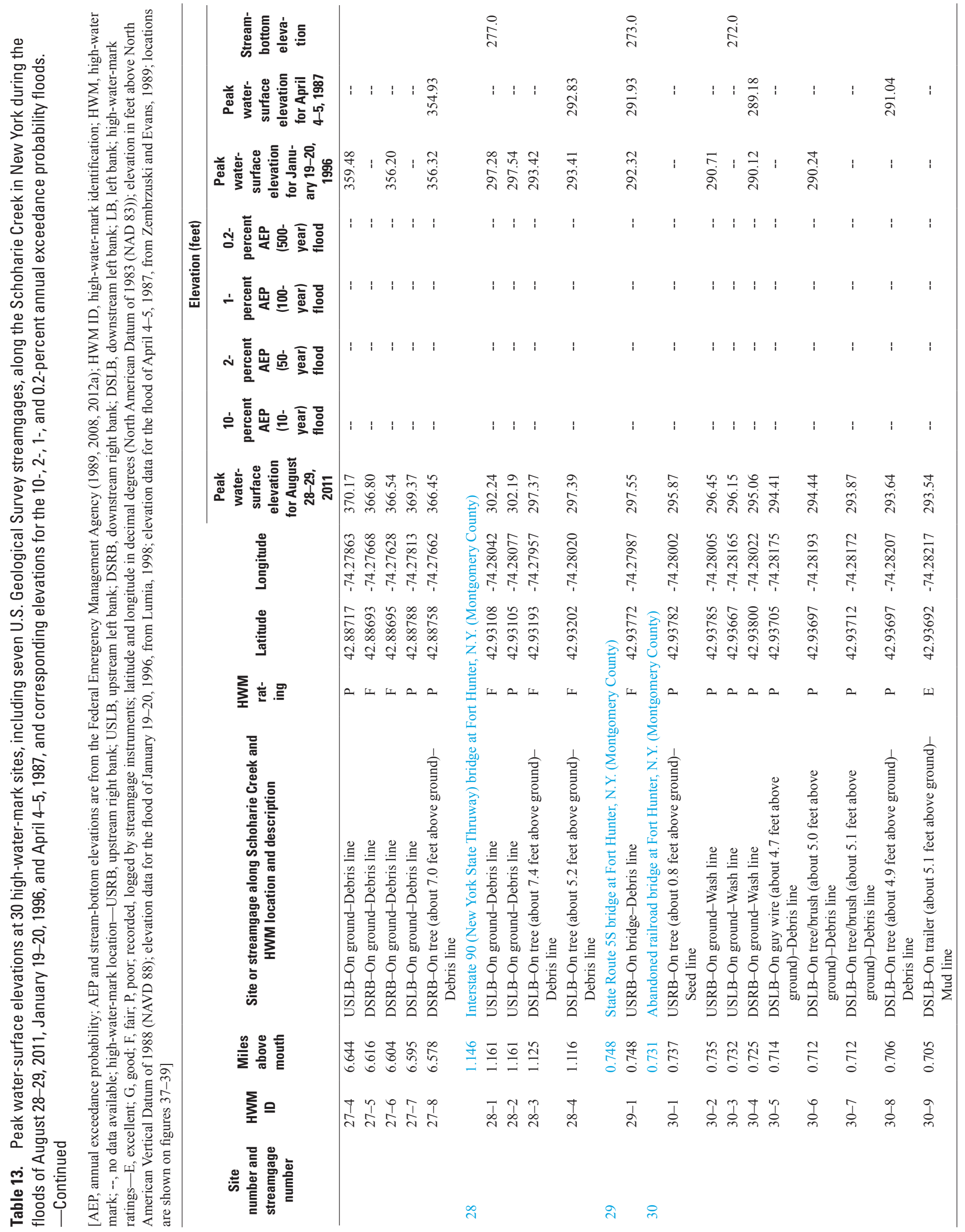



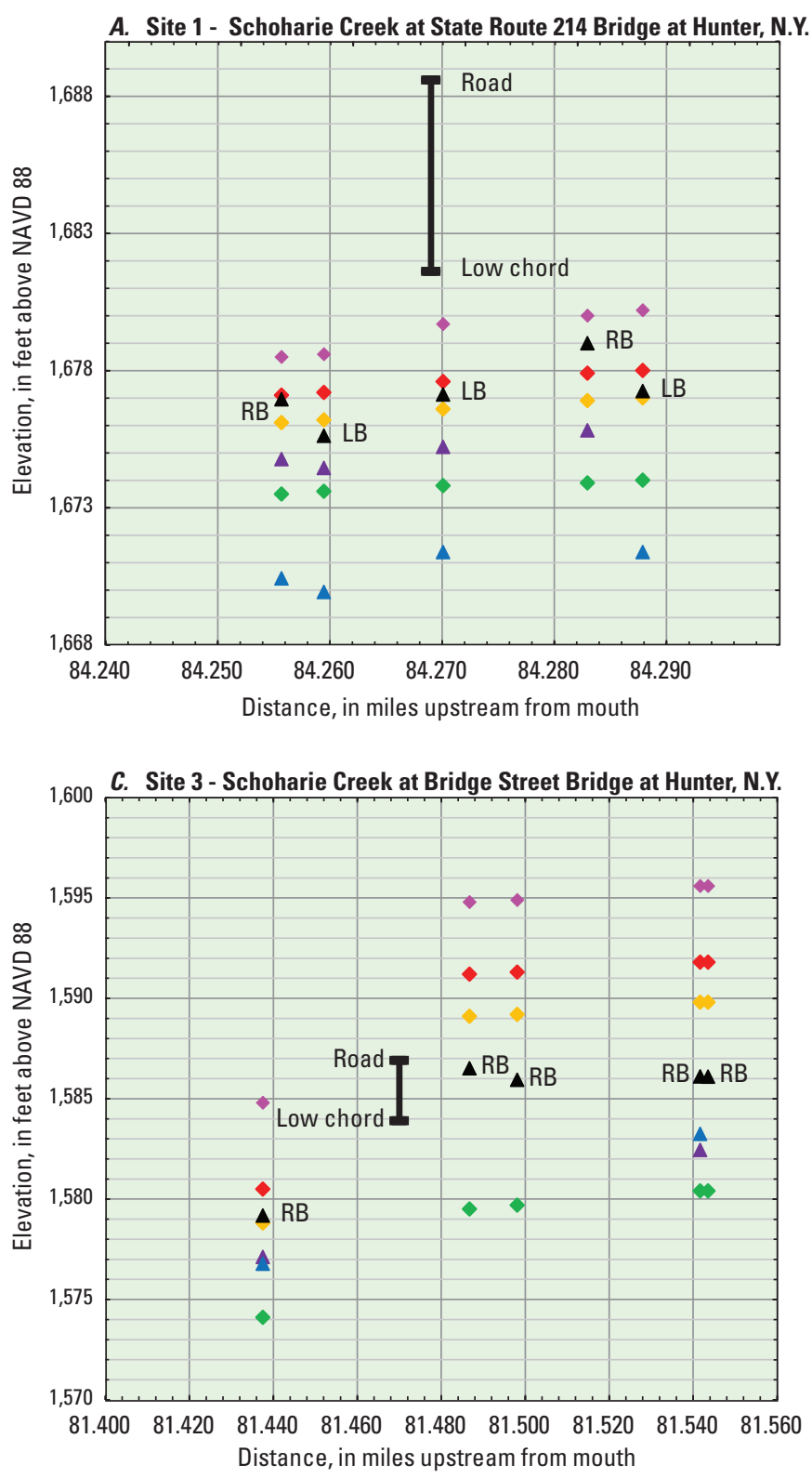

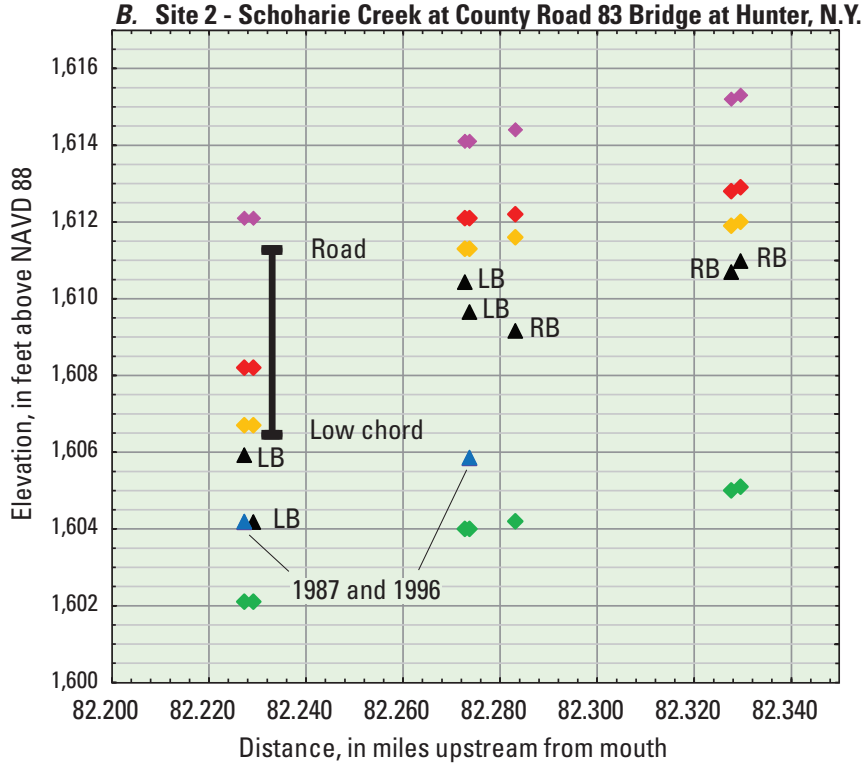

EXPLANATION

FEMA 0.2-percent AEP (500-year) elevation

FEMA 1-percent AEP (100-year) elevation

FEMA 2-percent AEP (50-year) elevation

- FEMA 10-percent AEP (10-year) elevation

$\Delta$ USGS high-water mark for August 28-29, 2011

$\triangle$ USGS high-water mark for January 19-20, 1996

$\triangle$ USGS high-water mark for April 4-5, 1987

LB - High-water mark on Left bank RB- High-water mark on Right bank USGS - U.S. Geological Survey

Figure 39. Peak water-surface elevations of Schoharie Creek (as indicated by high-water marks) at 30 sites from Hunter to Fort Hunter, New York, during the flood of August 28-29, 2011, and annual exceedance probability (AEP) elevations from published Federal Emergency Management Agency (FEMA) profiles. (Site data are given in table 13 and locations are shown on figure 38. NAVD 88, North American Vertical Datum of 1988) 

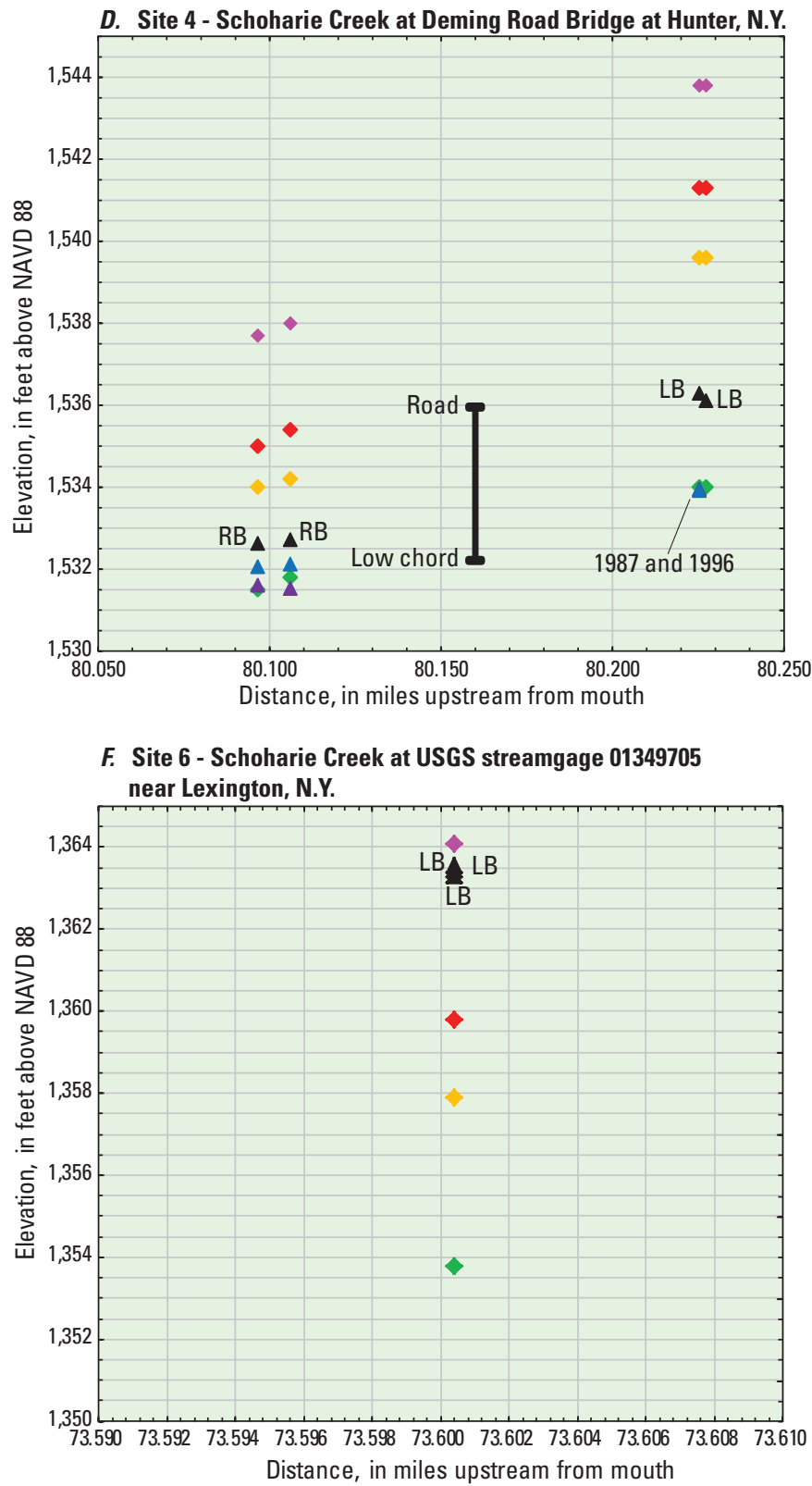

Figure 39.-Continued

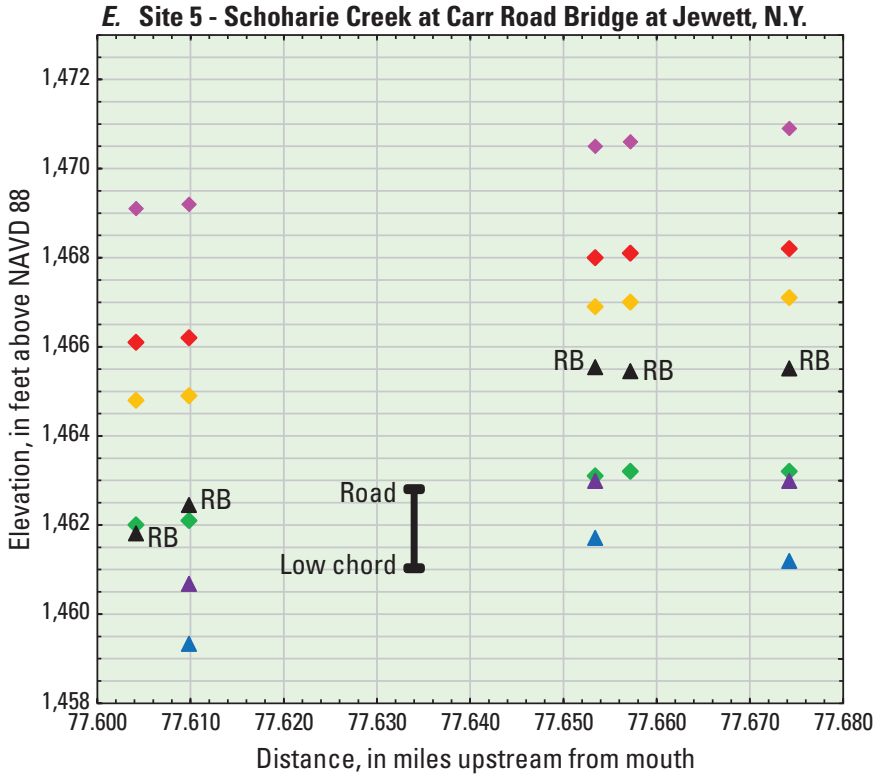

\section{EXPLANATION}

$\checkmark$ FEMA 0.2-percent AEP (500-year) elevation

$\checkmark$ FEMA 1-percent AEP (100-year) elevation

FEMA 2-percent AEP (50-year) elevation

FEMA 10-percent AEP (10-year) elevation

$\Delta$ USGS high-water mark for August 28-29, 2011

$\triangle$ USGS high-water mark for January 19-20, 1996

$\triangle$ USGS high-water mark for April 4-5, 1987

LB - High-water mark on Left bank

RB- High-water mark on Right bank

USGS - U.S. Geological Survey 
G. Site 7 - Schoharie Creek at State Route 42 Bridge at Lexington, N.Y.
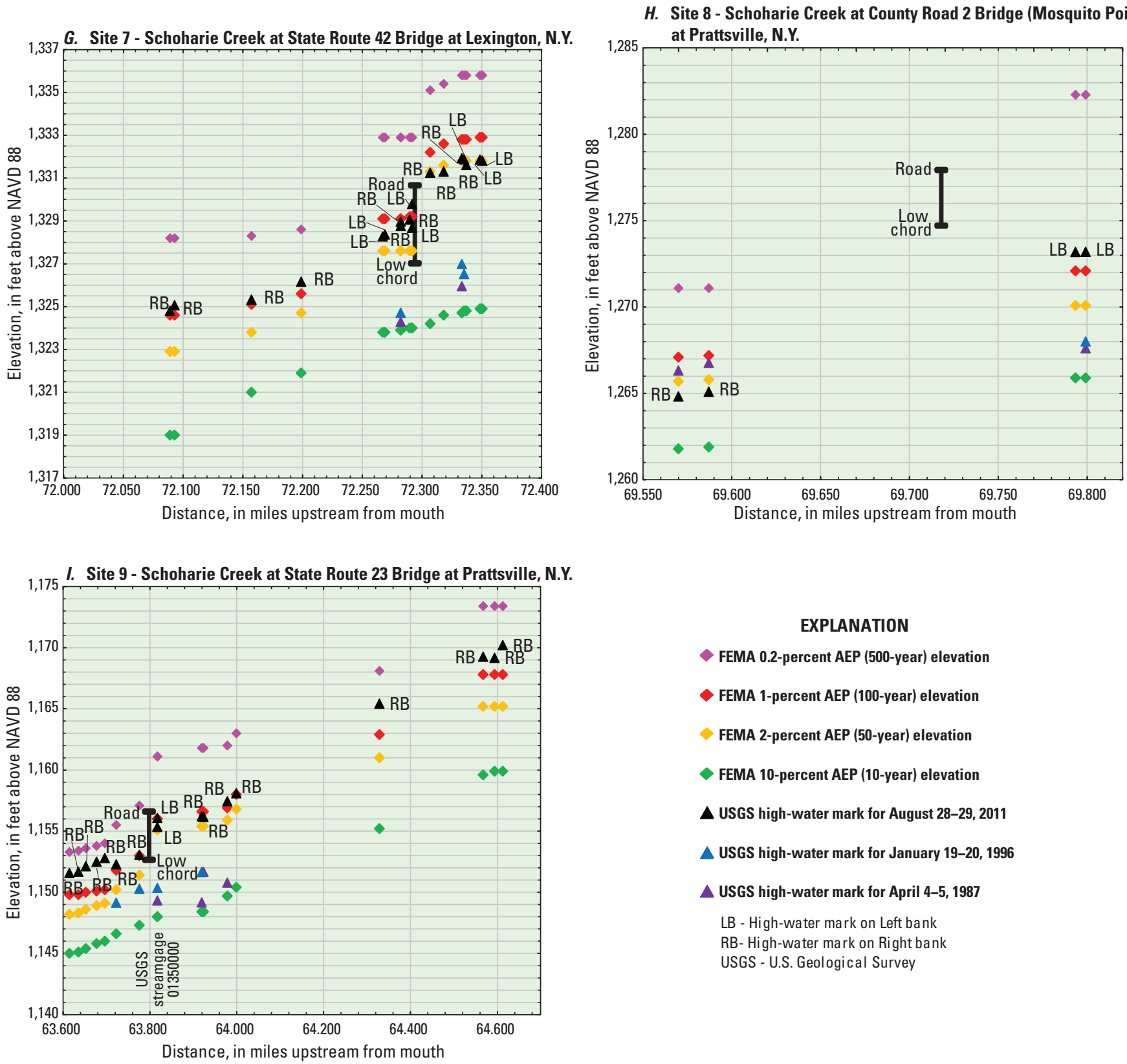

EXPLANATION

$\checkmark$ FEMA 0.2-percent AEP (500-year) elevation

FEMA 1-percent AEP (100-year) elevation

FEMA 2-percent AEP (50-year) elevation

FEMA 10-percent AEP (10-year) elevation

$\Delta$ USGS high-water mark for August 28-29, 2011

$\triangle$ USGS high-water mark for January 19-20, 1996

USGS high-water mark for April 4-5, 1987

LB - High-water mark on Left bank RB- High-water mark on Right bank USGS - U.S. Geological Survey

Figure 39.-Continued 

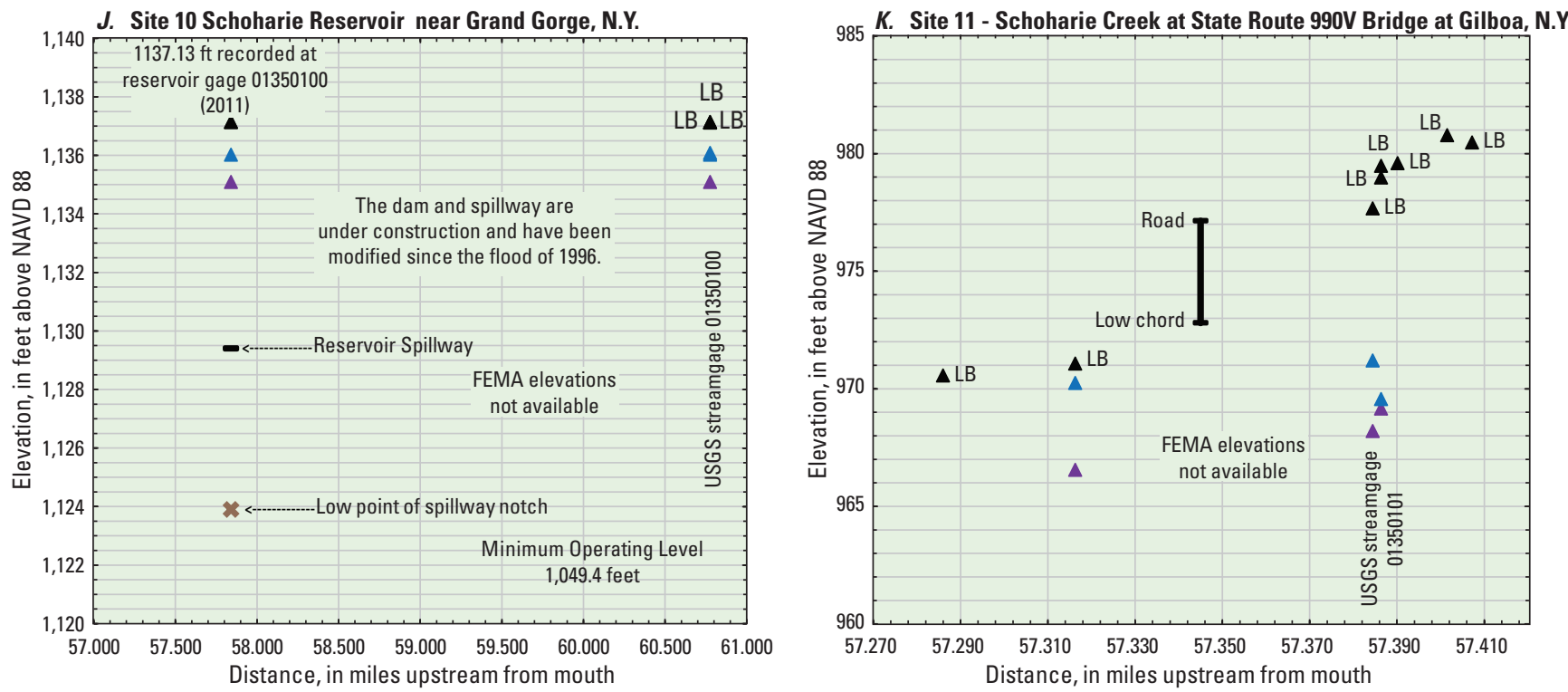

L. Site 12 - Schoharie Creek at Blenheim-Gilboa Lower Reservoir Dam at North Blenheim, N.Y.

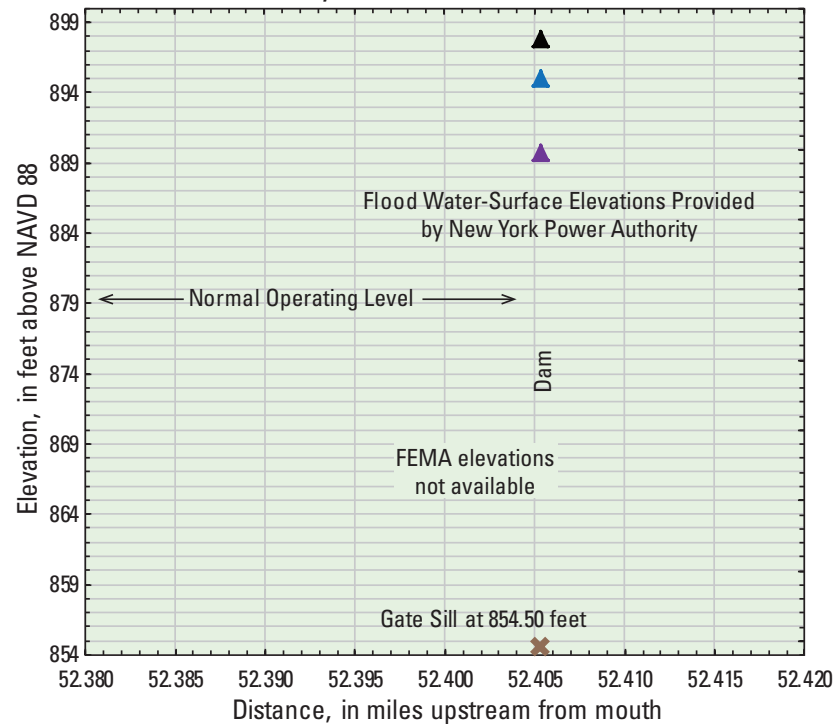

\section{EXPLANATION}

FEMA 0.2-percent AEP (500-year) elevation

- FEMA 1-percent AEP (100-year) elevation

FEMA 2-percent AEP (50-year) elevation

FEMA 10-percent AEP (10-year) elevation

A USGS high-water mark for August 28-29, 2011

$\triangle$ USGS high-water mark for January 19-20, 1996

$\triangle$ USGS high-water mark for April 4-5, 1987

LB - High-water mark on Left bank RB- High-water mark on Right bank USGS - U.S. Geological Survey

Figure 39.-Continued 

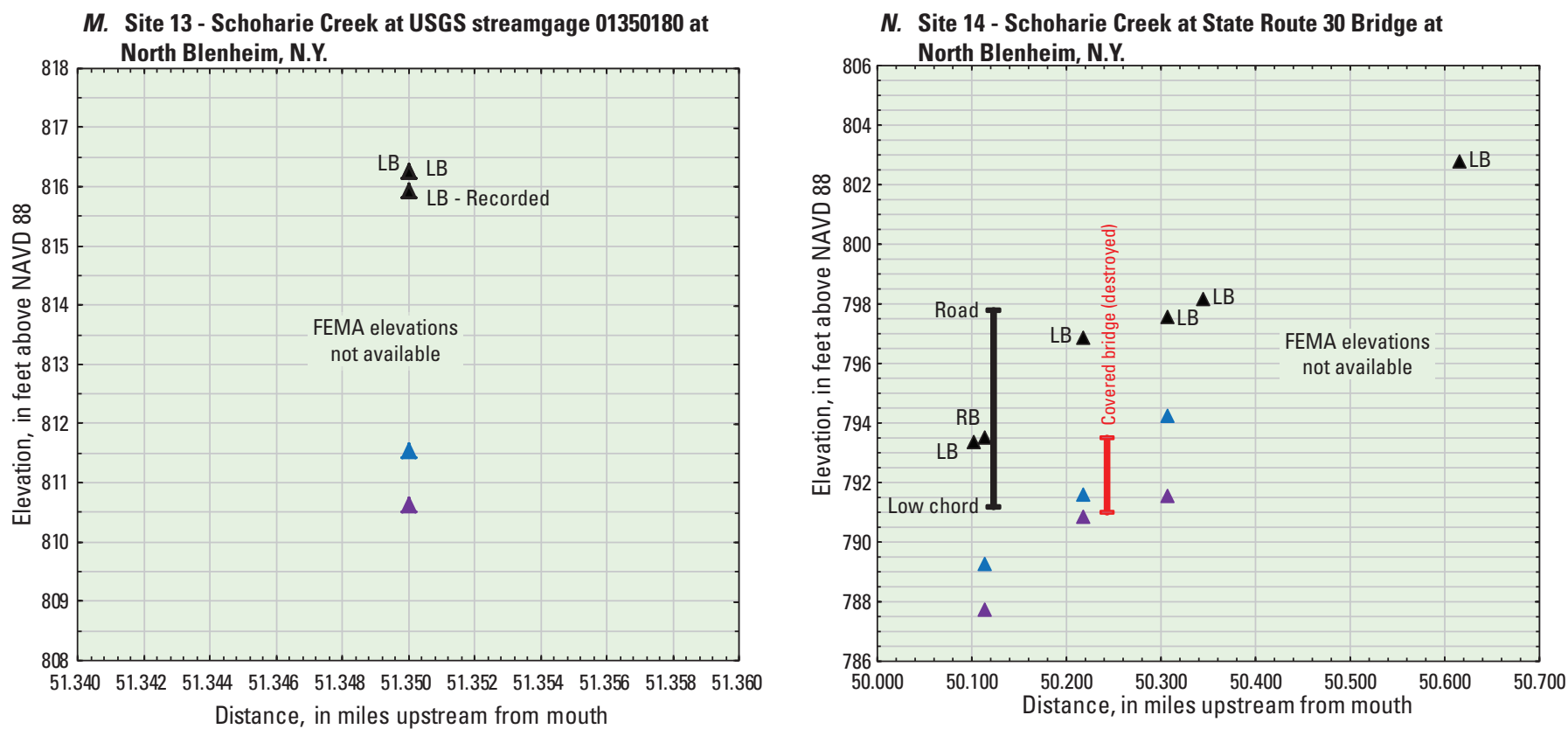

0. Site $\mathbf{1 5}$ - Schoharie Creek at State Route $\mathbf{3 0}$ Bridge at Breakabeen, N.Y.

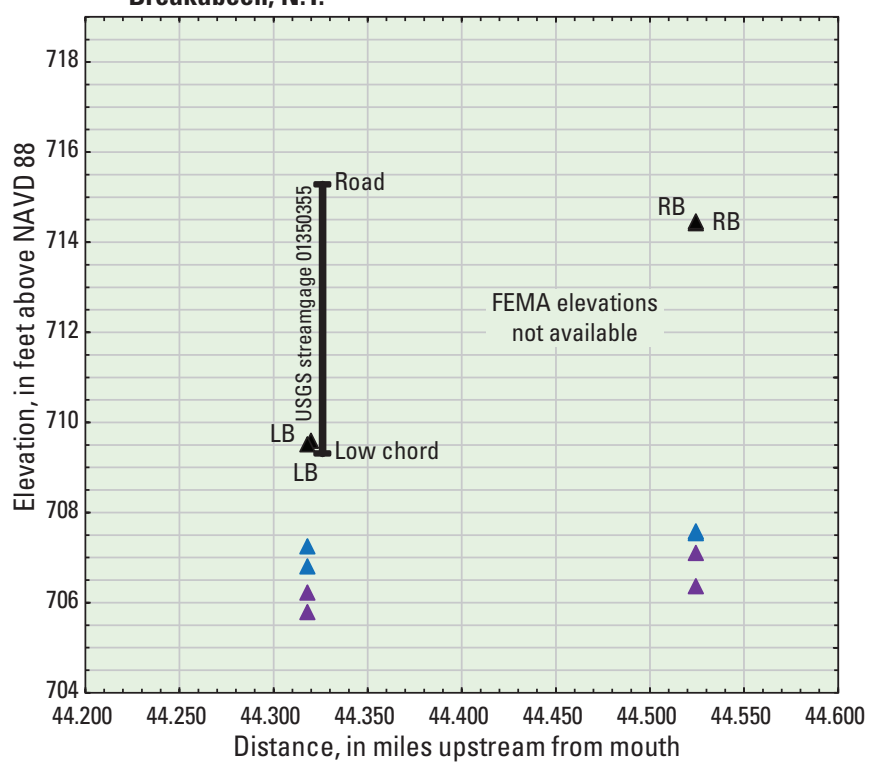

\section{EXPLANATION}

FEMA 0.2-percent AEP (500-year) elevation

FEMA 1-percent AEP (100-year) elevation

FEMA 2-percent AEP (50-year) elevation

FEMA 10-percent AEP (10-year) elevation

$\Delta$ USGS high-water mark for August 28-29, 2011

$\triangle$ USGS high-water mark for January 19-20, 1996

$\triangle$ USGS high-water mark for April 4-5, 1987

LB - High-water mark on Left bank RB- High-water mark on Right bank USGS - U.S. Geological Survey

Figure 39.-Continued 

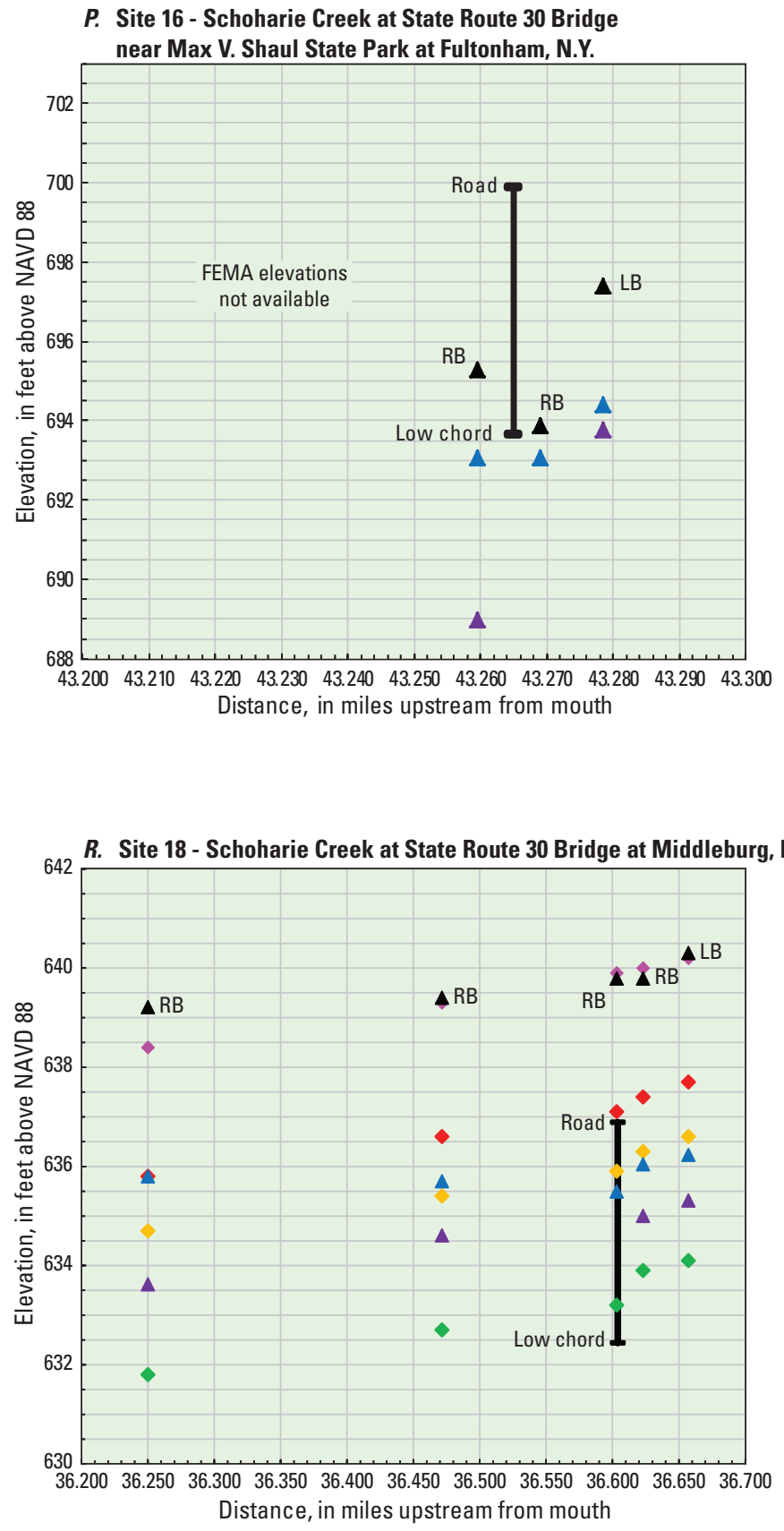

Figure 39.-Continued
0. Site 17 - Schoharie Creek at State Route $\mathbf{3 0}$ Bridge near Boucks Island at Fultonham, N.Y.

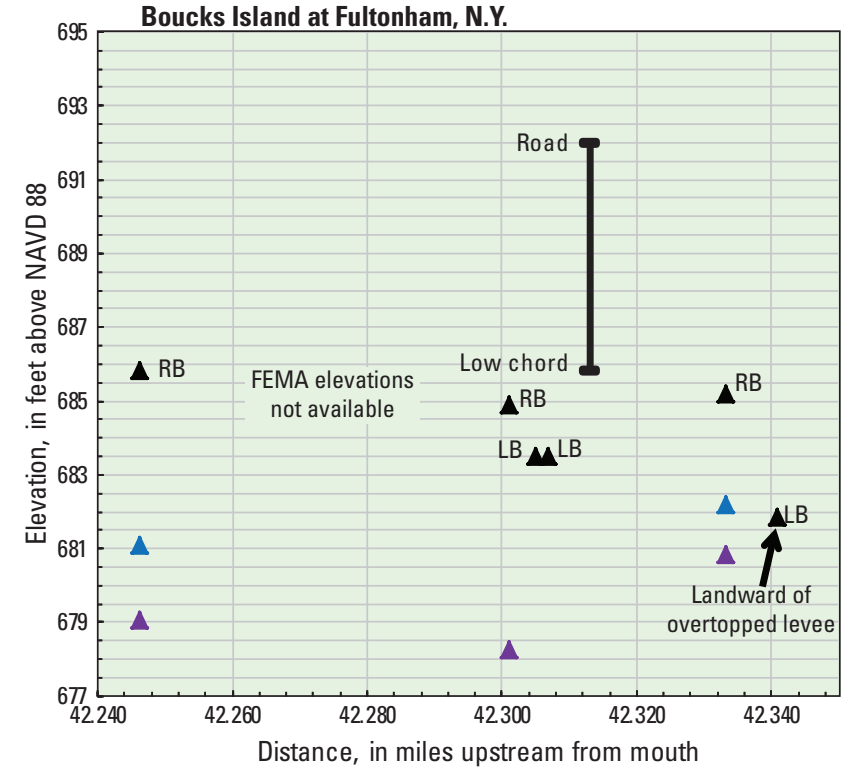

\section{EXPLANATION}

FEMA 0.2-percent AEP (500-year) elevation

FEMA 1-percent AEP (100-year) elevation

FEMA 2-percent AEP (50-year) elevation

FEMA 10-percent AEP (10-year) elevation

A USGS high-water mark for August 28-29, 2011

$\triangle$ USGS high-water mark for January 19-20, 1996

$\triangle$ USGS high-water mark for April 4-5, 1987

LB - High-water mark on Left bank RB- High-water mark on Right bank USGS - U.S. Geological Survey 
S. Site 19 - Schoharie Creek at Bridge Street Bridge at Schoharie, N.Y.

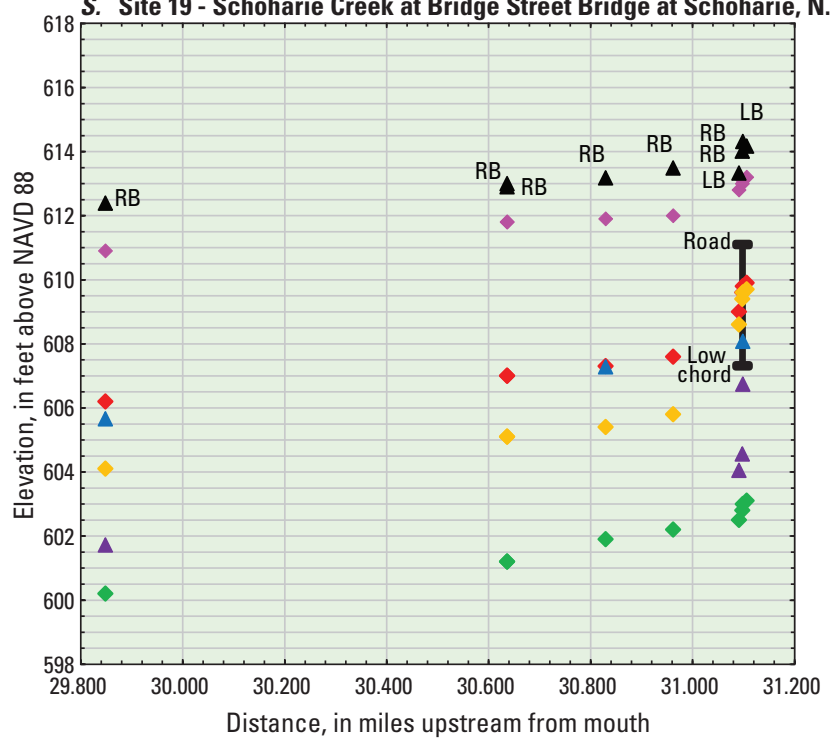

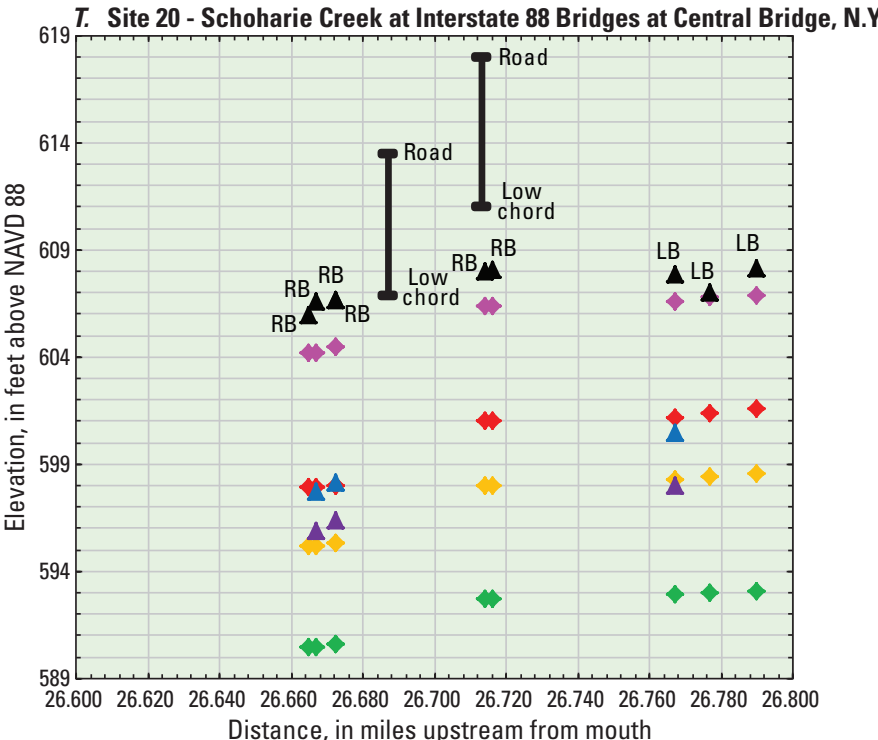

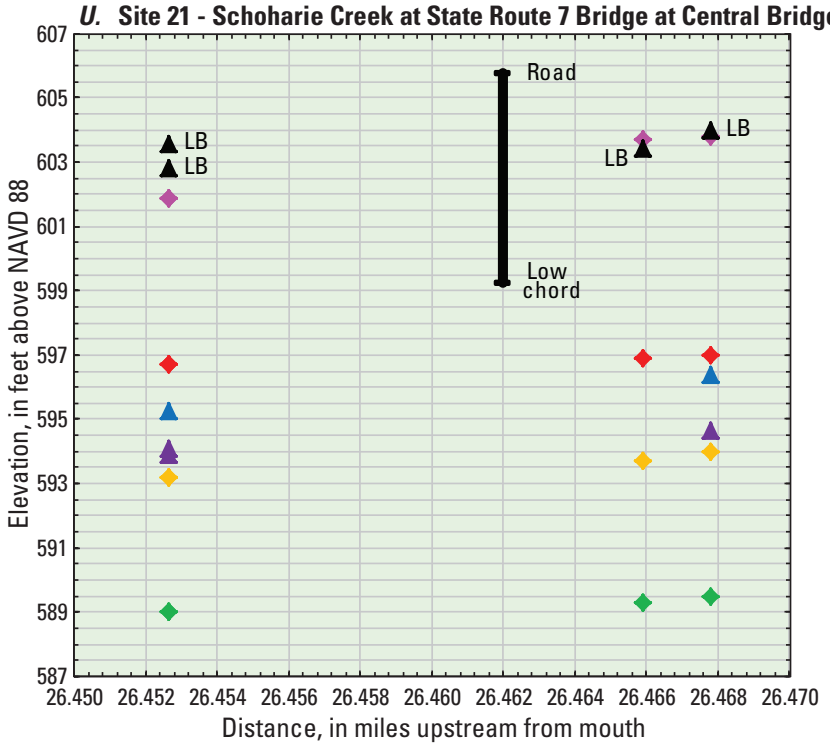

Figure 39.-Continued

\section{EXPLANATION}

FEMA 0.2-percent AEP (500-year) elevation

$\checkmark$ FEMA 1-percent AEP (100-year) elevation

FEMA 2-percent AEP (50-year) elevation

FEMA 10-percent AEP (10-year) elevation

A USGS high-water mark for August 28-29, 2011

$\triangle$ USGS high-water mark for January 19-20, 1996

$\triangle$ USGS high-water mark for April 4-5, 1987

LB - High-water mark on Left bank RB- High-water mark on Right bank USGS - U.S. Geological Survey 
V. Site 22 - Schoharie Creek at Railroad Bridge at Central Bridge, N.Y.

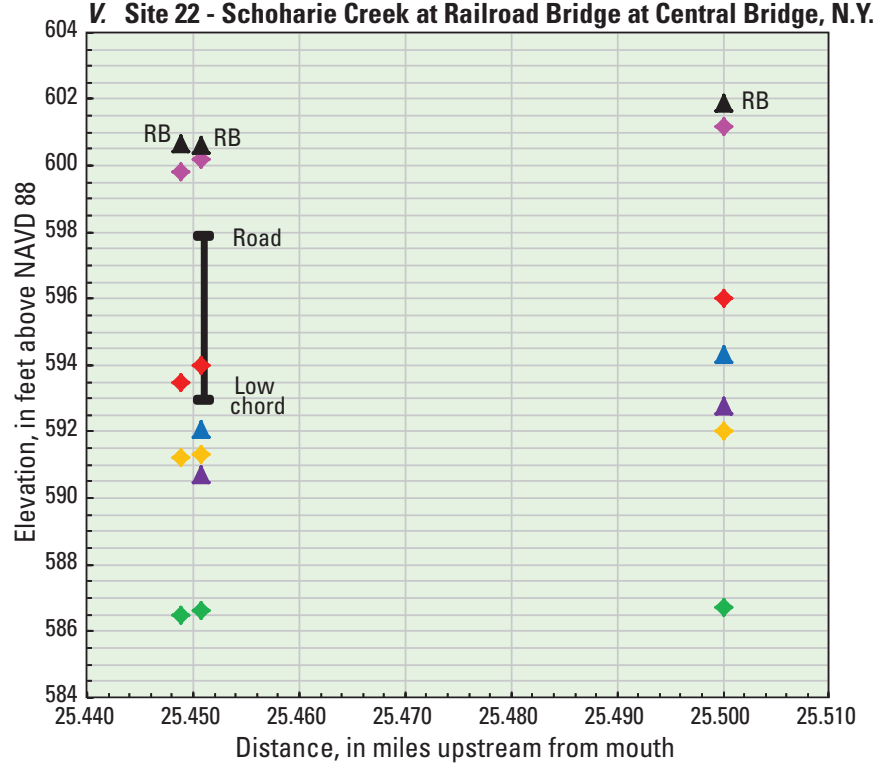

X. Site 24 - Schoharie Creek at State Route 20 Bridge at Esperance, N.Y.

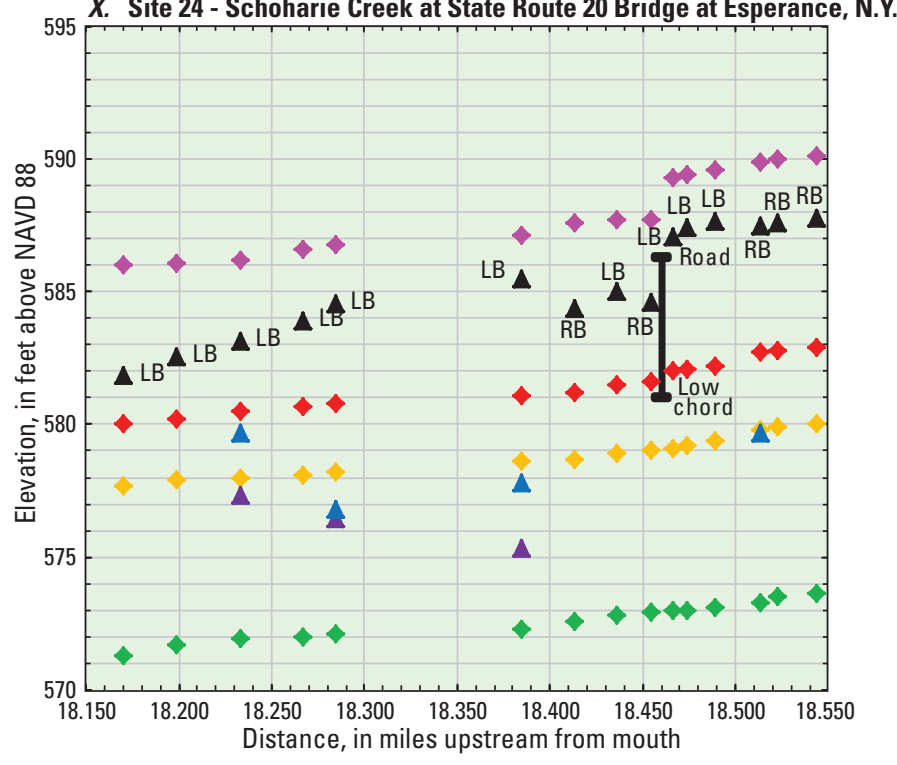

W. Site 23 - Schoharie Creek at Junction Road (County Road 27) Bridge at Sloansville, N.Y.

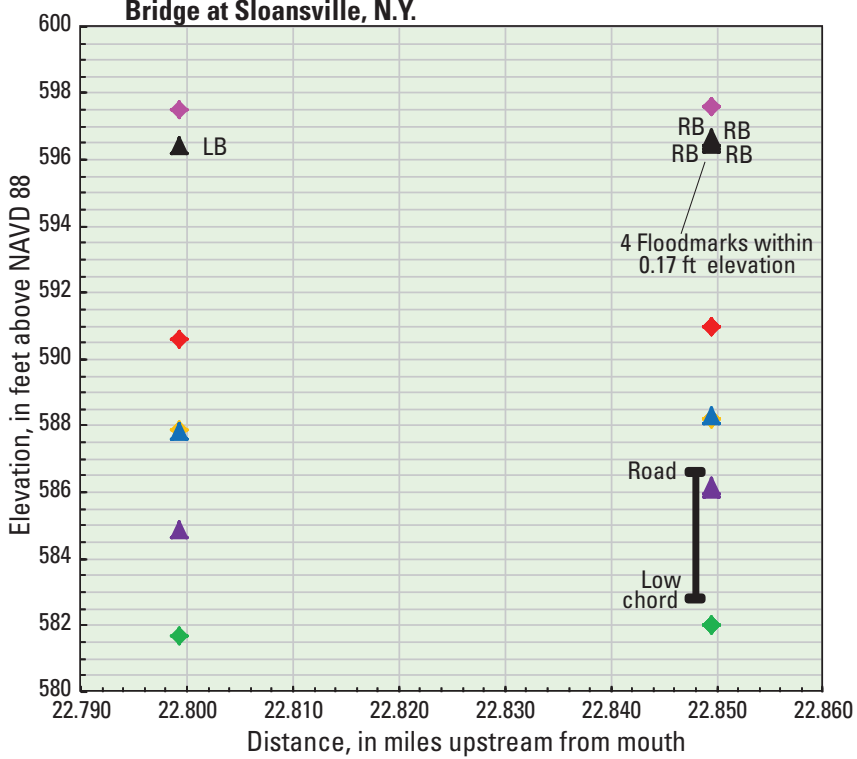

\section{EXPLANATION}

FEMA 0.2-percent AEP (500-year) elevation

$\checkmark$ FEMA 1-percent AEP (100-year) elevation

$\checkmark$ FEMA 2-percent AEP (50-year) elevation

$\checkmark$ FEMA 10-percent AEP (10-year) elevation

$\Delta$ USGS high-water mark for August 28-29, 2011

$\triangle$ USGS high-water mark for January 19-20, 1996

$\triangle$ USGS high-water mark for April 4-5, 1987

LB - High-water mark on Left bank RB- High-water mark on Right bank USGS - U.S. Geological Survey

Figure 39.-Continued 
Y. Site 25 - Schoharie Creek at USGS streamgage 01351500 at Burtonsville, N.Y.

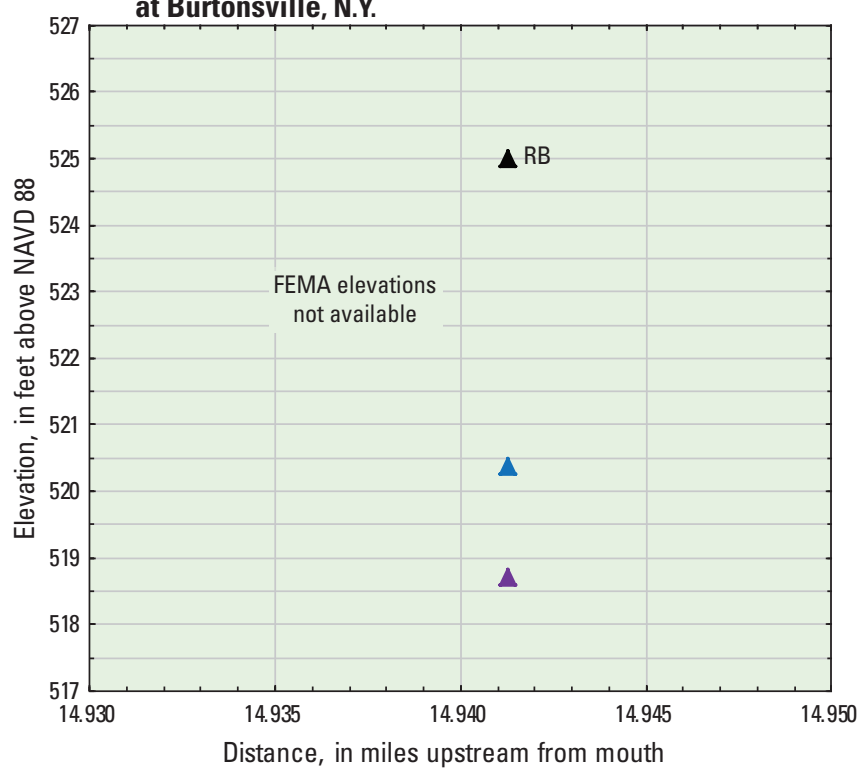

AA. Site 27 - Schoharie Creek at State Route 161 Bridge at Mill Point, N.Y.

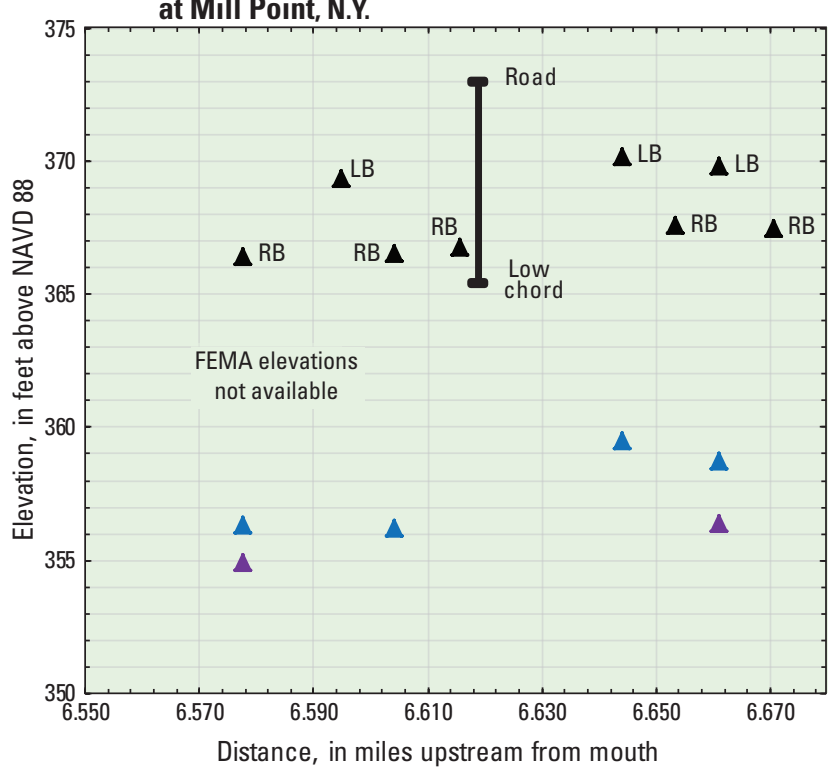

Figure 39.-Continued
Z. Site 26 - Schoharie Creek at County Road 160/102 Bridge at Burtonsville, N.Y.

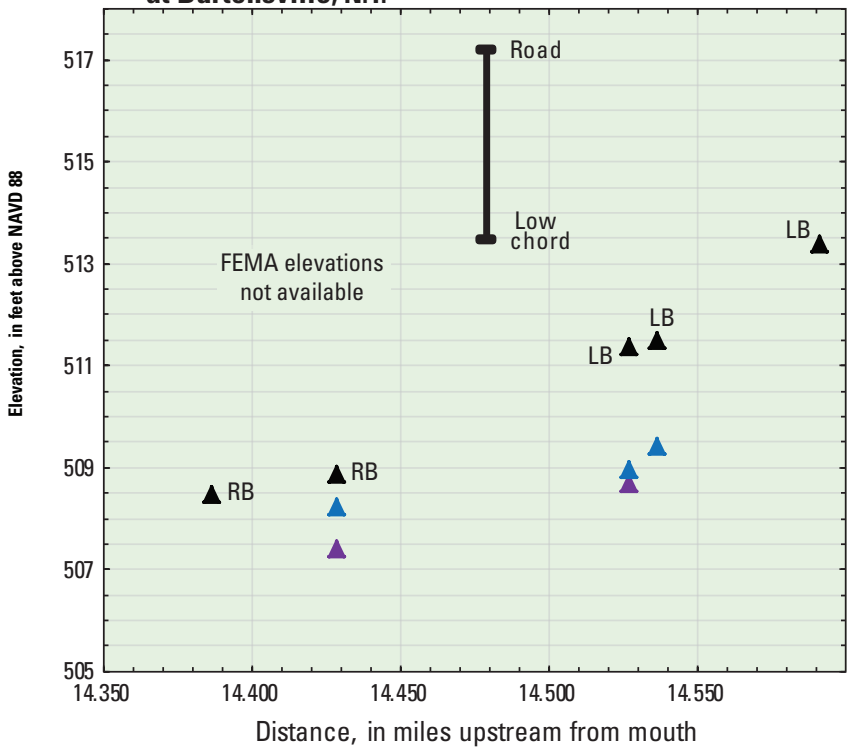

\section{EXPLANATION}

FEMA 0.2-percent AEP (500-year) elevation

FEMA 1-percent AEP (100-year) elevation

FEMA 2-percent AEP (50-year) elevation

$\rightarrow$ FEMA 10-percent AEP (10-year) elevation

A USGS high-water mark for August 28-29, 2011

$\triangle$ USGS high-water mark for January 19-20, 1996

$\triangle$ USGS high-water mark for April 4-5, 1987

LB - High-water mark on Left bank RB- High-water mark on Right bank USGS - U.S. Geological Survey 
AB. Site 28 - Schoharie Creek at Interstate 90 Bridge at

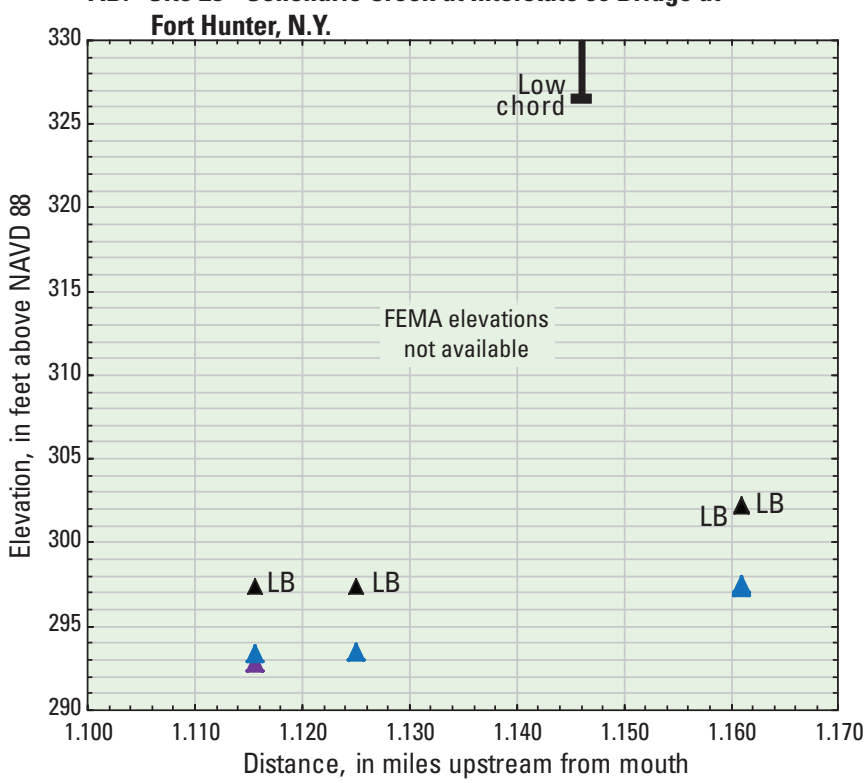

AD. Site 30 - Schoharie Creek at Railroad Bridge at Fort Hunter, N.Y

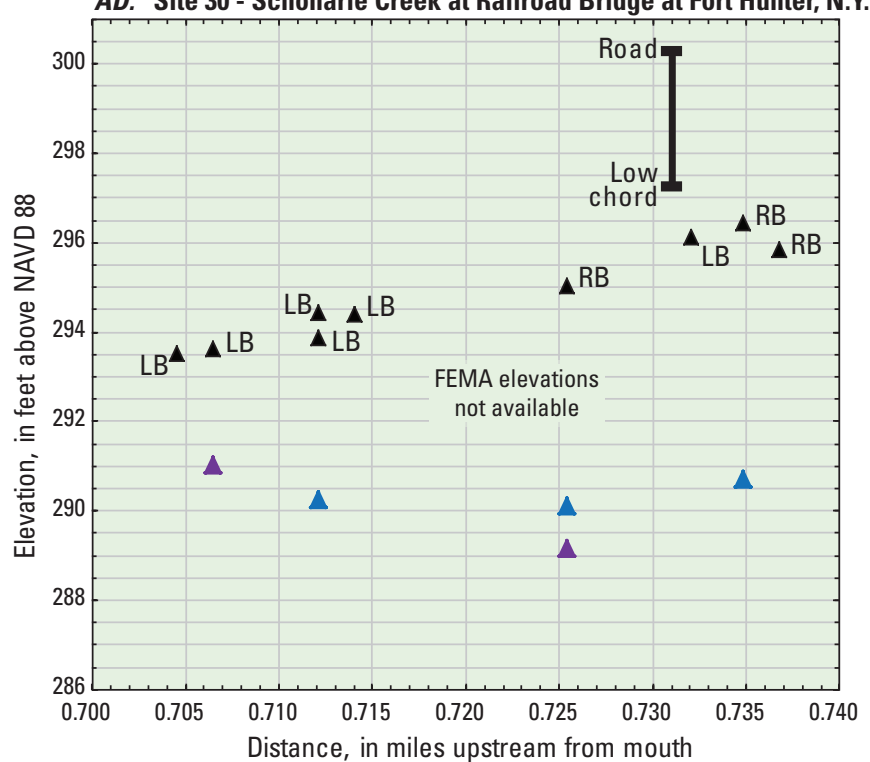

AC. Site 29 - Schoharie Creek at State Route 5S Bridge at

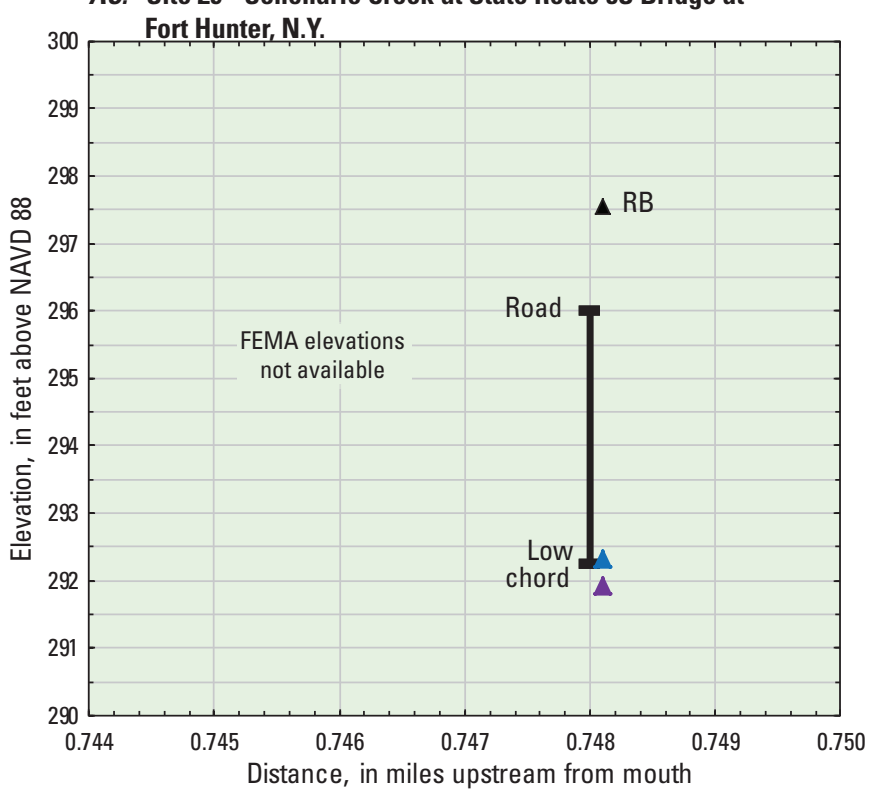

\section{EXPLANATION}

FEMA 0.2-percent AEP (500-year) elevation

$\checkmark$ FEMA 1-percent AEP (100-year) elevation

$\checkmark$ FEMA 2-percent AEP (50-year) elevation

$\checkmark$ FEMA 10-percent AEP (10-year) elevation

$\triangle$ USGS high-water mark for August 28-29, 2011

$\triangle$ USGS high-water mark for January 19-20, 1996

$\triangle$ USGS high-water mark for April 4-5, 1987

LB - High-water mark on Left bank RB- High-water mark on Right bank USGS - U.S. Geological Survey

Figure 39.-Continued 


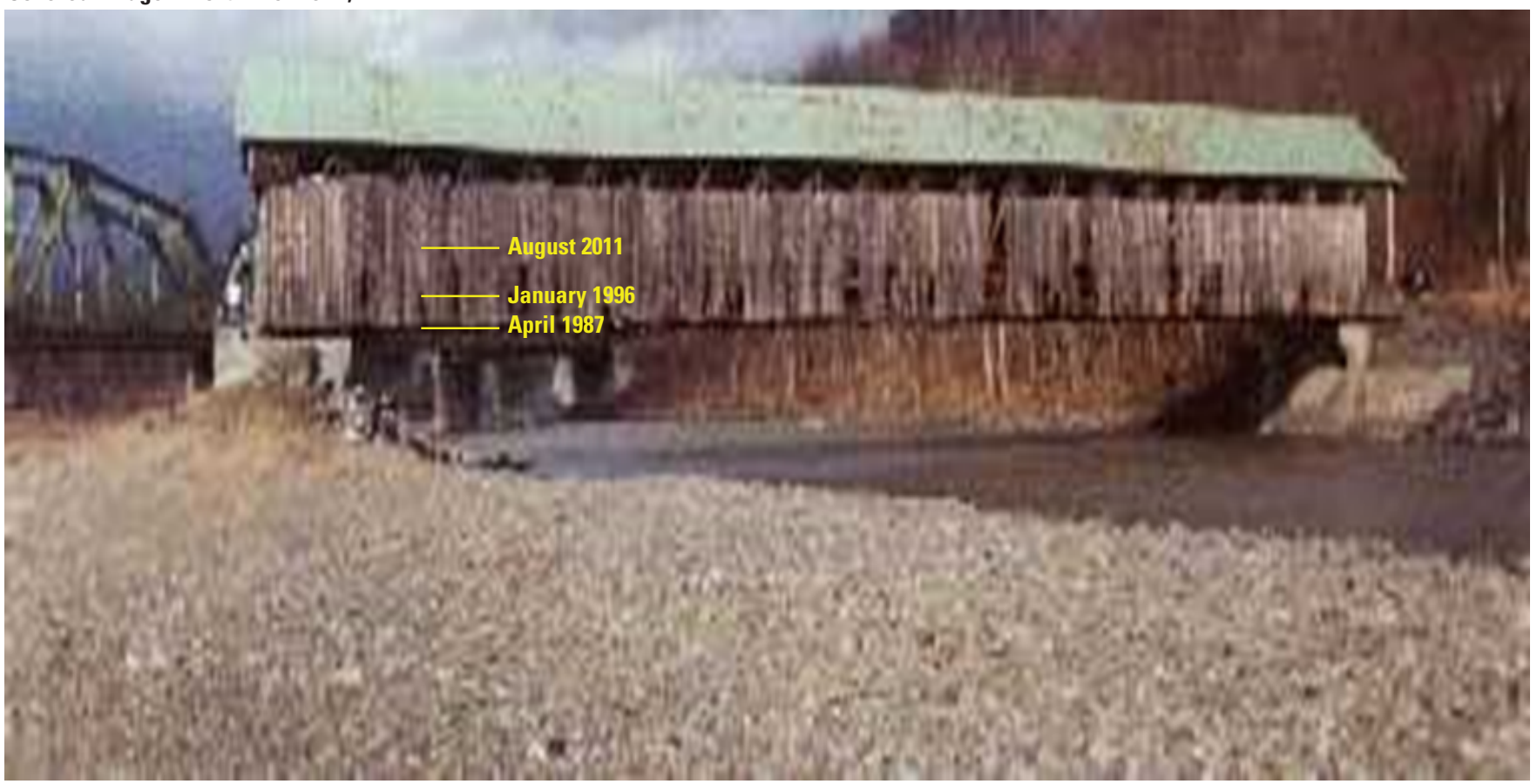

Figure 40. The covered bridge over Schoharie Creek in North Blenheim, New York, with the maximum elevations of the August 28, 2011, flood and two previous floods.

\section{Effects of Reservoirs}

Unlike the April-May flood, which had prolonged high flow prior to the major flooding that limited available storage, data for seven reservoirs in east-central and southeastern New York (table 18, figs. 44A-G) indicate that reservoir storage mitigated a moderate to a substantial amount of downstream flooding from Tropical Storm Irene. For six of the reservoirs, water level and release data were provided by the New York City Department of Environmental Protection (written commun., 2012).

The water levels in six of the seven reservoirs (except Cannonsville Reservoir) exceeded their spillway elevations during August 28-29. The highest water-surface elevations of record were documented (table 11) for Schoharie Reservoir (86 years of record) and the West Basin of the Ashokan Reservoir (99 years of record). Schoharie Reservoir, just downstream from Prattsville, stored over 1.3 in. of upstream runoff during 10 hours on August 28, and the Ashokan Reservoir (East and West Basins) in the Esopus Creek Basin stored about 4.0 in. of upstream runoff. Most of the reservoirs attenuated or substantially reduced outflows. For example, the maximum computed hourly inflow to Schoharie Reservoir (fig. 44A) was $137,000 \mathrm{ft}^{3} / \mathrm{s}$ on August 28, whereas the maximum outflow was $111,000 \mathrm{ft}^{3} / \mathrm{s}$, nearly a 20 -percent reduction. The peak inflow to Ashokan Reservoir was $99,900 \mathrm{ft}^{3} / \mathrm{s}$ on August 28, whereas the maximum hourly outflow to Esopus Creek was only 20,900 ft³ 3 s on August 29, nearly an 80-percent reduction (fig. 44C). Inflows to Ashokan
Reservoir were estimated by a drainage-area adjustment of hourly discharge data for two upstream streamgages (Esopus Creek at Coldbrook (01362500) and Bush Kill at West Shokan (01363382)), which together account for 81 percent of the drainage area to the reservoir $\left(256 \mathrm{mi}^{2}\right)$. A similar procedure was used to compute inflows to Rondout Reservoir (fig. 44D) from upstream streamgages at Rondout Creek near Lowes Corners (01365000) and Chestnut Creek at Grahamsville (01365500), which together account for 62 percent of the reservoir's drainage area $\left(95.4 \mathrm{mi}^{2}\right)$. Much of the outflow from Rondout Reservoir was attenuated by storage; the estimated peak hourly inflow was $15,700 \mathrm{ft}^{3} / \mathrm{s}$, and the maximum outflow was 5,560 $\mathrm{ft}^{3} / \mathrm{s}$ (fig. 44D). Similar analyses for the Pepacton Reservoir on the East Branch Delaware River, the Cannonsville Reservoir on the West Branch Delaware River, and the Neversink Reservoir on a tributary to the main stem of the Delaware River indicate that outflows were reduced by about 80-, 64-, and 65-percent, respectively (figs. 44E-G).

The National Resources Conservation Service (NRCS) maintains three flood-control dams in the headwaters of the Batavia Kill, a major tributary to Schoharie Creek. These dams are designed to detain the runoff from the 1-percent chance AEP (100-year recurrence interval) storm and have auxiliary spillways to pass flows that exceed the design storm. On August 28, the auxiliary spillways at all three dams were flowing, but the reservoirs retained a substantial amount of runoff before spilling (Peter Wright, National Resource Conservation Service, oral commun., 2013). 
Table 14. High-water marks collected by the Federal Emergency Management Agency at 72 selected sites in the Delaware and lower Hudson River Basins in New York for the flood of August 28-29, 2011.

[Latitude, longitude, and elevation are from the Federal Emergency Management Agency (FEMA, 2011e); HWM ID, high-water-mark identification; latitude and longitude in decimal degrees, North American Datum of 1983 (NAD 83); elevation in feet above North American Vertical Datum of 1988 (NAVD 88); locations are shown on figure 41A]

\begin{tabular}{|c|c|c|c|c|c|}
\hline Site number & FEMA HWM ID & Site name & Latitude & Longitude & Elevation \\
\hline 1 & D1_27 & West Kill upstream of West Kill, N.Y. & 42.20580 & -74.38117 & $1,496.4$ \\
\hline 2 & D1_26 & West Kill at West Kill, N.Y. & 42.20702 & -74.38361 & $1,485.8$ \\
\hline 4 & D3_14 & Manor Kill upstream of Conesville, N.Y. & 42.38717 & -74.36779 & $1,388.5$ \\
\hline 5 & D3_13 & Manor Kill upstream of Conesville, N.Y. & 42.38734 & -74.36964 & $1,386.5$ \\
\hline 8 & D2_11 & Bushnellsville Creek downstream of Bushnellsville, N.Y. & 42.14593 & -74.41097 & $1,345.3$ \\
\hline 9 & D1_15 & Esopus Creek at Allaben, N.Y. & 42.11736 & -74.38231 & $1,017.9$ \\
\hline 10 & D1_14 & Esopus Creek at Allaben, N.Y. & 42.11747 & -74.38120 & $1,015.7$ \\
\hline 11 & D1_13 & Esopus Creek at Allaben, N.Y. & 42.11723 & -74.38087 & $1,015.5$ \\
\hline 15 & D1_7 & Esopus Creek at Phoenicia, N.Y. & 42.08312 & -74.31396 & 813.7 \\
\hline 16 & D1_6 & Esopus Creek at Phoenicia, N.Y. & 42.08317 & -74.31419 & 815.2 \\
\hline 17 & D1_8 & Esopus Creek at Phoenicia, N.Y. & 42.08357 & -74.31358 & 813.2 \\
\hline 18 & D1_11 & Esopus Creek downstream of Phoenicia, N.Y. & 42.08206 & -74.30620 & 795.2 \\
\hline 19 & D1_10 & Esopus Creek downstream of Phoenicia, N.Y. & 42.08166 & -74.30608 & 794.1 \\
\hline 20 & D1_9 & Esopus Creek downstream of Phoenicia, N.Y. & 42.08101 & -74.30558 & 791.0 \\
\hline 21 & D1_22 & Esopus Creek downstream of Phoenicia, N.Y. & 42.07472 & -74.30095 & 776.9 \\
\hline 22 & D1_23 & Esopus Creek downstream of Phoenicia, N.Y. & 42.07451 & -74.30061 & 777.2 \\
\hline 29 & D1_18 & Esopus Creek at Mount Tremper, N.Y. & 42.04081 & -74.27913 & 691.3 \\
\hline 30 & D1_19 & Esopus Creek at Mount Tremper, N.Y. & 42.04026 & -74.27916 & 692.1 \\
\hline 31 & D1_1 & Esopus Creek at Boiceville, N.Y. & 42.00714 & -74.26854 & 630.0 \\
\hline 32 & D1_2 & Esopus Creek at Boiceville, N.Y. & 42.00685 & -74.26772 & 630.0 \\
\hline 33 & D2_26 & Maltby Hollow Brook upstream of West Shokan, N.Y. & 41.97146 & -74.30275 & 785.7 \\
\hline 34 & D2_27 & Bush Kill at West Shokan, N.Y. & 41.97018 & -74.27791 & 619.3 \\
\hline 35 & D1_16 & Kenozia Lake near Ashokan, N.Y. & 41.99302 & -74.16762 & 694.5 \\
\hline 36 & D2_13 & Rondout Creek upstream of Lowes Corners, N.Y. & 41.86774 & -74.48515 & 894.6 \\
\hline 37 & D2_12 & Rondout Creek upstream of Lowes Corners, N.Y. & 41.86700 & -74.48574 & 890.1 \\
\hline 38 & D2_14 & Rondout Creek at Lowes Corners, N.Y. & 41.86445 & -74.50440 & 850.9 \\
\hline 39 & D2_15 & Rondout Creek at Lowes Corners, N.Y. & 41.86414 & -74.50410 & 851.9 \\
\hline 40 & D3_18 & East Branch Delaware River at Roxbury, N.Y. & 42.28433 & -74.56630 & $1,476.5$ \\
\hline
\end{tabular}


Table 14. High-water marks collected by the Federal Emergency Management Agency at 72 selected sites in the Delaware and lower Hudson River Basins in New York for the flood of August 28-29, 2011.-Continued

[Latitude, longitude, and elevation are from the Federal Emergency Management Agency (FEMA, 2011e); HWM ID, high-water-mark identification; latitude and longitude in decimal degrees, North American Datum of 1983 (NAD 83); elevation in feet above North American Vertical Datum of 1988 (NAVD 88 ); locations are shown on figure $41 \mathrm{~A}]$

\begin{tabular}{|c|c|c|c|c|c|}
\hline Site number & FEMA HWM ID & Site name & Latitude & Longitude & Elevation \\
\hline 41 & D3_17 & East Branch Delaware River at Roxbury, N.Y. & 42.28418 & -74.56635 & $1,475.6$ \\
\hline 42 & D3_16 & East Branch Delaware River at Roxbury, N.Y. & 42.28406 & -74.56647 & $1,475.4$ \\
\hline 43 & D2_7 & East Branch Delaware River upstream of Margaretville, N.Y. & 42.16095 & -74.62281 & $1,342.9$ \\
\hline 44 & D2_5 & Dry Brook upstream of Arkville, N.Y. & 42.12422 & -74.57103 & $1,538.2$ \\
\hline 45 & D2_6 & Dry Brook upstream of Arkville, N.Y. & 42.13049 & -74.57738 & $1,500.3$ \\
\hline 46 & D2_4 & Dry Brook upstream of Arkville, N.Y. & 42.14119 & -74.60493 & $1,399.0$ \\
\hline 47 & D2_9 & Bush Kill at Fleischmanns, N.Y. & 42.15495 & -74.52707 & $1,515.9$ \\
\hline 48 & D2_8 & Bush Kill at Fleischmanns, N.Y. & 42.15500 & -74.54066 & $1,485.5$ \\
\hline 49 & D2_3 & East Branch Delaware River at Margaretville, N.Y. & 42.14925 & -74.64571 & $1,324.6$ \\
\hline 50 & D2_2 & East Branch Delaware River at Margaretville, N.Y. & 42.14812 & -74.64552 & $1,327.1$ \\
\hline 51 & D3_10 & East Branch Delaware River at Margaretville, N.Y. & 42.14278 & -74.65203 & $1,317.1$ \\
\hline 52 & D2_1 & Tremper Kill downstream of Andes, N.Y. & 42.14412 & -74.80129 & $1,371.0$ \\
\hline 53 & D3_7 & West Branch Delaware River at Delhi, N.Y. & 42.28157 & -74.90637 & $1,364.0$ \\
\hline 54 & D3_8 & West Branch Delaware River at Delhi, N.Y. & 42.28134 & -74.90666 & $1,363.6$ \\
\hline 55 & D3_9 & West Branch Delaware River at Delhi, N.Y. & 42.28122 & -74.90667 & $1,363.6$ \\
\hline 56 & D3_11 & West Branch Delaware River at Delhi, N.Y. & 42.27879 & -74.91233 & $1,361.3$ \\
\hline 57 & D3_6 & West Branch Delaware River downstream of Delhi, N.Y. & 42.26674 & -74.92113 & $1,348.7$ \\
\hline 58 & D3_3 & West Branch Delaware River at Hamden, N.Y. & 42.19558 & -74.98873 & $1,271.5$ \\
\hline 59 & D3_4 & West Branch Delaware River at Hawleys, N.Y. & 42.17505 & -75.01785 & $1,256.5$ \\
\hline 60 & D3_5 & West Branch Delaware River at Hawleys, N.Y. & 42.17499 & -75.01787 & $1,255.3$ \\
\hline 61 & D3_1 & West Branch Delaware River at Walton, N.Y. & 42.16830 & -75.13471 & $1,205.3$ \\
\hline 62 & D3_2 & West Branch Delaware River at Walton, N.Y. & 42.16822 & -75.13478 & $1,204.7$ \\
\hline 63 & D2_22 & East Branch Neversink River downstream of Ladleton, N.Y. & 41.93744 & -74.52519 & $1,801.4$ \\
\hline 64 & D2_21 & East Branch Neversink River downstream of Ladleton, N.Y. & 41.93544 & -74.52876 & $1,797.6$ \\
\hline 65 & D2_20 & East Branch Neversink River upstream of Claryville, N.Y. & 41.92522 & -74.55094 & $1,703.5$ \\
\hline 66 & D2_25 & West Branch Neversink River upstream of Claryville, N.Y. & 41.96126 & -74.54168 & $1,830.9$ \\
\hline 67 & D2_24 & West Branch Neversink River upstream of Claryville, N.Y. & 41.95846 & -74.54369 & $1,822.2$ \\
\hline 68 & D2_23 & West Branch Neversink River upstream of Claryville, N.Y. & 41.94216 & -74.57444 & $1,708.4$ \\
\hline 69 & D2_19 & Neversink River downstream of Claryville, N.Y. & 41.90172 & -74.58047 & $1,576.2$ \\
\hline 70 & D2_18 & Neversink River downstream of Claryville, N.Y. & 41.89317 & -74.58569 & $1,546.5$ \\
\hline 71 & D2_17 & Neversink River downstream of Claryville, N.Y. & 41.89235 & -74.58870 & $1,541.7$ \\
\hline 72 & D2_16 & Neversink River downstream of Claryville, N.Y. & 41.89204 & -74.58882 & $1,543.4$ \\
\hline
\end{tabular}




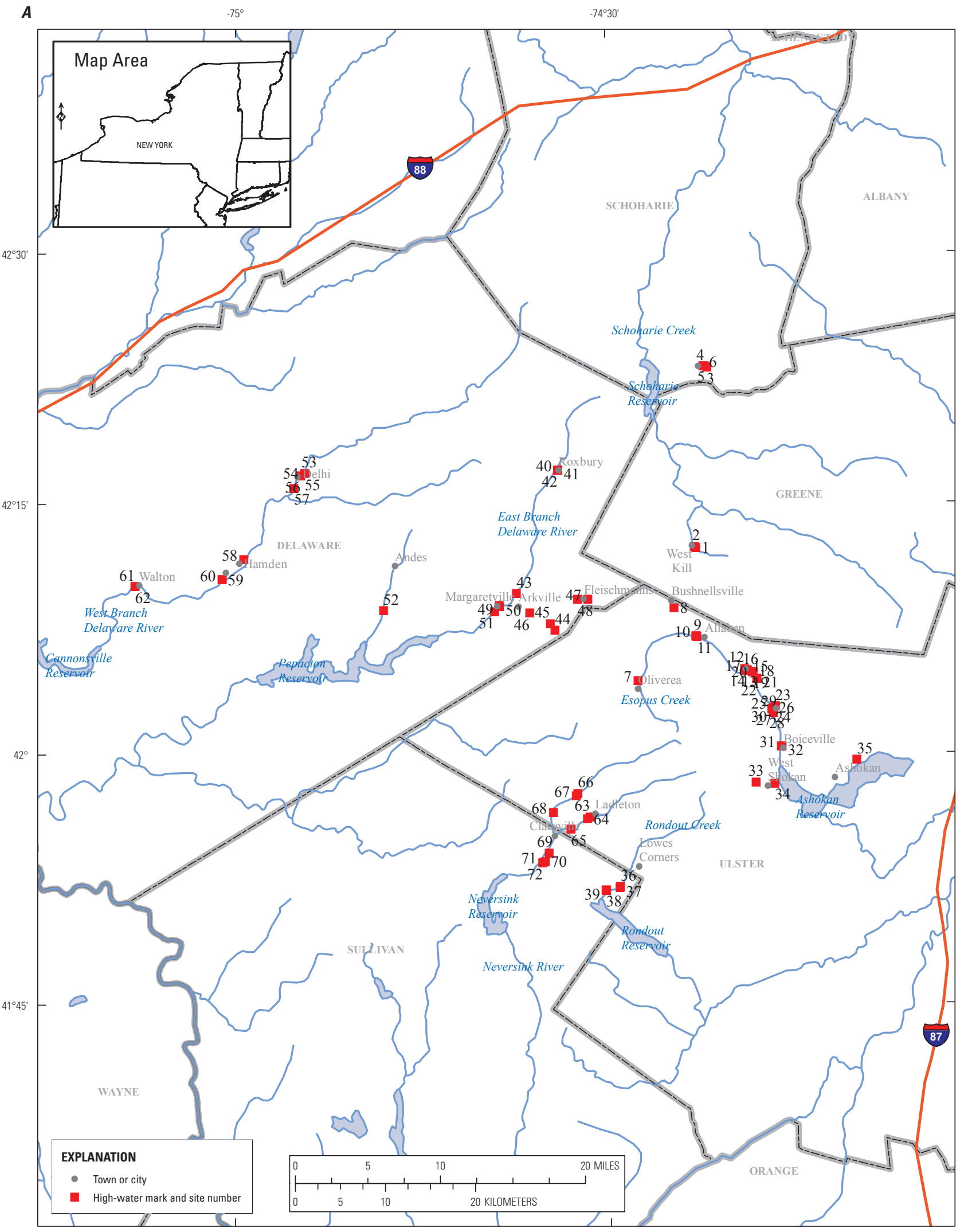

Base from U.S. Geological Survey Digital Data. Universal Transverse Mercator Projection, Zone 18N, NAD83

Figure 41. The locations of high-water marks collected $A$, by Federal Emergency Management Agency at 72 selected sites in the Delaware and lower Hudson River Basins and $B$, by the New York State Canal Corporation at 13 sites along the main-stem Mohawk River for the flood of August 28-29, 2011. 


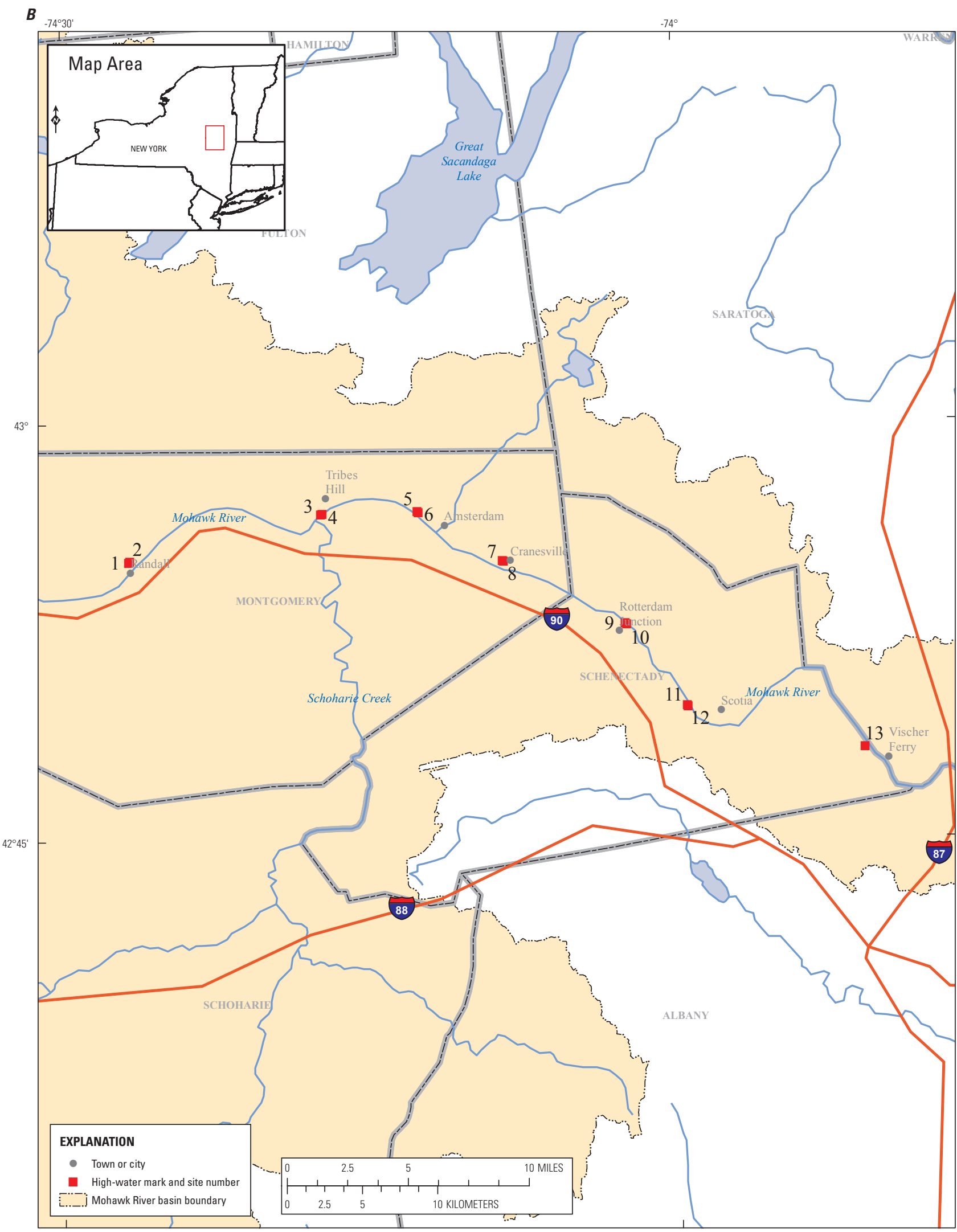

Base from U.S. Geological Survey Digital Data. Universal Transverse Mercator Projection, Zone 18N, NAD83

Figure 41. The locations of high-water marks collected $A$, by Federal Emergency Management Agency at 72 selected sites in the Delaware and lower Hudson River Basins and $B$, by the New York State Canal Corporation at 13 sites along the main-stem Mohawk River for the flood of August 28-29, 2011.-Continued 
Table 15. High-water marks collected along the Mohawk River in New York by the New York State Canal Corporation at 13 selected sites for the flood of August 28-29, 2011, and by the U.S. Geological Survey at 8 selected sites for the flood of June 26-29, 2006.

[High-water-mark elevations are from the New York State Canal Corporation (NYSCC, written commun., 2012); latitude and longitude in decimal degrees, North American Datum of 1983 (NAD 83); elevation in feet above North American Vertical Datum of 1988 (NAVD 88); elevation data for flood of June 26-29, 2006, from Suro and others, 2009; --, no data available; locations are shown on figure 41B]

\begin{tabular}{|c|c|c|c|c|c|}
\hline $\begin{array}{c}\text { Site } \\
\text { num- } \\
\text { ber }\end{array}$ & Site name & Latitude & Longitude & $\begin{array}{c}\text { August } \\
28-29, \\
2011 \\
\text { elevation }\end{array}$ & $\begin{array}{c}\text { June } \\
26-29, \\
2006 \\
\text { elevation }\end{array}$ \\
\hline 1 & Mohawk River at Erie Canal Lock 13 (upstream cabin) at Randall, N.Y. & 42.91738 & -74.44602 & 292.10 & -- \\
\hline 2 & Mohawk River at Erie Canal Lock 13 (downstream cabin) at Randall, N.Y. & 42.91791 & -74.44501 & 290.85 & -- \\
\hline 3 & Mohawk River at Erie Canal Lock 12 (upstream cabin) at Tribes Hill, N.Y. & 42.94548 & -74.28921 & 288.60 & 287.20 \\
\hline 4 & Mohawk River at Erie Canal Lock 12 (downstream cabin) at Tribes Hill, N.Y. & 42.94588 & -74.28806 & 285.27 & a279.20 \\
\hline 5 & Mohawk River at Erie Canal Lock 11 (upstream cabin) at Amsterdam, N.Y. & 42.94703 & -74.21051 & 280.44 & 273.03 \\
\hline 6 & Mohawk River at Erie Canal Lock 11 (downstream cabin) at Amsterdam, N.Y. & 42.94642 & -74.20962 & 276.44 & 272.68 \\
\hline 7 & Mohawk River at Erie Canal Lock 10 (upstream cabin) at Cranesville, N.Y. & 42.91720 & -74.14145 & 270.20 & 263.42 \\
\hline 8 & Mohawk River at Erie Canal Lock 10 (downstream cabin) at Cranesville, N.Y. & 42.91680 & -74.14030 & 264.54 & 262.91 \\
\hline 9 & Mohawk River at Erie Canal Lock 9 (upstream cabin) at Rotterdam Junction, N.Y. & 42.87905 & -74.04162 & 253.86 & 248.82 \\
\hline 10 & Mohawk River at Erie Canal Lock 9 (downstream cabin) at Rotterdam Junction, N.Y. & 42.87848 & -74.04062 & 250.86 & 247.12 \\
\hline 11 & Mohawk River at Erie Canal Lock 8 (upstream cabin) at Scotia, N.Y. & 42.82966 & -73.99186 & 236.64 & -- \\
\hline 12 & Mohawk River at Erie Canal Lock 8 (downstream cabin) at Scotia, N.Y. & 42.82890 & -73.99114 & 232.47 & -- \\
\hline 13 & Mohawk River at Erie Canal Lock 7 (upstream staff gage) at Vischer Ferry, N.Y. & 42.80365 & -73.84758 & 216.83 & -- \\
\hline
\end{tabular}

${ }^{a}$ Downstream 180 feet and landward 180 feet from downstream cabin.

The USGS New York Water Science Center operates two gages on Lake Champlain, one at the south end of the lake just north of Whitehall (04279085) and the other at the north end near the outlet of the lake at Rouses Point (04295000). The drainage areas at the two gages are 725 and $8,277 \mathrm{mi}^{2}$, respectively. The maximum lake level $(97.89 \mathrm{ft})$ at Rouses Point on September 3 was nearly $1 \mathrm{ft}$ lower than the maximum at Whitehall on August 29. The USGS also operates a gage on Lake Champlain at Burlington, Vermont (04294500); lake elevations at the three gages during August 20 to September 5 were substantially different (fig. 45A). Wind speed and direction during August 27-30, combined with substantial inflows to the lake, caused the large differences between lake levels at the ends of the lake (figs. 45A-B). On August 28, the lake level at the north end (Rouses Point) was lowered by nearly $1 \mathrm{ft}$ as a result of the strong north winds. At nearly the same time, the level at the south end of the lake rose about $3 \mathrm{ft}$ in a few hours as the water was pushed southward into the narrow lake channel near Whitehall. A second rise on August 29 (as winds shifted to the west) reflects major inflows from Mettawee and Poultney Rivers, which enter from the east side of the lake at a point where the lake is narrow. These rivers produced record or near-record floods on August 28-29. Winds and seiche also caused variable lake levels during other specific times at each of the three lake gages (fig. 45A).

\section{Flood Damage}

Hurricane Irene, which became Tropical Storm Irene when it made landfall in the Northeast, caused widespread destruction and 56 deaths along its path from the Caribbean Sea northward to New England during August 21-30, 2011. Damages throughout the United States from Irene are estimated to be nearly $\$ 16$ billion, making it the seventh costliest storm in the United States (Avila and Cangialosi, 2011).

Hurricane Irene entered New York State on August 28 as a tropical storm and traveled up the eastern corridor of the State, leaving a path of destruction and damage never before seen in many parts of New York. Thirty-one counties in New York were declared disaster areas (fig. 46) on August 31, 2011, with damages and subsequent distribution of Federal disaster assistance of nearly $\$ 600$ million (as of February 24, 2014); 10 deaths were reported (Federal Emergency Management Agency, 2011a). More than 33,000 citizens in New York registered for individual Federal assistance, and 74 Disaster Resource Centers were created during the recovery period (New York State, 2012). More than one million people in New York were left without power during and after the storm. 
Table 16. Peak storm-tide data for Hurricane Irene at U.S. Geological Survey tide gages and at selected coastal sites in New York for August 28, 2011.

[Latitude and longitude in decimal degrees, NAD 83 (North American Datum of 1983); NAVD 88, North American Vertical Datum of 1988; GMT, Greenwich Mean Time; --, not applicable; data from McCallum and others, 2012; locations are shown on figure 42]

\begin{tabular}{|c|c|c|c|c|c|c|c|c|}
\hline $\begin{array}{c}\text { Site } \\
\text { num- } \\
\text { ber }\end{array}$ & $\begin{array}{c}\text { Internal site } \\
\text { identification number }\end{array}$ & County & Latitude & Longitude & Site type & $\begin{array}{l}\text { Type } \\
\text { of data } \\
\text { recorded }\end{array}$ & $\begin{array}{c}\text { Peak } \\
\text { storm-tide } \\
\text { elevation } \\
\text { (feet above } \\
\text { NAVD 88) }\end{array}$ & $\begin{array}{l}\text { Peak storm-tide } \\
\text { date and time } \\
\text { (GMT) }\end{array}$ \\
\hline \multicolumn{9}{|c|}{ Peak storm-tide data at U.S. Geological Survey permanent monitoring sites } \\
\hline 1 & 01302050 & Queens & 40.75583 & -73.74639 & Real-time streamgage & Riverine & 9.46 & $8 / 28 / 2011$ 13:15:00 \\
\hline 2 & 01302250 & Nassau & 40.86622 & -73.71020 & Real-time-tide gage & Storm tide & 9.48 & 8/28/2011 13:30:00 \\
\hline 3 & 01302600 & Nassau & 40.88856 & -73.63800 & Real-time-tide gage & Storm tide & 9.30 & 8/28/2011 13:30:00 \\
\hline 4 & 01302845 & Nassau & 40.90511 & -73.59319 & Real-time-tide gage & Storm tide & 9.13 & $8 / 28 / 2011$ 14:24:00 \\
\hline 5 & 01303500 & Nassau & 40.85722 & -73.46389 & Real-time streamgage & Riverine & 9.14 & $8 / 28 / 2011$ 13:45:00 \\
\hline 6 & 01304057 & Suffolk & 40.96286 & -73.14317 & Real-time-tide gage & Storm tide & 8.88 & 8/28/2011 14:06:00 \\
\hline 7 & 01304705 & Suffolk & 40.93333 & -72.22500 & Real-time streamgage & Riverine & 7.67 & $8 / 28 / 2011$ 14:45:00 \\
\hline 8 & 01309225 & Suffolk & 40.66927 & -73.35567 & Real-time-tide gage & Storm tide & 5.27 & 8/28/2011 12:30:00 \\
\hline 9 & 01310521 & Nassau & 40.62760 & -73.57541 & Real-time-tide gage & Storm tide & 7.35 & $8 / 28 / 2011$ 11:36:00 \\
\hline 10 & 01310740 & Nassau & 40.59344 & -73.58374 & Real-time-tide gage & Storm tide & 7.07 & 8/28/2011 11:18:00 \\
\hline 11 & 01311143 & Nassau & 40.60883 & -73.65611 & Real-time-tide gage & Storm tide & 7.75 & 8/28/2011 11:48:00 \\
\hline 12 & 01311145 & Nassau & 40.59316 & -73.73736 & Real-time-tide gage & Storm tide & 7.43 & 8/28/2011 11:18:00 \\
\hline 13 & 01311850 & Queens & 40.61733 & -73.75791 & Real-time-tide gage & Storm tide & 7.52 & $8 / 28 / 2011$ 12:24:00 \\
\hline 14 & 01311875 & Queens & 40.57372 & -73.88514 & Real-time-tide gage & Storm tide & 7.58 & 8/28/2011 11:30:00 \\
\hline 15 & 01374019 & Putnam & 41.38620 & -73.95514 & Real-time streamgage & Riverine & 7.65 & $8 / 28 / 2011$ 14:45:00 \\
\hline 16 & 01376269 & Rockland & 41.04319 & -73.89606 & Real-time streamgage & Riverine & 7.56 & 8/28/2011 13:30:00 \\
\hline \multicolumn{9}{|c|}{ Poststorm high-water marks obtained by the U. S. Geological Survey } \\
\hline 17 & HWM-NY-KIN-001 & Kings & 40.58026 & -74.01005 & -- & -- & 9.50 & $8 / 28 / 2011$ \\
\hline 18 & HWM-NY-KIN-002 & Kings & 40.70473 & -73.98951 & -- & -- & 6.74 & $8 / 28 / 2011$ \\
\hline 19 & HWM-NY-NAS-001 & Nassau & 40.64742 & -73.46229 & -- & -- & 6.68 & $8 / 28 / 2011$ \\
\hline 20 & HWM-NY-NAS-002 & Nassau & 40.58396 & -73.63749 & -- & -- & 20.77 & $8 / 28 / 2011$ \\
\hline 21 & HWM-NY-NAS-003 & Nassau & 40.88760 & -73.56374 & -- & -- & 8.40 & $8 / 28 / 2011$ \\
\hline 22 & HWM-NY-QUE-001 & Queens & 40.76184 & -73.85864 & -- & -- & 8.23 & $8 / 28 / 2011$ \\
\hline 23 & HWM-NY-QUE-002 & Queens & 40.64572 & -73.83648 & -- & -- & 7.20 & $8 / 28 / 2011$ \\
\hline 24 & HWM-NY-RIC-001 & Richmond & 40.59436 & -74.06024 & -- & -- & 7.84 & $8 / 28 / 2011$ \\
\hline 25 & HWM-NY-RIC-002 & Richmond & 40.50200 & -74.23027 & -- & -- & 8.59 & $8 / 28 / 2011$ \\
\hline 26 & HWM-NY-SUF-001 & Suffolk & 41.01207 & -72.55773 & -- & -- & 6.92 & $8 / 28 / 2011$ \\
\hline 27 & HWM-NY-SUF-002 & Suffolk & 40.84913 & -72.50310 & -- & -- & 5.57 & $8 / 28 / 2011$ \\
\hline 28 & HWM-NY-SUF-003 & Suffolk & 40.99074 & -72.47138 & -- & -- & 5.12 & $8 / 28 / 2011$ \\
\hline 29 & HWM-NY-SUF-004 & Suffolk & 40.63473 & -73.20216 & -- & -- & 5.17 & $8 / 28 / 2011$ \\
\hline 30 & HWM-NY-SUF-005 & Suffolk & 40.75018 & -73.01311 & -- & -- & 4.33 & $8 / 28 / 2011$ \\
\hline
\end{tabular}


Table 16. Peak storm-tide data for Hurricane Irene at U.S. Geological Survey tide gages and at selected coastal sites in New York for August 28, 2011.-Continued

[Latitude and longitude in decimal degrees, NAD 83 (North American Datum of 1983); NAVD 88, North American Vertical Datum of 1988; GMT, Greenwich Mean Time; --, not applicable; data from McCallum and others, 2012; locations are shown on figure 42]

\begin{tabular}{|c|c|c|c|c|c|c|c|c|}
\hline $\begin{array}{l}\text { Site } \\
\text { num- } \\
\text { ber }\end{array}$ & $\begin{array}{c}\text { Internal site } \\
\text { identification number }\end{array}$ & County & Latitude & Longitude & Site type & $\begin{array}{l}\text { Type } \\
\text { of data } \\
\text { recorded }\end{array}$ & $\begin{array}{c}\text { Peak } \\
\text { storm-tide } \\
\text { elevation } \\
\text { (feet above } \\
\text { NAVD 88) }\end{array}$ & $\begin{array}{l}\text { Peak storm-tide } \\
\text { date and time } \\
\text { (GMT) }\end{array}$ \\
\hline \multicolumn{9}{|c|}{ Temporary continuous-record gages deployed by the U. S. Geological Survey } \\
\hline 31 & 403836073154801 & Suffolk & 40.64328 & -73.26334 & Real-time water level & Storm tide & 3.43 & $8 / 28 / 2011$ 13:30:00 \\
\hline 32 & SSS-NY-KIN-001WL & Kings & 40.58000 & -74.01161 & Water level & Storm tide & 8.10 & 8/28/2011 12:53:00 \\
\hline 33 & SSS-NY-KIN-002WL & Kings & 40.70458 & -73.98832 & Water level & Storm tide & 6.22 & 8/28/2011 13:19:00 \\
\hline 34 & SSS-NY-NAS-001WL & Nassau & 40.87791 & -73.53057 & Water level & Storm tide & 8.20 & $8 / 28 / 2011$ 14:54:30 \\
\hline 35 & SSS-NY-NAS-004WL & Nassau & 40.58275 & -73.64068 & Water level & Storm tide & 9.72 & 8/28/2011 11:13:00 \\
\hline 36 & SSS-NY-NAS-005WL & Nassau & 40.64733 & -73.46234 & Water level & Storm tide & 6.24 & 8/28/2011 13:13:00 \\
\hline 37 & SSS-NY-QUE-001WL & Queens & 40.76229 & -73.85828 & Water level & Storm tide & 8.03 & 8/28/2011 13:52:30 \\
\hline 38 & SSS-NY-QUE-002WL & Queens & 40.64533 & -73.83638 & Water level & Storm tide & 7.04 & $8 / 28 / 2011$ 13:16:30 \\
\hline 39 & SSS-NY-RIC-001WL & Richmond & 40.59388 & -74.05985 & Water level & Storm tide & 8.86 & $8 / 28 / 2011 \quad 12: 33: 30$ \\
\hline 40 & SSS-NY-RIC-003WL & Richmond & 40.50188 & -74.23034 & Water level & Storm tide & 8.36 & 8/28/2011 11:52:30 \\
\hline 41 & SSS-NY-SUF-001WL & Suffolk & 41.01259 & -72.55828 & Water level & Storm tide & 6.94 & $8 / 28 / 2011$ 15:35:30 \\
\hline 42 & SSS-NY-SUF-002WL & Suffolk & 40.96438 & -72.86320 & Water level & Storm tide & 8.05 & $8 / 28 / 2011$ 15:35:00 \\
\hline 43 & SSS-NY-SUF-003WL & Suffolk & 40.94617 & -73.07227 & Water level & Storm tide & 7.54 & 8/28/2011 15:13:30 \\
\hline 44 & SSS-NY-SUF-004WL & Suffolk & 40.78712 & -72.75025 & Water level & Storm tide & 5.93 & $8 / 28 / 2011$ 13:33:30 \\
\hline 45 & SSS-NY-SUF-005WL & Suffolk & 40.91608 & -72.63774 & Water level & Storm tide & 4.10 & $8 / 28 / 2011$ 15:09:00 \\
\hline 46 & SSS-NY-SUF-006WL & Suffolk & 40.84887 & -72.50285 & Water level & Storm tide & 6.13 & 8/28/2011 11:57:00 \\
\hline 47 & SSS-NY-SUF-008WL & Suffolk & 40.89331 & -72.50300 & Water level & Storm tide & 3.94 & $8 / 28 / 2011$ 15:05:30 \\
\hline 48 & SSS-NY-SUF-009WL & Suffolk & 41.00197 & -72.29030 & Water level & Storm tide & 3.72 & $8 / 28 / 2011$ 13:37:30 \\
\hline 49 & SSS-NY-SUF-011WL & Suffolk & 40.90048 & -73.35304 & Water level & Storm tide & 8.09 & 8/28/2011 15:05:00 \\
\hline 50 & SSS-NY-SUF-014WL & Suffolk & 40.99070 & -72.47074 & Water level & Storm tide & 4.99 & $8 / 28 / 2011$ 15:59:00 \\
\hline 51 & SSS-NY-SUF-015WL & Suffolk & 41.10104 & -72.36144 & Water level & Storm tide & 4.41 & 8/28/2011 14:06:00 \\
\hline 52 & SSS-NY-SUF-017WL & Suffolk & 40.64316 & -73.15750 & Water level & Storm tide & 9.32 & $8 / 28 / 2011 \quad 10: 55: 30$ \\
\hline 53 & SSS-NY-SUF-018WL & Suffolk & 40.63473 & -73.20216 & Water level & Storm tide & 6.33 & 8/28/2011 11:40:30 \\
\hline 54 & SSS-NY-SUF-019WL & Suffolk & 40.65932 & -73.26486 & Water level & Storm tide & 3.16 & 8/28/2011 13:18:30 \\
\hline 55 & SSS-NY-SUF-021WL & Suffolk & 40.74918 & -73.01338 & Water level & Storm tide & 4.37 & $8 / 28 / 2011$ 15:15:00 \\
\hline 56 & SSS-NY-SUF-022WL & Suffolk & 40.68523 & -73.27990 & Water level & Storm tide & 4.52 & $8 / 28 / 2011 \quad 13: 35: 30$ \\
\hline \multicolumn{9}{|c|}{ National Oceanic and Atmospheric Administration tide gages } \\
\hline 57 & 8510560 & Suffolk & 41.04830 & -71.96000 & Real-time-tide gage & Storm tide & 4.08 & $8 / 28 / 2011$ 13:12:00 \\
\hline 58 & 8518750 & New York & 40.70060 & -74.01420 & Real-time-tide gage & Storm tide & 6.70 & $8 / 28 / 201112: 42: 00$ \\
\hline 59 & 8519483 & Richmond & 40.63670 & -74.14170 & Real-time-tide gage & Storm tide & 7.26 & 8/28/2011 12:42:00 \\
\hline
\end{tabular}




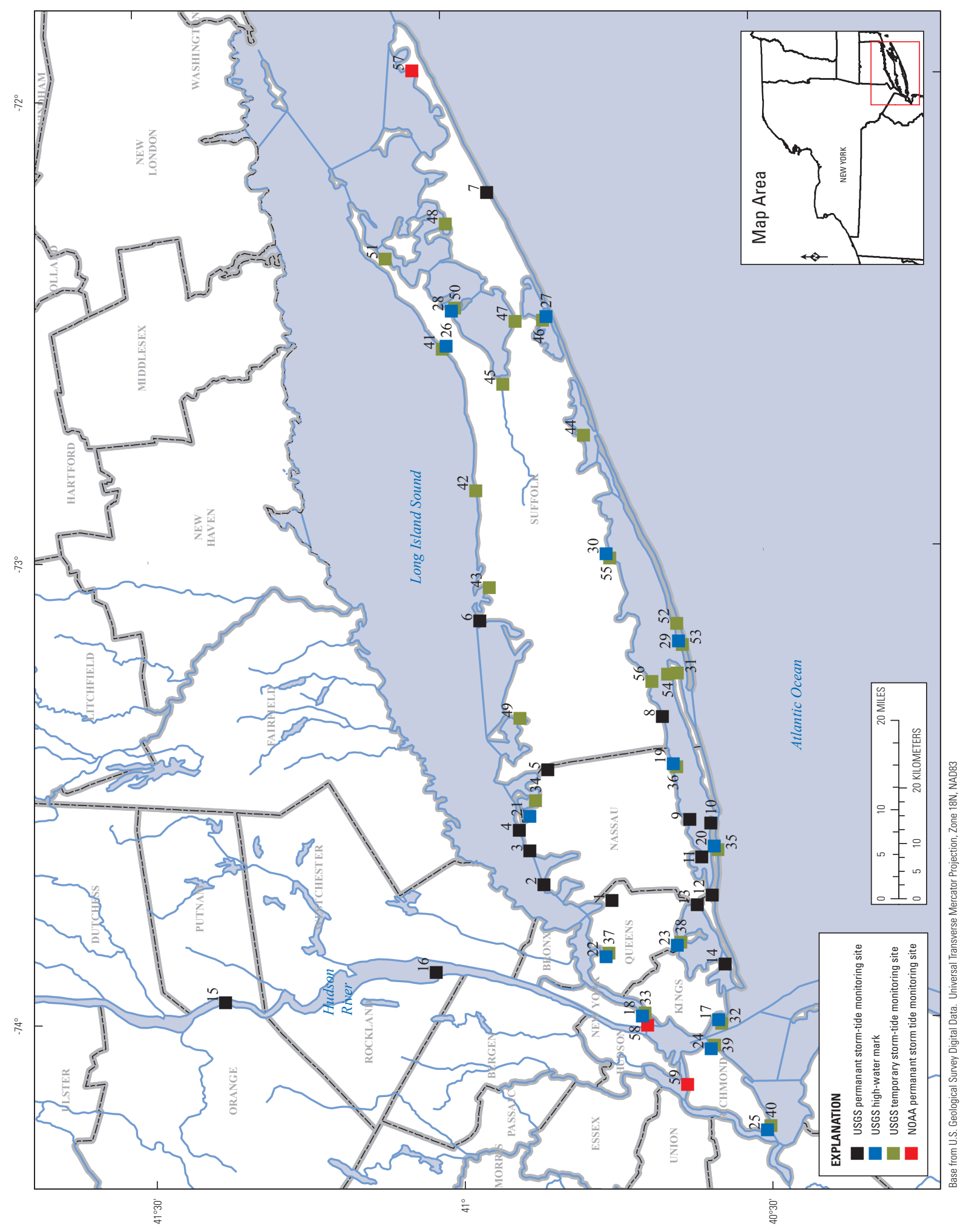

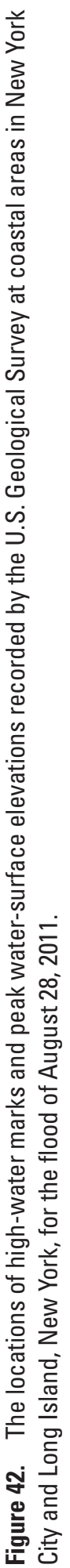


Table 17. High-water marks collected by the Federal Emergency Management Agency at 43 selected coastal sites in Richmond, Kings, Queens, Nassau, and Suffolk Counties, New York, for the flood of August 28-29, 2011.

[Latitude, longitude, and elevation are from the Federal Emergency Management Agency (FEMA, 2011d); HWM ID, high-water-mark identification; latitude and longitude in decimal degrees, North American Datum of 1983 (NAD 83); elevation in feet above North American Vertical Datum of 1988 (NAVD 88); locations are shown on figure 43]

\begin{tabular}{|c|c|c|c|c|c|}
\hline Site number & FEMA HWM ID & $\begin{array}{c}\text { County-borough (neighborhood/area) or } \\
\text { town (village/hamlet) }\end{array}$ & Latitude & Longitude & Elevation \\
\hline 1 & 005-CNY-01-003 & Richmond-Staten Island (Port Richmond), N.Y. & 40.63990 & -74.12555 & 6.7 \\
\hline 2 & 005-CNY-01-006 & Richmond-Staten Island (Arrochar), N.Y. & 40.59416 & -74.05983 & 6.2 \\
\hline 3 & 005-CNY-01-005 & Richmond-Staten Island (Arrochar), N.Y. & 40.59432 & -74.06004 & 8.9 \\
\hline 4 & 005-CNY-01-004 & Richmond-Staten Island (Arrochar), N.Y. & 40.59407 & -74.06039 & 9.0 \\
\hline 5 & 005-CNY-01-010 & Richmond-Staten Island (Midland Beach), N.Y. & 40.56647 & -74.09160 & 6.1 \\
\hline 6 & 005-CNY-01-008 & Richmond-Staten Island (Midland Beach), N.Y. & 40.56671 & -74.09190 & 10.3 \\
\hline 7 & 005-CNY-01-012 & Richmond-Staten Island (New Dorp Beach), N.Y. & 40.56046 & -74.10139 & 5.8 \\
\hline 8 & 005-CNY-01-011 & Richmond-Staten Island (New Dorp Beach), N.Y. & 40.56046 & -74.10139 & 5.6 \\
\hline 9 & 005-CNY-01-015 & Richmond-Staten Island (Oakwood), N.Y. & 40.55486 & -74.11153 & 4.1 \\
\hline 10 & 005-CNY-01-013 & Richmond-Staten Island (Oakwood), N.Y. & 40.54972 & -74.11204 & 12.0 \\
\hline 11 & 005-CNY-03-012 & Kings-Brooklyn (Dumbo), N.Y. & 40.70453 & -73.98950 & 8.0 \\
\hline 12 & 005-CNY-03-010 & Kings-Brooklyn (Red Hook), N.Y. & 40.67513 & -74.01783 & 6.8 \\
\hline 13 & 005-CNY-03-009 & Kings-Brooklyn (Fort Hamilton), N.Y. & 40.61060 & -74.03650 & 8.5 \\
\hline 14 & 005-CNY-03-007 & Kings-Brooklyn (Bath Beach), N.Y. & 40.59414 & -74.00169 & 9.6 \\
\hline 15 & 005-CNY-03-006 & Kings-Brooklyn (Sea Gate), N.Y. & 40.58175 & -74.00683 & 7.9 \\
\hline 16 & 005-CNY-03-005 & Kings-Brooklyn (Brighton Beach), N.Y. & 40.57428 & -73.96312 & 10.2 \\
\hline 17 & 005-CNY-03-003 & Kings-Brooklyn (Gerritsen Beach), N.Y. & 40.58705 & -73.91803 & 5.5 \\
\hline 18 & 005-CNY-03-004 & Kings-Brooklyn (Plumb Beach), N.Y. & 40.58515 & -73.91273 & 6.7 \\
\hline 19 & 005-CNY-02-002 & Kings-Brooklyn (Marine Park), N.Y. & 40.58736 & -73.89929 & 7.7 \\
\hline 20 & 005-CNY-02-003 & Kings-Brooklyn (Bergen Beach), N.Y. & 40.60536 & -73.89844 & 5.3 \\
\hline 21 & 005-CNY-02-004 & Kings-Brooklyn (Canarsie), N.Y. & 40.62894 & -73.88639 & 6.1 \\
\hline 22 & 005-CNY-02-001 & Kings-Brooklyn (Floyd Bennet Field), N.Y. & 40.60469 & -73.88345 & 6.0 \\
\hline 23 & $005-\mathrm{CNY}-02-010$ & Queens-Queens (Breezy Point), N.Y. & 40.56153 & -73.92385 & 7.9 \\
\hline 24 & 005-CNY-02-012 & Queens-Queens (Roxbury), N.Y. & 40.56744 & -73.89128 & 6.8 \\
\hline 25 & 005-CNY-02-011 & Queens-Queens (Roxbury), N.Y. & 40.56212 & -73.88091 & 10.6 \\
\hline 26 & 005-CNY-02-006 & Queens-Queens (Broad Channel), N.Y. & 40.60524 & -73.82235 & 6.0 \\
\hline 27 & 005-CNY-02-014 & Queens-Queens (Hammels), N.Y. & 40.59233 & -73.81091 & 7.7 \\
\hline 28 & 005-CNY-02-015 & Queens-Queens (Arverne), N.Y. & 40.59914 & -73.79866 & 6.5 \\
\hline 29 & 005-CNY-02-017 & Queens-Queens (Bayswater), N.Y. & 40.61252 & -73.77358 & 6.3 \\
\hline 30 & 005-CNY-02-016 & Queens-Queens (Edgemere), N.Y. & 40.59154 & -73.77270 & 10.4 \\
\hline 31 & 005-CNY-02-020 & Queens-Queens (Far Rockaway), N.Y. & 40.59514 & -73.74402 & 6.9 \\
\hline 32 & 005-CNY-02-018 & Nassau-Hempstead (Inwood), N.Y. & 40.62159 & -73.75647 & 6.8 \\
\hline 33 & 005-CNY-02-025 & Nassau-Hempstead (Atlantic Beach), N.Y. & 40.58571 & -73.75410 & 11.1 \\
\hline 34 & 005-CNY-02-019 & Nassau-Hempstead (Woodmere), N.Y. & 40.63697 & -73.74214 & 6.7 \\
\hline 35 & 005-CNY-02-021 & Nassau-Hempstead (Lawrence), N.Y. & 40.61256 & -73.70908 & 6.7 \\
\hline 36 & 005-CNY-02-022 & Nassau-Hempstead (Hewlett Harbor), N.Y. & 40.63056 & -73.67668 & 6.3 \\
\hline 37 & 005-CNY-02-023 & Nassau-Hempstead (Oceanside), N.Y. & 40.62342 & -73.66040 & 7.4 \\
\hline 38 & 005-CNY-02-027 & Nassau-Hempstead (Island Park), N.Y. & 40.61242 & -73.65222 & 6.5 \\
\hline 39 & $005-\mathrm{CNY}-02-028$ & Nassau-Hempstead (Lido Beach), N.Y. & 40.58586 & -73.62305 & 14.1 \\
\hline 40 & 005-CNY-02-024 & Nassau-Hempstead (Baldwin Harbor), N.Y. & 40.62312 & -73.59589 & 6.8 \\
\hline 41 & 005-CNY-02-029 & Nassau-Hempstead (Jones Island), N.Y. & 40.60912 & -73.55185 & 6.0 \\
\hline 42 & $005-\mathrm{CNY}-02-030$ & Suffolk-Babylon (West Gilgo Beach), N.Y. & 40.61299 & -73.41391 & 10.9 \\
\hline 43 & 005-CNY-02-031 & Suffolk-Babylon (Oak Beach), N.Y. & 40.63820 & -73.29280 & 5.5 \\
\hline
\end{tabular}




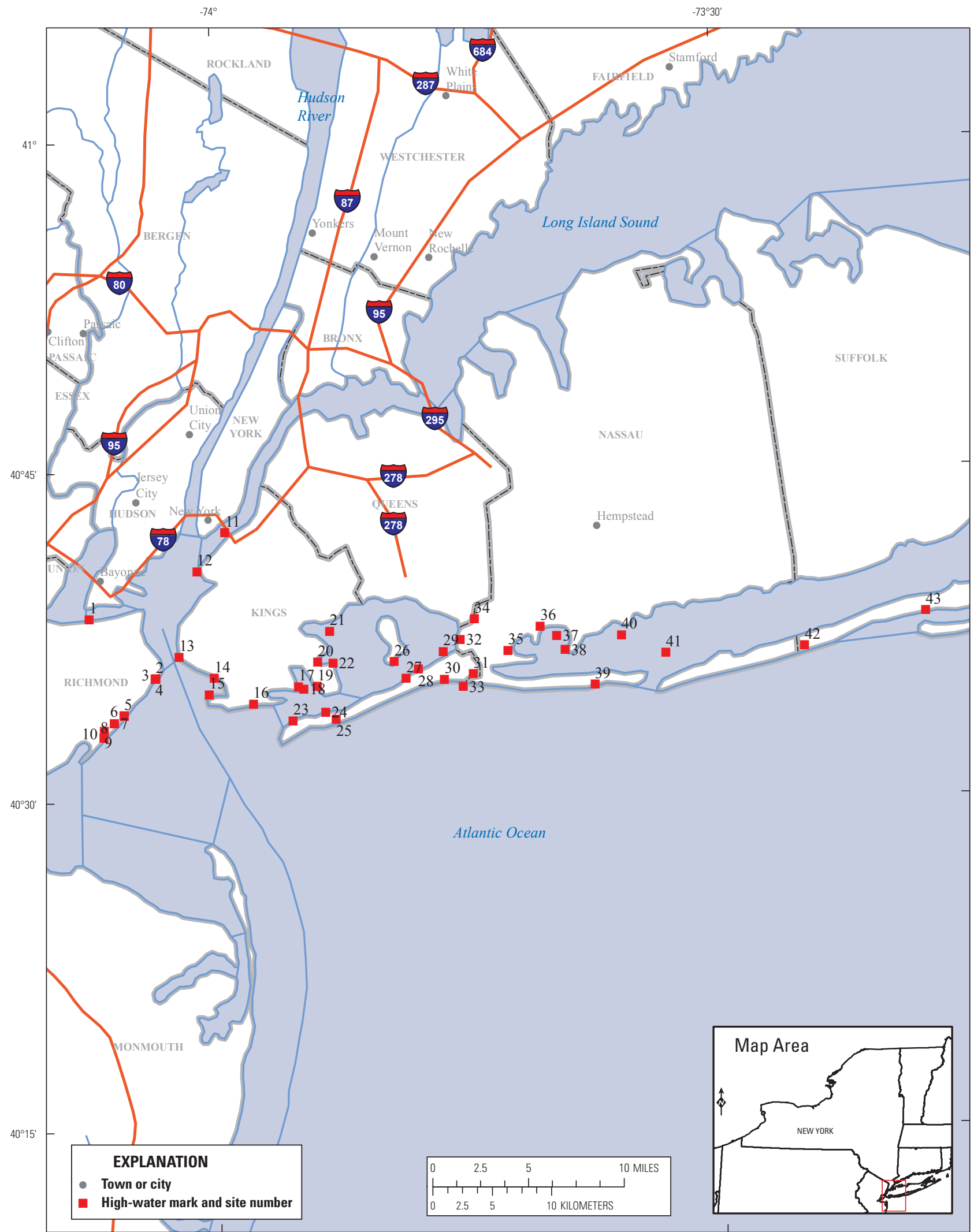

Base from U.S. Geological Survey Digital Data. Universal Transverse Mercator Projection, Zone 18N, NAD83

Figure 43. The locations of 43 high-water marks in selected coastal areas in New York City and on Long Island, New York, for the flood of August 28, 2011. 


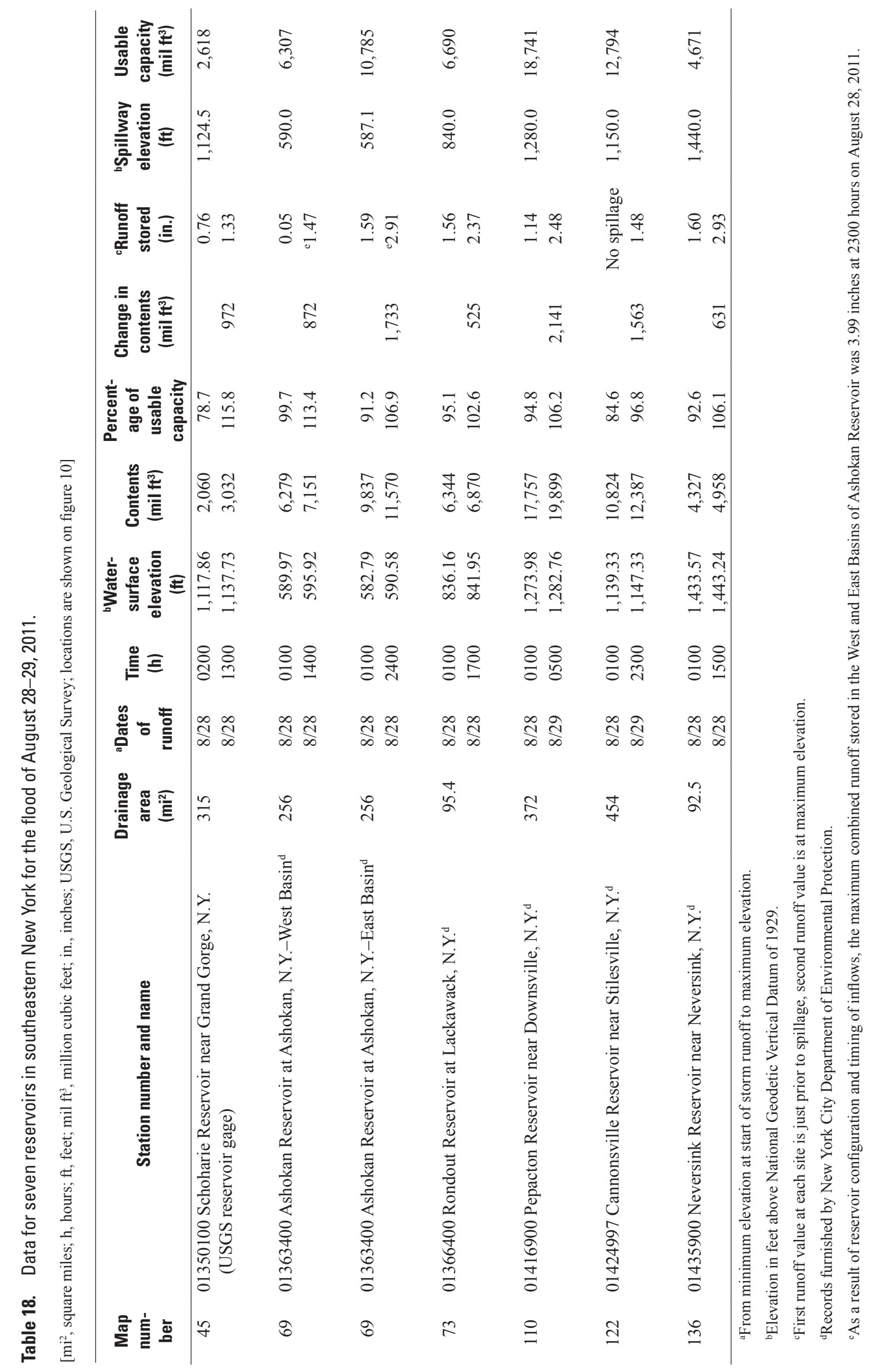



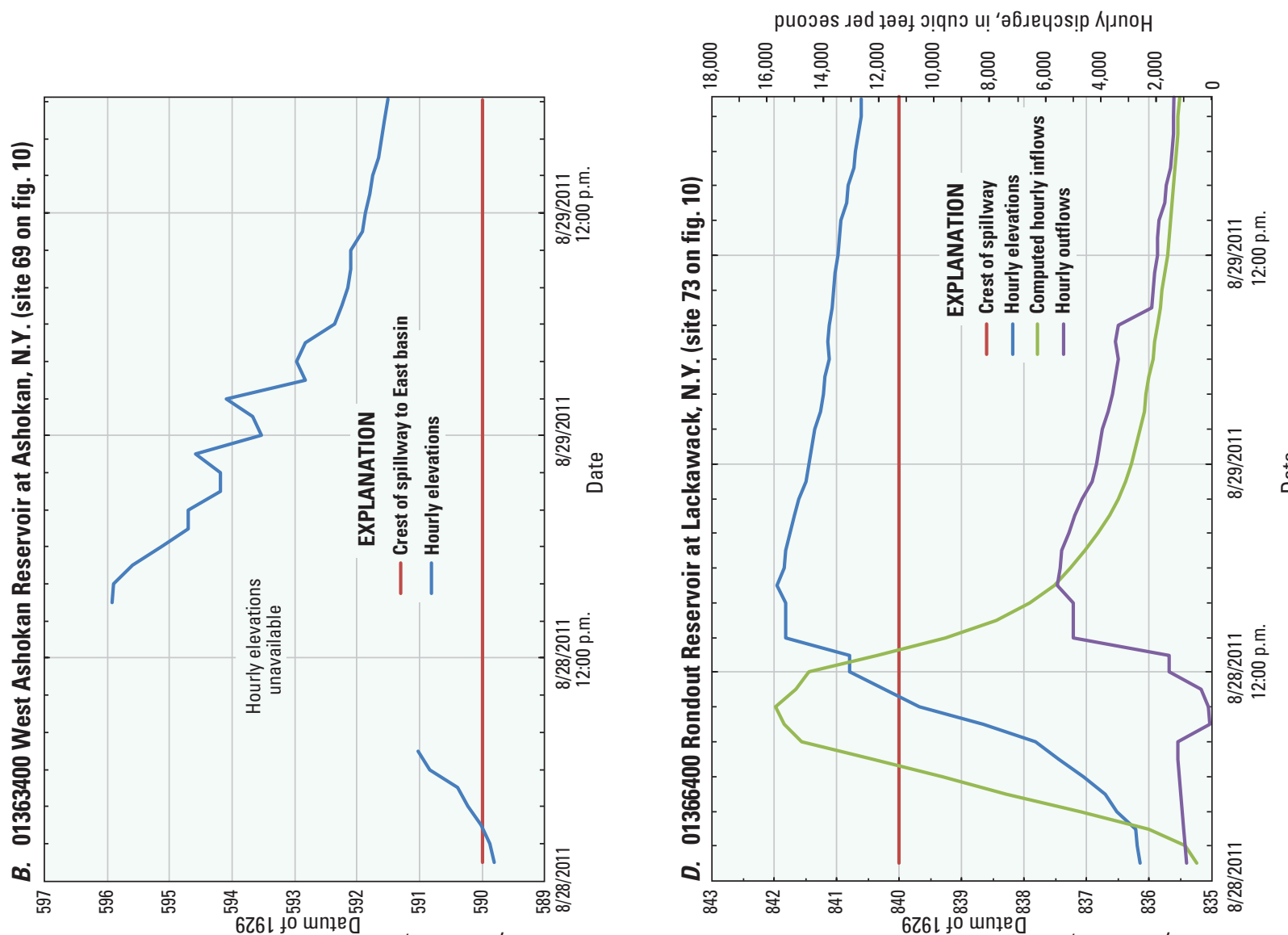

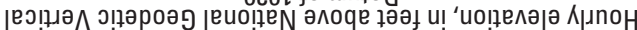

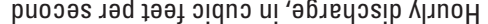

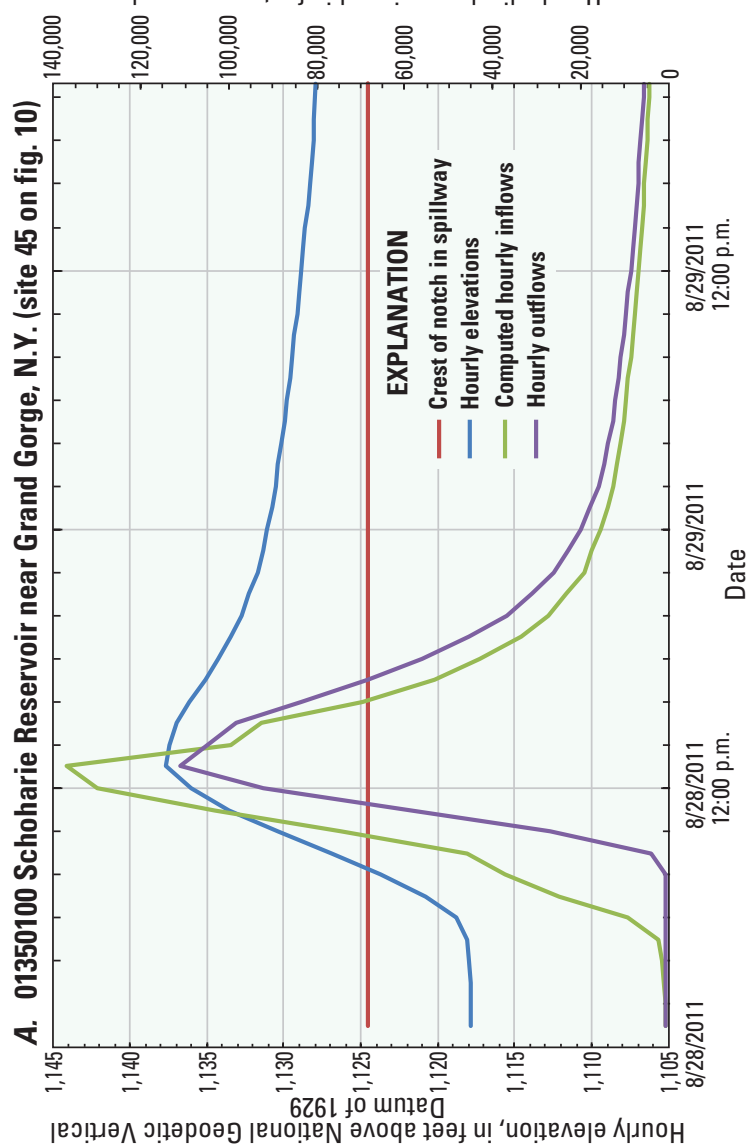

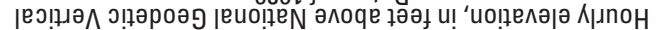

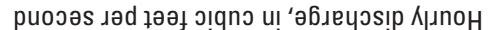

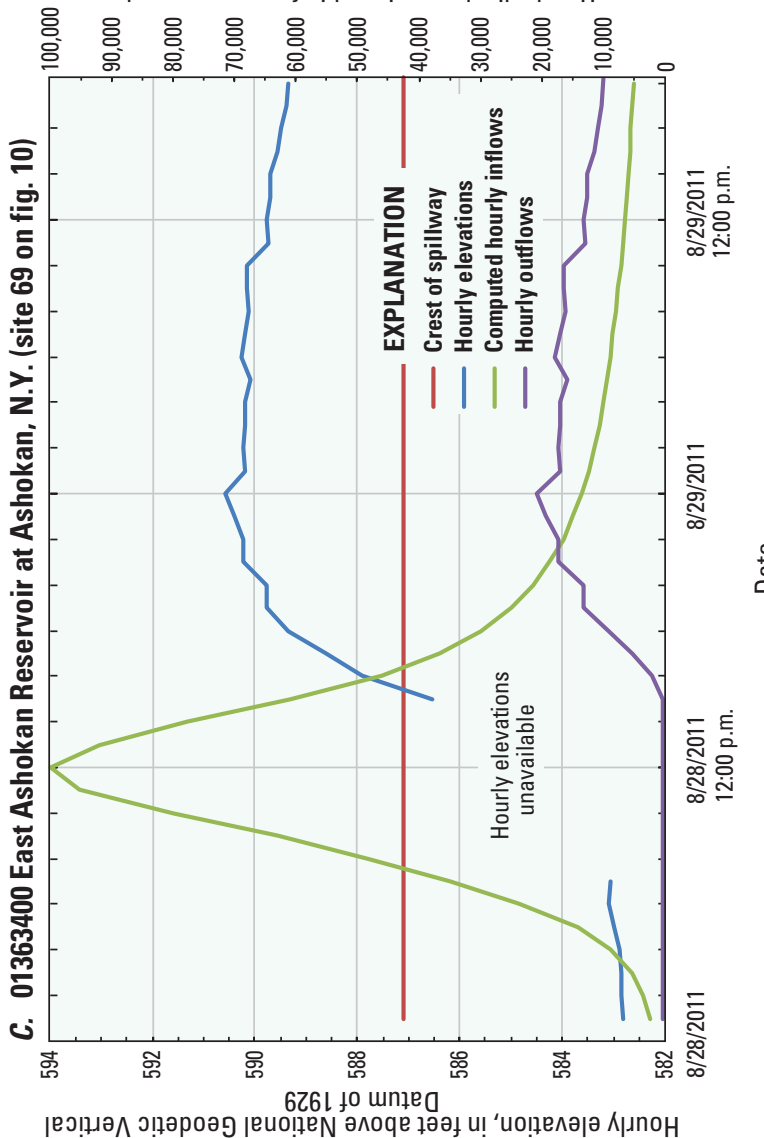



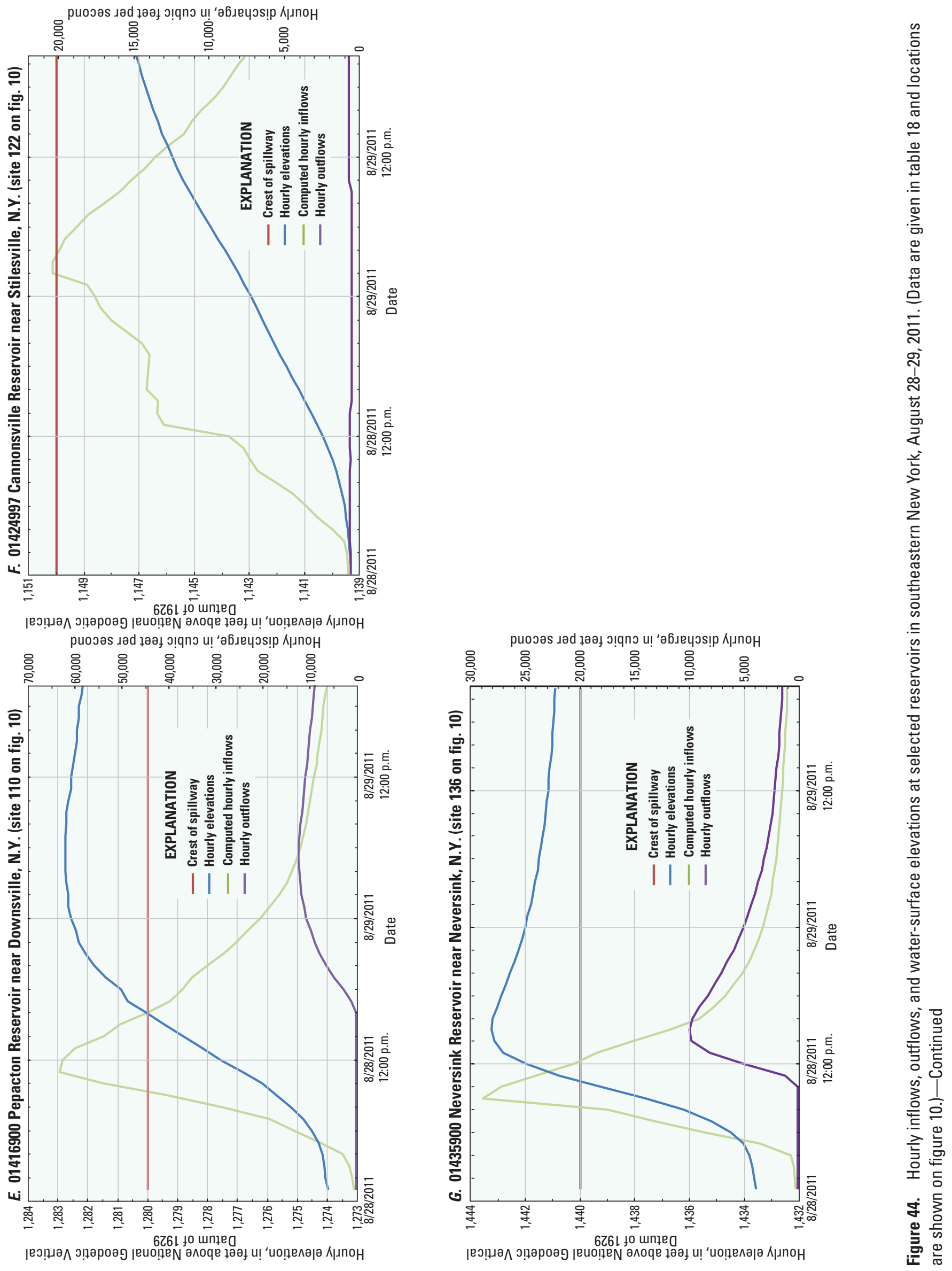

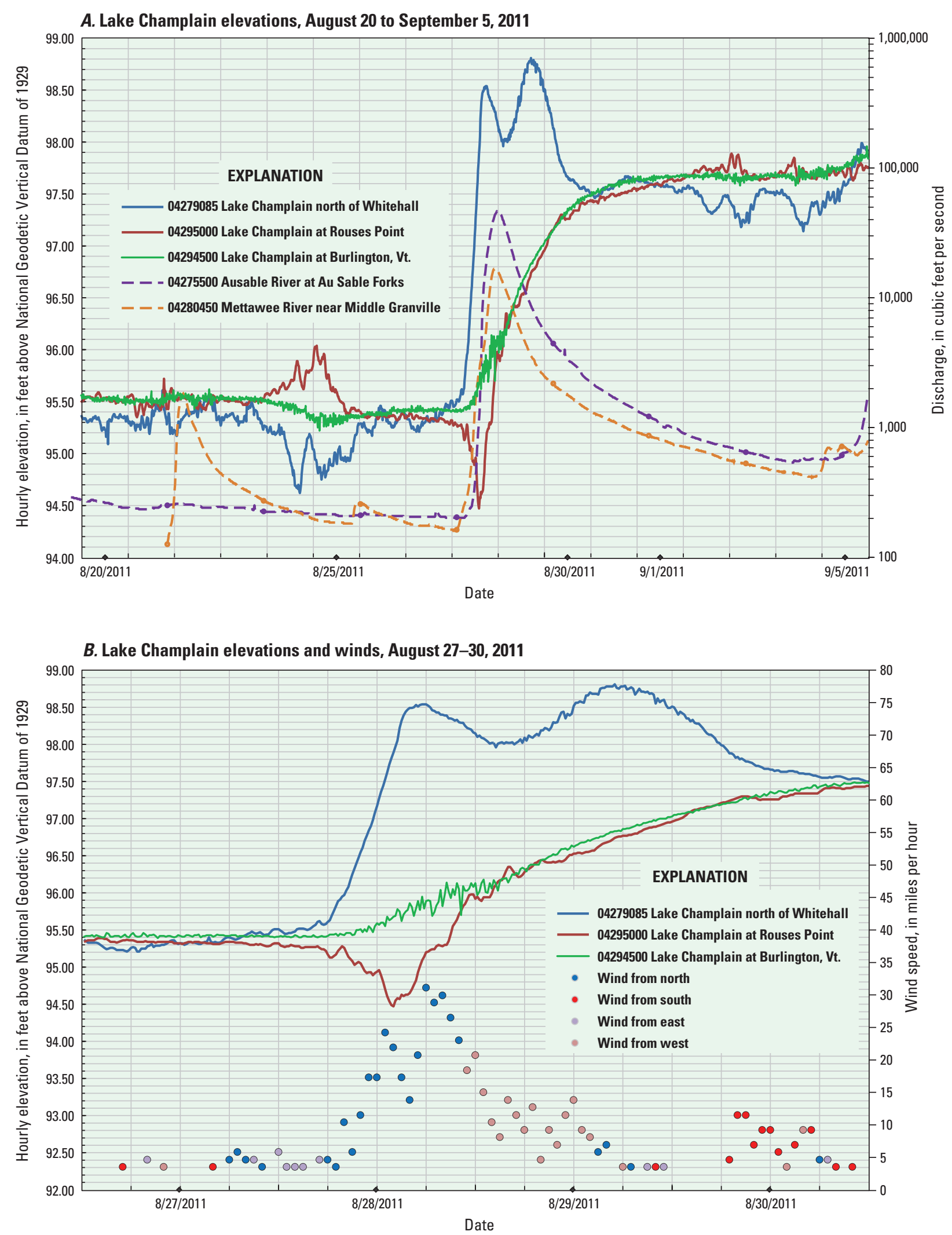

Figure 45. Water-surface elevations at three lake gages on Lake Champlain and $A$, inflows from two tributaries, and $B$, wind direction and speed, for late August to early September 2011. (All gages are in New York unless otherwise specified; locations are shown on figure 10) 

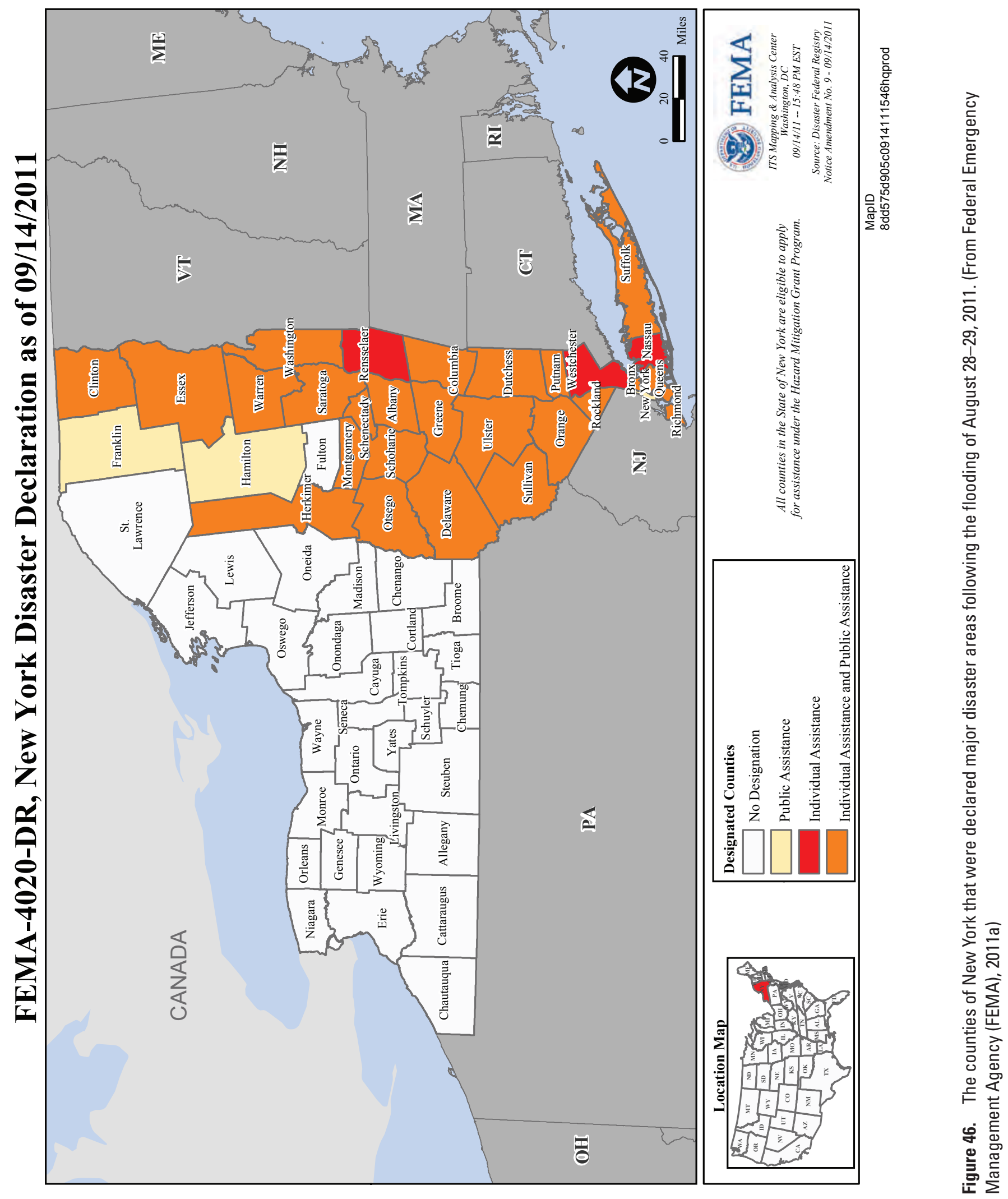
Communities along Schoharie Creek were particularly hard hit. Local officials estimated that about one-third of homes and businesses in the village of Schoharie were destroyed as a result of the flooding. Similar destruction occurred within other villages (Prattsville, Middleburg, Esperance, and many others) along the creek. Other streams in parts of the Catskill Mountains area, southeastern New York, the eastern Adirondack Mountains, and areas west of Lake Champlain also incurred major damage. Many farms sustained damage during the flood, and New York received a Federal relief fund to help farmers cope with the destruction. The State's transportation-system infrastructure also sustained major damage, totaling \$297 million (New York State, 2012). The New York State Department of Transportation (NYSDOT) reopened more than 80 percent of closed roads and bridges within 10 days of the storm and received the Award of Merit from the American Council of Engineering Companies of New York for its response to Tropical Storm Irene. Several other restoration and flood-mitigation programs were initiated following the most destructive and costly disaster in New York to date (New York State, 2012).

\section{Storm and Floods of September 7-11, 2011 (Tropical Storm Lee)}

Tropical Storm Lee was the 12th named storm of the 2011 Atlantic hurricane season. Lee made landfall near the mouth of the Mississippi River on September 2 and slowly traveled north-northeast along the western Appalachian Mountains, where its remnants entered New York near Binghamton in the south-central part of the State on September 7. The remnants of Lee were able to pull moisture from Hurricane Katia in the south-southeast far off the Atlantic coast and, as a result, left over 12 in. of rain in parts of the State during September 7-8. Major flooding resulted from the extreme rainfall in many locations, especially along the Susquehanna River and its tributaries as well as several other streams in east-central to southeast New York, including the Wallkill River, which was still recovering from flooding caused by Tropical Storm Irene. The USGS surveyed $20 \mathrm{HWMs}$ at 18 locations along a 114-mi reach of the Susquehanna River and compared the elevations to those published by FEMA for the 10-, 2-, 1-, and 0.2-percent AEP (10-, 50-, 100-, and 500-year) floods.

Remnants of Tropical Storm Lee reached southcentral New York on September 7, 2011. The heaviest rains were centered over the already saturated Susquehanna River Basin in south-central New York with over 12 in. recorded in some areas during September 7-9 (and most falling on September 8). Flooding in the lower reaches of the Susquehanna River exceeded the record levels of 2006 by more than $4 \mathrm{ft}$ (Tioga County). Ten streamgages in the Susquehanna River Basin recorded new maximum discharges and elevations on September 8, each greater than the 1-percent AEP discharge. The stage-frequency plot for the Susquehanna
River near Waverly (01515000) streamgage shows that the water-surface elevation remained above the 1-percent AEP (100-year) flood elevation for nearly 24 hours during September $8-9$. The peak discharge at Waverly $\left(167,000 \mathrm{ft}^{3} / \mathrm{s}\right)$ was the largest in 76 years (the previous maximum was $128,000 \mathrm{ft}^{3} / \mathrm{s}$ in 1936 and 2006). Major disaster declarations were made for 15 counties in and around central New York with about $\$ 1$ billion in estimated damages (Federal Emergency Management Agency, 2011b).

\section{Antecedent Conditions}

The heavy rains from the remnants of Tropical Storm Lee moved over south-central New York on September 7-8, 2011, only 10 days after Tropical Storm Irene had saturated the area with several inches of rain. Soil moisture increased further in early September as 1 to $2 \mathrm{in}$. of rain fell over the area during September 5-6.

Streamgages in the Susquehanna River Basin and other areas of south-central New York indicated flows that were already far above normal at the beginning of September; these flows were representative of antecedent conditions prior to the arrival of Lee on September 7 (figs. 47A-D). At each of the streamgages, daily mean flows remained above their 25 th percentiles during late August through at least mid-September. The high flows prior to the early-September storm combined with the extreme rainfalls of Tropical Storm Lee during September 8-9 led to record floods on the Susquehanna River and some of its tributaries.

\section{Precipitation}

Tropical Storm Lee's large circulation, covering much of the mid-Atlantic region of the United States, pulled moisture north from Hurricane Katia, which had formed over the Atlantic Ocean (fig. 48, Masters, 2011). Rainfall from Lee exceeded 20 in. in some areas along its path from Louisiana to New England (fig. 49, Brown, 2011). Radar images of 1-day total rainfall (fig. 50) indicate that more than $10 \mathrm{in.}$ fell in the Susquehanna River Basin during September 6-9, 2011 (National Oceanic and Atmospheric Administration, $2011 \mathrm{~m})$. Precipitation gages in south-central New York and adjacent parts of Pennsylvania recorded totals of nearly 13 in. of rain during the storm (table 19) with most of the rain falling on September 8 (10.40 in. at Apalachin, N.Y.); nine stations reported rainfall totals greater than $10 \mathrm{in}$. The greatest rainfall in the region was over south-central New York near Binghamton, which received about 10 to 12 in. of rain during the storm (fig. 51). Southeastern New York also received substantial amounts of rain (6-8 in.), causing streams like the Wallkill River to rise to nearly $5 \mathrm{ft}$ above flood stage. Beyond central and southeastern New York, rainfall from Lee diminished greatly, with western New York receiving less than 1 in. (National Oceanic and Atmospheric Administration, 2011f, h). 

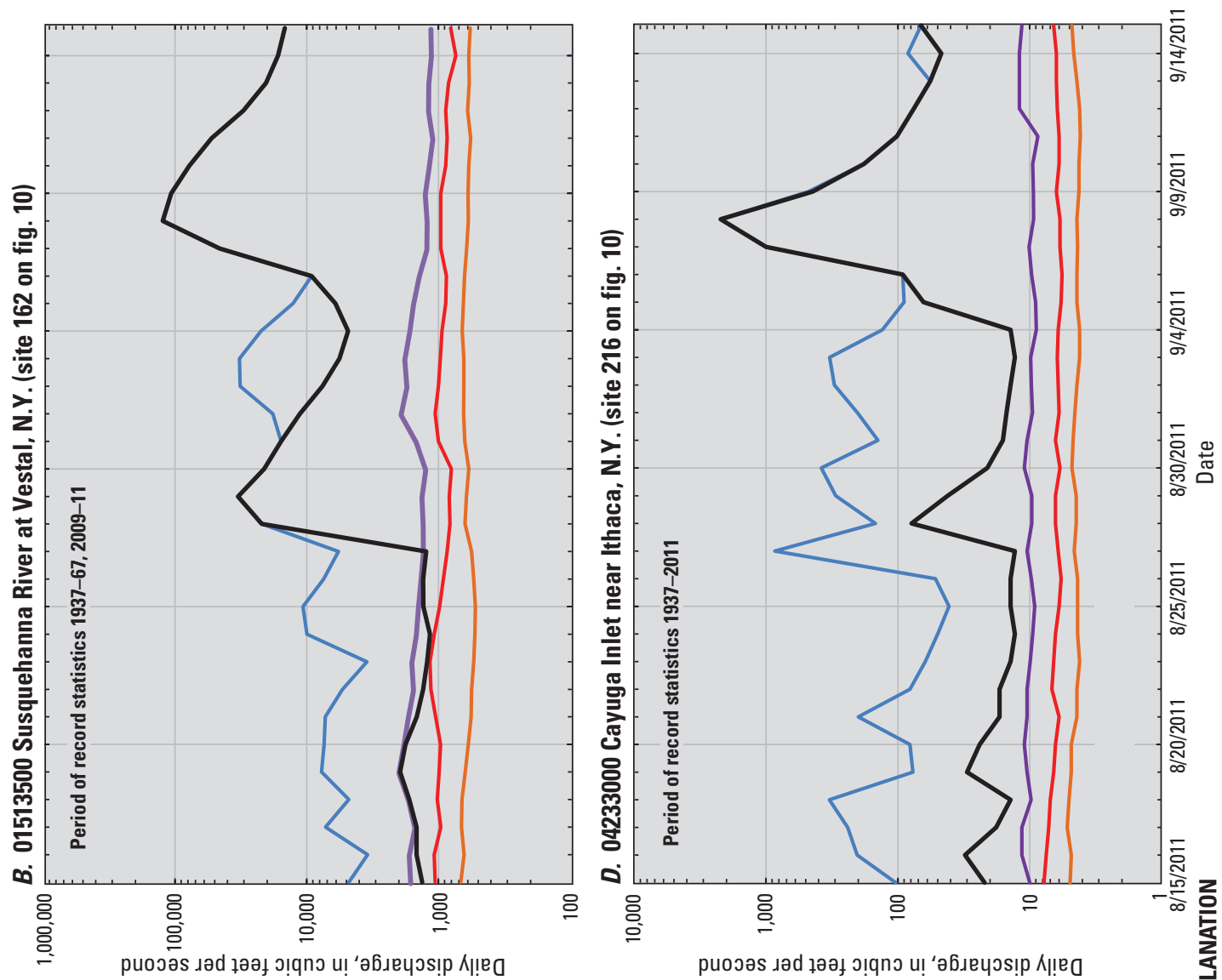

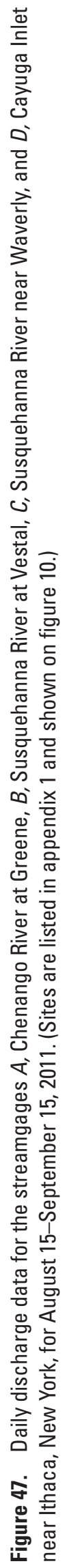
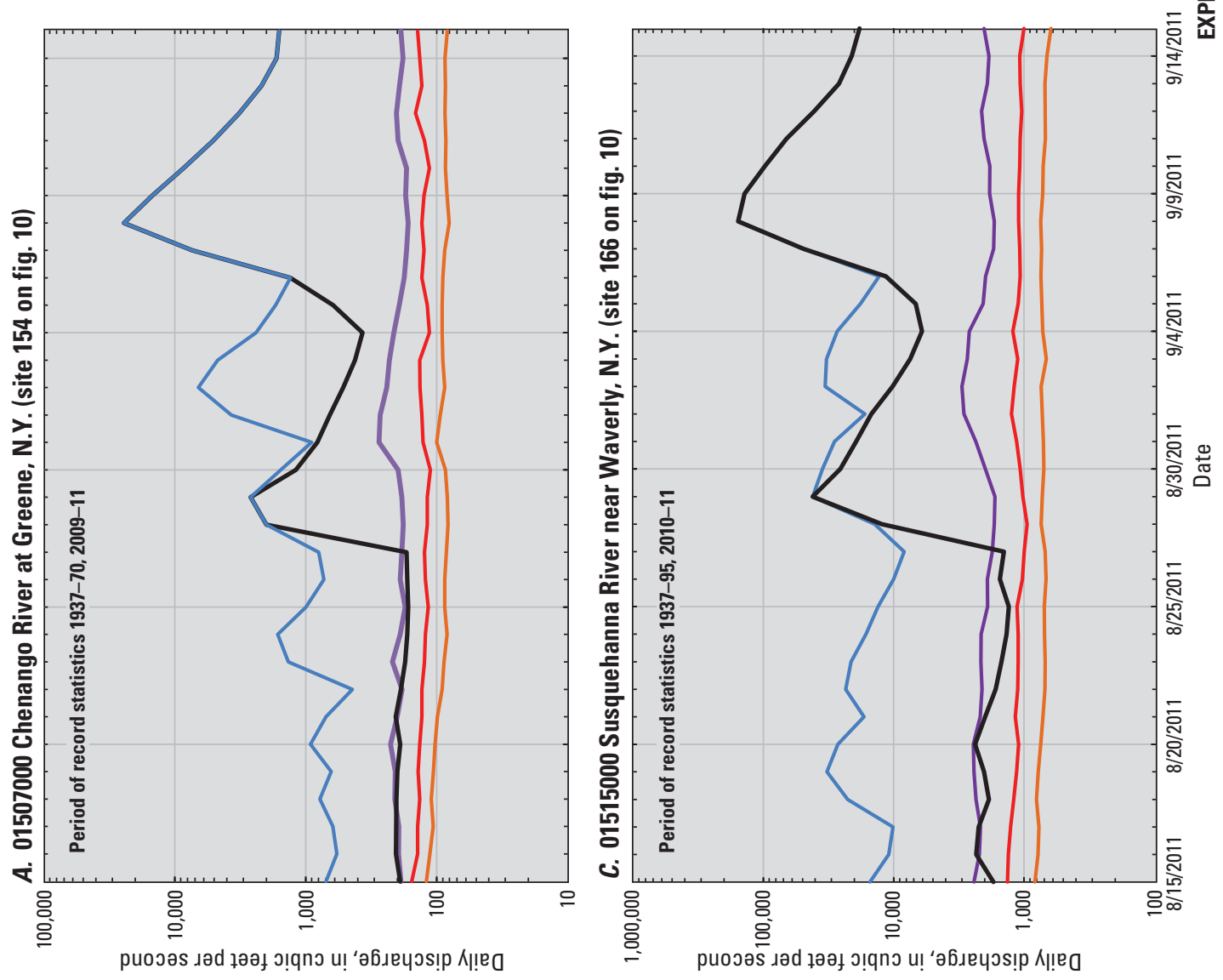

政

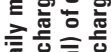

능 튼

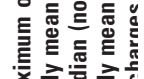

列

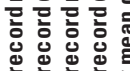

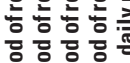

은 은 은 은 


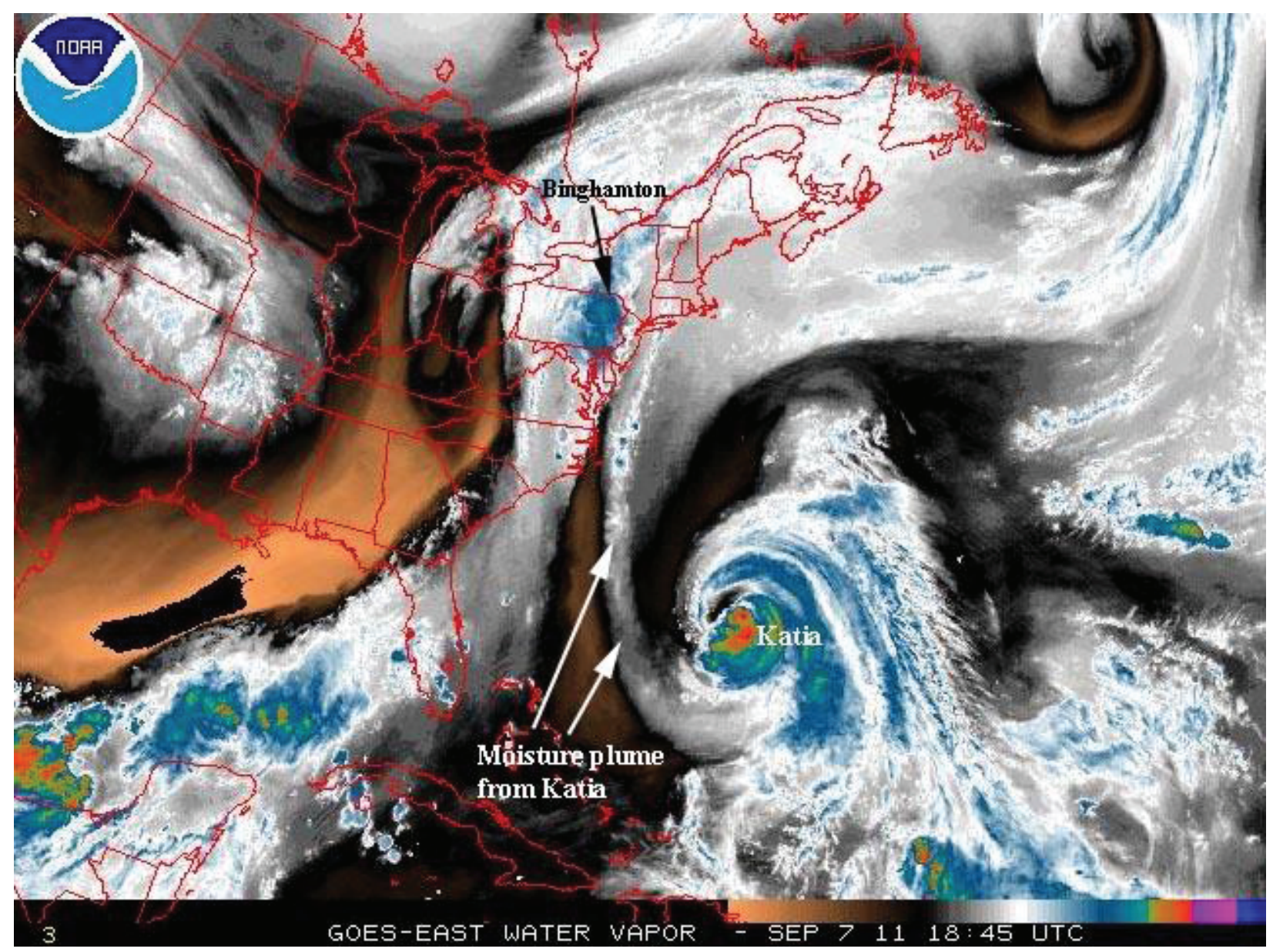

Figure 48. Moisture from the remnants of Tropical Storm Lee and Hurricane Katia on September 7, 2011. (From Masters, 2011)

Record rainfall intensities were set at Binghamton, where 8.70 in. fell in less than 24 hours (National Oceanic and Atmospheric Administration, 2011j). Accumulated hourly rainfalls at three weather stations in south-central to east-central New York indicate that most of the total storm rain fell in less than 24 hours, mostly on September 7, 2011 (fig. 52). Rainfall-frequency data at the three climate stations (table 20) and maximum 3-, 6-, 12-, and 24-hour rainfall during September 7-8, 2011 (shown in red), indicate that the intensities of rainfall were notable at Binghamton and Ithaca but not at Albany. Rainfall intensity at Binghamton for the 12- and 24-hour durations exceeded the 100- and 200-year recurrence intervals, respectively, and was nearly a 500-year, 24-hour storm (8.87 in.). At Ithaca, rainfall intensities for a 24-hour period were at about the 25-year recurrence interval. The durations of rainfall totals at Albany were less than 2 years.

September 2011 was the wettest September throughout south-central New York (climate division 2 in fig. 1) since at least 1895 , averaging 11.60 in. of rain for the month, nearly
8 in. above normal (National Oceanic and Atmospheric Administration, 2011k). Total rainfall during August and September 2011 (20.99 in.) in south-central New York was the greatest 2-month late-summer total on record (since 1895), mostly from Tropical Storm Irene in August and Lee in September. The previous maximum total for August and September was 13.86 in. in 1977.

\section{Flooding}

The heavy rains from the remnants of Tropical Storm Lee, especially in south-central New York, resulted in record streamflows at 10 active streamgages in the Susquehanna River Basin and 2 other streamgages in the Cayuga Lake Basin (Finger Lake tributary to Lake Ontario) during early September 2011 (table 21, fig. 10). Flooding in the lower reaches of the Susquehanna River in New York exceeded the record levels of 2006 by more than $4 \mathrm{ft}$, and peak discharges exceeded the 1-percent AEP flow. 


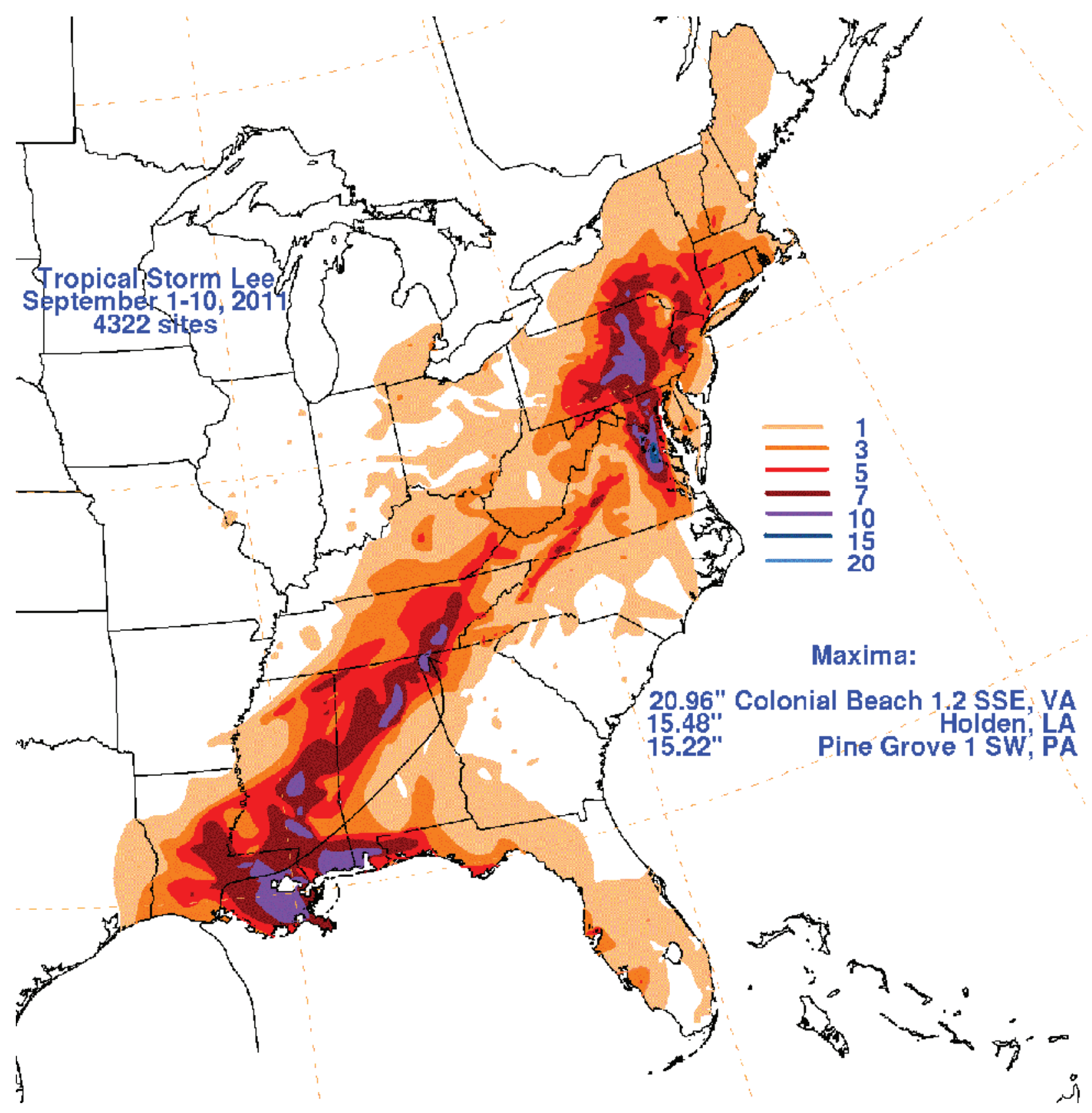

Figure 49. Rainfall totals in inches from Tropical Storm Lee and its remnants during September 1-10, 2011. (From Brown, 2011) 
$\boldsymbol{A}$

New York: 9/6/2011 1-Day Observed Precipitation

Valid at $9 / 6 / 20111200$ UTC- Created 10/15/12 8:24 UTC

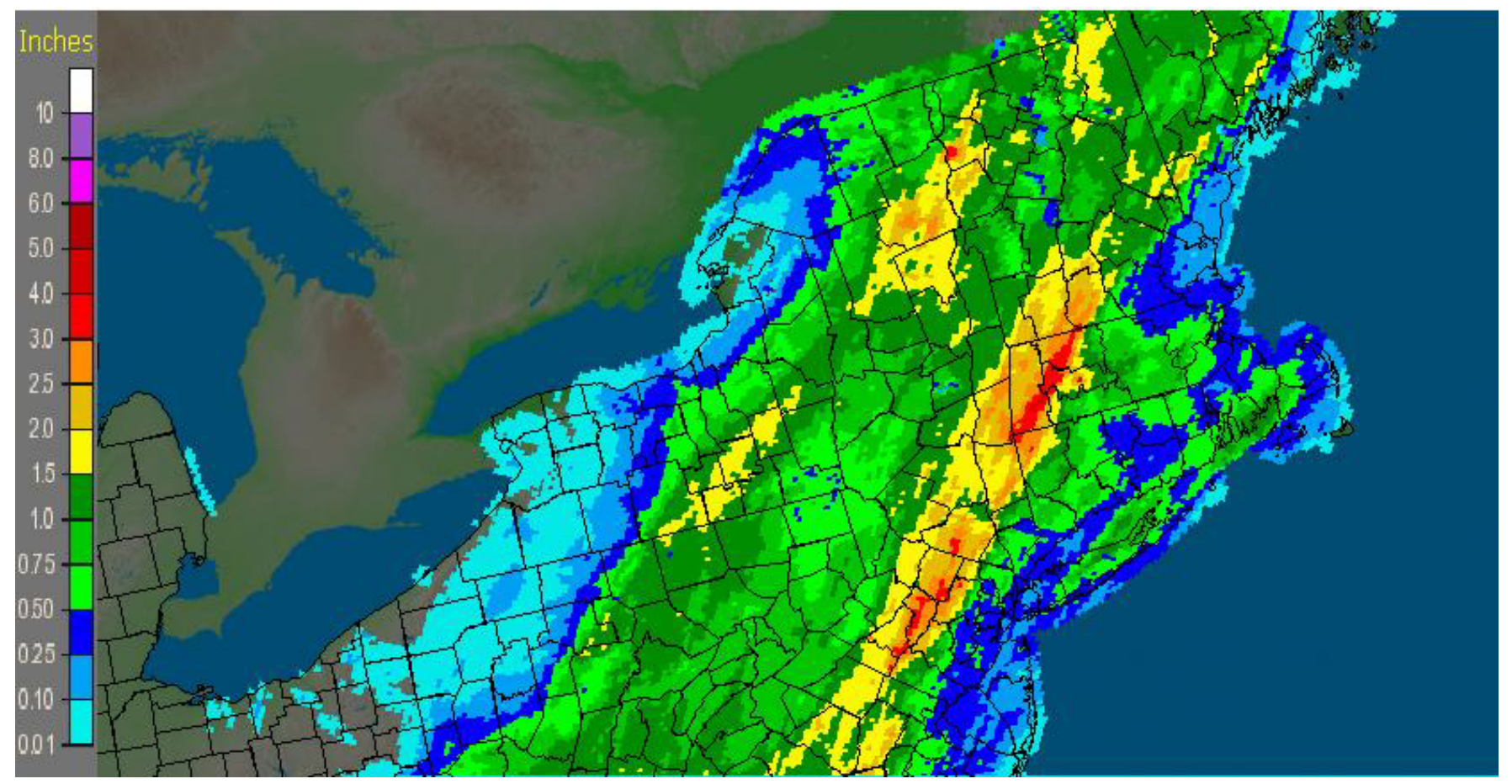

$\boldsymbol{B}$

New York: 9/7/2011 1-Day Observed Precipitation

Valid at $9 / 7 / 20111200$ UTC- Created $10 / 15 / 128: 26$ UTC

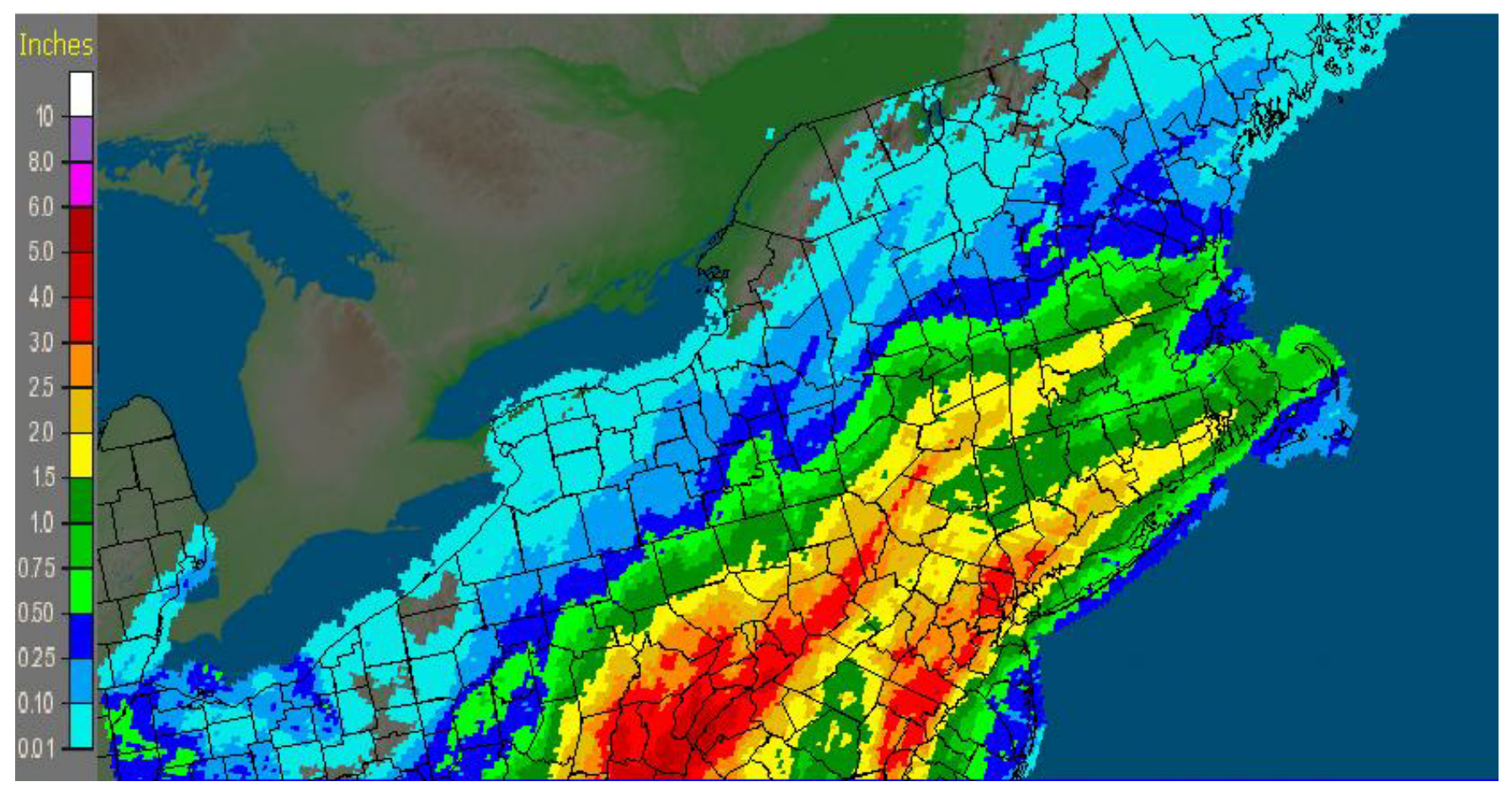

Figure 50. Daily rainfall totals from the remnants of Tropical Storm Lee during $A$, September 6, B, September 7, C, September 8, and $D$, September 9, 2011, for New York and surrounding areas. (From National Oceanic and Atmospheric Administration, 2011m) 
C

New York: 9/8/2011 1-Day Observed Precipitation

Valid at $9 / 8 / 20111200$ UTC- Created 10/15/12 $8: 28$ UTC

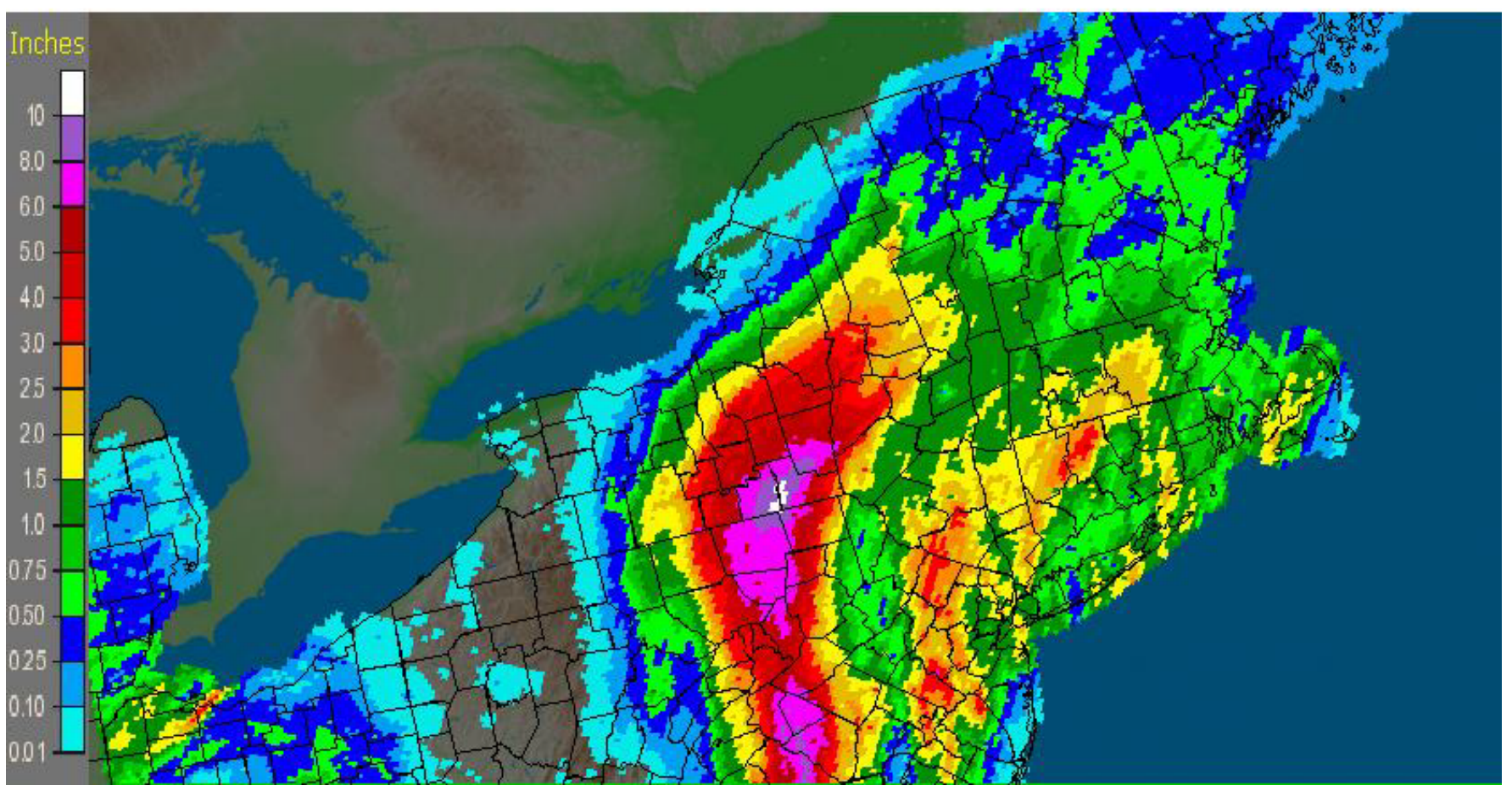

D

New York: 9/9/2011 1-Day Observed Precipitation

Valid at $9 / 9 / 20111200$ UTC- Created 10/15/12 $8: 30$ UTC

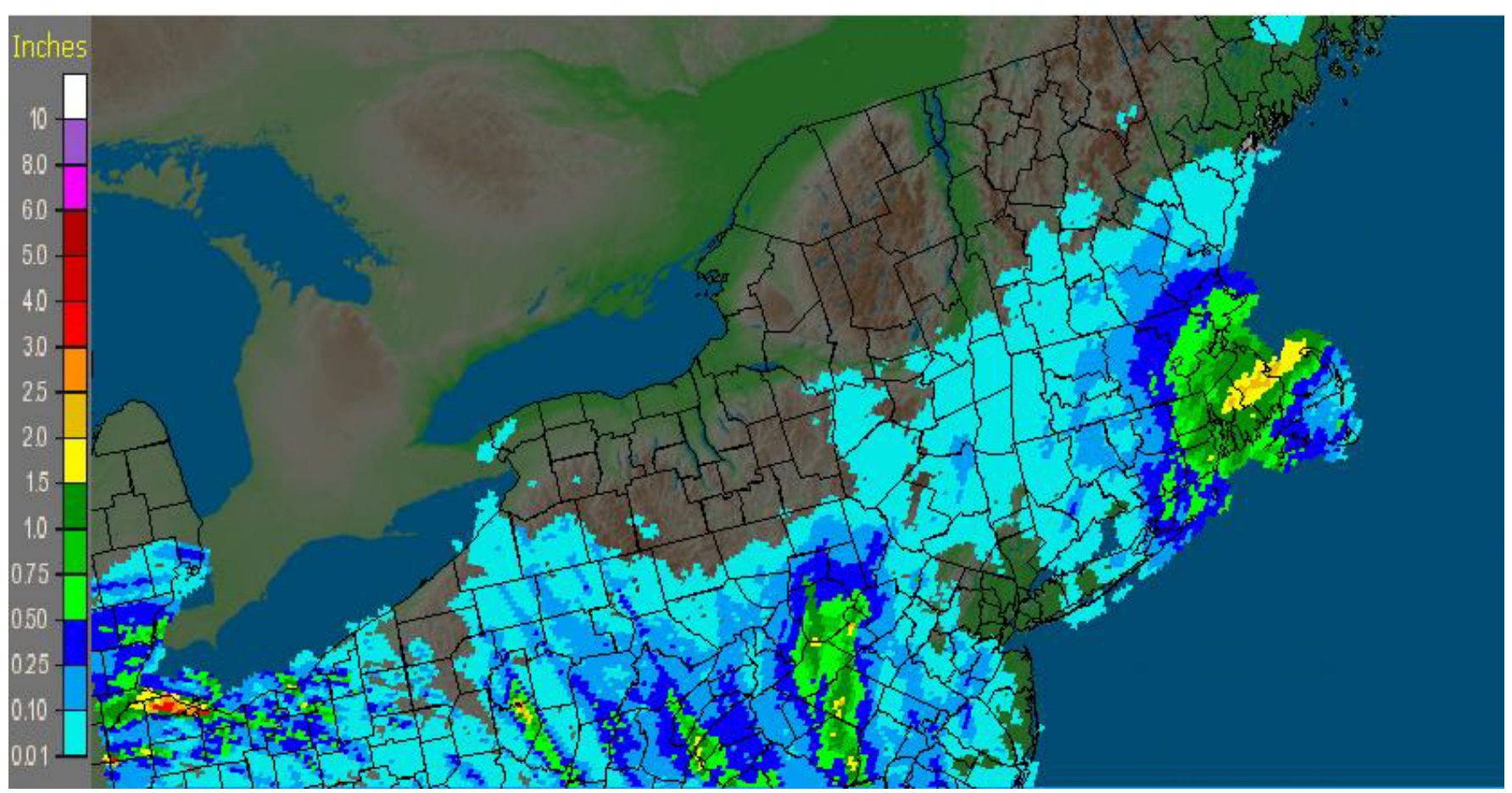

Figure 50. Daily rainfall totals from the remnants of Tropical Storm Lee during $A$, September 6, B, September 7, C, September 8, and $D$, September 9, 2011, for New York and surrounding areas. (From National Oceanic and Atmospheric Administration, 2011m) -Continued 
Table 19. Rainfall for the storm of September 5-9, 2011, at selected locations in New York and surrounding areas.

[Data provided by the National Oceanic and Atmospheric Administration (2011f,h) and Community Collaborative Rain, Hail \& Snow Network; Sept., September; N, north; S, south; E, east; W, west; SUNY-ESF, State University of New York College of Environmental Science and Forestry; locations are given on figure 51]

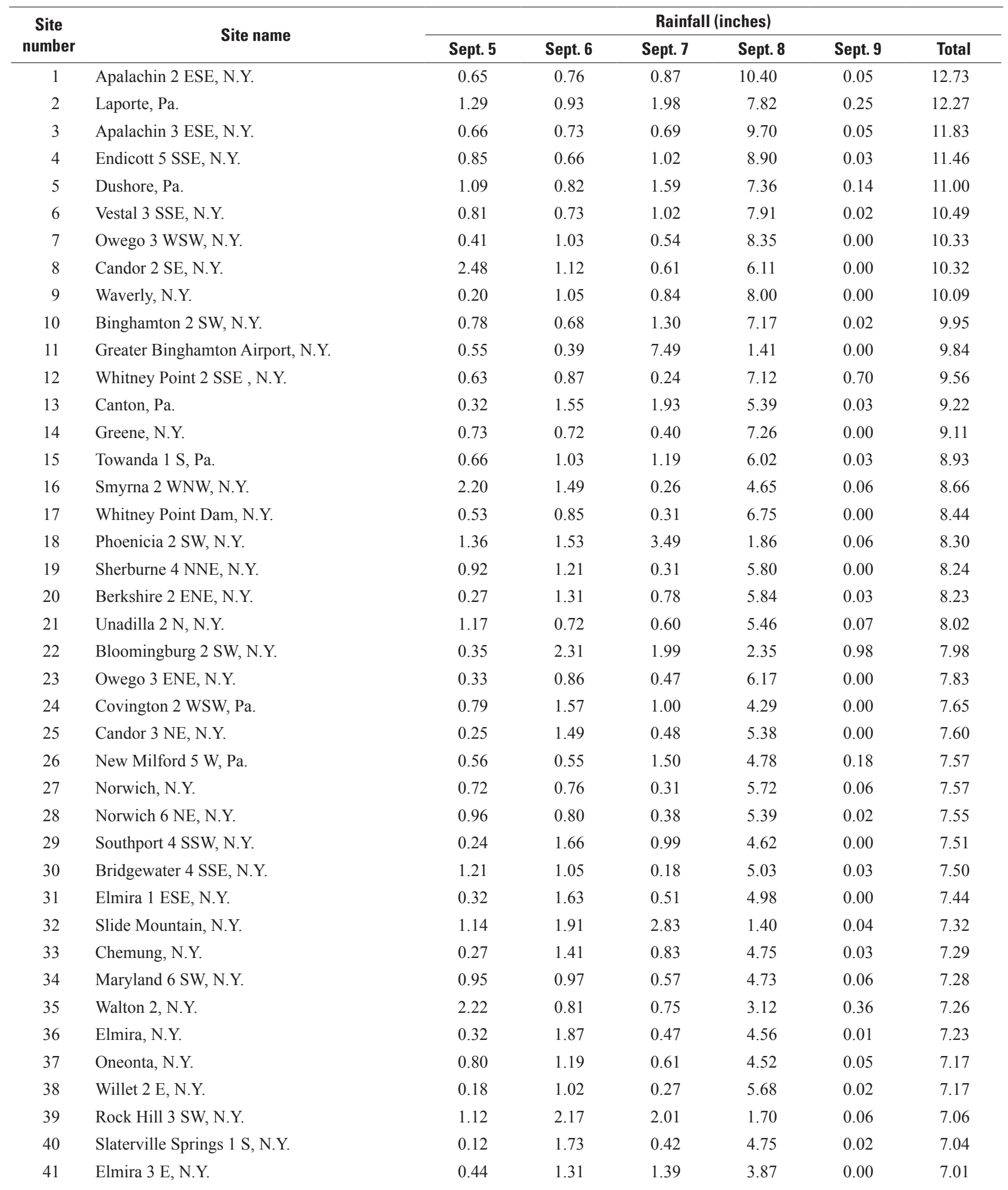


Table 19. Rainfall for the storm of September 5-9, 2011, at selected locations in New York and surrounding areas. - Continued

[Data provided by the National Oceanic and Atmospheric Administration (2011f,h) and Community Collaborative Rain, Hail \& Snow Network; Sept., September; N, north; S, south; E, east; W, west; SUNY-ESF, State University of New York College of Environmental Science and Forestry; locations are given on figure 51]

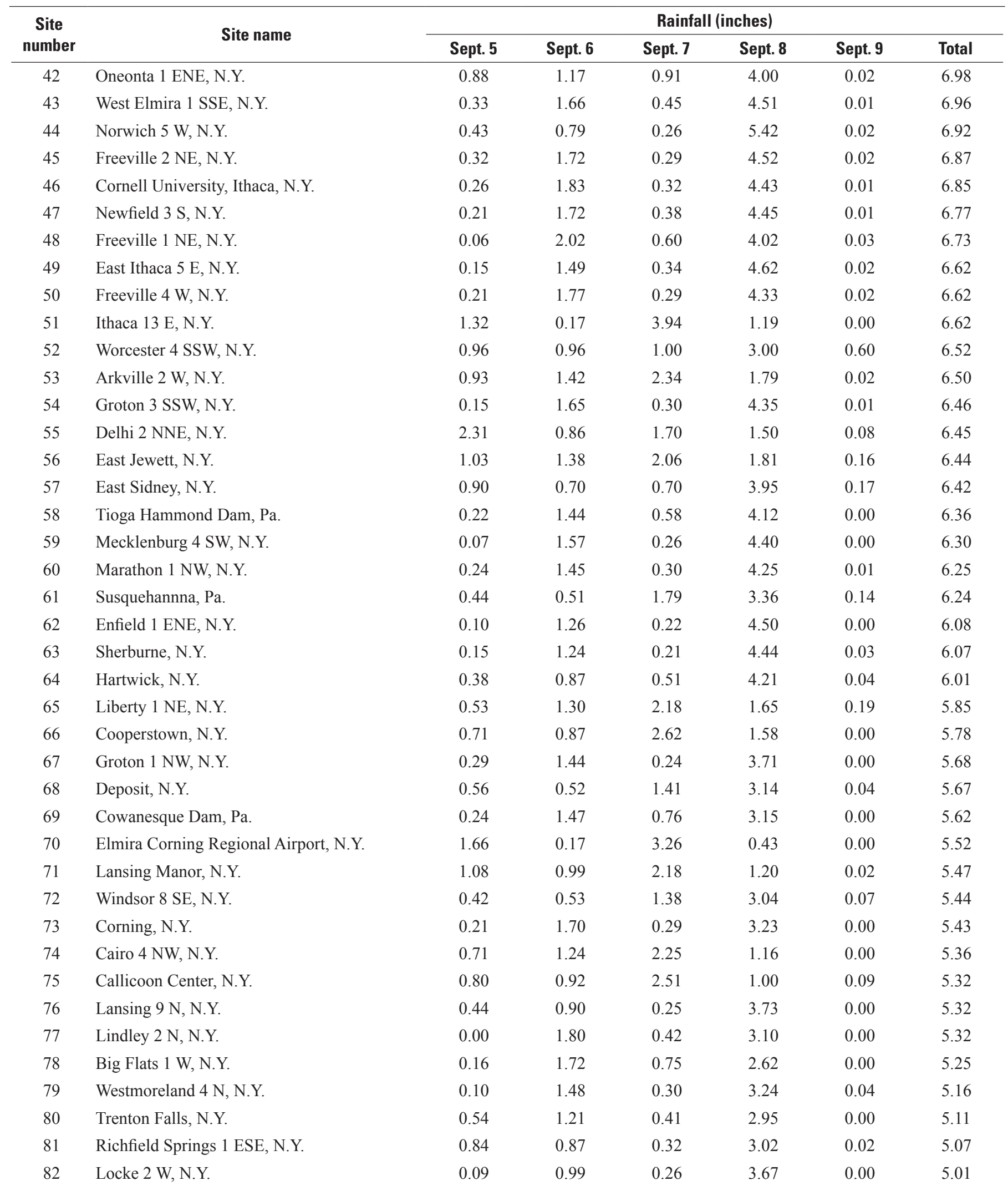


Table 19. Rainfall for the storm of September 5-9, 2011, at selected locations in New York and surrounding areas.-Continued

[Data provided by the National Oceanic and Atmospheric Administration (2011f,h) and Community Collaborative Rain, Hail \& Snow Network; Sept., September; N, north; S, south; E, east; W, west; SUNY-ESF, State University of New York College of Environmental Science and Forestry; locations are given on figure 51]

\begin{tabular}{|c|c|c|c|c|c|c|c|}
\hline \multirow{2}{*}{$\begin{array}{c}\text { Site } \\
\text { number }\end{array}$} & \multirow{2}{*}{ Site name } & \multicolumn{6}{|c|}{ Rainfall (inches) } \\
\hline & & Sept. 5 & Sept. 6 & Sept. 7 & Sept. 8 & Sept. 9 & Total \\
\hline 83 & South Kortright 1 W, N.Y. & 0.78 & 0.91 & 1.48 & 1.68 & 0.04 & 4.89 \\
\hline 84 & Cobleskill 2 ESE, N.Y. & 0.45 & 1.10 & 0.78 & 2.47 & 0.03 & 4.83 \\
\hline 85 & Cooperstown, N.Y. & 0.53 & 0.50 & 2.10 & 1.35 & 0.25 & 4.73 \\
\hline 86 & Gloversville 7 NW, N.Y. & 1.28 & 0.88 & 0.34 & 2.13 & 0.00 & 4.63 \\
\hline 87 & Schoharie, N.Y. & 0.20 & 1.30 & 0.90 & 1.85 & 0.20 & 4.45 \\
\hline 88 & Wellsboro $4 \mathrm{SW}, \mathrm{Pa}$. & 0.34 & 1.32 & 0.91 & 1.73 & 0.04 & 4.34 \\
\hline 89 & Rome Griffiss Airfield, N.Y. & 1.17 & 0.13 & 2.97 & 0.07 & 0.00 & 4.34 \\
\hline 90 & North Creek 5 SE, N.Y. & 0.97 & 2.20 & 0.12 & 0.98 & 0.02 & 4.29 \\
\hline 91 & Aurora Research Farm, N.Y. & 0.15 & 0.87 & 0.19 & 2.73 & 0.20 & 4.14 \\
\hline 92 & New London Lock 22, N.Y. & 0.25 & 0.83 & 0.17 & 2.70 & 0.03 & 3.98 \\
\hline 93 & Albany International Airport, N.Y. & 0.92 & 0.82 & 1.76 & 0.38 & 0.00 & 3.88 \\
\hline 94 & Delta Dam, N.Y. & 0.20 & 0.90 & 0.28 & 2.50 & 0.00 & 3.88 \\
\hline 95 & Delanson 2 NE, N.Y. & 0.55 & 0.91 & 0.98 & 1.29 & 0.12 & 3.85 \\
\hline 96 & Syracuse Hancock International Airport, N.Y. & 0.94 & 0.00 & 2.58 & 0.07 & 0.00 & 3.59 \\
\hline 97 & SUNY-ESF, Syracuse, N.Y. & 0.07 & 0.55 & 0.26 & 2.71 & 0.00 & 3.59 \\
\hline 98 & Griffiss Air Force Base, N.Y. & 0.38 & 0.92 & 0.30 & 1.78 & 0.00 & 3.38 \\
\hline 99 & Indian Lake 2 SW, N.Y. & 0.47 & 1.72 & 0.07 & 1.11 & 0.00 & 3.37 \\
\hline 100 & Skaneateles, N.Y. & 0.17 & 0.56 & 0.19 & 2.27 & 0.02 & 3.21 \\
\hline 101 & Tupper Lake Sunmount, N.Y. & 1.80 & 0.78 & 0.05 & 0.45 & 0.02 & 3.10 \\
\hline 102 & Sabinsville $3 \mathrm{SE}, \mathrm{Pa}$. & 0.04 & 0.52 & 1.01 & 1.33 & 0.10 & 3.00 \\
\hline 103 & Boonville 4 SSW, N.Y. & 0.22 & 0.80 & 0.11 & 1.87 & 0.00 & 3.00 \\
\hline 104 & Bath, N.Y. & 0.20 & 0.58 & 0.20 & 1.86 & 0.01 & 2.85 \\
\hline 105 & Auburn, N.Y. & 0.34 & 0.70 & 0.17 & 1.51 & 0.00 & 2.72 \\
\hline 106 & Highmarket, N.Y. & 1.05 & 0.52 & 0.02 & 0.98 & 0.00 & 2.57 \\
\hline 107 & Camden, N.Y. & 0.18 & 0.77 & 0.05 & 1.54 & 0.00 & 2.54 \\
\hline 108 & Lowville, N.Y. & 1.82 & 0.24 & 0.01 & 0.40 & 0.00 & 2.47 \\
\hline 109 & Whitesville, N.Y. & 0.55 & 0.50 & 0.21 & 1.11 & 0.01 & 2.38 \\
\hline 110 & Addison, N.Y. & 0.64 & 1.07 & 0.31 & 0.20 & 0.00 & 2.22 \\
\hline 111 & Baldwinsville, N.Y. & 0.44 & 0.46 & 0.07 & 1.20 & 0.00 & 2.17 \\
\hline 112 & Big Moose 3 SE, N.Y. & 0.11 & 0.37 & 0.60 & 1.04 & 0.00 & 2.12 \\
\hline 113 & Geneva Research Farm, N.Y. & 0.28 & 0.65 & 0.22 & 0.84 & 0.00 & 1.99 \\
\hline 114 & Attica 7 SW, N.Y. & 0.81 & 0.80 & 0.11 & 0.14 & 0.00 & 1.86 \\
\hline 115 & Wellsville, N.Y. & 0.74 & 0.48 & 0.09 & 0.40 & 0.10 & 1.81 \\
\hline 116 & Hooker 12 NNW, N.Y. & 1.30 & 0.19 & 0.05 & 0.24 & 0.00 & 1.78 \\
\hline 117 & Olean, N.Y. & 1.03 & 0.16 & 0.18 & 0.12 & 0.24 & 1.73 \\
\hline 118 & Brewerton Lock 23, N.Y. & 0.21 & 0.43 & 0.08 & 1.00 & 0.00 & 1.72 \\
\hline 119 & Newark, N.Y. & 0.31 & 0.47 & 0.47 & 0.47 & 0.00 & 1.72 \\
\hline 120 & Clyde Lock 26, N.Y. & 0.13 & 0.60 & 0.10 & 0.84 & 0.00 & 1.67 \\
\hline 121 & Old Forge, N.Y. & 0.23 & 0.92 & 0.48 & 0.00 & 0.00 & 1.63 \\
\hline 122 & Canandaigua 3 S, N.Y. & 0.40 & 0.43 & 0.20 & 0.52 & 0.00 & 1.55 \\
\hline 123 & Mount Morris $2 \mathrm{~W}, \mathrm{~N} . \mathrm{Y}$. & 0.66 & 0.60 & 0.09 & 0.15 & 0.00 & 1.50 \\
\hline
\end{tabular}


Table 19. Rainfall for the storm of September 5-9, 2011, at selected locations in New York and surrounding areas.-Continued

[Data provided by the National Oceanic and Atmospheric Administration (2011f,h) and Community Collaborative Rain, Hail \& Snow Network; Sept., September; N, north; S, south; E, east; W, west; SUNY-ESF, State University of New York College of Environmental Science and Forestry; locations are given on figure 51]

\begin{tabular}{|c|c|c|c|c|c|c|c|}
\hline \multirow{2}{*}{$\begin{array}{c}\text { Site } \\
\text { number }\end{array}$} & \multirow{2}{*}{ Site name } & \multicolumn{6}{|c|}{ Rainfall (inches) } \\
\hline & & Sept. 5 & Sept. 6 & Sept. 7 & Sept. 8 & Sept. 9 & Tota \\
\hline 124 & Hornell Almond Dam, N.Y. & 0.37 & 0.29 & 0.17 & 0.62 & 0.04 & 1.49 \\
\hline 125 & Angelica, N.Y. & 0.77 & 0.20 & 0.06 & 0.23 & 0.14 & 1.40 \\
\hline 126 & Allegany State Park, N.Y. & 1.03 & 0.11 & 0.14 & 0.03 & 0.05 & 1.36 \\
\hline 127 & Webster 2 NE, N.Y. & 1.06 & 0.00 & 0.17 & 0.05 & 0.00 & 1.28 \\
\hline 128 & Hemlock, N.Y. & 0.50 & 0.38 & 0.10 & 0.29 & 0.00 & 1.27 \\
\hline 129 & Palermo 2 SSE, N.Y. & 0.23 & 0.09 & 0.08 & 0.81 & 0.06 & 1.27 \\
\hline 130 & Fulton, N.Y. & 0.15 & 0.15 & 0.10 & 0.81 & 0.00 & 1.21 \\
\hline 131 & Watertown, N.Y. & 0.92 & 0.09 & 0.01 & 0.15 & 0.01 & 1.18 \\
\hline 132 & Alfred, N.Y. & 0.45 & 0.15 & 0.18 & 0.34 & 0.05 & 1.17 \\
\hline 133 & Honeoye, N.Y. & 0.47 & 0.22 & 0.18 & 0.25 & 0.00 & 1.12 \\
\hline 134 & Jamestown 4 ENE, N.Y. & 0.70 & 0.05 & 0.17 & 0.00 & 0.17 & 1.09 \\
\hline 135 & Little Valley, N.Y. & 0.57 & 0.27 & 0.20 & 0.00 & 0.02 & 1.06 \\
\hline 136 & Dansville, N.Y. & 0.21 & 0.34 & 0.17 & 0.22 & 0.02 & 0.96 \\
\hline 137 & New Albion 2, N.Y. & 0.52 & 0.05 & 0.12 & 0.01 & 0.25 & 0.95 \\
\hline 138 & Avon, N.Y. & 0.60 & 0.12 & 0.05 & 0.17 & 0.00 & 0.94 \\
\hline 139 & Portageville, N.Y. & 0.43 & 0.02 & 0.35 & 0.10 & 0.03 & 0.93 \\
\hline 140 & Fredonia, N.Y. & 0.65 & 0.08 & 0.11 & 0.00 & 0.09 & 0.93 \\
\hline 141 & Franklinville, N.Y. & 0.02 & 0.48 & 0.13 & 0.11 & 0.14 & 0.88 \\
\hline 142 & Pavilion, N.Y. & 0.61 & 0.05 & 0.09 & 0.09 & 0.00 & 0.84 \\
\hline 143 & Rushford, N.Y. & 0.36 & 0.07 & 0.23 & 0.04 & 0.08 & 0.78 \\
\hline 144 & Silver Springs 3 N, N.Y. & 0.44 & 0.16 & 0.06 & 0.09 & 0.00 & 0.75 \\
\hline 145 & Watertown Airport, N.Y. & 0.69 & 0.00 & 0.05 & 0.00 & 0.00 & 0.74 \\
\hline 146 & Wales, N.Y. & 0.51 & 0.10 & 0.10 & 0.00 & 0.00 & 0.71 \\
\hline 147 & Oswego East, N.Y. & 0.28 & 0.02 & 0.22 & 0.18 & 0.00 & 0.70 \\
\hline 148 & North Tonawanda, N.Y. & 0.53 & 0.04 & 0.00 & 0.11 & 0.01 & 0.69 \\
\hline 149 & Victor 2 NW, N.Y. & 0.00 & 0.32 & 0.09 & 0.22 & 0.00 & 0.63 \\
\hline 150 & Colden $1 \mathrm{~W}, \mathrm{~N} . \mathrm{Y}$. & 0.48 & 0.03 & 0.08 & 0.02 & 0.00 & 0.61 \\
\hline 151 & Perrysburg, N.Y. & 0.42 & 0.00 & 0.00 & 0.12 & 0.00 & 0.54 \\
\hline 152 & Rochester International Airport, N.Y. & 0.38 & 0.00 & 0.11 & 0.00 & 0.00 & 0.49 \\
\hline 153 & Lyndonville, N.Y. & 0.14 & 0.23 & 0.00 & 0.04 & 0.07 & 0.48 \\
\hline 154 & Niagara Falls International Airport, N.Y. & 0.32 & 0.00 & 0.02 & 0.04 & 0.00 & 0.38 \\
\hline 155 & Youngstown 2 NE, N.Y. & 0.32 & 0.00 & 0.01 & 0.02 & 0.03 & 0.38 \\
\hline 156 & Batavia, N.Y. & 0.20 & 0.04 & 0.06 & 0.02 & 0.00 & 0.32 \\
\hline 157 & Dunkirk Chautauqua Airport, N.Y. & 0.02 & 0.02 & 0.06 & 0.01 & 0.10 & 0.21 \\
\hline 158 & Buffalo Niagara International Airport, N.Y. & 0.01 & 0.01 & 0.05 & 0.00 & 0.01 & 0.08 \\
\hline
\end{tabular}




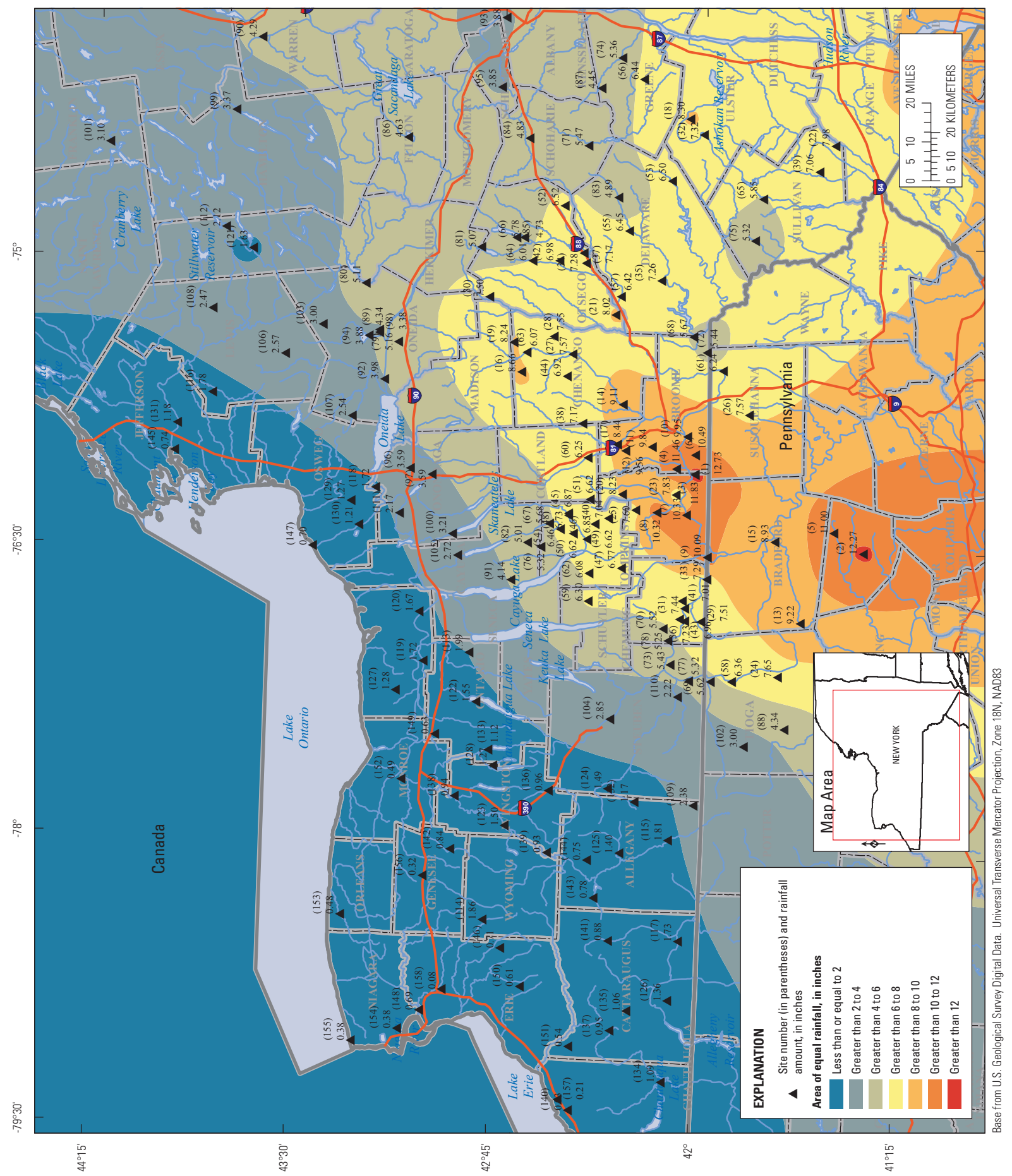

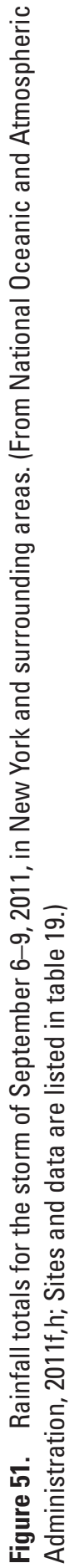




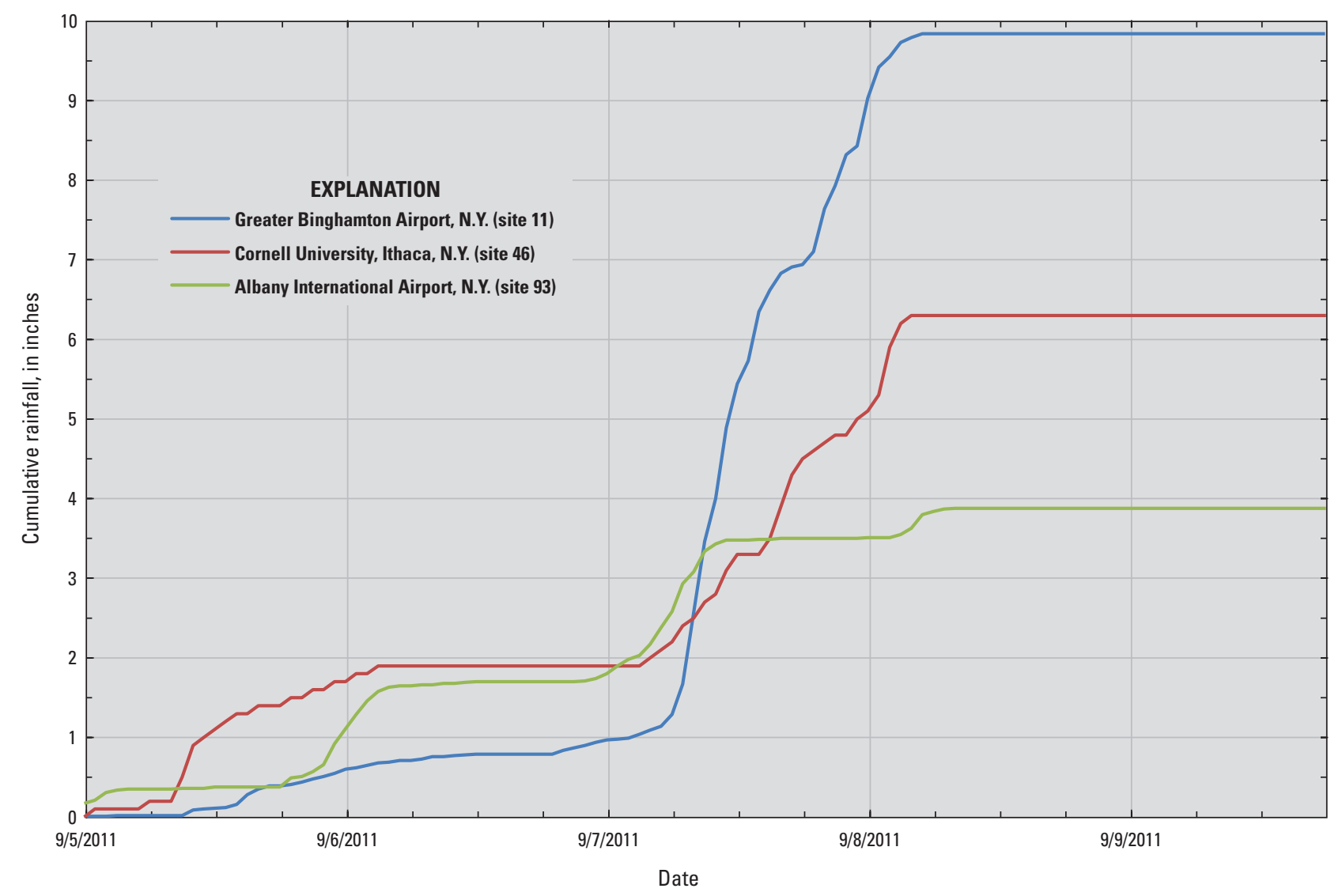

Figure 52. Cumulative hourly rainfall during September 5-9, 2011, recorded at three weather stations in south-central New York. (From National 0ceanic and Atmospheric Administration, 2011j; Sites are listed in table 19 and locations are shown on figure 51.)

\section{Flood Discharge and Frequency}

The flood frequencies at selected streamgages are indicated by the color codes of their associated drainage basins (fig. 53). A full-size view of the map on figure 53 can be accessed by the computer link at the end of the figure caption. The most extreme flooding was along and around the Susquehanna River from Oneonta through Binghamton to Waverly in south-central New York but decreased substantially north and west of these areas.

Record flood discharges were documented at 10 streamgages in the Susquehanna River Basin (table 21), and 10 sites in the flooded areas had AEP values equal to or less than 1 percent (recurrence intervals equal to or greater than 100 years). Peak discharges plotted as a function of drainage area for the September 2011 flood at 43 selected streamgages at which the September 2011 flood was the maximum for the year (fig. 54) indicate that many peaks were near or above the previous peak discharge of record and the 1-percent AEP (100-year) discharge. Streamgage numbers are plotted at their respective drainage area for sites with peak discharges exceeding their 1-percent AEP (100-year) flows; however, flooding affected streams of all drainage basin sizes. A generally strong relation of peak discharge and drainage area for streamgages on unregulated streams is indicated by the solid line (fig. 54). Most unregulated streamgages shown are in the Susquehanna River Basin.

Of the seven streamgages on the Susquehanna River with computed flood frequencies, the five most downstream recorded peak discharges were equal to or greater than the 1-percent AEP (100-year) flood (fig. 55) on September 8, but each peak was less than the 0.2-percent AEP (500-year) discharge. The Susquehanna River near Waverly (01515000) streamgage recorded its greatest stage $(26.67 \mathrm{ft})$ and discharge $\left(167,000 \mathrm{ft}^{3} / \mathrm{s}\right)$ since record collection began in 1936; the stage was about $4.2 \mathrm{ft}$ higher than that during the previous record flood on June 29, 2006. The 2011 peak discharges at the Susquehanna River streamgages near Waverly and at Owego were about 1.3 times greater than those recorded during the June 2006 flood, whereas recorded peaks at four upstream gages on the Susquehanna River (Unadilla, Bainbridge, Windsor, and Conklin) were less than those during 2006 (table 21). Flooding occurred on other streams south of the eastern Finger Lakes and within the Mohawk River Basin (upstream from the confluence with Schoharie Creek), the Wallkill River, and several tributaries to the lower Hudson River (fig. 53), but the magnitudes were not as great as those on streams in south-central New York. 
Table 20. Rainfall frequencies for storms of 3-, 6-, 12-, and 24-hour durations at selected locations in south-central and east-central New York.

[Maximum rainfall totals for selected durations during September 8-9, 2011, are shown in red; Data from the Northeast Regional Climate Center, 2010); locations are shown on figure 51]

\begin{tabular}{|c|c|c|c|c|c|c|c|}
\hline \multirow{2}{*}{$\begin{array}{l}\text { Site } \\
\text { num- } \\
\text { ber }\end{array}$} & \multirow[b]{2}{*}{ Site name } & \multirow[b]{2}{*}{ County } & \multirow{2}{*}{$\begin{array}{c}\text { Recur- } \\
\text { rence } \\
\text { inter- } \\
\text { val } \\
\text { (years) }\end{array}$} & \multicolumn{4}{|c|}{$\begin{array}{l}\text { Rainfall (inches) for } \\
\text { selected duration }\end{array}$} \\
\hline & & & & $\begin{array}{c}\text { 3- } \\
\text { hour }\end{array}$ & $\begin{array}{c}\text { 6- } \\
\text { hour }\end{array}$ & $\begin{array}{l}12- \\
\text { hour }\end{array}$ & $\begin{array}{l}24- \\
\text { hour }\end{array}$ \\
\hline \multirow[t]{12}{*}{11} & Greater Binghamton Airport & Broome & 2 & 1.46 & 1.74 & 2.05 & 2.39 \\
\hline & & & 5 & 1.84 & 2.19 & 2.56 & 2.97 \\
\hline & & & 10 & 2.21 & 2.62 & 3.04 & 3.49 \\
\hline & & & & 2.33 & & & \\
\hline & & & 25 & 2.79 & 3.29 & 3.81 & 4.34 \\
\hline & & & 50 & 3.34 & 3.94 & 4.53 & 5.12 \\
\hline & & & & & 4.15 & & \\
\hline & & & 100 & 3.99 & 4.69 & 5.37 & 6.04 \\
\hline & & & & & & 5.77 & \\
\hline & & & 200 & 4.77 & 5.59 & 6.37 & 7.12 \\
\hline & & & & & & & 8.70 \\
\hline & & & 500 & 6.03 & 7.04 & 7.98 & 8.87 \\
\hline
\end{tabular}

46 Cornell University, Ithaca $\quad$ Tompkins $\quad 1.10 \quad 1.50$

$\begin{array}{lllll}2 & 1.43 & 1.70 & 2.01 & 2.34\end{array}$

$\begin{array}{lllll}5 & 1.78 & 2.13 & 2.50 & 2.91\end{array}$

2.70

$\begin{array}{lllll}10 & 2.11 & 2.52 & 2.96 & 3.43\end{array}$

$\begin{array}{lllll}25 & 2.64 & 3.15 & 3.70 & 4.27\end{array}$

4.30

$\begin{array}{lllll}50 & 3.12 & 3.74 & 4.38 & 5.04\end{array}$

$\begin{array}{lllll}100 & 3.71 & 4.43 & 5.18 & 5.95\end{array}$

$\begin{array}{lllll}200 & 4.39 & 5.25 & 6.12 & 7.02\end{array}$

$\begin{array}{lllll}500 & 5.49 & 6.57 & 7.65 & 8.75\end{array}$

93 Albany International Airport Albany

$\begin{array}{llll}0.76 & 1.31 & 1.74 & 1.80\end{array}$

$\begin{array}{lllll}2 & 1.51 & 1.82 & 2.18 & 2.59\end{array}$

$\begin{array}{lllll}5 & 1.90 & 2.28 & 2.71 & 3.18\end{array}$

$\begin{array}{lllll}10 & 2.26 & 2.71 & 3.19 & 3.72\end{array}$

$\begin{array}{lllll}25 & 2.84 & 3.39 & 3.97 & 4.58\end{array}$

$\begin{array}{lllll}50 & 3.39 & 4.03 & 4.69 & 5.37\end{array}$

$\begin{array}{lllll}100 & 4.03 & 4.78 & 5.53 & 6.29\end{array}$

$\begin{array}{lllll}200 & 4.80 & 5.67 & 6.53 & 7.37\end{array}$

$\begin{array}{lllll}500 & 6.04 & 7.10 & 8.13 & 9.11\end{array}$
The several inches of rain that fell in the flooded areas resulted in large volumes of runoff (the amount of water discharged from a drainage basin and passing a specific location during a given amount of time) occurring during a relatively short period of time in early September. The maximum consecutive 1-, 3-, and 7-day mean discharges during the period of record at two streamgages on the Susquehanna River were among the highest of record at Conklin (01503000) (fig. 56A) and the highest of record near Waverly (01515000) (fig. 56B). The maximum 1-day (September 8) and 3-day (September 8-10) mean discharges at Susquehanna River at Conklin (01503000) were the second largest in 98 years of record (2006 flows were larger) and were equal to the 1-percent AEP (100-year) n-day discharges (fig. 56A). The maximum consecutive 7-day mean discharge (September 7-13) at Conklin was less than the 2-percent AEP (50-year) 7-day discharge. The maximum 1-day (September 8), 3-day (September 8-10), and 7-day (September 7-13) mean discharges at the Susquehanna River near Waverly streamgage (01515000) were the highest for the station's period of record (fig. 56B). The 1- and 3-day discharges exceeded the 1-percent AEP (100-year) discharge, whereas the maximum 7-day discharge (September 7-13) was slightly less than the 2-percent AEP (50-year) 7-day discharge. The 7-day volume of water passing the Waverly streamgage (which averaged $82,100 \mathrm{ft}^{3} / \mathrm{s}$ and totaled 371.4 billion gallons) would fill 562,000 Olympic-sized swimming pools and cover the entire State of Rhode Island or the five boroughs of New York City with 1.5 and $5.9 \mathrm{ft}$ of water, respectively. No significant trends in computed flood volumes are indicated at the Conklin or Waverly streamgages since record collection began in 1914 and 1938, respectively.

Annual peak discharges at 12 selected streamgages in the flooded areas indicate that the September 2011 peak flow was the greatest or second greatest for the period of record (table 21, figs. 57A-L). The September 2011 peak discharges exceeded the 1-percent AEP (100-year) discharges for most of the selected streamgages and many by a wide margin. A couple of tributaries (figs. 57A, J) in the Susquehanna River Basin and three streamgages on the lower reaches of the main stem from Vestal to Waverly (figs. 57H, I, and K) recorded their greatest stages and discharges of record (some with data collected since the 1930s) with a few peak discharges exceeding the 0.5 -percent AEP (200-year) flow (table 21). Annual short-term trend lines for peak discharges during the most recent 24-30 years at most of the selected streamgages in the Susquehanna River Basin were significantly upward (figs. 57A-L, table 6); however, with the exception of Little Elk Creek near Westford (01497805, fig. 57A), a station with 34 years of record, long-term trends (more than 30 years of record) were not pronounced and not statistically significant (p-value greater than 0.10). Outside the Susquehanna River Basin, the September 2011 peak discharge $\left(7,190 \mathrm{ft}^{3} / \mathrm{s}\right)$ at Cayuga Inlet near Ithaca (04233000) was the greatest of record, which began in 1935 (fig. 57L). 


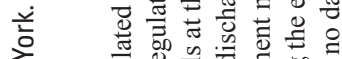

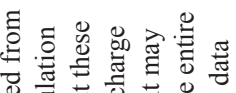

ङ

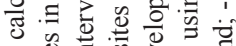

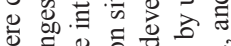

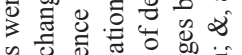

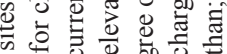

\&े

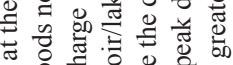

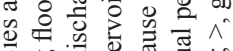

可

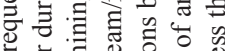

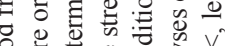

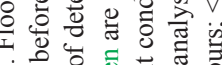

ธี่

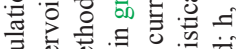

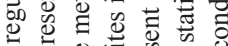

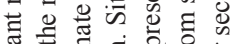

氖

总品

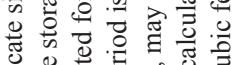

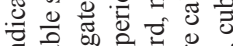

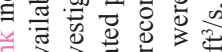

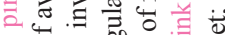

झ范。

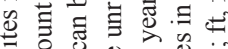

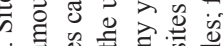

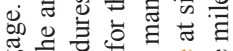

范

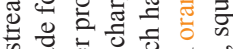

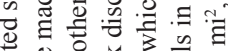

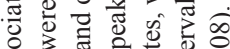

के की

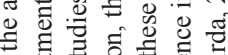

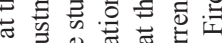

च 肎

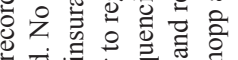

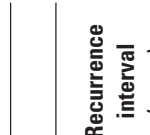

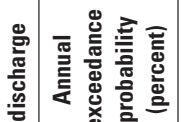

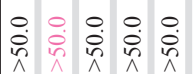

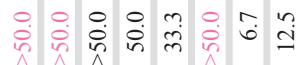

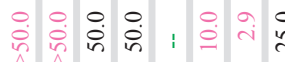

$\stackrel{\circ}{\circ} \stackrel{0}{\circ}$

in

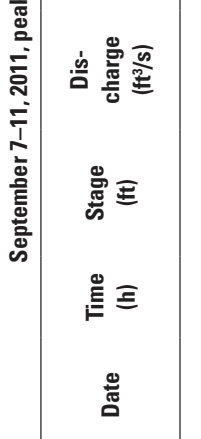

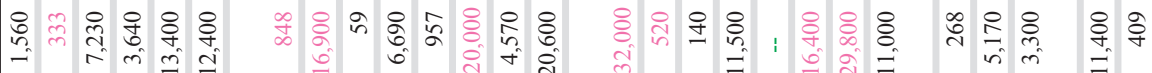

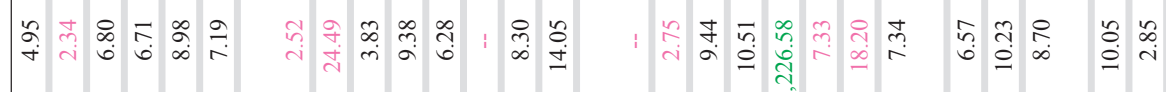

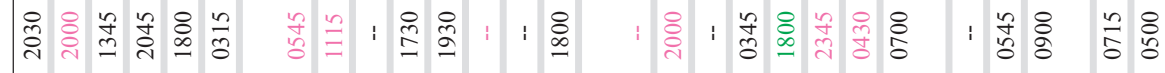

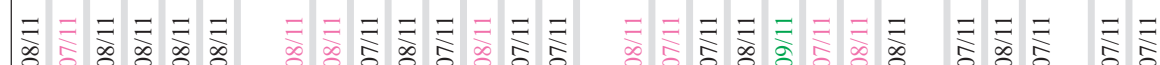

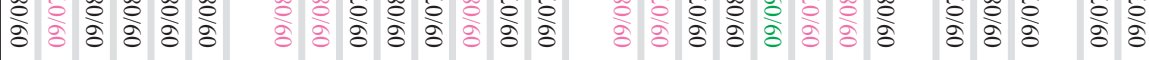

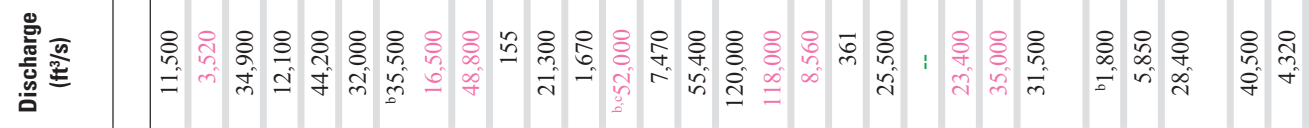

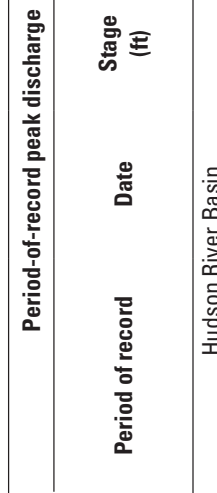

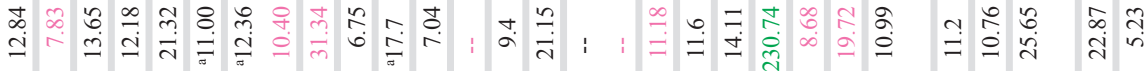

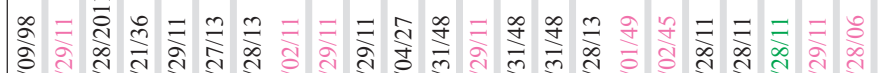

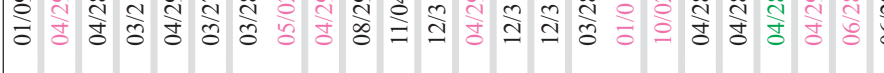

$\underset{\infty}{\vec{\infty}} \vec{\infty} \underset{\infty}{\vec{\infty}}$

$\underset{\infty}{\vec{T}} \underset{\infty}{\overrightarrow{1}}$

.

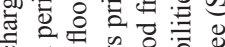

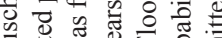

눌

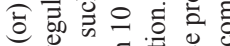

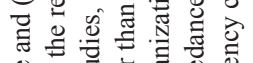

落

फ

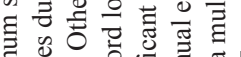

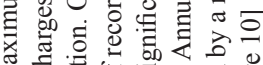

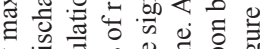

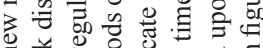

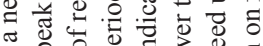

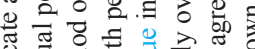

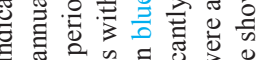

चั

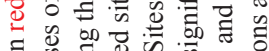

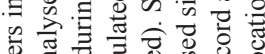

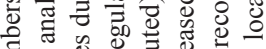

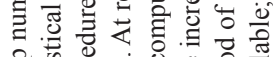

焉莺

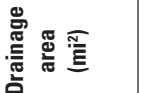

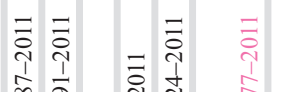

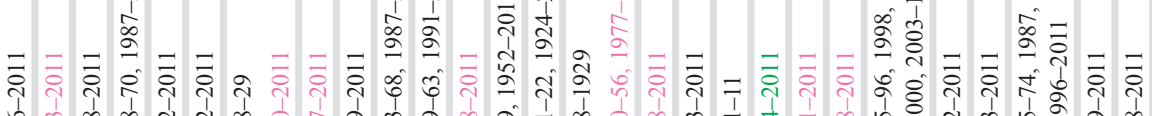

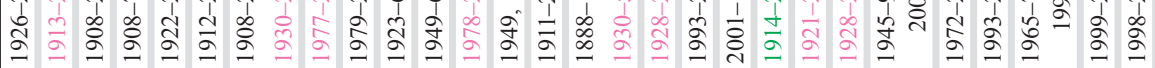

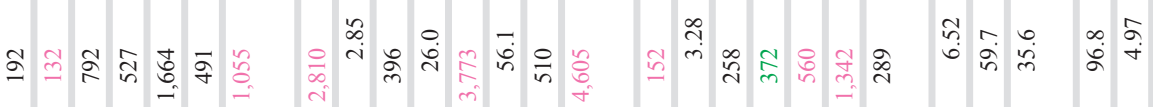
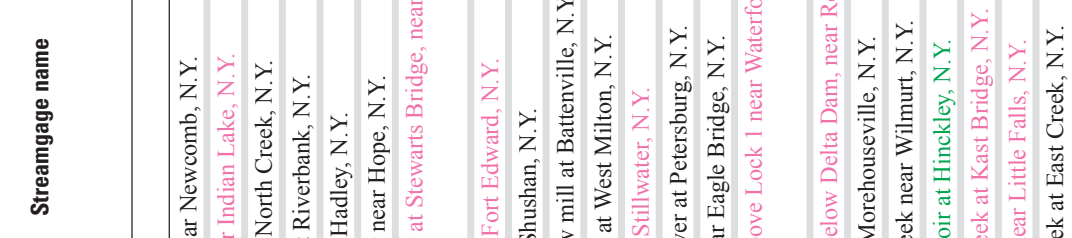

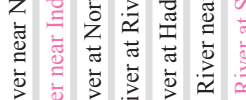

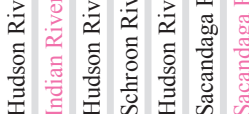

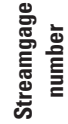

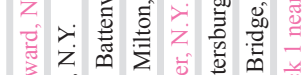

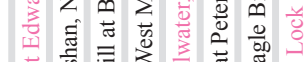

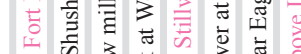

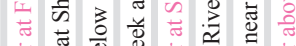

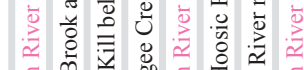

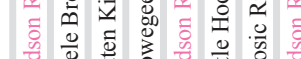

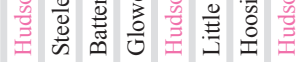

气ั

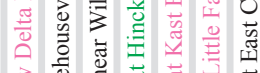

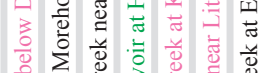

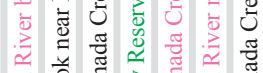

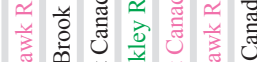

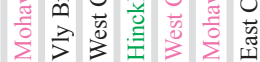
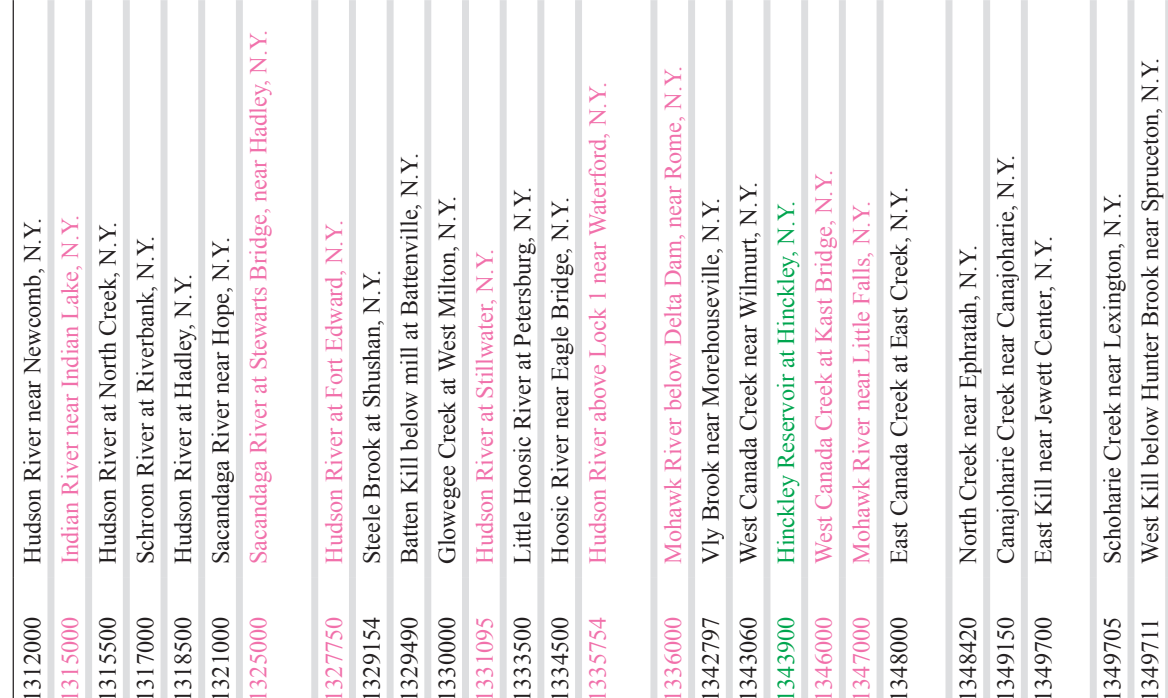

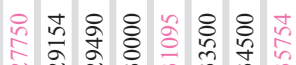

लै ले సे

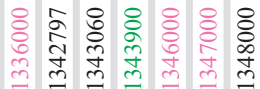

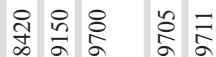

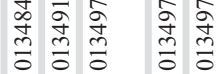

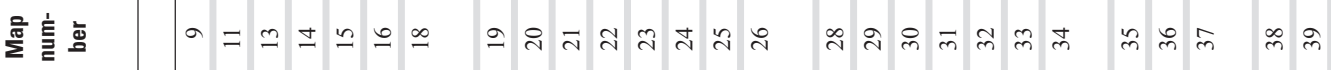




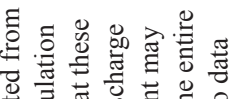

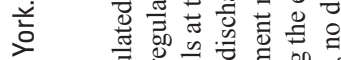

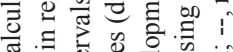

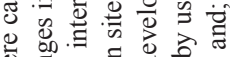

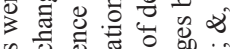

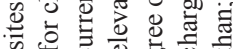

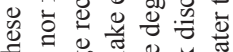

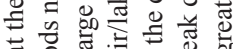

पै 8 ट

. 00 :

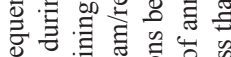

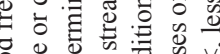

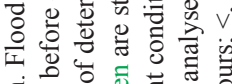

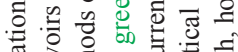

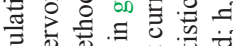

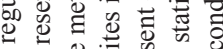

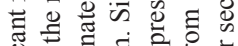

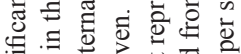

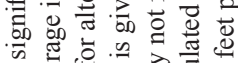

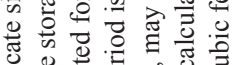

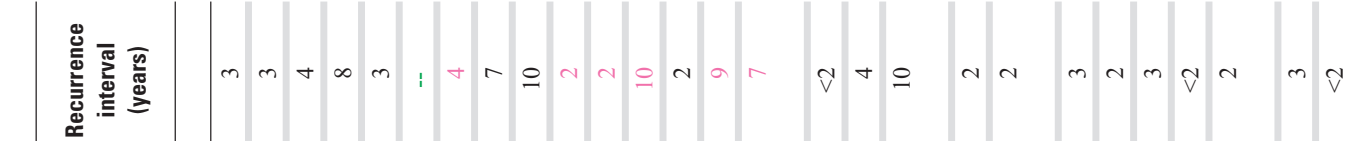

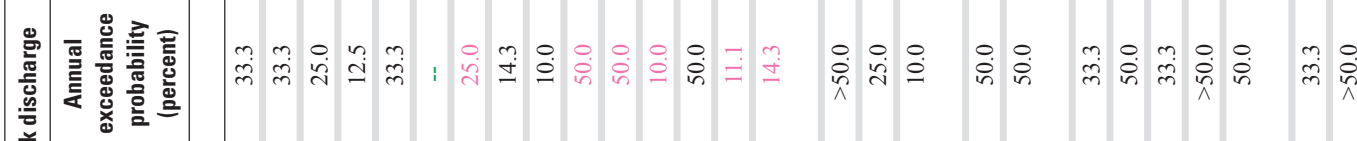

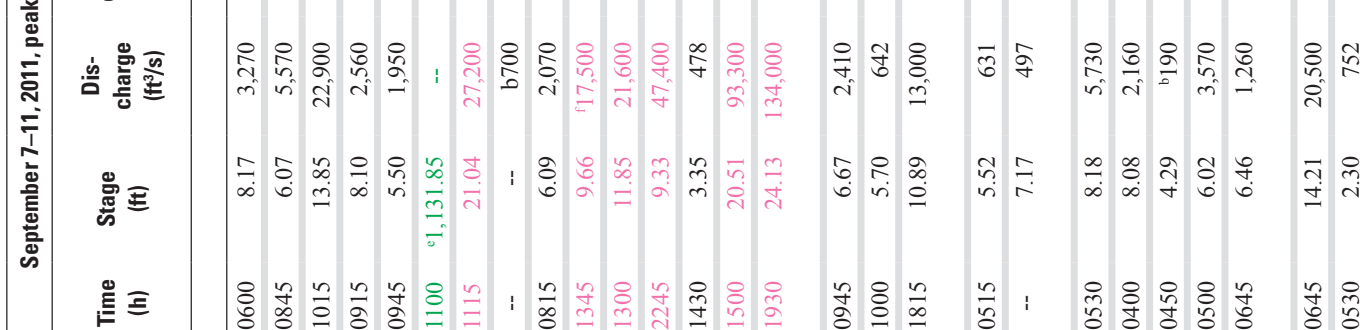

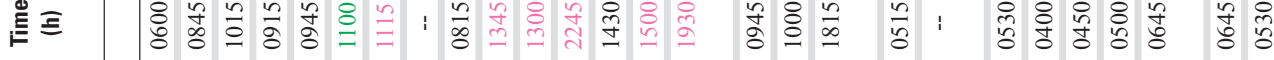

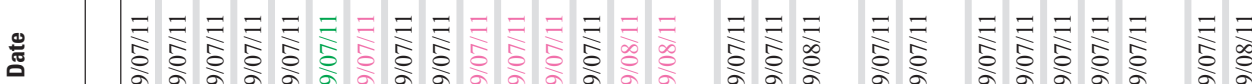

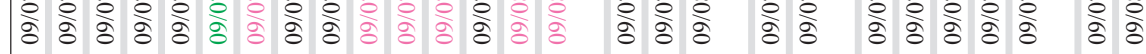

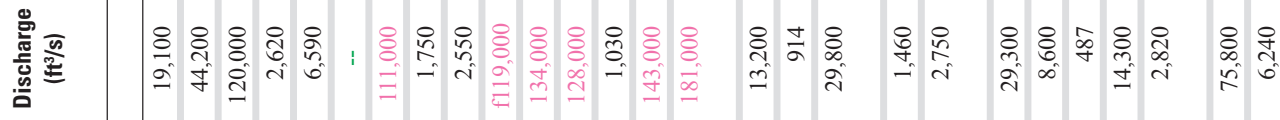

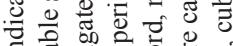

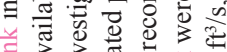

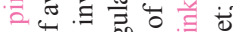

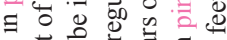

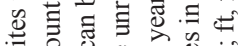

फे

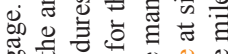

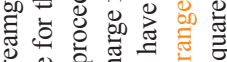

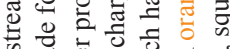

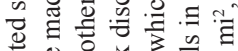

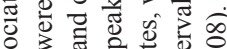

की की क्ष

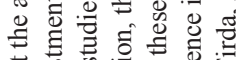

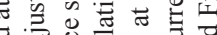

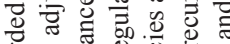

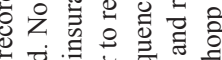

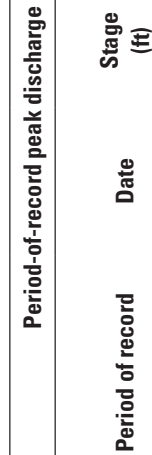

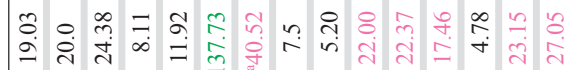

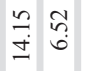

$\stackrel{\infty}{\rightarrow} \underset{i}{\stackrel{0}{ }}$

गे 20 के

मे ๑

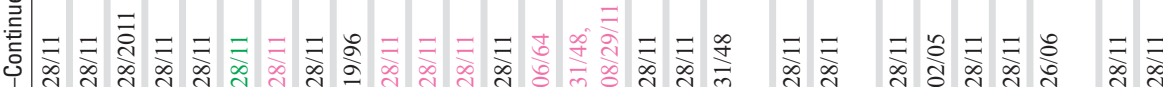

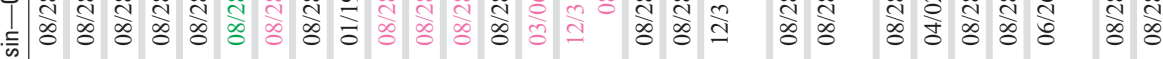

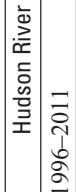

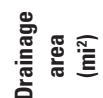

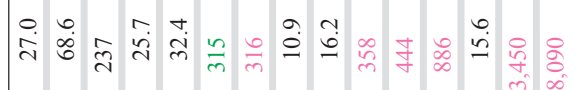

تิ

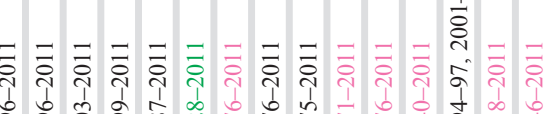

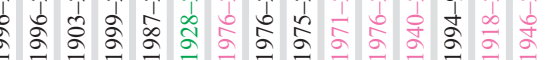

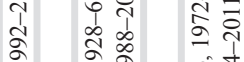

.

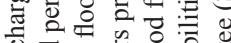

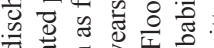

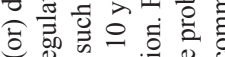

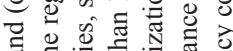

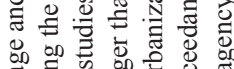

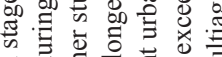

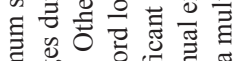

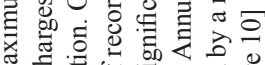

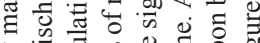

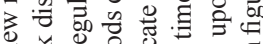

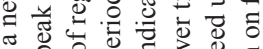

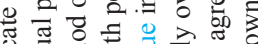

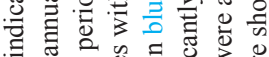

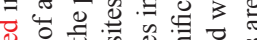

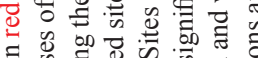

은

ब。

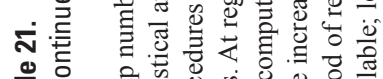

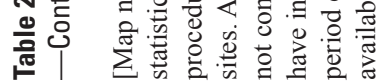

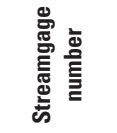

产言亶

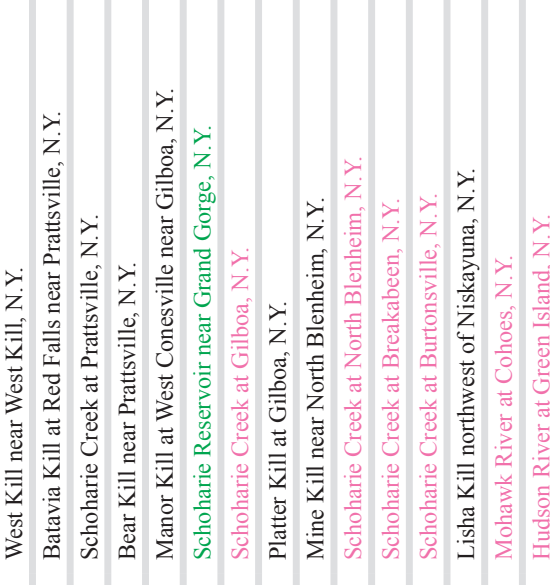

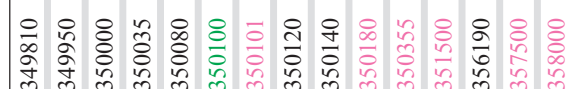

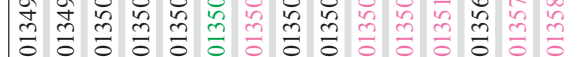

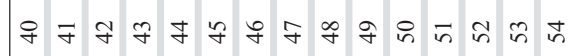

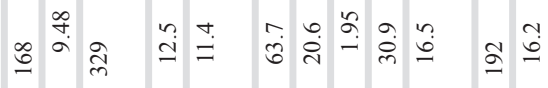

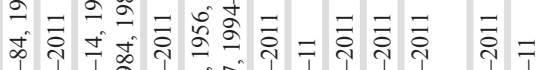

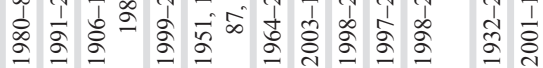

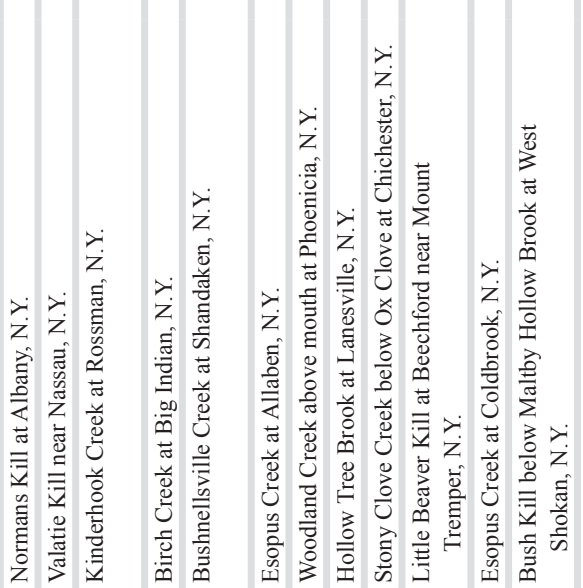

帘过:

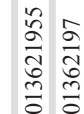

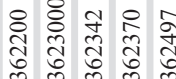

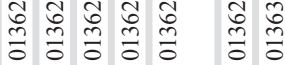

वे

in in
เู่ 


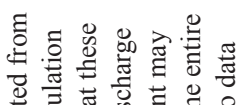

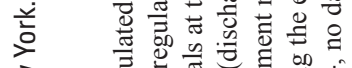

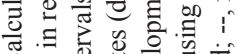

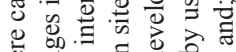

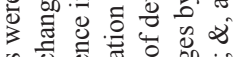

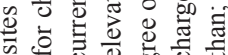

o

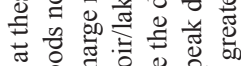

s

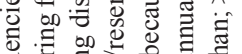

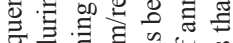

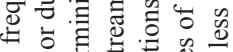

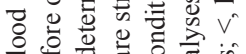

工 0

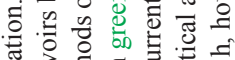

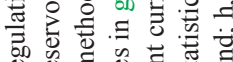

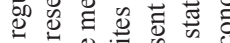

ह

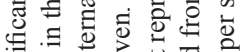

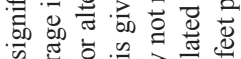

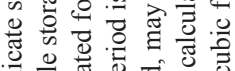

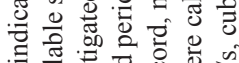

的政

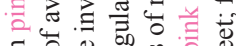

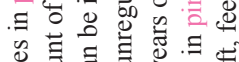

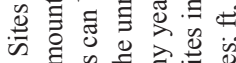

क 즌

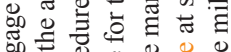

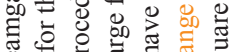

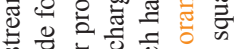

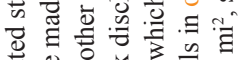

范

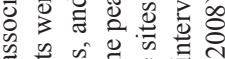

o

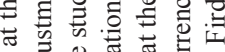

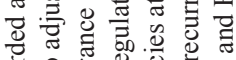

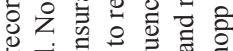

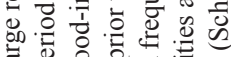

造迸

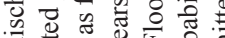

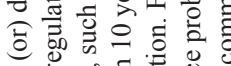

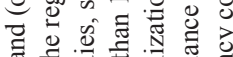

on

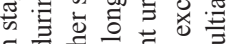

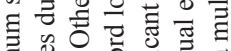

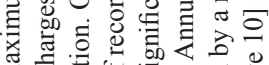

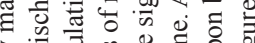

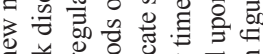

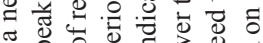

궁

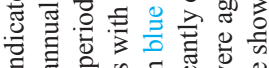

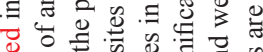

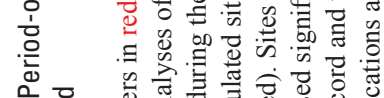

Ф。

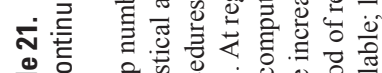

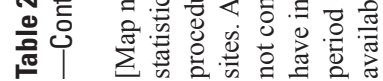

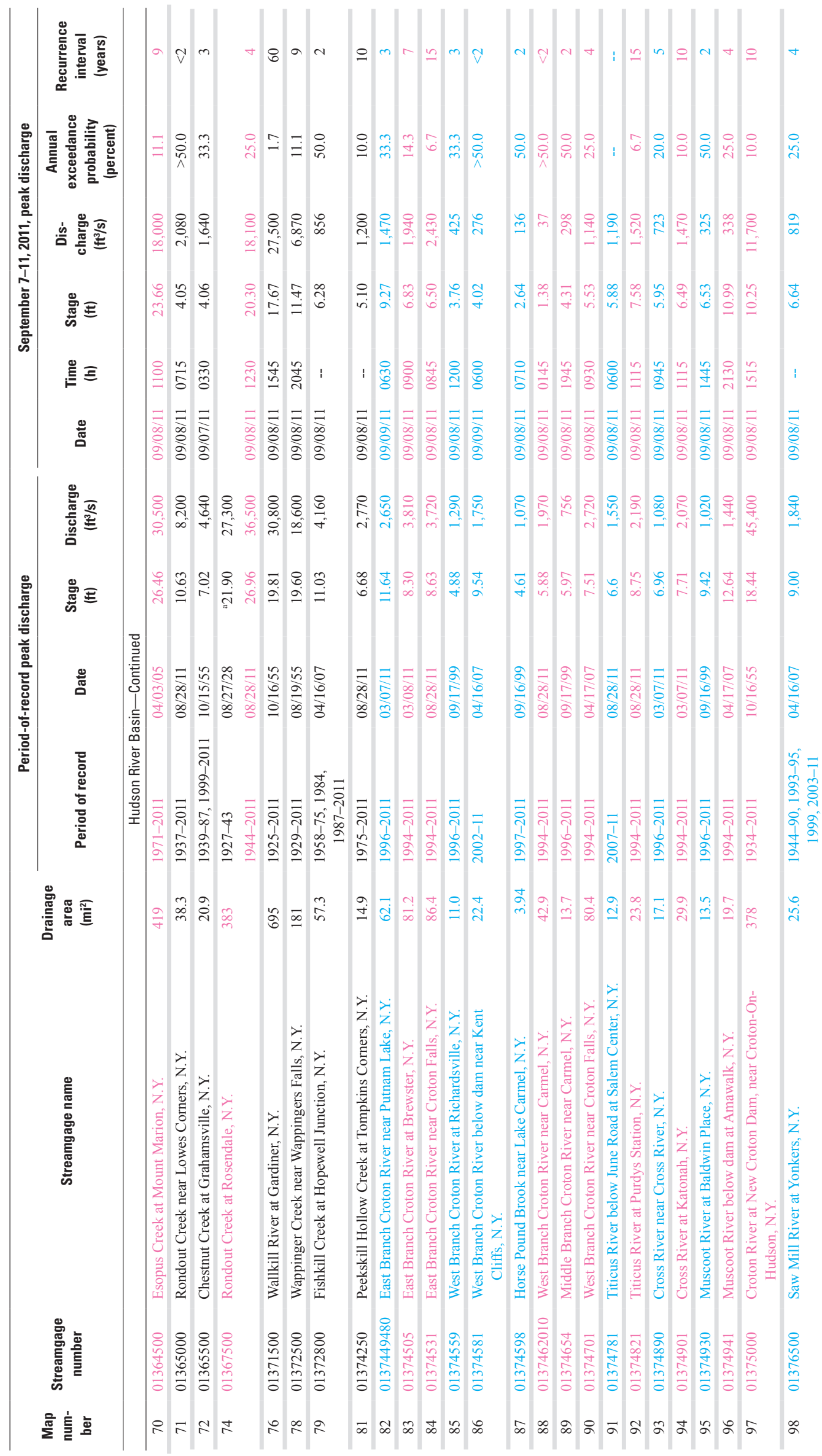


气

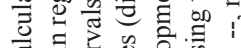

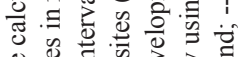

品

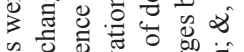

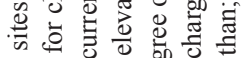

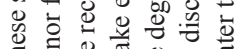

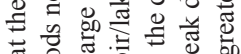

क人

它 on on

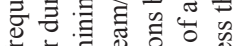

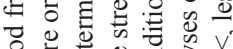

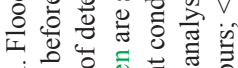

运

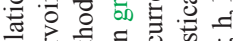

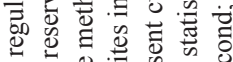

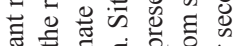

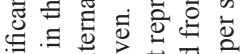

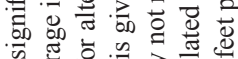

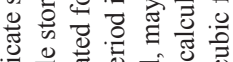

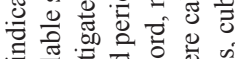

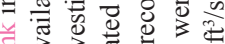

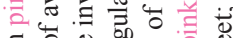

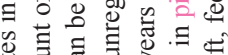

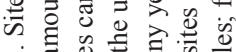

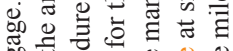

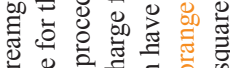

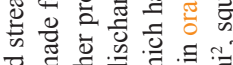

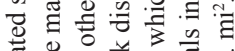

卷

क人

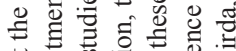

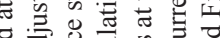

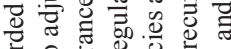

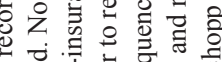

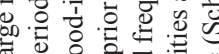

矛边

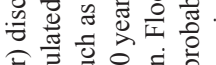

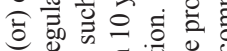

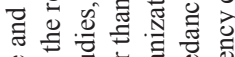

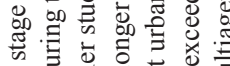

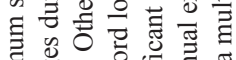

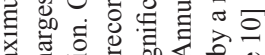

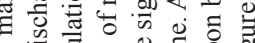

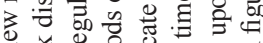

券

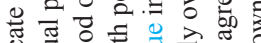

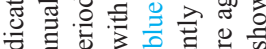

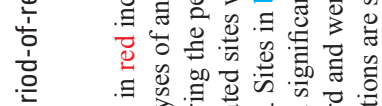

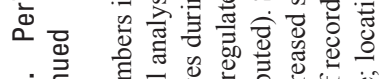

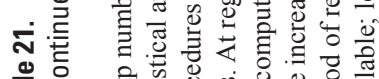

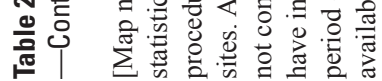

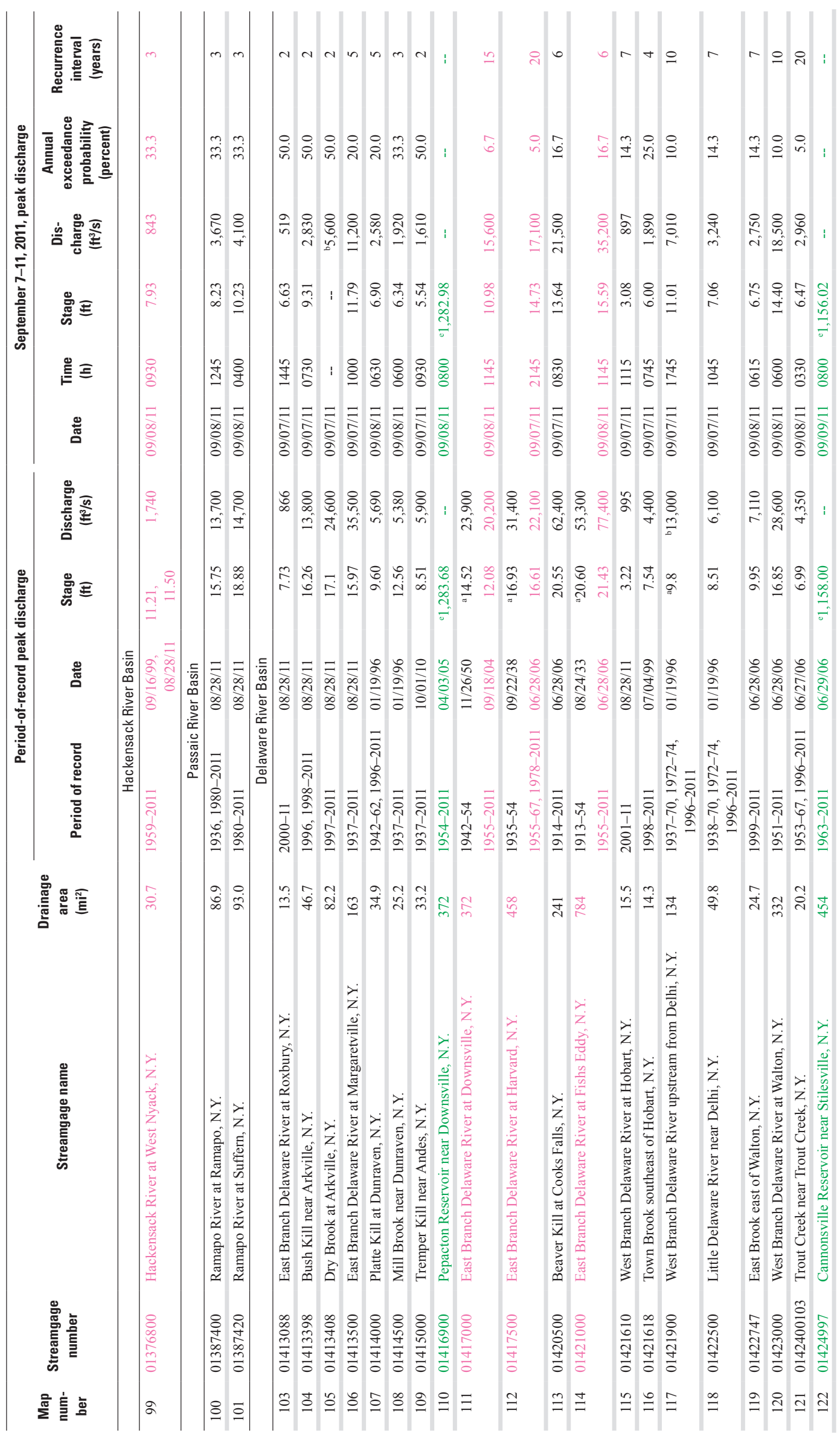




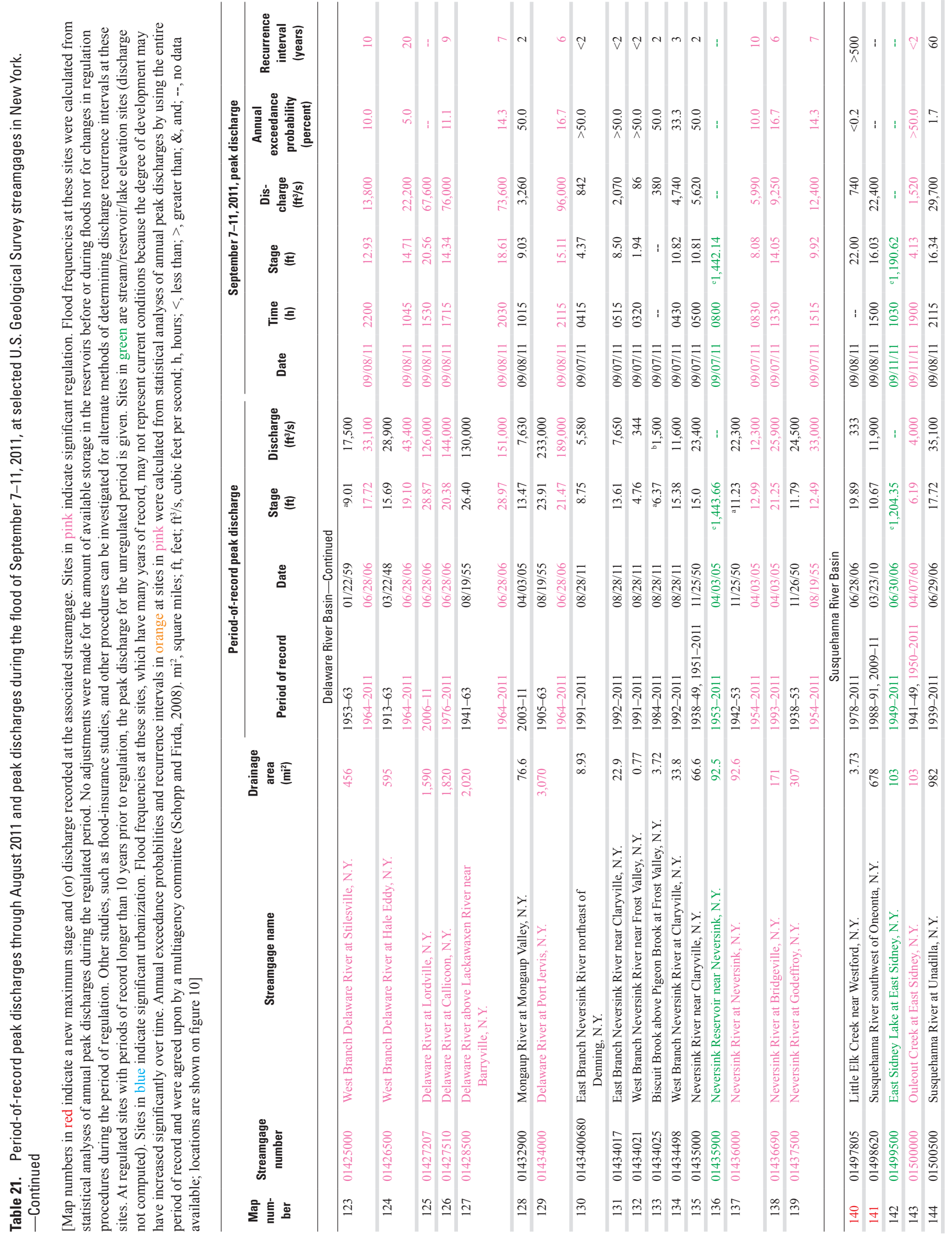




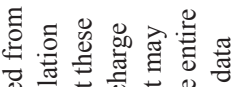

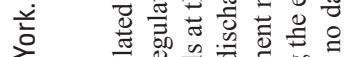

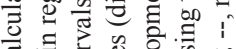

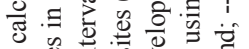

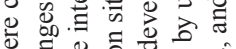

空

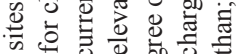

\&

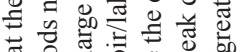

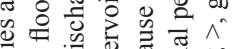

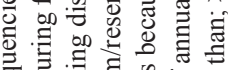

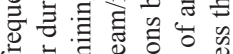

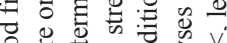

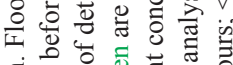

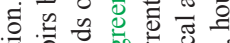

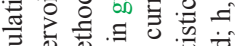

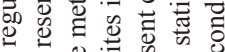

芩记

氙.

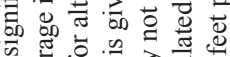

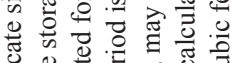

记

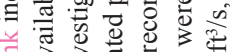

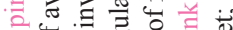

$\exists$ 更

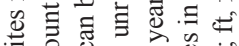

के

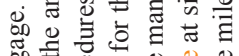

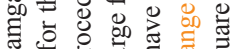

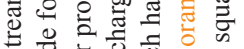

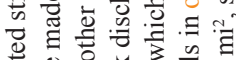

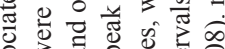

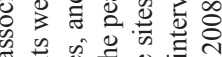

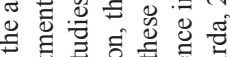

其款.

敢

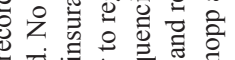

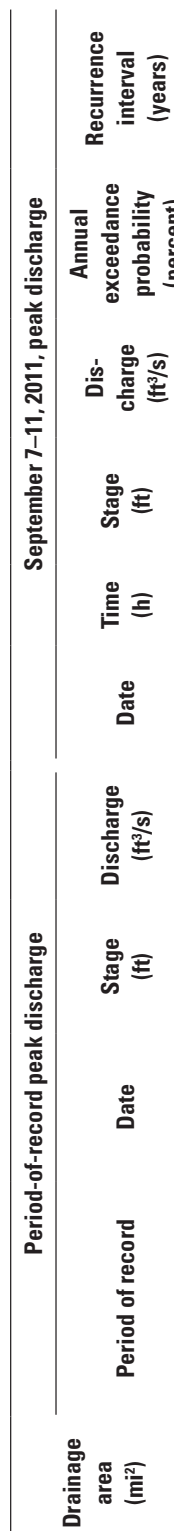

通

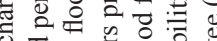

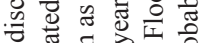

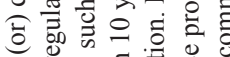

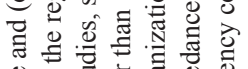

品

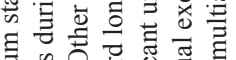

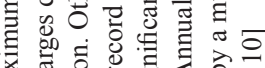

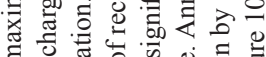

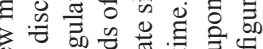

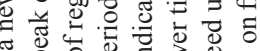

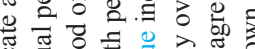

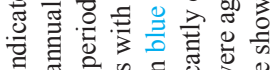

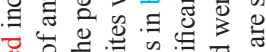

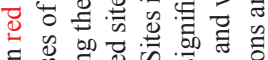

음

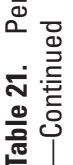

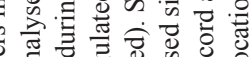

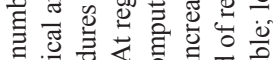

낭

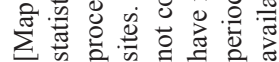

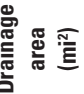
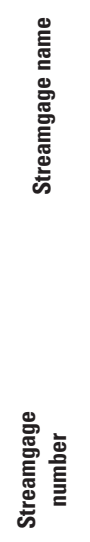

离竞㐫
(1)

$\therefore \circ \frac{1}{8}$

인

- - - $\begin{array}{ccc}n & n \\ i & n \\ i\end{array}$

$\stackrel{\leftrightarrow}{\vec{v}} \stackrel{\leftrightarrow}{\vec{v}}$

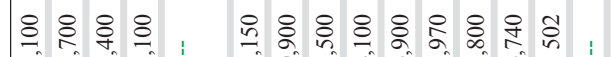

$\overrightarrow{\text { ते }}$ in

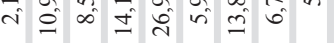

ये

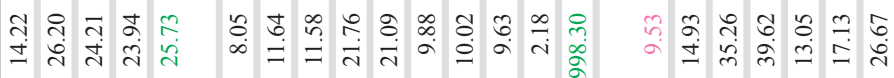

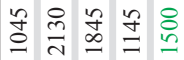

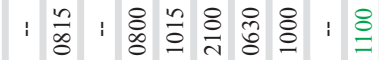

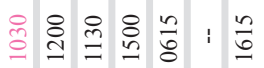

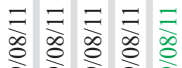

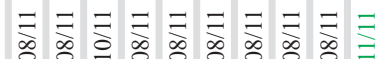

$\underset{\infty}{\vec{\infty}} \underset{\infty}{\vec{\infty}} \underset{\infty}{\vec{\infty}} \underset{\infty}{\vec{\infty}} \underset{\infty}{\vec{\infty}} \underset{\infty}{\vec{\infty}} \vec{\infty}$

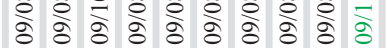

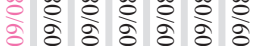

\&:

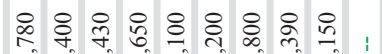

$\frac{8}{6}$

$8: 8 \%:$

तो in in

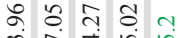

กิ

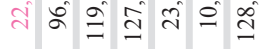

\&:

ఫ

站

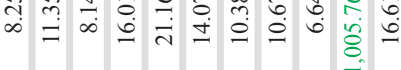

$\stackrel{0}{2}=0$

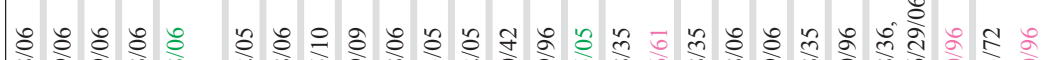

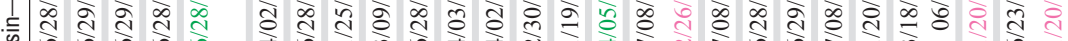

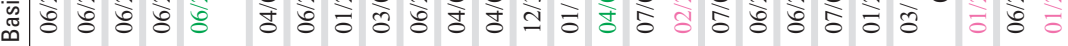

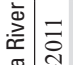

产

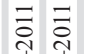

จี

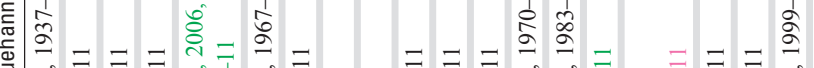

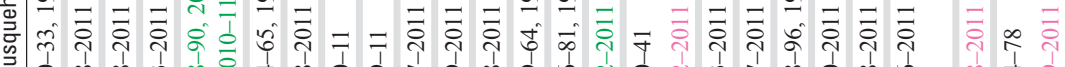

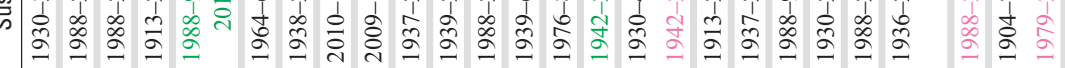

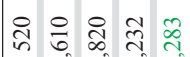

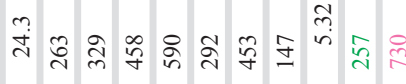

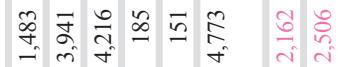

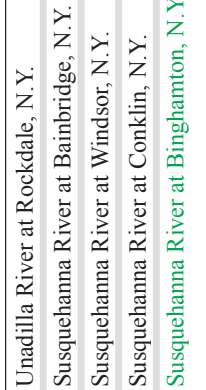

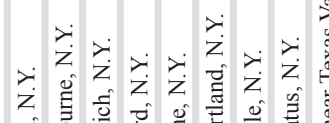

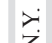

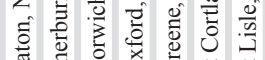

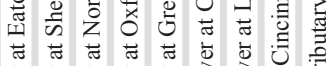

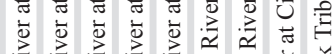

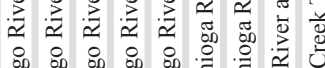

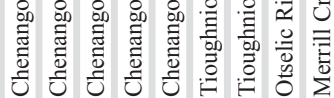

恶部

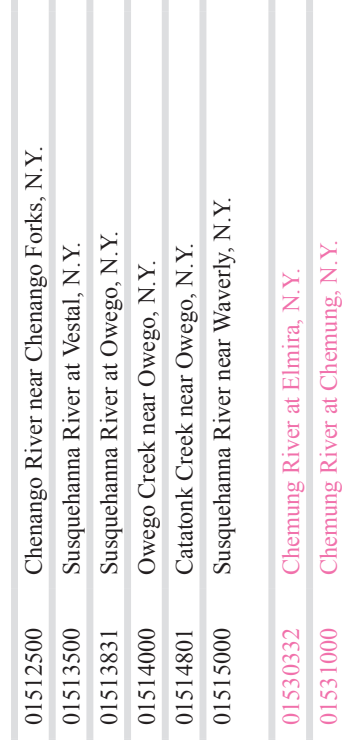

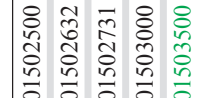

ஓ

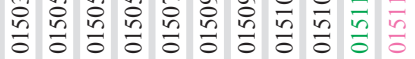

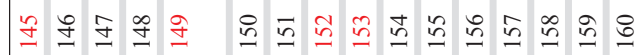

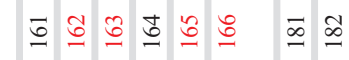




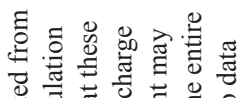

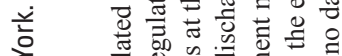

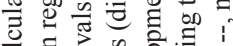

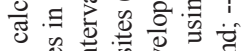

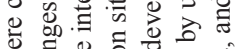

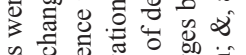

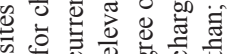

o :

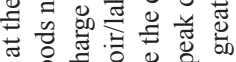

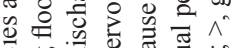

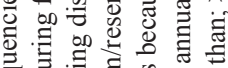

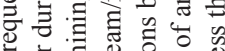

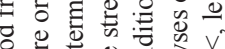

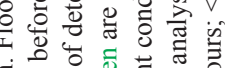

ठี.

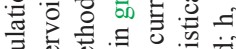

क्ष

氜的范

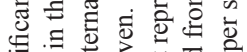

䎡品

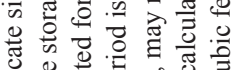

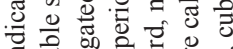

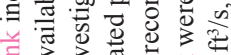

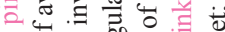

$\exists \circ$ \& 500

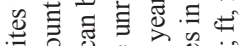

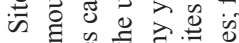

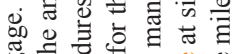

है

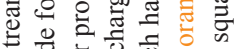

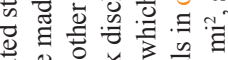

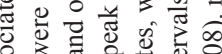

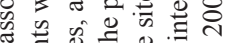

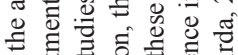

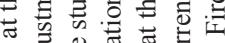

च 肎

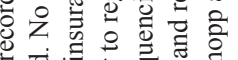

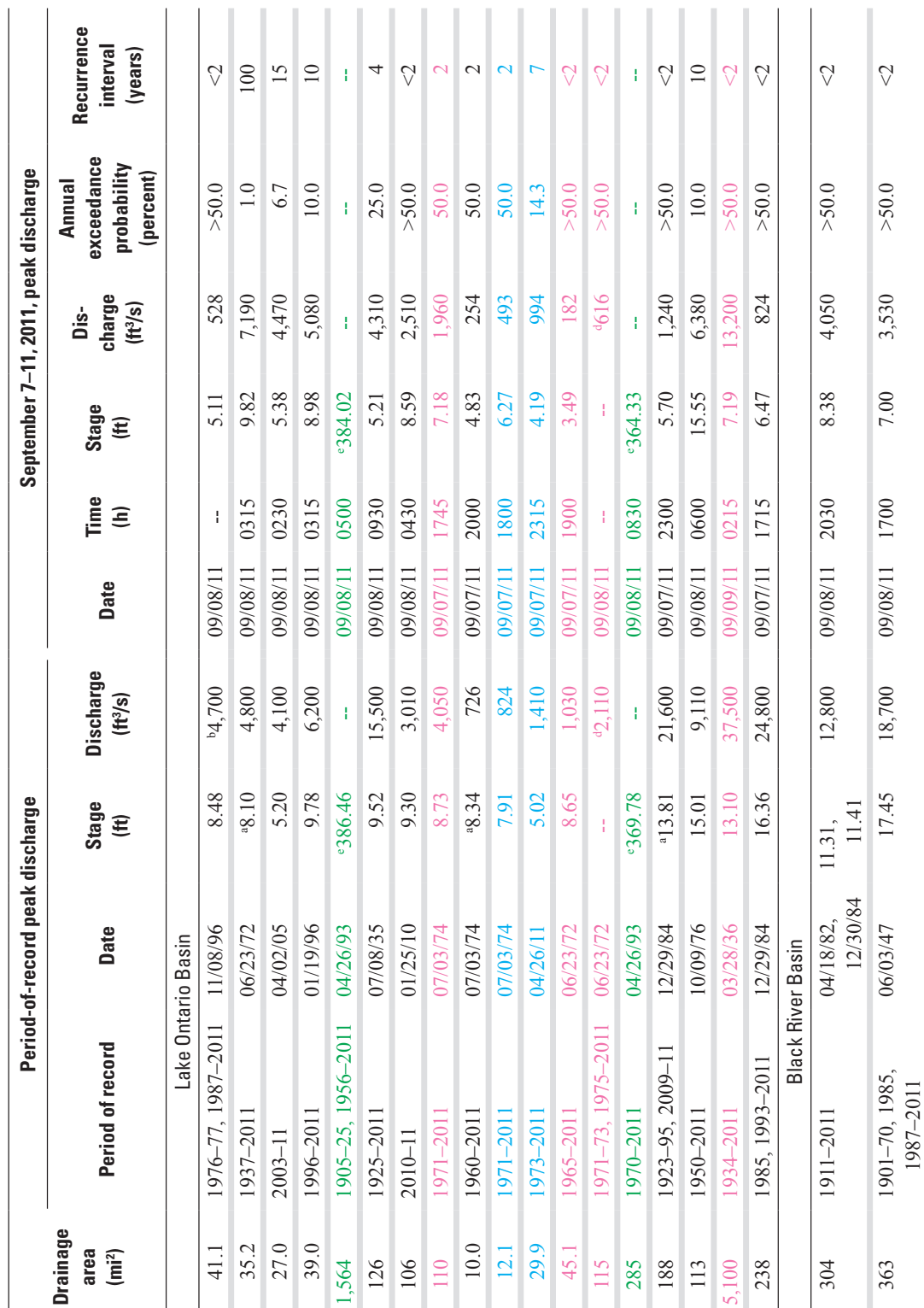

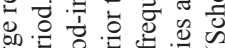

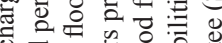

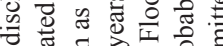

흥

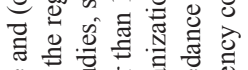

0 on

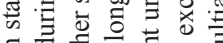

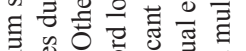

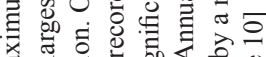

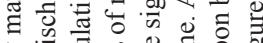

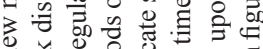

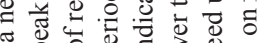

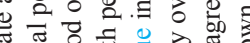

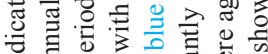

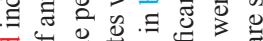

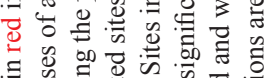

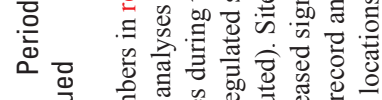

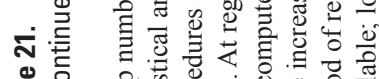

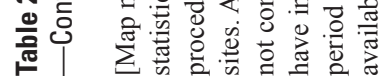

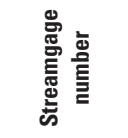

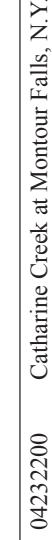

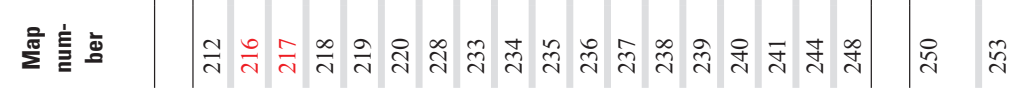

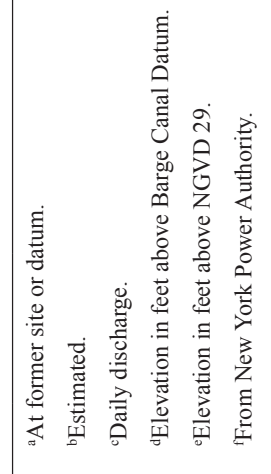




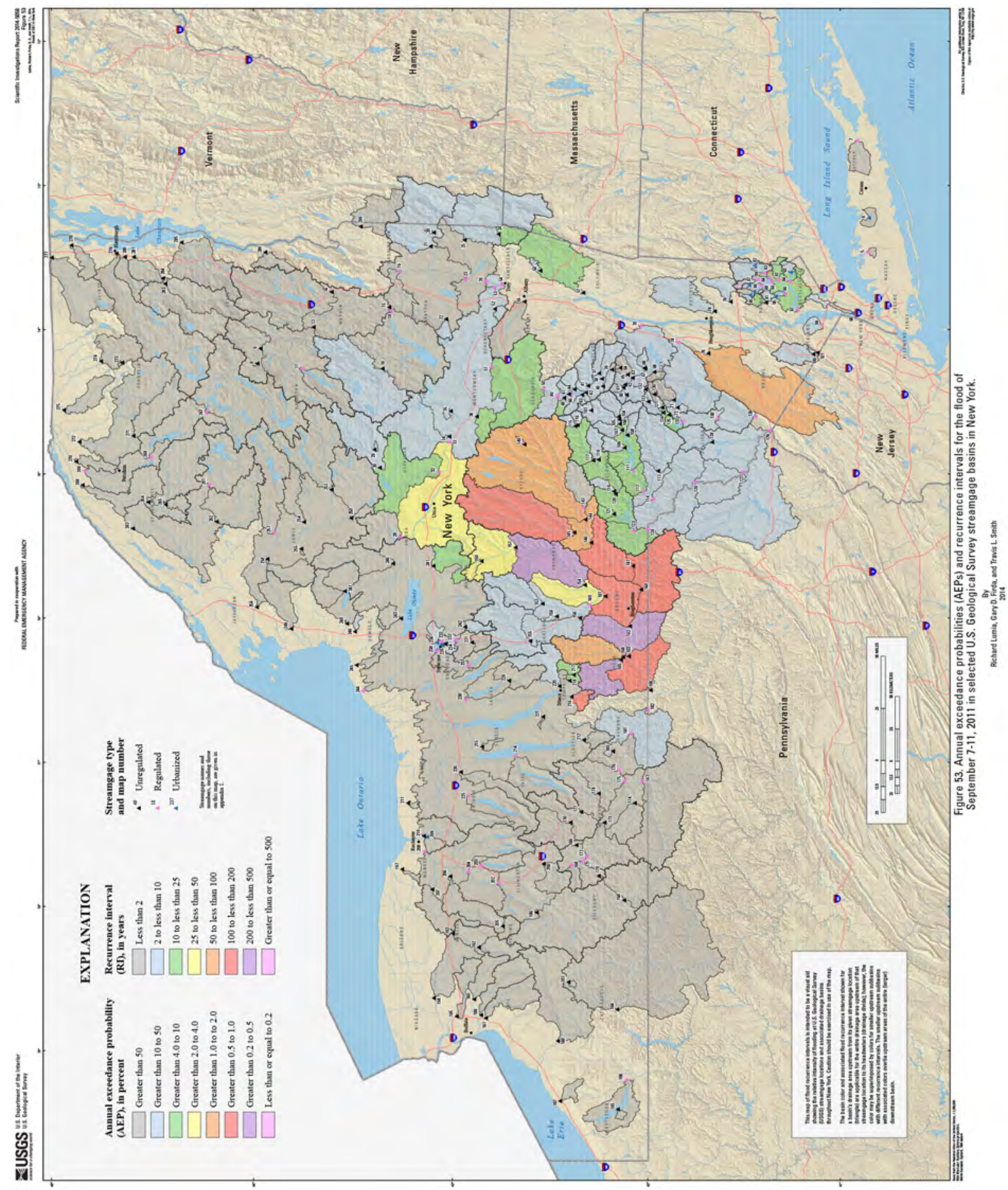

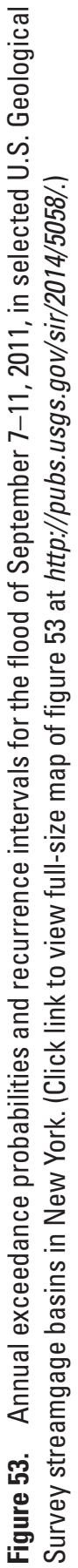




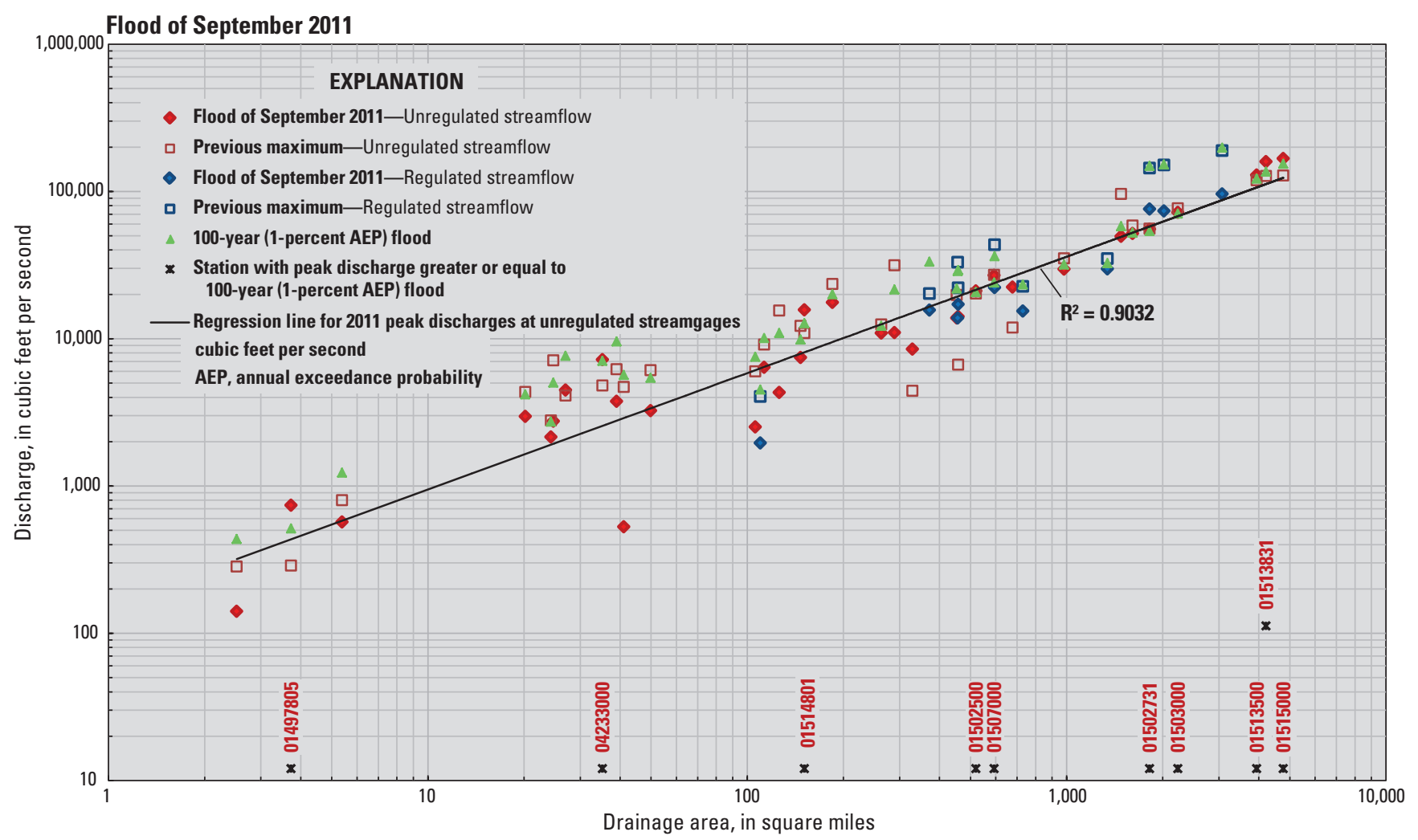

Figure 54. Peak discharges for the flood of September 8-9, 2011, previous maximum known discharges, and 1-percent annual exceedance probability (100-year) discharges at selected streamgages as a function of drainage area in New York. (Sites are listed in appendix 1 and shown on figure 10.)

Flood AEP flows computed for first 10 years of record (1935-44) for the Susquehanna River at Vestal (01513500) streamgage and recomputed for each additional year of record through 2011 (the maximum discharge for the year occurred on September 8) illustrate the effects of individual annual peak discharges on the magnitudes of the AEP flows over time (fig. 58). The 10-year moving average and trend line for the moving 100-year (1-percent AEP) flood-frequency discharges indicate a slightly downward trend at Vestal over its entire 77 -year period of record, but the 10-year moving average of the 100-year moving frequency curve indicates a slightly upward trend over the past 25 years.

Discharge hydrographs for selected streamgages throughout the flooded areas for September 5-11, 2011, compare the magnitudes, relative frequencies, and timings of flows during September 5-11, 2011 (figs. 59A-L). Some unit (15-minute) discharge data are missing because of equipment malfunction or damage to the streamgage housing the equipment. Discharges at seven streamgages on the Susquehanna River (figs. 59A-C) peaked near or above their respective 1-percent AEP (100-year) discharges on September 8 with consistent hydrograph shape and timing. The Chenango River (figs. 59D-E) enters the Susquehanna
River just upstream from Vestal, and peak flows coincided with those along the main stem of the Susquehanna River.

The remnants of Tropical Storm Lee produced the third flood along the Mohawk River in 2011. The flows from the headwaters of the Mohawk River below Delta Dam near Rome (01336000) were minor during Tropical Storm Lee, but inflows from West Canada Creek (01346000) and other tributaries increased flows at Little Falls (01347000) to the 35-year (2.8-percent AEP) flood (fig. 59F). Because inflows from East Canada Creek (01348000), Schoharie Creek (01351500), and the upper Hudson River were minor, downstream flooding remained less than the 10-percent AEP (10-year) flood at the Mohawk River at Cohoes (01357500) and the Hudson River at Green Island (01358000) streamgages (figs. 59G-I).

Discharge hydrographs for selected streamgages in the Susquehanna River Basin for September 5-11, 2011, and for previous floods during 2005-06 compare flow magnitude and frequency, hydrograph shape, and antecedent conditions (figs. 60A-F). The peak discharges for previous floods were overlaid on that for the September flood to allow hydrographshape comparisons, which are similar except for the much higher base flows prior to the April 2005 flood (figs. 60C-E). Discharge hydrographs for the Mohawk River at Little Falls 


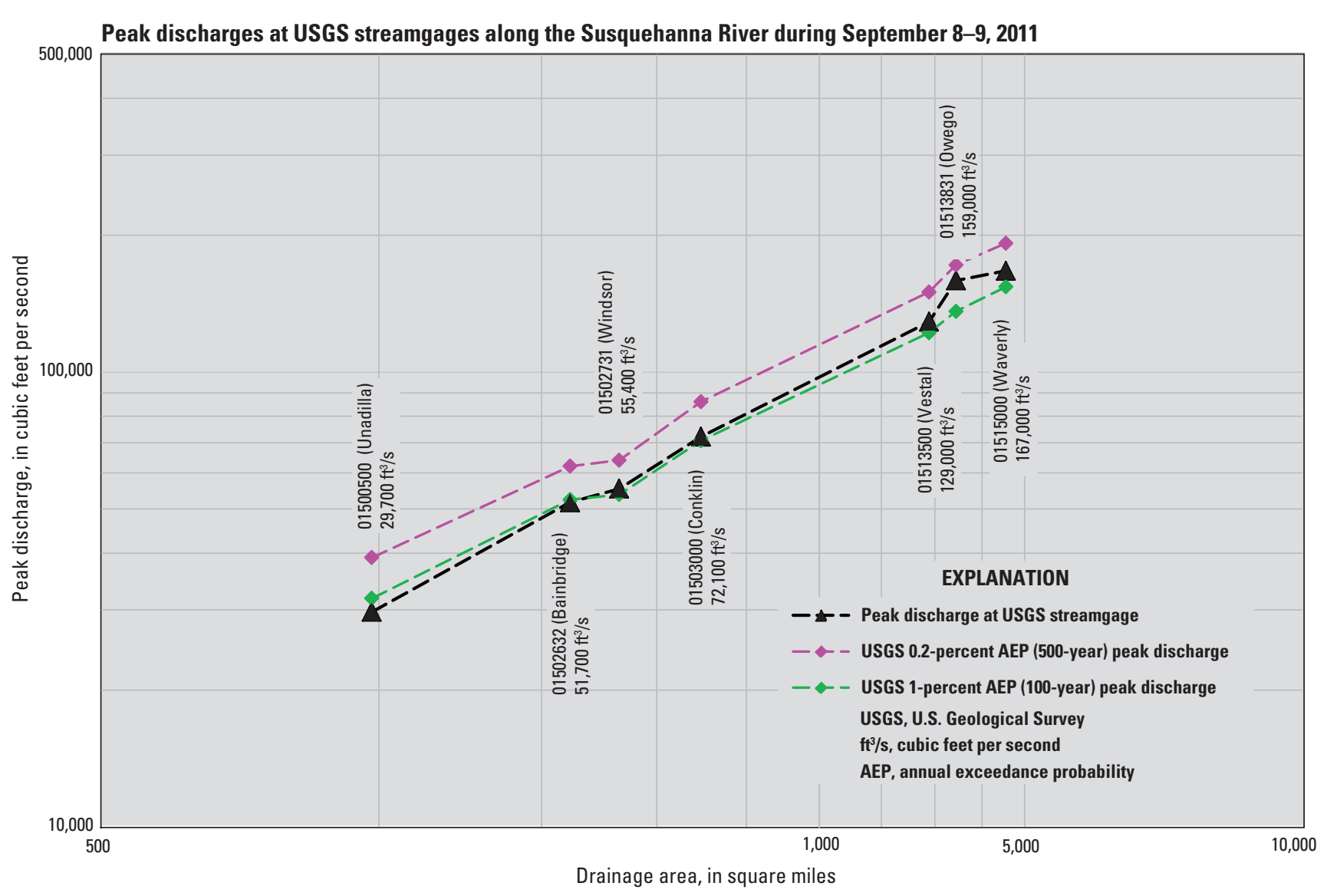

Figure 55. Peak discharges for the flood of September 8-9, 2011, and 1- and 0.2-percent annual exceedance probability (100- and 500 -year) discharges at seven U.S. Geological Survey streamgages on the Susquehanna River as a function of drainage area in New York. (Sites are listed in appendix 1 and shown on figure 10.)

(01347000) and at Cohoes (01357500) (figs. 60G-I) are much wider for the spring floods of April 2011 and March 1977 because snowmelt sustained high base flows prior to the maximum discharge. The September 2011 hydrographs also indicate high antecedent flows as a result of runoffs from Tropical Storm Irene a week earlier. As discussed earlier, an additional 1-percent AEP (100-year) discharge at Cohoes is included to reflect the adjustment of annual peaks for releases from upstream ice jams (fig. 60I): the March 1964 peak flow (which was greater than the 1-percent AEP or 100-year discharge) would have been closer to the 10-percent AEP (10-year) discharge if not for the surge of water from the upstream ice-jam release.

Stage-frequency hydrographs for five selected streamgages in the Susquehanna River Basin indicate that stream stage at Susquehanna River at Conklin (01503000) rose nearly $16 \mathrm{ft}$ in about 30 hours during September 7-8 and remained above the 1-percent AEP (100-year) flood stage for about 12 hours and above the 2-percent AEP (50year) stage for about 26 hours (fig. 61A). The stage at the Conklin streamgage remained above the NWS flood stage for nearly 5 days. The stages at the Susquehanna River at Vestal
(01513500) (fig. 61D) and near Waverly (01515000) (fig. 61E) peaked at or near their 0.5-percent AEPs (200-year) stage, and the water levels rose 25.5 and $20.6 \mathrm{ft}$., respectively, in about 30 hours.

\section{Flood Profiles of the Susquehanna River}

The severe flooding along the Susquehanna River prompted a more detailed evaluation of the flood stages throughout the length of its reach. The elevations of $20 \mathrm{HWMs}$ were surveyed at 18 sites along a 114-mi reach of the Susquehanna River (fig. 62) from Unadilla, N.Y., to Athens, Pennsylvania (just south of the New York-Pennsylvania border) to enable the documentation and evaluation of the extent and severity of the September 2011 flood. The HWMs were surveyed where marks had previously been documented following the June 2006 flood (Suro and others, 2009). Descriptions of the HWMs from the September 2011 and June 2006 floods, FEMA AEP water-surface elevations, and other pertinent information are summarized in table 22; a map showing the locations of the HWM sites in the Susquehanna River Basin is given on figure 63. 

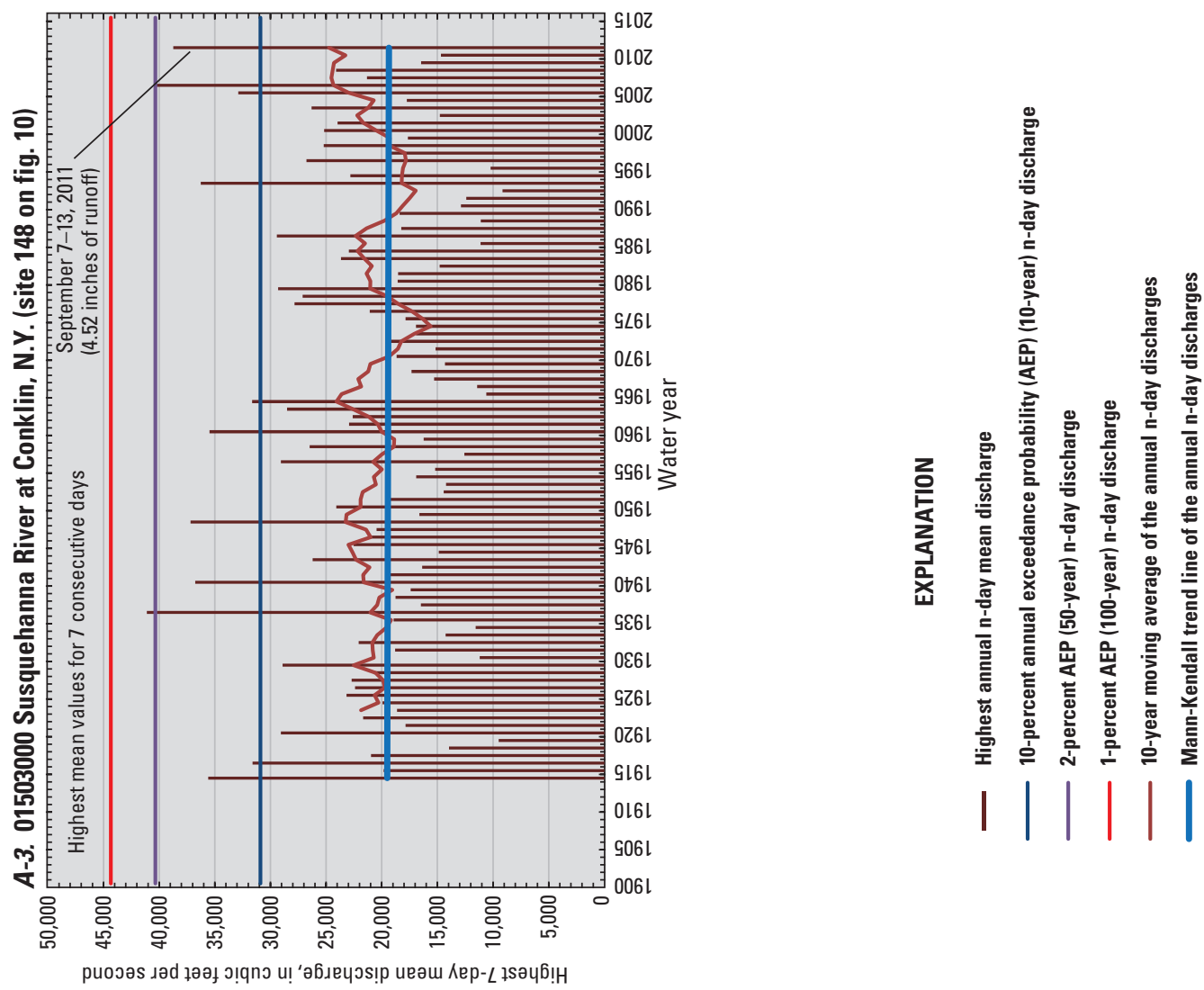

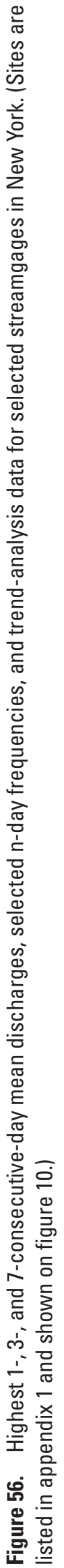
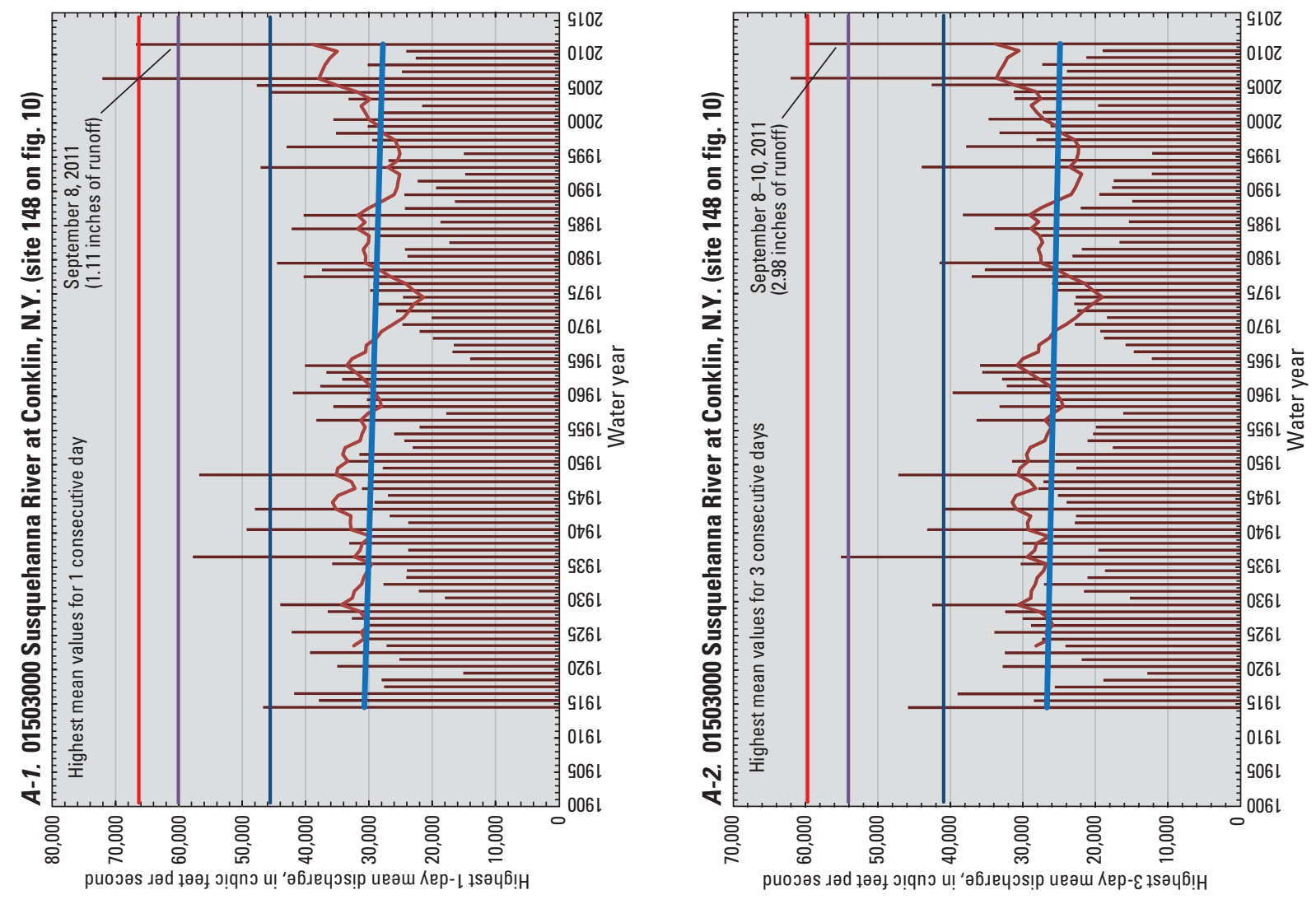

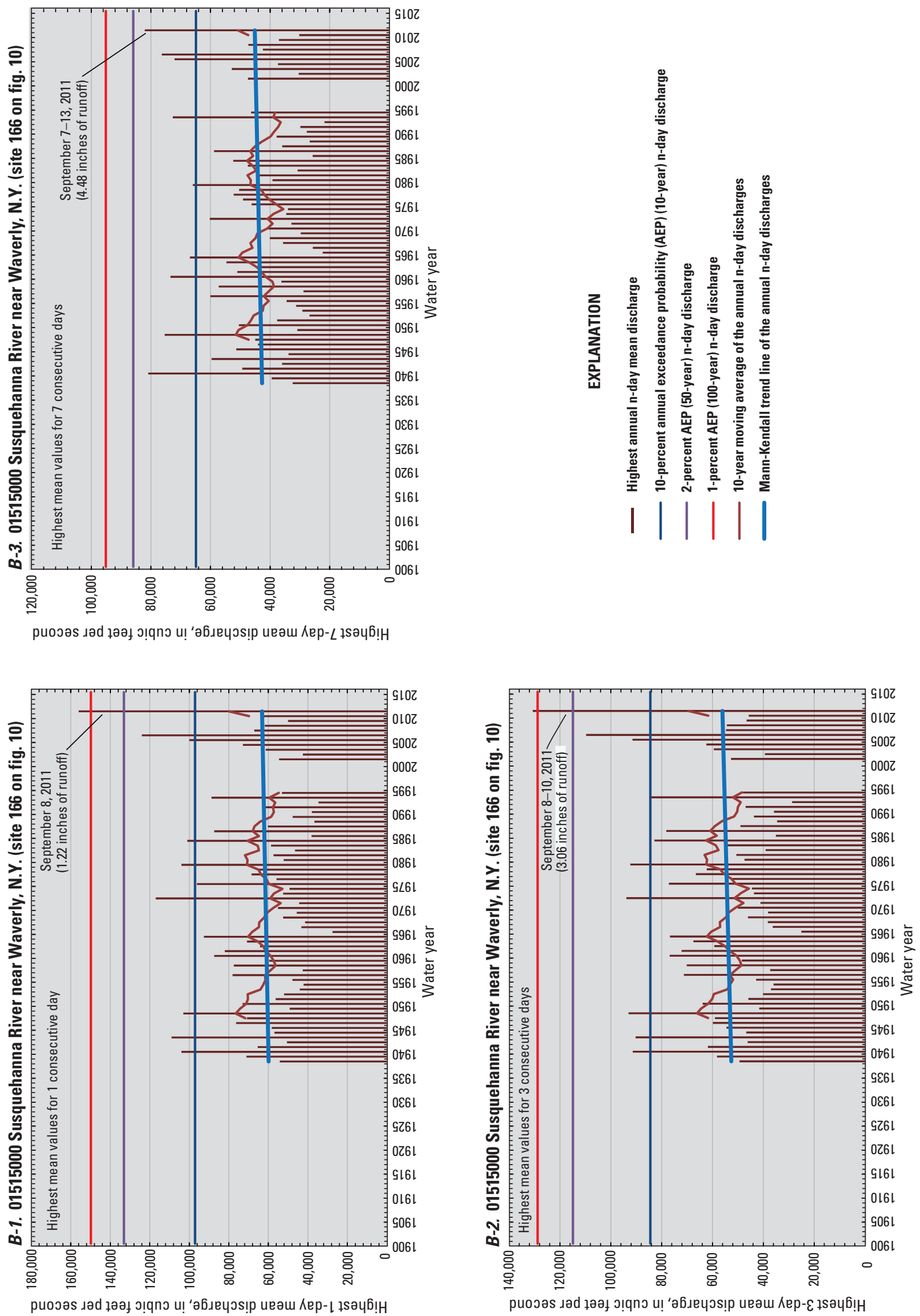

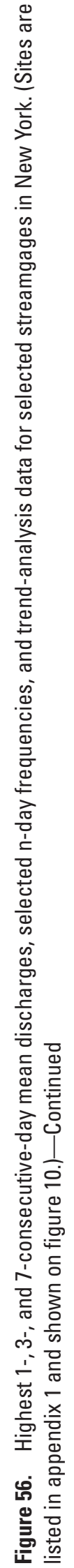



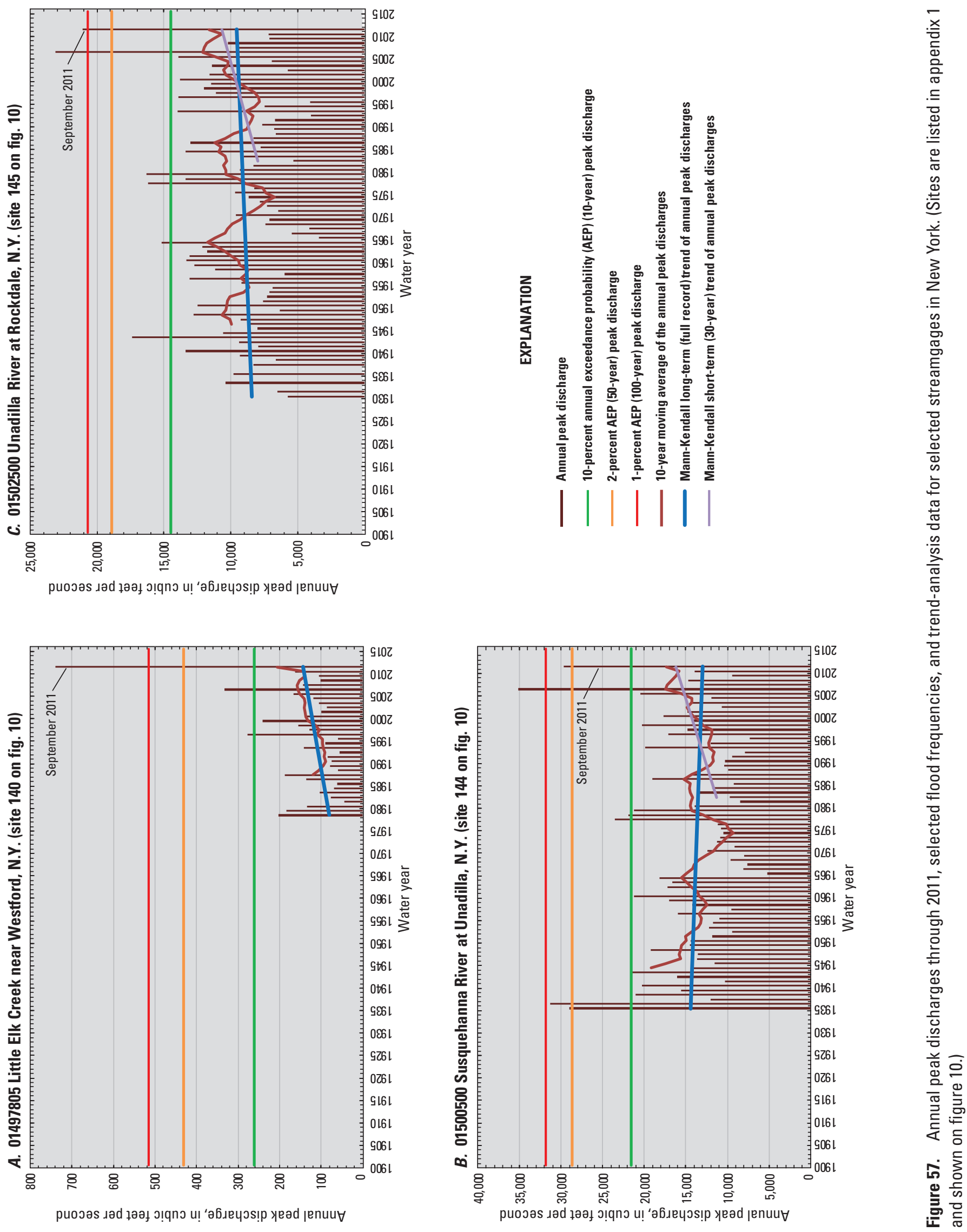

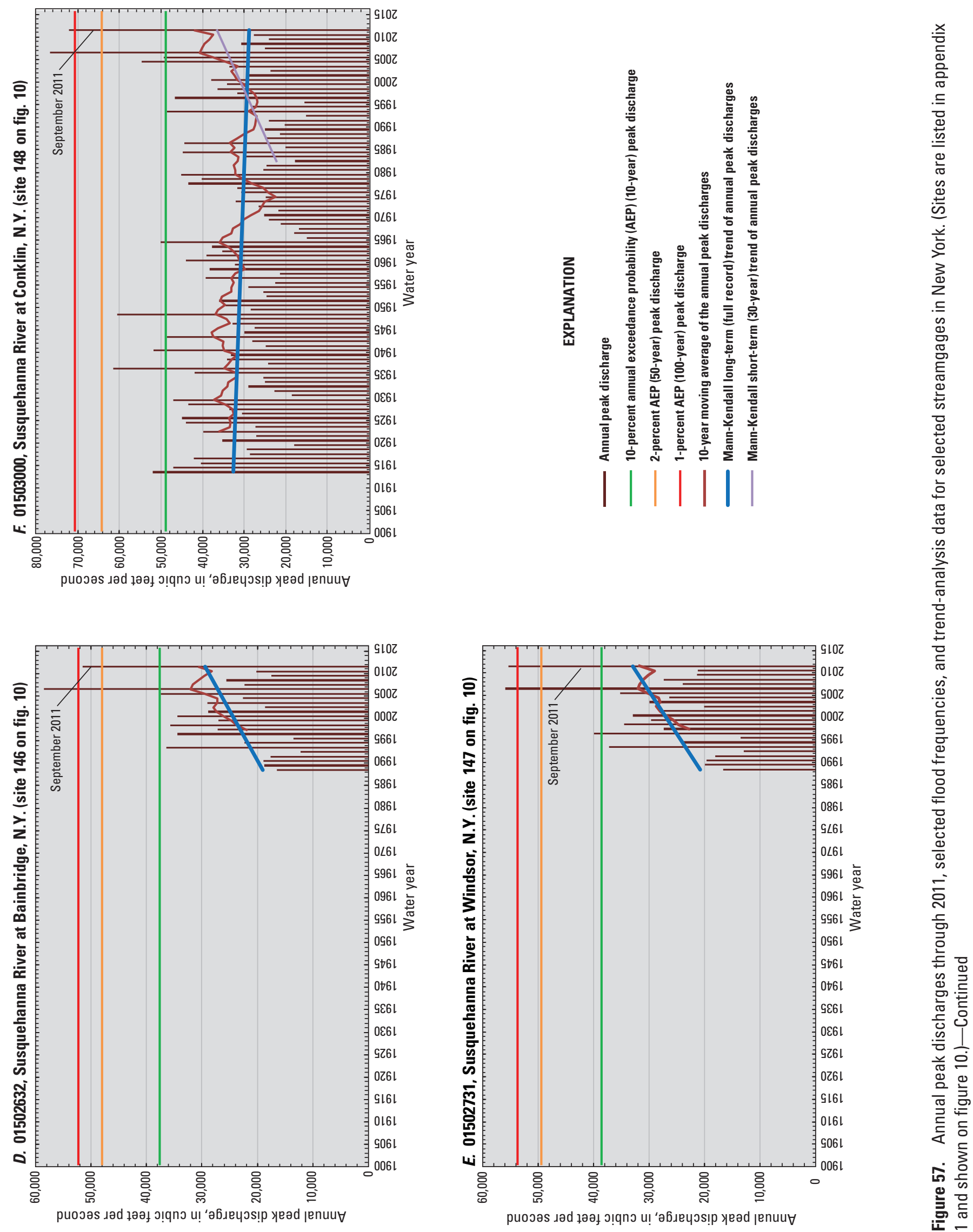

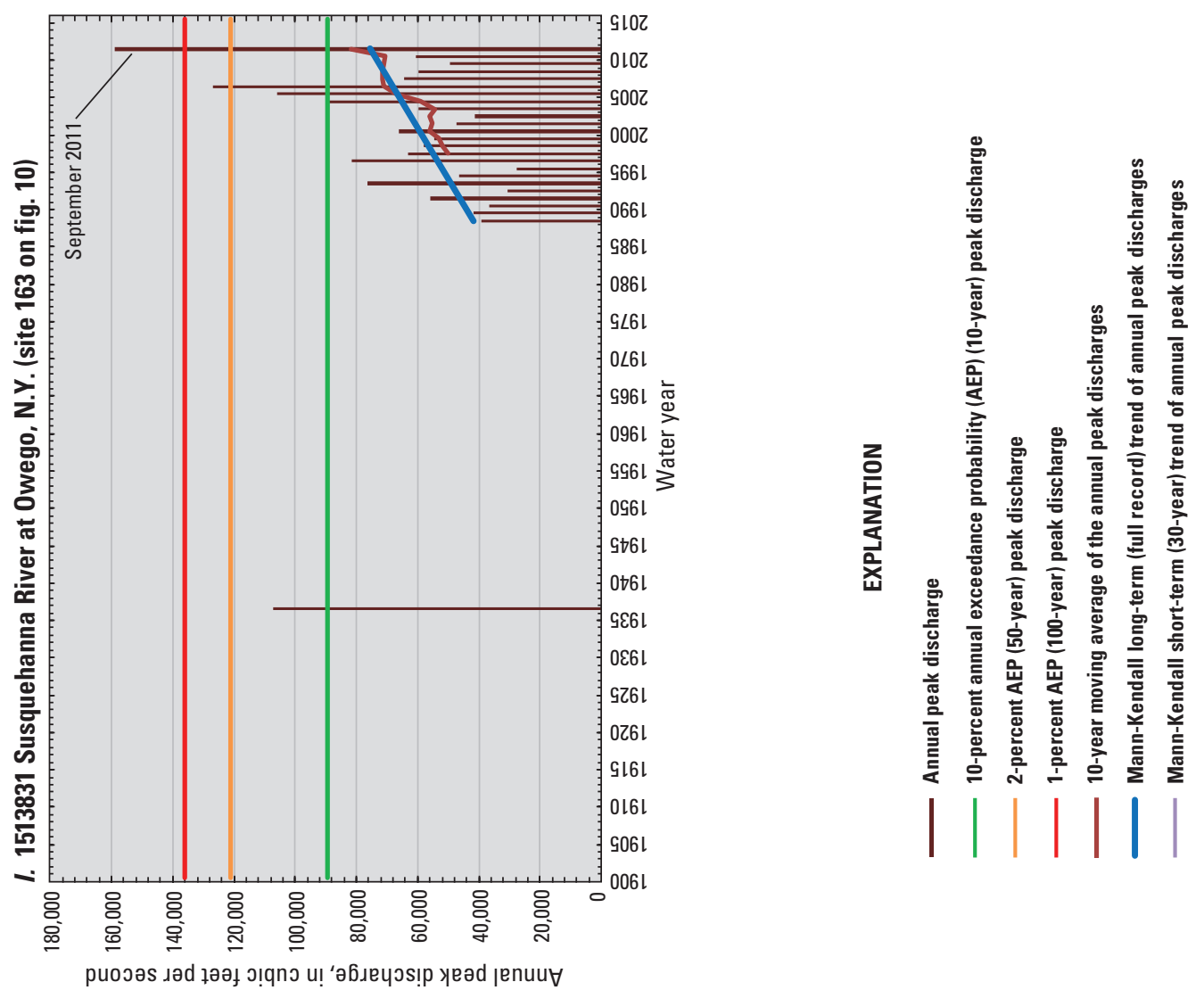

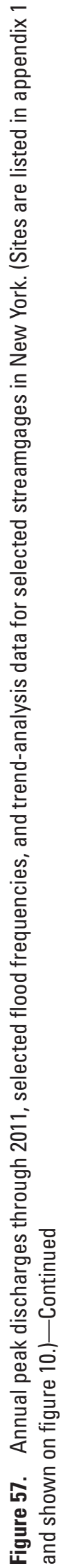
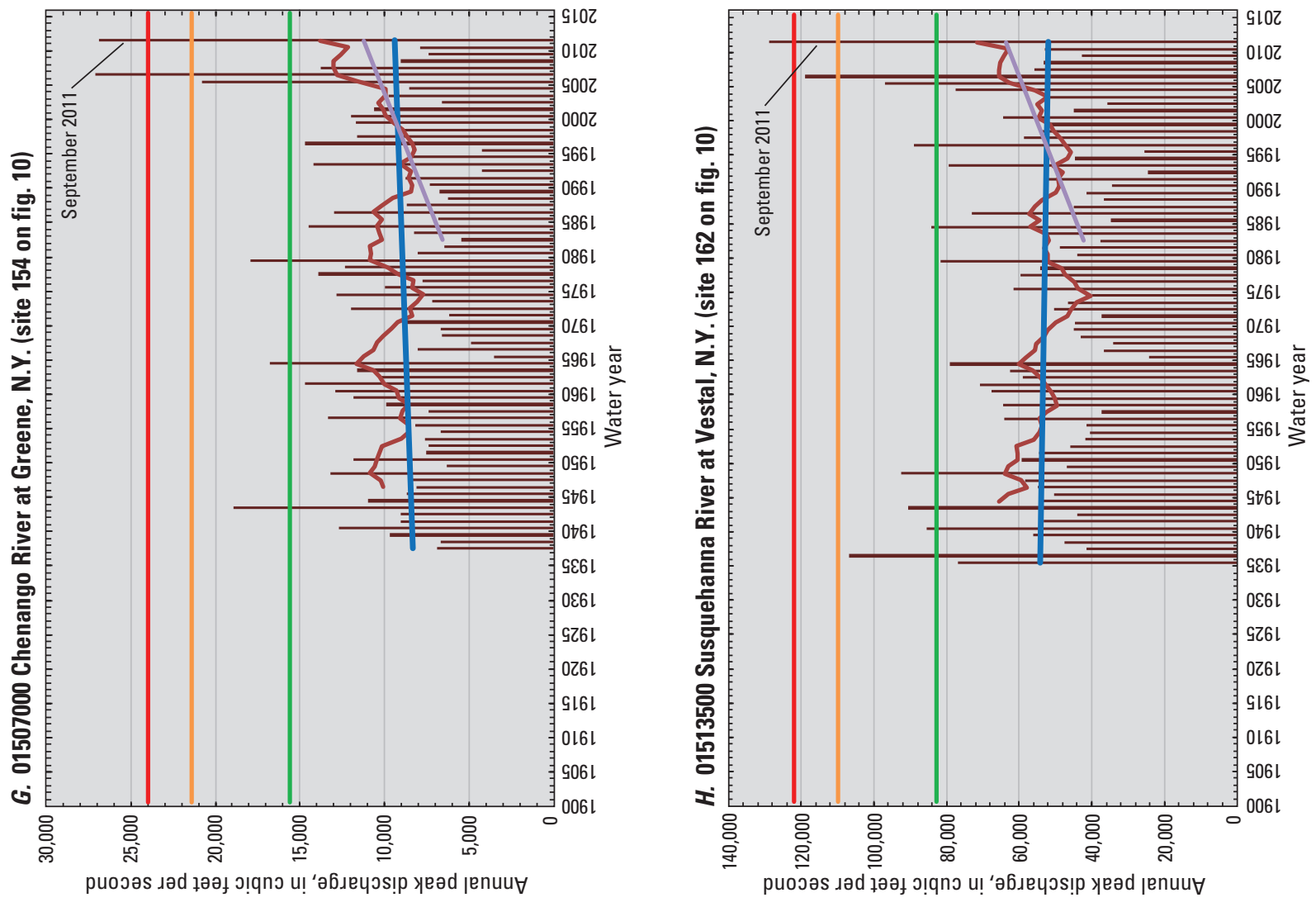

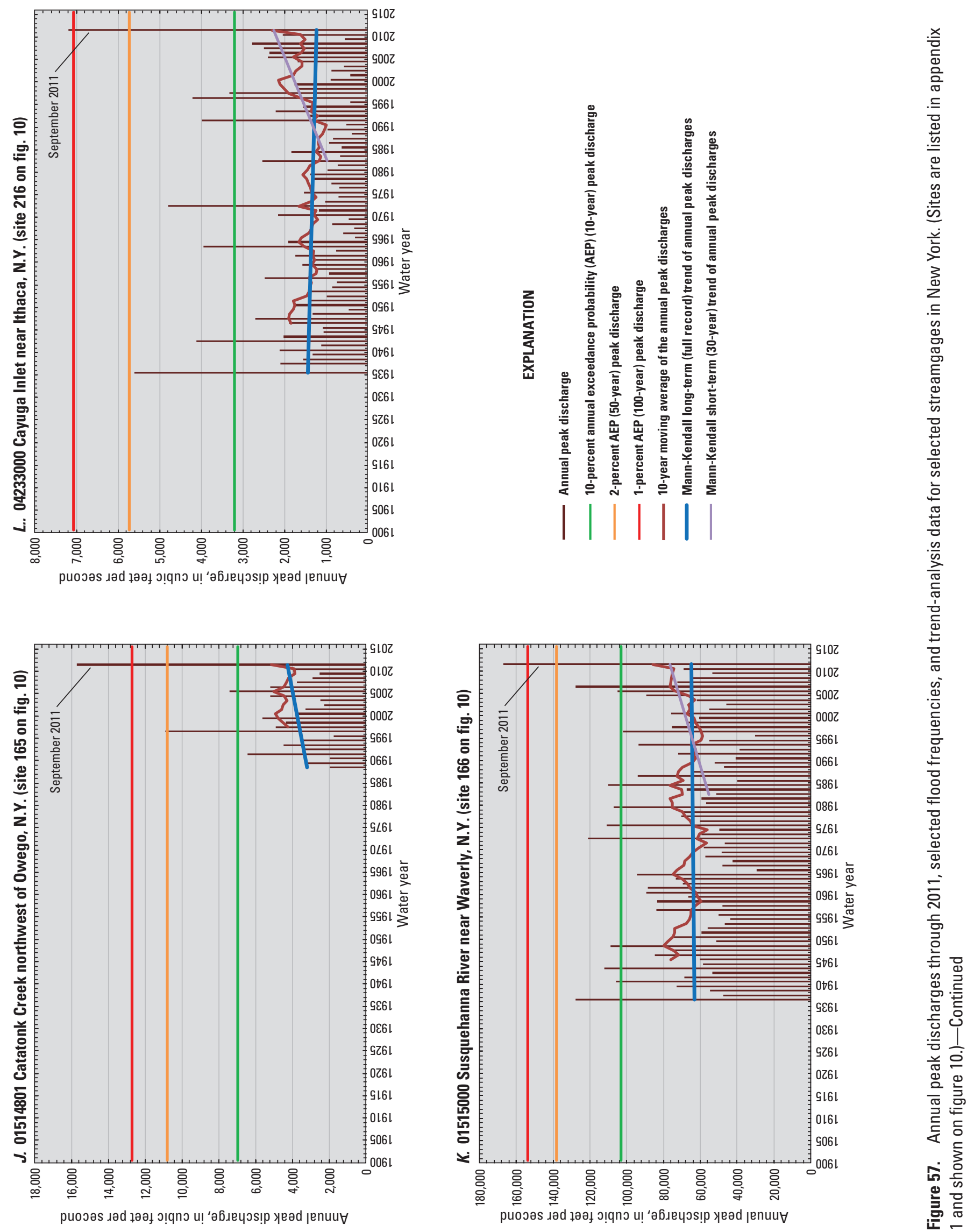
01513500 Susquehanna River at Vestal, N.Y. (site 162 on fig. 10)
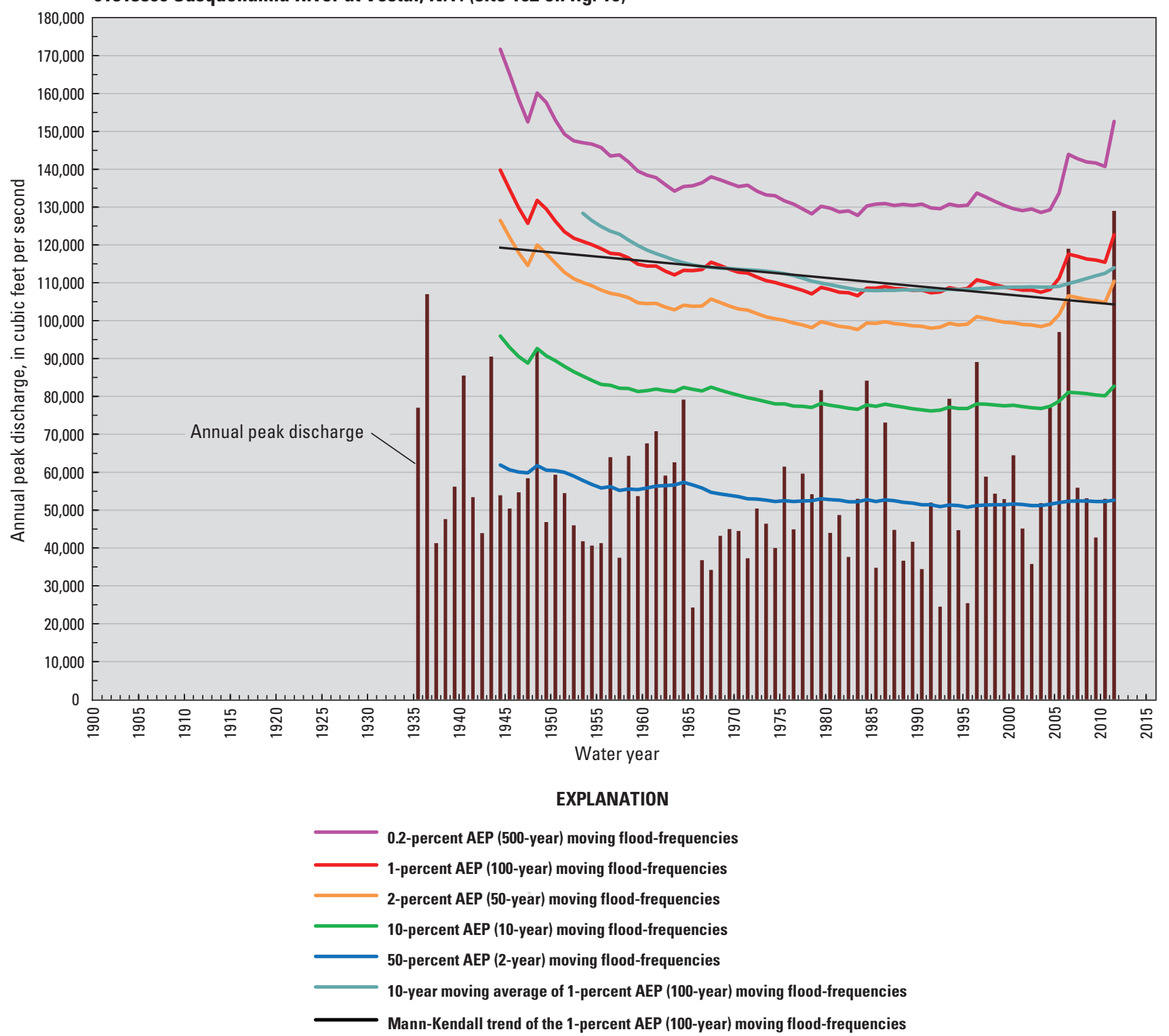

Figure 58. Annual peak discharges, moving flood frequencies, and trends of the moving 1-percent annual exceedance probability (AEP) (100-year) discharges through 2011 at the Susquehanna River at Vestal, New York streamgage. (Site is listed in appendix 1 and shown on figure 10.)

Peak water-surface elevations for the September 2011 and June 2006 floods on the Susquehanna River were compared with flood-profile elevations (10-, 50-, 100-, and 500-year) published in FEMA flood-insurance studies (Federal Emergency Management Agency, 1976a, b, 1977, 1979, 1987, 1988, 1992, 1998, 2010, 2012b) (table 22 and fig. 64). The elevations of the HWMs relative to NAVD 88 indicate that the September 2011 flood elevations along the Susquehanna River were lower than those during 2006 in the upper reaches (Unadilla to Conklin, figs. 64A-E) by as much as $1.38 \mathrm{ft}$ (Unadilla). Flood elevations downstream from Binghamton, N.Y. to Athens, Pa. (figs. 64F-R), however, were higher in 2011 than 2006 by as much as $4.41 \mathrm{ft}$ (in the town of Nichols in Tioga County). The September 2011 HWMs in upstream study areas indicated elevations that ranged from less than the FEMA 2-percent AEP (50-year) elevation (at Bainbridge, fig. 64B) to $1.3 \mathrm{ft}$ higher than the FEMA 0.2-percent AEP (500-year) elevation (at Windsor and Conklin, figs. 64C-D). Farther downstream, the September 2011 elevations were as much as $4.55 \mathrm{ft}$ higher than the FEMA 1-percent AEP (100-year) flood elevations from Binghamton to Tioga (figs. 64G-N) and exceeded the FEMA 0.2-percent AEP (500-year) elevations by as much as $1.45 \mathrm{ft}$ (site 15 at Nichols, fig. 64O). No additional elevations of HWMs along the Susquehanna River were surveyed by the USGS or other agencies. 

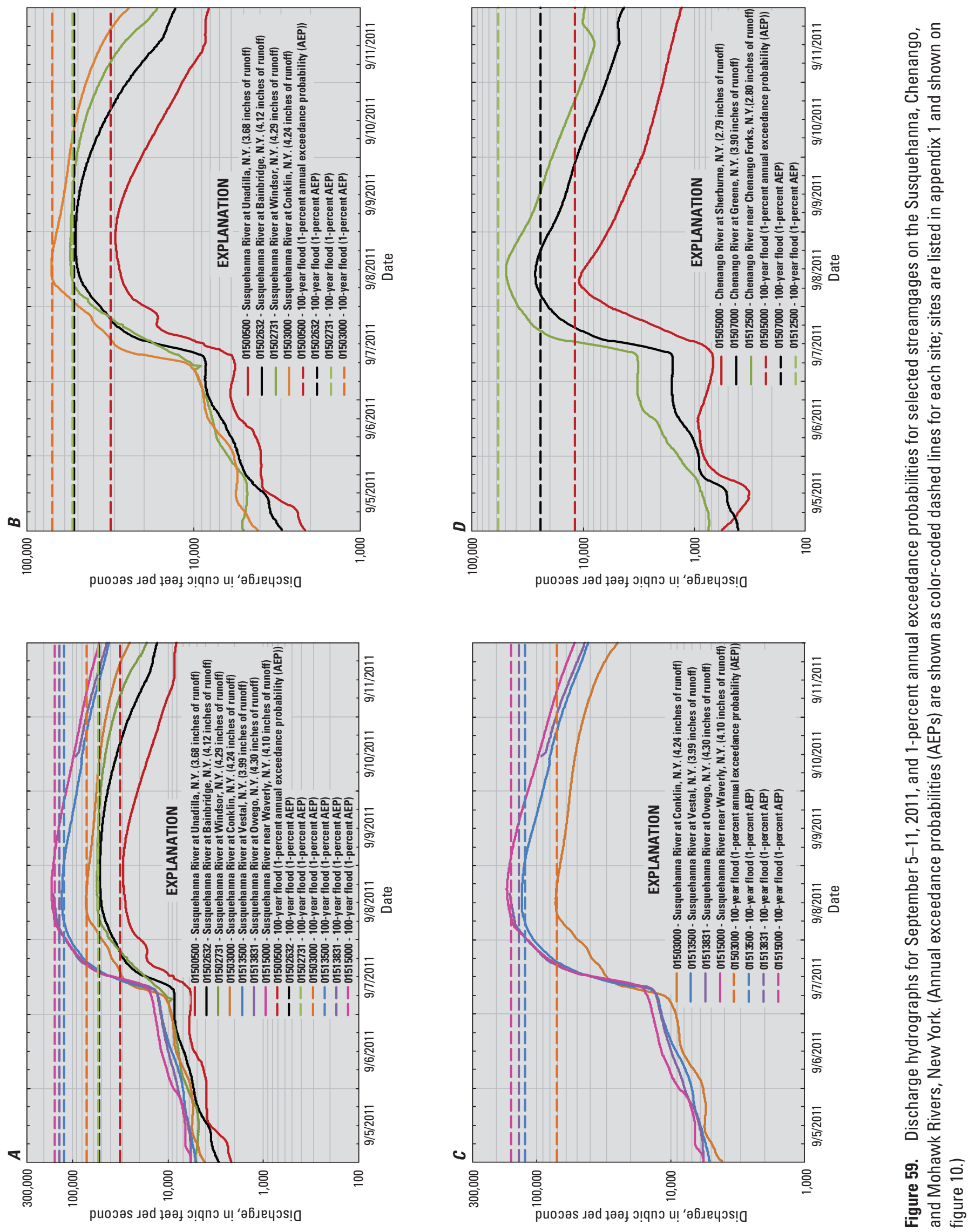

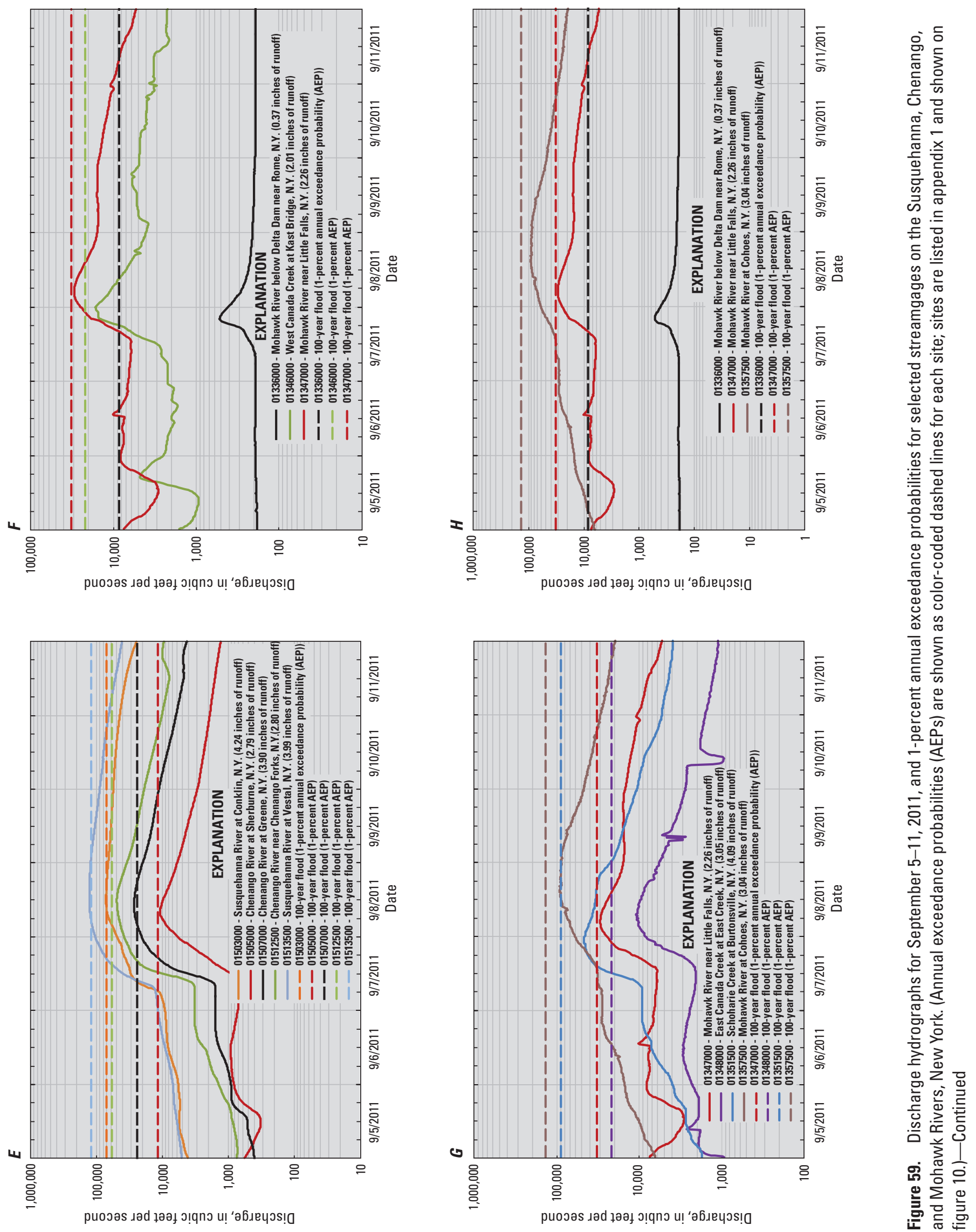

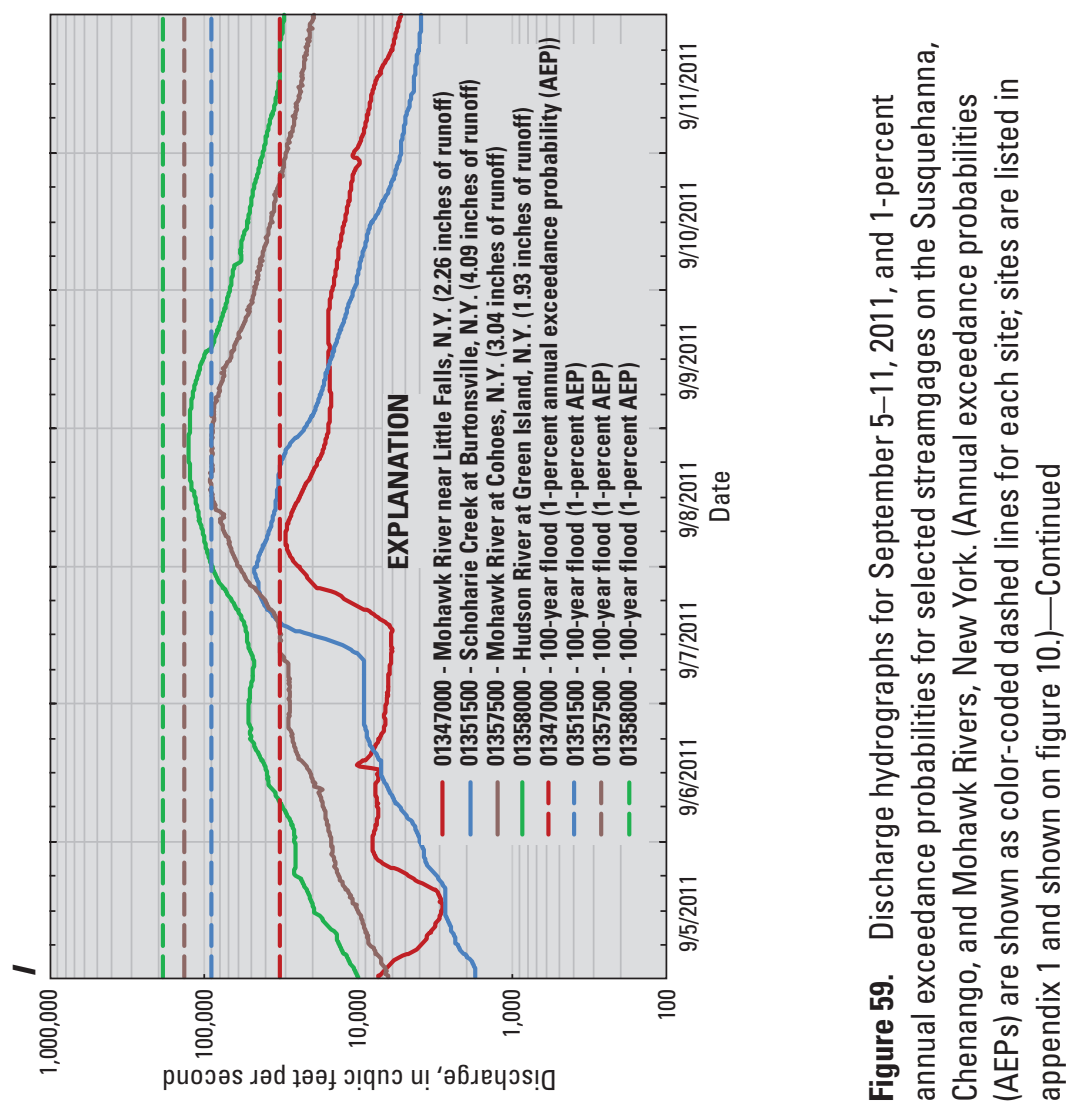

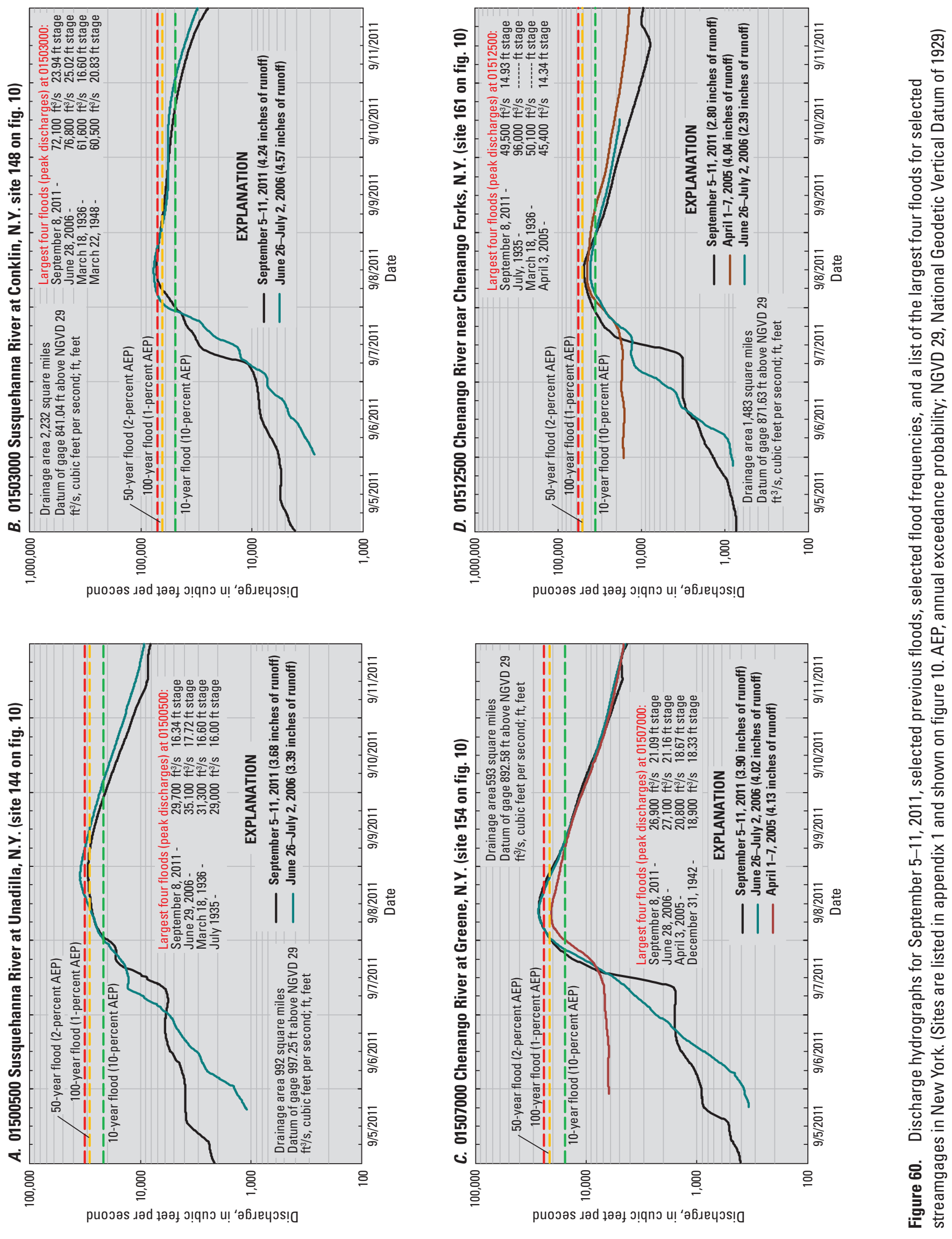

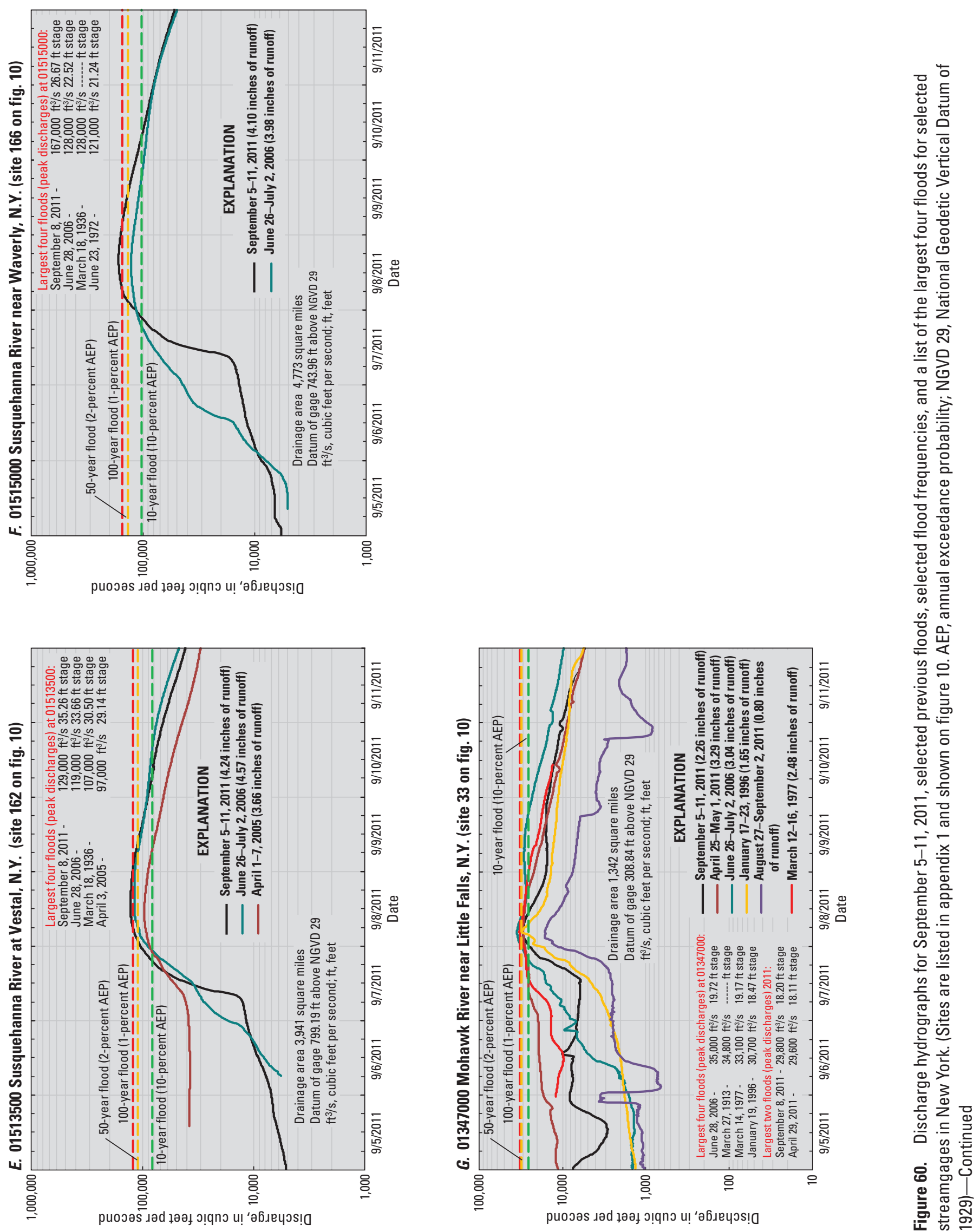

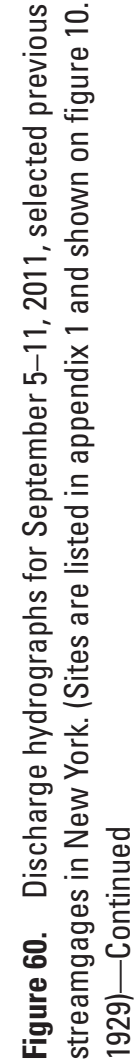



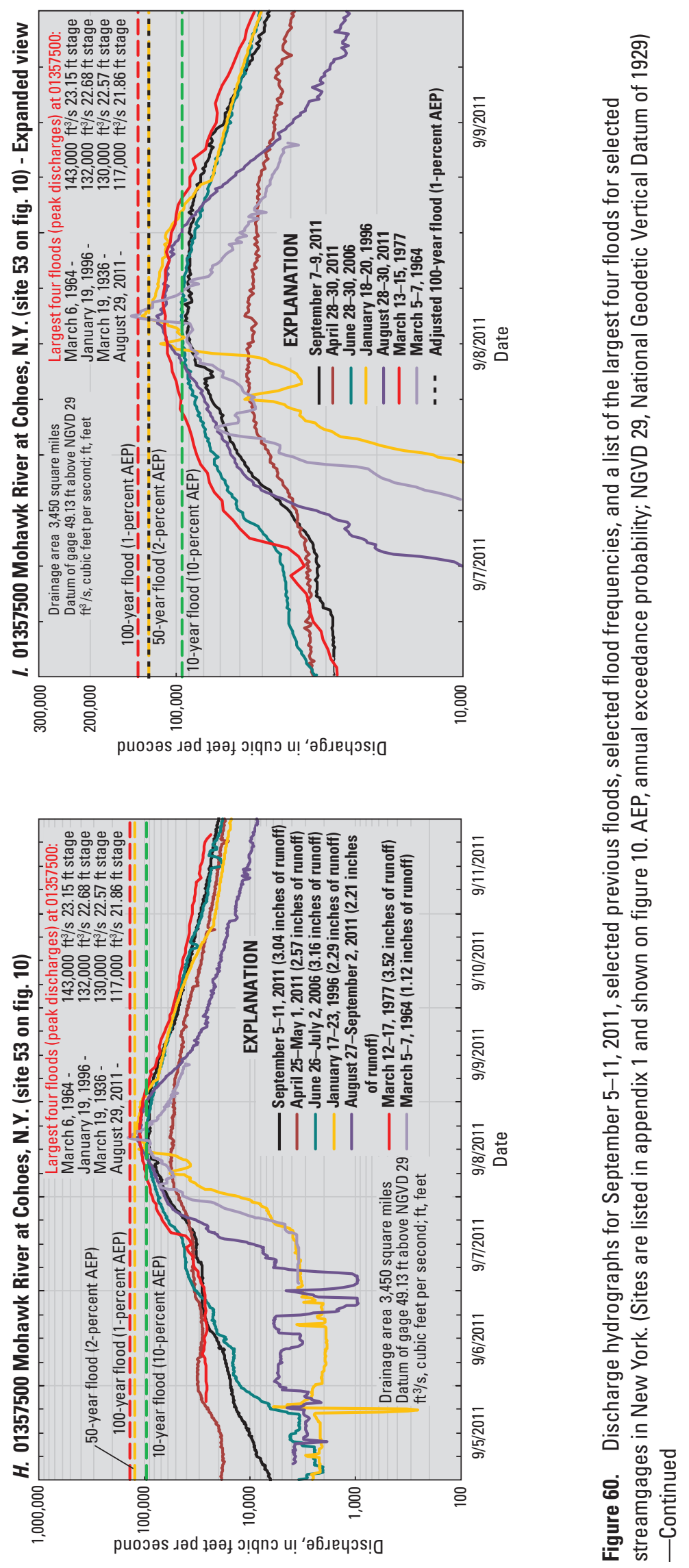

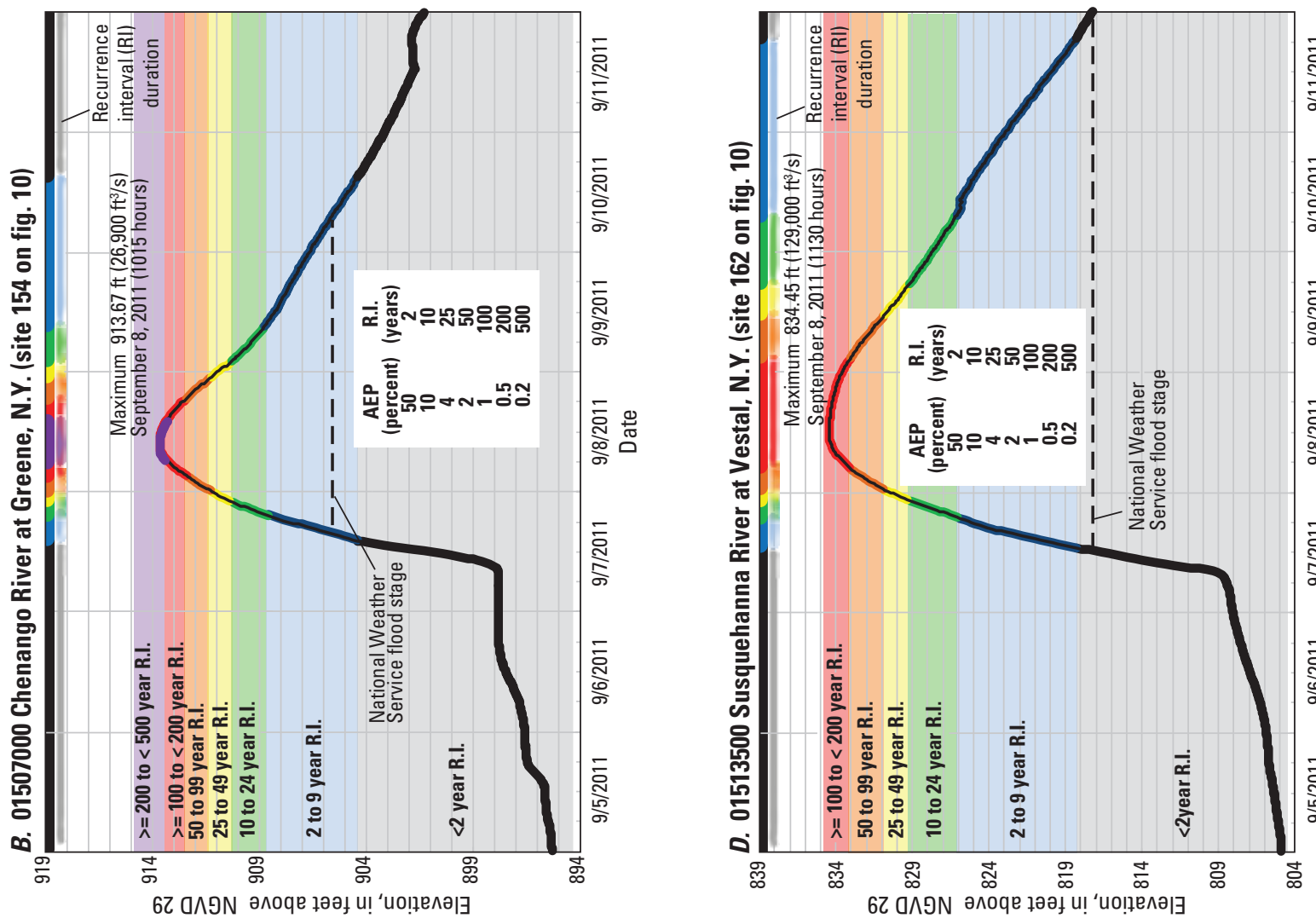

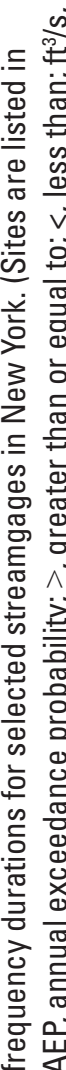

ฮั่
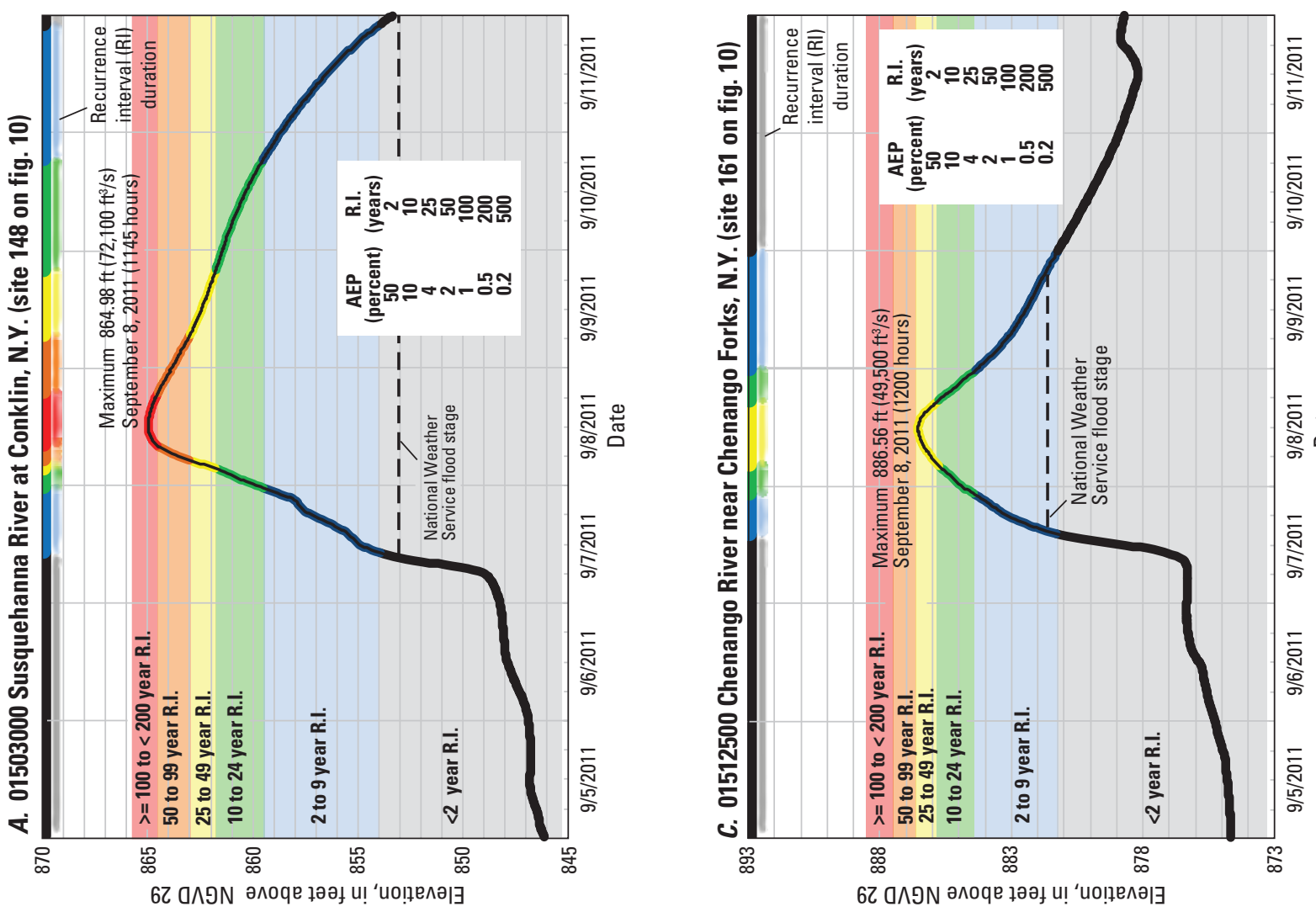

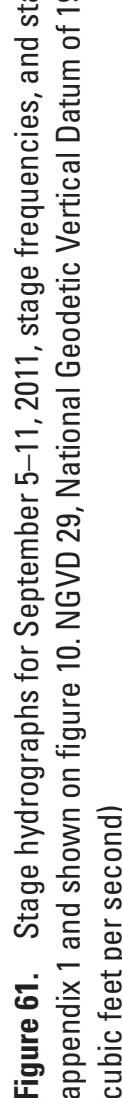



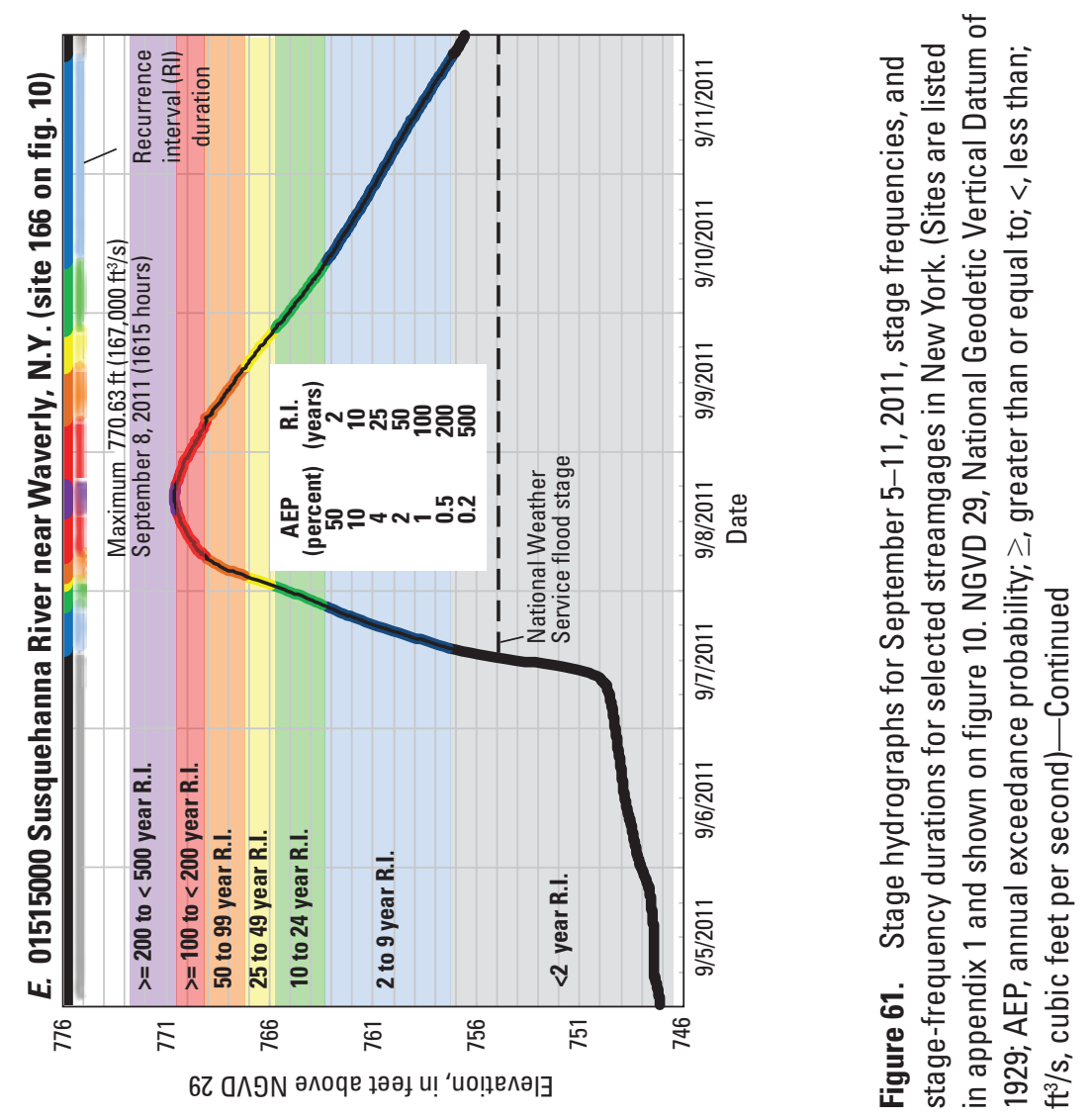


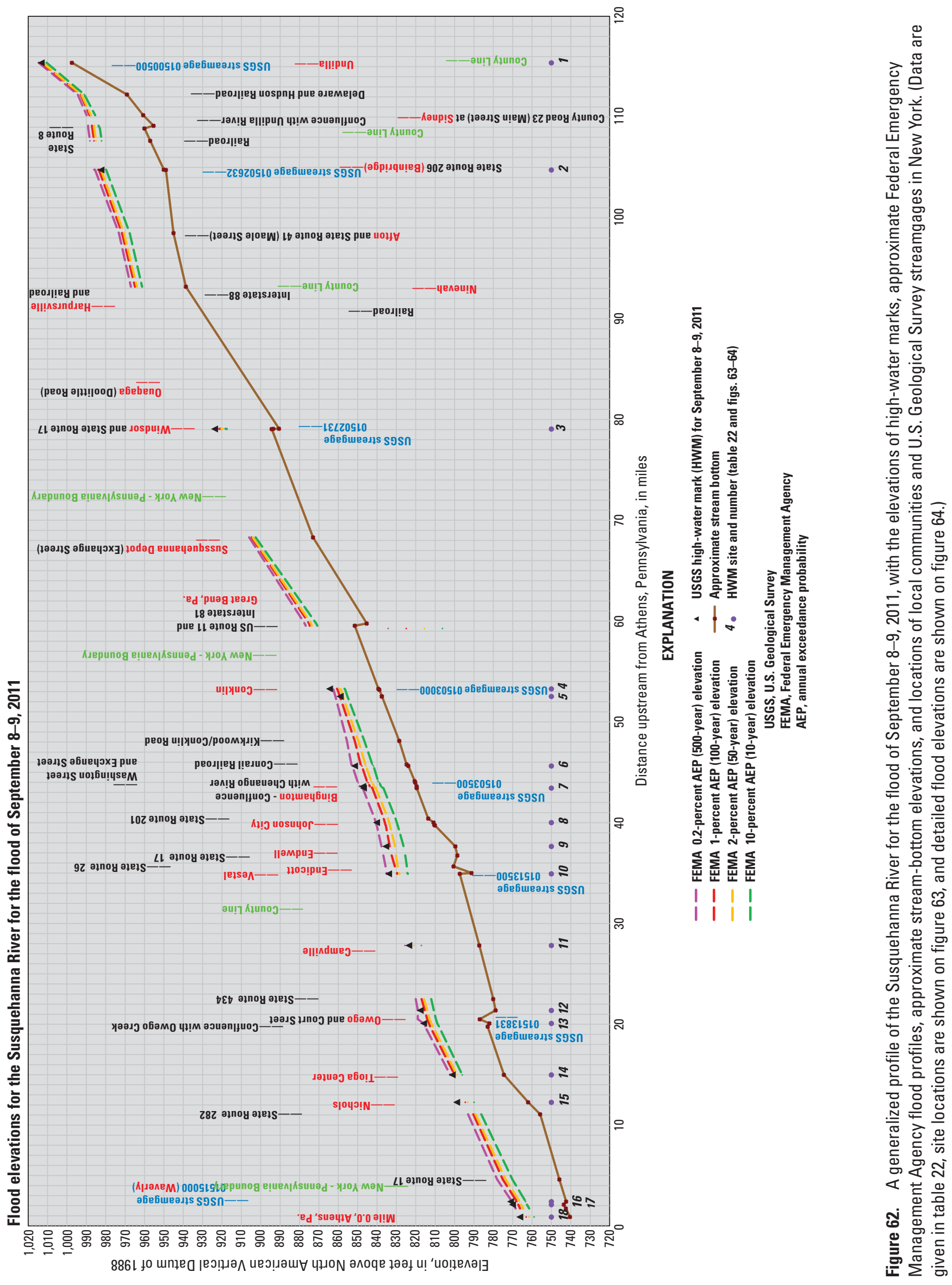




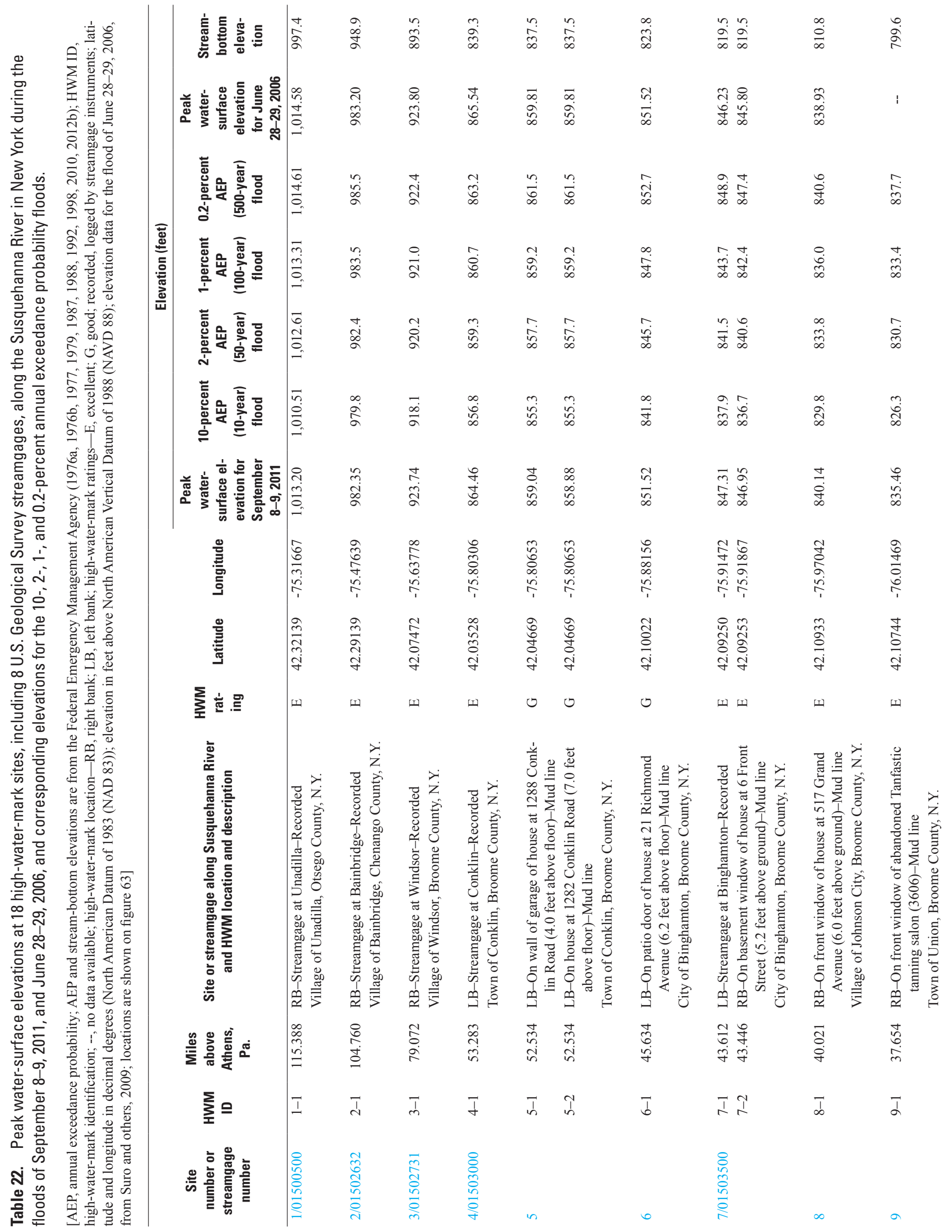




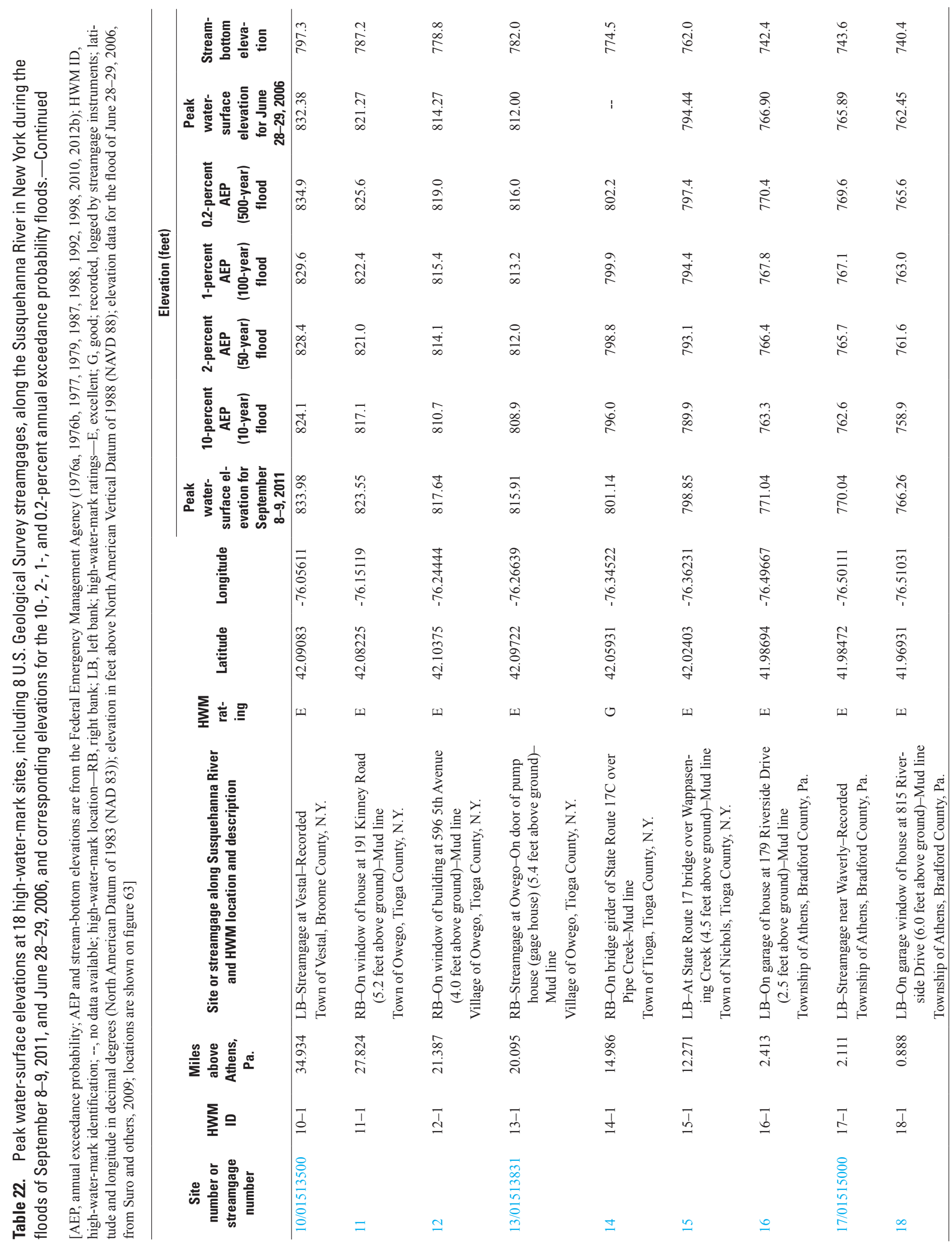




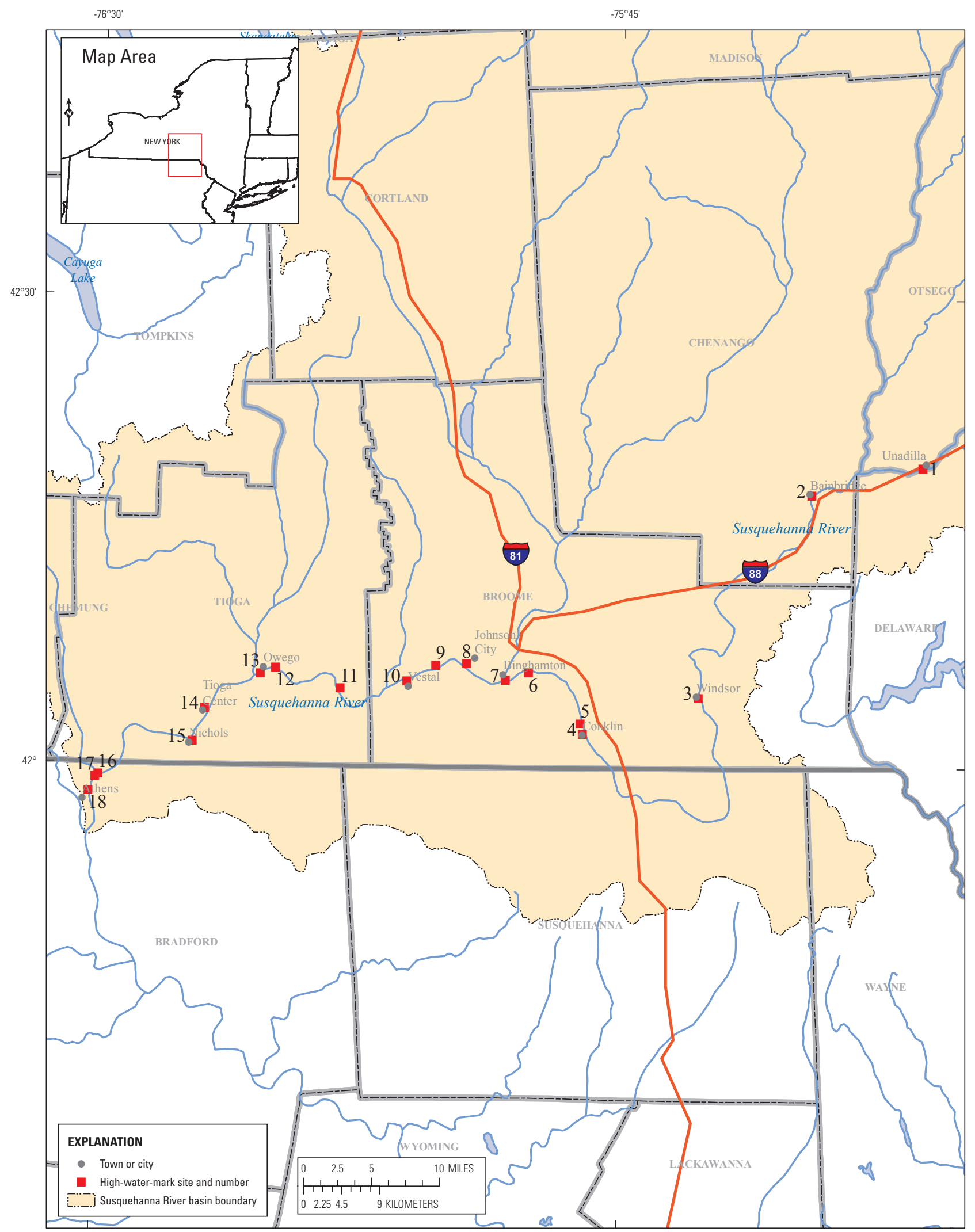

Base from U.S. Geological Survey Digital Data. Universal Transverse Mercator Projection, Zone 18N, NAD83

Figure 63. Locations of high-water-mark sites selected for the flood of September 8-9, 2011 along the Susquehanna River from Unadilla, New York to Athens, Pennsylvania. (Data are given in table 22 and detailed flood elevations are shown on figure 64.) 

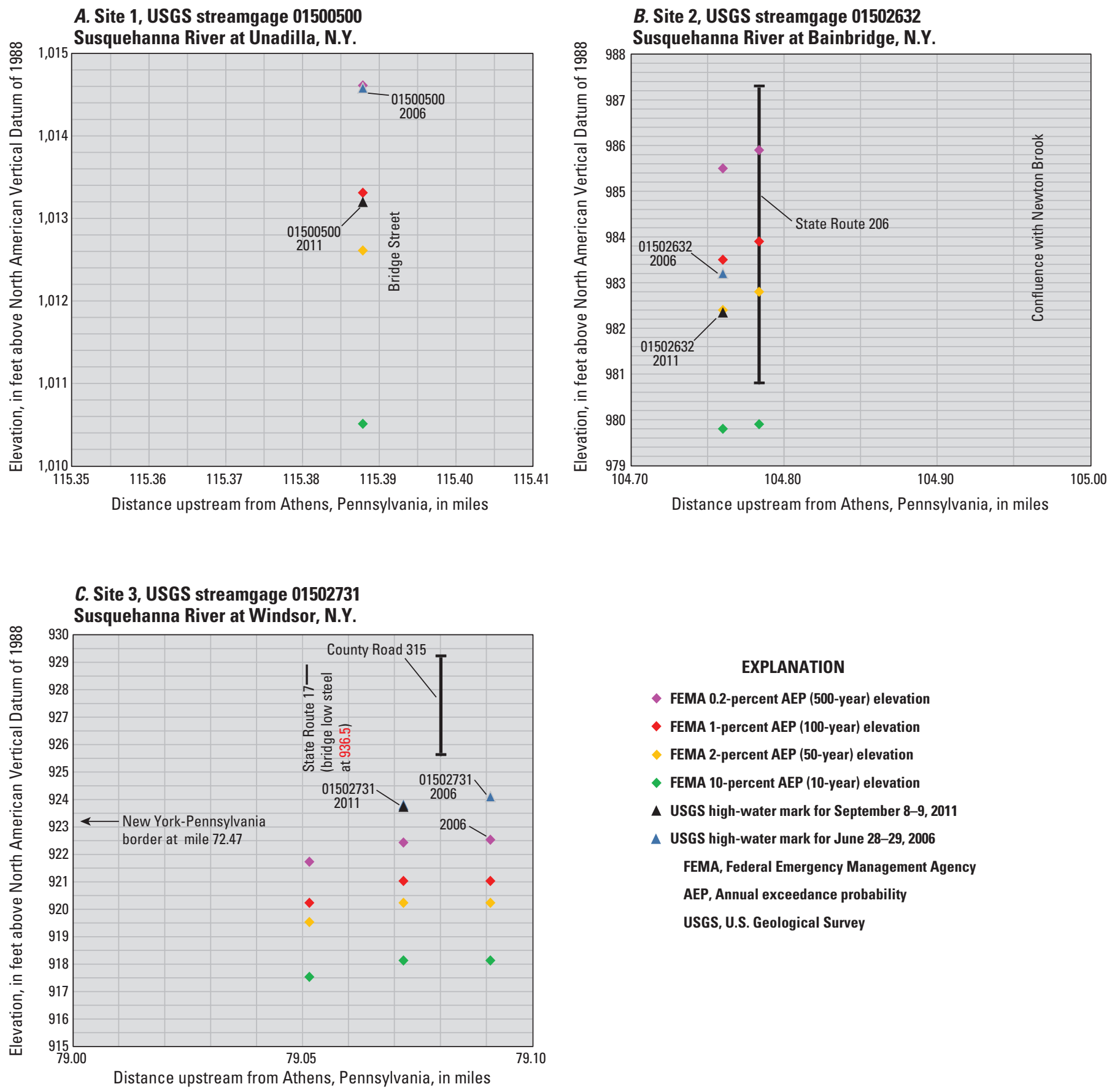

\section{EXPLANATION}

- FEMA 0.2-percent AEP (500-year) elevation

- FEMA 1-percent AEP (100-year) elevation

- FEMA 2-percent AEP (50-year) elevation

- FEMA 10-percent AEP (10-year) elevation

$\triangle$ USGS high-water mark for September 8-9, 2011

$\triangle$ USGS high-water mark for June 28-29, 2006

FEMA, Federal Emergency Management Agency

AEP, Annual exceedance probability

USGS, U.S. Geological Survey

Figure 64. Peak water-surface elevations of the Susquehanna River at 18 sites from Unadilla, New York, to Athens, Pennsylvania, during the flood of September 8-9, 2011, and Federal Emergency Management Agency flood elevations for selected frequencies. (Data are given in table 22 and locations are shown on figure 63.) 

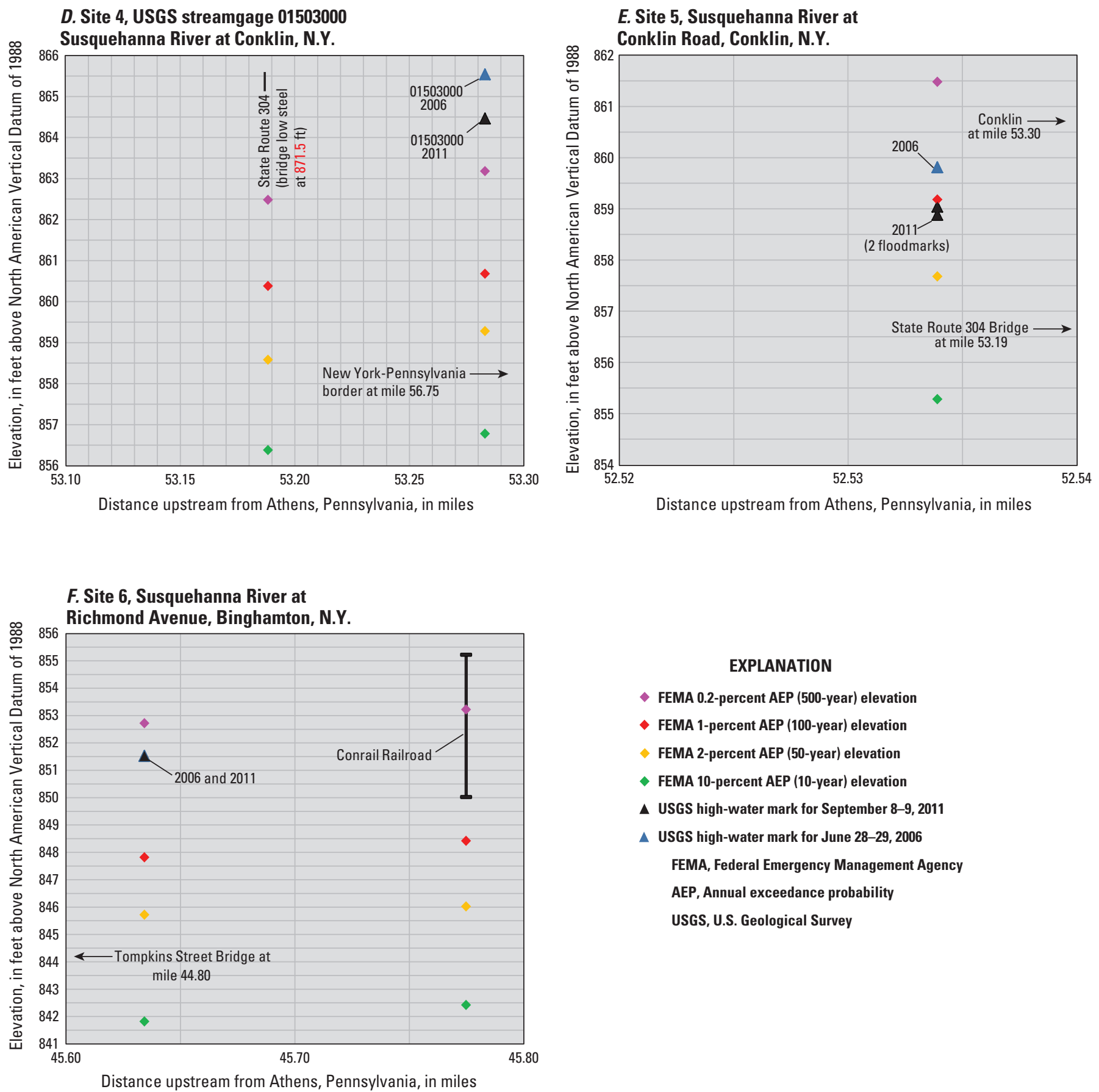

\section{EXPLANATION}

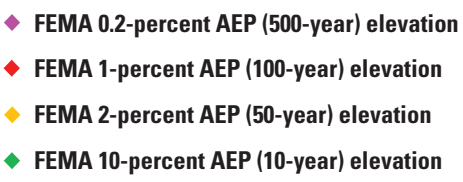

$\Delta$ USGS high-water mark for September 8-9, 2011

$\triangle$ USGS high-water mark for June 28-29, 2006

FEMA, Federal Emergency Management Agency

AEP, Annual exceedance probability

USGS, U.S. Geological Survey

Figure 64. Peak water-surface elevations of the Susquehanna River at 18 sites from Unadilla, New York, to Athens, Pennsylvania, during the flood of September 8-9, 2011, and Federal Emergency Management Agency (FEMA) flood elevations for selected frequencies. (Data are given in table 22 and locations are shown on figure 63.) - Continued 
G. Site 7, Susquehanna River at

Front Street, Binghamton, N.Y.

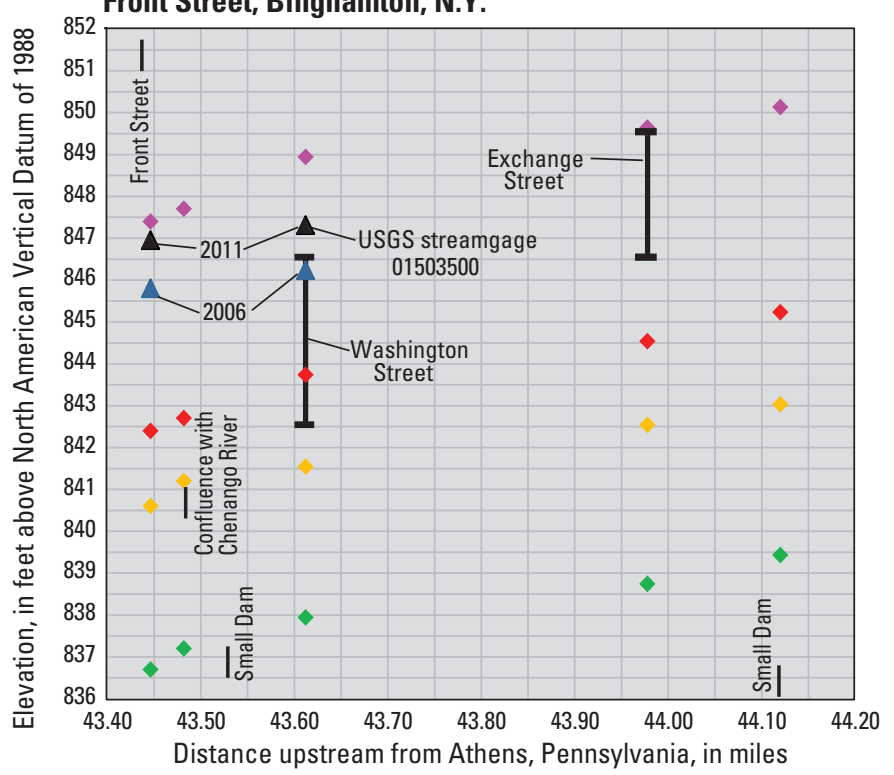

I. Site 9, Susquehanna River at Endwell, N.Y.

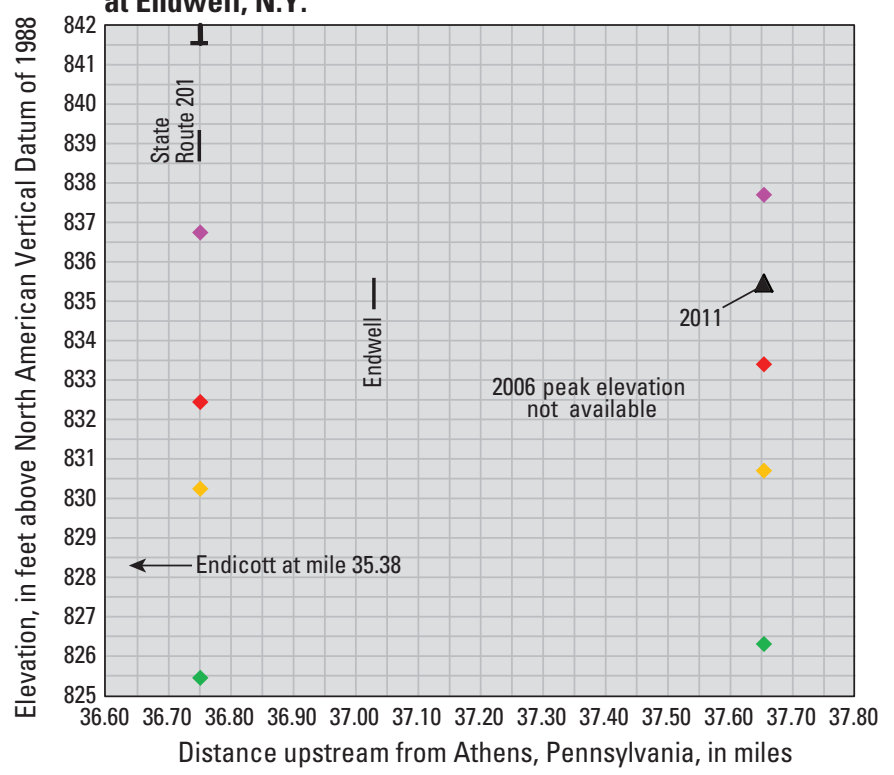

H. Site 8, Susquehanna River at Grand Avenue, Johnson City, N.Y.

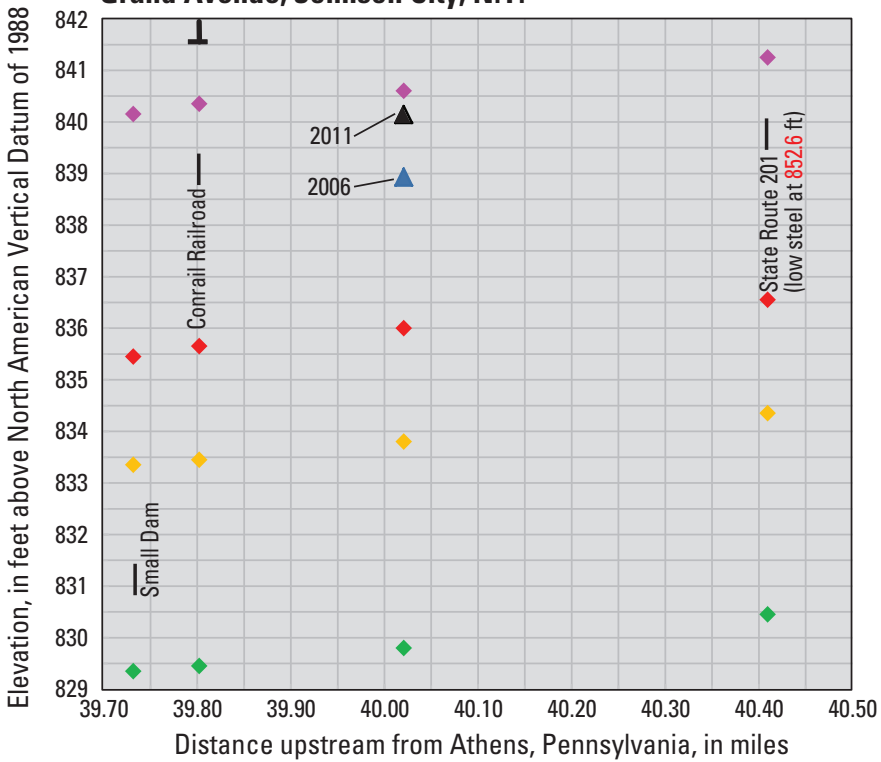

EXPLANATION

- FEMA 0.2-percent AEP (500-year) elevation

- FEMA 1-percent AEP (100-year) elevation

- FEMA 2-percent AEP (50-year) elevation

- FEMA 10-percent AEP (10-year) elevation

A USGS high-water mark for September 8-9, 2011

$\triangle$ USGS high-water mark for June 28-29, 2006

FEMA, Federal Emergency Management Agency

AEP, Annual exceedance probability

USGS, U.S. Geological Survey

Figure 64. Peak water-surface elevations of the Susquehanna River at 18 sites from Unadilla, New York, to Athens, Pennsylvania, during the flood of September 8-9, 2011, and Federal Emergency Management Agency (FEMA) flood elevations for selected frequencies. (Data are given in table 22 and locations are shown on figure 63.) —Continued 
J. Site 10, USGS streamgage 01513500 ,

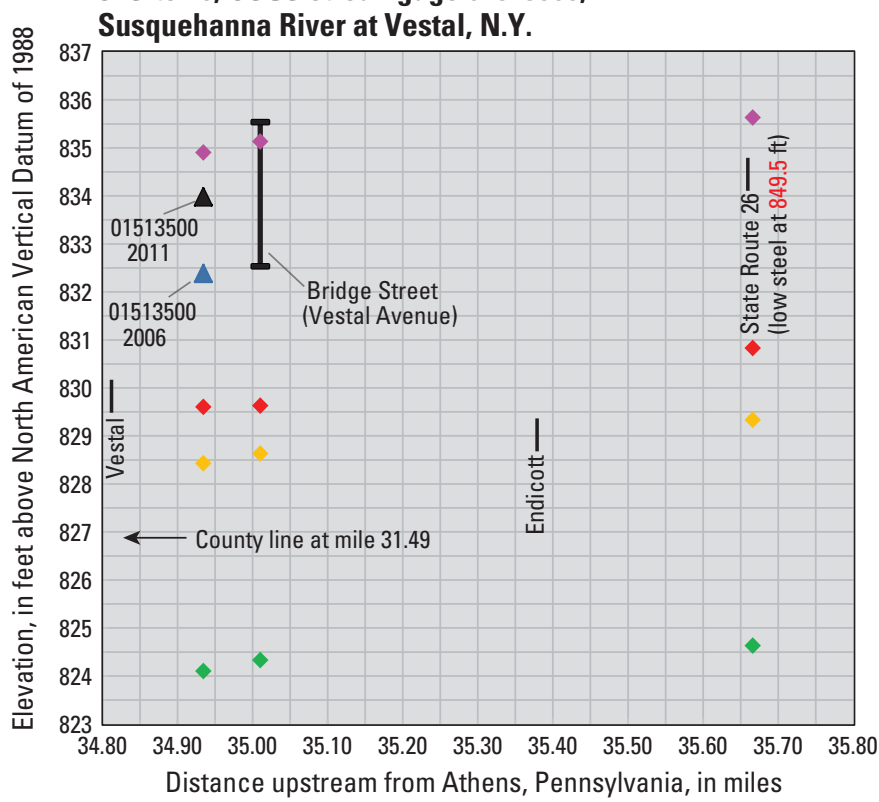

Distance upstream from Athens, Pennsylvania, in miles

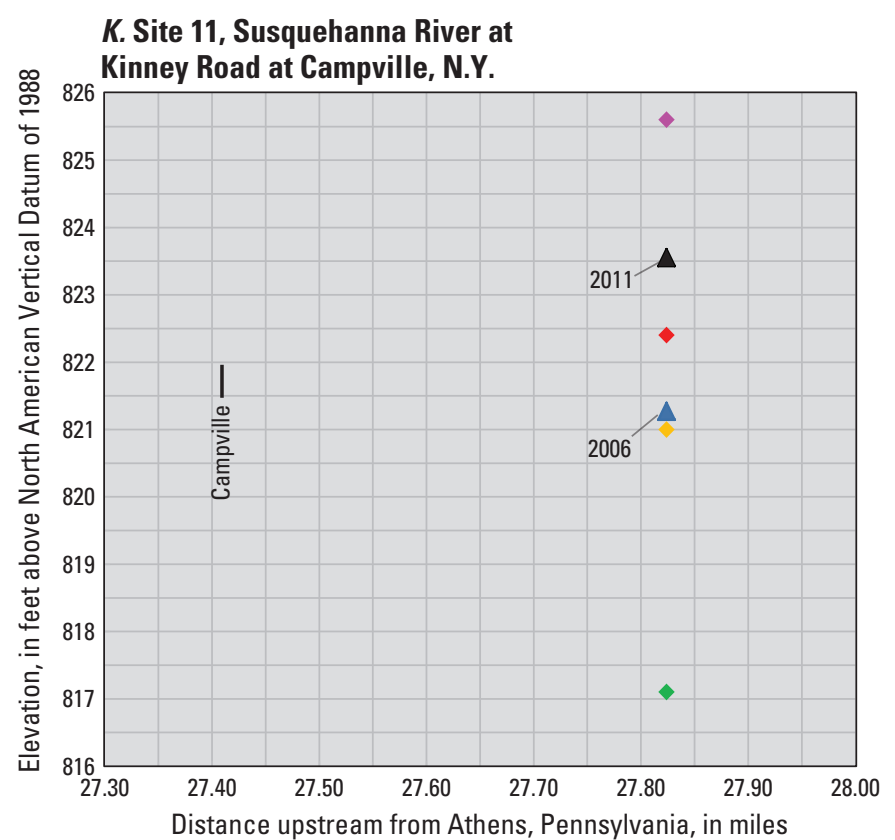

\section{EXPLANATION}

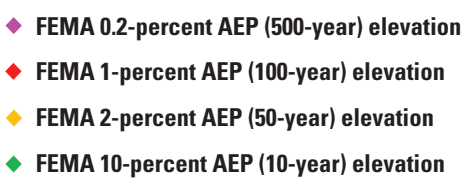

A USGS high-water mark for September 8-9, 2011

A USGS high-water mark for June 28-29, 2006

FEMA, Federal Emergency Management Agency

AEP, Annual exceedance probability

USGS, U.S. Geological Survey

Figure 64. Peak water-surface elevations of the Susquehanna River at 18 sites from Unadilla, New York, to Athens, Pennsylvania, during the flood of September 8-9, 2011, and Federal Emergency Management Agency (FEMA) flood elevations for selected frequencies. (Data are given in table 22 and locations are shown on figure 63.) —Continued 
M. Site 13, USGS streamgage 01513831

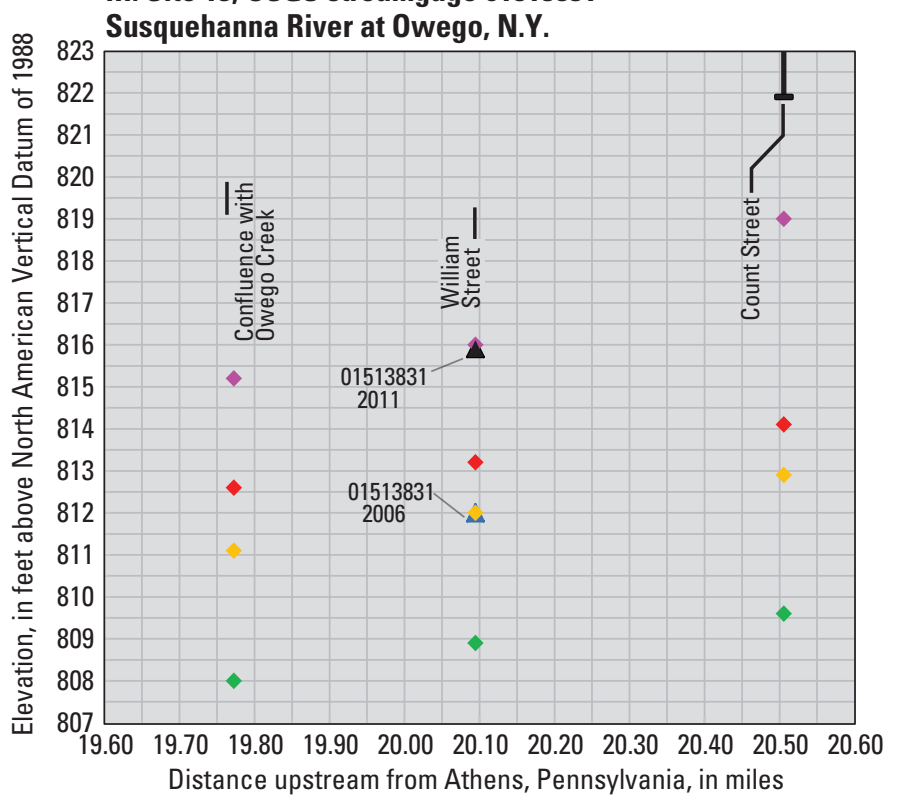

Distance upstream from Athens, Pennsylvania, in miles

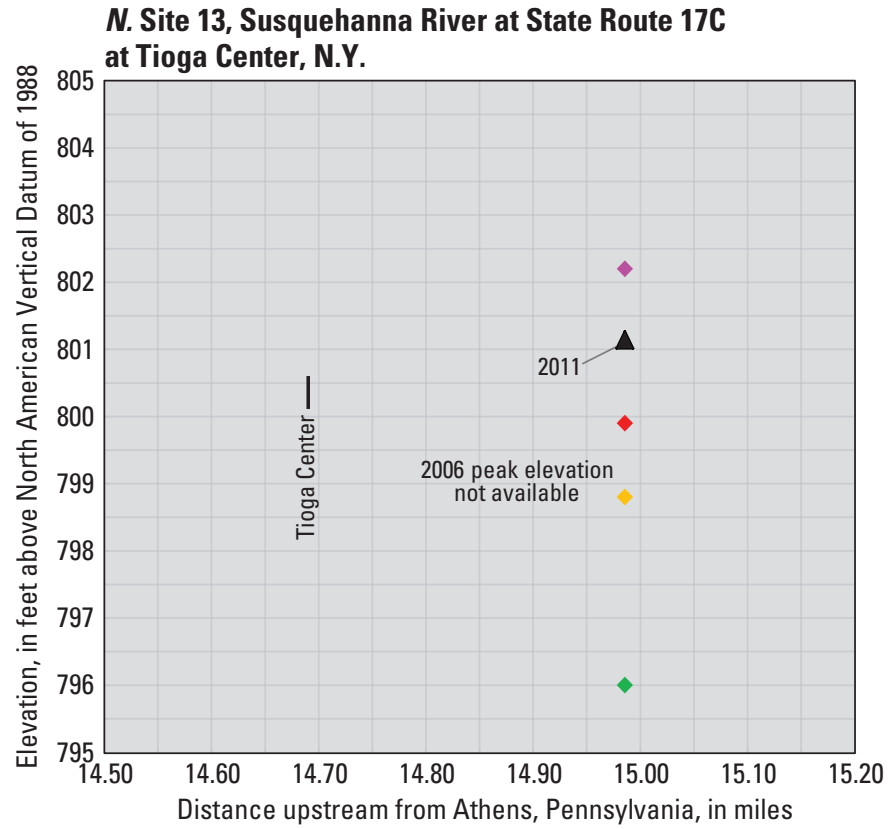

\section{EXPLANATION}

- FEMA 0.2-percent AEP (500-year) elevation

- FEMA 1-percent AEP (100-year) elevation

- FEMA 2-percent AEP (50-year) elevation

- FEMA 10-percent AEP (10-year) elevation

$\Delta$ USGS high-water mark for September 8-9, 2011

$\Delta$ USGS high-water mark for June 28-29, 2006

FEMA, Federal Emergency Management Agency

AEP, Annual exceedance probability

USGS, U.S. Geological Survey

Figure 64. Peak water-surface elevations of the Susquehanna River at 18 sites from Unadilla, New York, to Athens, Pennsylvania, during the flood of September 8-9, 2011, and Federal Emergency Management Agency (FEMA) flood elevations for selected frequencies. (Data are given in table 22 and locations are shown on figure 63.)—Continued 

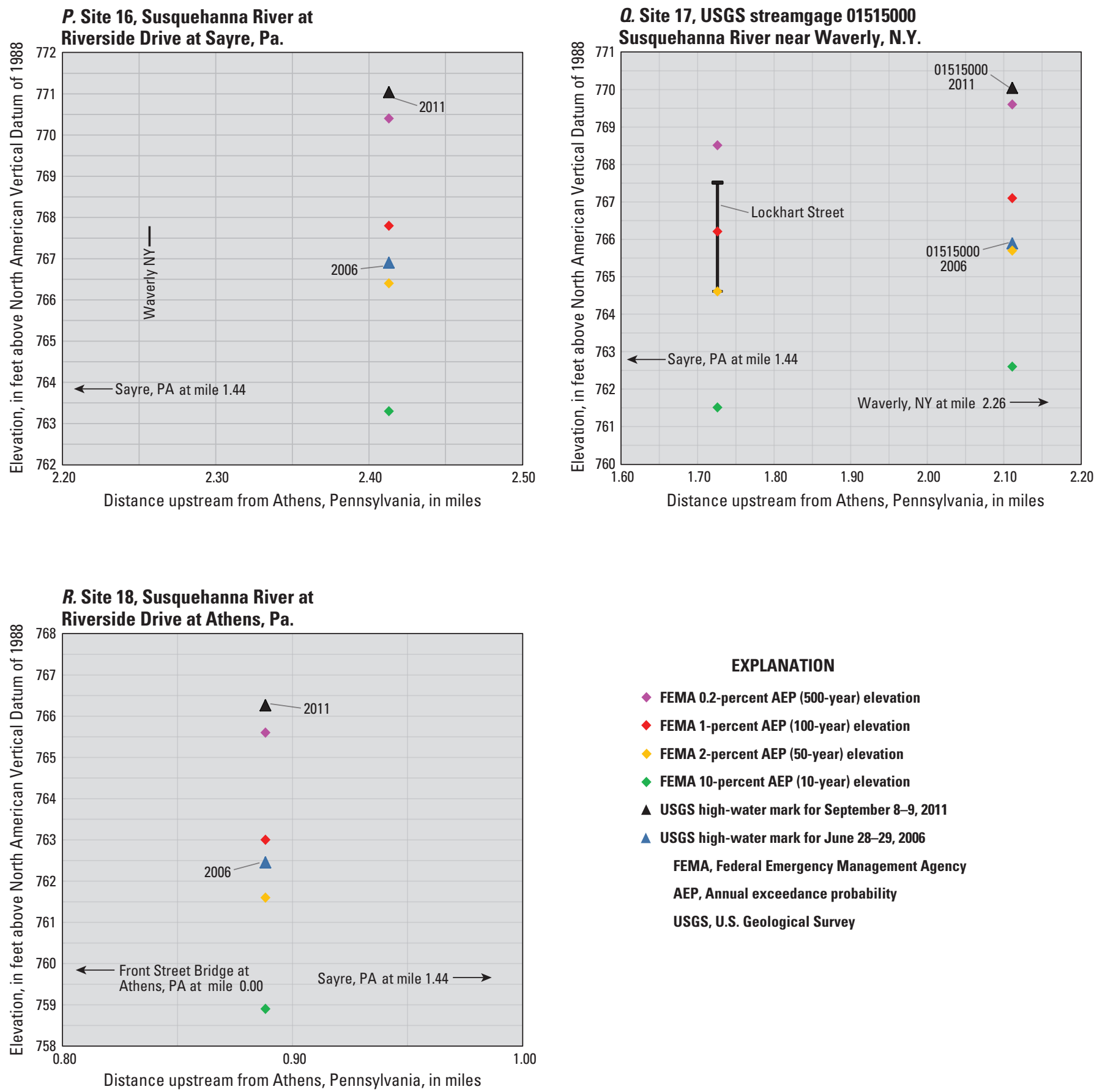

\section{EXPLANATION}

- FEMA 0.2-percent AEP (500-year) elevation

- FEMA 1-percent AEP (100-year) elevation

- FEMA 2-percent AEP (50-year) elevation

- FEMA 10-percent AEP (10-year) elevation

$\triangle$ USGS high-water mark for September 8-9, 2011

$\triangle$ USGS high-water mark for June 28-29, 2006

FEMA, Federal Emergency Management Agency

AEP, Annual exceedance probability

USGS, U.S. Geological Survey

Figure 64. Peak water-surface elevations of the Susquehanna River at 18 sites from Unadilla, New York, to Athens, Pennsylvania, during the flood of September 8-9, 2011, and Federal Emergency Management Agency (FEMA) flood elevations for selected frequencies. (Data are given in table 22 and locations are shown on figure 63.)—Continued 


\section{Effects of Reservoirs}

Flows during the September 2011 flood, particularly in the upper reaches of the Susquehanna River, were affected by two tributary reservoirs (East Sidney Lake and Whitney Point Lake, figs. 65A-B). Water-surface elevations, changes in reservoir contents, and inches of runoff stored during September 5-11 are given in table 23 and show that substantial amounts of storm runoff were stored in each of the lakes up to the time of their maximum stage.

East Sidney Lake at East Sidney (01499500) is on Ouleout Creek 4.4 mi upstream from its confluence with the Susquehanna River just upstream from Unadilla; this lake was built as a flood-control reservoir in 1950 and has a contributing area of $103 \mathrm{mi}^{2}$, or about 12 percent of the drainage area of the Susquehanna River above its confluence with the creek. The lake crested on September 11, 2011, after storing 789 million cubic feet (3.30 in.) of runoff over 1 week (fig. 65A, table 23). The lake rose $40 \mathrm{ft}$ during the runoff period, with the peak elevation $(1,190.62 \mathrm{ft})$ remaining $12.38 \mathrm{ft}$ below the crest of the dam spillway $(1,203.0 \mathrm{ft})$ or about 65 percent of full capacity before levels receded. The maximum water level $(1,190.62 \mathrm{ft})$ on September 11, 2011, was almost $14 \mathrm{ft}$ lower than the record water level of $1,204.35 \mathrm{ft}$ during the flood of June 30, 2006 (the only time the lake had spilled during its 57-year history; Suro and others, 2009). Hourly inflows to East Sidney Lake were estimated from hourly lake elevations (01499500), lake-capacity data provided by the U.S. Army Corps of Engineers, and hourly outflows recorded at streamgage 01500000 (Ouleout Creek at East Sidney). The estimated peak inflow of about $8,400 \mathrm{ft}^{3} / \mathrm{s}$ occurred on September 8 at 7:00 a.m. with minimal controlled outflow $\left(26 \mathrm{ft}^{3} / \mathrm{s}\right)$ at the time.

Whitney Point Lake at Whitney Point (01511000) controls runoff from $257 \mathrm{mi}^{2}$ (99.6 percent) of the Otselic River drainage area just upstream of its confluence with the Tioughnioga River. The Tioughnioga River is a tributary to the Chenango River, which drains to the Susquehanna River at Binghamton, N.Y. Discharges recorded at the Otselic River at Cincinnatus (01510000) (fig. 65B) represent 57 percent of the total inflow to Whitney Point Lake, which rose $25 \mathrm{ft}$ and crested on September 11 at $998.30 \mathrm{ft}$, storing 1,852 million cubic feet (3.11 in.) of runoff during September 5-11 but remaining $11.7 \mathrm{ft}$ below its spillway elevation $(1,010.0 \mathrm{ft})$ and at about 64 percent of its usable capacity. The maximum water level recorded at Whitney Point Lake during its 70 years of operation was $1,005.76 \mathrm{ft}$ on April 5, 2005. The lake stage peaked at $999.57 \mathrm{ft}$ during the June 2006 flood (Suro and others, 2009).

In addition to the major dams that are maintained by the U.S. Army Corps of Engineers, the NRCS maintains
27 flood-control reservoirs on tributaries to the Susquehanna River upstream from the confluence with the Chemung River just south of Sayre, Pa. Twenty of these reservoirs are located in Broome County, N.Y. Most are designed to control runoff from a 1-percent chance AEP (100-year) storm, and each has auxiliary spillways, which pass flows that exceed the design storm. On September 8, 19 of the 20 reservoirs in Broome County overtopped their spillways for the first time since their construction in the 1960s and 1970s (Peter Wright, National Resources Conservation Service, oral commun., 2013).

\section{Flood Damage}

Tropical Storm Lee caused over $\$ 1.6$ billion in damages with 18 fatalities along its path from the Gulf of Mexico to New England (Federal Emergency Management Agency, 2011b). Fifteen counties in New York were declared disaster areas on September 13, 2011 (fig. 66). Flood damages had cost nearly $\$ 300$ million in Federal disaster assistance as of February 24, 2014 (Federal Emergency Management Agency, $2011 \mathrm{~b}$ ) and are ongoing at the time this report was published. In Binghamton, the flood waters spilled over a levee that had protected the city since the 1940s. The flooding inundated 25,000 homes and businesses along the Susquehanna River and its tributaries, and 30,000 people were evacuated.

Hundreds of roads and bridges were flooded, and dozens of both were destroyed (National Oceanic and Atmospheric Administration, 2012).

Communities in the lower reaches of the Susquehanna River in New York were particularly hard hit by Lee, which inundated many areas for the first time since the 1930s, when levees had been constructed. More than 20,000 residents were evacuated in Broome County as the flood waters overtopped the levees in Binghamton by a few tenths of a foot, and the downtown area was closed off. Much of the Village of Owego was inundated (The Owego Pennysaver, 2011), and several roads, including Interstate 88 (blocked by a mudslide) and New York State Route 17, were closed. Estimates of damage in the flooded areas were more than $\$ 500$ million each in Broome and Tioga Counties, and two deaths were related to the storm (National Oceanic and Atmospheric Administration, 2012). Damages and costs in New York from the remnants of Tropical Storm Lee exceeded those from the June 2006 flood, and several restoration and flood-mitigation programs were initiated as a result of the storm. Selected photographs of flooding from the remnants of Tropical Storm Lee, as well as the April-May and August floods during 2011, are presented in appendix 2 at the end of the report. A detailed discussion on the selection, accuracy, and documentation of HWMs with example photographs is given in appendix 3 at the end of the report. 
A. 01499500 East Sidney Lake at East Sidney, N.Y. (site 142 on fig. 10)

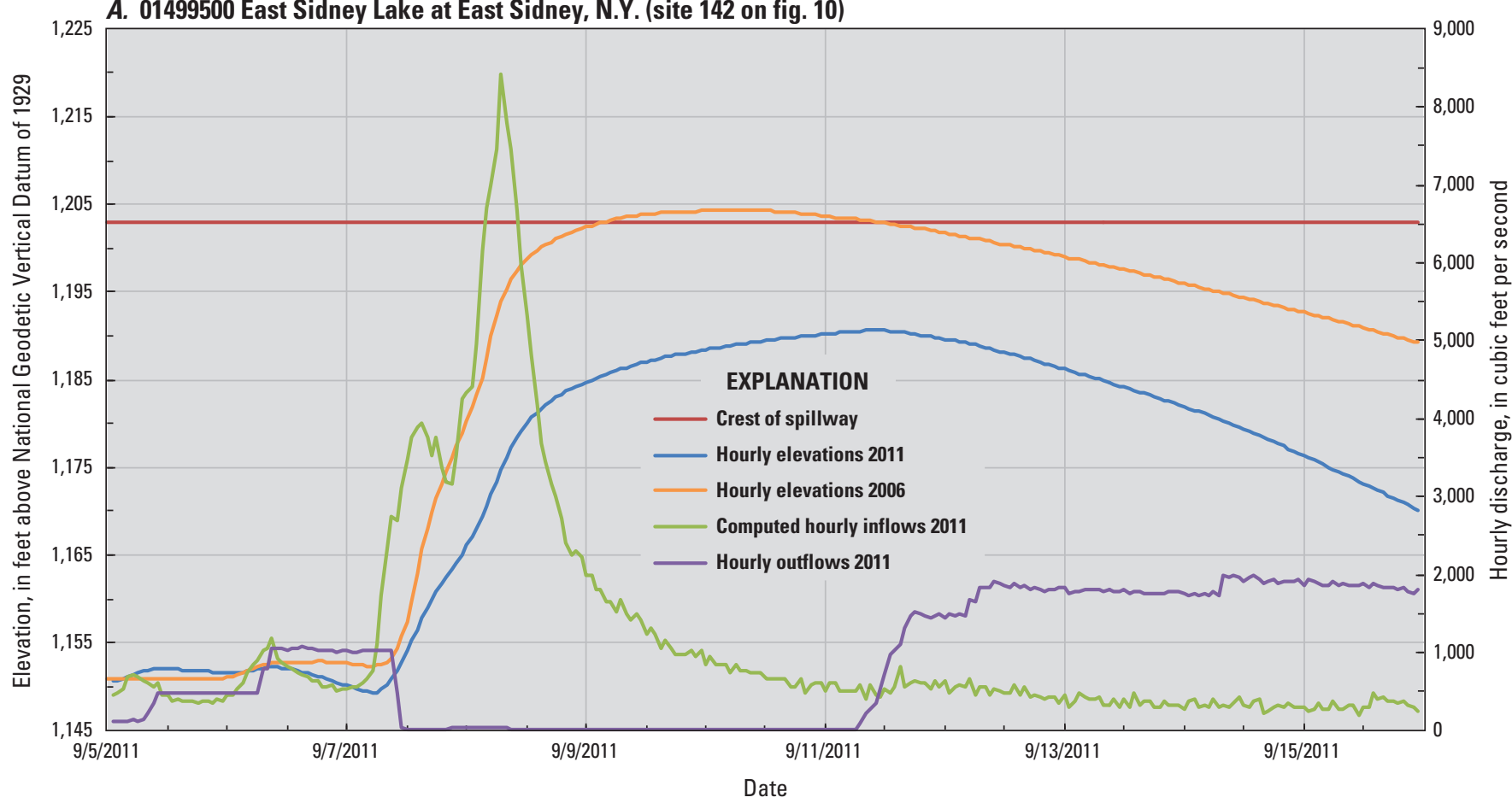

B. 01511000 Whitney Point Lake at Whitney Point, N.Y. (site 159 on fig. 10)

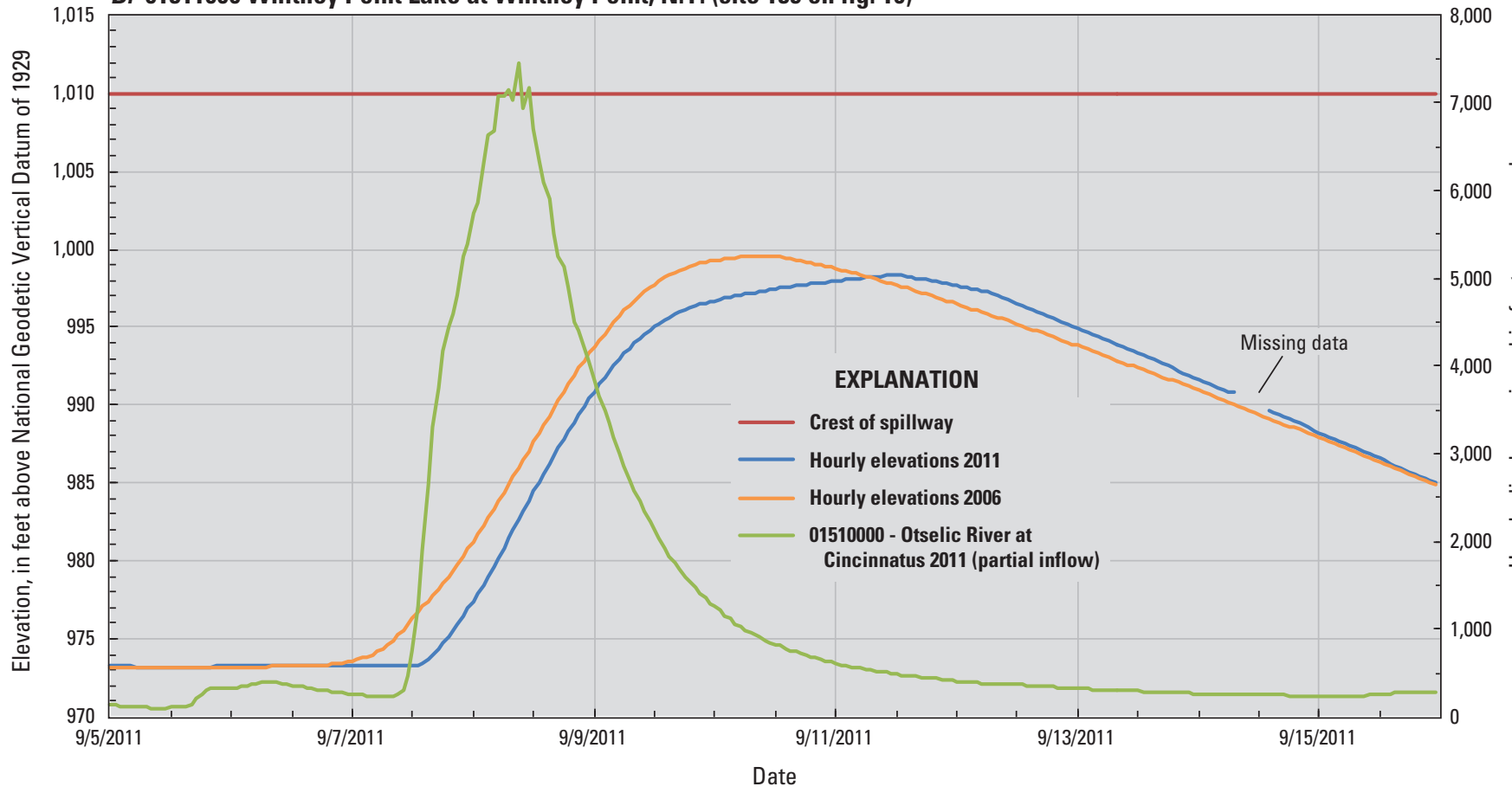

Figure 65. Hourly inflows, outflows, and water-surface elevations at $A$, East Sidney Lake and $B$, Whitney Point Lake with hourly discharges at the Otselic River at Cincinnatus streamgage in New York for September 5-15, 2011. (Data are given in table 23 and locations are shown on figure 10.) 


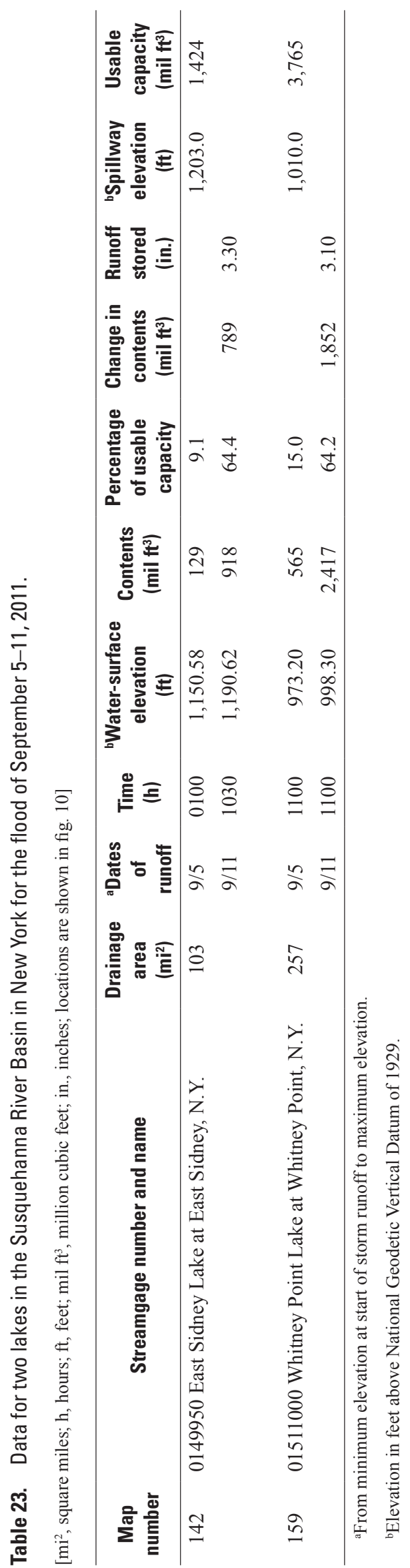



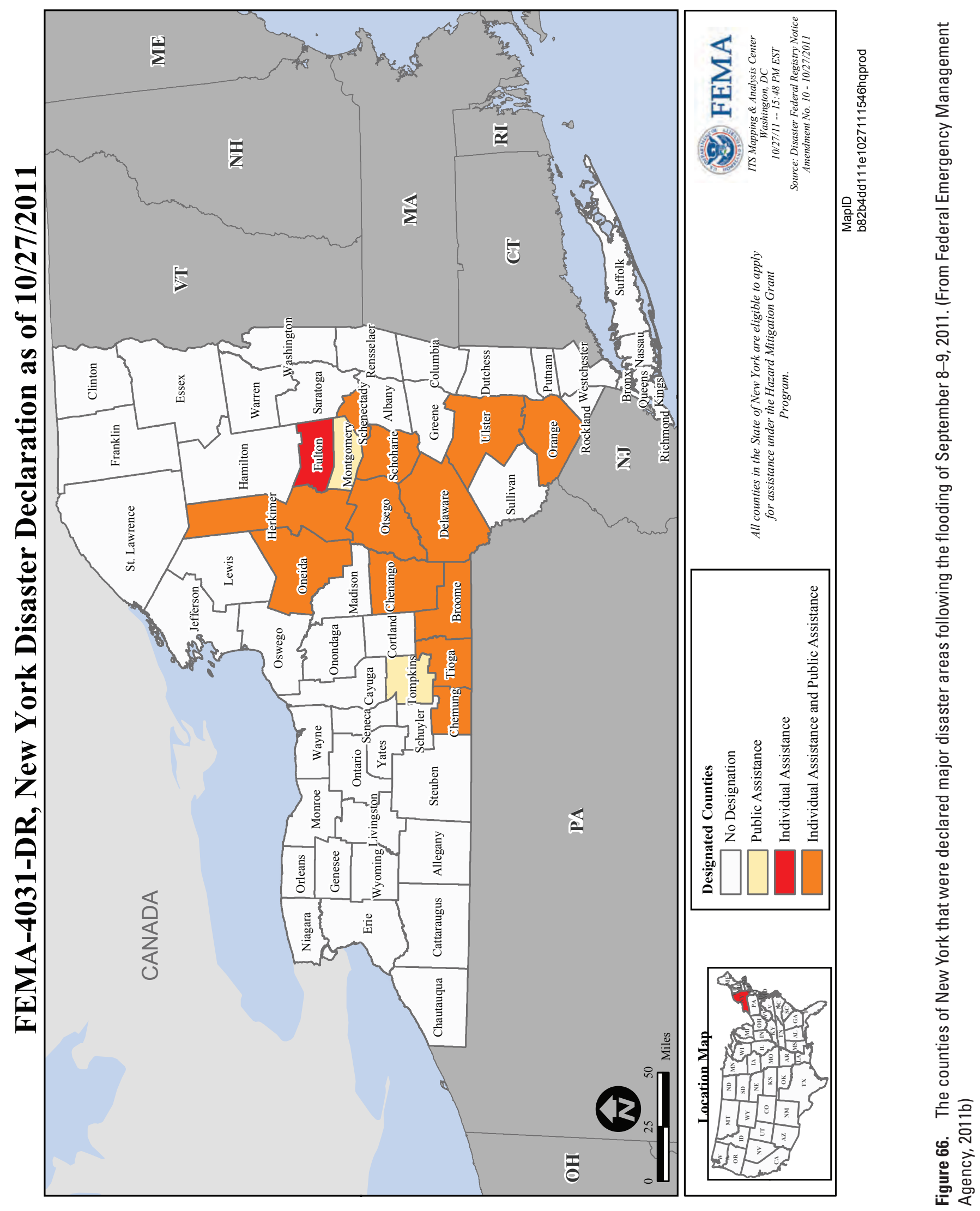


\section{Summary}

Three major floods occurred during 2011 in central, eastern, and northern New York State as a result of extreme rainfall and warm springtime temperatures that caused rapid melting of a thick snowpack: (1) spring storm during April and May, (2) Tropical Storm Irene during late August, and (3) remnants of Tropical Storm Lee in early September. These events caused 2011 rainfall totals in eastern New York to be the greatest since 1895 and were as much as 60 percent above the long-term averages for areas within the Catskill Mountains area and the Susquehanna River Basin. The winter of 2010-11 delivered normal quantities of precipitation, but below-normal temperatures delayed the melting of more than 16 in. of the water equivalent of snow in the Adirondack Mountains of northern New York. The wettest spring on record combined with above-normal temperatures melted the dense snowpack and resulted in major flooding across northern New York during late April and early May. The summer of 2011 brought two major tropical-storm systems through New York. Hurricane Irene weakened to a tropical storm that moved onshore at New York City, travelling north through eastern New York on August 28 with torrential downpours of up to 18 in. recorded in less than 24 hours in the Catskill Mountains area. The result was record flooding throughout much of eastern New York. The remnants of Tropical Storm Lee brought heavy rains again to an already rain-soaked New York in early September. The heaviest rains were centered over the Susquehanna River Basin in south-central New York with rainfall totaling more than 12 in. in some areas during September 6-9. Record flooding occurred within the Susquehanna River Basin and in other areas of southcentral New York. The U.S. Geological Survey (USGS), in cooperation with the Federal Emergency Management Agency (FEMA), conducted this study to characterize and document the three storms.

The very warm and wet spring of 2011 in northern New York resulted in record flooding at 21 USGS active streamgages during late April and early May, with 11 peak discharges equaling or exceeding the 1-percent annual exceedance probability (AEP) (100-year) discharges at those streamgages. Four streamgages on the upper Hudson River recorded their maximum peak stage and discharge on April 28-29, including the Hudson River at North Creek, which had its greatest flood in more than 104 years of record (greater than the 0.5-percent AEP discharge). Nearly 5 in. of rain during late April, combined with a rapidly melting snowpack, caused widespread flooding of streams throughout northern New York and in some parts of the Finger Lakes region. Many road closures along with millions of dollars in damages resulted in 23 counties being declared disaster areas and eligible for public assistance. On May 6, Lake Champlain recorded its highest lake level in over 140 years at Rouses Point.

On August 28, Tropical Storm Irene moved inland and north through New York bringing torrential rains that resulted in catastrophic flooding and damage to many areas of eastern New York. Record rainfall totals (over 18 in. at some locations) were reported at several National Weather Service stations in the Catskill Mountains area. Record stages and discharges were recorded at 62 lake gages and streamgages throughout eastern New York. Areas especially hard hit by this storm were the Schoharie Creek Basin, the eastern Delaware River Basin, the Ausable and Bouquet River Basins in northeastern New York, and several other basins throughout southeastern parts of the State. Peak discharges exceeded their 1-percent AEP (100-year) discharges at 25 streamgages and their respective 0.2-percent AEP (500-year) discharges at 6 sites in the Schoharie Creek Basin. The USGS surveyed 184 high water marks (HWMs) at 30 locations along an 84-mile reach of Schoharie Creek. Elevations of the HWMs in the lower reaches of the basin exceeded those published by FEMA for their respective 0.2-percent AEP (500-year) floods. Storage in several reservoirs in and around the Catskill Mountains area mitigated flooding, but most reservoirs exceeded their capacity on August 28. Thirty-one counties in the State were declared disaster areas with damages of over $\$ 1.3$ billion and 10 deaths reported as a result of Tropical Storm Irene.

Remnants of Tropical Storm Lee reached south-central New York in early September. The heaviest rains were centered over the already saturated Susquehanna River Basin in south-central New York with over 12 in. recorded in some areas during September 7-9. Flooding in the lower reaches of the Susquehanna River exceeded levels recorded in June 2006, the previous flood of record, by more than $4 \mathrm{ft}$ (Tioga County). Ten streamgages in the Susquehanna River Basin measured record peak discharges on September 8 that exceeded their 1-percent AEP (100-year) discharges. The Susquehanna River near Waverly remained above the 1-percent AEP (100-year) elevation for nearly 24 hours during September 8-9, and the peak discharge $\left(167,000 \mathrm{ft}^{3} / \mathrm{s}\right)$ was the largest in at least 76 years (the previous maximum was $128,000 \mathrm{ft}^{3} / \mathrm{s}$ in 1936 and 2006). The USGS surveyed 20 HWMs at 18 locations along a 114-mi reach of the Susquehanna River. The elevations of the HWMs exceeded the published FEMA 0.2 -percent AEP (500-year) elevations at many locations and the 1-percent AEP (100-year) elevations at other sites. Major disaster declarations were issued for 15 counties in and around central New York, making them eligible for individual or public assistance. 


\section{Selected References}

Avila, L.A., and Cangialosi, John, 2011, Tropical cyclone report, Hurricane Irene (AL092011), August 21-28, 2011: National Hurricane Center, December 14, 2011, updated April 11, 2012, 45 p., accessed on April 4, 2013, at http://www.nhc.noaa.gov/data/tcr/AL092011_Irene.pdf.

Benson, M.A., and Dalrymple, Tate, 1967, General field and office procedures for indirect discharge measurements: U.S. Geological Survey Techniques of Water-Resources Investigations, book 3, chap. A1, 30 .

Brown, D.P., 2011, Tropical cyclone report, Tropical Storm Lee (AL132011): National Oceanic and Atmospheric Administration, National Hurricane Center, December 15, 2011, 35 p., accessed on April 24, 2013, at http://www.nhc. noaa.gov/data/tcr/AL132011_Lee.pdf or accessible at http://www.hpc.ncep.noaa.gov/tropical/rain/lee2011.html.

Federal Emergency Management Agency, 1976a, Flood insurance study, City of Binghamton, Broome County, New York: Federal Emergency Management Agency, Federal Insurance Administration, 18 p.

Federal Emergency Management Agency, 1976b, Flood insurance study, Town of Conklin, Broome County, New York: Federal Emergency Management Agency, Federal Insurance Administration, 17 p.

Federal Emergency Management Agency, 1977, Flood insurance study, Village of Johnson City, Broome County, New York: Federal Emergency Management Agency, Federal Insurance Administration, 14 p.

Federal Emergency Management Agency, 1979, Flood insurance study, Township of Athens, Bradford County, Pennsylvania: Federal Emergency Management Agency, Federal Insurance Administration, 25 p.

Federal Emergency Management Agency, 1987, Flood insurance study, Village of Unadilla, Otsego County, New York: Federal Emergency Management Agency, Federal Insurance Administration, $13 \mathrm{p}$.

Federal Emergency Management Agency, 1988, Flood insurance study, Town of Union, Broome County, New York: Federal Emergency Management Agency, Federal Insurance Administration, $16 \mathrm{p}$.

Federal Emergency Management Agency, 1989, Flood insurance study, Town of Duanesburg, Schenectady County, New York: Federal Emergency Management Agency, Federal Insurance Administration, 14 p.

Federal Emergency Management Agency, 1992, Flood insurance study, Village of Windsor, Broome County, New York: Federal Emergency Management Agency, Federal Insurance Administration, 14 p.
Federal Emergency Management Agency, 1998, Flood insurance study, Town of Vestal, Broome County, New York: Federal Emergency Management Agency, Federal Insurance Administration, $19 \mathrm{p}$.

Federal Emergency Management Agency, 2008, Flood insurance study, Greene County, New York: Federal Emergency Management Agency, Federal Insurance Administration, $54 \mathrm{p}$.

Federal Emergency Management Agency, 2010, Flood insurance study, Village of Bainbridge, Chenango County, New York: Federal Emergency Management Agency, Federal Insurance Administration, 29 p.

Federal Emergency Management Agency, 2011a, New YorkHurricane Irene (DR-4020), accessed April 4, 2013, at http://www.fema.gov/ar/disaster/4020.

Federal Emergency Management Agency, 2011b, New Yorkremnants of Tropical Storm Lee (DR-4031), accessed April 4, 2013, at http://www.fema.gov/ar/disaster/4031.

Federal Emergency Management Agency, 2011c, New Yorksevere storms, flooding, tornadoes, and straight-line winds (DR-1993), accessed April 4, 2013, at http://www.fema.gov/ ar/disaster/1993.

Federal Emergency Management Agency, 2011d, Rapid Response-New York coastal high water marks, Tropical Storm Irene, Disaster number FEMA-DR-4020-NY, Region 2: New York, prepared by Risk Assessment, Mapping, and Planning Partners, 18 p.

Federal Emergency Management Agency, 2011e, Rapid response-New York west of Hudson watershed riverine high water marks, Hurricane/Tropical Storm Irene, disaster number FEMA-DR-5000-NY, Region 2, New York, N.Y.: prepared by Risk Assessment, Mapping, and Planning Partners, 9 p.

Federal Emergency Management Agency, 2012a, Flood insurance study, Schoharie County, New York: Federal Emergency Management Agency, Federal Insurance Administration, $22 \mathrm{p}$.

Federal Emergency Management Agency, 2012b, Flood insurance study, Tioga County, New York: Federal Emergency Management Agency, Federal Insurance Administration, $24 \mathrm{p}$.

Helsel, D.R., and Hirsch, R.M., 1992, Studies in environmental science 49-Statistical methods in water resources: Amsterdam, Elsevier, 522 p.

Helsel, D.R., and Hirsch, R.M., 2002, Statistical methods in water resources: U.S. Geological Survey Techniques of Water Resources Investigations, book 4, chap. A3, 522 p. 
Interagency Advisory Committee on Water Data, 1982, Guidelines for determining flood flow frequency: U.S. Geological Survey, Office of Water Data Coordination, Bulletin 17B of the Hydrology Subcommittee, 183 p.

Lorenz, D.L., and others, 2011, USGS library for S-PLUS for Windows-Release 4.0: U.S. Geological Survey Open-File Report 2011-1130. (Also available at http://water.usgs.gov/ software/S-PLUS/.)

Lumia, Richard, 1998, Flood of January 19-20, 1996, in New York State: U.S. Geological Survey Water-Resources Investigations Report 97-4252, 61 p. (Also available at http://ny.water.usgs.gov/pubs/wri/wri974252/.)

Lumia, Richard, Freehafer, D.A., and Smith, M.J., 2006, Magnitude and frequency of floods in New York: U.S. Geological Survey Scientific Investigations Report 2006-5112, 152 p. (Also available at http://pubs.usgs.gov/ $\operatorname{sir} / 2006 / 5112 /$.

Masters, Dr. Jeff, 2011, Tropical Storm Lee's flood in Binghamton-Was global warming the final straw?: Dr. Jeff Masters WunderBlog, posted December 14, 2011, accessed April 24, 2013, at http://www.wunderground.com/blog/ JeffMasters/comment.html? entrynum $=2002$.

McCallum, B.E., Painter, J.A., and Frantz, E.R., 2012, Monitoring inland storm tide and flooding from Hurricane Irene along the Atlantic coast of the United States, August 2011: U.S. Geological Survey Open-File Report 2012-1022, 28 p.

National Oceanic and Atmospheric Administration, 2004, National Weather Service, Climate Prediction Center, Climate Divisions with counties, map for New York,

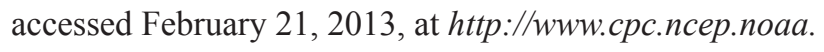
gov/products/analysis_monitoring/regional_monitoring/ CLIM_DIVS/new_york.gif.

National Oceanic and Atmospheric Administration, 2011a, Climatological data New England, April 2011, April precipitation by year: Asheville, N.C., National Oceanic and Atmospheric Administration, Environmental Data and Information Service, National Climatic Data Center, v. 123, no. $04,56 \mathrm{p}$.

National Oceanic and Atmospheric Administration, 2011b, Climatological data New England, August 2011, August precipitation by year: Asheville, N.C., National Oceanic and Atmospheric Administration, Environmental Data and Information Service, National Climatic Data Center, v. 123, no. $08,44 \mathrm{p}$.
National Oceanic and Atmospheric Administration, 2011c, Climatological data New Jersey, August, 2011, August precipitation by year: Asheville, N.C., National Oceanic and Atmospheric Administration, Environmental Data and Information Service, National Climatic Data Center, v. 116, no. $08,14 \mathrm{p}$.

National Oceanic and Atmospheric Administration, 2011d, Climatological data New York, April 2011, April precipitation by year : Asheville, N.C., National Oceanic and Atmospheric Administration, Environmental Data and Information Service, National Climatic Data Center, v. 123, no. $04,34 \mathrm{p}$.

National Oceanic and Atmospheric Administration, 2011e, Climatological data New York, August 2011, August precipitation by year: Asheville, N.C., National Oceanic and Atmospheric Administration, Environmental Data and Information Service, National Climatic Data Center, v. 123, no. $08,27 \mathrm{p}$.

National Oceanic and Atmospheric Administration, 2011f, Climatological data New York, September, 2011, September precipitation by year: Asheville, N.C., National Oceanic and Atmospheric Administration, Environmental Data and Information Service, National Climatic Data Center, v. 123, no. $09,28 \mathrm{p}$.

National Oceanic and Atmospheric Administration, 2011g, Climatological data Pennsylvania, August, 2011, August precipitation by year: Asheville, N.C., National Oceanic and Atmospheric Administration, Environmental Data and Information Service, National Climatic Data Center, v. 116, no. $08,27 \mathrm{p}$.

National Oceanic and Atmospheric Administration, 2011h, Climatological data Pennsylvania, September, 2011, September precipitation by year: Asheville, N.C., National Oceanic and Atmospheric Administration, Environmental Data and Information Service, National Climatic Data Center, v. 123, no. 09, 26 p.

National Oceanic and Atmospheric Administration, 2011i, Hourly precipitation data, New York, August, 2011: Asheville, N.C., National Oceanic and Atmospheric Administration, Environmental Data and Information Service, National Climatic Data Center, v. 61, no. 08, 15 p.

National Oceanic and Atmospheric Administration, 2011j, Hourly precipitation data, New York, September, 2011: Asheville, N.C., National Oceanic and Atmospheric Administration, Environmental Data and Information Service, National Climatic Data Center, v. 61, no. 9, 15 p.

National Oceanic and Atmospheric Administration, 2011k, National Climatic Data Center, Climate at a glance, annual time-series plot for New York, 1895-2011, temperature and precipitation analysis, accessed February 27, 2013, at http://www.ncdc.noaa.gov/temp-and-precip/time-series/. 
National Oceanic and Atmospheric Administration, 20111, National Operational Hydrologic Remote Sensing Center, Interactive Snow Information, snow water equivalent for New York, April 1, 15, 26, and 29, 2011, accessed February 21, 2013, at http://www.nohrsc.noaa.gov/ interactive/html/map.html.

National Oceanic and Atmospheric Administration, 2011m, National Weather Service, Advanced Hydrologic Prediction Center, daily precipitation totals for New York, April 26-29, August 28-29, and September 6-9, 2011, accessed February 21, 2013, at http://water.weather.gov/precip/.

National Oceanic and Atmospheric Administration, 2011n, Storm data and unusual weather phenomena with late reports and corrections: Ashville, N.C., NOAA, Environmental Data and Information Service, National Climatic Data Center, v. 53, no. 4.

National Oceanic and Atmospheric Administration, 2012, Regional service assessment - remnants of Tropical Storm Lee and the Susquehanna River Basin flooding of September 6-10, 2011: U.S. Department of Commerce, National Oceanic and Atmospheric Administration, National Weather Service, 45 p.

New York State, 2012, New York State Responds, Hurricane Irene and Tropical Storm Lee, one year later, August 2012, 23 p., accessed on February 27, 2013, at http://www. governor.ny.gov/assets/documents/Irene-Lee-One-YearReport.pdf.

Northeast Regional Climate Center, 2010, Extreme precipitation in New York and New England-An interactive web tool for extreme precipitation analysis, accessed March 5, 2013, at http://precip.eas.cornell.edu/.
Northeast Regional Climate Center, 2013, Climod, monthly time series, Lake Placid, New York, accessed March 5, 2013, at http://climod.nrcc.cornell.edu/climod/timeSeries/.

Schopp, R.D., and Firda, G.D., 2008, Flood magnitude and frequency of the Delaware River in New Jersey, New York, and Pennsylvania: U.S. Geological Survey Open-File Report 2008-1203, 7 p.

Suro, T.P., Firda, G.D., and Szabo, C.O., 2009, Flood of June 26-29, 2006, Mohawk, Delaware, and Susquehanna River Basins, New York: U.S. Geological Survey Open-File Report 2009-1063, 354 p.

The Owego Pennysaver, 2011, 181-183 Front Street, Owego, NY 13827, (607) 687-2434; E-mail: opennysaver@stny. rr.com; http://www.owegopennysaver.com, accessed at http://owegopennysaver.com/index.php/2011/10/10/ village-grapples-with-budget-funding-and-repairs/ and http://en.wikipedia.org/wiki/Tropical_Storm_Lee_(2011).

Walter, Meghan, and Vogel, R.M., 2010, Increasing trends in peak flows in the northeastern United States and their impacts on design: 2nd Joint Federal Interagency Conference, Las Vegas, Nev., June 27-July 1, 2010, 16 p., accessed at http://acwi.gov/sos/pubs/2ndJFIC/Contents/2F_ Walter_03_01_10.pdf.

Weaver, J.C., Feaster, T.D., and Gotvald, A.J., 2009, Magnitude and frequency of rural floods in the southeastern United States, through 2006: Volume 2, North Carolina: U.S. Geological Survey Scientific Investigations Report 2009-5158, 111 p. (Also available at http://pubs.usgs.gov/ sir/2009/5158/.) 
Appendix 1. Map Numbers, U.S. Geological Survey Streamgage Numbers and Names, and Selected Flood Information Used in the Study 

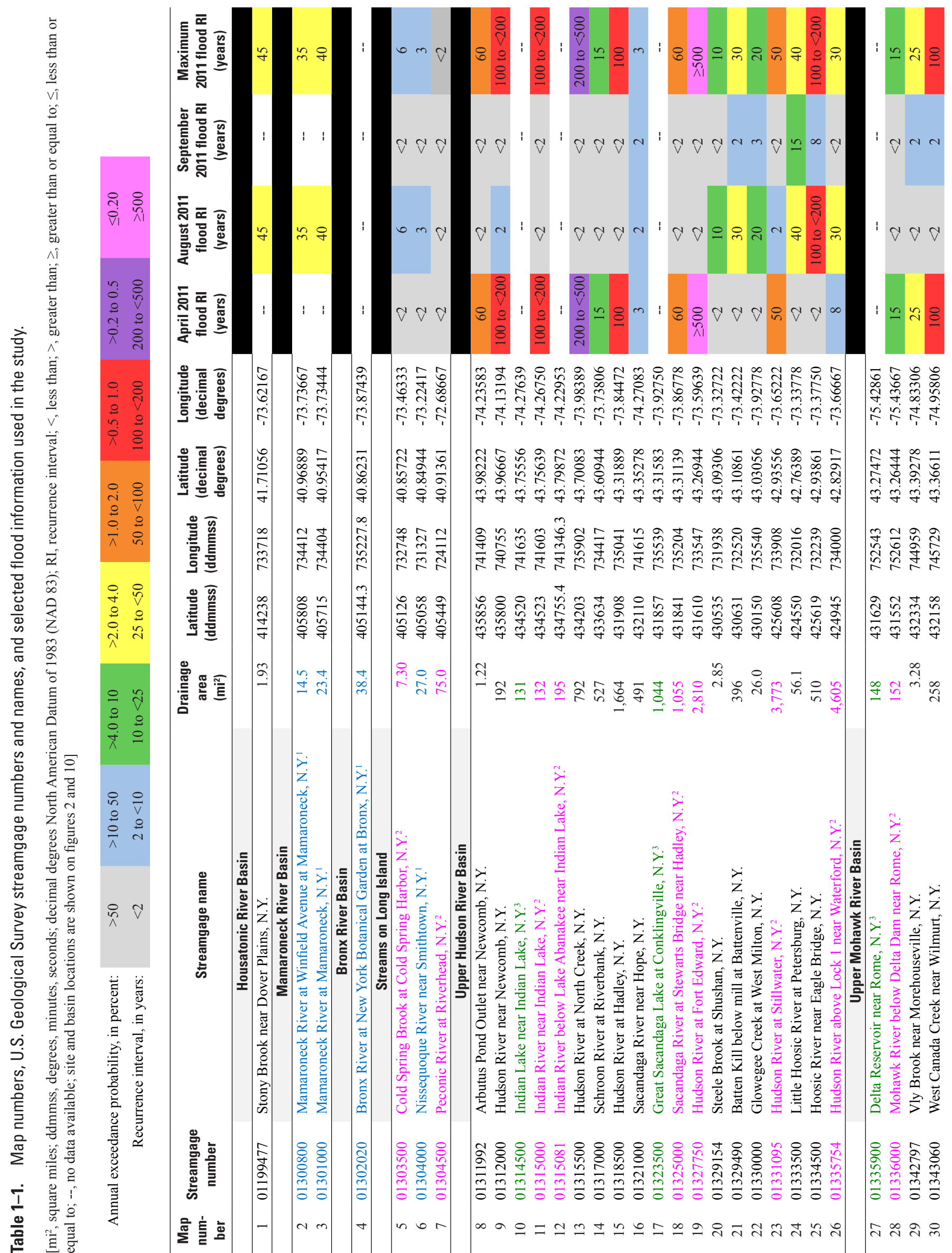

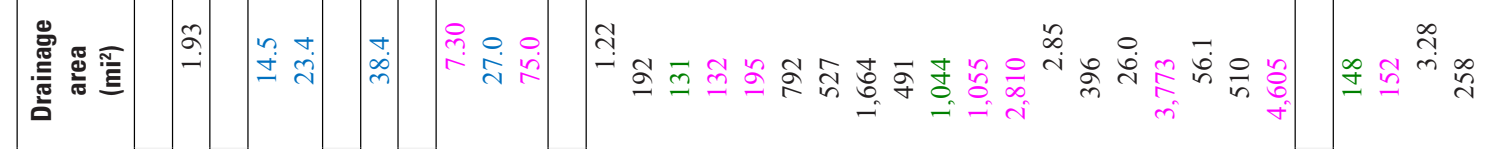

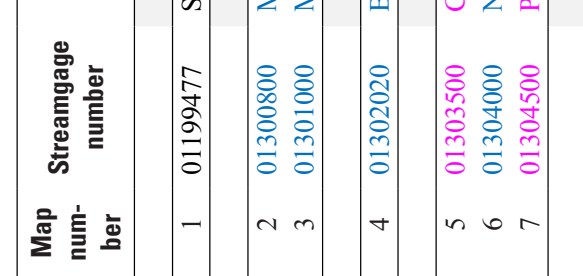

每

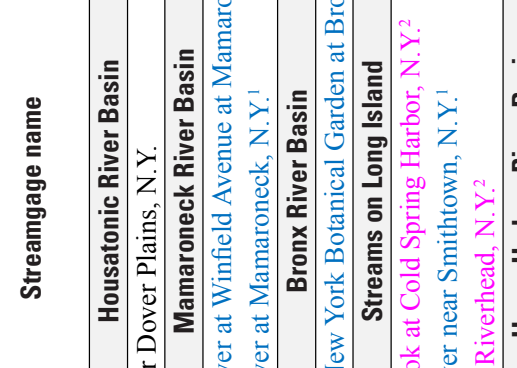

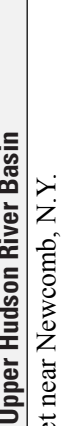

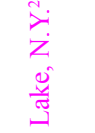

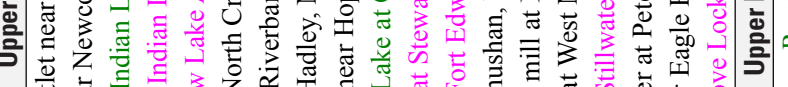
ठ च

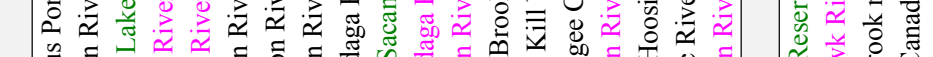

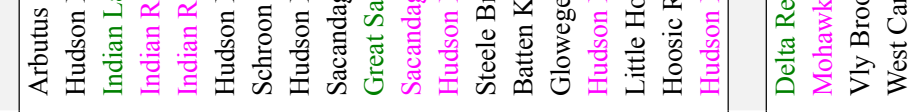
L。

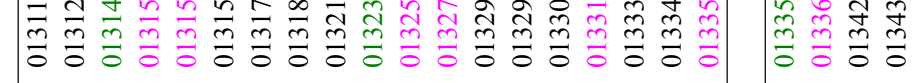

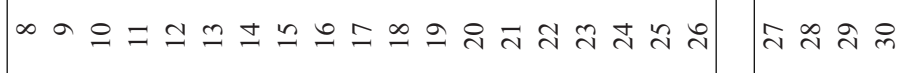



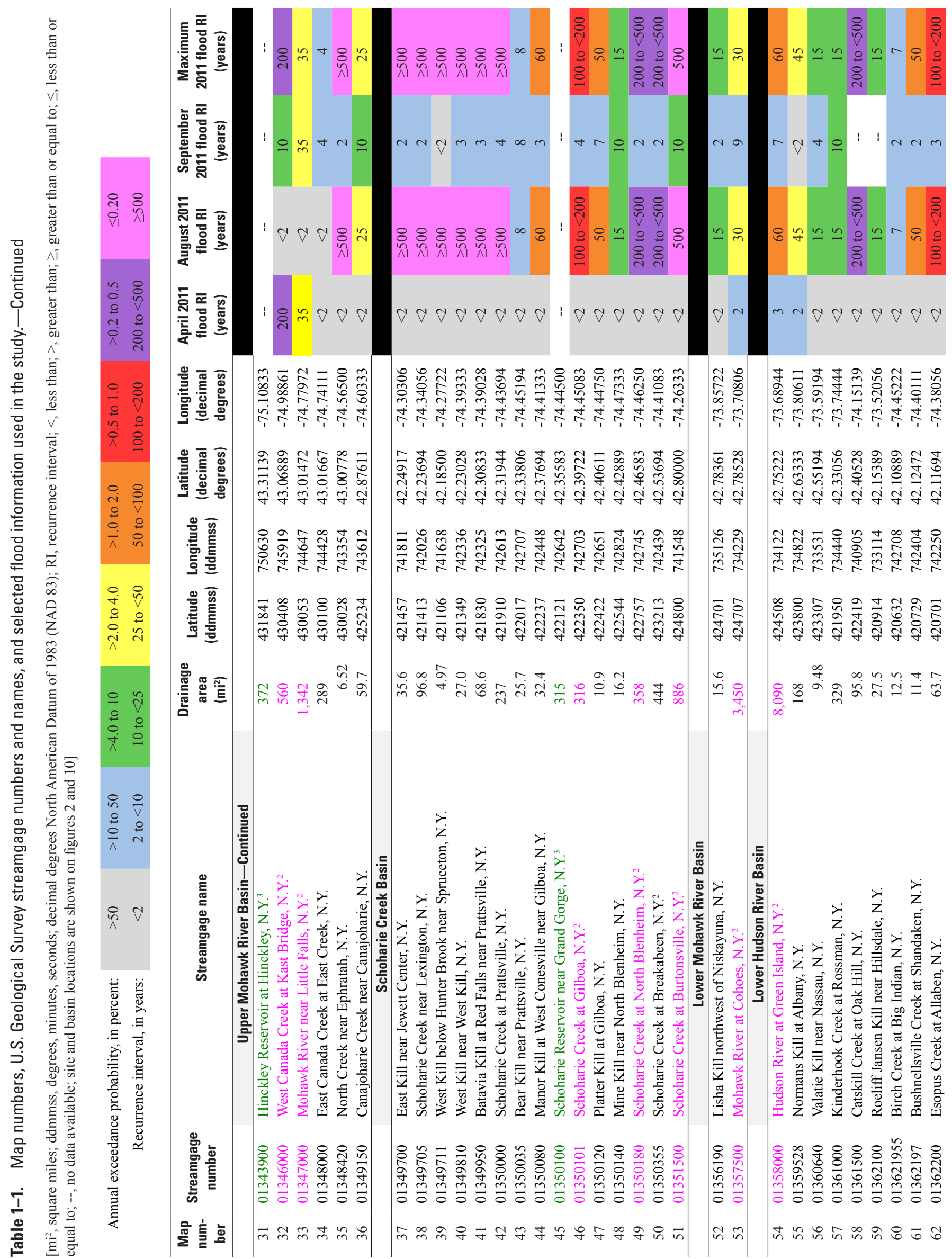

\begin{tabular}{|c|c|c|c|}
\hline 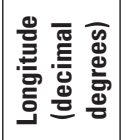 & 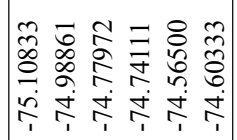 & 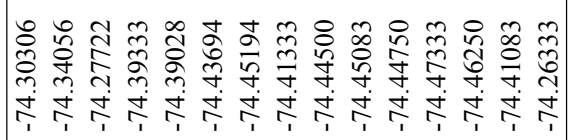 & 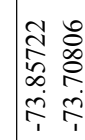 \\
\hline 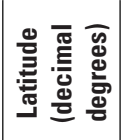 & 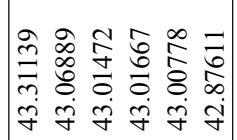 & 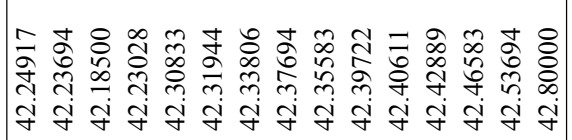 & 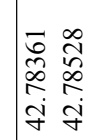 \\
\hline 言 & 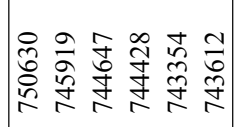 & 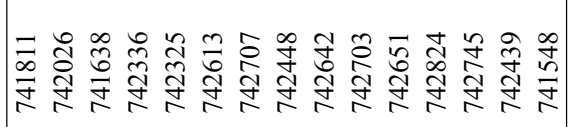 & $\underset{\substack{n \\
m}}{\dddot{n}}$ \\
\hline & \%०० & 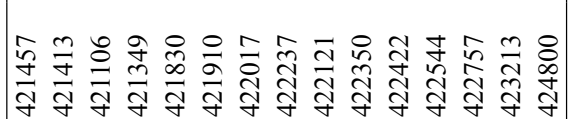 & \\
\hline
\end{tabular}

\begin{tabular}{|c|c|c|c|c|}
\hline 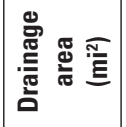 & 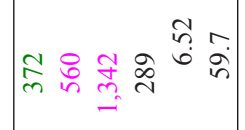 & 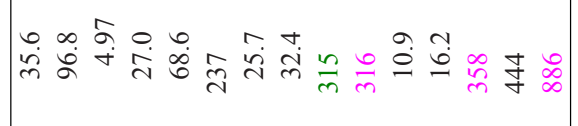 & 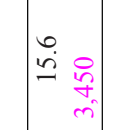 & 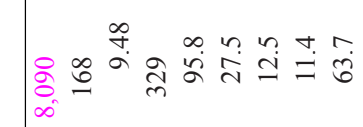 \\
\hline
\end{tabular}

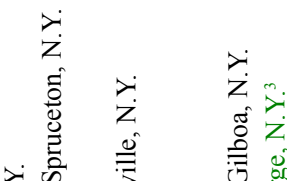

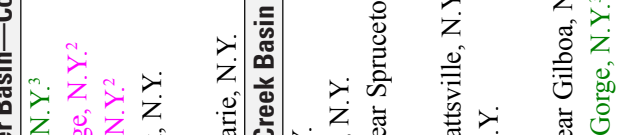

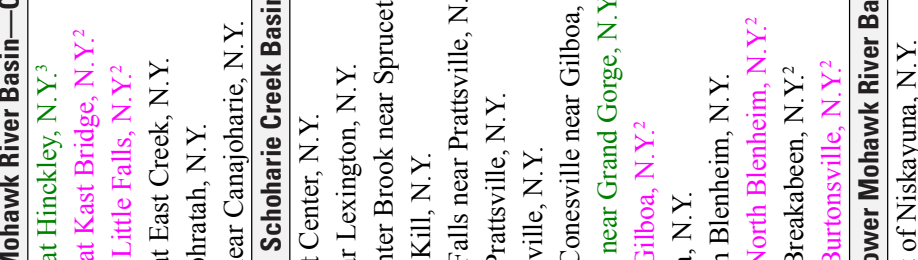

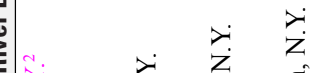

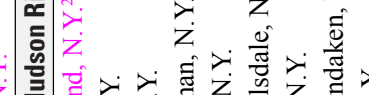

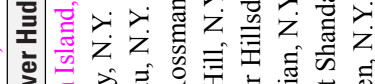

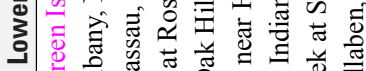

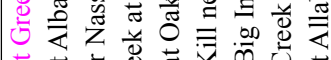

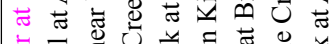

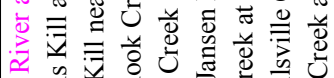

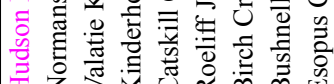
\&용ㅊㅎㅇ 齐

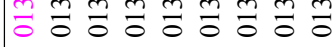

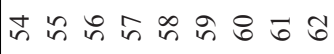




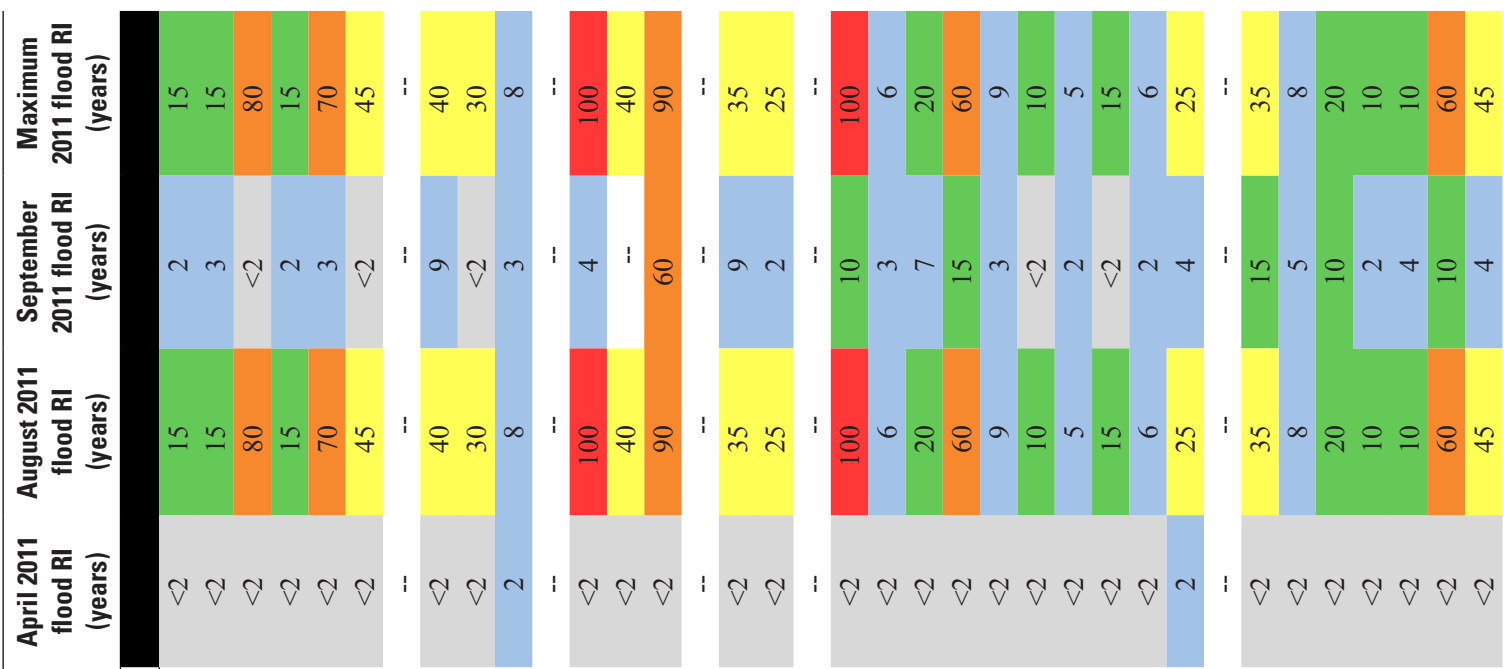

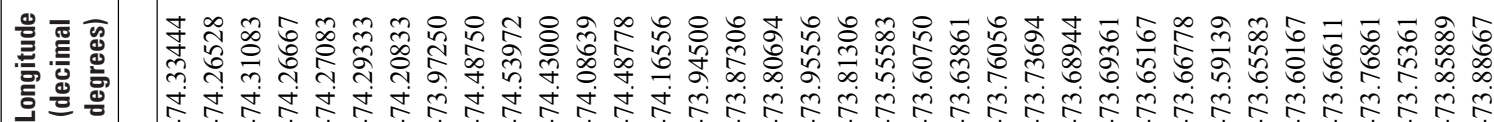

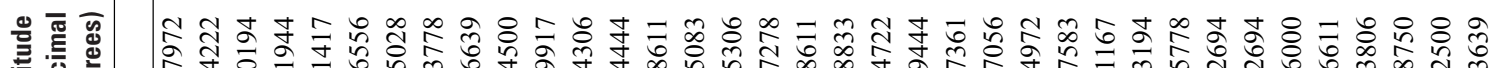

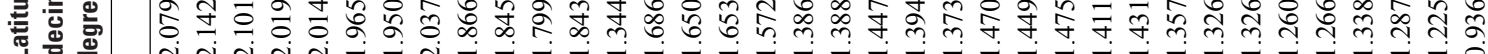

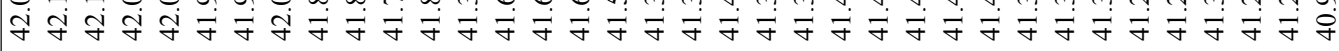

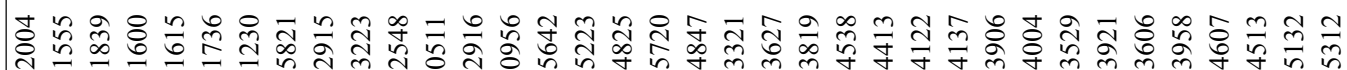

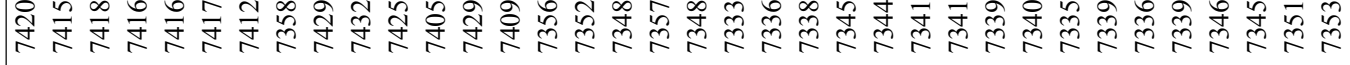

告

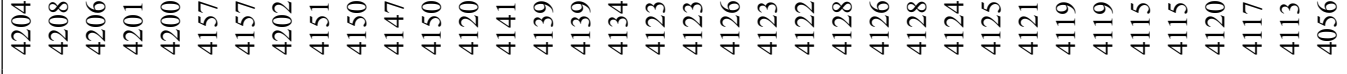

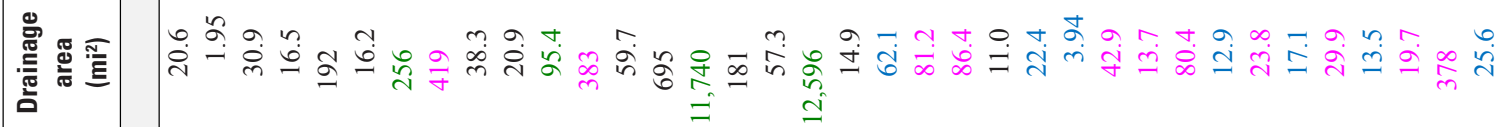

¿

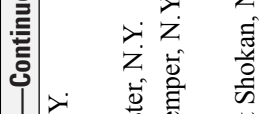

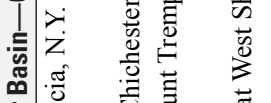

产

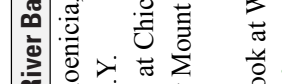

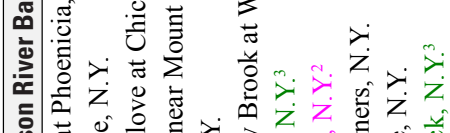

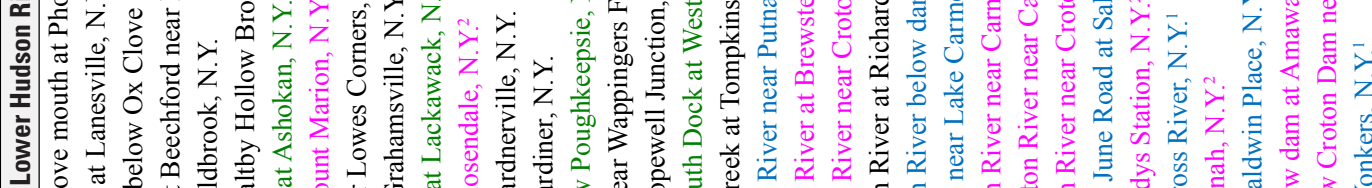

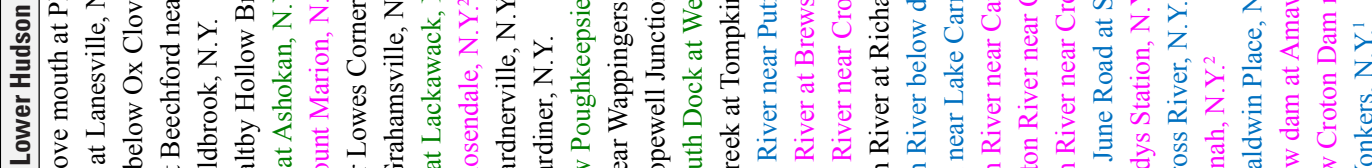

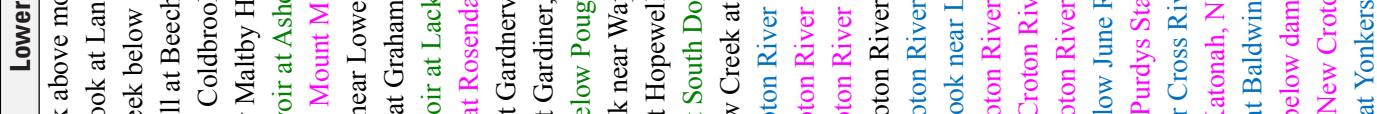

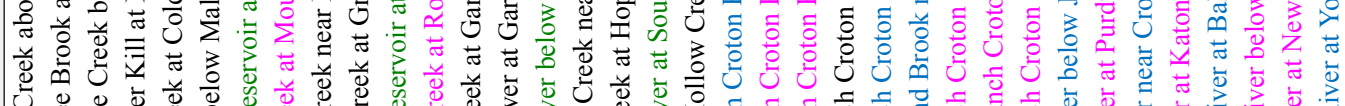

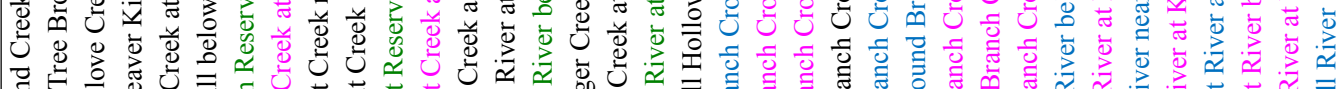

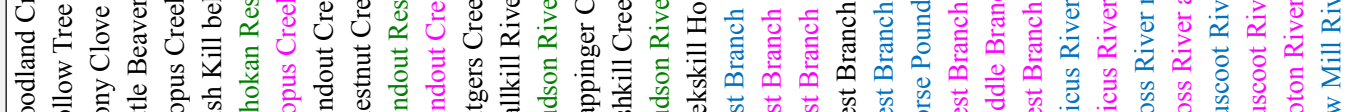

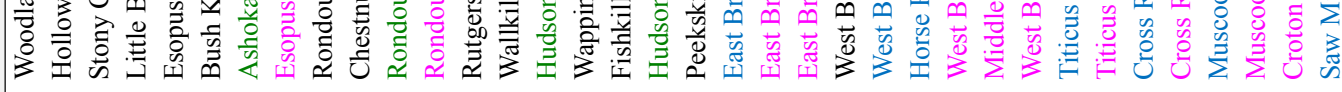
ठิे ๆ

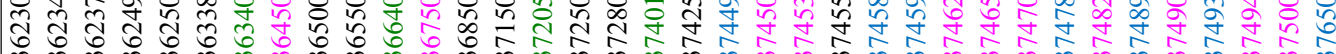

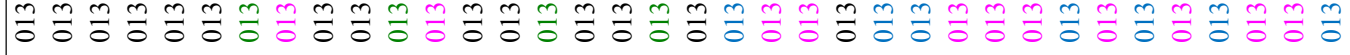

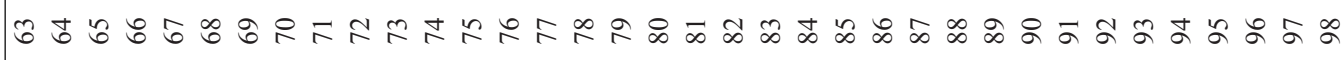



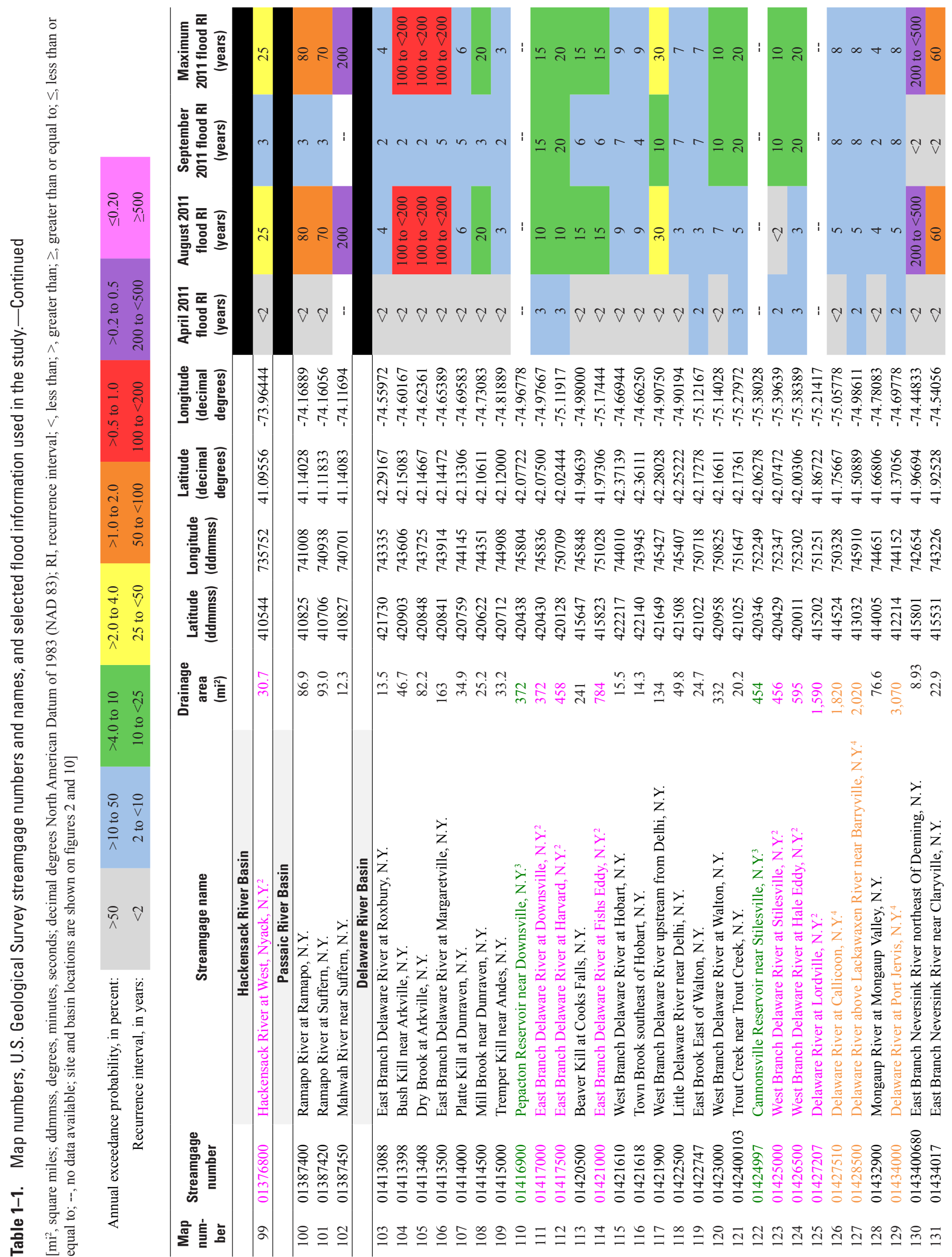

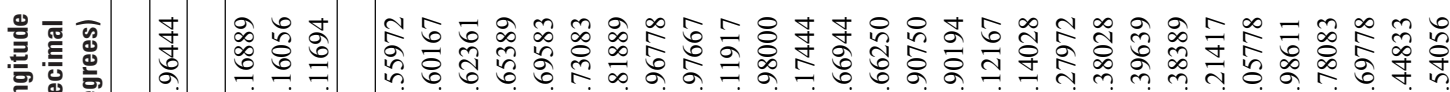

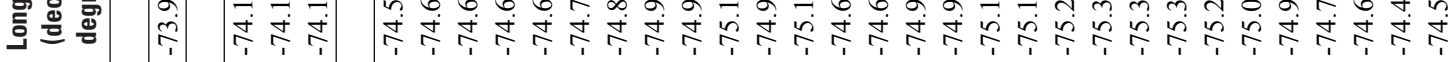

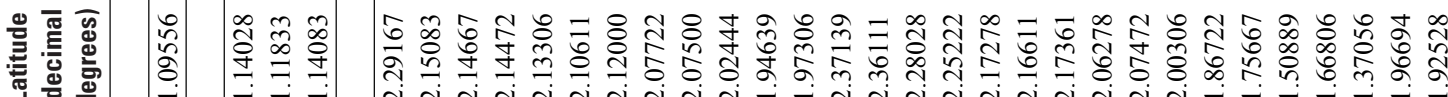

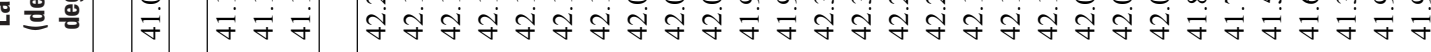
慈商

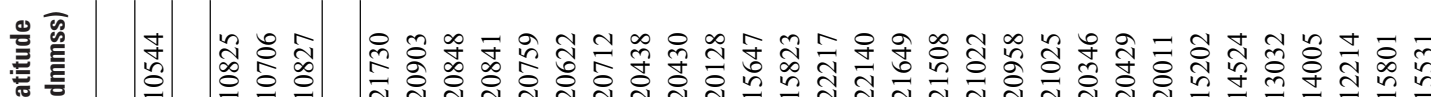

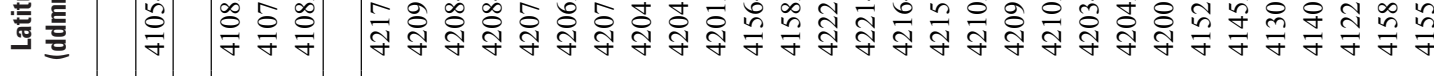

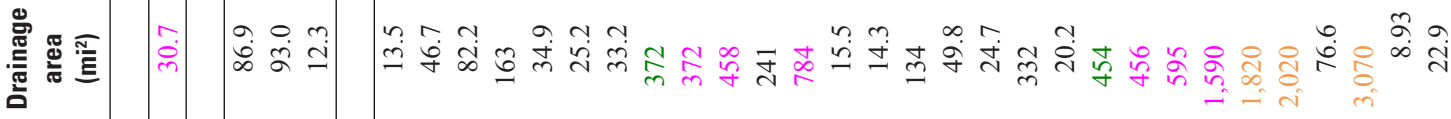

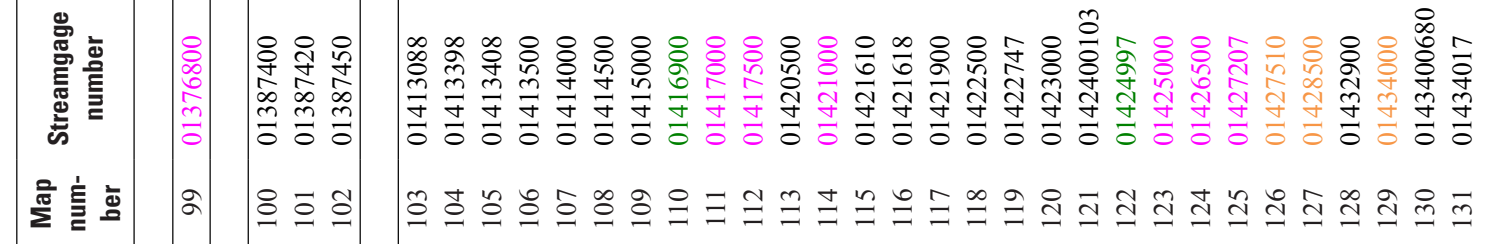




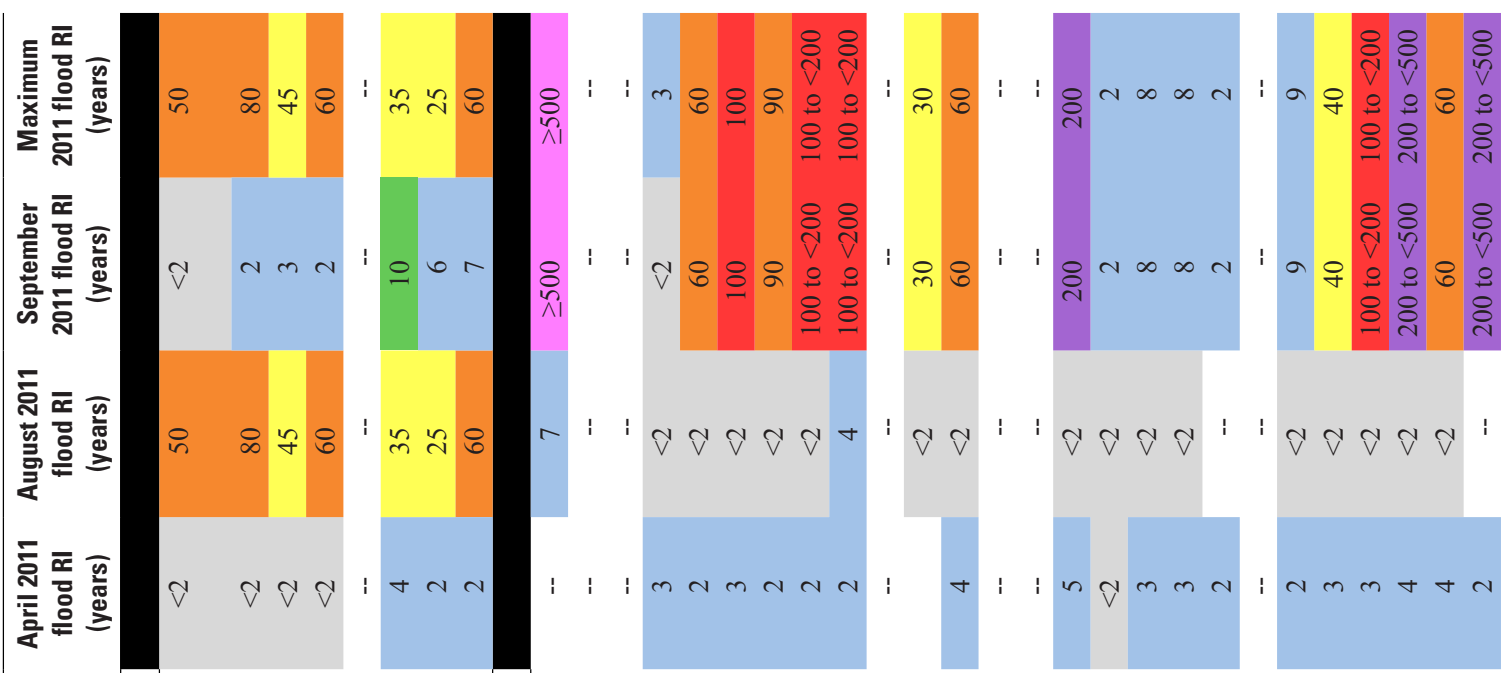

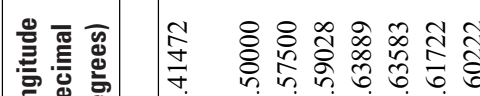

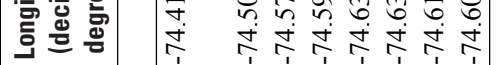

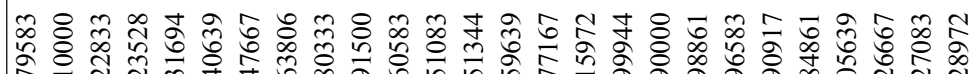

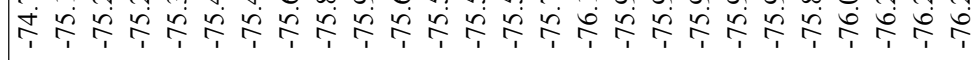

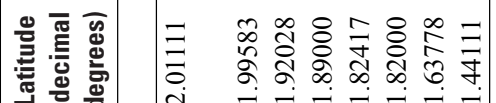

它各定

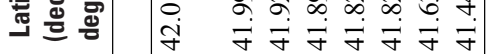

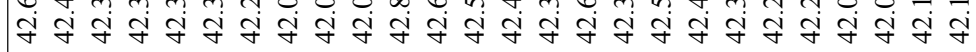

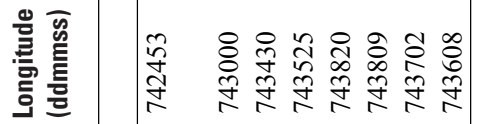

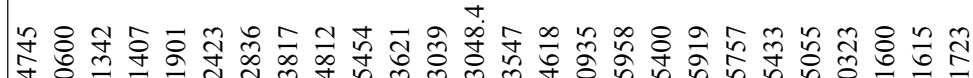

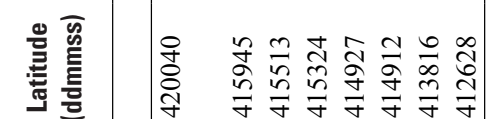

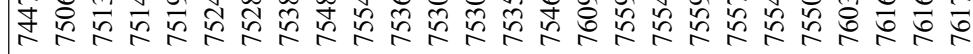

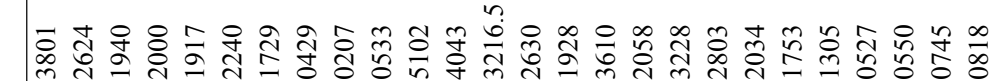

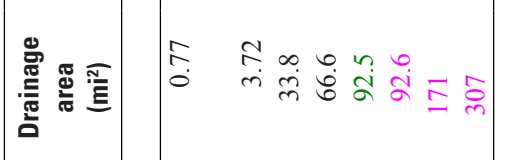

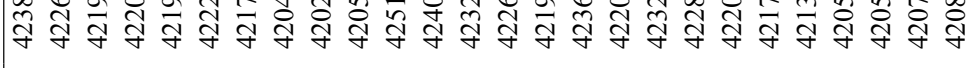

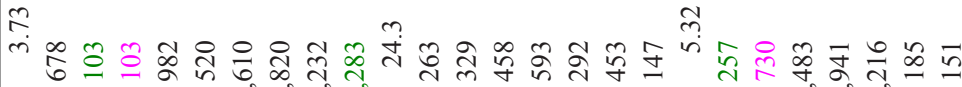

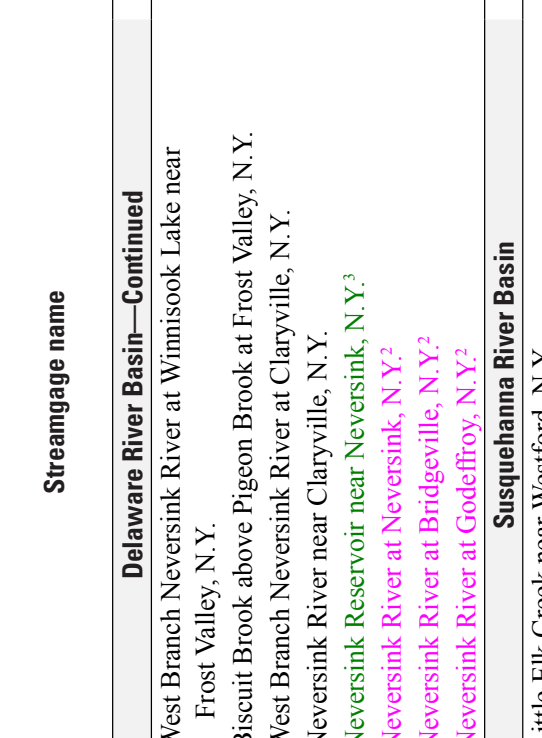


के

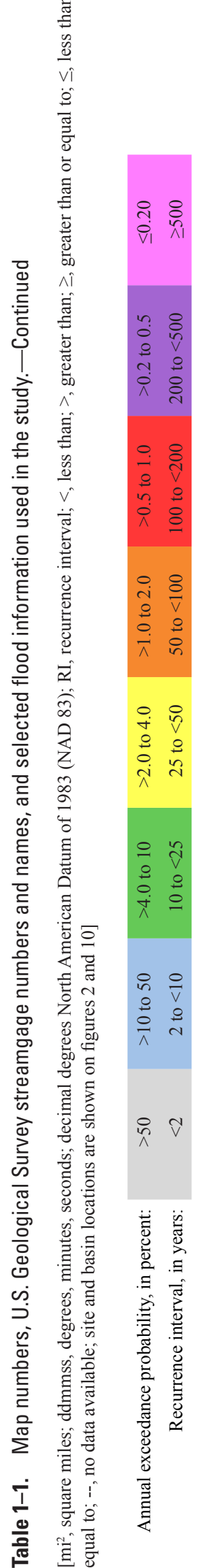

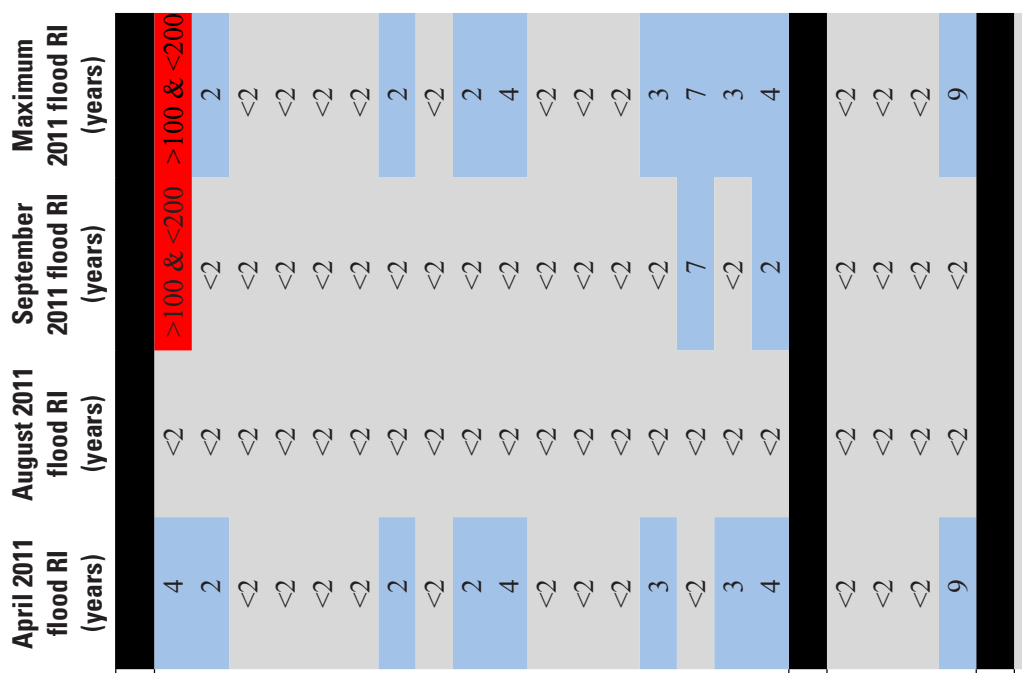

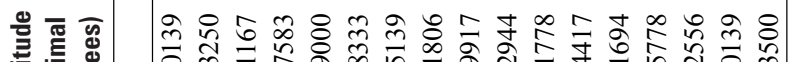

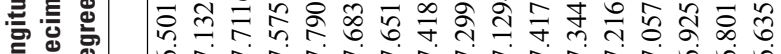
言

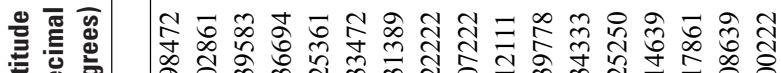

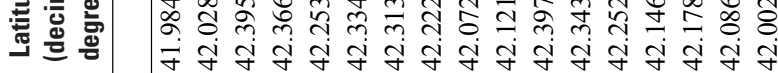

\section{竞要} 홍

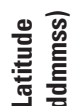

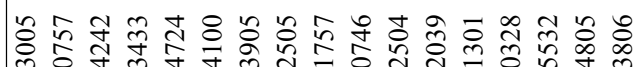

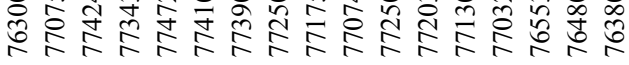

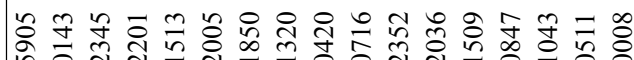

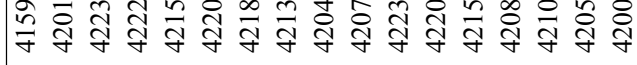
苞

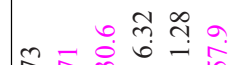
产 ํㅡㄹ $\infty$ क 주

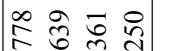

of $n=$

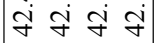

m

क्र

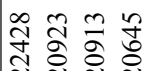

光年辛 $\simeq \infty$

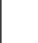

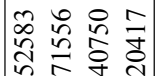

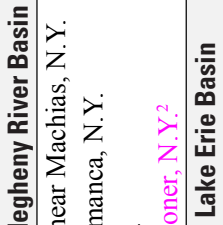

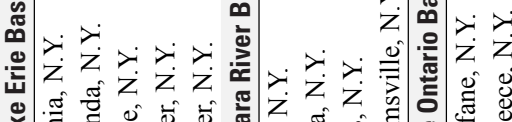

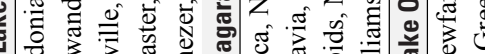

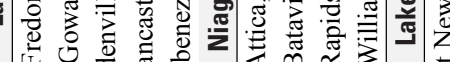

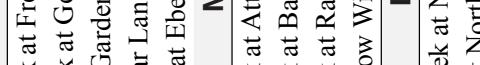

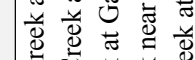

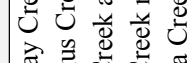

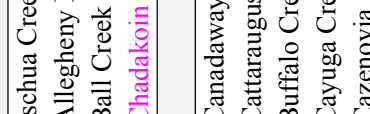

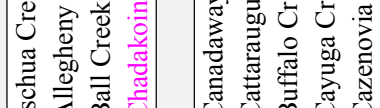

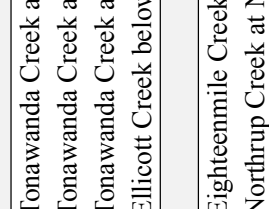

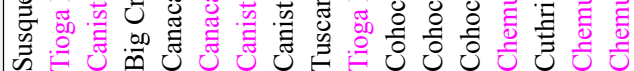

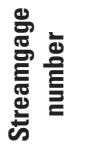

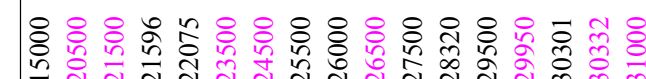

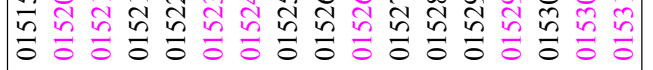

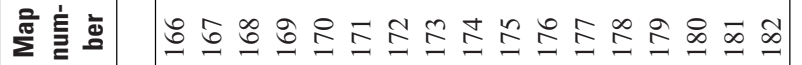
的 产

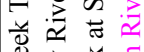

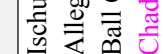

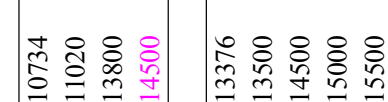

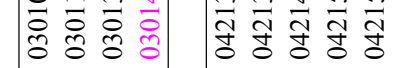

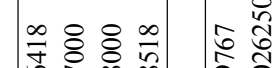

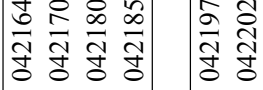

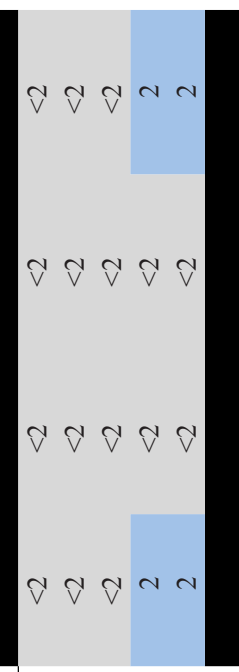

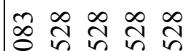

कर है दे

रे $\infty \stackrel{\infty}{\uparrow} \infty$

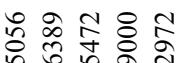

of $\begin{aligned} & 4 \\ & \text { के }\end{aligned}$

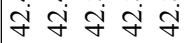

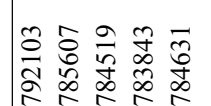

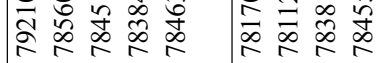

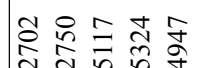

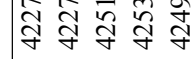

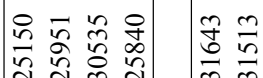

究

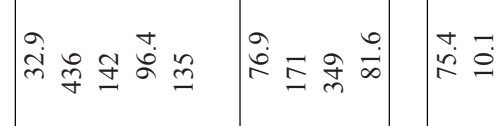

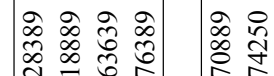
$\stackrel{\infty}{\uparrow}$

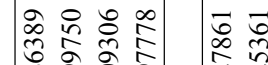

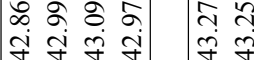

ขึ 采点

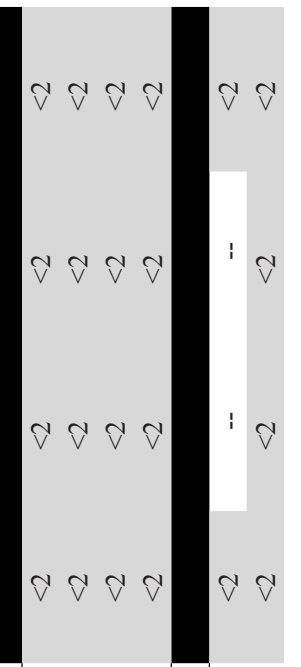

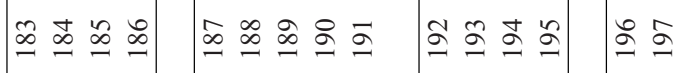




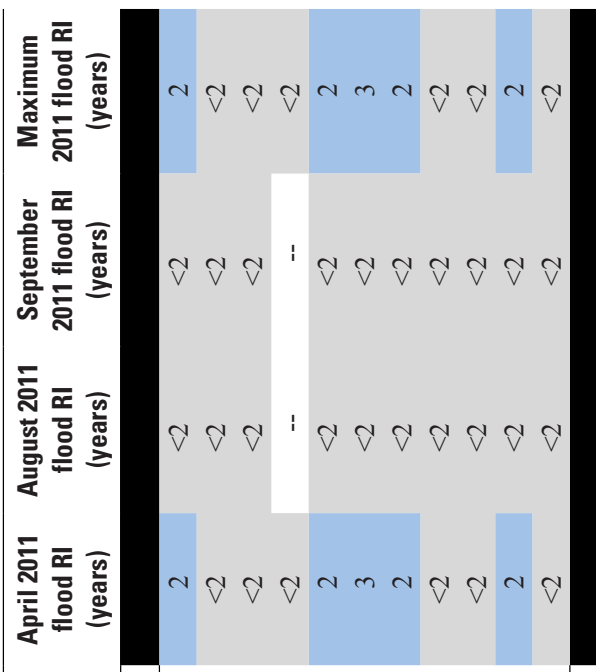

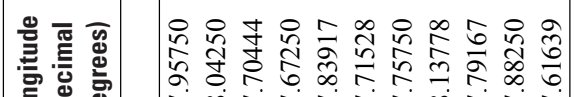
揞热

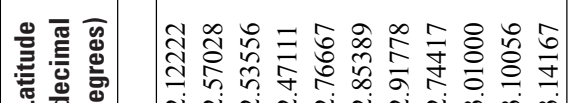
覀 莺

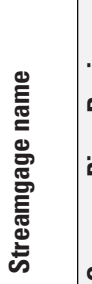

焉

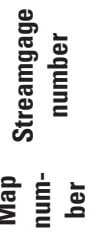

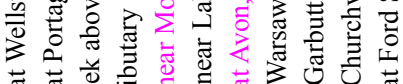

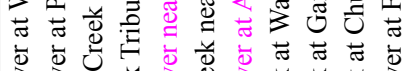

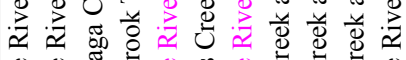

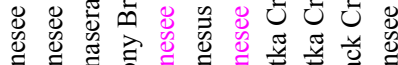

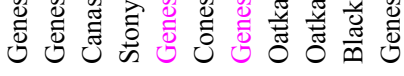

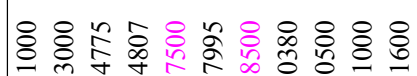

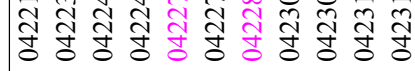

didid

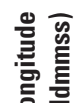

흘 틍

蓄

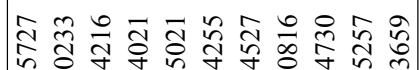

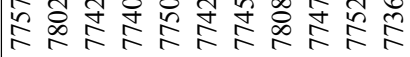

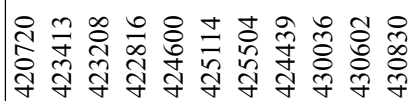

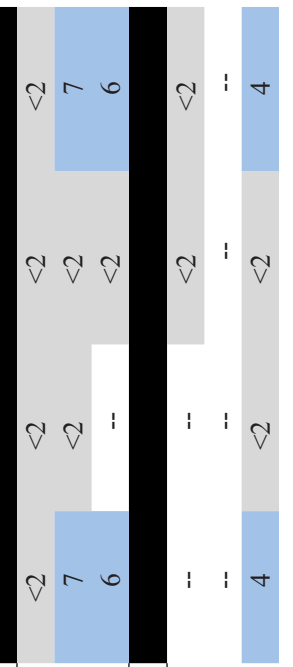

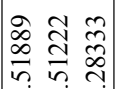

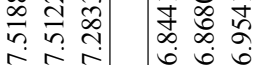

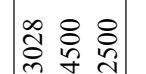

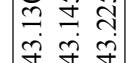

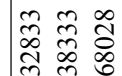
过方

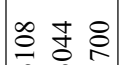

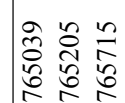

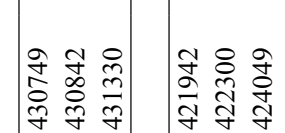

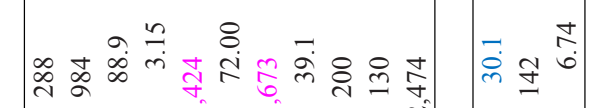

字苍客 西 순순?

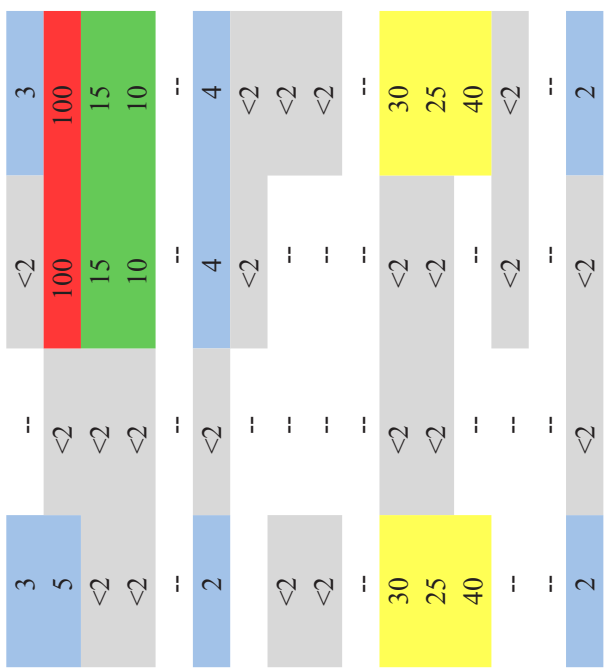

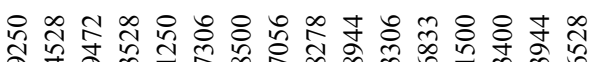
के fै

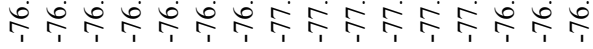

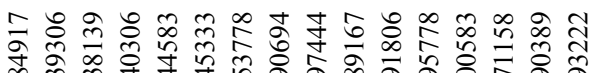

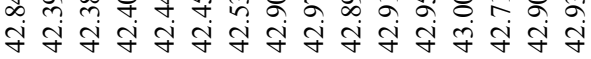

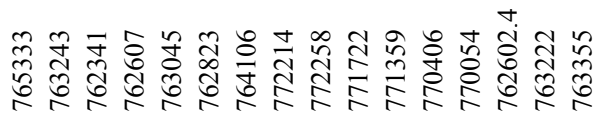

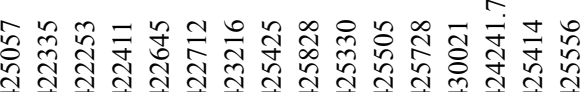

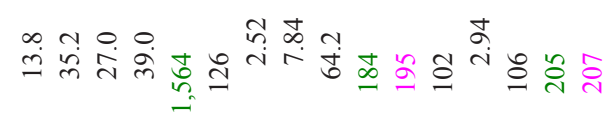

.

造

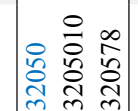
đิ่

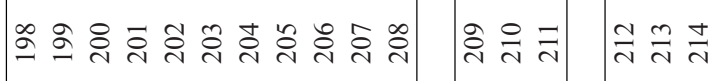

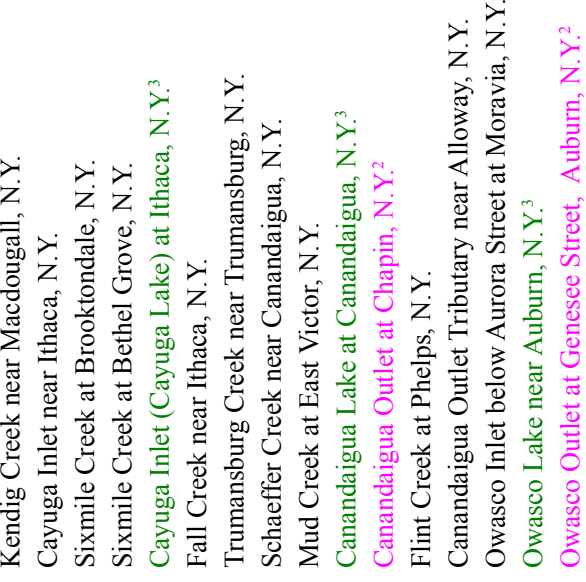

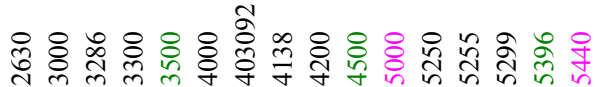

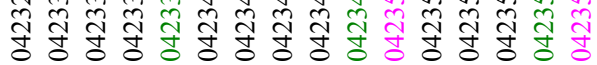

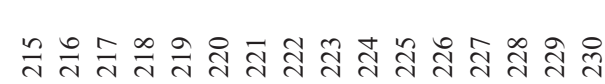



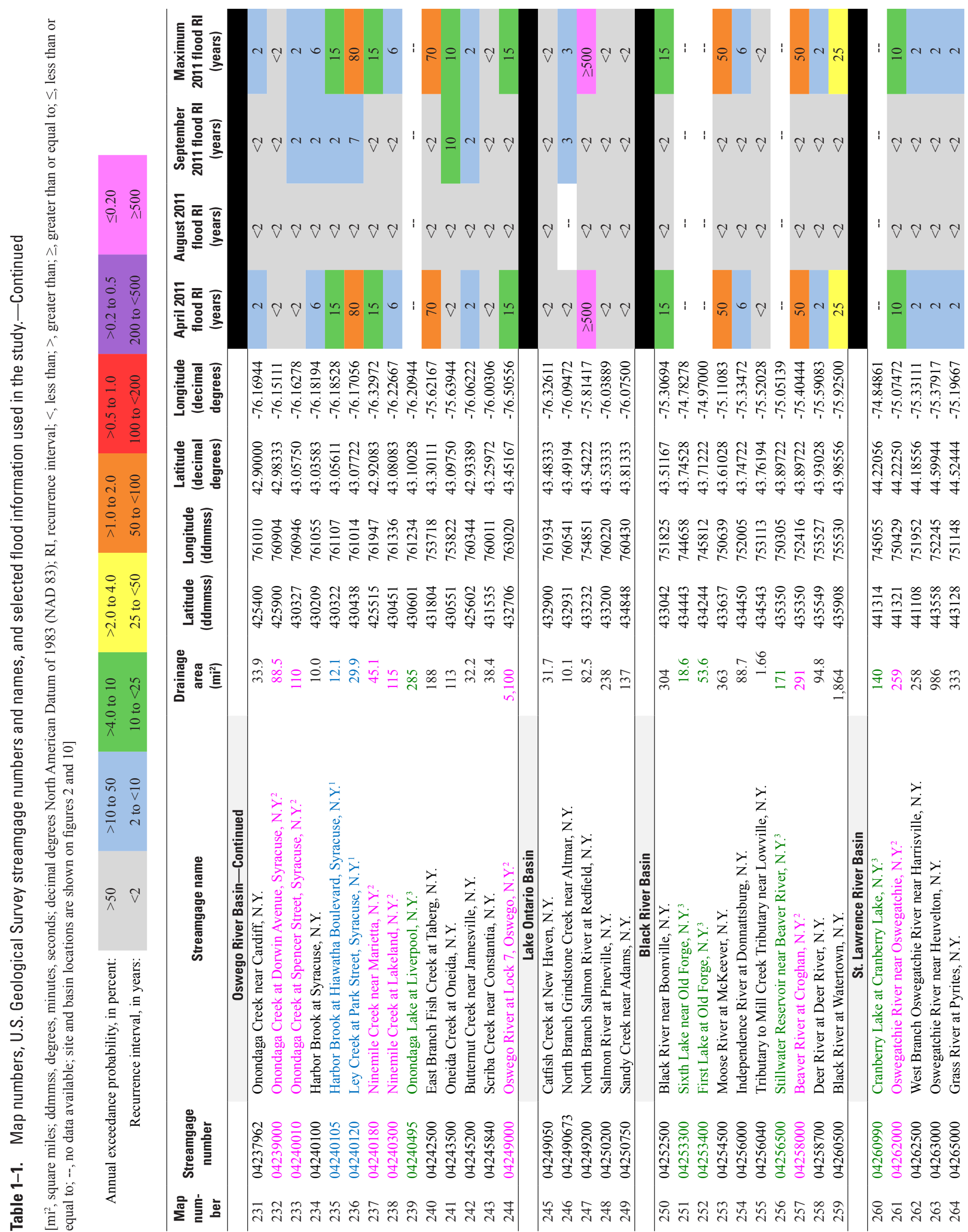

\begin{tabular}{|c|c|c|c|}
\hline 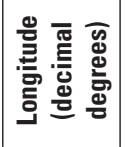 & 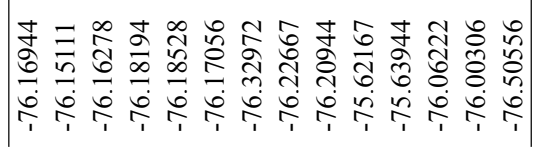 & 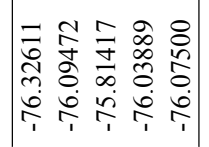 & 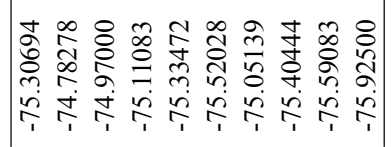 \\
\hline : & 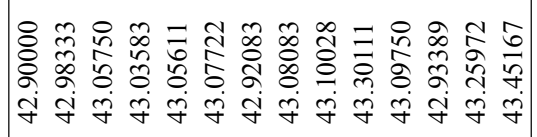 & 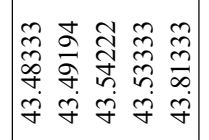 & 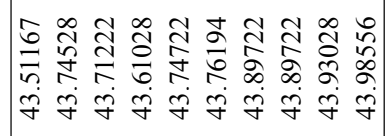 \\
\hline & 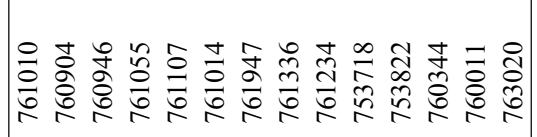 & 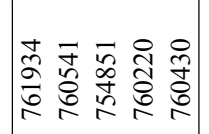 & D \\
\hline
\end{tabular}

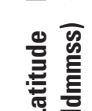

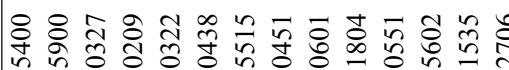

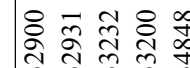

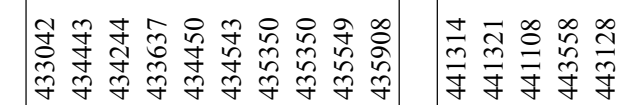

总

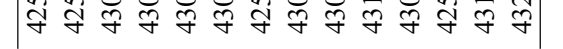

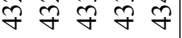

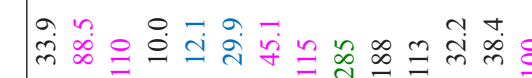

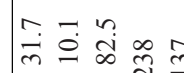

(1)

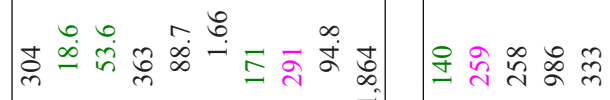

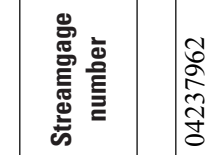

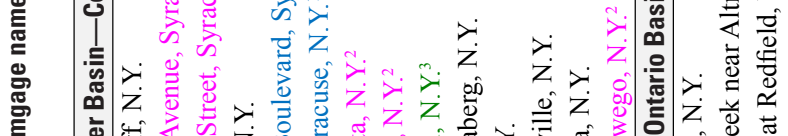

के

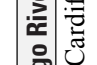

要

它

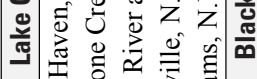

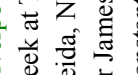

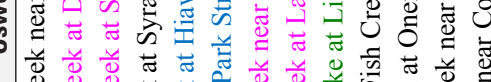

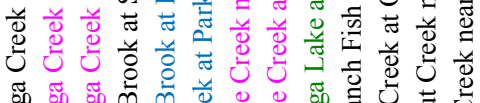

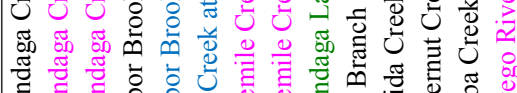

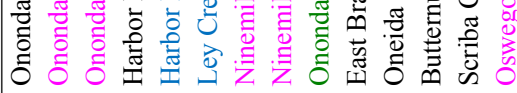

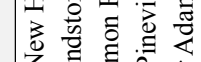

至过表壳

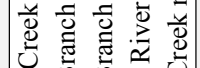

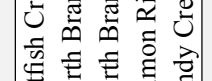

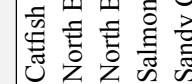

딩 웅응

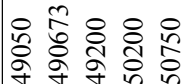

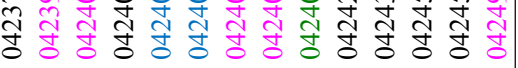

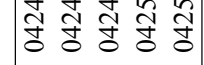

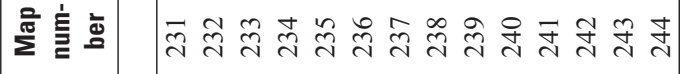

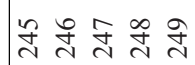

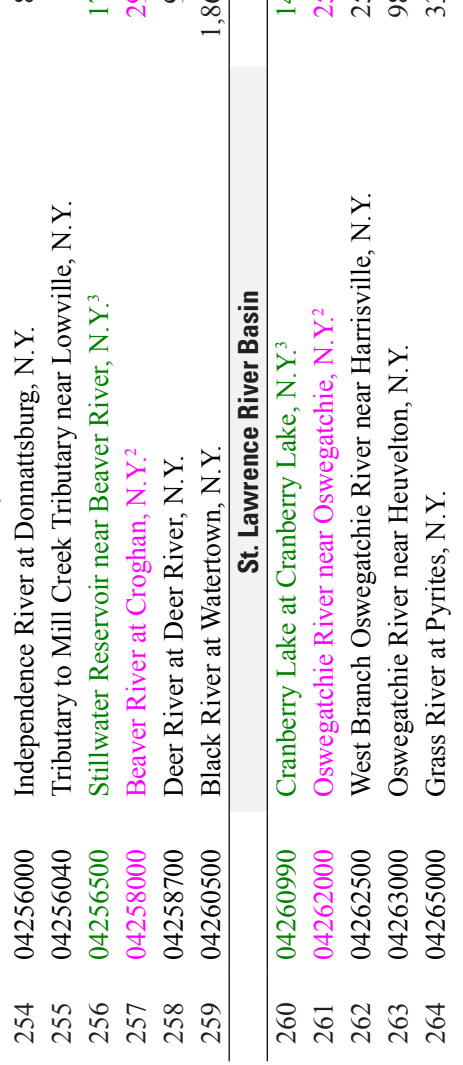


졸 类
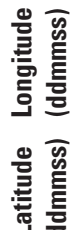

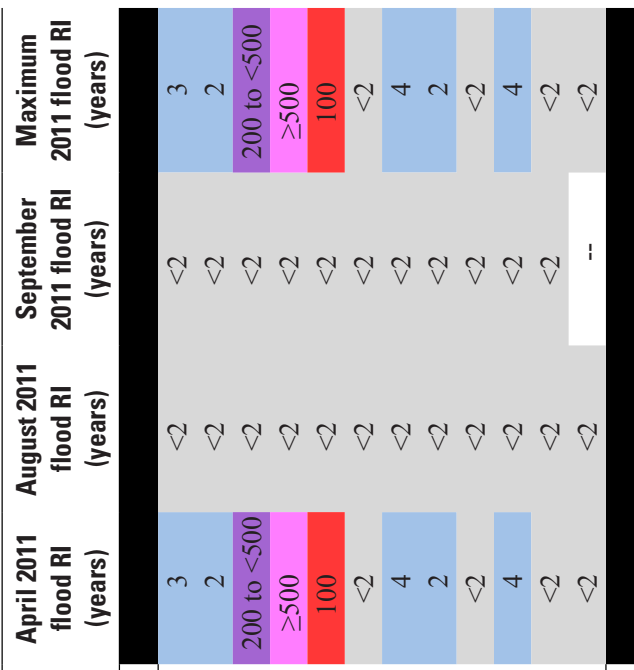

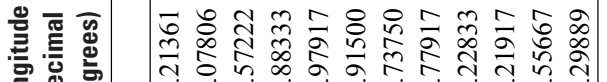

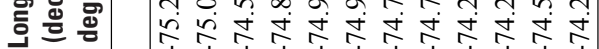

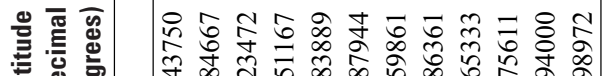

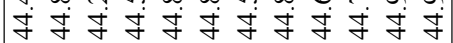

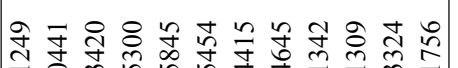

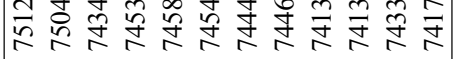

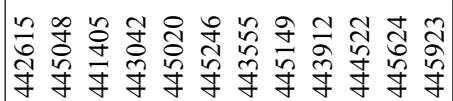

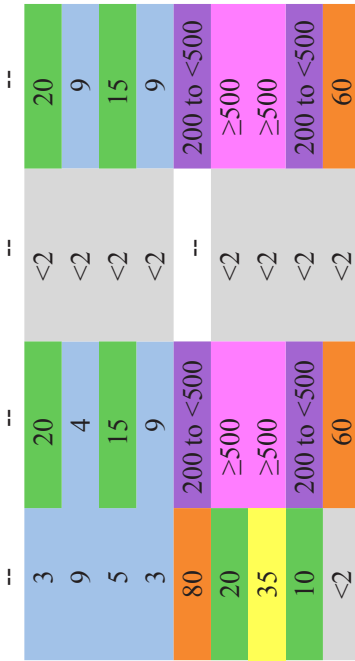

$\stackrel{0}{\rightleftarrows}$

蹗

离

क त

छ

量章

\&

宅

:

矛

局

$\underset{ \pm}{ \pm}$

章

总离

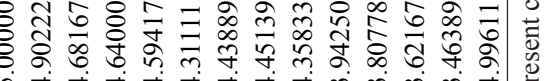

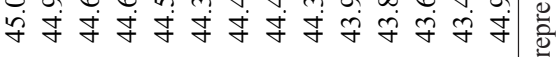

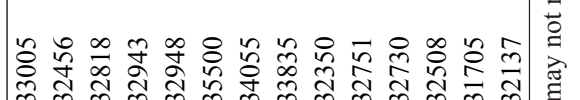

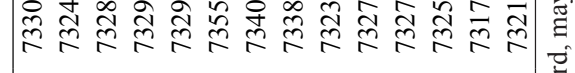

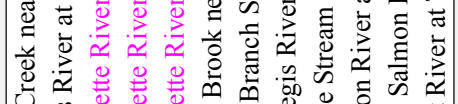

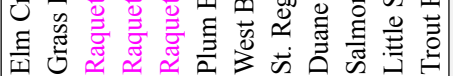

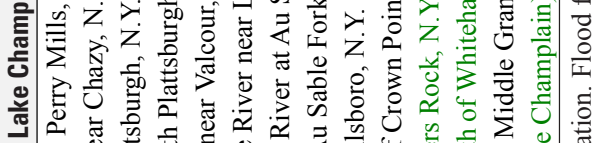

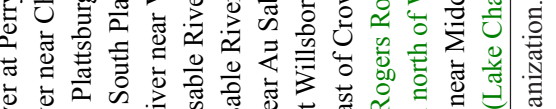

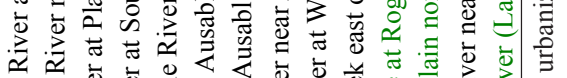

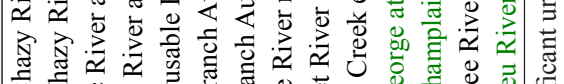
WnIn \& $\sim$ \% \& \& \& \& \& \&

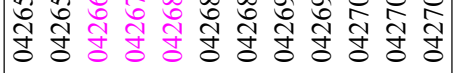

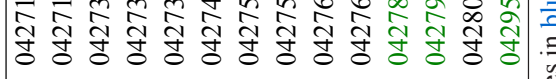
完茪 


\section{Appendix 2. Selected Photographs of Flood Damage Caused by the Floods of 2011 in New York}

Photographs were taken by U.S. Geological Survey personnel unless noted otherwise. 


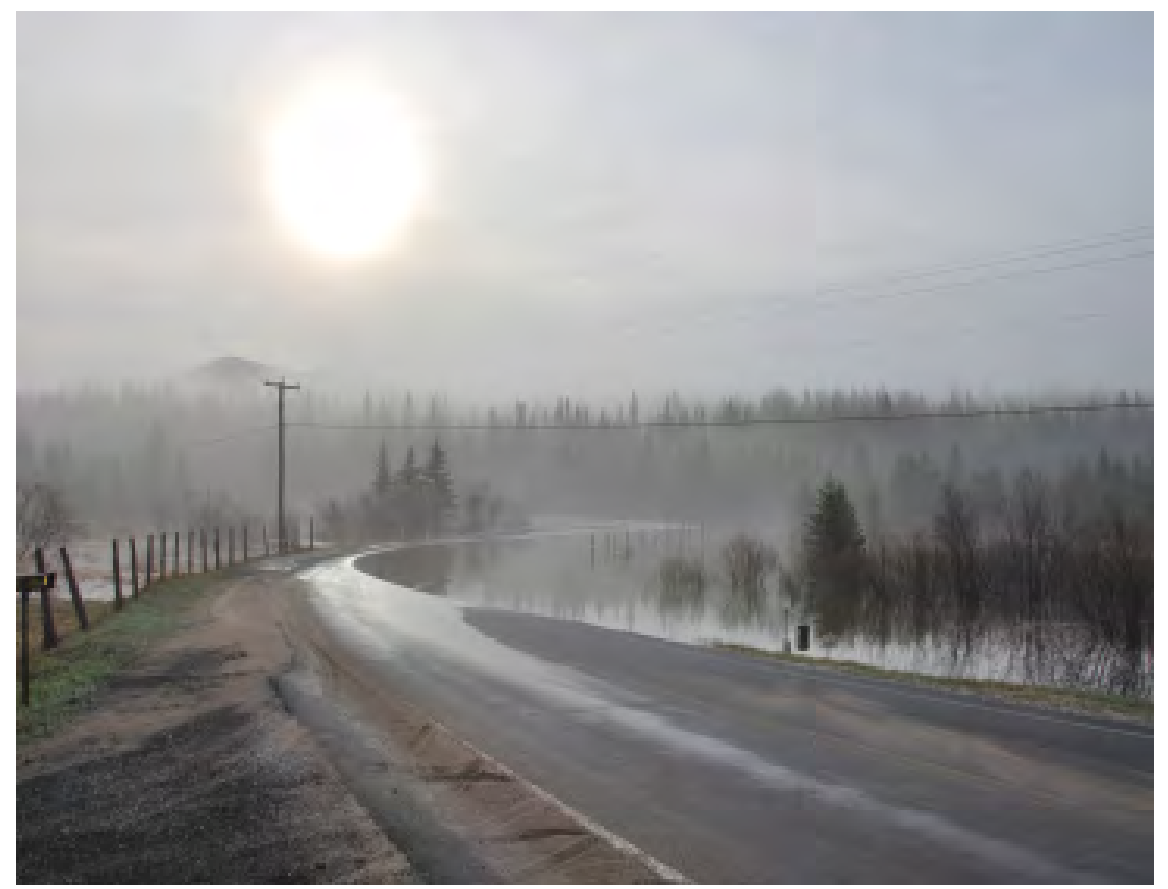

Figure 2-1. Flood of April 2011, West Branch Ausable River near Lake Placid, New York. Photo courtesy of Adirondack Daily Enterprise by Eric Voorhis.

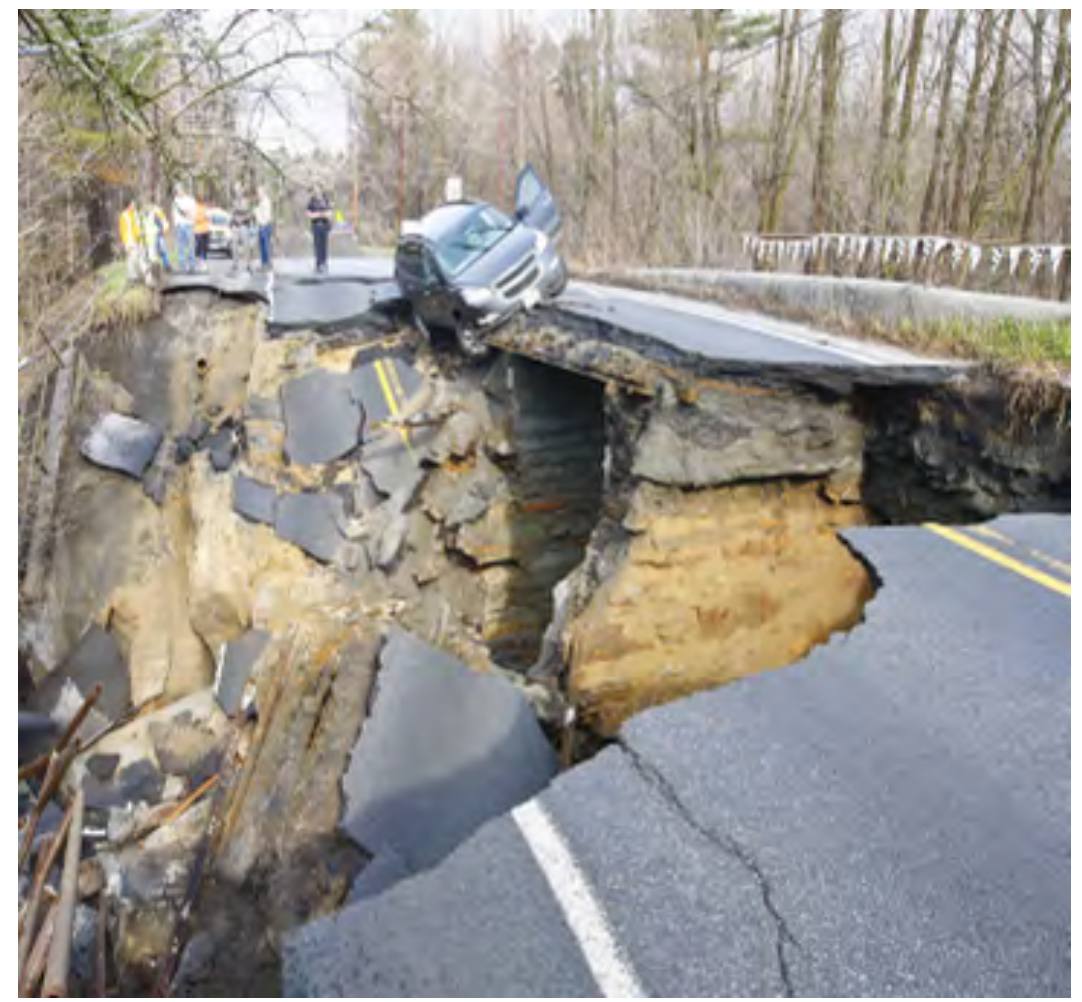

Figure 2-2. Flood of April 2011, Broad Street bridge washout caused by Mill Brook near Port Henry, New York. Photo courtesy of Lohr McKinstry/Press-Republican. 


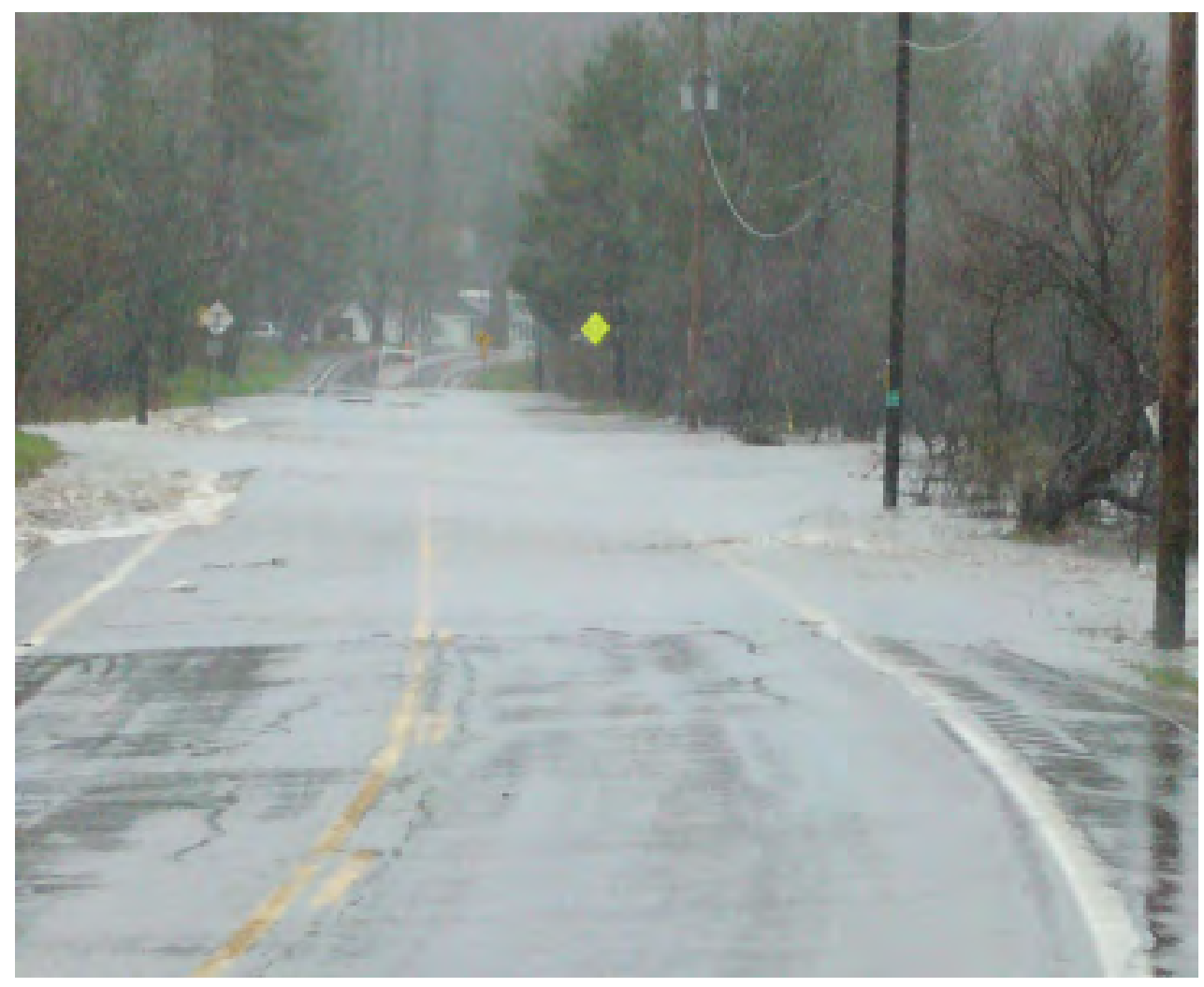

Figure 2-3. Flood of April 2011, West Canada Creek at Wilmurt, New York.

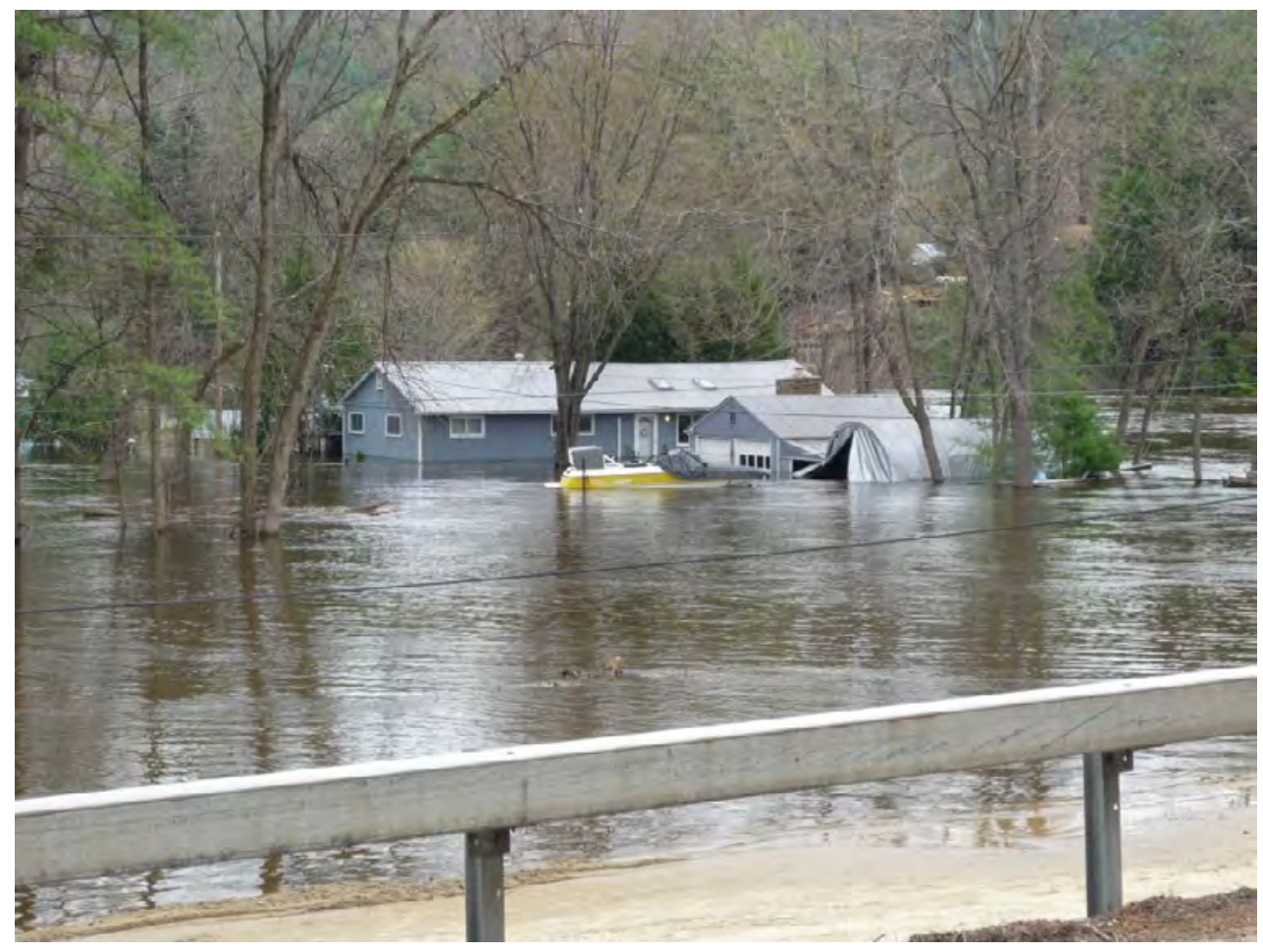

Figure 2-4. Flood of April 2011, Hudson River at Lake Luzerne, New York. 


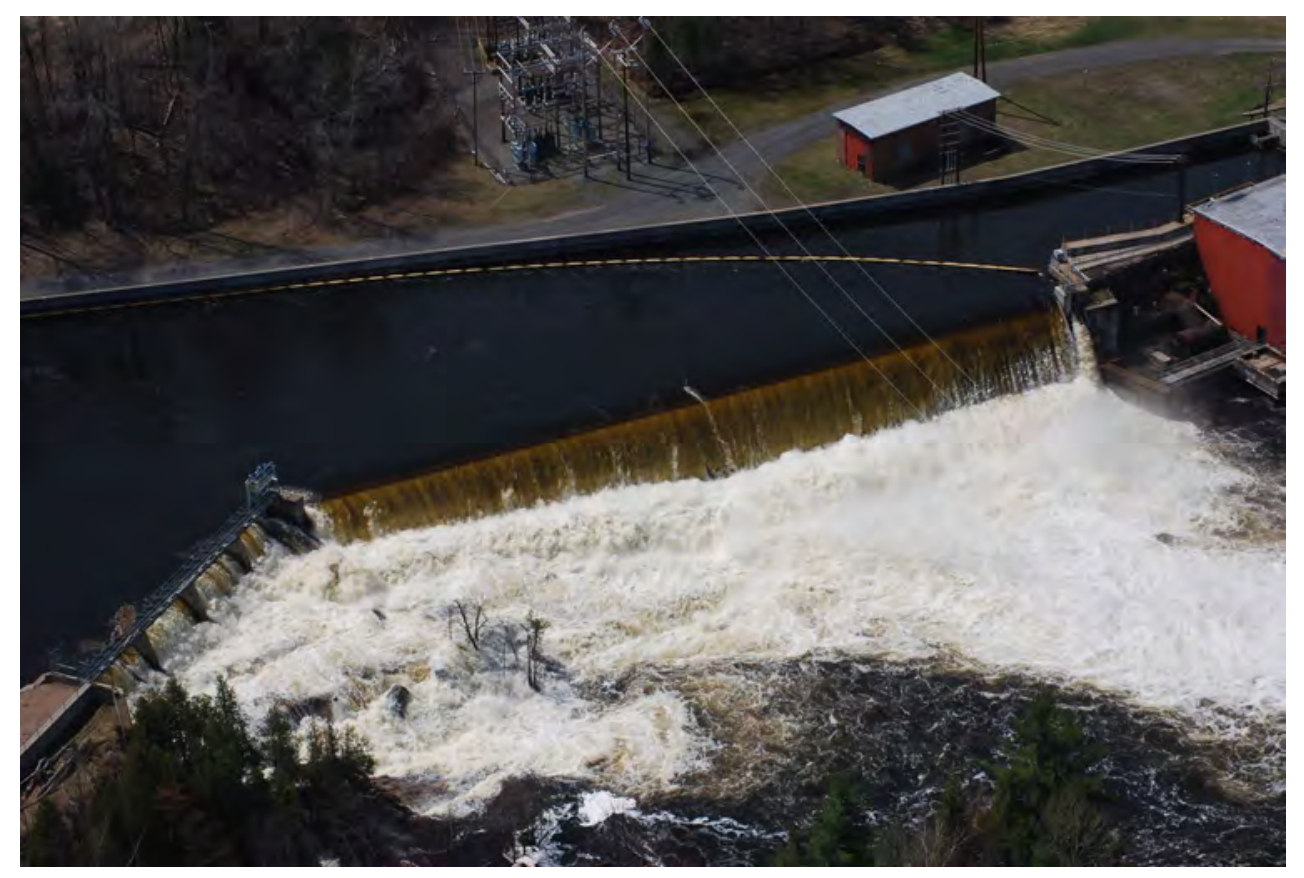

Figure 2-5. Flood of April 2011, Raquette River at Piercefield Dam, Piercefield, New York. Photo courtesy of John Derby, Saranac Lake Fire Department.

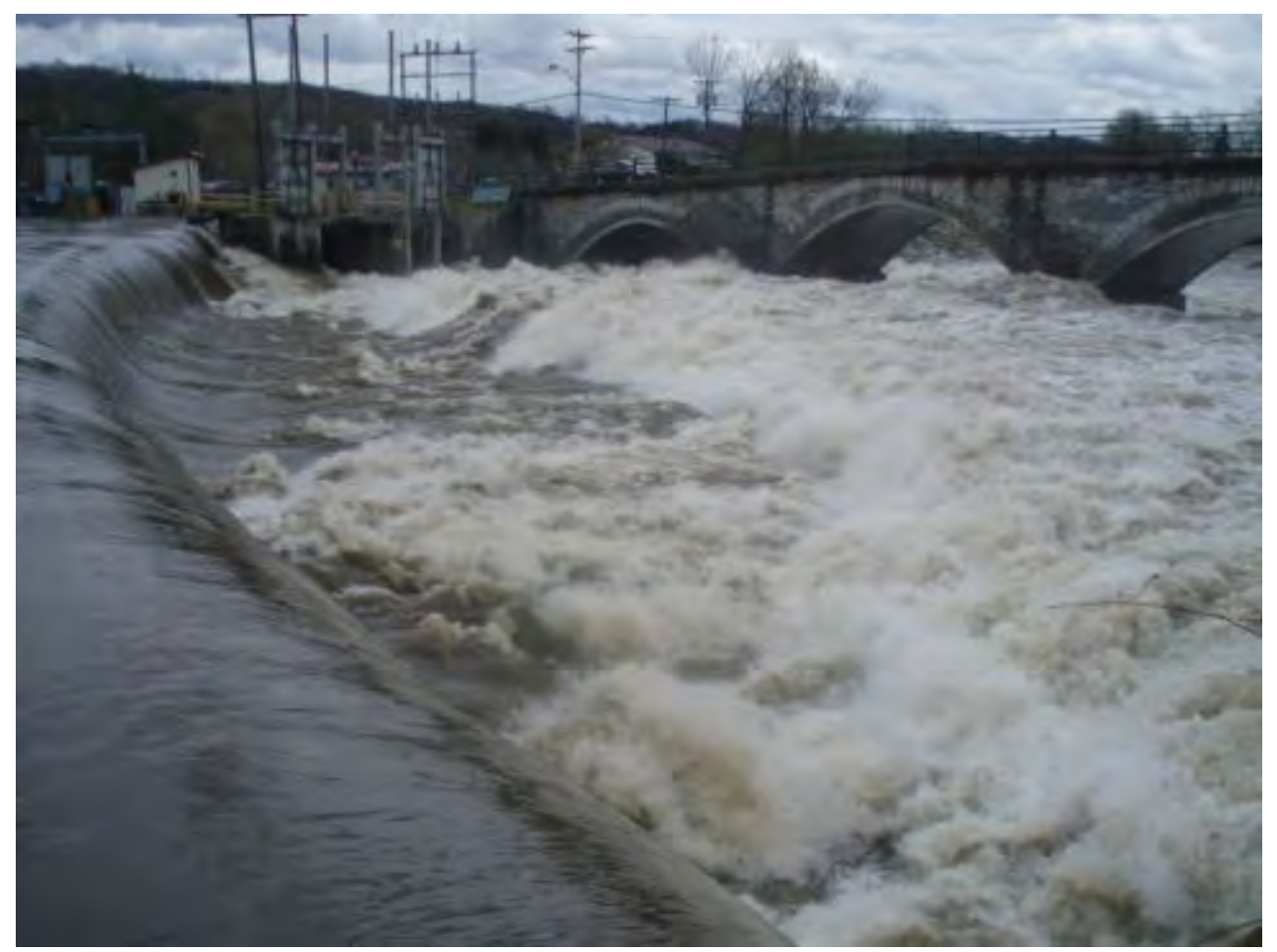

Figure 2-6. Flood of April 2011, West Canada Creek at Newport Dam, Newport, New York (April 28, 2011). Photo courtesy of New York State Department of Environmental Conservation. 


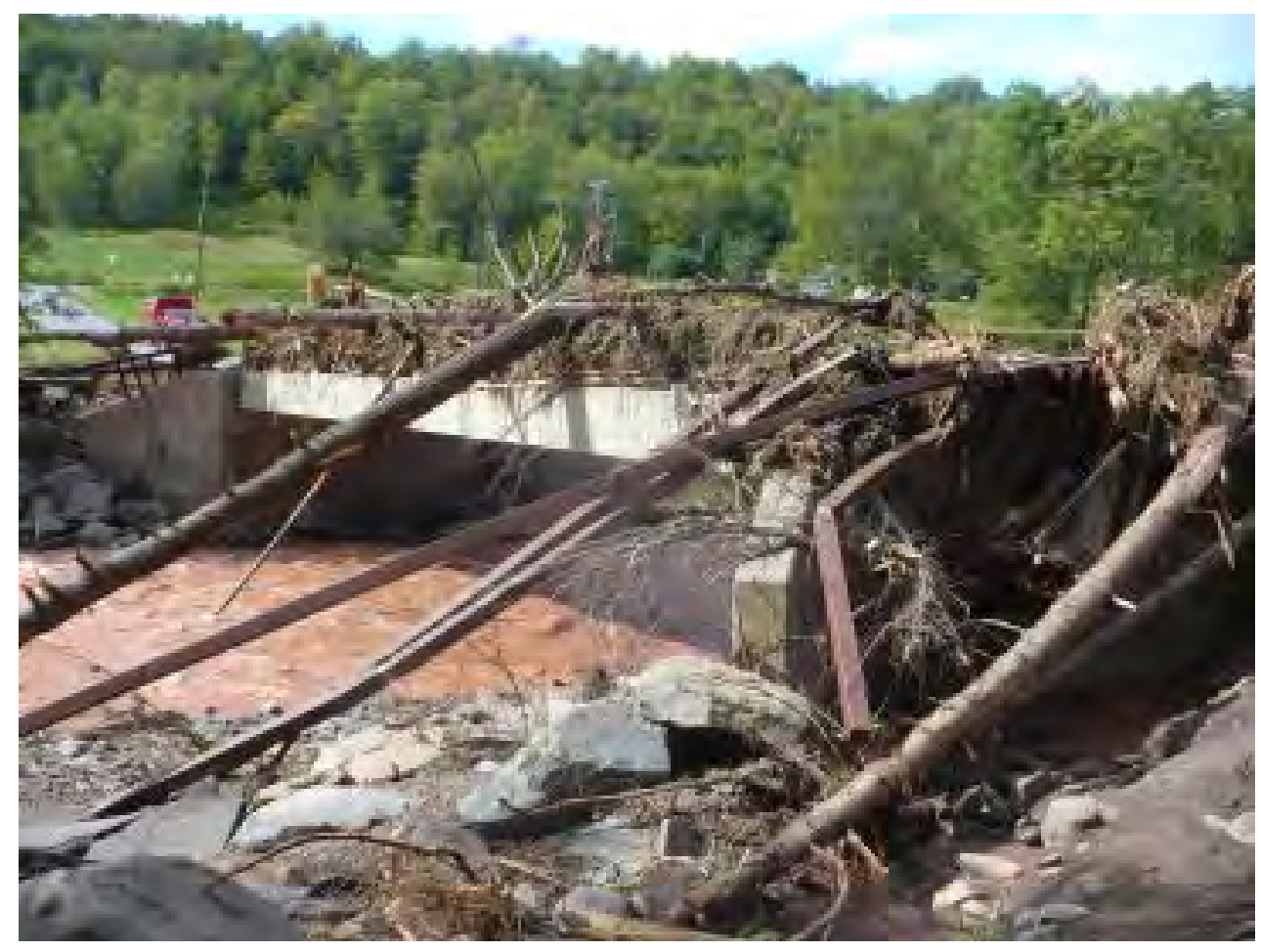

Figure 2-7. Flood of August 2011, flood debris on Mill Hollow Road bridge over East Kill near Jewett Center, New York.

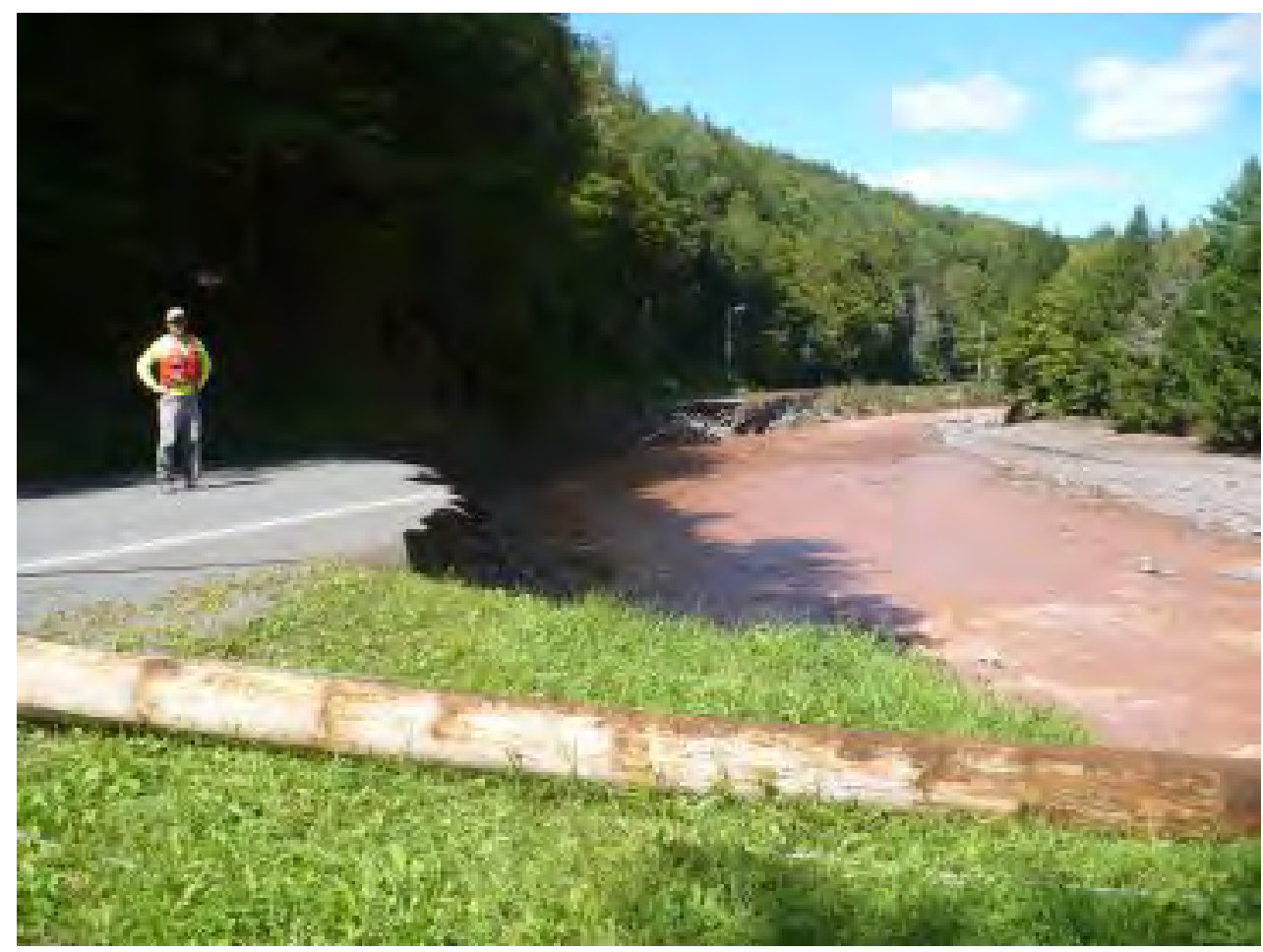

Figure 2-8. Flood of August 2011, County Route 17 road washout caused by East Kill near Jewett Center, New York. 


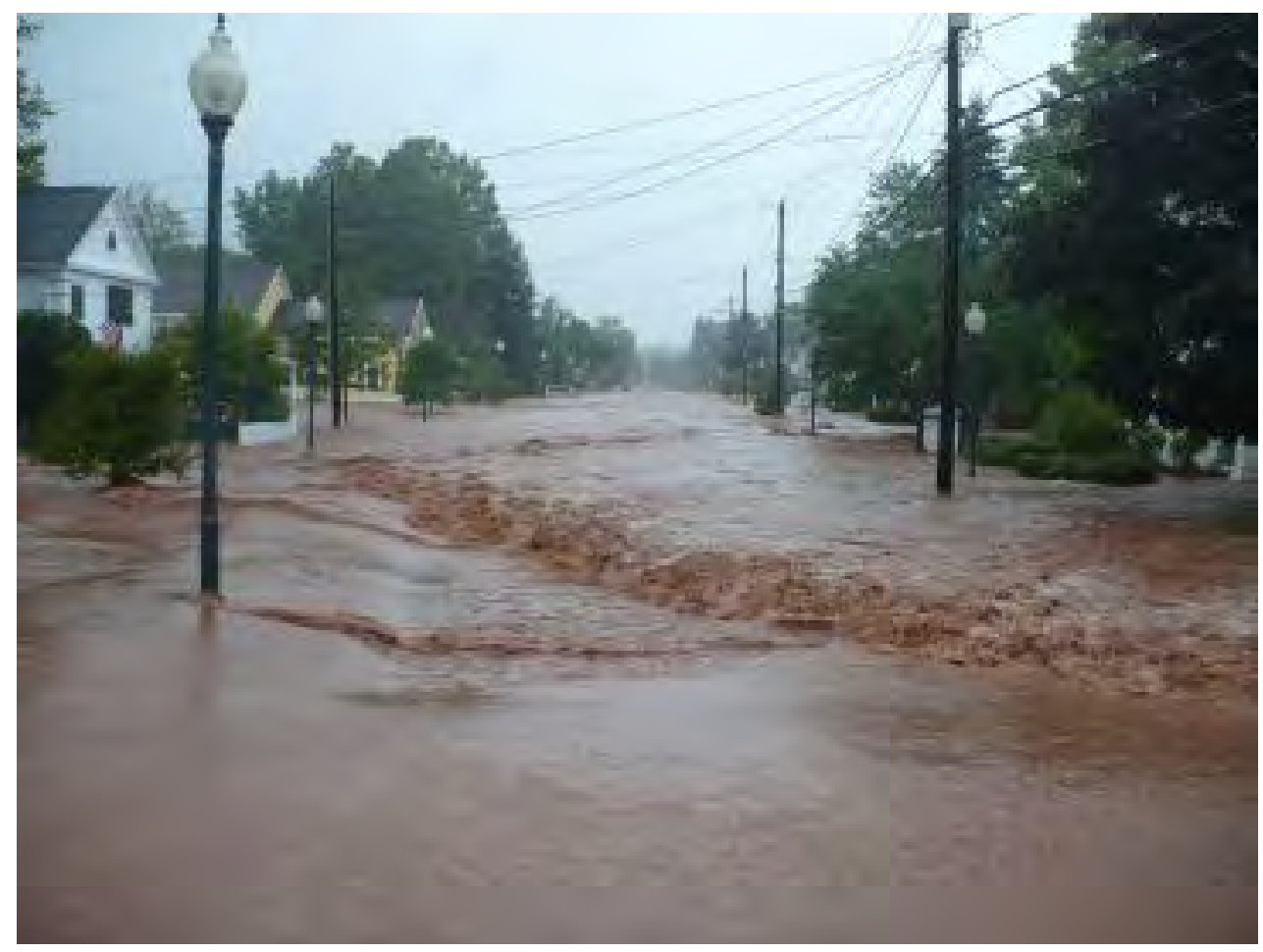

Figure 2-9. Flood of August 2011, State Route 23 near Batavia Kill at Windham, New York.

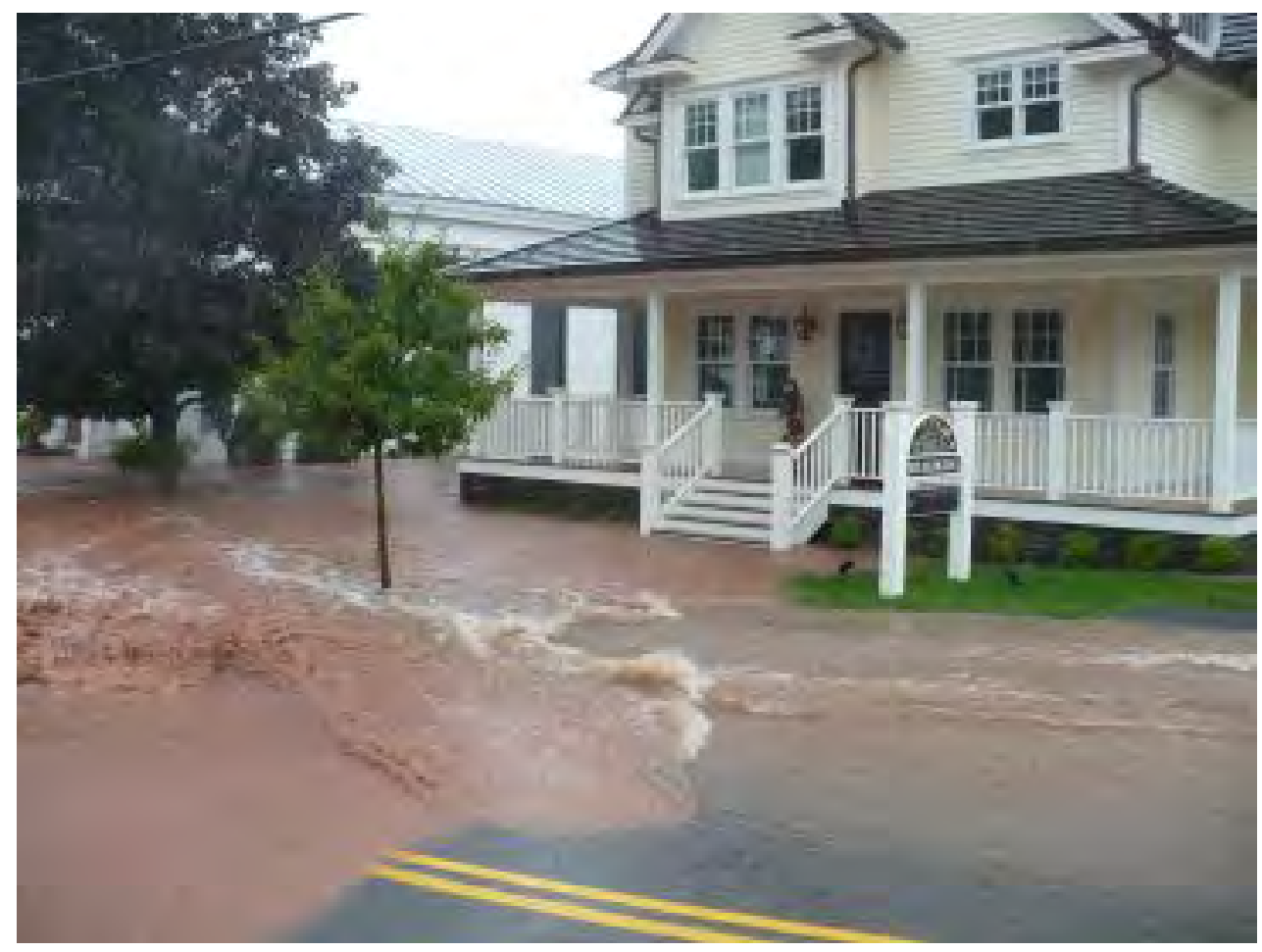

Figure 2-10. Flood of August 2011, State Route 23 near Batavia Kill at Windham, New York. 


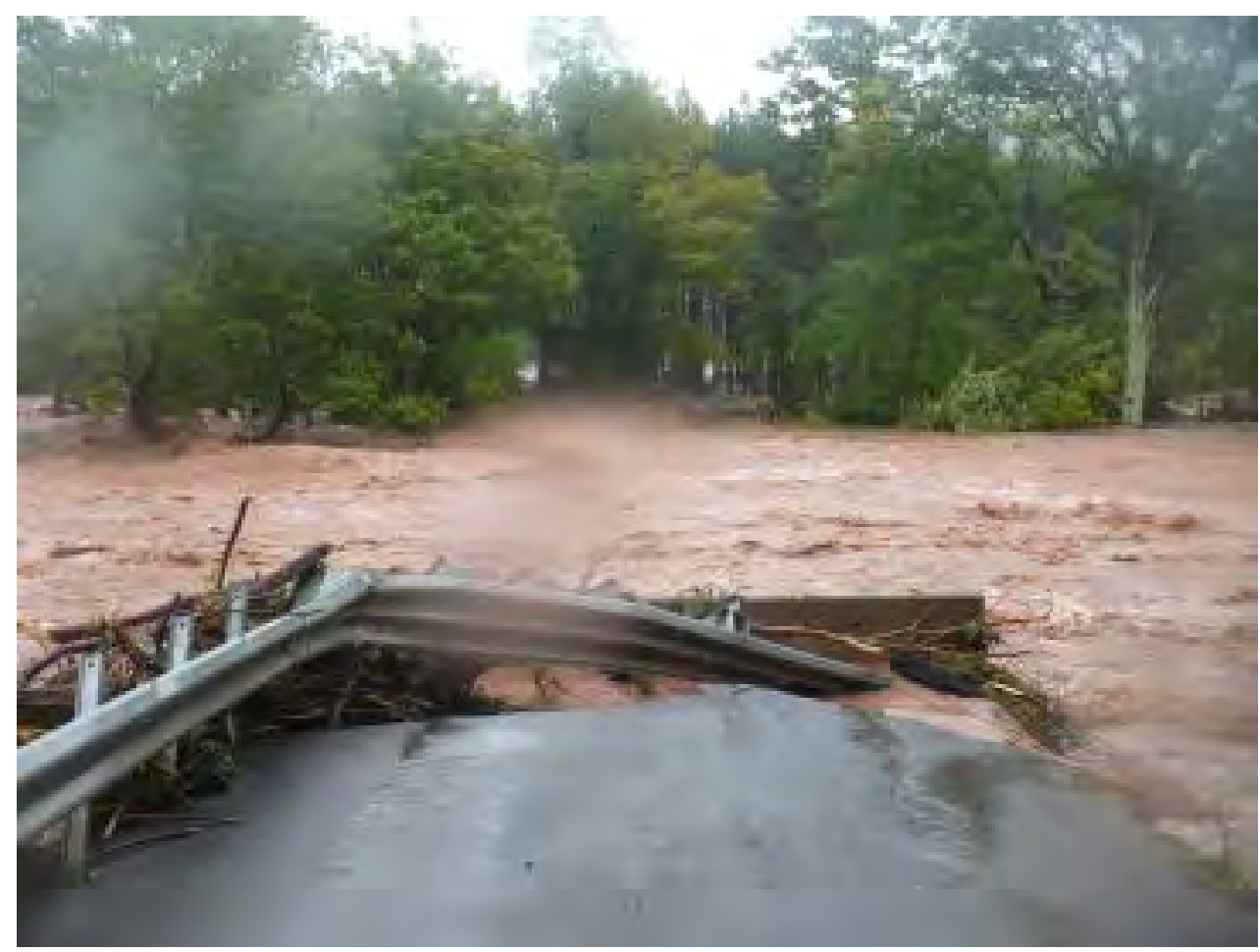

Figure 2-11. Flood of August 2011, Bush Road bridge washout caused by Schoharie Creek near Lexington, New York.

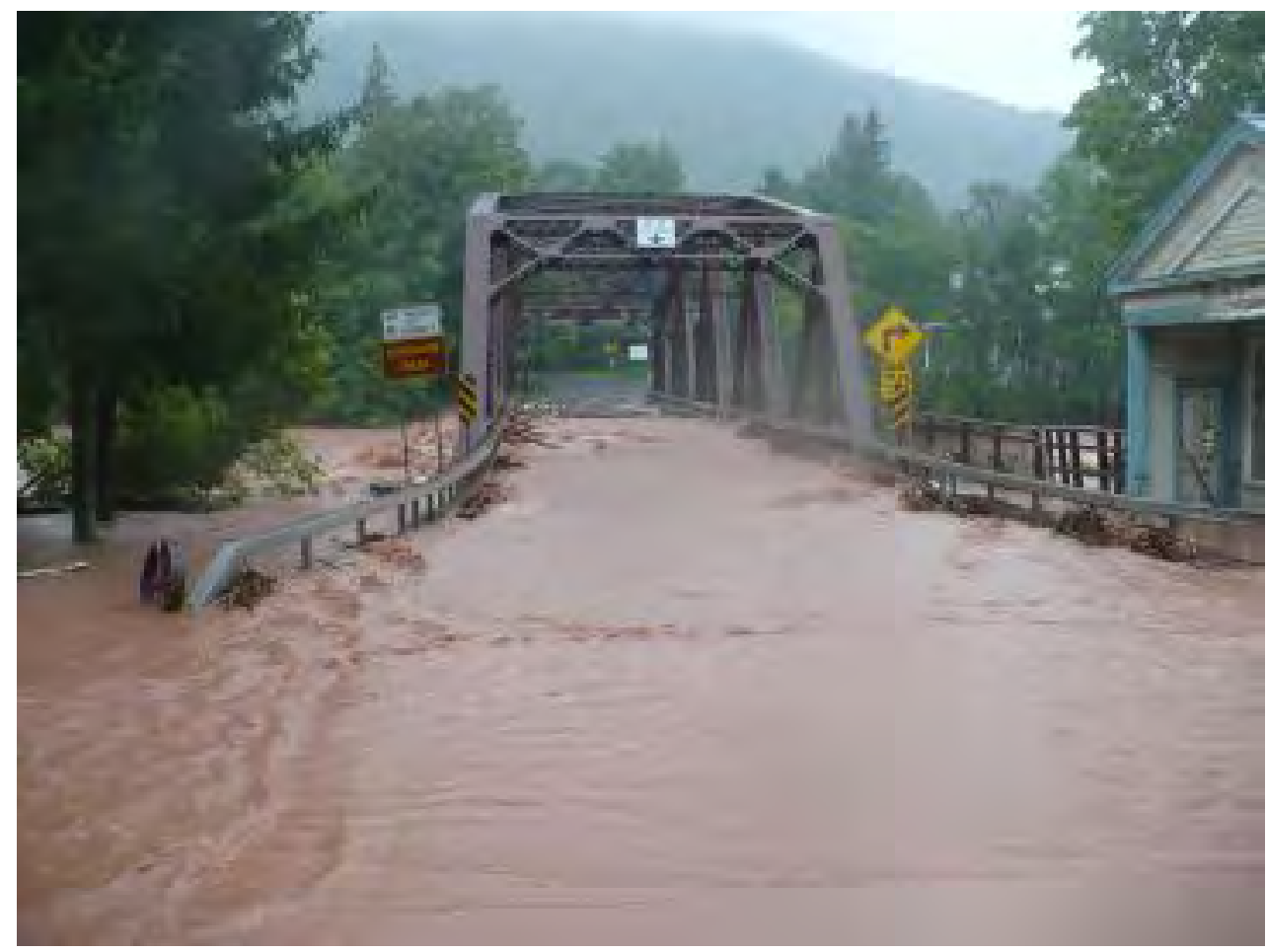

Figure 2-12. Flood of August 2011, State Route 42 bridge over Schoharie Creek at Lexington, New York. 


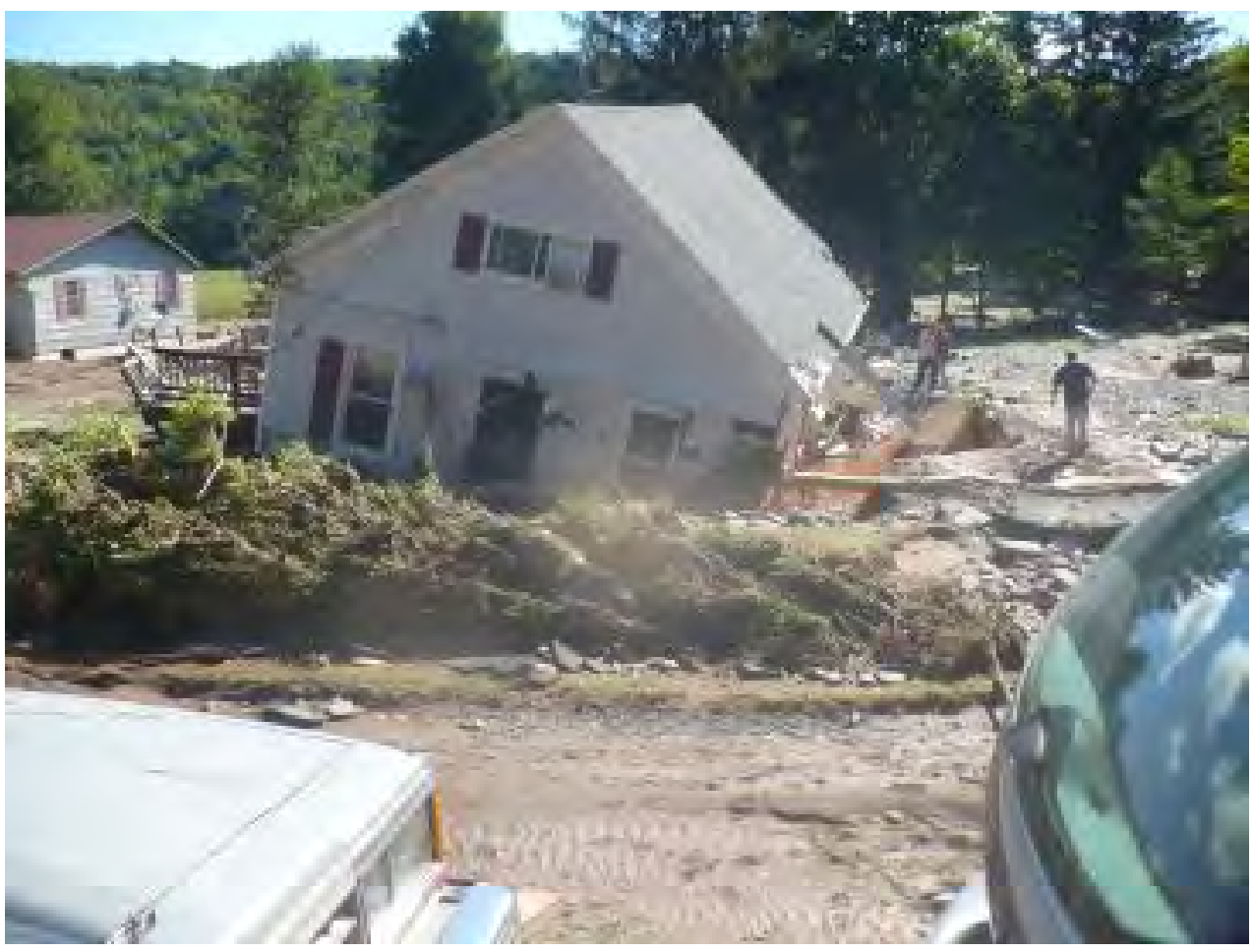

Figure 2-13. Flood of August 2011, flood damaged house caused by Schoharie Creek at Prattsville, New York (September 28, 2011).

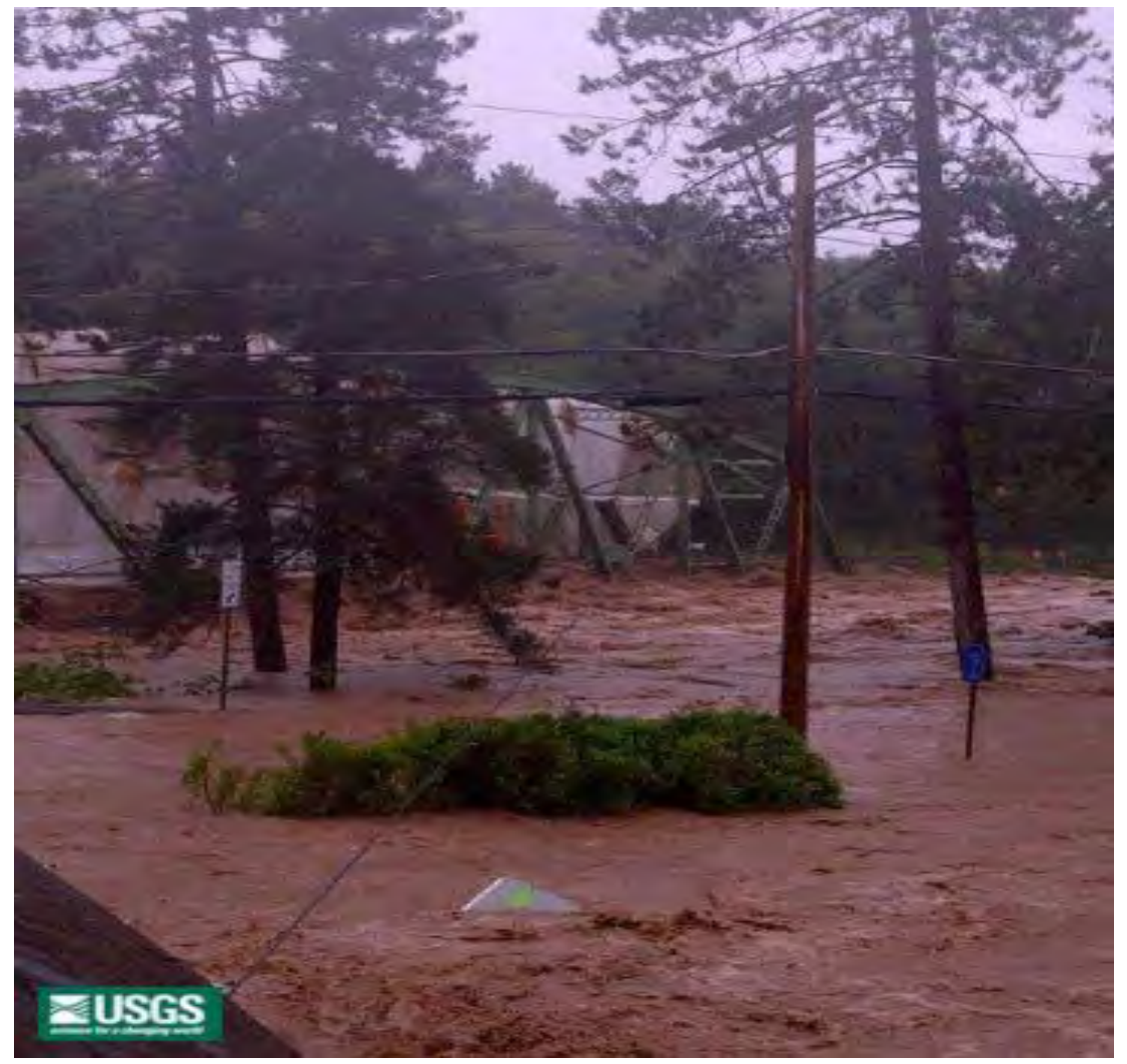

Figure 2-14. Flood of August 2011, State Route 23 bridge over Schoharie Creek at Prattsville, New York. 


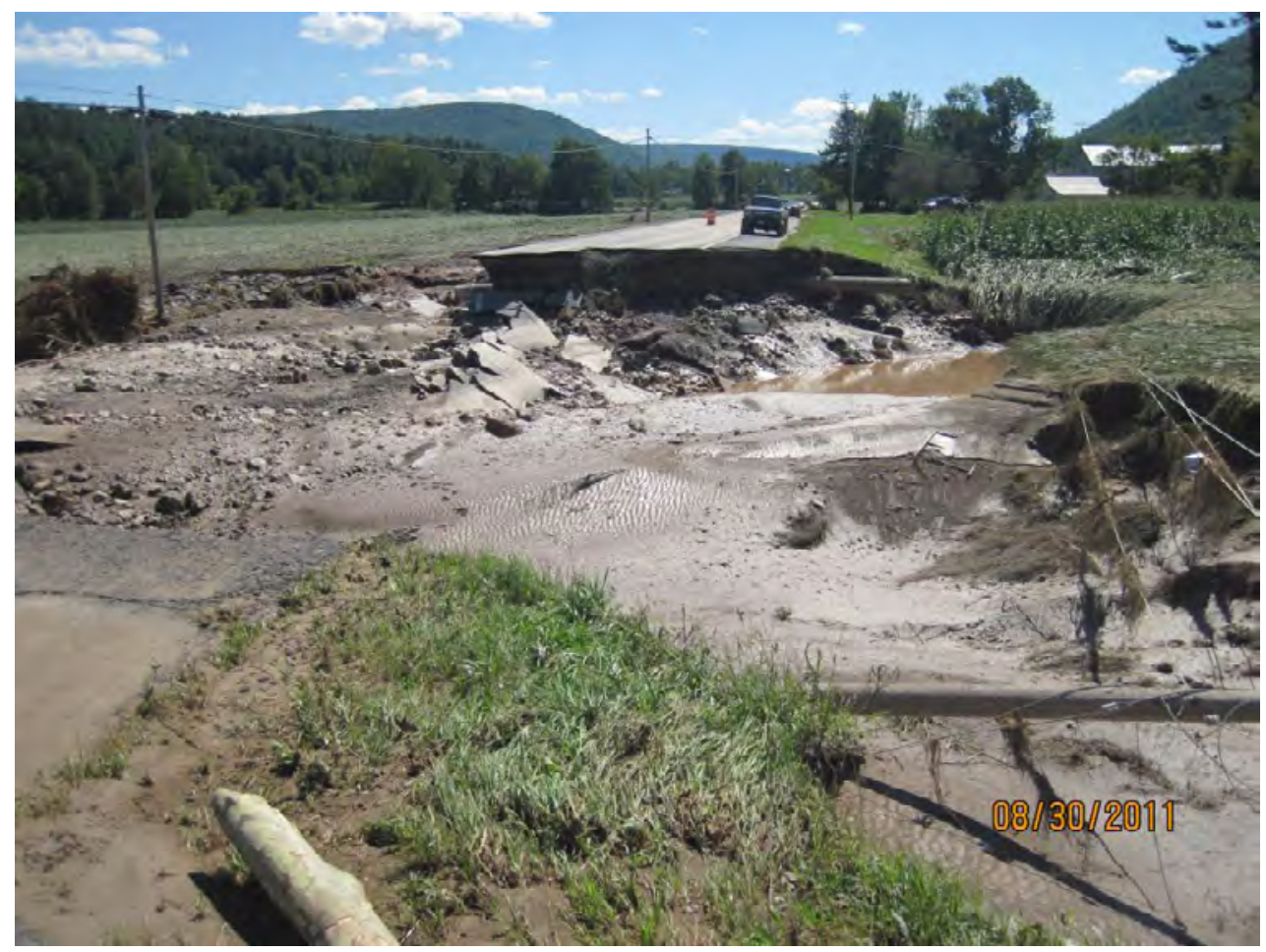

Figure 2-15. Flood of August 2011, State Route 30 road washout caused by Schoharie Creek at Breakabeen, New York. Photo by Joseph Griffin, courtesy of New York State Department of Transportation.

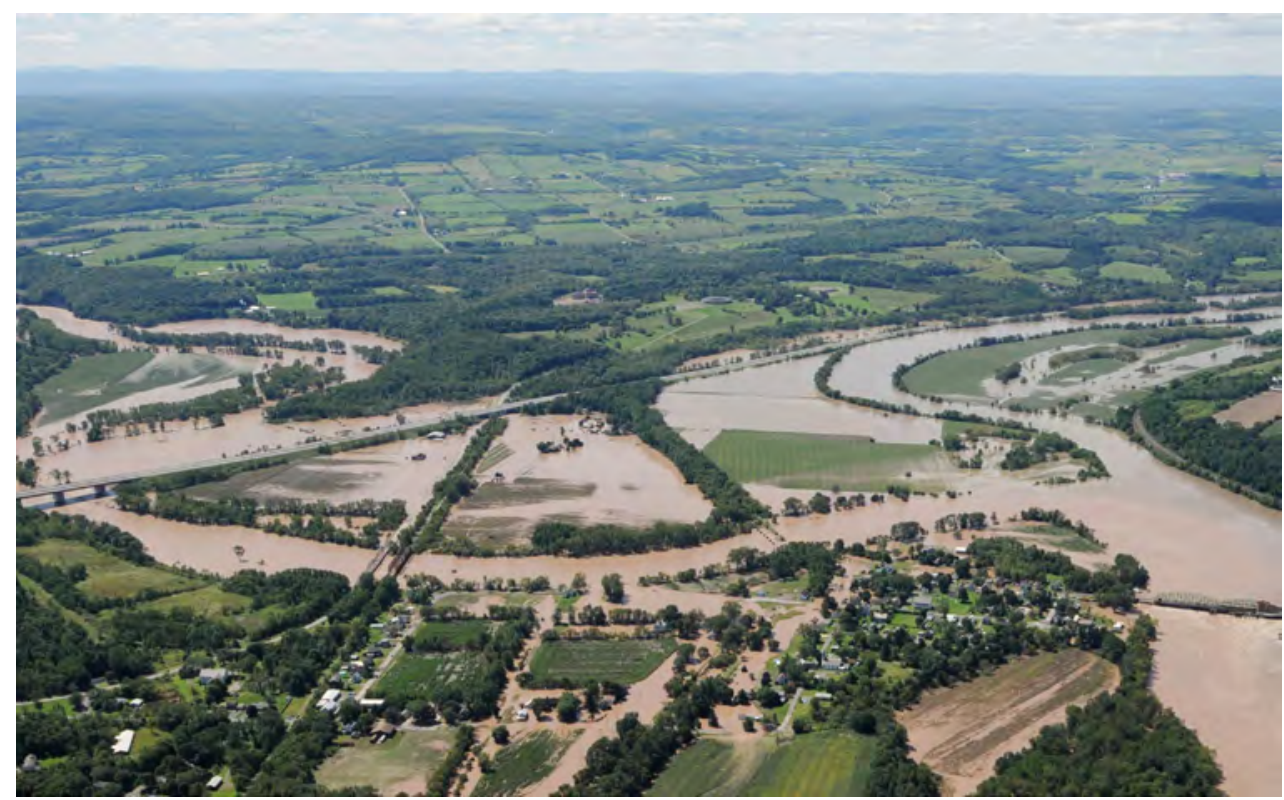

Figure 2-16. Flood of August 2011, Schoharie Creek at Fort Hunter, New York. Photo courtesy of the Times Union, Albany, New York. 


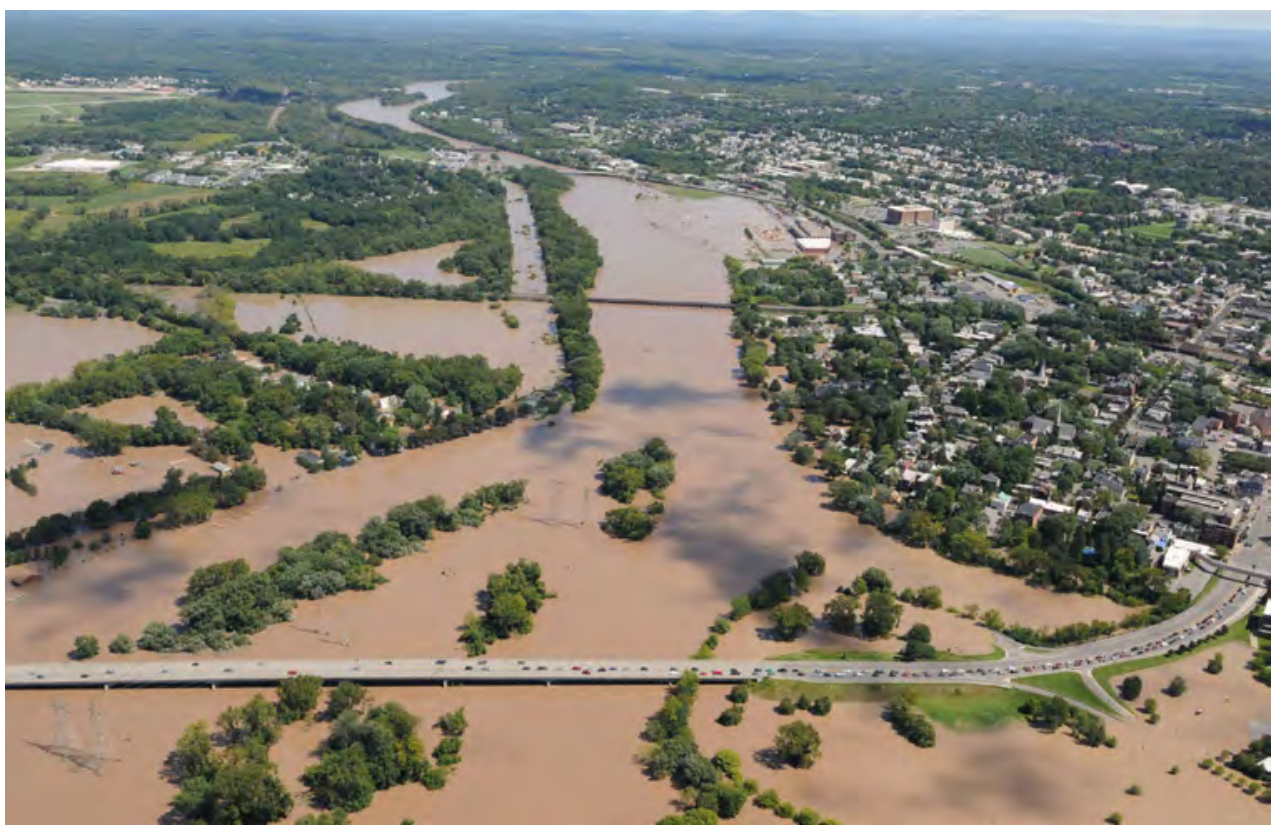

Figure 2-17. Flood of August 2011, Mohawk River at Scotia and Schenectady, New York. Photo courtesy of the Times Union, Albany, New York.

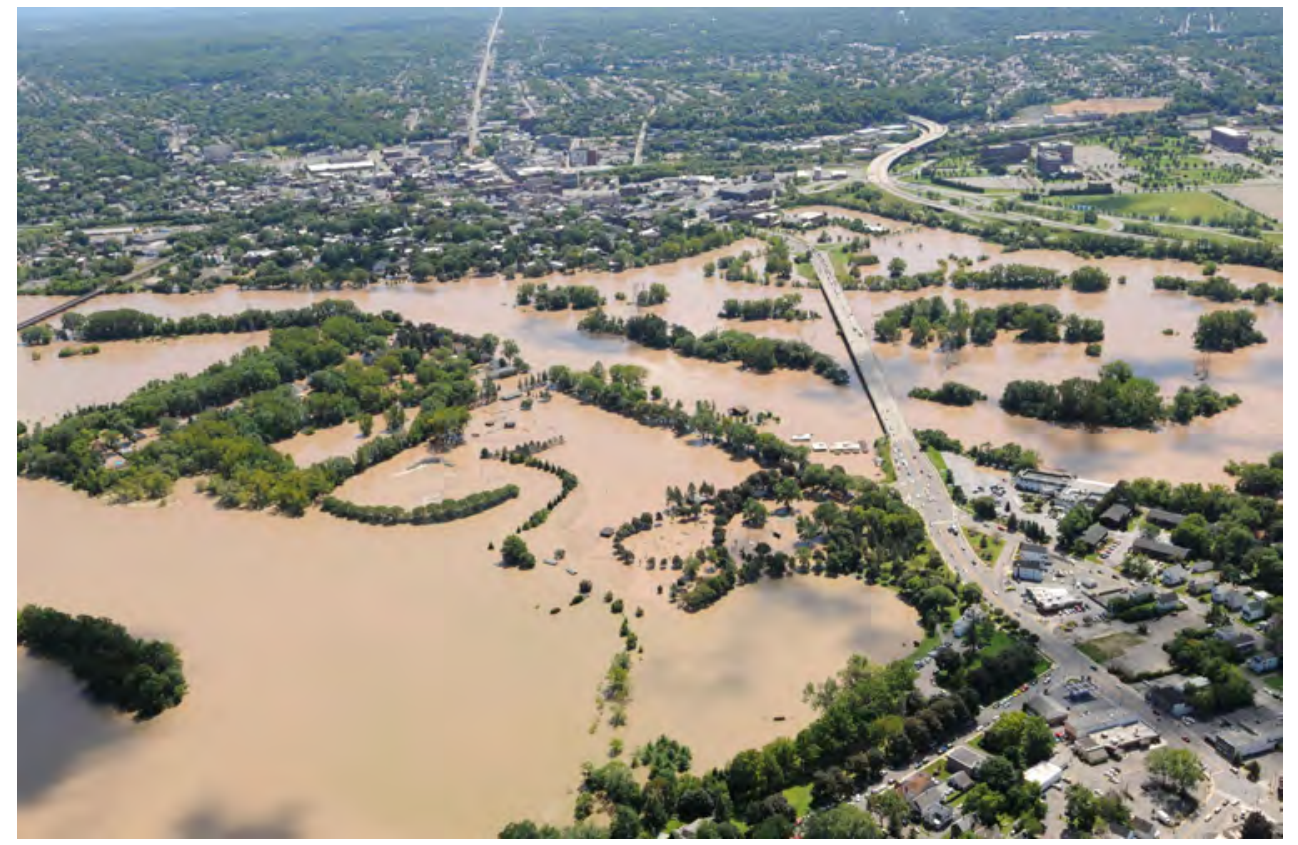

Figure 2-18. Flood of August 2011, Mohawk River at Scotia and Schenectady, New York. Photo courtesy of the Times Union, Albany, New York. 


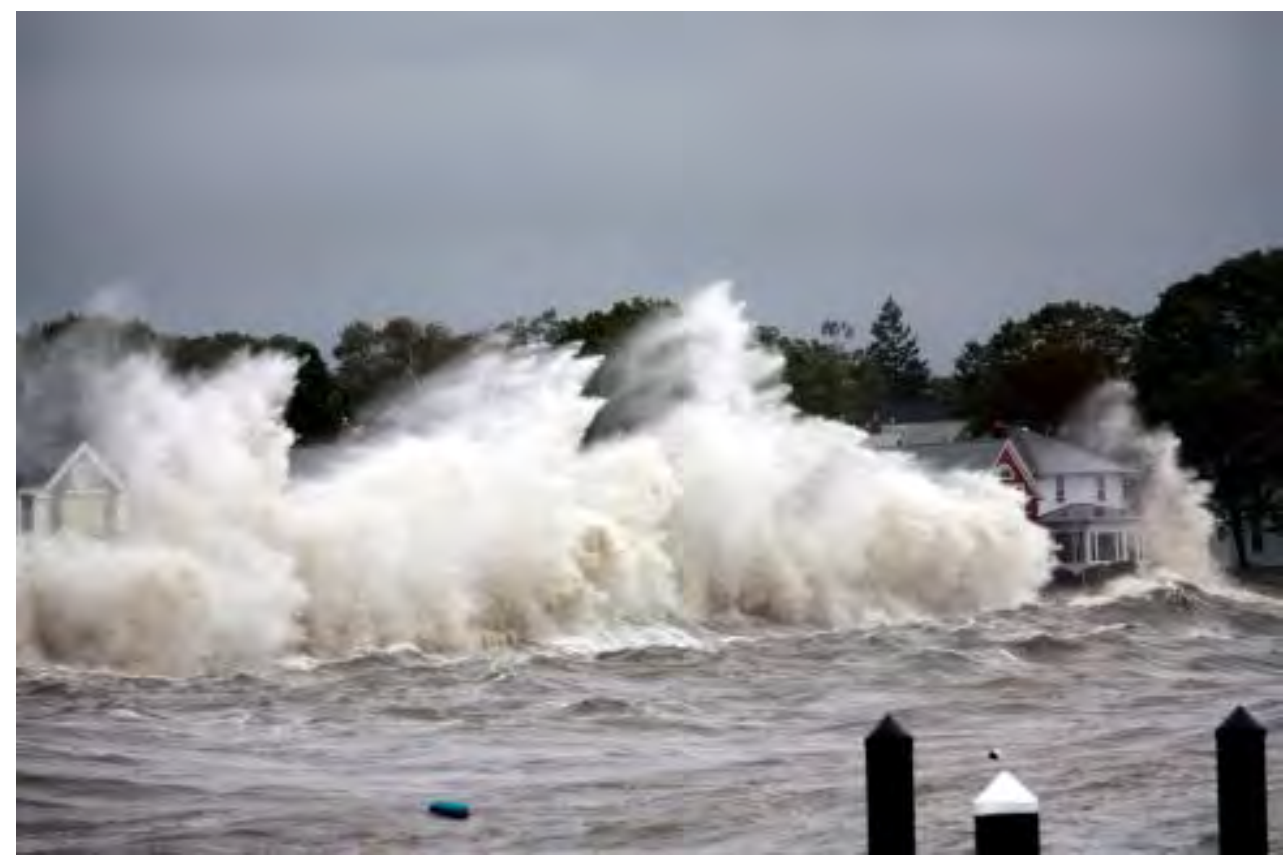

Figure 2-19. Flood of August 2011, coastal flooding from Long Island Sound near Branford, Connecticut. Photo courtesy of Connecticut Fund for the Environment and its program Save the Sound.

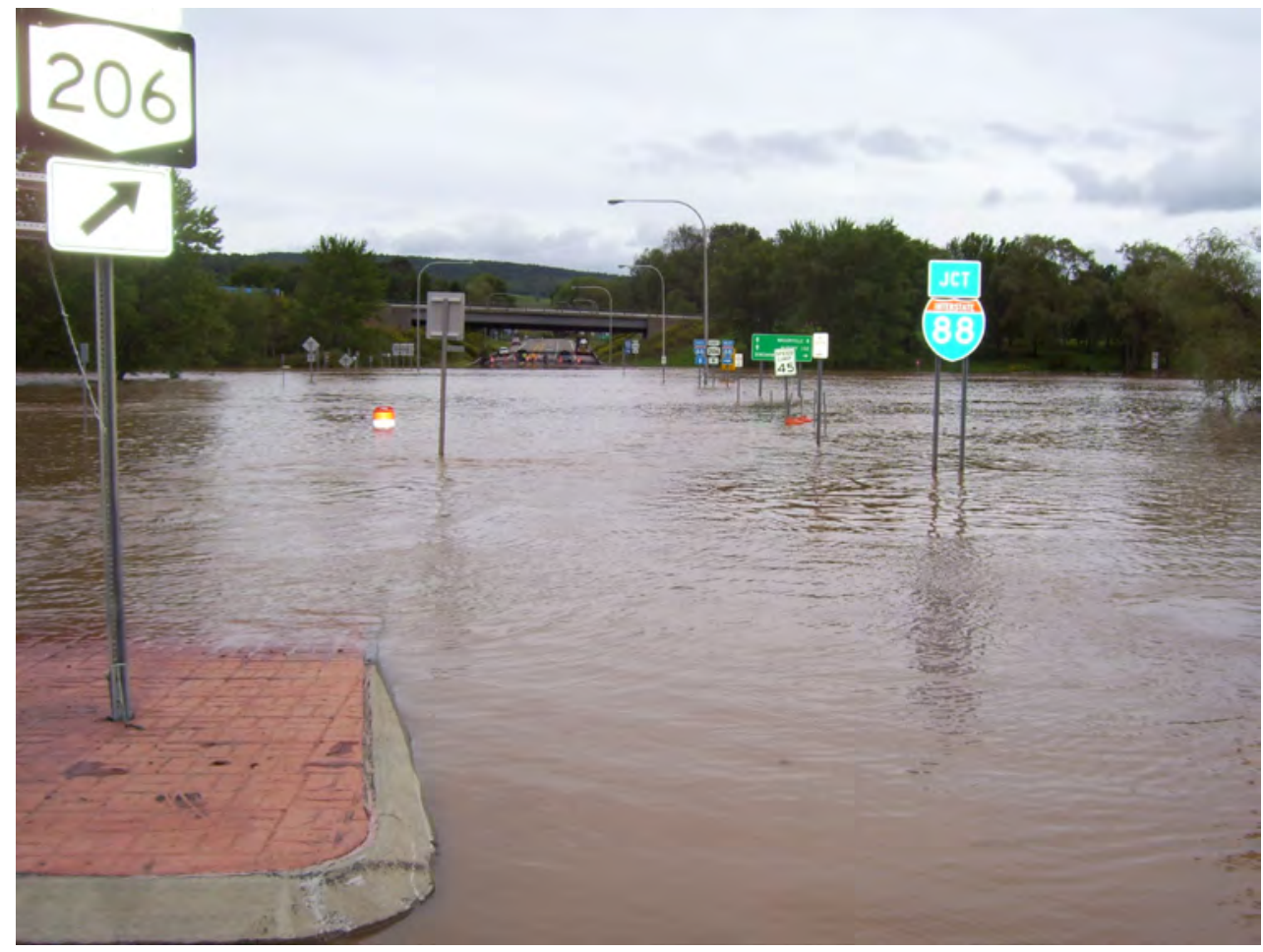

Figure 2-20. Flood of September 2011, Susquehanna River at Bainbridge, New York. 


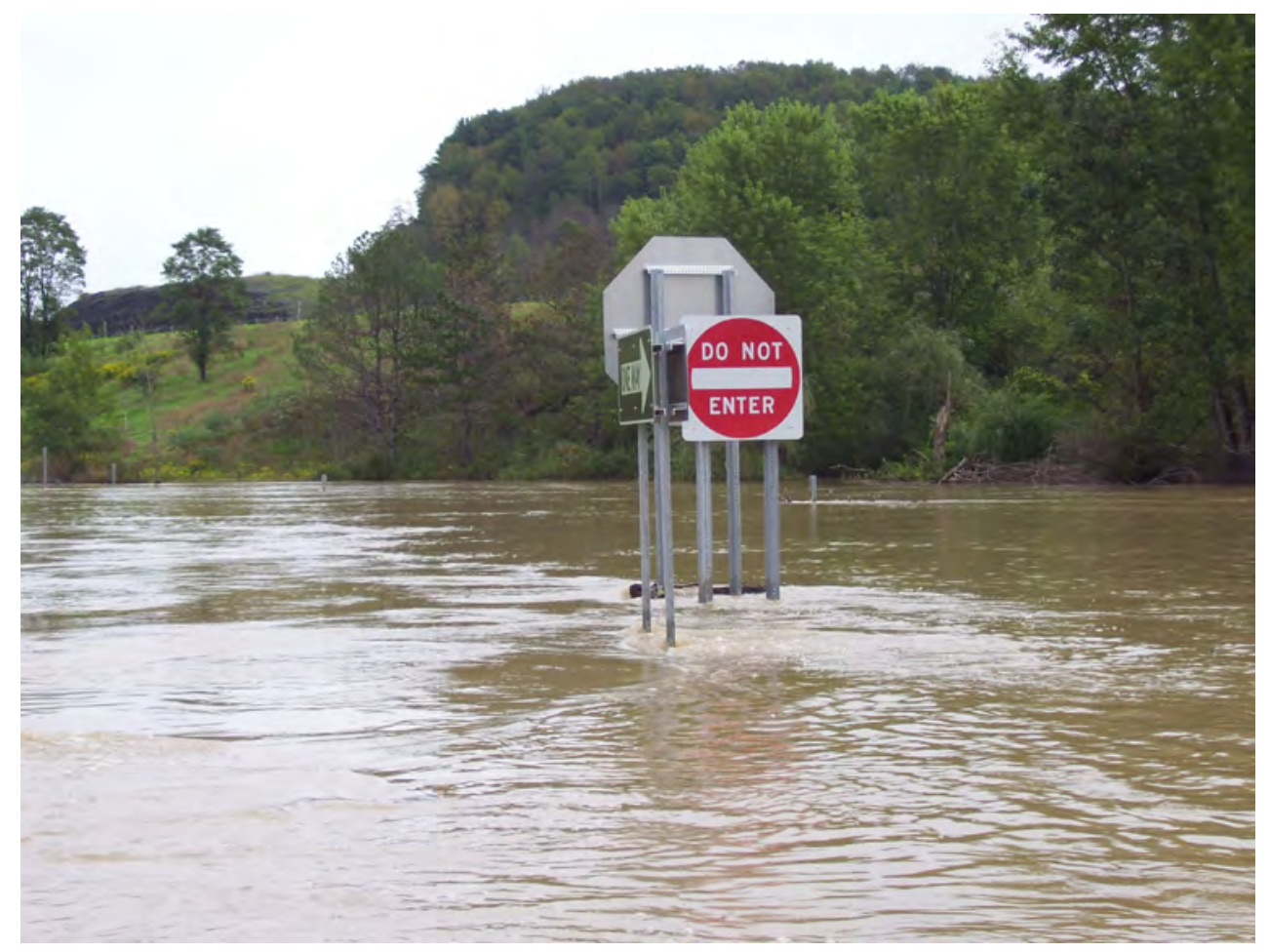

Figure 2-21. Flood of September 2011, Susquehanna River at Bainbridge, New York.

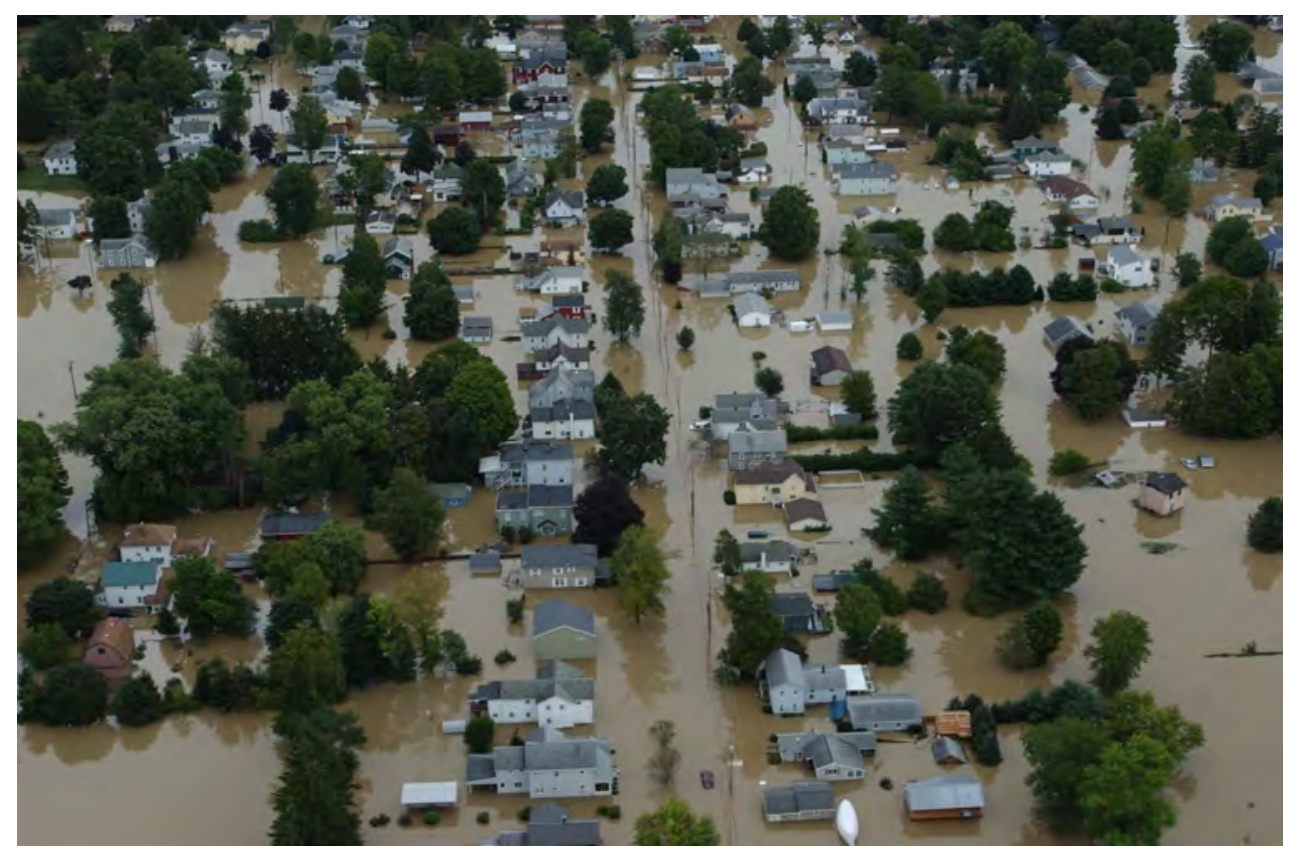

Figure 2-22. Flood of September 2011, Susquehanna River at Binghamton, New York (September 8, 2011). Photo by Sargeant 1st Class Steven Petibone, 42nd Combat Aviation Brigade, courtesy of New York Division of Military and Naval Affairs. 


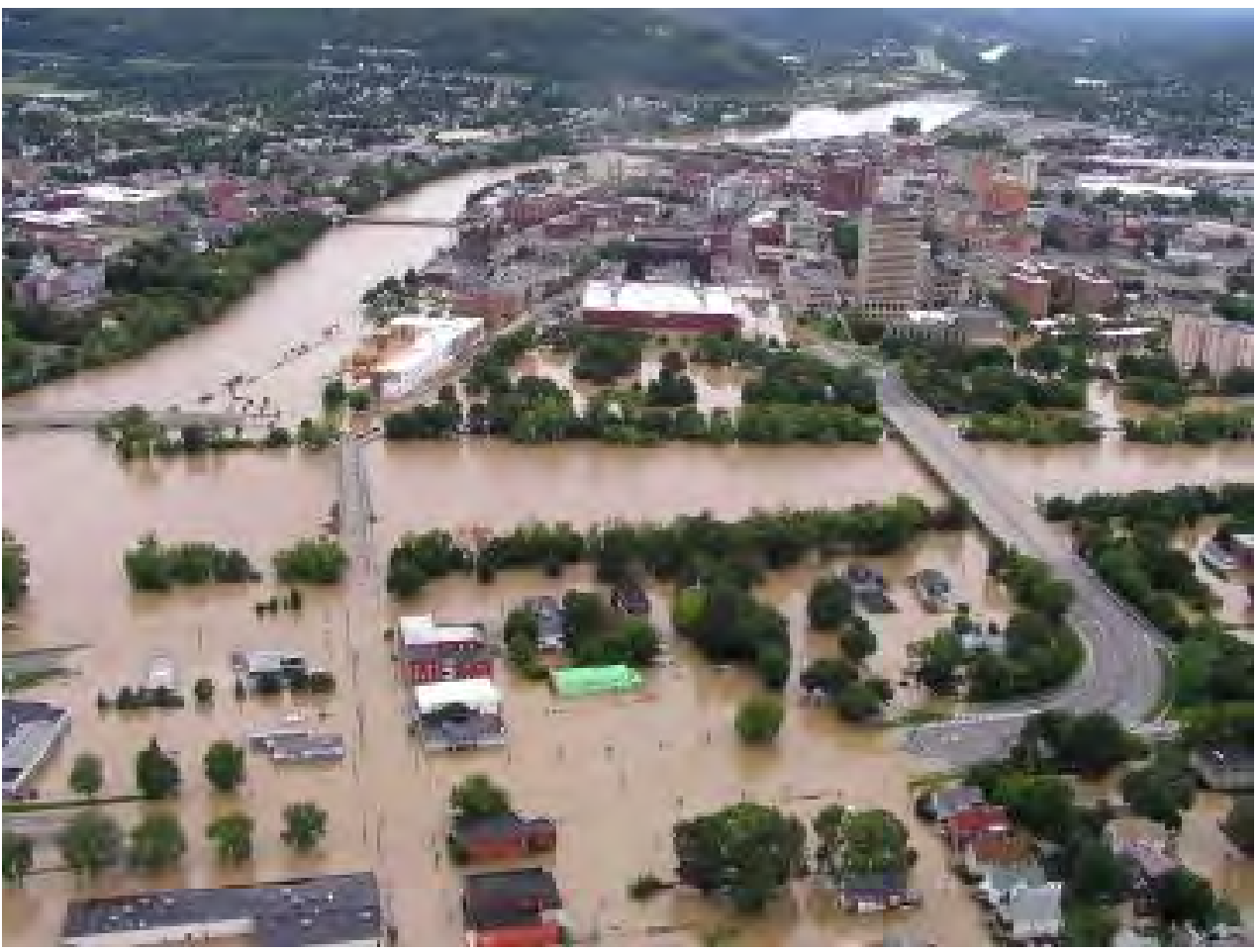

Figure 2-23. Flood of September 2011, Susquehanna River at Binghamton, New York (September 8, 2011). Photo courtesy of Bill Walsh.

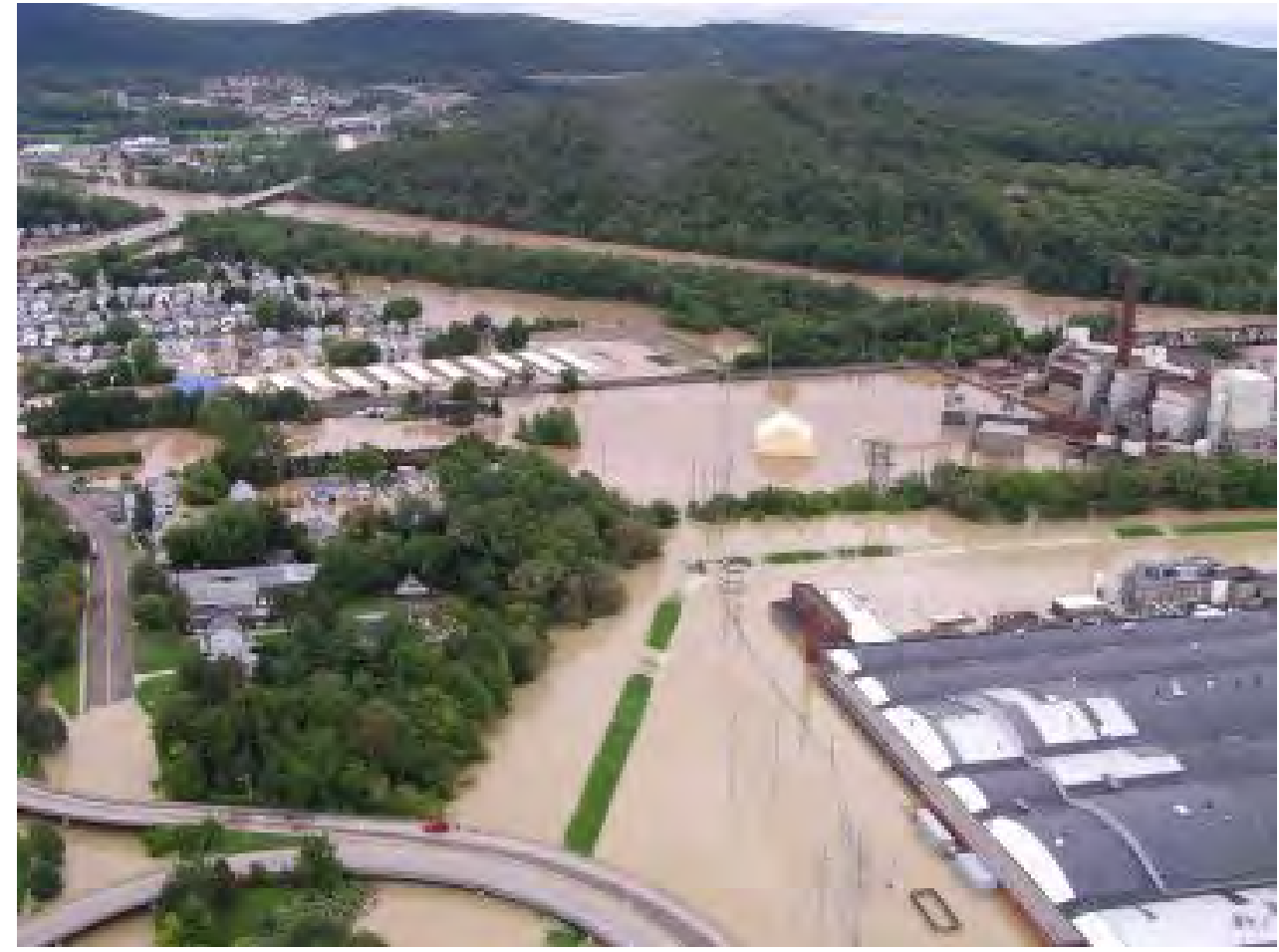

Figure 2-24. Flood of September 2011, Goudy Station, Susquehanna River at Johnson City, New York (September 8, 2011). Photo courtesy of Bill Walsh. 


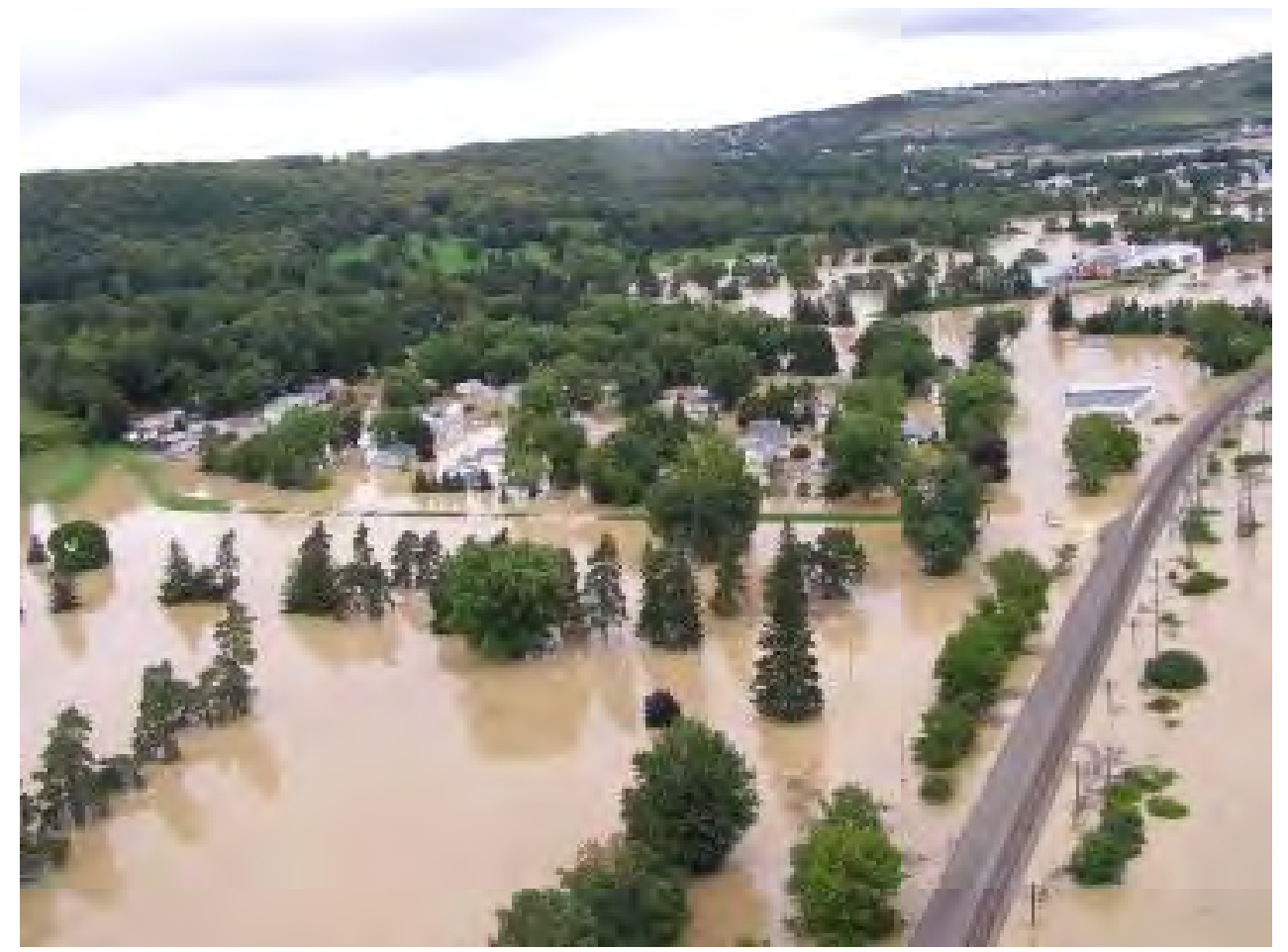

Figure 2-25. Flood of September 2011, Susquehanna River at Johnson City, New York (September 8, 2011). Photo courtesy of Bill Walsh.

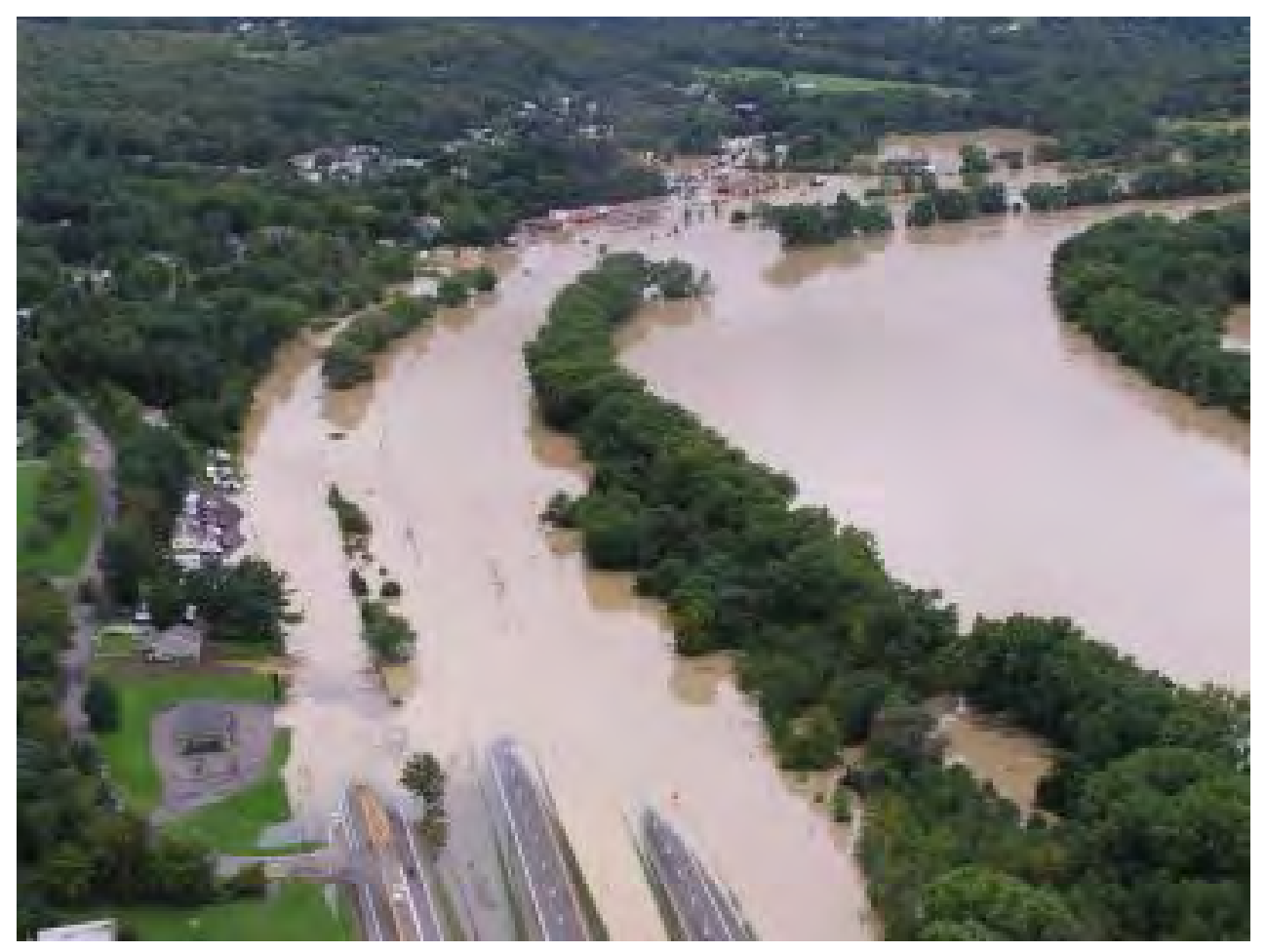

Figure 2-26. Flood of September 2011, State Route 17/Vestal Parkway, Susquehanna River at Apalachin, New York (September 8, 2011). Photo courtesy of Bill Walsh. 


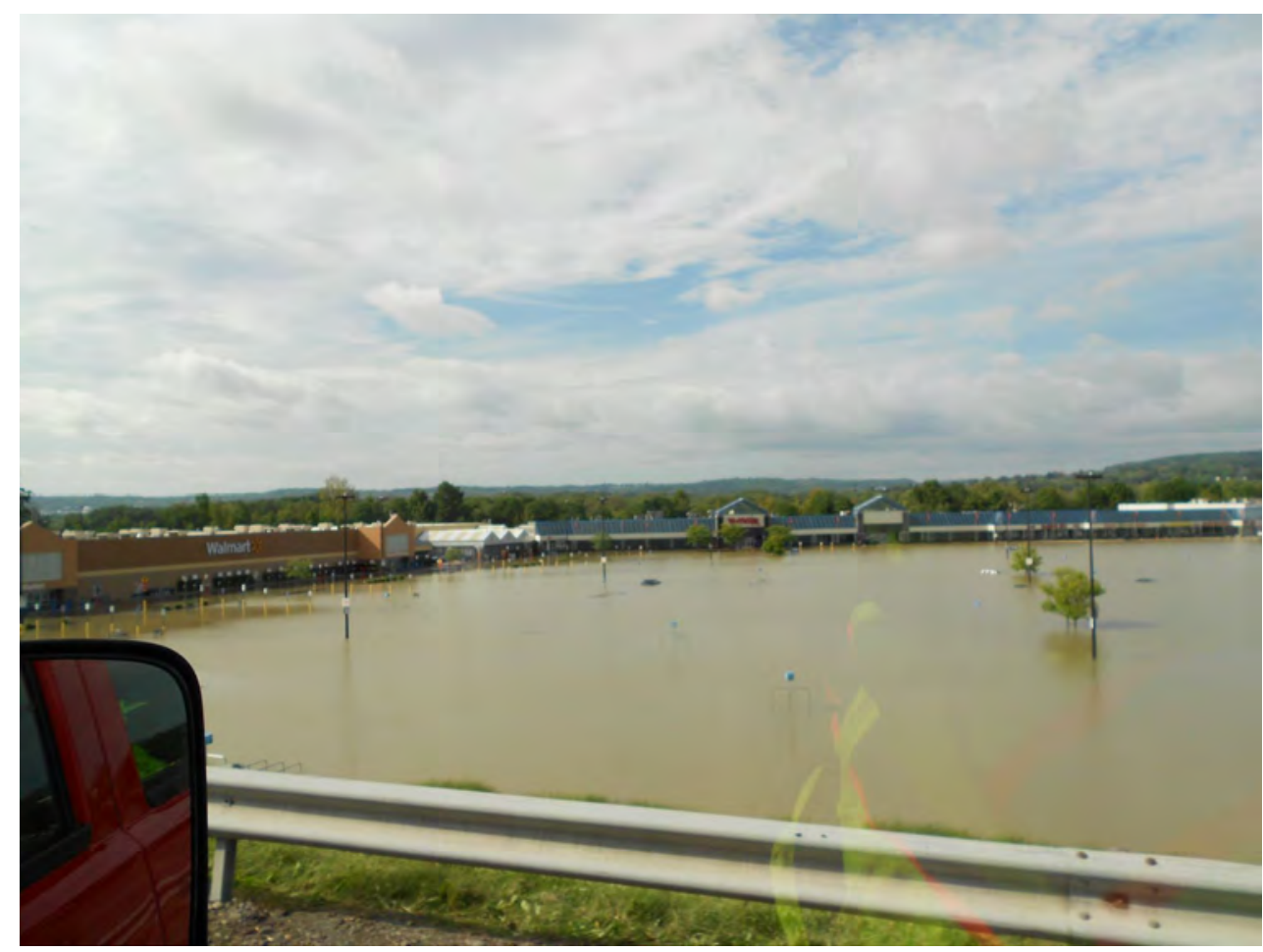

Figure 2-27. Flood of September 2011, Susquehanna River at Owego, New York (September 8, 2011).

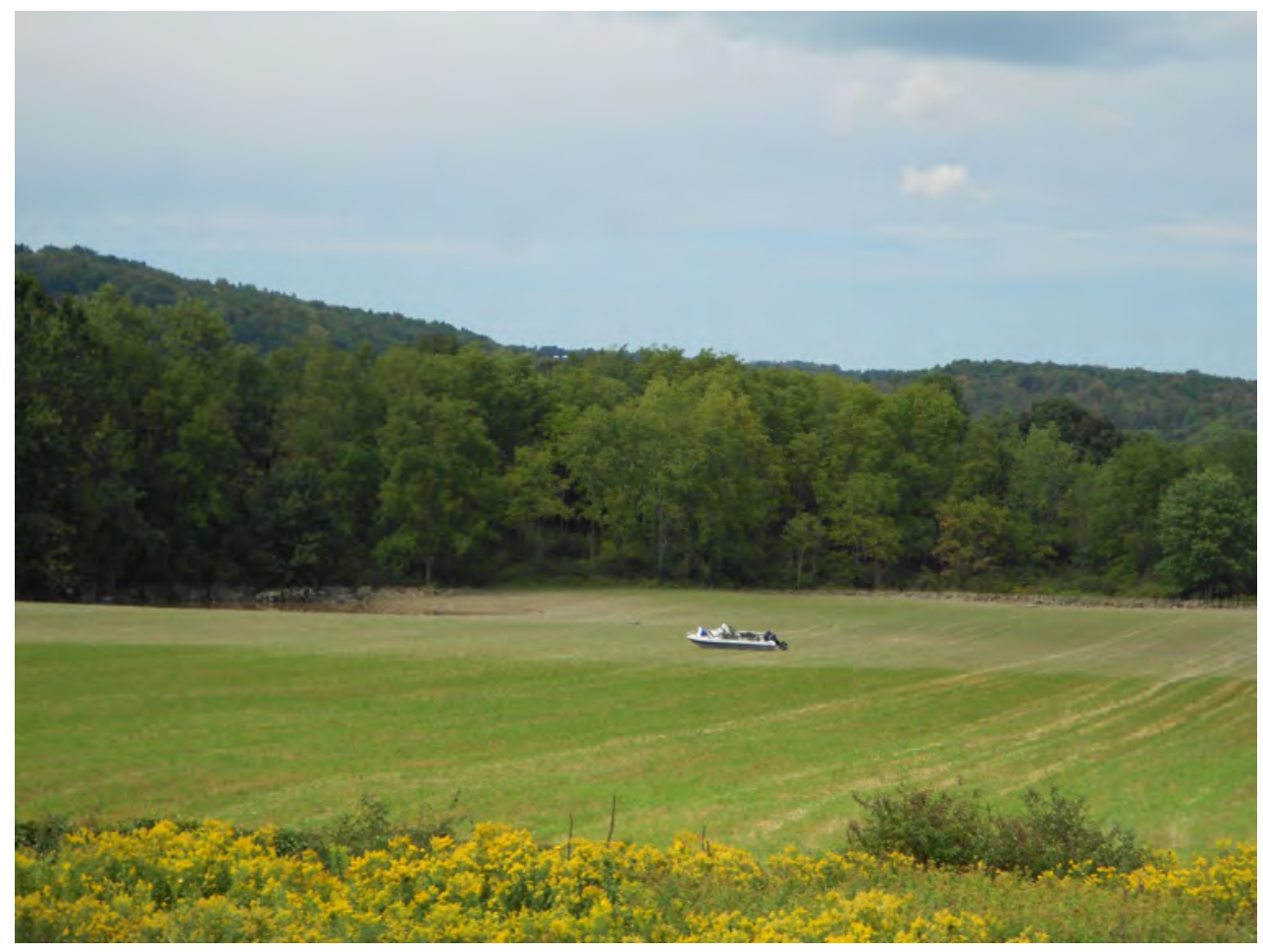

Figure 2-28. Flood of September 2011, runaway boat stranded in field after floodwaters receded, Susquehanna River at Waverly, New York. 



\section{Appendix 3. Selection and Accuracy of High-Water Marks}




\section{Appendix 3. Selection and Accuracy of High-Water Marks}

High-water marks (HWMs) are evidence of the highest elevations reached by a flood (Benson and Dalrymple, 1967). HWM-elevation data have many uses such as assessing the accuracy of flood-insurance-study profiles, developing flood-inundation maps, calibrating future flood-profile models, and examining the effects of highway embankments, bridges, culverts, dams, levees, and floodwalls on the flood profile. In hydraulic analyses, the stream channel is assumed to be free of debris and downstream obstructions.

After a flood, HWMs usually deteriorate quickly from rain, wind, and residential cleanup efforts. A subsequent lower magnitude flood could also interfere with the accurate identification of HWMs from an earlier flood. Although HWMs inside abandoned or condemned buildings or outbuildings might be preserved for many years, a timely response to identify (mark with a flag) HWMs as soon as possible after a flood is imperative.

The four most common types of HWMs are seed lines, mud lines, debris piles or lines, and wash lines; a HWM can be a combination of these types. HWMs are rated as "excellent," "good," "fair," or "poor" (Benson and Dalrymple, 1967). "Excellent" means that the rated HWM is considered to be within 0.02 foot (ft) of the true highwater elevation, "good" within $0.05 \mathrm{ft}$, "fair" within $0.10 \mathrm{ft}$, and the rating "poor" implies less than "fair" accuracy (Suro and others, 2009). The following paragraphs reproduced and rearranged from Benson and Dalrymple (1967) discuss the various types of HWMs.

"Many kinds of material which float, chiefly vegetative, are left stranded at the high-water line (and at lower elevations) when the water subsides. The finer material produces more definite and better marks and is apt to represent the highest elevation that the water attained than would some scattered clumps of large drift. Leaves or cornstalks are apt to become waterlogged, and at the very edge in slow velocities they will not rise with a slight rise of the water surface. In this manner, a mound of material, sometimes a foot or more in height, will form at the edge of the channel. Where this occurs, the elevation found by holding the rod on the top of the mound would be the proper high-water elevation if the material is consolidated; if the material is loose, the shoreward toe would be the correct elevation."

$(* * * * * *)$

"Often the small seeds of various plants will provide excellent high-water marks, remaining in the crevices of bark or in the cracks in fence posts or utility poles. The highest of such particles should be used. At times, seeds will adhere to smooth surfaces and encircle trees, poles, metal posts, or guy wires. When present, seeds are an excellent source of high-water data."

\section{$(* * * * * * *)$}

"Water carrying mud or silt will at times leave easily recognizable lines along banks, on trees, brush, rocks, and buildings. If there is only a slight difference in color, the mud line may be more readily visible from a distance."

$$
(* * * * * * *)
$$

"Much drift usually will be found on bushes or trees within the channel. Such marks are not generally as dependable as those on the banks. In swift water, varying amounts of pileup due to velocity will affect the marks at the upstream side of such objects. Marks at the downstream sides of large objects may be lower than normal. Brush in fast velocities often will be bent downstream by the flow, and drift will be caught on the upper limbs. When the velocities slow down, the brush becomes erect once more, and the drift will appear to be at an elevation much higher than that of the actual water surface. In quiet water on overflow plains, the highest drift in brush or trees may be reliable."

$$
(* * * * * * *)
$$

"In arid regions, or where sandy soil or steepness of banks prevent vegetative growth, the water surface may lap against bare banks. Soil will be washed away by the moving water and under some conditions will show "wash lines" which may be reliable high-water indicators. Good marks are indicators by the straightness of the top of the wash line. Where the bank is steep or the soil unstable, the material may slough to elevations above the water surface. This condition may be recognized by the uneven ragged line at the top edge of the washing-such marks should be avoided. Usually wash lines are poor."

$$
(* * * * * * *)
$$

"Buildings within the flood plain should be investigated; they sometimes are an excellent source of highwater marks. Even relatively clean water will leave stain marks within buildings. Excellent marks may be found 
on windowpanes or screens. Use care to select marks that are not affected by velocity head, as are marks on the upstream side of buildings in an area where velocities were high. The exposure of flood-water entrances into buildings should be noted in order to judge drawdown or pileup."

A few examples of the different types and ratings of HWMs are shown on figures 3-1 to 3-8. Figure 3-1 shows a "good" seed line on a tree; figure 3-2 shows an "excellent" mud/seed line on a wall; figure 3-3 shows an "excellent" mud line on a door; figure 3-4 shows a "fair" debris line on the ground; figure 3-5 shows a "fair" debris line on the upstream face of a highway embankment; and figure 3-6 shows a flagged "poor" wash line on a stream bank. Figure 3-7 shows debris caught in vegetation along a stream bank. This HWM would be rated "poor" because its proximity to the stream channel and associated high velocities would make accurate identification of the actual highwater elevation difficult. Figure 3-8 shows a debris line on the ground that would be rated "poor" because of the thickness of the unconsolidated, loosely packed material.

The best location to search for a HWM along a given stream reach depends largely on the gradient of the stream and the degree to which the land has been developed. Generally, there are four types of stream reaches: (1) highgradient rural (slope greater than 1 percent (Jarrett, 1985), (2) high-gradient developed, (3) low-gradient rural, and (4) low-gradient developed. In all reach types, HWMs chosen for surveying should be in areas as far away from the stream channel as possible to avoid pileup or drawdown associated with high water velocities.

High-gradient rural reaches are the most difficult type of reach in which to identify good HWMs because of high velocities and lack of buildings. High velocities may occur up to the edge of inundation, and only fair or poor debris lines and wash lines may be present at the edges. The selection of debris in trees and bushes as HWMs should be avoided because of pileup. At times debris will slide down a tree during recession and produce a false seed line that appears like a scatter of fine particles; this debris should not be flagged. The field person should check for natural depressions in the overbank, where the water will slow because of increased depths, and search for seed lines on trees in these areas.

In high-gradient developed reaches, building surfaces offer another source for HWMs, but several factors should be considered. The field person should avoid HWMs on upstream or downstream sides of buildings because of pile up or drawdown. Mud lines on the streamward or landward sides of buildings are the best indicators of the true water-surface elevation and are usually most distinct on windows and screens. HWMs inside a building need to be flagged with caution in high-gradient reaches because they may not represent the true water-surface elevation in a well-sealed building; the water in the building may not have reached equilibrium with the water outside because of rapidly rising and falling stages. It is common for mud lines on the inside of a window to be several inches lower than mud lines on the outside of the same window. Good or excellent HWMs can usually be found inside small outbuildings that are not well sealed.

In low-gradient rural reaches, the field person should check for HWMs near the edges of inundation; good debris lines can usually be found on the ground and good or excellent seed lines on trees. Seed lines that encircle a tree are preferable to debris lines on the ground in the same vicinity.

In low-gradient developed reaches, HWMs near the edges of inundation are again preferable. Good or excellent seed lines and mud lines can usually be found on trees, fences, buildings, and outbuildings (for example, sheds or garages), and good debris lines can usually be found on the ground. In areas where emergency vehicles or boats may have caused wakes, HWMs inside buildings are preferable because they are less affected by these conditions.

In all four reach types, HWMs can be used to help define the effects that bridges or culverts may have on the flood profile. HWMs should be flagged (1) near the edges of inundation (2) one bridge- or culvert-opening width upstream from the bridge or culvert (to avoid the drawdown zone), and (3) laterally along both sides of the opening on the upstream face of the embankment (Matthai, 1967). HWMs should also be flagged at the downstream ends of bridge abutments. Eddies can form where the downstream highway embankment meets the abutment, and debris lines usually can be found at these locations; if not, however, debris lines should be flagged laterally along both sides of the opening on the downstream face of the embankment. If the road has been overtopped by floodwaters, HWMs should be flagged along the end segments of the downstream embankment near the edges of inundation. The HWMs surveyed upstream and downstream from the bridge or culvert can be used to help determine if backwater was created by the structure. A field form that is used by the U.S. Geological Survey New York Water Science Center in flagging HWMs is shown on figure 3-9. 


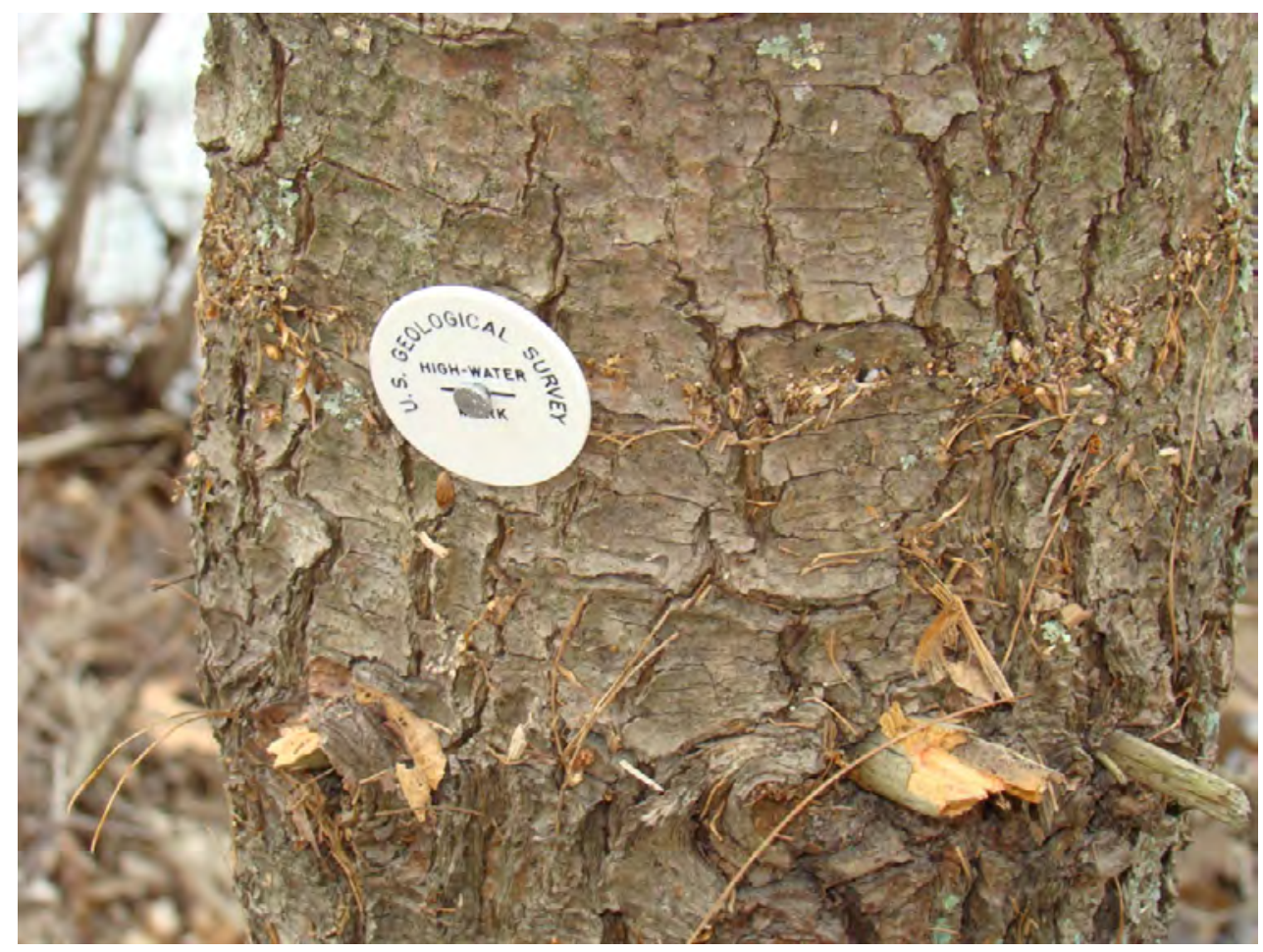

Figure 3-1. Good seed line on a tree.

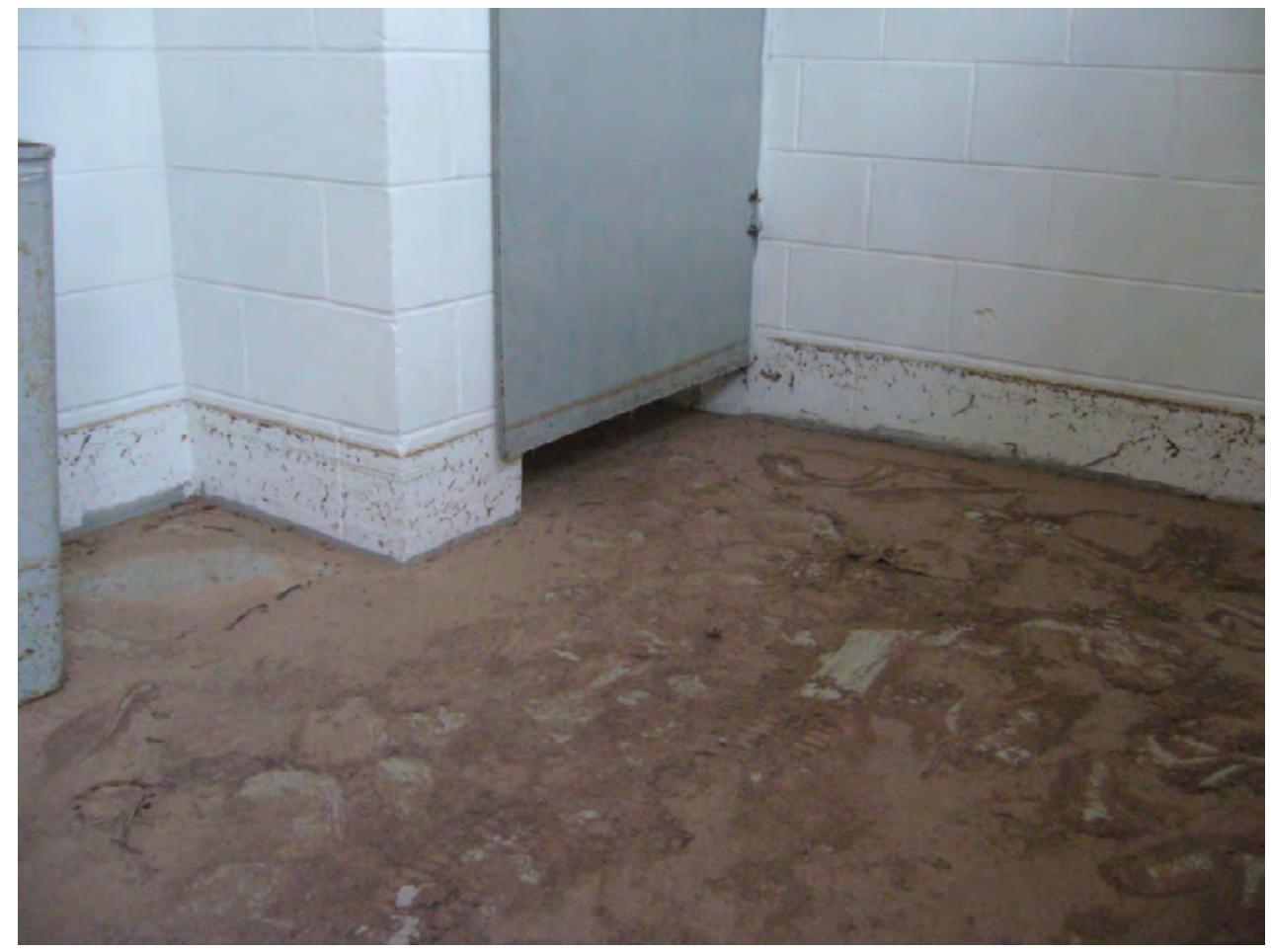

Figure 3-2. Excellent seed/mud line on a wall. 

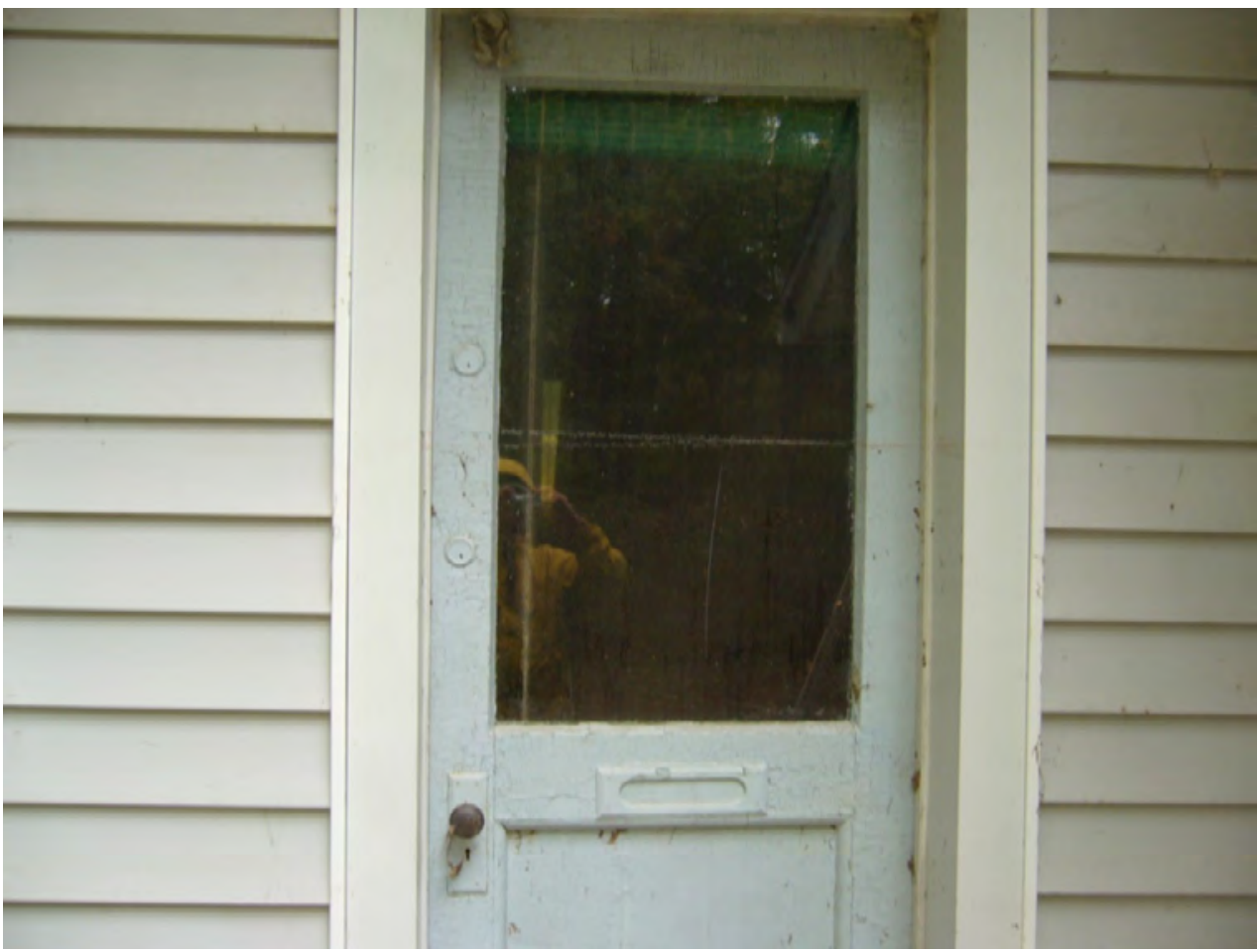

Figure 3-3. Excellent mud line on a door.

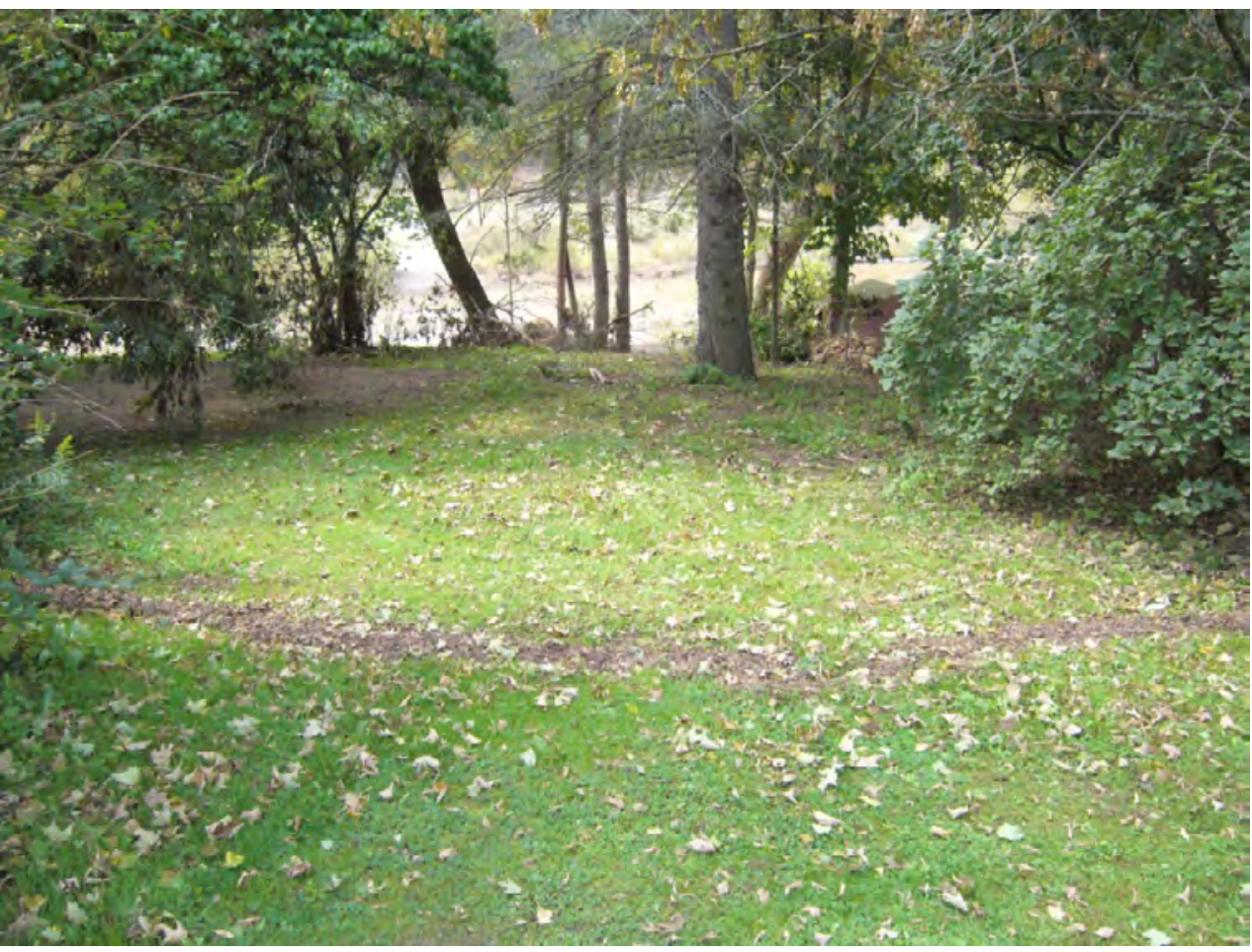

Figure 3-4. Fair debris line on a river overbank. 


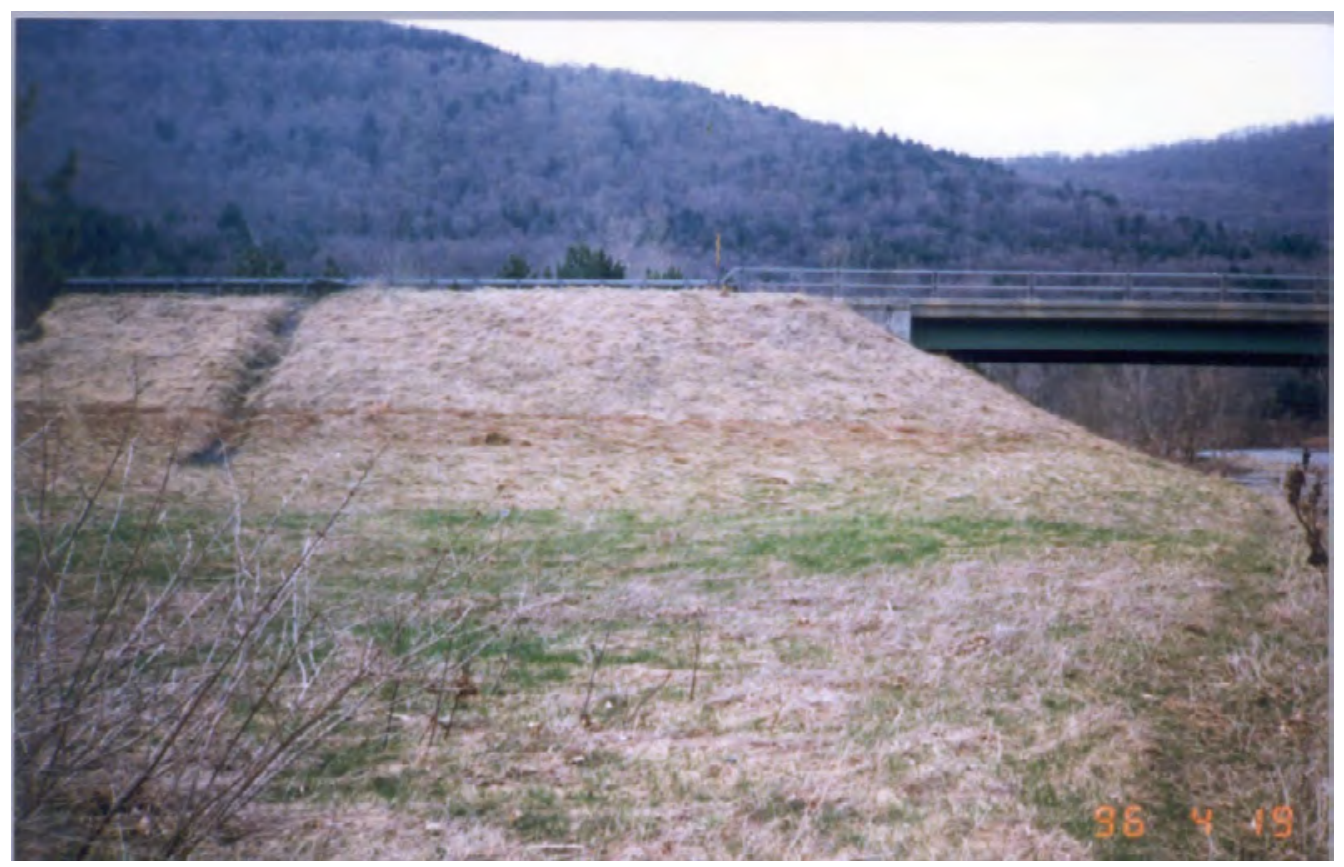

Figure 3-5. Fair debris line on an upstream-left road embankment.

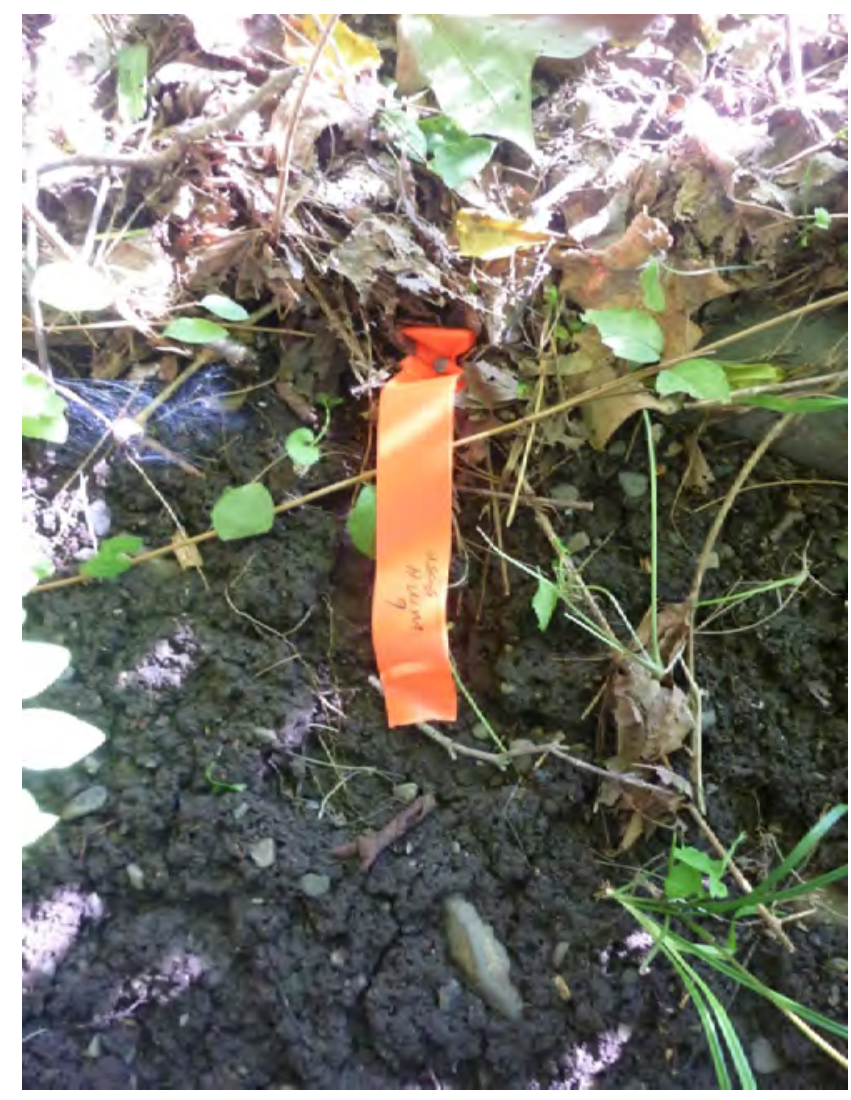

Figure 3-6. Poor wash line on the river bank. 


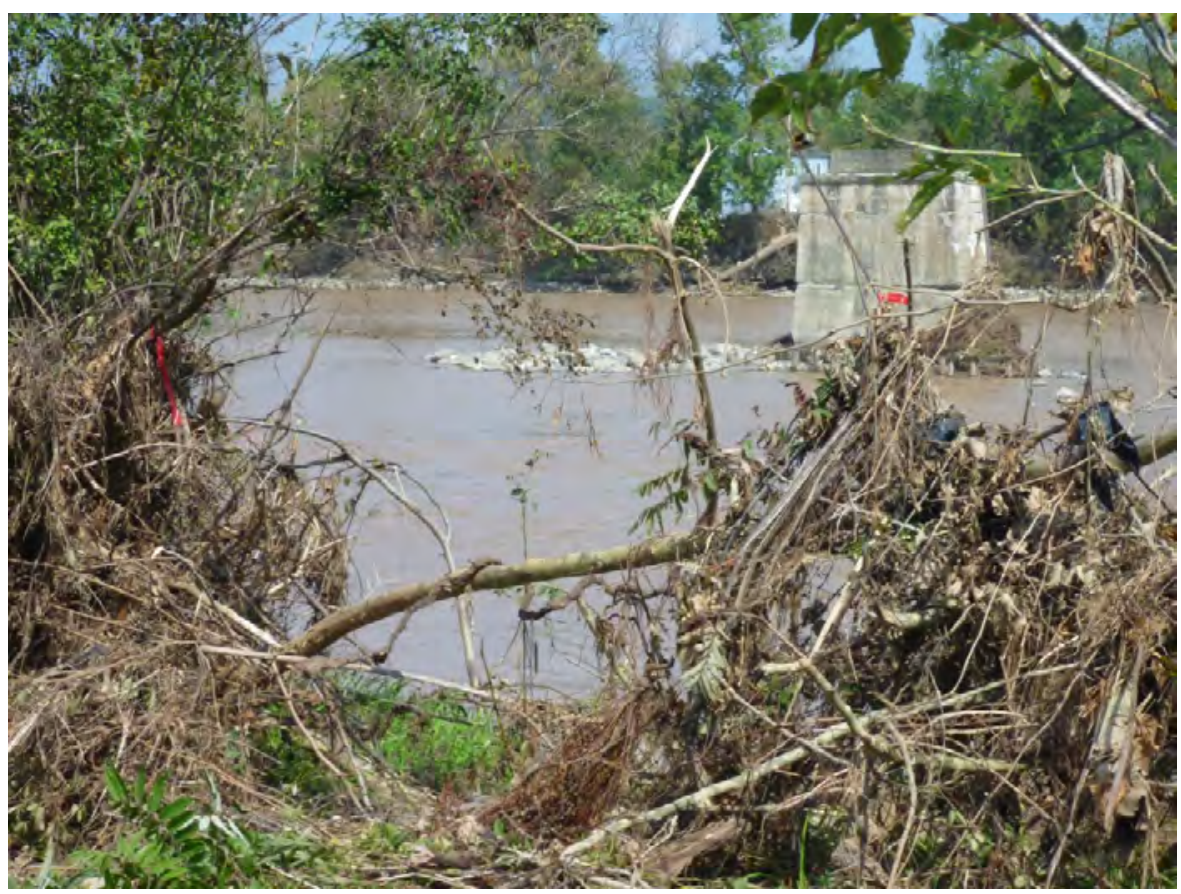

Figure 3-7. Poor debris pile on the bank near the river.

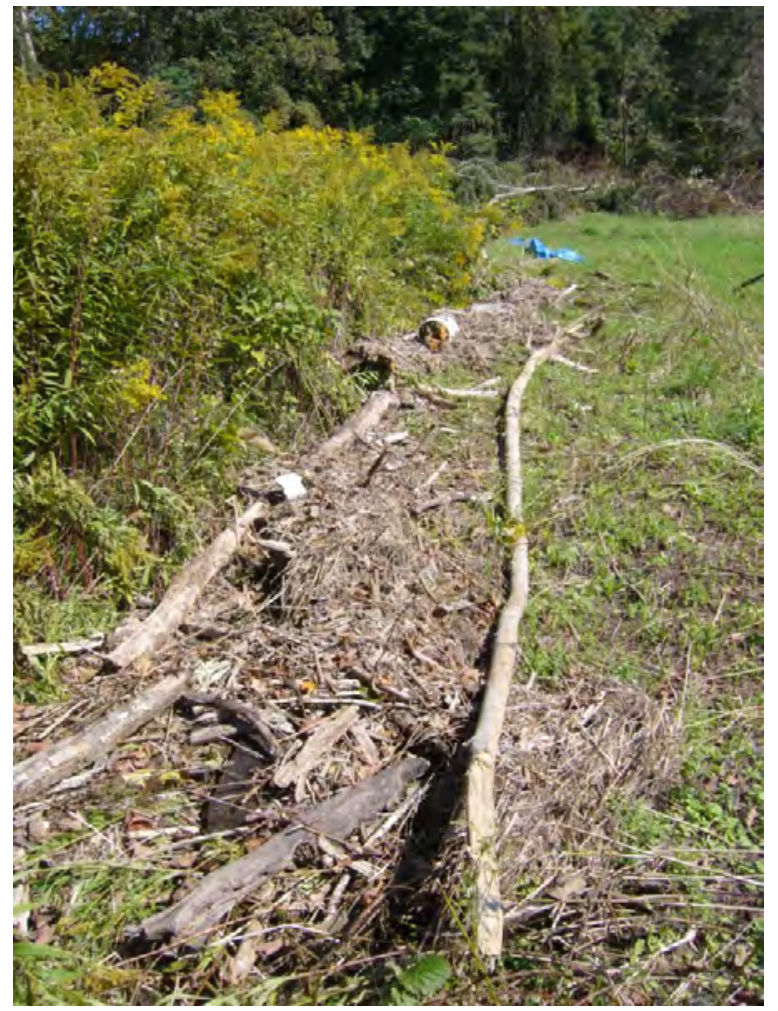

Figure 3-8. Poor debris line on the ground. 


\section{U.S. Department of the Interior \\ Geological Survey \\ High-Water Mark Documentation Notes}

Date of Flood:

Site Number:

Sketch

River / Stream :

Road / Highway Name:

Nearest Community:

FEMA Study Community:

County :

Party : Date :

Horizontal datum used: (circle one) 1927 NAD/1983 NAD

Vertical datum used: (circle one) 1929 NGVD/1988 NAVD

Thalweg Elevation : (at bridge crossing sites)

BM / RM Description:

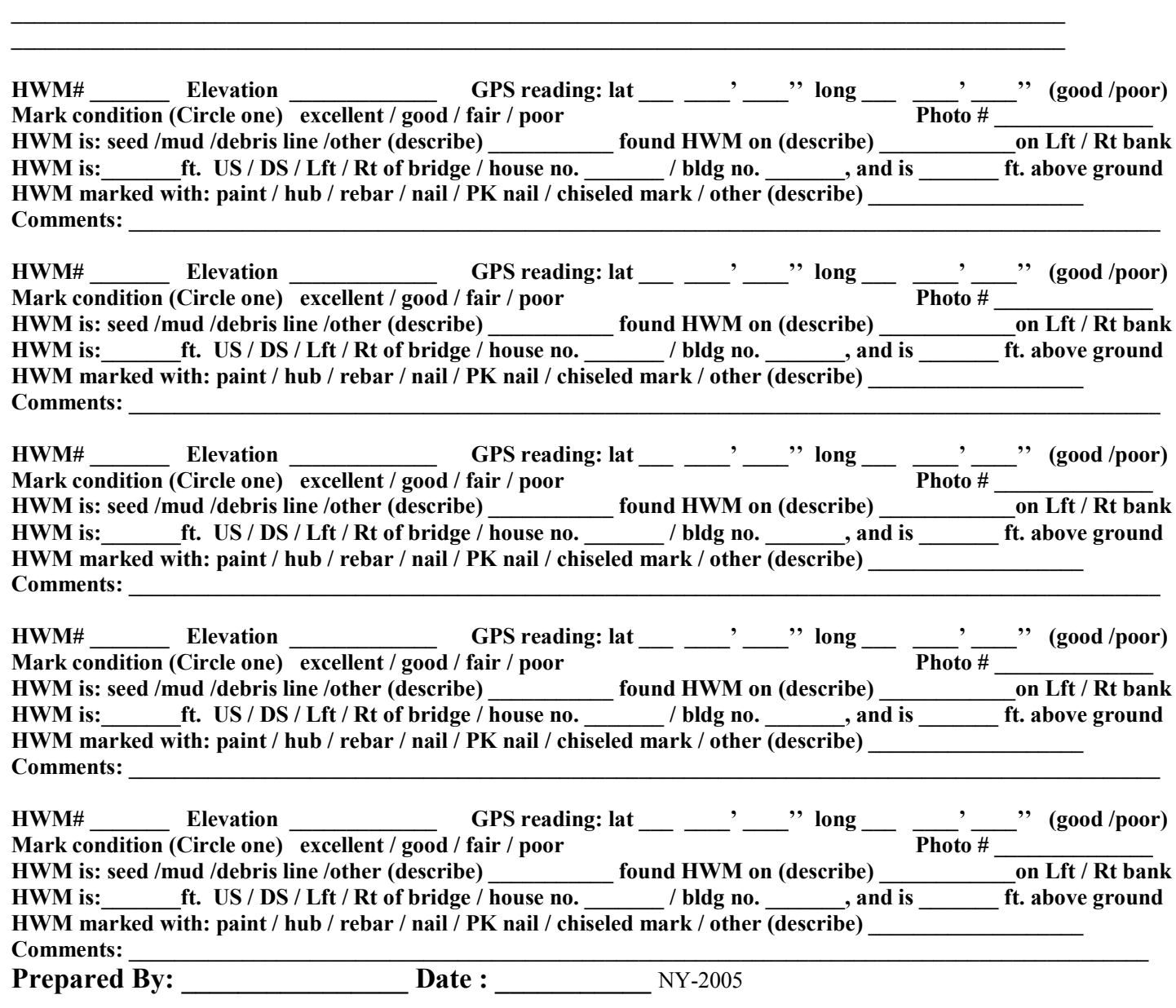

Figure 3-9. Sample form for documenting high-water marks. 


\section{References Cited}

Benson, M.A., and Dalrymple, Tate, 1967, General field and office procedures for indirect discharge measurements: U.S. Geological Survey Techniques of Water-Resources Investigations, book 3, chap. A1, 30 p.

Jarrett, R.D., 1985, Determination of roughness coefficients for streams in Colorado: U.S. Geological Survey WaterResources Investigations Report 85-4004, 54 p.

Matthai, H.F., 1967, Measurement of peak discharge at width contractions by indirect methods: U.S. Geological Survey Techniques of Water-Resources Investigations, book 3, chap. A4, 44 p.

Suro, T.P., Firda, G.D., and Szabo, C.O., 2009, Flood of June 26-29, 2006, Mohawk, Delaware, and Susquehanna River Basins, New York: U.S. Geological Survey Open-File Report 2009-1063, 354 p. 

Prepared by the Pembroke and West Trenton Publishing Service Centers.

For more information concerning this report, contact:

\section{Director}

U.S. Geological Survey

New York Water Science Center

425 Jordan Road

Troy, NY 12180-8349

dc_ny@usgs.gov

or visit our Web site at:

http://ny.water.usgs.gov 
